\title{
OCEANOGRAPHIC SHIPS
}

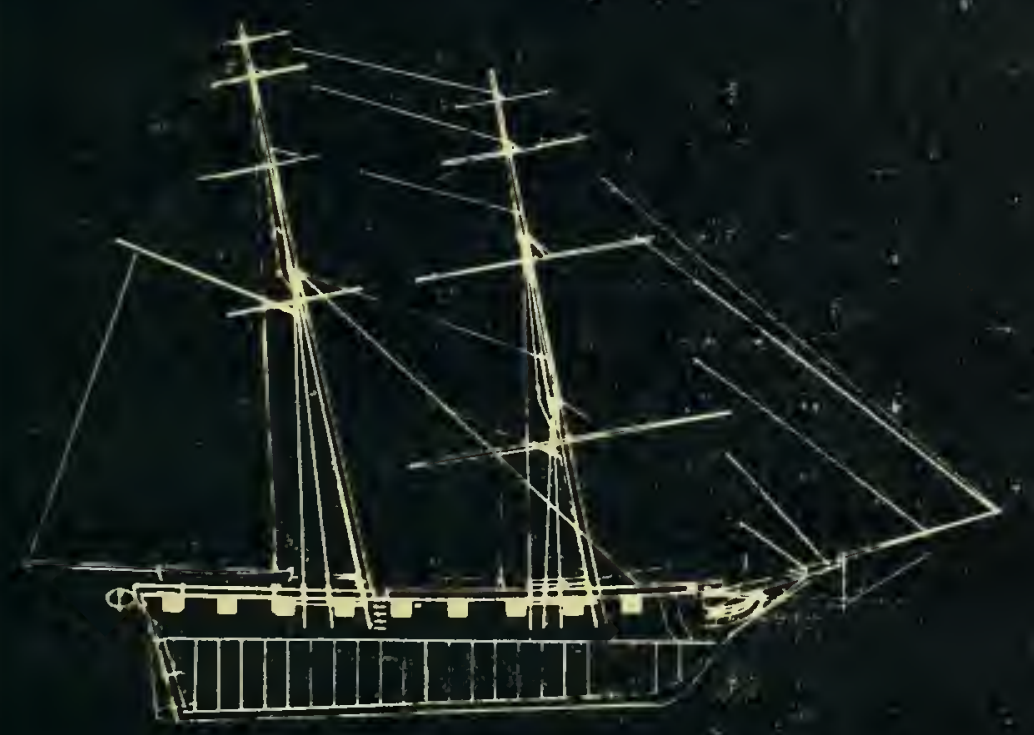

fore $\mathbb{G} a f t$

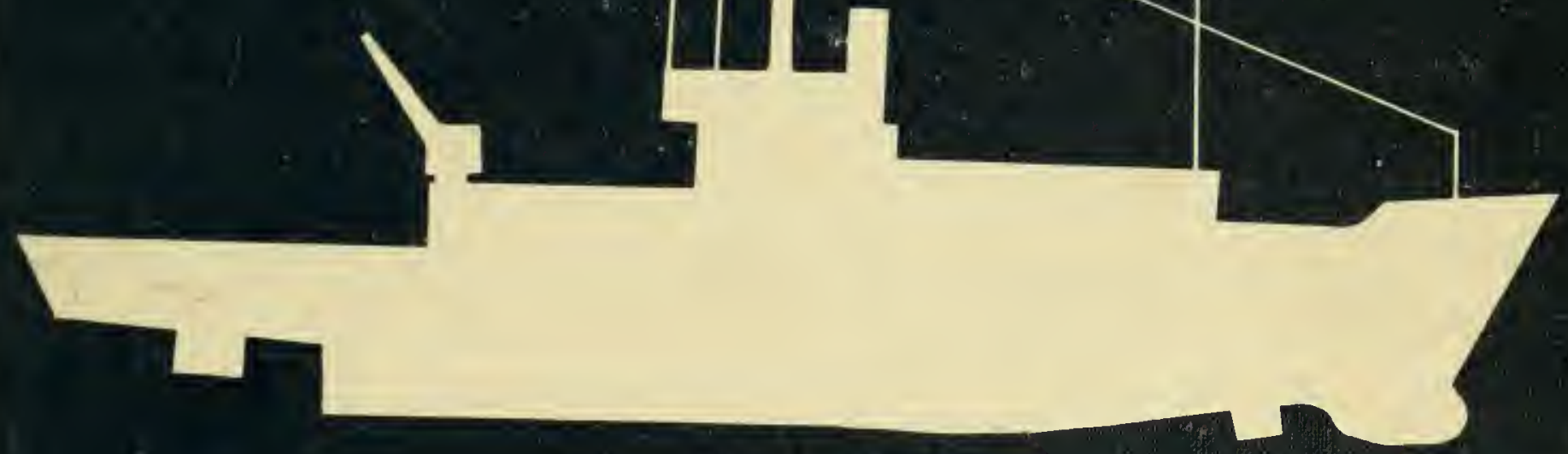




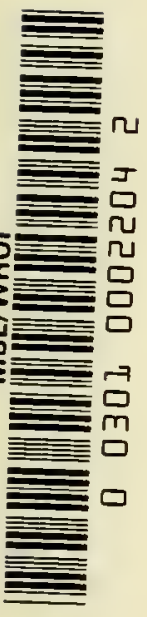



Office of the Oceanographer of the Navy

\section{OCEANOGRAPHIC SHIPS}

\section{Fore and Aft}

by

Stewart B. Nelson
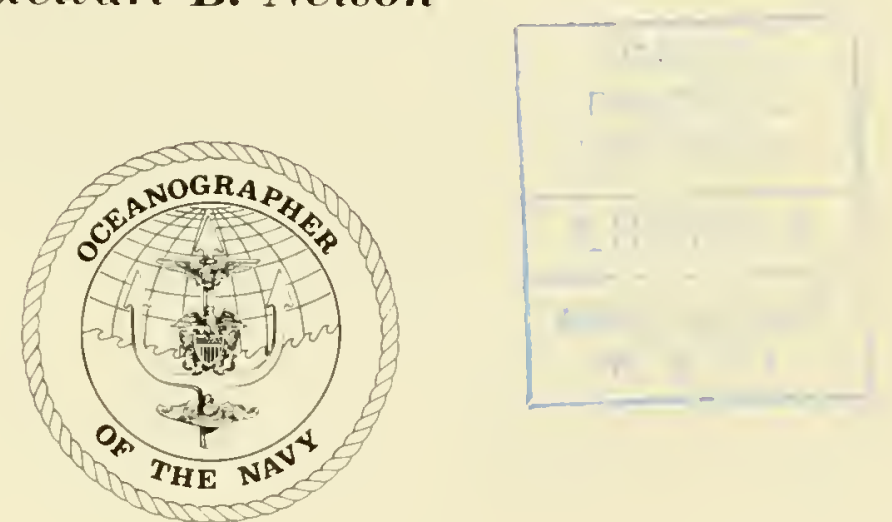

1971 
And Neptune mused, "What manner of men be these that disturb me in my depths?

"I feel the lash of their wire, the bite of their hooks, the sting of their cores and drills.

"I shall forgive them these abuses and tolerant be of their demands if they show deference to my domain.

"But be they thoughtless guests, and I shall give them fish not fit to eat and water not fit to touch." 


\section{FOREWORD}

For oceanographers the ocean itself is the laboratory, and the adequacy of the ships used will significantly affect the oceanographers' ability to work at sea.

As Mr. Nelson has depicted, prior to 1960 , the oceanographer in his ships, with few exceptions, had to content himself with miscellaneous, jury-rigged conversions. The immense progress we have made in this past decade to explore and exploit our planet's water resources has in large measure been made possible by the specially designed oceanographic ships that have been built. Yet we are caught in a paradoxical web... the more we learn and the further we venture, the greater the demands we must place upon our facilities. Our new tools of yesterday thus become tomorrow's obsolescent ships.

We are now faced with a tremendous challenge in trying to achieve a quality environment. This challenge can be met ... but it will require resources and a major cooperative effort.

As in the past, the Navy will continue its leadership in the marine sciences and will continue to work with and share its knowledge with other national and international programs to the maximum extent consistent with our country's security.

Rear Admiral W. W. Behrens, Jr., USN Oceanographer of the Navy 



\section{PREFACE}

The early history of oceanography is inseparable from that of discovery and exploration, which in turn depended upon a thirst for knowledge and the quest for trade. The sailors of old, despite knowing little or nothing of what lay beyond and inadequately provided with ships and gear, put to sea resolved to do their best to accomplish something of note and to bring back their data and conclusions.

Today we are confronted with challenges that need the sprit and imagination of yesterday's adventurers.

Through tales of ships and deeds, Mr. Nelson's treatise illustrates the long and mutually beneficial association of the Navy with science and industry, with fisherman, and with the merchant marine in the broad field known as oceanography. It is by this continuing spirit of cooperation that we will ensure that our country maintains its leadership in the effective use of the sea and fulfills its obligation to mankind.

Rear Admiral O. D. Waters, Jr., USN Oceanographer of the Navy (1966-1970) 



\title{
ACKNOWLEDGMEN'TS
}

This book is written primarily for the general public and for those who may become the future marine scientists, naval architects, marine engineers and ship operators. Hopefully it will excite their imagination and also instill an appreciation for the efforts of those who have preceded them. It is also my intention to provide a record of those men and ships which expanded the frontiers of oceanography and to remind us of both past accomplishments and future aspirations.

For their invaluable assistance and cooperation during the preparation of this book I am especially indebted to Captain James E. Ayres, USN, of the Office of the Oceanographer of the Navy; Captain Francis L. Slattery, USN, Commander of the Naval Oceanographic Office; Mr. Aubrey W. Bailey of the Naval Ship Systems Command; Mr. Frank Guaragna of the Naval Oceanographic Office; Lieutenant J. Michael Kirchberg, Jr., USN, of the Office of the Oceanographer of the Navy; and Mr. Maxwell Silverman of Scripps Institution of Oceanography.

For their great trouble in helping me to locate long-buried photographs, drawings, biographies, and ship histories 1 gratefully acknowledge Mr. Frank Bean of the University of Washington; Mr. Howard I. Chapelle of the Smithsonian lustitution; Dr. John Dermody of the University of Washington; Mr. Jack Dullaghan of Scripps Institution of Oceanography; Mr. Richard Edwards of Woods Hole Oceanographic Institution; Mr. William Geoghegan of the Smithsonian Institution: Mr. James Gibbons of the University of Miami; Mr. Clarles Haberlain of the Office of the Chief of Naval Operations, Naval History Division; Miss Mary Johrde of the National Science Foundation; Mr. Lawrence Liebrecht of the Naval Oceanographic Office; Mr. Jonathan Lieby of Woods Hole Oceanographic Institution; Mr. John Leavitt of the Marine Historical Association, Mystic Seaport; Mr. John Lochhead of The Mariners Museum; Mr. Larry Manning of the Military Scalift Command; Mr. James Pollack of Scripps Institution of Oceanography; Mr. Jolnn Rowe of the publication SHIPS AND AIRCRAFT, U. S. FLEET; Mr. Edward Schaefers of the Department of Commerce, National Marine Fisheries Service; Mr. Phillip C. F. Smith of the Peabody Museun; Mr. Dale Tidrick of the Naval Oceanographic Office; Mr. Peter Trapani of Scripps Institution of Oceanograplıy; Mr. James Walczak of the Naval Oceanographic Office; Mr. Paul Watson of OUR NAVY magazine; and Messrs. William West and Raymond Wilcove of the Department of Commerce. National Oceanic and Atmospheric Administration. Lastly, but not least, to ny wife and children for their patience and always ready lielping liands.

\author{
STEWART B. NELSON \\ Director of Facilities Accuisition \\ Office of the Oceanographer of the Navy
}





\section{CONTENTS}

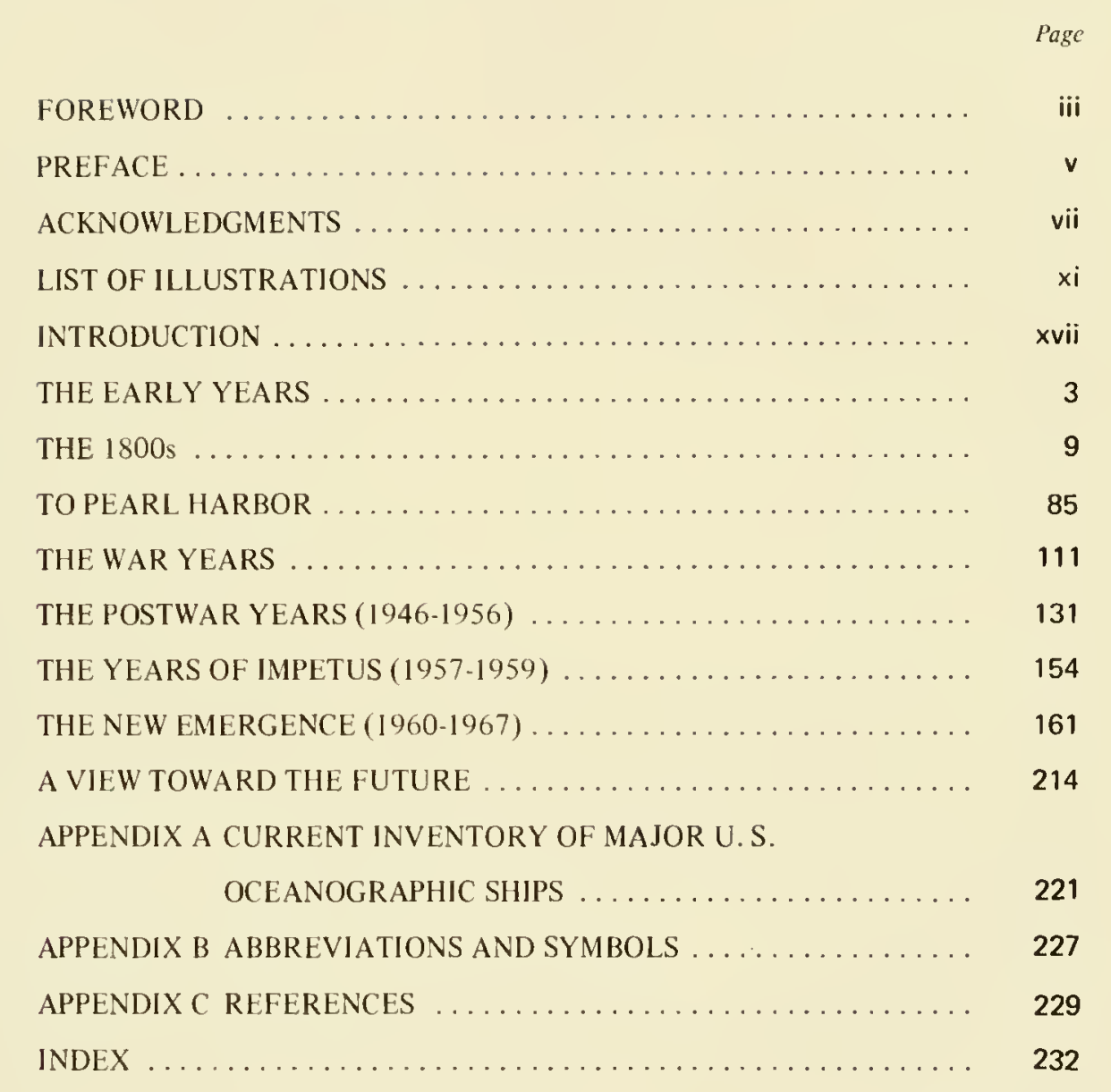





\section{LIST OF \\ ILLUSTRATIONS}

THE EARLY YEARS

Page

Benjamin Franklin . . . . . . . . . . . . .

Franklin's Chart of the Gulf Stream . . . . . . . . . . . . . . 4

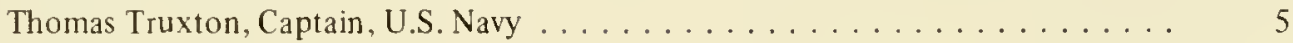

THE 1800s

Nathaniel Bowditch, "Father of Modern Navigation" . . . . . . . . . . 8

John Rodgers, Commodore, U.S. Navy . . . . . . . . . . . . . . . . . . 24

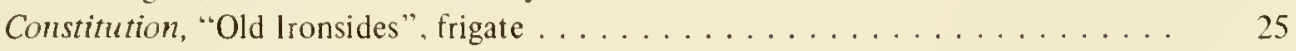

Ferdinand Rudolph Hassler, First Superintendent of the Coast Survey . . . . . . . 26

Hassler's 24-inch Theodolite . . . . . . . . . . . . . . . . . . . . . 27

Louis M. Goldsborough, Rear Admiral, U. S. Navy, First Officer-in-Charge of the

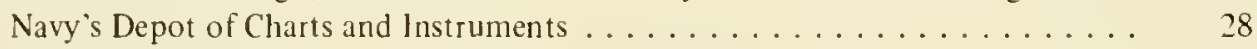

Experiment, schooner . . . . . . . . . . . . . . . . . . 29

Charles Wilkes, Rear Admiral, U.S. Navy . . . . . . . . . . . . . . . . . 30

Porpoise, brig, accompanied by schooners Maria and Badassah .......... 31

Chart of Georges Shoal and Bank (published 1837) . . . . . . . . . . 32

Consort and Pioneer, brigs . . . . . . . . . . . . . . . . . . 33

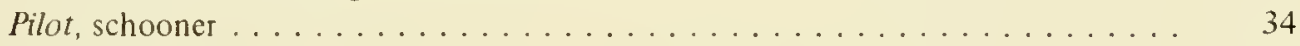

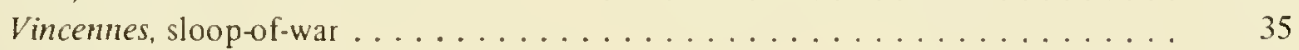

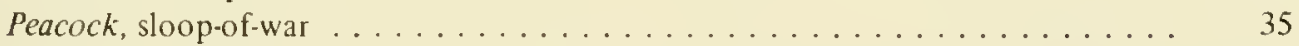

Sea Gull, schooner . . . . . . . . . . . . . . . . . . . 36

Flying Fish, Schooner . . . . . . . . . . . . . . . . . . . 36

Relief, storeship . . . . . . . . . . . . . . . . . 37

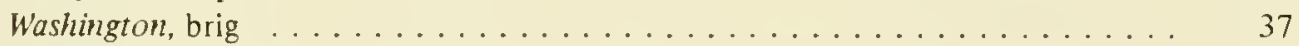

Matthew Fontaine Maury, Commander, U. S. Navy, "Pathfinder of the Seas" . . . 38

Roger B. Taney, schooner . . . . . . . . . . . . . . . . . . 39

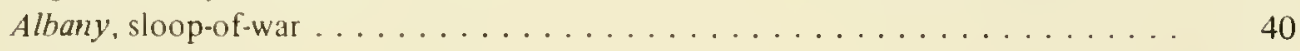

Dolphin, brig . . . . . . . . . . . . . . . . . . . . 40

Midshipman John Mercer Brooke's deep sea sounding devices . . . . . . . . . 41

Niagara, frigate, and Agamemnon, British battleship, laying first trans-Atlantic tele-

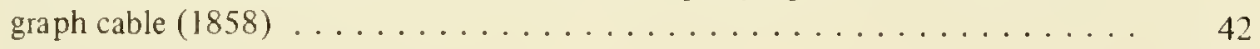

Matthew Calbraith Perry, Commodore, U. S. Navy ............... 43

Silas Bent, Lieutenant, U. S. Navy . . . . . . . . . . . . . . . . . . 44

Perry's Expedition to Japan in Tokyo Bay (July 1853) . . . . . . . . . . . 45

Cadwalader Ringgold, Rear Admiral, U. S. Navy . . . . . . . . . . . . . . . . 46

John Rodgers, Rear Admiral, U. S. Navy . . . . . . . . . . . . . . . . . . . . 47

Elisha Kent Kane, Passed Assistant Surgeon, U. S. Navy . . . . . . . . . . . . 48

Advance, brig, accompanied by the brig Rescue . . . . . . . . . . . . . . 49

William Francis Lynch, Captain, U.S. Navy . . . . . . . . . . . . 50

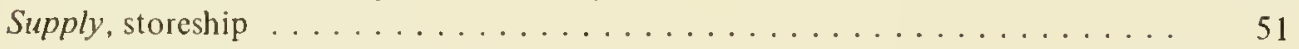

Chart Engraving by James Abbot McNeil Whistler . . . . . . . . . . . . 52

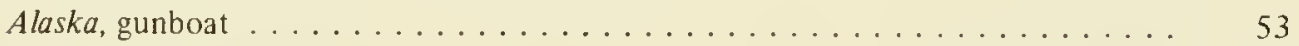

Benicia, sloop-of-war . .......................... 53

Palos, gunboat ......................... 54 
Kansas, gunboat .......................... 54

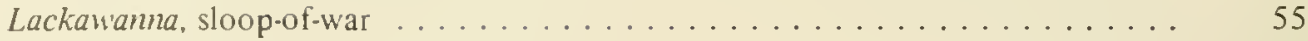

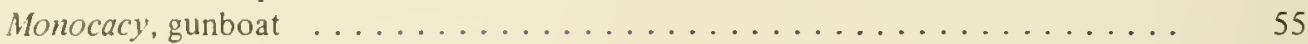

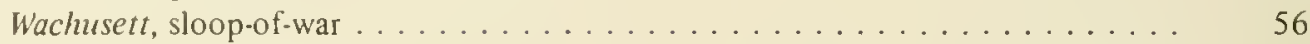

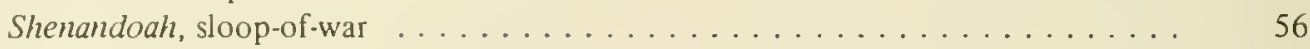

Narragansett, sloop . . . . . . . . . . . . . . . . . . . . 57

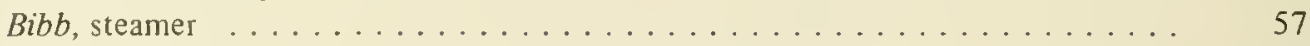

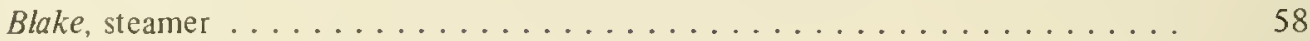

Lincoln, cutter . . . . . . . . . . . . . . . . . . . . . . . . . . 58

Spencer Fullerton Baird, First Commissioner of the U. S. Fish Commission . . . . . 59

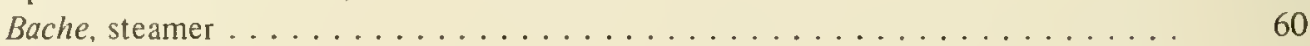

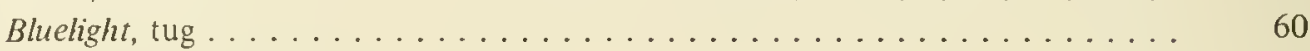

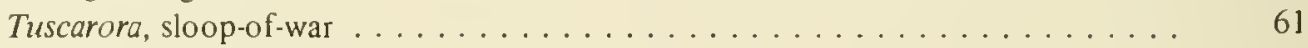

George Eugene Belknap, Rear Admiral, U.S. Navy . . . . . . . . . . . . . . . 62

Tuscarora's Sounding Outfit . . . . . . . . . . . . . . . . . . . . 63

Sir William Thomson's sounding machine . . . . . . . . . . . . . . . . . . . 64

Tuscarora's Journal of Deep Sea Soundings (Cast No. 28-4,356 fathoms) . . . . . . . . . 65

Tuscarora's steam reel for rope soundings . . . . . . . . . . . . . . 66

Gettysburg, steamer . . . . . . . . . . . . . . . . . . . 67

Jainestown, sloop-of-war . . . . . . . . . . . . . . . . . . . 67

Alexander Agassiz, Scientist . . . . . . . . . . . . . . . . 68

Fish Hawk, steamer . . . . . . . . . . . . . . . . . . . . . . . . 69

George Washington DeLong, Lieutenant Commander, U. S. Navy . . . . . . . . 70

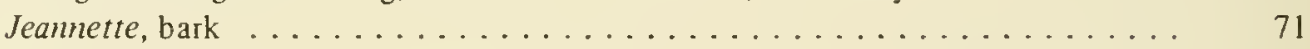

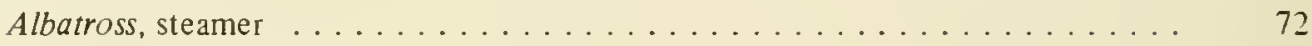

Zera Luther Tanner, Captain, U. S. Navy . . . . . . . . . . . . . . . . 73

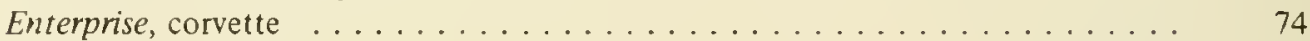

Ranger, sloop-of-war . . . . . . . . . . . . . . . . . . . 75

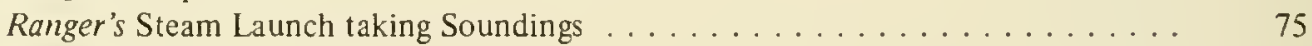

Concord, gunboat . . . . . . . . . . . . . . . . . . . . . . 76

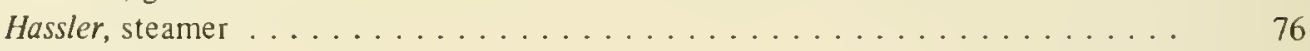

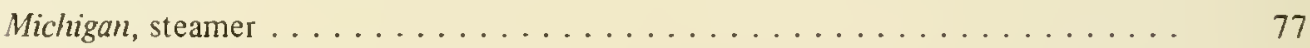

Thetis, gunboat . . . . . . . . . . . . . . . . . . . 77

Charles Dwight Sigsbee. Rear Admiral, U. S. Navy . . . . . . . . . . . . 78

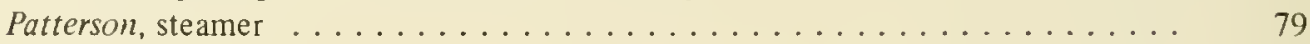

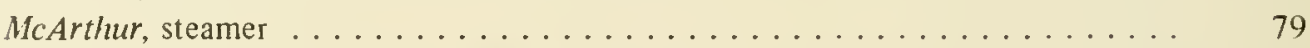

Path finder, steamer (renamed Research in 1940) . . . . . . . . . . . . . . . . . . . . . . . . . . . . . .

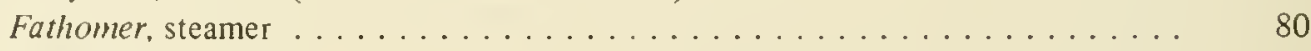

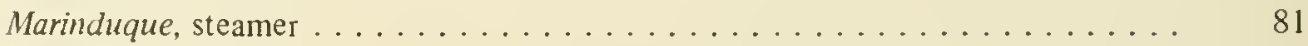

Romblon, steamer ........................ 81

\section{TO PEARL HARBOR}

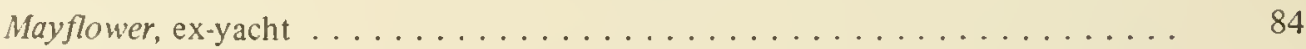

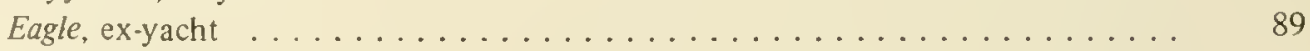

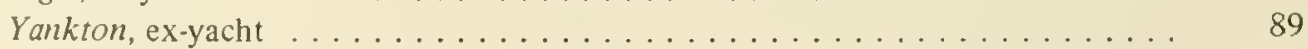

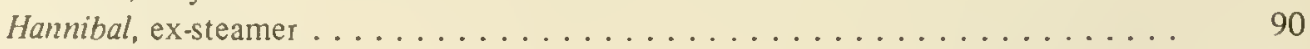

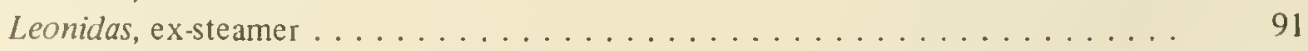

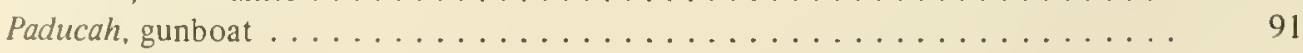




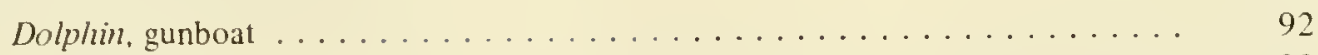

Olympia, cruiser . . . . . . . . . . . . . . . . . . . . . 93

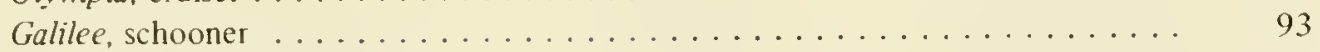

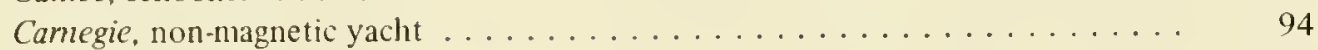

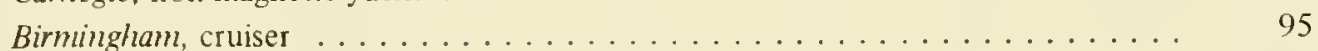

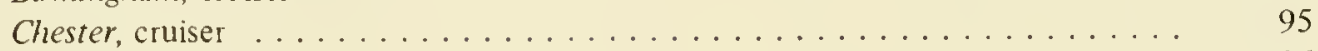

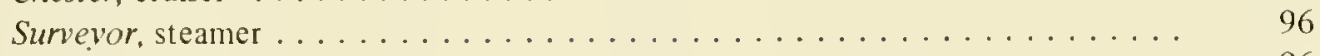

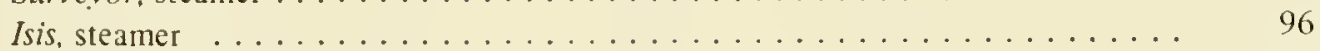

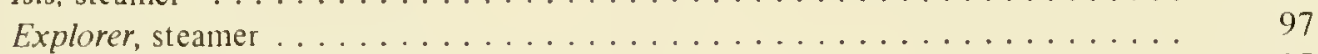

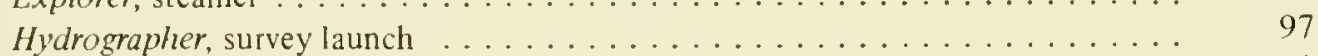

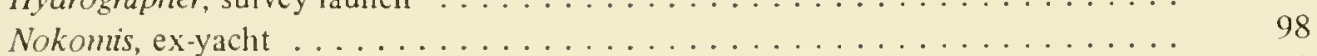

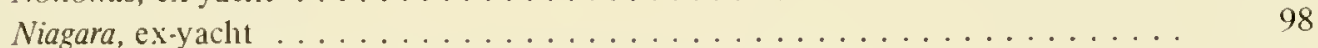

Harvey Comelius Hayes, developer of the sonic depth finder . . . . . . . . . . . . . . . . 99

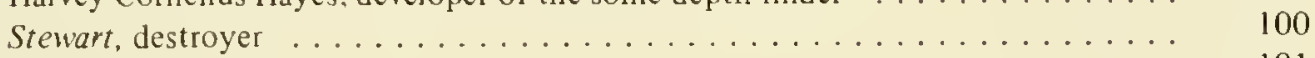

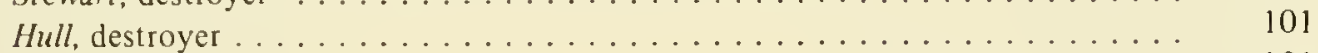

Corry, destroyer ............................ 101

First Bathymetric Chart compiled from sonic soundings $\ldots \ldots \ldots \ldots \ldots$

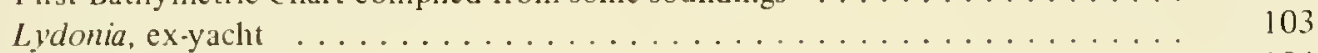

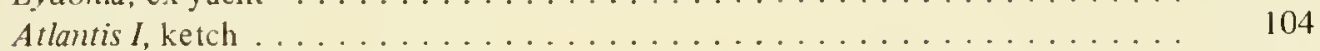

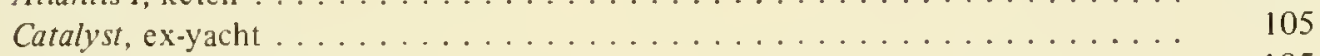

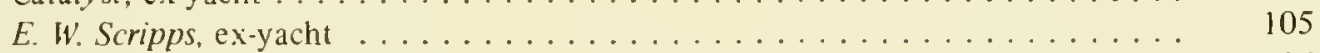

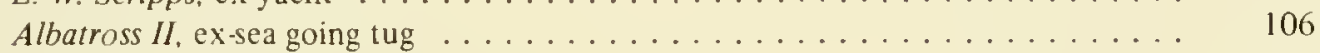

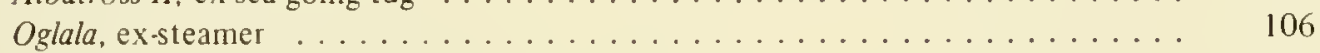

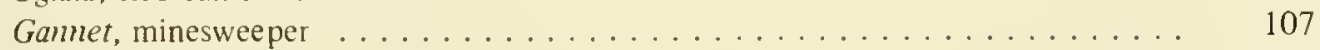

Ramapo, tanker .......................... 107

\section{THE WAR YEARS}

Summer (former submarine tender Bushmell) ................. 110

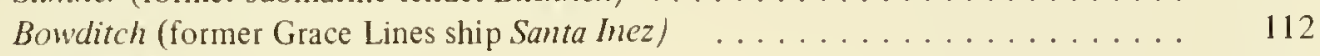

Effie M. Morrissey, schooner ........................ 114

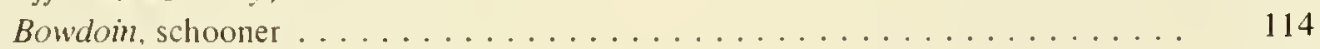

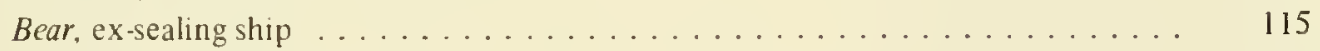

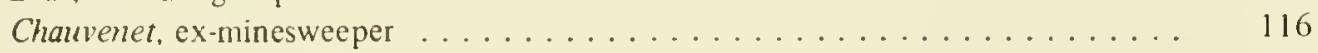

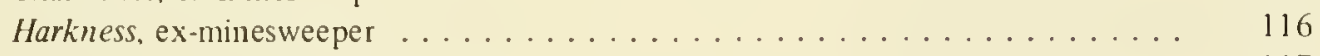

James M. Gilliss, ex-minesweeper . . . . . . . . . . . . . . . . . . 117

Simon Newcomb, ex-minesweeper ...................... 117

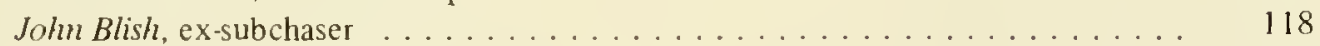

Armistead Rust, ex-subchaser . . . . . . . . . . . . . . . . . . 118

Littlehales, ex-subchaser ......................... 119

Dutton, ex-subchaser ............................. 119

Guide, ex-minesweeper ........................ 120

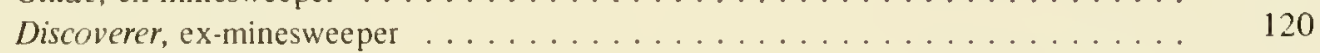

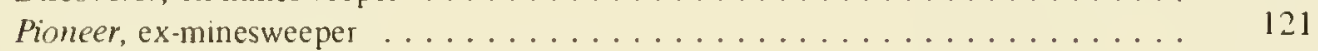

Oceanographer, ex-yacht ...................... 121

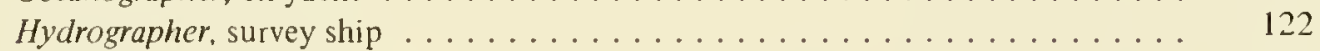

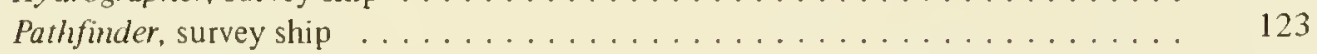

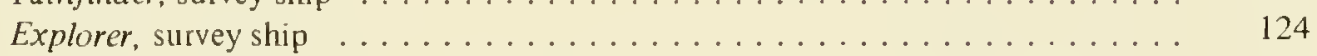

Derickson, ex-subchaser . . . . . . . . . . . . . . . . . . . . 124 


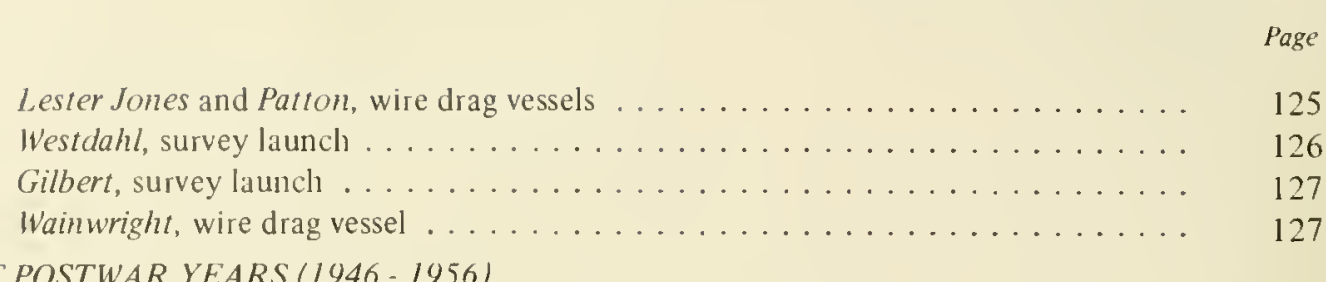

Page

THE POSTWAR YEARS (1946 - 1956)

Velero $I V$, modified tuna clipper . .................. 130

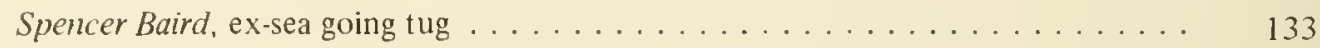

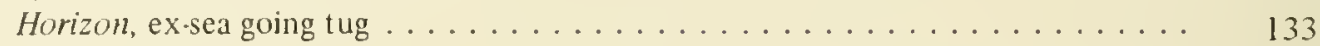

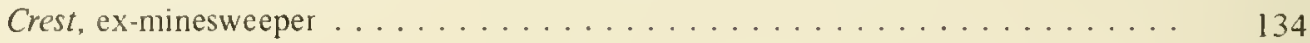

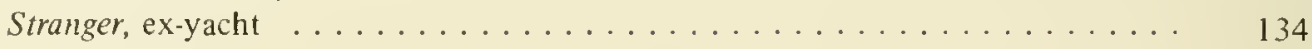

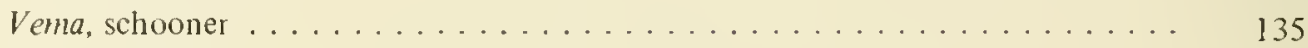

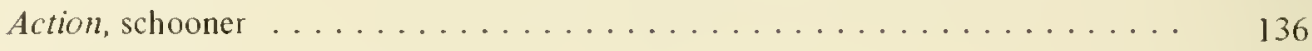

Paolina-T, seiner . . . . . . . . . . . . . . . . . . . . . 137

Hugh M. Smith, tuna clipper . . . . . . . . . . . . . . . . 137

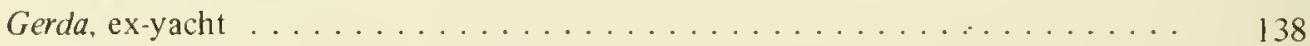

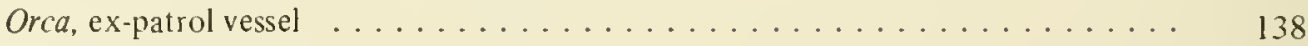

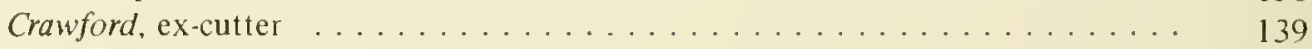

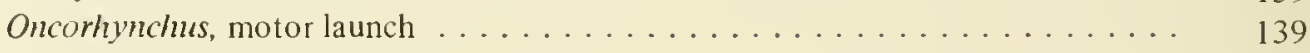

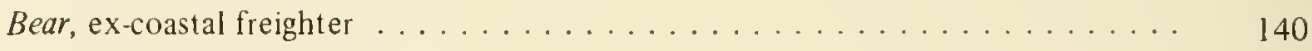

Brown Bear, ex-coastal freighter . . . . . . . . . . . . . . . . 140

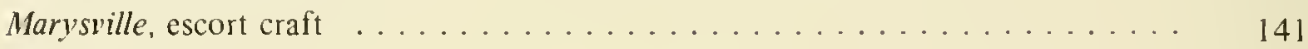

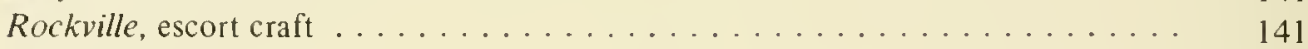

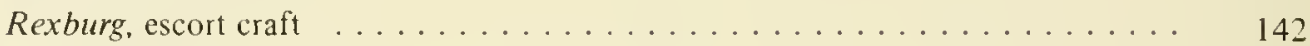

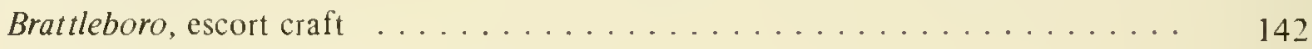

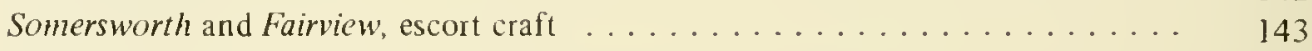

Albatross III, ex-trawler . . . . . . . . . . . . . . . . . . . . 144

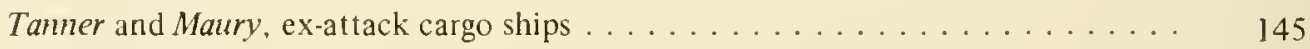

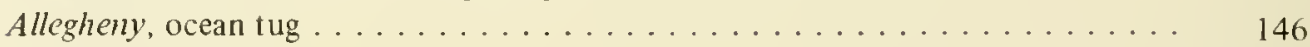

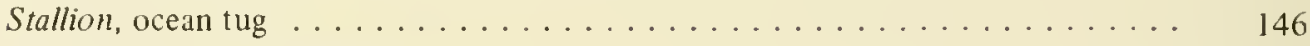

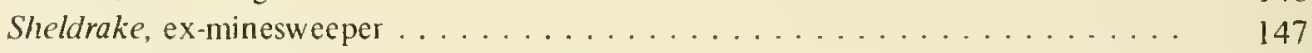

Prevail, ex-minesweeper . . . . . . . . . . . . . . . . . . . 147

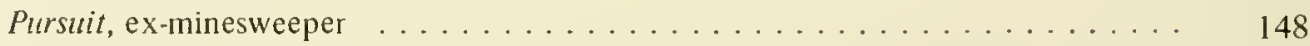

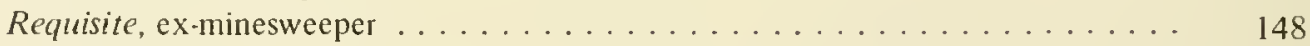

Serrano, ex-ocean tug ......................... 149

Towhee, ex-minesweeper ........................... 149

San Pablo, ex-seaplane tender . . . . . . . . . . . . . . . . . . . 150

Rehoboth, ex-seaplane tender . . ................... 150

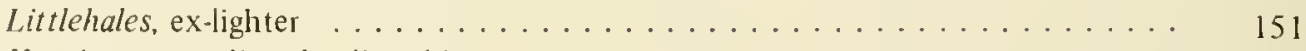

Hunting, ex-medium landing ship $\ldots \ldots \ldots \ldots \ldots \ldots \ldots \ldots \ldots \ldots$

\section{THE YEARS OF IMPETUS (1957 - 1959)}

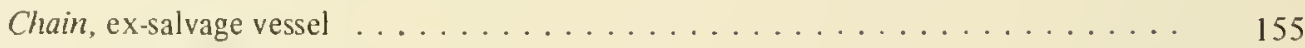

Argo, ex-salvage vessel . . . . . . . . . . . . . . . . . . . . . 155

Josiah Willard Gibbs, ex-seaplane tender . . . . . . . . . . . . . . 156

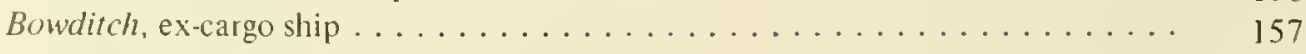

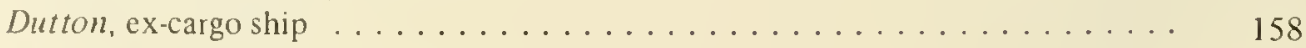

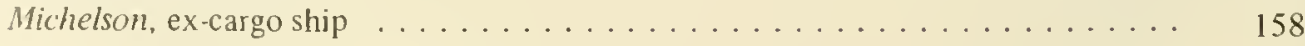


Robert D. Conrad (AGOR 3) ..................... 160

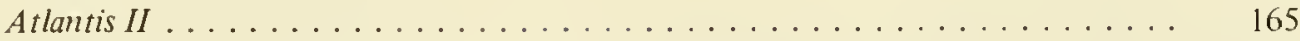

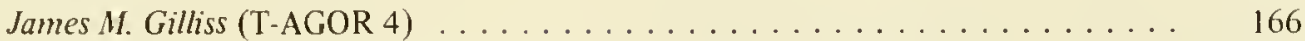

Charles H. Davis (T-AGOR 5) (while under construction - launching) . . . . . . 166

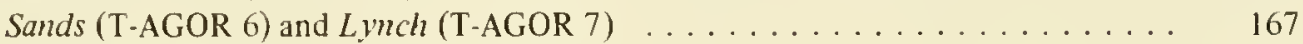

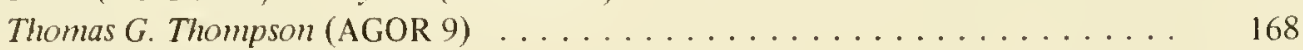

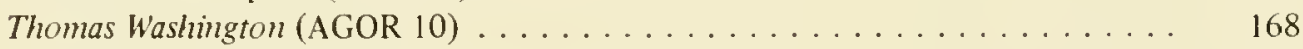

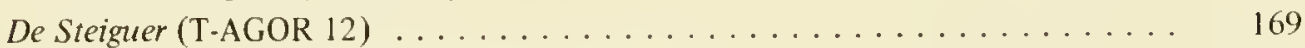

De Steiguer's bow propulsion unit - extended . . . . . . . . . . . . 170

De Steiguer's Propulsive Rudder . . . . . . . . . . . . . . . . . . . 170

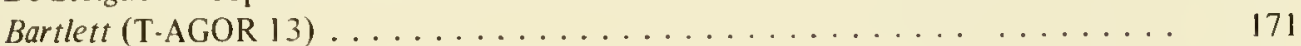

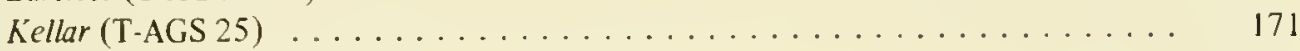

Kellar capsized in Mississippi River at New Orleans . . . . . . . . . . . 172

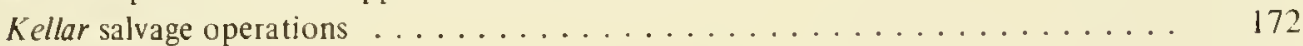

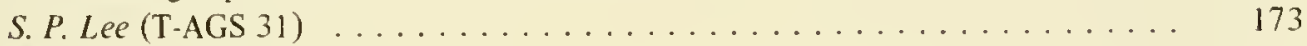

Mission Capistrano, ex-tanker ...................... 174

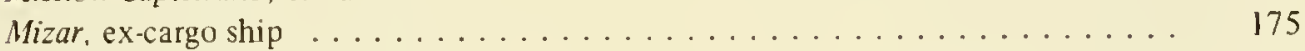

Sir Horace Lamb, ex-minesweeper . . . . . . . . . . . . . . . . . . . 176

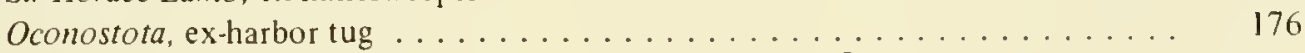

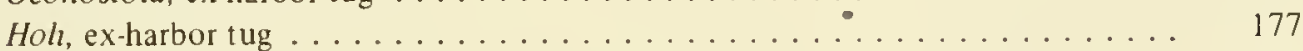

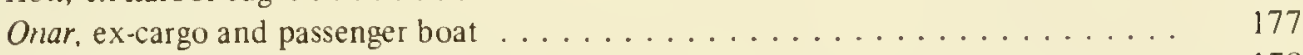

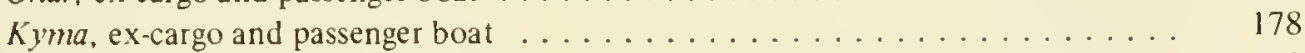

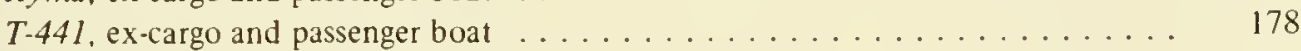

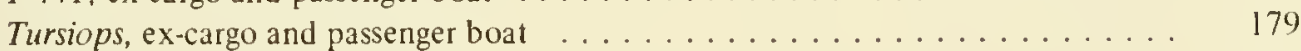

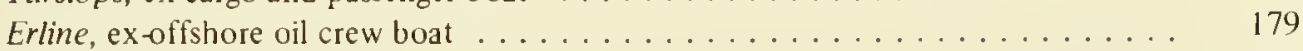

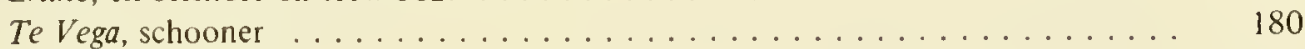

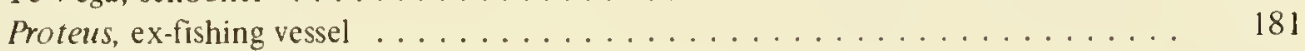

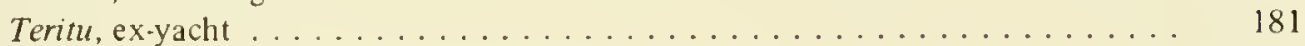

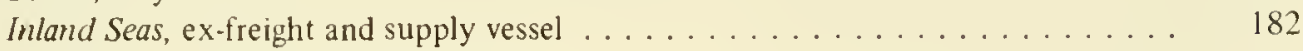

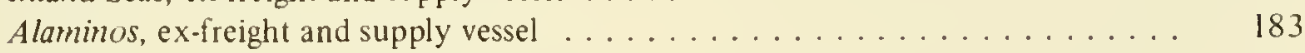

Hidalgo, ex-freight and supply vessel $\ldots \ldots \ldots \ldots \ldots \ldots \ldots \ldots \ldots \ldots$

Trident, ex-freight and supply vessel $\ldots \ldots \ldots \ldots \ldots \ldots \ldots \ldots \ldots$

Pillsbury, ex-freight and supply vessel . . . . . . . . . . . . . . . . 184

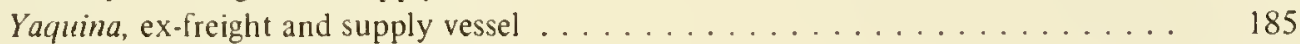

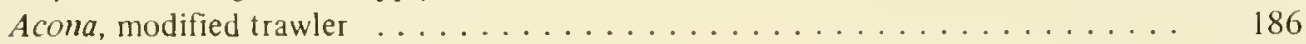

Cayuse, modified fishing vessel . . . . . . . . . . . . . . . . 186

Eastward, biological research vessel . . . . . . . . . . . . . . . . 187

Alpha Helix, biological research vessel . . . . . . . . . . . . . . 187

Anton Brutu, ex-yacht . . . . . . . . . . . . . . . . . . 188

Eltanin, ex-cargo ship . . . . . . . . . . . . . . . . . . . . 189

Hero, modified trawler . . . . . . . . . . . . . . . . . . . . . . 190

Alexander Agassiz, ex-freight and supply vessel . . . . . . . . . . . . . 191

Ellen B. Scripps, ex-offshore oil supply boat . . . . . . . . . . . . . . . . 191

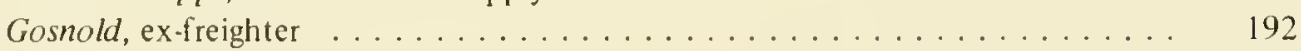

Kit Jones, ex-tug . . . . . . . . . . . . . . . . . . . 192

Silas Bent $(\mathrm{T}-\mathrm{AGS} 26) \ldots \ldots \ldots \ldots \ldots \ldots \ldots \ldots \ldots \ldots . \ldots \ldots \ldots$

Kane $(\mathrm{T}-\mathrm{AGS} 27) \ldots \ldots \ldots \ldots \ldots \ldots \ldots \ldots \ldots \ldots . \ldots \ldots \ldots$

Wilkes (T-AGS 33) (while under construction - launching) . . . . . . . . . 194 


\section{LIST OF ILLUSTRATIONS (Continued)}

Chanvenet (T-AGS 29) . . . . . . . . . . . . . . . . . . . . . . 195

Harkness (T-AGS 32) (while under construction - launching) . . . . . . . 195

Wyman (T-AGS 34) (while under construction) . . . . . . . . . . . . . 196

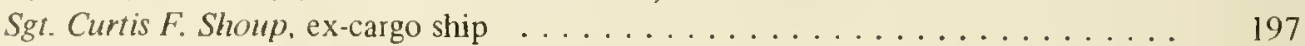

Sgt. George D. Keathley, ex-cargo ship . . . . . . . . . . . . . . . . . . 197

Melville $($ AGOR 14) . . . . . . . . . . . . . . . . . . . . . . . . . 198

Melville's underwater bow observation chamber and forward cycloidal propeller . . 199

Melville's aft cycloidal propeller . . . . . . . . . . . . . . . . . . . . 199

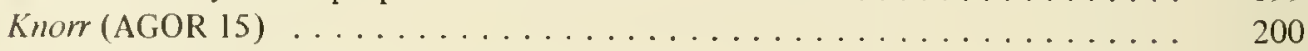

Ridgely Warfield, catamaran ........................ 201

Hayes (T-AGOR 16), catamaran (construction model) . . . . . . . . . . . . 202

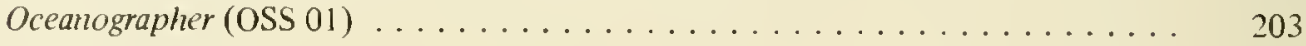

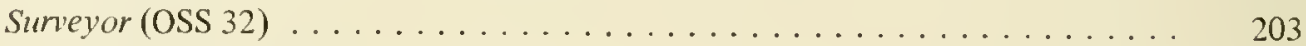

Researcher (OSS 03) (artist's concept) ..................... 204

Mt. Mitchell $($ MSS 22) ......................... 205

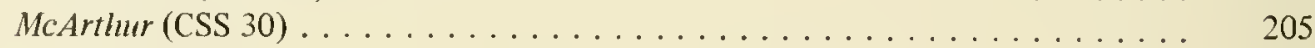

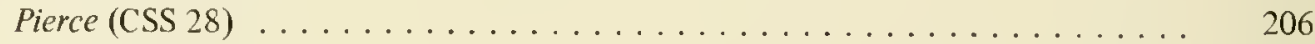

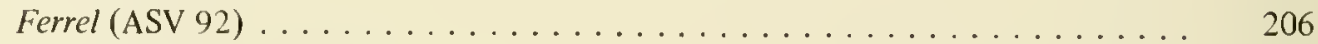

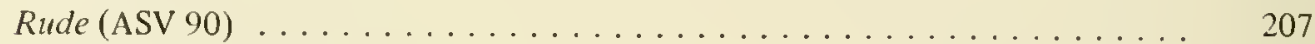

Survey Launch $1255 \ldots \ldots \ldots \ldots \ldots \ldots \ldots$. . . . . . . . . . . . . . . . . . . . . . . . . . . . . . . . . . . . . . . . . .

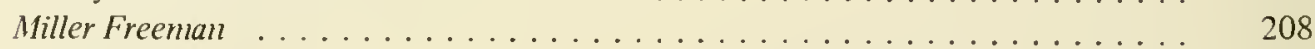

Albatross IV ................................ 208

David Starr Jordan . . . . . . . . . . . . . . . . . . . . . . . . . 209

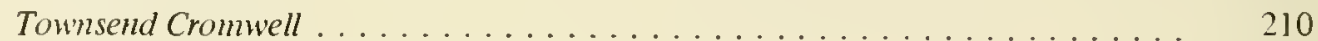

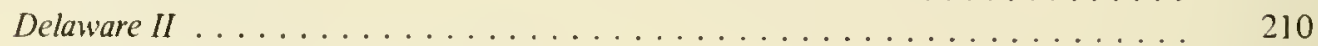

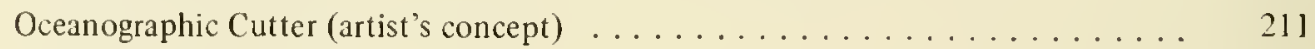

Evergreen, ex-buoy tender ....................... 211

\section{A VIEW TOWARD THE FUTURE}

AGOR (Utility) (artist's concept) . . . . . . . . . . . . . . . . . 215

Future Coastal Hydrographic Survey Ship System ... . . . . . . . . . 216

Seagoing Platform of Acoustic Researclı (SPAR) . . . . . . . . . . . . 217

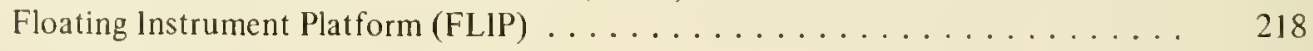

DELOS Stable Ocean Platform ....................... 219 


\section{INTRODUCTION}

The sea has always beckoned man unto its broad domain: first fishermen, then explorers, then sailors of commerce and then sea fighters to protect that commerce. As man became bolder and ventured farther and longer in ever increasing numbers of ships, his need for protection and knowledge became more demanding. Thus, among its early acts, Congress established in 1790 a sea-going Revenue Service (later the Coast Guard) to enforce our laws at sea. In 1798 it authorized a Navy to defend our coasts and our ocean commerce. The Coast Survey (later the Coast and Geodetic Survey, now the National Ocean Survey of the National Oceanic and Atmospheric Administration, NOAA) was established in 1807 to improve navigation in coastal waters of the United States. The Depot of Charts and Instruments (now the Naval Oceanographic Office) was created in 1830 to provide clarting and routing services to our merchant and naval ships. To improve the managenent of our fishery resources the U. S. Fish Commission (later the Bureau of Commercial Fisheries and the Bureau of Sport Fisheries and Wildlife, both now under NOAA) was established in 1871 . The assumption by the federal government of these early responsibilities marked the birth of "oceanographic" ships. Today our involvement with the oceans is far broader than the original concepts of national security and commerce. The realization that the oceans were no longer limited to highways of commerce awakened the Nation to their tremendous resources and potential. The need to explore and exploit the oceans gave new impetus to the establisliment of the necessary oceanographic fleet.

But new ships, designed and built for a specific mission, evolve with excruciating slowness. In the interim an unbelievable potpourri of ships and conversions had to be utilized.

This is an attempt to delineate the evolution of oceanographic ships used by the Navy and other agencies-past and present-and to offer a view toward the future. 



\section{CHAPTER I.}

THE EARLY YEARS 


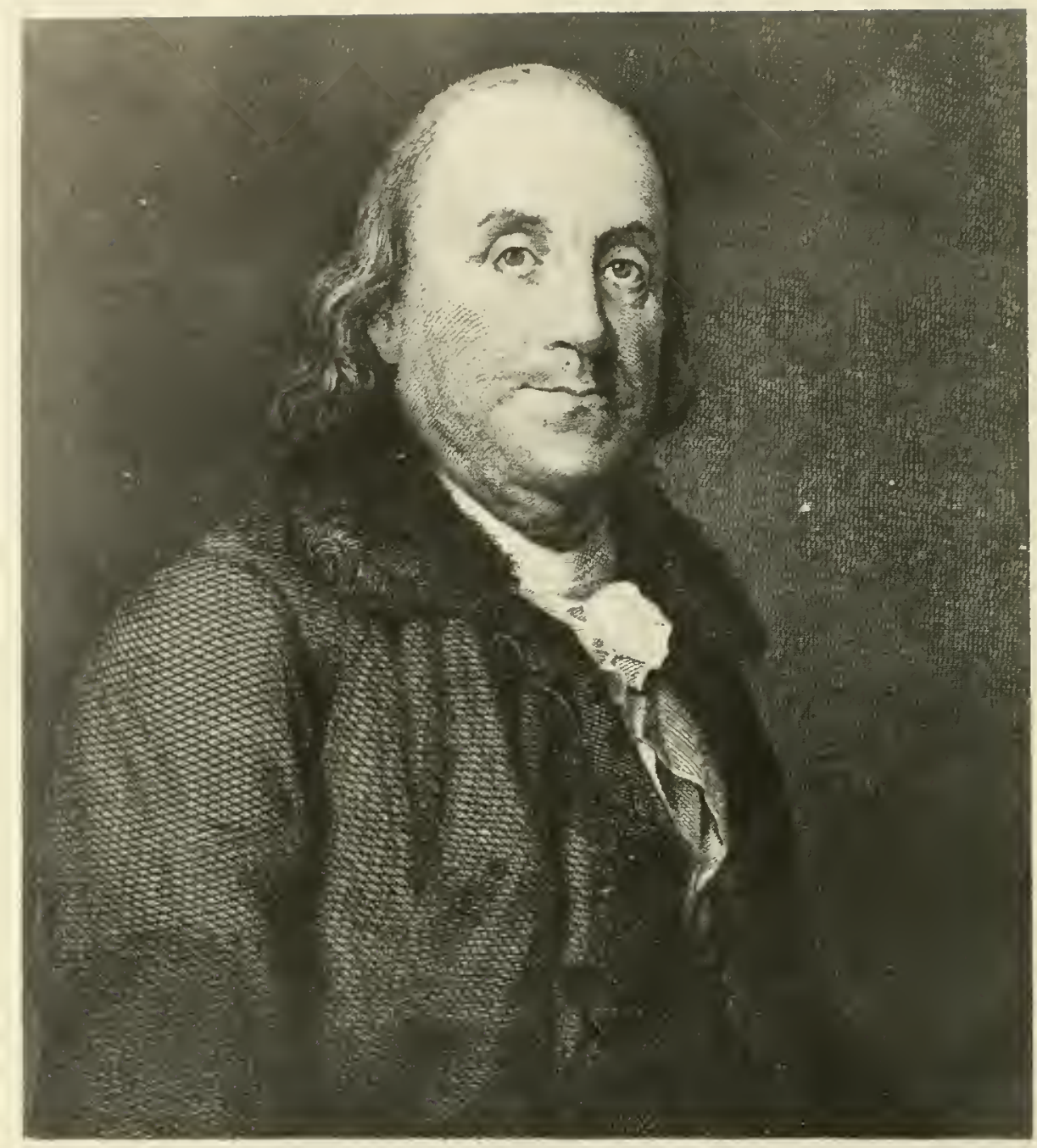

ii

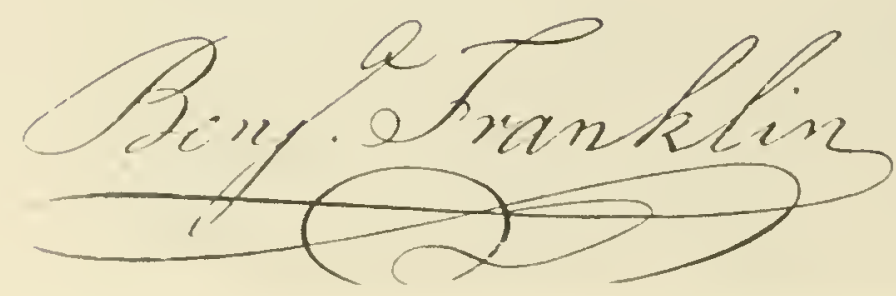

Benjamin Franklin (1706 - 1790)

American printer, author, publisher, inventor, scientist, public servant, diplomat and first United States "oceanographer". 
Among the primary concerns of any seafarer are navigation and safe passage. Two thousand years before Christ, the Egyptians on the island of Crete had a war fleet of some 400 ships, but centuries before that Crete was carrying on commerce with Egypt. The Cretan warships in the Mediterranean are the earliest on record, which makes Crete the world's first great Western sea power. As seafarers, they certainly would have been familiar with the vagaries of wind, tide, currents and ocean depth known to their age. This perhaps is sufficient justification for recognizing the Cretans as the first practicing oceanographers (although hydrographers would be a more appropriate title). Leaving the island of Crete and traveling ahead in time approximately 4,000 years to the British colonies in North America, interestingly, the credit for the earliest recorded American oceanographic work belongs to the man who has been called "the first civilized American", Benjamin Franklin.

When Franklin was Postmaster General of the Colonies, complaints were raised that the mail packets coming from England took two weeks longer to make the westward crossing than did the Nantucket whalers. Taking the problem to Timothy Folger, a cousin and a Nantucket sea captain, Franklin discovered that the whalers had learned to use the Gulf Stream currents to their advantage. Folger further advised that the whalers "... in crossing it have sometimes met and spoke with those packets who were in the middle of and stemming it. We have informed them that they were stemming a current that was against them to the value of three miles an hour and advised them to cross it, but they were too wise to be counseled by simple American fishermen." Franklin had Folger mark out the Gulf Stream current which was then engraved on an old chart of the Atlantic. In 1769 Franklin sent the chart to Falmouth, England for the captains of the packets, "who slighted it, however." The chart was subsequently published after the American Revolution in the Transactions of the American Philosophical Society (1786) but was combined in one plate with another chart illustrating a paper by John Gilpin on the "Annual Migrations of the Herring."

Following the outbreak of the American Revolution, the American merchant marine entered its "golden age" led by the mariners and ships from Salem. The boom came from privateering during the Revolution when Salem ships captured over 400 vessels. With great success these Salem ships engaged in commerce to distant ports, beyond the Cape of Good Hope to India and, particularly, the East Indies, with pepper from Sumatra a specialty. New trade contacts were also opened with ports in the Baltic and the Mediterranean Seas. Recognizing the need to collect and exchange navigational information, a group of Salem ship captains formed, in 1799, the East India Marine Society of Salem (their old granite headquarters building now houses the Peabody Museum).

Concurrent with this golden age, the fledgling Navy, mainly through the efforts of enterprising individuals, was beginning to make its first entrance into oceanography. (The word "oceanography" actually doesn't appear in English usage until 1883. Prior to that time, the term "hydrography" was commonly applied and still is in many countries.) Thomas Truxtun, who was one of the first U.S. Navy captains appointed by President George Washington in 1794, published, in that same year, his own manual of navigation. During the Revolution, Truxtun was a privateer bringing supplies from France and the West Indies to America. Following the war he engaged in the China trade. He was an early proponent of thermometrical navigation and collected data on sea surface temperatures and other oceanographic variables. His manual of navigation is considered one of the most productive works of the 18 th century. Truxtun's place in history was established by his military prowess, particularly as the first commanding of ficer of the frigate Constellation, rather than his scientific endeavors. An interesting footnote about Truxtun's involvement with the China trade concerns the prosaic sea-letter granted him by the Continental Congress in 1776. Truxtun, commanding the ship Canton which was to be the first vessel from Philadelphia to visit the Orient, received the following sea-letter prescribing the conduct of his mission: 


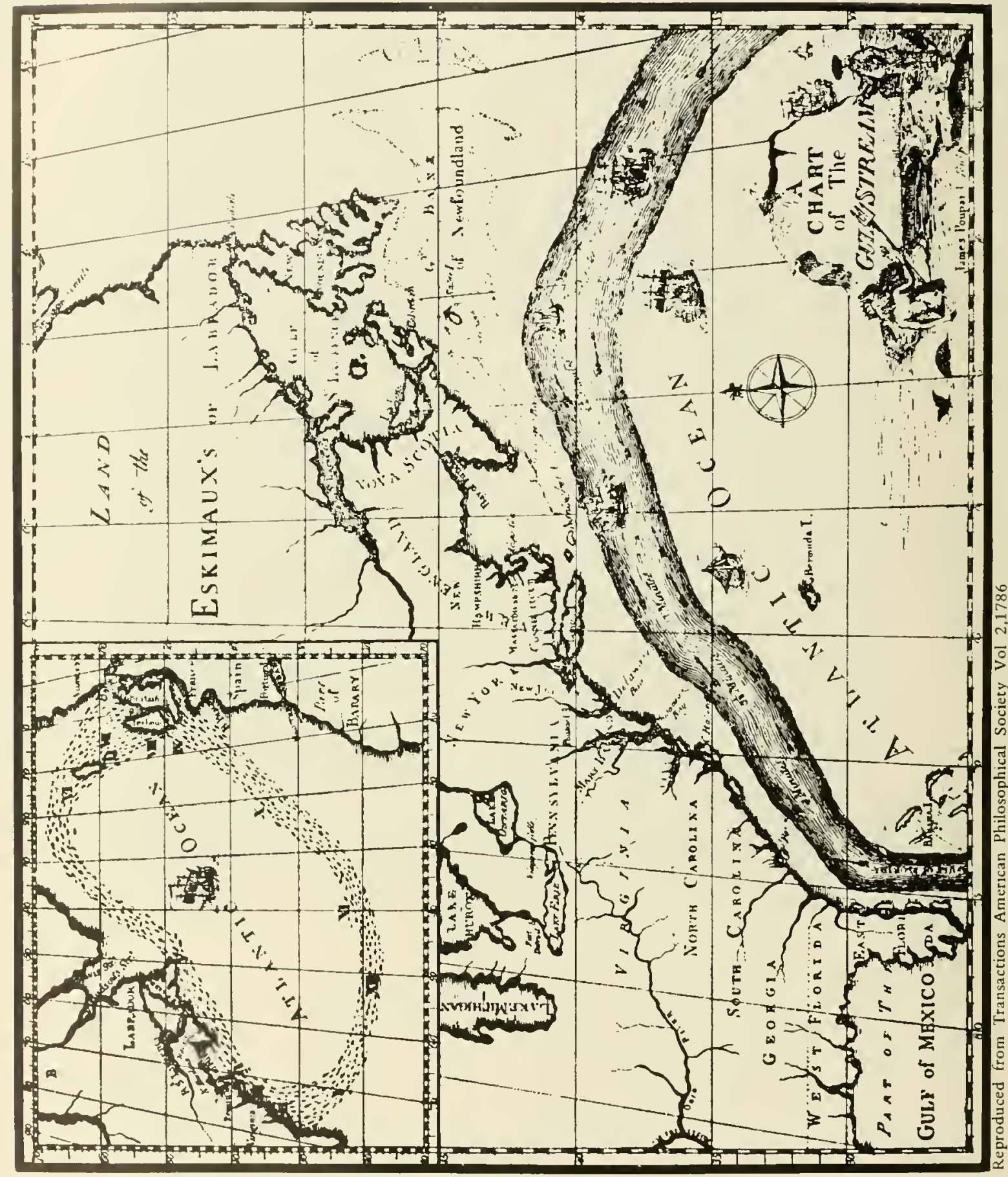

Benjarnin Franklin's Chart of the Gulf Stream. Prepared by Franklin in 1769 to aid the English captains of the mail packets in speeding their trip across the Atlantic. Subsequently published in 1786 in the Transactions of the American Philosophical Society, Franklin's chart, for reasons of economy, was combined in one plate with another chart (shown in the upper left) illustrating the annual migrations of herring. 


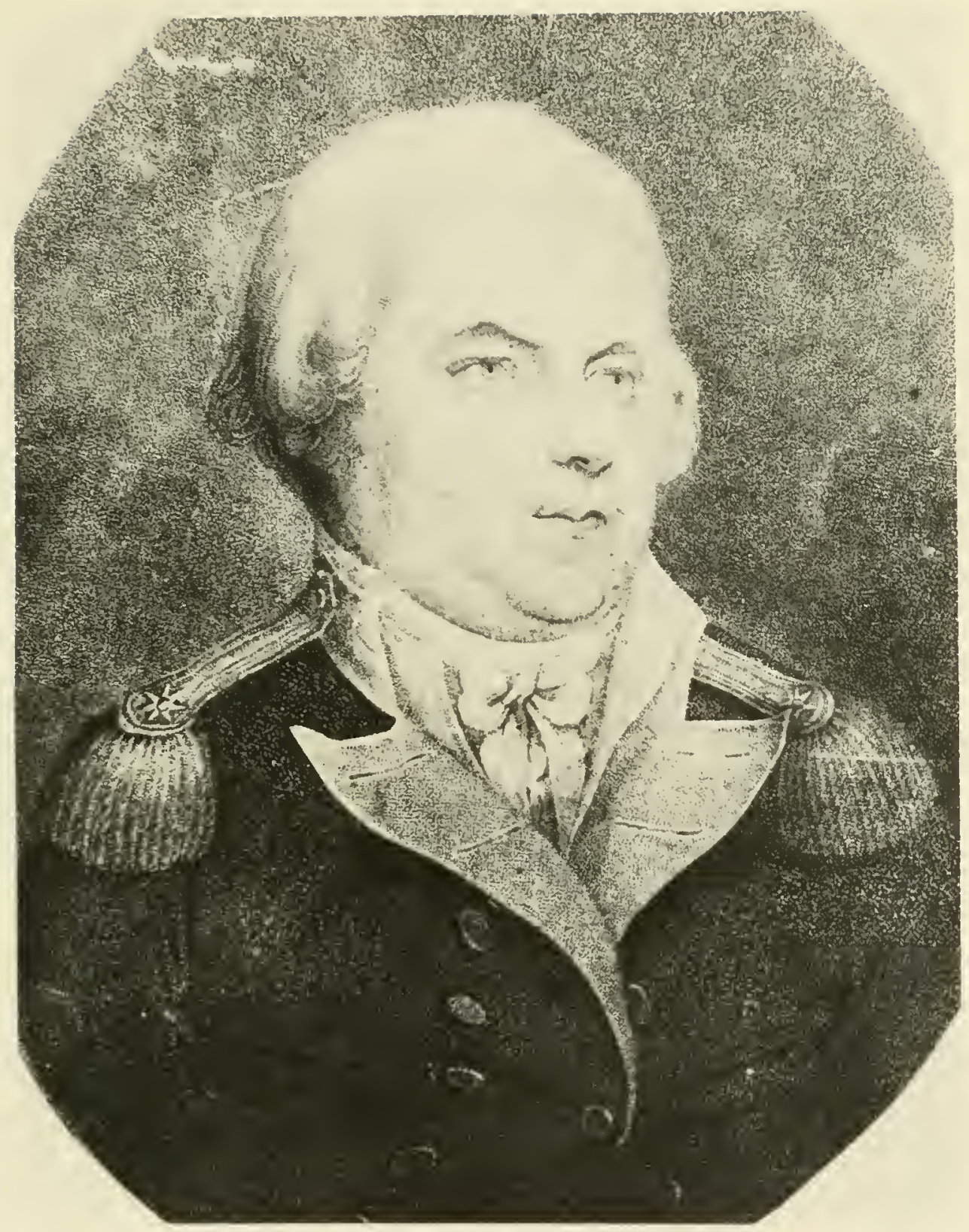

Captain Thomas Truxtun, U.S. Navy (1755 - 1822)

Commissioned a Captain in the new U.S. Navy in 1794, Truxtun supervised the construction of the frigate Constellation at Baltimore, Maryland and, as her commanding officer, became the most distinguished American naval officer of the Franco-American dispute. An early proponent of thermometrical navigation, he collected data on sea surface temperatures and other variables and published his own manual of navigation which was considered one of the most productive works of the $18 \mathrm{th}$ century. 
"Most serene, serene, most puissant, puissant, high illustrious, noble, honorable, venerable, wise, and prudent emperors, kings, republics, princes, dukes, earls, barons, lords, burgomasters, counsellors, as also judges, officers, justiciaries, and regents, of all the good cities and places whether ecclesiastical or secular, who shall see these presents, or hear them read:

'We, the United States in Congress assembled, make known that Thomas Truxtun, captain of the ship called the Canton is a citizen of the United States of America, and that the ship which he commands belongs to citizens of the said United States, and as we wish to see the said Thomas Truxtun prosper in his lawful affairs, our prayer is to all the before-mentioned, and to each of them separately, where the said Thomas Truxtun shall arrive with his vessel and cargo, that they may please to receive hin with the goodness and treat him in a becoming manner, permitting him upon the usual tolls and expenses in passing and repassing, to pass, navigate, and frequent the ports, passes, and territories, to the end to transact his business where and in what manner he shall judge proper, whereof we shall be willingly indebted.' " 


\section{CHAPTER II.}

\section{THE 1800s}



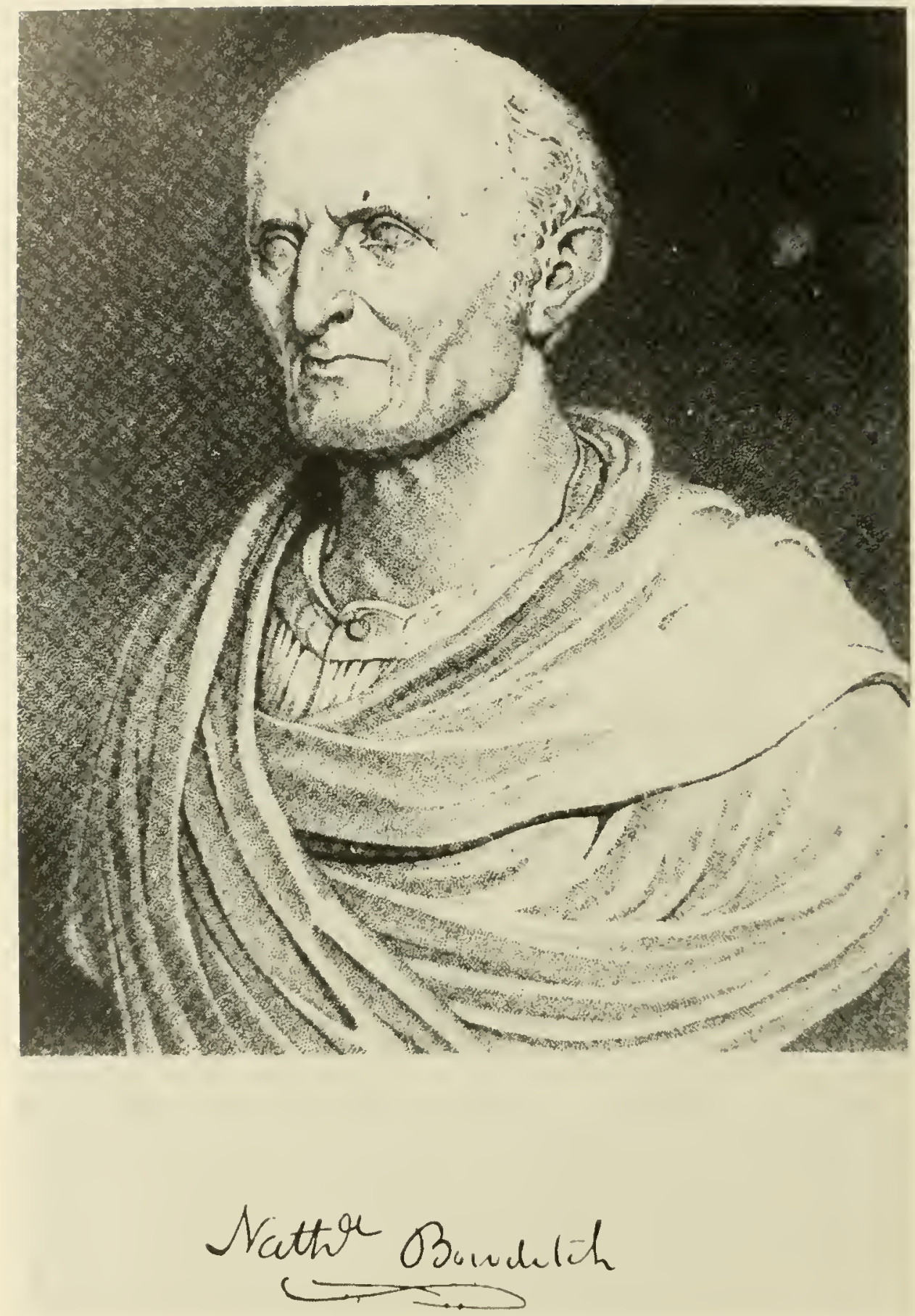

Nathaniel Bowditch $(1773 \cdot 1838)$

Astronomer and navigator, and one of Salem, Massachusetts' most distinguished men, Bowditch published the first edition of TIIE NEW AMERICAN PRACTICAL NAVIGATOR in 1802. This book, which became known as "The Seamen's Bible", has earned hin the title of the "Father of Modern Navigation." 
As American merchant ships continued to ply their trade in growing numbers, they found their way across the ocean with no exact calculations of their courses.

One of Salem, Massachusetts" most distinguished men of intellect, however, was soon to publish what has been referred to as "The Seamen's Bible." Nathaniel Bowditch, who served as clerk and captain of Salem ships, had found over 8,000 errors in the British maritime tables. In 1802. he published THE NEW AMERICAN PRACTICAL NAVIGATOR, which made it possible for ships, through the use of his book, to sail in as nearly a straight ]ine as weather would permit by the first workable system of navigation. This book was to become one of the best sellers of all time and after some 70 editions, it is still the standard work in its field. It is found on the bridge of practically every seagoing merchant and naval ship. This volume is now published under the authority of the U.S. Navy. It is therefore fitting that Nathaniel Bowditch, the "Father of Modern Navigation" be the introduction to this phase of our chronology.

The first documented survey by any agency of the federal government was conducted by the U. S. Navy in 1811. Comnodore John Rodgers used the 204 foot frigate Constitution, "Old Ironsides" (one of the first six frigates built for the Navy, at a cost of approximately $\$ 300,000$ ) to conduct a survey of the New London Harbor, and a chart was produced that same year.

If this first survey was conducted in the same spirit that permeated the Constitution during the American Revolution, the data collected for the resulting chart were indeed the efforts of a "happy" crew. This spirit is best described in a story related by Harold Peterson, chief curator of the National Park Service, in his lecture "Our Alcoholic Ancestors."

"On August 23, 1779, the USS Constitution set sail from Boston loaded with 475 officers and men, 48,600 gallons of water, 74,000 cannon shot, 11,500 pounds of black powder and 79,400 gallons of rum. Her mission: To destroy and harass English shipping.

On October 6 , she made Jamaica, took on 826 pounds of flour and 68.300 gallons of rum. Three weeks later the Constitution reached the Azores, where she provisioned with 550 pounds of beef and 64,300 gallons of Portuguese wine.

On November 18, the ship set sail for England, where her crew captured and scuttled 12 English merchant vessets and took aboard their rum.

But the Consitution had run out of shot. Nevertheless, she made her way unarmed up the Firth of Clyde for a night raid. Here her landing party captured a whiskey distillery, transferred 40,000 gallons aboard and headed for home.

On February 20, 1780, the Constitution arrived in Boston with no cannon, no shot, no food, no powder, no rum, no whiskey. Just 48,600 gallons of water."

At this point it should be noted that hydrographic surveying in the United States actually came into being when Congress in 1807 authorized the President (Jefferson) ". . . to cause a survey to be taken of coasts of the United States in which shall be designated the islands and shoals and places of anchorage..." Upon the approval of the American Philosophical Society. Jefferson appointed Ferdinand Hassler, a Swiss geologist and scientist of outstanding reputation, first Superintendent of the Survey of the Coast (under the Treasury Department) which in 1836 became the Coast Survey then, in 1878, the Coast and Geodetic Survey under the Commerce Department and now, in 1970, is the National Ocean Survey under Commerce.

Born in Switzerland in 1770, Hassler migrated to the United States with his family in 1805. He was proud and intolerant and constantly drawing official censure upon himself by his irascibility. The early history of the Survey of the Coast was, to say the least, fraught with difficulties. In its first 4 years of existence, nothing was accomplished because dissension at home interfered with the release of appropriated funds and unsettled political conditions in Europe 
prevented purchase of required instruments and equipnent from abroad. During this period Hassler first occupied himself as acting professor of mathematics in the newly created United States Military Academy at West Point (1807-1810) and then for one year as professor of natural philosophy and mathematics at Union College in Schenectady, New York. In 1811 Congress finally appropriated funds in the amount of $\$ 25,000$ for the Survey and Hassler almost immediately sailed for Europe where in London and Paris he obtained his equipment and instruments, many of which he designed himself, including his famous 24-inch theodolite. The War of 1812, however, prolonged his stay and Hassler did not return to the United States until 1815. In 1818, Congress, charging that Hassler's work was lagging, placed the Survey under the Navy and excluded Hassler and other civilian personnel from further work. The Survey of the Coast was thus abolished and would not reappear again until 1832. During this period of suspension Hassler had a brief appointment to survey the northeast boundary between the United States and Canada as specified by the Treaty of Ghent. He made an unsuccessful attempt at farming and then to meet financial obligations took a position as gager in the New York Customs House. In 1830, because of his training and background he was appointed, at the age of 60 , Superintendent of the new Office of Weights and Measures later to become the National Bureau of Standards.

The growing need for reliable navigational information was sufficient to warrant the establishment in 1830 of the Navy's Depot of Charts and Instruments (under the Bureau of Ordnance) which later evolved into both the Hydrograplic Office (now the U. S. Naval Oceanographic Office) and the Naval Observatory. The first Officer-in-Clarge of the Depot was Lieutenant Louis Goldsborough, who suggested its creation to the Board of Navy Commissioners.

The Navy however had been doing little survey work and in 1832 Congress, acting upon the recommendation of the Secretary of the Navy, reestablished the Survey of the Coast placing the work again under the Treasury Department. A small appropriation was made, and Ferdinand Hassler was reappointed to its Superintendency. Two years later, because the Treasury Department was overloaded with work, the Survey was again transferred to the Navy, but this time with Hassler still in charge and civilian employees retained. Hassler strongly objected to this cliange and after threatening to resign the Survey was again restored in 1836 to the Treasury Department with its title now changed to the Coast Survey.

The first hydrographic surveys began by Hassler's Survey were in late 1834 and 1835 using the schooner Jersey under the command of Lieutenant T. R. Gedney and the schooner Experiment under Lieutenant George Blake. Their work was concentrated along the soutl shore of Long 1sland in New York Harbor, and in Great South Bay. One of the important results of this work was the finding of a previously unknown channel leading to New York Harbor from the southeast with more than 25 feet of water at high tide. Gedney Channel is now one of the main entrances to New York Harbor. The first chart by the Coast Survey, which was from a stone engraving of Newark Harbor, wasn't produced however until 1839.

In 1837, a Navy survey was conducted by Lieutenant Charles Wilkes of Georges Shoal and Bank, a great fishing ground eastward of Cape Cod, Massachusetts, using the 88-foot brig Porpoise and the schooners Maria and Badassah. Four engraved charts resulted from this survey and were published by the Depot of Charts and lnstruments the same year.

The need for accurate hydrographic surveys was again gaining the attention of Congress. In 1838, Wilkes was placed in command of the first scientific expedition sent out by the United States, the U. S. Exploring Expedition. This expedition, authorized by Congress in 1836 with an appropriation of $\$ 300,000$, simply directed the President to "send out a surveying and exploring expedition to the Pacific Ocean and South Seas." A. bill authorizing this expedition had actually been introduced in 1826 for the purpose of surveying and cliarting those parts of the world nost frequented by our whaling vessels in the Pacific and our sealing vessels in the Antarctic regions. 
For a myriad of reasons or excuses (economy, retrenchment, politics, etc.) it required ten years and the continuing support and appeals by such organizations as the East India Marine Society of Salem and the American Philosophical Society to gain Congressional authorization for the expedition. Support even came from the distinguished Russian navigator, Admiral Krusenstern, who provided information and recommendations, along with the most improved charts of his ATLAS OF THE PACIFIC OCEAN. In preparation for this undertaking the Navy had designed and built two exploring vessels and one tender. The two exploring vessels were the brigs Consort and Pioneer, which were approximately 85 feet long and displaced 230 tons. The tender was the schooner Pilot, approximately 70 feet long. These three vessels were tested in 1837 and were found to be too slow to participate in the expedition. The Navy next purchased in 1837 the schooner Clara as a candidate for the expedition. Renamed the Active, she also was found to be too slow and was subsequently sold the following year. Suffice to say that Wilkes did obtain his fleet of ships and the general orders given to him by Secretary of the Navy, J. K. Paulding, contained the following instructions: "Although the primary objective of the Expedition is the promotion of the great interests of commerce and navigation, yet you will take all occasions to extend the bounds of science and promote the acquisition of knowledge." Particular attention was directed in the orders to the "Feejee" lslands, where Wilkes was enjoined to "teach the natives of the modes of cultivation," and to encourage them to "raise hogs in greater abundance." The real purpose of the Expedition, however, was best expressed by the words:

"... you will use your best endeavors wherever you may go, to leave

behind a favourable impression of your country and countrymen. The Expedition is not for conquest but for discovery. Its objects are all peaceful; they are to extend the empire of commerce and science; to diminish the hazards of the ocean and point out to future navigators a course by which they may avoid dangers and find safety."

The expedition, which included a philologist, conchologist, botanist, mineralogist, horticulturist, two naturalists and two draughtsmen (artists), left Hampton Roads August 1838 following a visit by President Martin Van Buren. After four years, the expedition returned to New York in June 1842, having sailed completely around the world. The ships initially comprising the exploring expedition were the 127-foot sloop-of-war Vincenmes (Wilkes' flagship); the 118-foot sloop-of-war Peacock; the 88-foot brig Porpoise, the tenders Sea-Gull and Flying-Fish (two former New York pilot boats of 96 and 86 feet, respectively); and the 109-foot storeship Relief. Of these original six ships, only the Vincennes and the Porpoise completed the entire voyage. The Sea-Gull was lost at sea without a trace in May 1839, and also that year the Relief was sent home from Callao, Peru, by way of the Hawaiian 1slands and Sydney, Australia as being too slow a sailer. The Peacock was wrecked 18 July 1841 on a bar at the mouth of the Columbia River and replaced by a merchant vessel, the 85-foot brig Thomas Perkins which was renamed the Oregon, and the Flying-Fish, having become unseaworthy, was sold in Singapore on the return trip.

The expedition which covered nearly 90,000 miles resulted in the survey of 280 islands, the determination of about 2,000 geographic positions and an atlas containing 106 new nautical charts.

Wilkes was the first to assert the existence of a southern continental land mass which, in a letter to Secretary Paulding, dated 11 March 1840, he named the "Antarctic Continent." Nineteen volumes covering the expedition were published. Of these Wilkes wrote the NARRATIVE (5 volumes, published 1844) and the volumes METEOROLOGY (published 1851) and HYDROGRAPHY (published 1861).

Recognizing his tremendous contribution to oceanography, it is ironical to note that, upon his return to the United States, he was greeted not with honor and recognition, but with animosity 
and personal jealousy. He had been condemned for promoting himself for the duration of the expedition to the temporary rank of Captain of the Navy in the absence of specific authorization and for alleged cruelty to his crewmen. (A stern disciplinarian, he often ordered severe punishment, in some cases ordering up to forty-one lashes instead of the prescribed twelve. In addition, Wilkes was also quite self-opinionated and possessed of a fiery temper, which, combined with an innate stubbornness, kept him engaged in controversies with his superiors throughout his entire naval career.) in 1842, he was court-martialed, received a public reprimand, and his name was omitted from the Navy's promotion list. Nevertheless, his achievements were widely recognized, especially abroad, and he received the Founders Gold Medal of the Royal Geographic Society of England in 1848 for his accomplishments. From 1844 to 1861 , he remained on special duty engaged with the preparation and publication of the expedition results. During the Civil War, Wilkes was commissioned Commodore in 1862, and placed in command of a squadron sent to the West Indies to protect U. S. commerce in that region. In his zealous efforts to capture Confederate raiders he offended several foreign governments and also incurred the wrath of the Secretary of the Navy. In 1864 he was again court-martialed, this time for insubordination and conduct unbecoming an officer, suspended from duty, and placed in retirement .

As 1838 had marked the beginning of the first U. S. scientific expedition, it also marked the construction of the first Coast Survey ship specifically constructed for surveying: the 76-foot schooner, Nautilus, whose survey career spanned approximately 20 years.

The 94-foot brig Washington, built in 1837 as a revenue cutter, was used by the Coast Survey during the Summers until it was permanently transferred to the Survey in 1840 . Slow and clumsy, she still managed to achieve public notice when in 1839 under the command of Lieutenant Gedney she took into custody the Cuban ship Amistad and her company of African mutineers. The Coast Survey also managed to acquire some additional public notice when "Harper's Monthly" related the following exchange which took place when Ferdinand Hassler once asked President Jackson for a raise, to $\$ 6,000$ a year and Jackson protested that it was as much as the Government paid Levi Woodbury, Secretary of the Treasury and Hassler's superior:

"Mr. Voodbury!" screamed Hassler, rising from his chair and vibrating his long finger toward his own heart. "Pl-e-e-n-ty Mr. Voodburys, pl-e-en-ty Mr. Everybodys, for Secretary of de Treasury; v-o-ne, v-o-ne Mr. Hassler for de head of de Coast Survey!" and erecting himself in a haughty attitude, he looked down upon Jackson in supreme scorn at his daring comparison.

The increase was granted.

Hassler spent the Fall of 1843 in the field making geodetic surveys in New Jersey and Delaware. In Delaware he was caught in a severe wind and hail storm that swept away the tents protecting his instruments. Attempting to save the instruments, he fell on a pointed rock, suffering an injury in his left side and undergoing several hours of exposure which left him with a severe cold. He returned to Philadelphia, extremely ill, but wrote reports until his death on November 20 , 1843 at the age of 73 .

Although his life had been stormy and subject to many trials, he lived to see the value of his work at last being recognized and his sincerity and integrity won political and public acclaim in the end.

Other tragedies visited the Coast Survey in the 1840s. In September 1846, the brig Washington under the command of Lieutenant George M. Bache, brother of the Coast Survey's second Superintendent, Alexander D. Bache, was engaged in making observations of the Gulf Stream. Caught in a violent hurricane north of Cape Hatteras, Bache and 10 members of his crew were washed overboard and lost. The crippled Washington drifted for more than a week after the storm but was finally towed to port by the U. S. frigate Constitution. In 1849, the steamer Ewing, 
under the command of Lieutenant Commander W. P. McArthur, was making detailed surveys at San Francisco to accommodate the frantic increase in ship traffic because of the gold rush. McArther had difficulty holding his crew against the lure of the gold fields, and desertions were common. On September 13, 1849, the five-man crew of the Ewing's gig threw the boat officer overboard and escaped with the boat. The officer, Midshipman William Gibson, was rescued in critical condition, and the men were caught heading for the gold fields. As the men were naval seamen and subject to Navy discipline, they were tried by court martial and convicted of "Mutiny, Desertion, and running away with a boat, the property of the United States." One was convicted also of "Attempt to Kill". He and another were hanged from the yard arm and the rest sentenced to prison for the remainder of their enlistments.

The first formal scientific investigations of our marine environment are credited to Navy Lieutenant Matthew Fontaine Maury, who in 1842 was appointed Officer-in-Charge of the Depot of Charts and Instruments, and undertook the systematic study of the ocean on a full time basis. Maury gained international fame as "The Pathfinder of the Seas" and the "Founder of the Science of Oceanography" for his research and scientific publications on the seas. In 1834, he published A THEORETICAL AND PRACTICAL TREATISE ON NAVIGATION which was later adopted as a textbook in the U.S. Navy and in 1855 published what is frequently referred to as the first textbook on the subject of oceanography, THE PHYSICAL GEOGRAPHY OF THE SEA. The practical benefits resulting from Maury's efforts drew the direct support of Congress, who authorized the Secretary of the Navy to assign three ships "for testing new routes, and perfecting the discoveries made by Maury in the course of his investigations of winds and currents of the oceans."

With the invention of telegraphy, Maury commenced deep ocean surveys of the North Atlantic in support of a commercially sponsored plan to lay a telegraph cable between Newfoundland and lreland. Using the three U.S. Navy ships assigned, the 85-foot schooner Roger B. Taney, a former revenue cutter built in 1833, the 164-foot sloop-of-war Albany (which was lost at sea without a trace in late 1854), and the 88 -foot brig Dolphin.

In 1854 Maury reported to Navy Secretary James D. Dobbin that there was, at the bottom of the sea between Newfoundland and heland, "a plateau which seems to have been placed there especially for the purpose of holding wires of a submarine telegraph, and of keeping them out of harm's way." The significant accomplishments resulting from this North Atlantic survey were the use of the new deep-sea sounding devices, developed by Midshipman John Mercer Brooke, which enabled the Dolphin to bring up "the first specimen that was ever obtained from the bottom of the sea", the publication in 1854 of the first bathymetric chart of the North Atlantic, and finally the laying of the first successful transatlantic cable in 1858. This cable laying effort was accomplished by the 329-foot steam frigate Niagara representing the United States and the British battleship Agamemnon.

While deep ocean surveys were being conducted in the North Atlantic, the Navy's attention was also being directed to the Pacific. Commodore Matthew Perry's expedition to Japan (1852 . 1854), although primarily a diplomatic mission, produced the first definitive study of the Kuroshio, the "Gulf Stream" of the Pacific, through the efforts of Lieutenant Silas Bent. The expedition consisted of the steam frigates Susquehanna (Perry's flagship) and Mississippi (built in 1841, she was one of the pioneer steam vessels of the Navy), the ship of the line Vermont, the sloops-of-war Plymouth, Saratoga, and Vandalia, the steamers Powhatan and Alleghany, the corvette Macedonia, and the storeships Supply, Southampton, and Lexington. Also assigned to the expedition was the steamer Princeton but on her way down the Chesapeake, her new steam boilers developed so much trouble she had to return to Norfolk Navy Yard. Commodore Perry was to survey the coasts of Japan and the adjacent islands provided it could be done without interfering 
with the expedition's primary mission. In July 1853 Perry, in his first confrontation with the Japanese, entered Yedo (Tokyo) Bay with a squadron consisting of the Susquehanna, Mississippi, Saratoga and Plymouth. The following exerpt from Perry's narrative best describes the subtleties of executing a survey of foreign shores:

"I had directed that a surveying boat, well manned and armed, from each ship of the squadron, should commence at daylight this morning, the 9 th, the survey of the harbor and bay of Urage, and thinking it quite possible, they might meet with some resistance, I instructed Lieutenant Silas Bent, in command of the surveying party, not to go beyond the range of our guns, and caused a lookout to be kept upon them, that assistance might be sent should they be attacked; but though they were followed by numbers of Japanese boats, they did not, on seeing our men well armed, venture to molest them.

The governor inquired what these boats were doing, and, on being told they were surveying the harbor, he said it was against the Japanese laws to allow of such examinations; and he was told that, though the Japanese law forbade such surveys, the American laws command them, and that we were as much bound to obey the American as he was the Japanese laws. Here was a second and most important point gained."

The Northern Pacific and Arctic Surveying Expedition (1853 - 1856) commenced an extensive effort of nautical surveys and scientific investigations involving astronomy, magnetism, meteorology and natural history. This expedition under the command of Commodore Cadwalader Ringgold, and later Lieutenant John Rodgers, was composed of the ships Vincennes and Porpoise, which had earlier participated in the U. S. Exploring Expedition, the 166-foot bark-rigged screw steamer John Hancock, the 85-foot schooner Fenimore Cooper (originally the New York pilot boat Skiddy) and the storeship John P. Kermedy (the former 350-ton sailing ship Sea Nymph). The results of this expedition combined with earlier ventures resulted in the publication of detailed charts of the entire coast of Japan, the coasts and islands of the Bering Strait, and the Arctic Ocean as far north as Wrangel Island. Accompanying this expedition were five zoologists (including Spencer Baird, then Assistant Secretary of the Smithsonian Institution) and three botanists. Misfortune, however, plagued this expedition. In mid-year 1854, while the ships were in Hong Kong, undergoing repairs, Ringgold was requested to lend assistance in that area to protect American merchant interests from the threatening Chinese Revolutionists. In the midst of overseeing these operations, Ringgold was stricken with an intermittent fever which at times affected his mental bearings. During one of these attacks he became incensed over an incident involving Lieutenant John Rodgers. Believing Rodgers was negligent in failing to take more aggressive action against a sniper on shore who fired upon his boat, Ringgold preferred charges against him and several others who in turn preferred charges against each other. Into their caldron of confusion came Conmodore Perry. He promptly relieved Ringgold from command because of medical reasons, dismissed all charges preferred against the officers, and placed Rodgers in command of the expedition. Shortly thereafter fate again became the hunter when the Porpoise disappeared at sea without a trace. Following the completion of the expedition, a special office was established in Washington, D. C., in 1857, with Rodgers as superintendent to publish the results of the expedition. Although several charts were published, the Civil War precluded further efforts and a complete publication of the expeditions work was never accomplished. The final irony occurred when the Chicago fire in 1871 destroyed the expedition's stored invertebrate collection.

Another expedition, which also began in 1853, was the Second Grinnell Expedition to search the Arctic for the explorer Sir John Franklin, missing since 1845. This second expedition was 
under the command of Passed Assistant Surgeon Elisha Kent Kane, U.S. Navy. In 1850, using the 90-ton brig Rescue and the 140-ton brig Advance, loaned to the Navy by Henry Grinnell, the first govermment expedition was organized to search for Franklin. Kane, who was at tached to the Coast Survey, sought and obtained the post of senior medical officer with the expedition. This first expedition was unsuccessful and upon its return in I851, Kane immediately launched plans for a new attempt. With the enthusiastic personal support of the Secretary of the Navy, Joseph P. Kennedy, the Second Grinnell Expedition sailed from New York in May 1853 with Kane in command. Henry Grinnell again donated the brig Adrance and private subscription was used to finance the project. The expedition wintered in Rensselaer Bay and here their troubles began. Equipment was found to be deficient, sled dogs began to die, and scurvy appeared. Kane, himself scurvy-ridden and at times near death, resolutely pushed on. No trace of Franklin's party was found and in May 1855 the ice-bound Advance was abandoned. Kane escaped inevitable death in the Arctic by an 83-day march of indomitable courage to Upernavik. The party, carrying the invalids, lost only one man in a retreat which stands high in the annals of Arctic exploration. A government relief expedition composed of the steamer Arctic and the bark Release located Kane and his party in South Greenland and landed them in New York in October 1855. Although the rescue expedition was unsuccessful, its scientific achievements were laudable. Kane's party chartered the coasts of Smith Sound (now called Kane Basin) and penetrated farther north than any other explorer had done up to that time. At Cape Constitution they discovered the ice-free Kennedy Channel, later to be the route of other explorers as they drove toward the North Pole. Meteorological, magnetic, astronomical, tidal observations, botanical, glacial and geological surveys, and studies of animal and Eskimo life established sound foundations for the scientific study of the Arctic.

Following the rescue of Kane and his party, the Arctic (a screw steamer of 235 tons built at Keyport, New Jersey in 1853 as the Thomas C. Haight was purchased by the Navy in 1855 especially for the rescue expedition and renamed Arctic) conducted sounding surveys during I856 and 1857 for cable routes between St. Johns, Newfoundland and Queenstown, Ireland. In 1859, she was transferred to the Lighthouse Service for use as a light ship.

At this point, we would be remiss if we moved on without giving due note to another Navy expedition, somewhat forgotten, but nevertheless equally as ambitious as those already mentioned. In the year 1847 a bored young Navy officer, Lieutenant W. F. Lynch, notes in his journal:

"On the 8th of May, 1847, the town and castle of Vera Cruz having some time before surrendered, and there being nothing left for the Navy to perform, I preferred an application to the Hon. Joln. Y. Mason, the head of the department, for permission to circumnavigate and thoroughly explore the Lake Asplattities or Dead Sea.

On the 2nd of October, I received an order to take command of the U.S. storeship Supply, formerly called the Crusader."

The following month the I4I-foot storeship Supply sailed from New York, and, after stopping at various points to leave stores for the Mediterranean squadron, arrived at Acre in March 1848. On board the Supply' were two boats and their crews best described in Lynch's words:

"I had, by special authority, two metallic boats, a copper and galvanized iron one, constructed, and shipped to sea for their crews. I was very particular in selecting young, muscular, native-born Americans, of sober habits, from each of whom I extracted a pledge to abstain from all intoxicating drinks."

It had been Lynch's intention to use horses to transport the boats overland from the Mediterranean to the Sea of Galilee. The Arab steeds, however, were so undersized that Lynch resorted to the use of camels, which much to his surprise, proved eminently successful. After a two 
week overland trek, Lynch and his party finally reached their jumping-off point and commenced a 200-mile trip down the winding course of the Jordan River to the Dead Sea. Three weeks were spent sailing the Dead Sea, charting, sounding and collecting scientific data. A surveying party was also organized to run a level to the Mediterranean which finally established the fact that the Dead Sea was 1,300 feet below sea level. The boats were again taken apart, packed on camels, and the party marched to Jerusalem, leveling as they went; and then down to Jaffa. Lynch then started off to map the Upper Jordan, by going overland to Nazareth, to the source of the Jordan. From this point, via Damascus and Baalbek, his party traveled to Beirut, arriving there in June 1848.

The great adventure over, all hands exhausted and sick, Lynch charted a small French brig for passage to Malta. Upon arriving, they boarded their ship Supply and headed for home.

Although Lynch's expedition has faded with time, there is a peculiar postscript to his efforts. Some seven years later the successful use of camels by Lynch caught someone's interest and in the proceedings of the Thirty-third Congress, appears this paragraph:

"And be it further enacted, that the sum of thirty thousand dollars be, and

the same is hereby, appropriated, to be expended under the direction of the War Department in the purchase of camels and the importation of dromedaries, to be employed for military purposes. - Approved March 3,1855."

Secretary of the Navy Dobbins was thus requested by Secretary of War Jefferson Davis to arrange for a camel "sealift"! Consequently, Lieutenant David D. Porter (destined to become one of the first two admirals of the U. S. Navy) was ordered to take command of Lynch's old ship Supply, sail to the Middle East, procure the camels for the U. S. Army, and disembark them on the Texas coast.

A camel post was established at Camp Verde, Texas, and camel caravans were quite common across the plains and deserts of Texas. The Civil War, however, saw the camels turned loose to become victims of the desolate regions of the Southwest.

Another juxtapositional footnote to cceanography's past concerns the American artist, James Abbot McNeill Whistler. In 1854 he obtained a job as a draftsman with the Coast Survey following his expulsion from West Point after failing chemistry in his third year. He was an indifferent draftsman of charts and was not to be bound by office hours. There is a story that he brought an extra hat to his office; when a superior came looking for him, one hat was on its peg. Whistler, it is said, was wearing the other hat in a nearby tavern. He did however take an interest in copperplate etching and mastered the technique of engraving. His preferences, though, were caricature and landscape sketching rather than charting. The charts he did execute were generally embellished with landscapes and fanciful figures. Dismissed from the Survey for prankishness after slightly more than 3 months, Whistler in 1855 sailed for Europe and fame, never again to return to the United States.

With the outbreak of the Civil War, oceanography, with the exception of surveys and charts needed to support the war effort, came to a standstill. Its principal advocate, Matthew Maury, resigned from his position as Superintendent of the Naval Observatory and Hydrographic Office and put his considerable talents at the disposal of the Confederate States Navy as Chief of the Naval Bureau of Seacoast, River and Harbor Defenses of the South. Because his resignation had been refused by Lincoln, he was classed on the official Union records as a deserter. He was accused of treachery to the Union, namely, of removing buoys from the Chesapeake Bay, and a price was set on his head by the city of Boston. Maury wrote from Richmond, in justification of his position: "I have lost none of my interest in these enclianting fields of plysical research which 1 lave revelled in for near twenty years. 1 am here to war, not against science, but against the oppressor and for my fatherland. As for the 'buoys' I have touched them not." Following the war, Maury accepted, in 1868, the professorship of meteorology at the Virginia Military Institute after 
his involvement in an unsuccessful scheme for the colonization of Mexico by Virginia expatriates.

In 1863 the National Academy of Sciences was established, primarily through the efforts of Jean Louis Randolphe Agassiz of Harvard University, with the stated mission "to investigate, examine, experiment and report upon any subject of science or art ... whenever called upon by any Department of the Government." One of the first acts of the new Academy was to examine the desirability of continuing Maury's charts and sailing directions. The results of this examination, which was requested by Rear Adniral C. H. Davis, Chief of the Bureau of Navigation, and a veteran of service with the Coast Survey in the 1850 s, determined that they "... embrace much which is unsound in philosophy and little that is practically useful." Fortunately, these sentiments were not shared by the seafaring community.

In 1866 Congress established the Hydrographic Office as a separate institution and divorced it from the Naval Observatory. The Act consummating this separation stated in part:

"There shall be a Hydrographic Office attached to the Bureau of Navigation in the Navy Department, for the improvement of the means for navigating safely the vessels of the Navy and of the mercantile marine, by providing under the authority of the Secretary of the Navy accurate and cheap nautical charts, sailing directions, navigators, and manuals of instructions for the use of all vessels of the United States, and for the benefit and use of navigators generally."

Oceanographic interest was revived again shortly after the Civil War, motivated primarily by the need for survey data required for submarine telegraph cable routes in the North Pacific and for interoceanic canal routes across Central America. Typical of the Navy ships used for these surveys were the 250-foot gunboat Alaska, the 250-foot sloop Benicia, the 137-foot gunboat Palos, the 130-foot gunboat Kansas, the 237-foot sloop Lackawanna, the 265-foot sidewheel gunboat Monocacy, the 201-foot sloop Wachusett, the 237-foot sloop Shenandoah, the 186-foot sloop Narrangansett and the 198-foot sloop Tuscarora.

The Coast Survey, after the War, resumed its exploration of the Gulf Stream using their 150-foot steamer Bibb, which was the first steam propelled survey vessel, the 148-foot steamer Blake and the 76-foot schooner Drift. The Revenue Cutter Lincoln was meanwhile dispatched to work with the Survey on the first official U.S. exploration of Alaskan waters after the Territory was acquired from Imperial Russia.

In 1871, the famous zoologist and naturalist, Spencer Fullerton Baird. Assistant Secretary of the Smithsonian Institution, and newly appointed by President Ulysses Grant, first U.S. Commissioner of Fisheries arrived in Woods Hole, Massachusetts. His arrival initiated a long series of events which changed a small New England fishing settlement into an internationally famous center of research in marine sciences and oceanic fisheries.

The creation of the U.S. Fish Commission in 1871 was prompted by the alarming decrease in catches of fish which had continued for more than 15 years. This decline was particularly noticeable in the waters of Vineyard Sound. Being centrally located in relation to the principal fishing grounds of New England and having good dock facilities and water depth, Woods Hole was selected by Baird as the first base of sea coast operations for the Fish Commission. Interestingly, Woods Hole was something less than a significant fishing center. In the 1880 census, the fishing activity at Woods Hole is described in the following words:

"Of the male inhabitants only seven are regularly engaged in fishing, the remainder being enployed in the guano factory, in farming and other minor pursuits... There is one ship carpenter in Woods Hole, but he finds employment in his legitimate business only at long intervals. Of sailmakers, riggers, caulkers, and other artisans there are none. Four men are employed by Mr. Spindel, during the height of the fishing season, in icing and boxing fish. The 
boat fishery is carried on by seven men from April until September, inclusive. Only three species of fish are usually taken, namely, scup, tautog, and sea bass. The total catch of each fisherman is about 15 barrels, or about 2.400 pounds. In addition about 6,720 lobsters are annually taken.".

Various vessels were placed at Baird's disposal to assist him in his research efforts.

A small steam launch was provided by the Boston Navy Yard; the New Bedford Custom House provided a small yacht, and the U. S. Revenue Service made available two of their cutters. The assignment of the 145-foot Coast Survey steamer Bache to the Fish Commission provided the capability of extending operations further offshore. The Navy, in 1873, placed the 100-foot steam tug Bluclight under the jurisdiction of the Commission. This tug was sufficiently large to provide an opportunity of trying, for the first time, the steam windlass for hoisting the dredges and trawls.

Meanwhile from 1873 to 1875 , the Narrangansett, under the command of Commodore George Dewey, using a Congressional appropriation of $\$ 50,000$ for the survey of the Pacific Ocean, was employed in surveying a number of islands lying on or near the trade routes between San Francisco and Australia and along the coasts of the peninsula of lower California and the Gulf of California. The Tuscarora, a single screw sloop of wood construction under the command of Commodore George Belknap, was the first ship equipped with a Thomson sounding machine. This machine ("winch" would be more descriptive) contained 5,000 fathoms of piano wire used for taking deep sea soundings and also for obtaining bottom specimens. During its two year mission (1873 - 1874) to survey a cable route from the United States to Japan, the Tuscarora using the Thomson device established two records, a sounding of 4,655 fathoms or five and one-quarter statute miles and a bottom specimen from 4,356 fathoms, which was at that time the deepest ever obtained. A broken wire precluded recovery of a bottom sample from the 4,655 fathom cast.

The sounding machine used by the Tuscarora was the invention of Sir William Thomson (later Lord Kelvin), professor of natural philosophy at Glasgow University, in 1872. He had tried to interest his own government in its use to replace the age-old rope soundings and, in fact, is was originally intended to so equip the British ship H.M.S. Challenger which was then being outfitted for her famous research expedition. The new device, however, was not installed for as Thomson stated "innovation is very distasteful to sailors". But the U.S. Navy was interested even though the sounding machine had only been tested once by its inventor and the 2,700 fathoms test sounding-obtained from a schooner in the Bay of Biscay-resulted in a crushed winch drum. The Thomson sounding machine was used with much success onboard the Tuscarora and 483 casts were actually accomplished. Much credit belongs to Commodore Belknap and his crew for their ingenuity in correcting many design faults. The accomplishment of the Tuscarora in perfecting the Thomson machine saw the end of rope soundings and the Navy's adoption of wire for deep sea sounding.

The 221-foot sidewheel steamer Gettysburg from 1877 to 1879 was assigned to collect hydrographic information concerning the Mediterranean, and in 1879 the 164 -foot sloop Jamestown made a survey of the harbor of Sitka, Alaska.

In 1877, the Coast Survey, inspired by the success of Britian's Challenger Expedition, invited Alexander Agassiz, of the Harvard Museum of Comparative Zoology, to take charge of a similar expedition using their steamer Blake. Agassiz, a Swiss-American scientist and mining engineer, and son of the famed Harvard naturalist, Jean Louis Randolphe Agassiz, was a specialist in marine ichthyology. Between 1877 and 1880 Agassiz, who was usually violently seasick, conducted three dredging expeditions examining the physical and biological conditions of the Gulf Stream and the waters around Cuba, Key West, Yucatan and the Tortugas. Eight years later a full account of these dredging expeditions was published by Agassiz. 
The Fish Commission Steamer Fish Hawk, designed by Charles W. Copeland, naval architect of the Lighthouse Service Board, was completed in 1879 by Pusey and Jones Company of Wilmington, Delaware. The 157-foot, 484-ton, coal-burning steamer was the first vessel specifically constructed for the Fish Commission and served as a floating hatchery for the production of such fish as shad, herring, and striped bass. Her hatching equipment consisted of 36-inch cone-shaped containers each capable of holding over seven million shad eggs. Built primarily as a "hatchery" ship the Fish Hawk was not suitable for offshore work but was intensively used in dredging and trawling in the coastal water of New England. Her long (47 years) career was briefly interrupted during World War I, when, for one year, the Navy assumed control and she was assigned to duty in New London, Connecticut to assist in the development of sonic submarine detection devices.

In 1879, Lieutenant Commander George Washington DeLong embarked upon a disastrous Arctic expedition aboard the 142-foot steamer Jeannette. Attempting to sail their ship through the Bering Straits, reach Wrangel "Land" and then sled "overland" to the Pole, the Jeamette was caught in the polar ice pack in September 1879. For almost two years, she drifted along the Siberian coast until finally crushed in June 1881. DeLong, and part of his crew, on their long trek to the Siberian coast succeeded in reaching the mouth of the Lena River only to die of starvation in November 1881. DeLong's journal, in which lıe made regular entries until his death, solved the problem of Wrangel Land by determining it to be an island (Wrangel Island, U.S.S.R.). Some three years after the Jeamette's loss, several articles of the ship's crew were found on an ice floe on the southwest coast of Greenland. This discovery gave new support to the theory of a continuous ocean current passing along the then unknown polar regions.

The Navy, lacking actual surveying ships, encouraged ships-of-the-line to make special surveys and explorations at every opportunity. Records for the year 1881 indicate that the vessels from which hydrographic information was received at the old Hydrographic Office, comprised nearly all the active Navy ships. Of particular note was the 137-foot screw gunboat Palos, attached to the Asiatic Squadron; in 1881 she was assigned to Lieutenant Commander F. M. Green who was in charge of the Hydrographic Office's Department of Longitudes. By the close of 1881 Green and his party had established the geographical positions of a number of prominent places on the east coast of Asia and in the East lndia Islands. These same records of 1881 contain the following anguished statement:

"In spite of the repeated and urgent appeals of the Hydrographer, the Chief of the Bureau of Navigation, and the Secretary of the Navy, for reasonable appropriations for carrying out the work of the Office, the policy of Congress seemed to be to place the American naval and merchant marine under the humiliating necessity of depending upon the hydrographic offices of foreign powers for the means of safely navigating the oceans. A comparison of the issues of the British and the French hydrographic offices with those of our own for this year shows that, while the British published two thousand seven hundred and fifty-five and the Freuch three thousand one hundred and fifty-seven engraved charts, the United States sent out but two hundred and five."

In 1882 two significant efforts occurred-the first U.S. magnetic chart of the world was published by the Navy Hydrographic Office, and the first new U.S. oceanographic research ship was built. The 234-foot, 1,074 ton, iron-hull, twin-screw, U.S. Fish Commission Steamer Albatross, designed by Charles W. Copeland and built by Pusey and Jones Company, was the first ship to be built especially for marine research by any government. The Navy Department contracted for her construction with a Congressional appropriation of $\$ 148,000$, and the crew was composed of Naval personnel. Her construction was supervised by Commander Zera L. Tanner who then commanded her for over 12 years. The Albatross was the first government ship fitted 
throughout with electric lights, and Edison electric lamps were used at night for attracting and observing marine life. Her long service career (1882 to 1921) included surveying the Newfoundland Banks and the Caribbean and Bering Seas, visiting the scattered archipelagos of the Pacific and serving in two wars. An example of the thoroughness with which the Albatross's operations were conducted is illustrated by the orders issued Commander Tanner on April 10, 1883:

"Sir: As soon as you can be ready for the service (of which you will give me a week's notice), you will go to sea for the purpose of investigating the conditions which govern the movements of the mackeral, menhaden, bluefish, and other migratory species along the coast of the United States in the spring, commencing your investigations off Hatteras, or in the region where these fish usually make their first appearance, and following up the schools in their movements.

The special work to be performed will be to determine the rate of progress of the fish along the coast, their comparative abundance and condition, the places where they first show themselves, the physical condition of their surroundings as to temperature and currents of the water, its chemical and biological peculiarities, etc.

You will endeavor to ascertain whether the appearance of the fish at or near the surface depends upon the condition of temperature, wind or sky, and atso, by the use of the apparatus at your command, what character of food in the water seems to determine their movements. You will cause examination to be made of the stomachs of such of these fish as you can capture and carefully preserve a portion at least of the contents of the stomach for immediate or future examination.

Should you deem it expedient you will cruise off the coast a sufficient distance to determine the outward line of the motion of the fish, and you will communicate to such fishing vessels as you may meet any information that may enable them the more successfully to prosecute their labors. The time of this work is left to your discretion. You will whenever you touch at any port of the United States send a telegram to me and await instructions as to further operations, if there be nothing to detain you.

You will give to the naturalist of the expedition all possible facilities for collecting and preserving such specimens as you may meet during the cruise.

Very respectfully,

Spencer F. Baird, Commissioner

P.S. - The operations of dredging and trawling should be carried on as frequently as opportunity offers, and if no suitable bait can be had, the trawling line should be used for the purpose of determining the currents of desirable fishing grounds."

While ostensibly intended for lisheries research, her major contribution was in the field of marine biology and in her 40-year career the Albatross probably amassed one of the greatest collections of marine organisms made by a single ship.

Another ship which distinguished itself was the Enterprise, a 197-foot, wooden-hull, steam corvette with auxiliary sail power. From 1883 to 1886, under the command of Commander Albert S. Barker, she sounded her way around the world taking depth soundings by wire at intervals of one hundred miles and gathered an important collection of ocean bottom sediment samples.

From 1884 to 1894, attention was also focused upon the Caribbean and North Atlantic. Hydrographic surveys and a wide range of scientific investigations were conducted by such ships as 
the 200-foot, full-rigged, iron vessel with auxiliary steam power Ranger; the 244-foot, twin screw, gunboat Concord; and the 160-foot Coast and Geodetic Survey Steamer Hassler. In 1889 the Michigan commenced an intermittent survey, which would continue for twelve years, of the Great Lakes. The Michigan has the distinction of being the first iron hulled warship of the U.S. Navy. A side-wheel auxiliary steamer built in 1844, she was I63-feet long with a displacement of 685 tons. Her long career, spent entirely on the Great Lakes, was uneventful. In July 1905, she was renamed the Wolverine and was retired from active service in August 1923 after an accident to her machinery plant. In 1950 a monument to the pioneer "Iron Steamer" was erected at Erie, Pennsylvania which incorporates her actual bow.

The west coast of Mexico was surveyed by the Ranger during 1889 to 1890 . The trials and tribulations of conducting these early surveys are best described by the following extracts from a report by Lieutenant $\mathrm{O}$. W. Lowry of the Ranger in establishing a shore triangulation station at Asuncion Bay, Lower California:

"Sir: In compliance with your request $l$ herewith submit a detailed report of all the incidents which occurred during my recent trip to 'Peak' triangulation point.

I left the ship at 5:45 a.m., December 3 , with my party of five men ...

Eight canteens, each holding one gallon of water, had been filled the evening before starting, and, in addition to the water and provisions, each of the party took his blanket. Two rubber blankets, the theodolite, tripod, barometer and angle hooks made a weight which, when evenly divided, gave each of the party about 23 pounds to carry...

From the landing to the peak, in a straight line, is $162 / 3$ miles, but owing to the conformation of the country the route travelled was probably increased to 20 or 21 miles, with an ascent of 3,100 feet ...

... we were feeling the effects of thirst very severely, when we came to a halt near several bunches of cactus called Mescal. One of my men and myself had eaten of this on previous tramps, so we cut them down and sucked the juice from the butt of the leaves, finding the flavor not at all unpleasant; in fact it has scarcely any taste, and relieved our thirst very materially ...

By this time we were all complaining of sore lips, and I found it due to the poison from the cactus we had eaten. Each one's lips had large watery blisters, and our tongues a smarting sensation...

We reached the ship safely after an absence of $1051 / 2$ hours...

In concluding this report, 1 wish to call your attention to the provisions furnished the men who form the tramping parties, and see if some means can not be devised to furnish them with a variety of more nourishing food. In a tramping party, especially on main triangulation duty, I am absent at times for several days, with no means of preparing any food. The food carried must be already cooked and canned and put up in small tins.

The messes on board ship carry nothing in tins but oysters, clams, sardines and corned beef. The two first named have not sufficient nutriments to compensate for their weight, and the corned beef they have is in either 2 of 4 pound tins. When these are opened on a tramp, the whole amount can not be eaten at one meal, and if carried open in a haversack the heat of the sun and the frequent capsizing of the haversack causes the grease to run over everything.

It should be in tins of 1-pound size. Sardines are good in that they are nourishing, not salty and the oil they contain makes hard-tack much easier to masticate. Hard-tack is the only kind of bread that should be carried. It would 
be much better for the men, however, if a reasonable amount of lunch tongues, canned chicken, and beef extract could he furnished them, to give more variety to their diet."

Perplexing also were the efforts involved in obtaining bottom soundings by hand casts. The following samples from the sounding instructions issued by the ship Ranger are illustrative:

"The weights of hand leads must be proportioned to the work ... the heaviest lead that the leadsman can swing, without too great fatigue, is to be preferred.

In singing out the sounding the usual 'song' should be discarded, especially in rapid sounding. The form of report that the leadsman should make of his sounding is:

'Two lathoms' ( 12 feet)

'Three - one' ( 19 feet)

'One - one and a half (7 1/2 leet)

'Five feet' ( 5 feet)

'One fathom' (6 feet)

'One fathom and lialf al foot' $(61 / 2$ feet $)$

'One - one' (7 feet), and so forth.

All lad lines in use should be constantly soaked .... All lead lines, new or old, should be measured at least once a day when in use... Spare leads should be kept in the sounding boat at all times. Do nof increase the weight of lead on a line unnecessarily... A change from a 7 to a 10 pound lead will frequently stretch a small line unduly, with a consequent error in the soundings. Besides, a heavy lead on a small line will cut the leadsman's hands.

The recorder of each boat should be supplied with a small elock with a large second hand, a whistle (preferably of bone or ivory metal is apt to make the lips sore) a number of pencils (rather hard-records made in soft pencil smear readily), rubber, penknife, and working sounding book and one spare one, and an angle book... It is not possible to get reliable soundings with a hand lead in over 30 fathoms under average conditions. At each ten (fifteen or twenty) seconds the recorder will indicate to the leadsman to sound by means of his whistle."

In 189] - 1892, the gunboat Thetis, in company with the Fish Commission Steamer Alhatross, conducted surveys of proposed cable routes between Californial and Hawaii.

Commander Charles D. Sigsbee was appointed Hydrographer of the Navy in 1893 and served in that position until 1897. In 1896 he was the first to introduce the use of electrical equipment for processing marine meteorological data. Sigsbee was also the inventor of many other hydrographic and oceanographic instruments and technicues. He significantly improved Thomson's wire sounding machine and developed a wire cleaning attachment that eliminated the necessity of frequent washing of sounding wire in lime water. He developed a multiple container that took simultaneous water samples and temperatures, automatically registering the results. He also devised a clam-bucket type bottom sampler which made more certain the recovery of bottom specimens. Commander Sigsbee's next tour of duty was as commanding officer of the battleship Maine which blew up in Havana Harbor and precipitated the Spanish-American War.

Throughout most of the 19th century, the Navy, the Coast and Geodetic Survey (whose name was changed from Coast Survey in 1878) and the Smithsonian Institution (founded in $18+6$ and the only government agency at that time with a charter permitting it to conduct basic research) encouraged civilian scientists to accompany government sponsored expeditions, since lew scientists were then available in government to provide this support. 
During the late 1800s, ships of other countries were embarking on extended oceanographic cruises. In December 1872, the British research ship 11.M.S. Challenger, converted from a 2,300-ton spar decked corvette with auxiliary steam propulsion, set sail from Portsmouth, England on a scientific expedition which would take over three years, cover almost 69,000 miles and visit every ocean. The Germans sent out the S.M.S. Gazelle from 1874 to 1876 and shortly thereafter came research vessels from Russia, Sweden, Denmark and Norway.

The discovery of gold in soutlieastern Alaska in 1882 necessitated a rapid systematic survey of Alaska. The Coast and Geodetic Survey dispatched their ships Hassler, Patterson and McArthur and work progressed in southeastern Alaska, out along the Alaska peninsula in the Aleutians, and along the coast to Point Barrow. The Klondike gold rush in 1898 gave even greater impetus to these Alaskan surveys and the Survey's new 168-foot ship Pathfinder (renamed Research in 1940) was, upon completion of her construction in 1899, assigned to conduct surveys of Norton Sound and Fox Islands in the Aleutians.

The year 1898 was also a time of chaos for the Coast and Geodetic Survey. By Congressional action all Navy personnel were withdrawn from the Coast and Geodetic Survey. Gone were the Navy men who had for so long operated the Survey's slips, conducted the surveys, improved equipment and techniques, and added to the Survey's luster. The list is long and notable with such names as T. R. Gedney, George Blake, Charles H. Davis, J. E. Pillsbury, C. M. Chester, W. B. Fremont, George M. Bache, and Charles D. Sigsbee. This loss of Navy personnel required a major reorganization of the Survey's hydrographic work. To man their ships the Survey had to hire experienced seamen, establish the ranks of deck officer, junior officer and senior officer and provide appropriate uniforms.

Also in 1898, the Spanish-American War brought the Philippines, Guam and Puerto Rico under U.S. control which, with their need to be charted, created further problems for the Survey. The Patlfinder together with the Philippine Insular Government owned ships Fathomer, Marinduque and Romblon, which were under the command of Survey officers, were assigned to survey the Philippines. Native seamen and workers were employed and the problems of training were great. Add to this local insurrections, unfriendly natives, tropical heat with pests and fever, and violent typhoons, it is a wonder that charts were obtained-yet they were.

Before the century closed even a prince had become attracted to oceanography. This was Prince Albert 1 of Monaco who equipped his successive royal yachts, Hirondelle, Princess Alice, Hirondelle II, and Princess Alice $1 /$, as research vessels and made extensive studies of the Mediterranean and North Atlantic. 


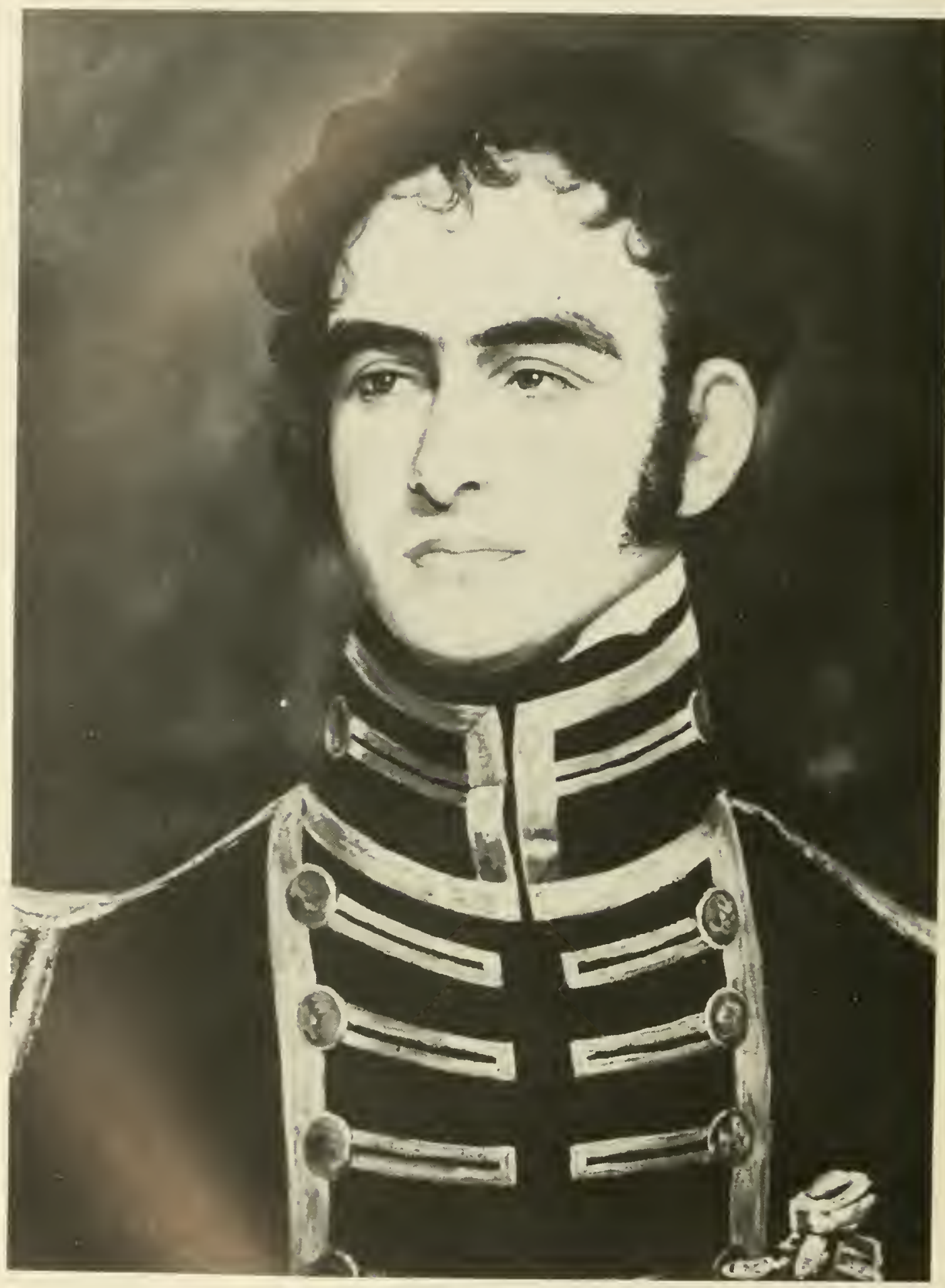

Commodore John Rodgers, U.S. Navy (1772 - 1838)

Conducted the first documented hydrographic survey (of New London Harbor) in $181 \mathrm{I}$ using his flagship, the frigate Constitution. 


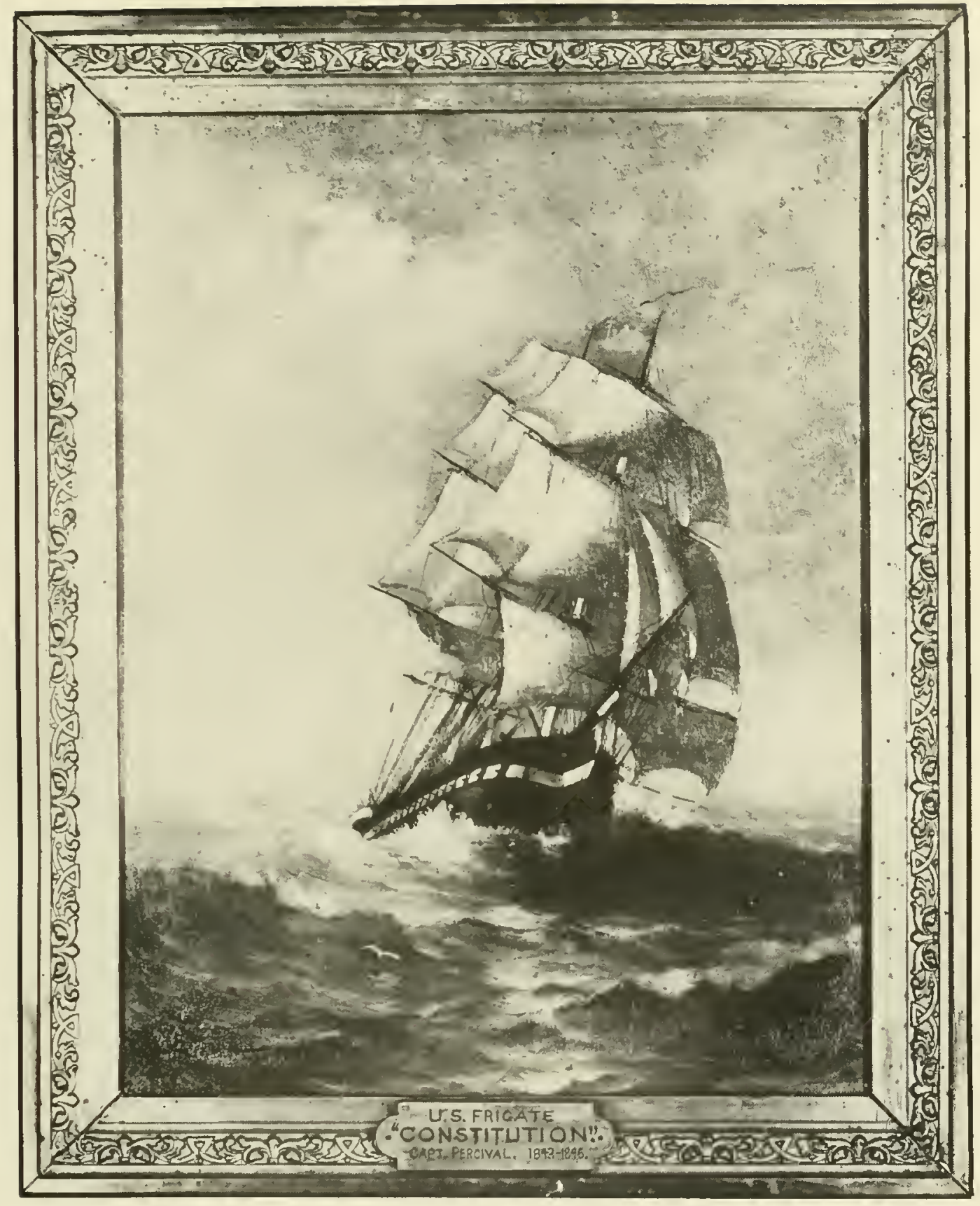

\section{U.S. Frigate Constitution}

Built in 1798 at Jartt's Shipyard of Boston, Massachusetts at a cost of approximately $\$ 300.000$, the Constitution conducted the first documented survey by any federal agency when, in 1811, a survey of New London llarbor was made, and a chart was produced that same year. Today "Old Ironsides" rests in Boston Harbor, the oldest commissioned ship in the Navy and a symbol of courage and patriotic service.

Length: 204' Displacement: 2,200 tons 


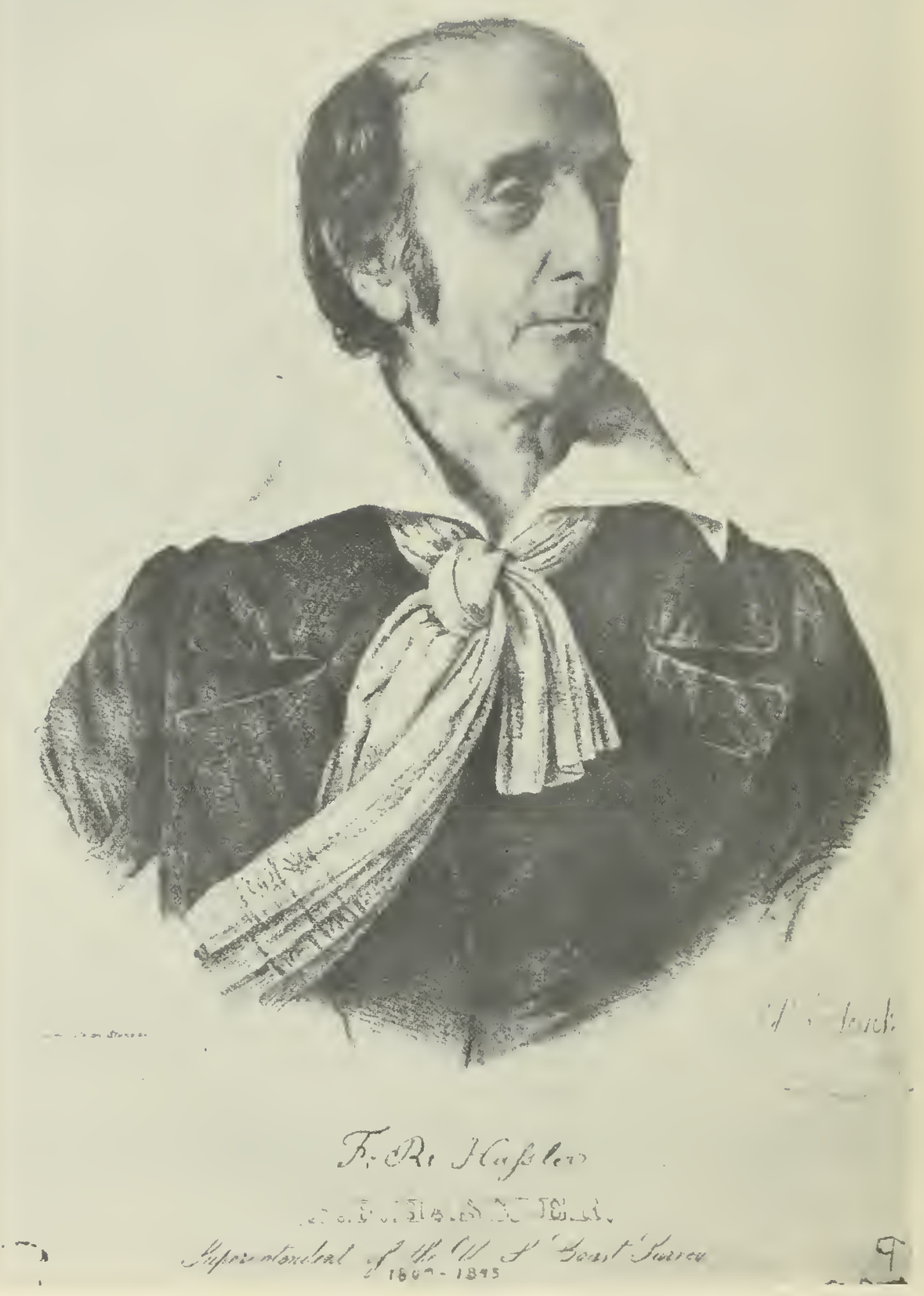

Ferdinand Rudolph Hassler (1770 - 1843)

A Swiss geologist of outstanding reputation, he was appointed in 1807 by President Thomas Jelferwon as the first Superintendent of the Coast Survey (later the Coast and Geodetic Survey and now the National Ocean Survey). 

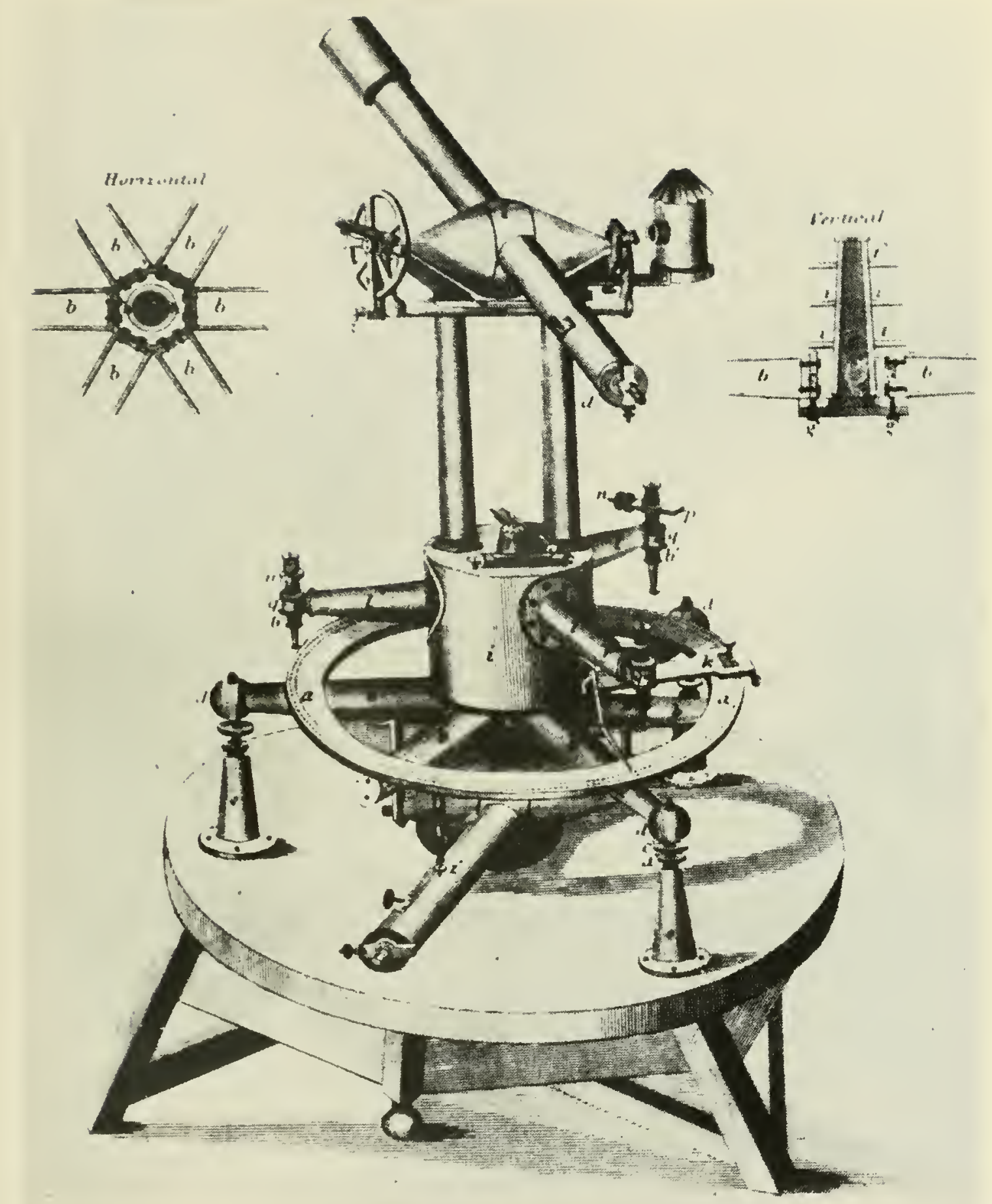

Hassler's 24-inch Theodolite. This 24-inch theodolite, a surveying instrument used to measure horizontal and vertical angles with a small telescope, was considered a marvel of precision in its Jay. 


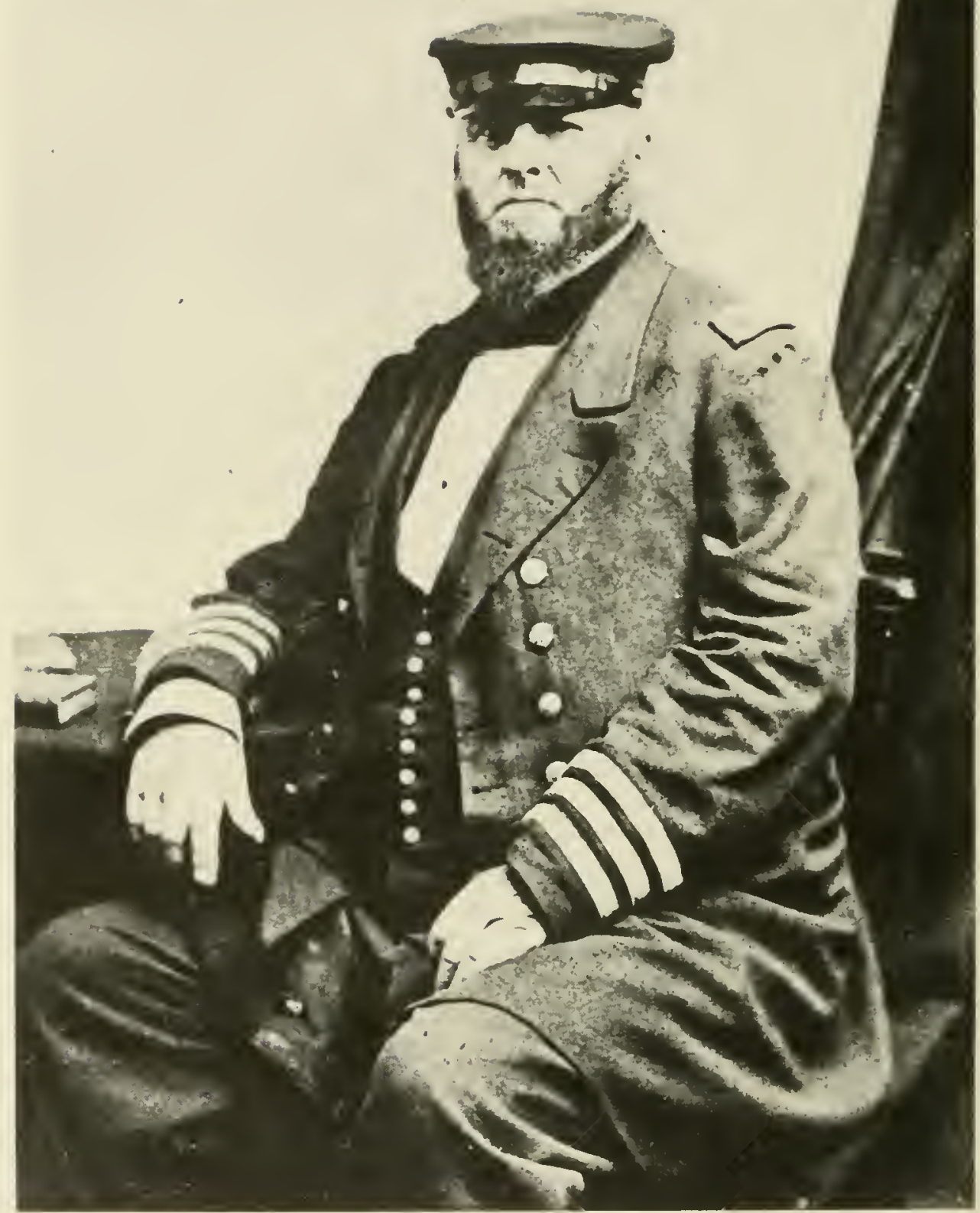

Rear Admiral Louis M. Goldsborough,

U.S. Navy (1805 - 1877)

Appointed in 1830, then a Lieutenant, he was the first Oflieer-in-Charge of the Navy's Depot of Charts and Instruments, predecessor of the Naval Oceanographic Office. This Depot was established in accordance with a plan which Goldstorough himself had suggested. Hlis long and varied naval career was interrupted when he took leave to participate in the Seminole Indian War commanding a company of mounted volunteers. 


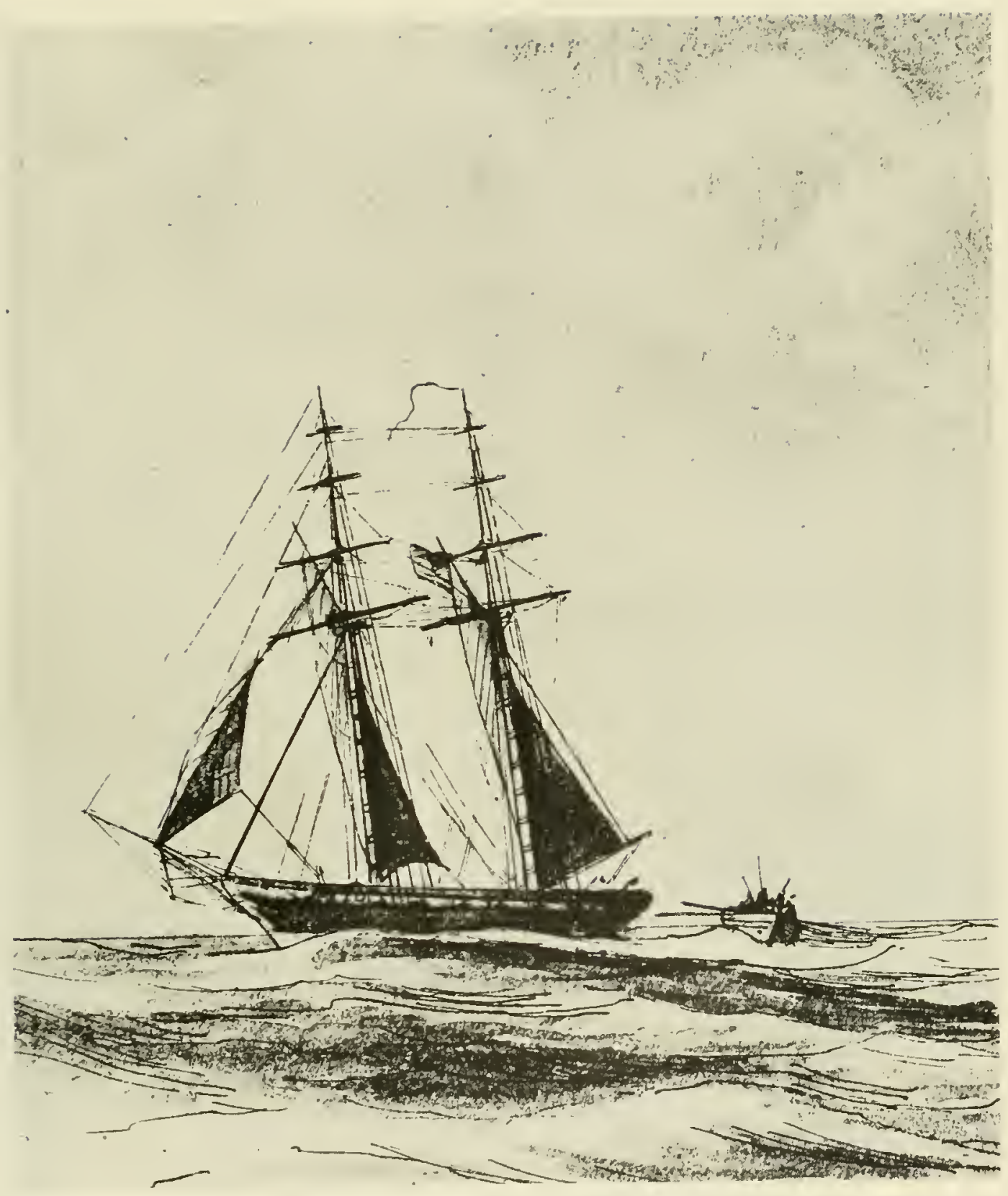

U.S. Sclowner Experimem

Built in 1831 by the Washington Navy Yard. From 1835101838 the Experument was assigned to the Coast Survey. She was disposed of in 1848

lengll: 911' Displacement: 209 tons 


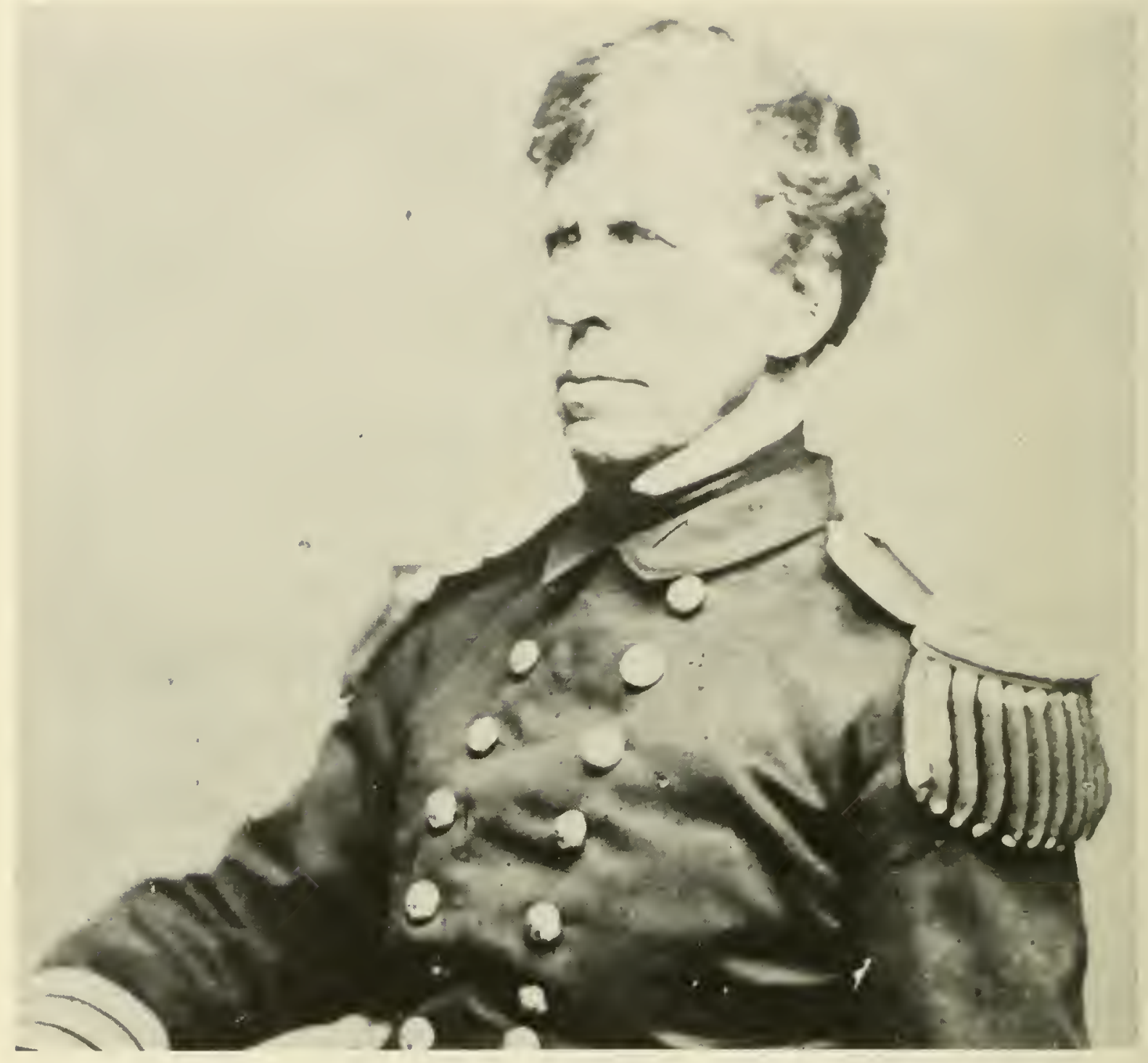

Rear Admiral Charles Wilkes,

U. S. Navy (1798 - 1877)

In I838 Wilkes, then a Licutenant, was placed in command of the first scientific expedition sent out by the United States, the U.S. Exploring Expedition which ended four years later alter having sailed completely around the world. lle werved with the Coast Survey irom 1842 to 1843 and advanced to the ranh of Commander. The years 1844 10 1861 Wilhes spent on special duty preparing the report of his evededion. Wilkes was commissioned Commodore in 1862 and placed in cenmond of a syuadron sent to the West Indies to protect L. S. commeree. Ilis eal for pursuing Confederate raiders offended weveral furcign governments and resulted in his court-martial and stupension fron duty in 1864 for insubordination and conduct unbecoming an oflieer. In 1866 . however. He was promoted to Rear Admiral on the retured list. 


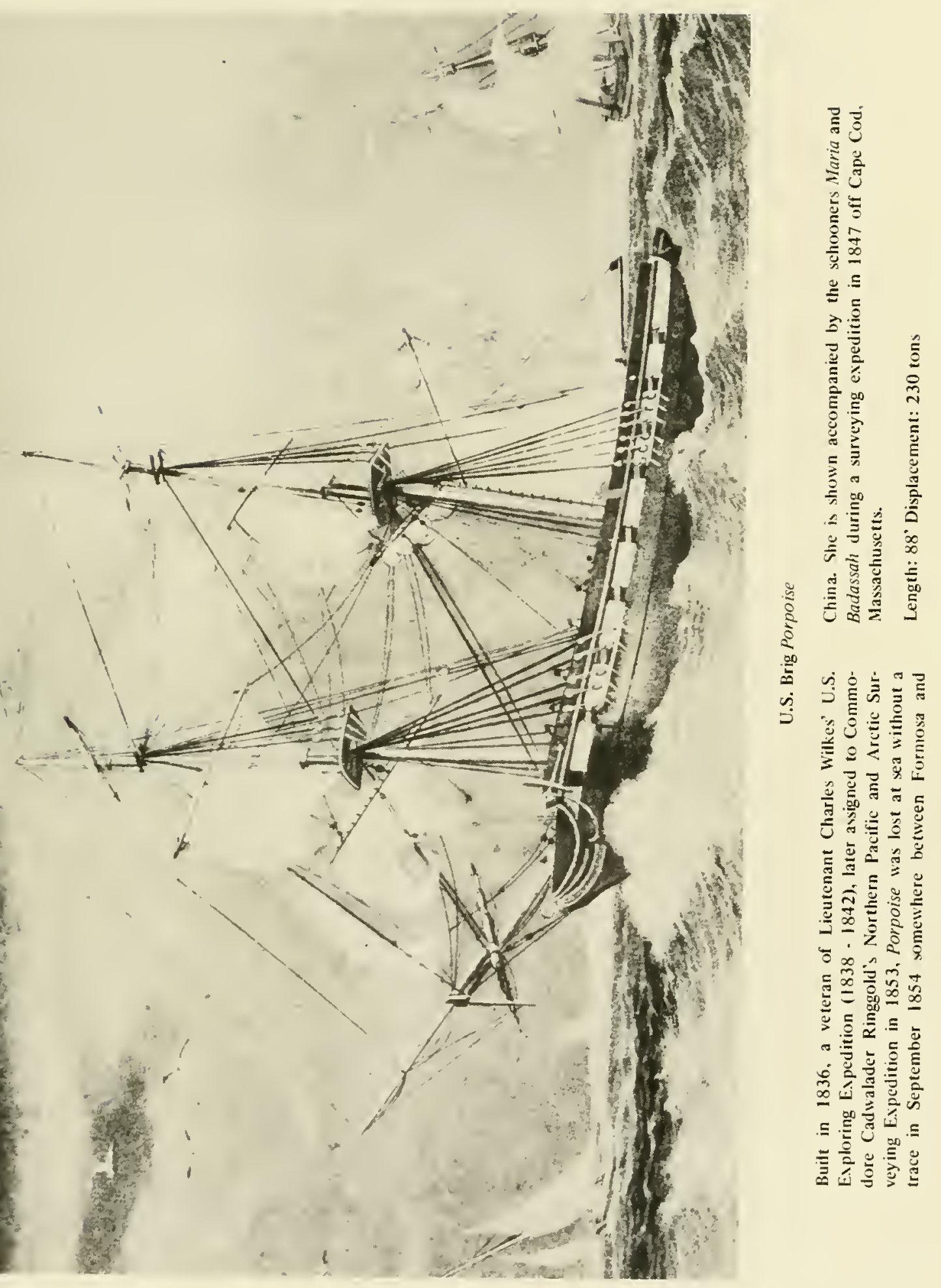



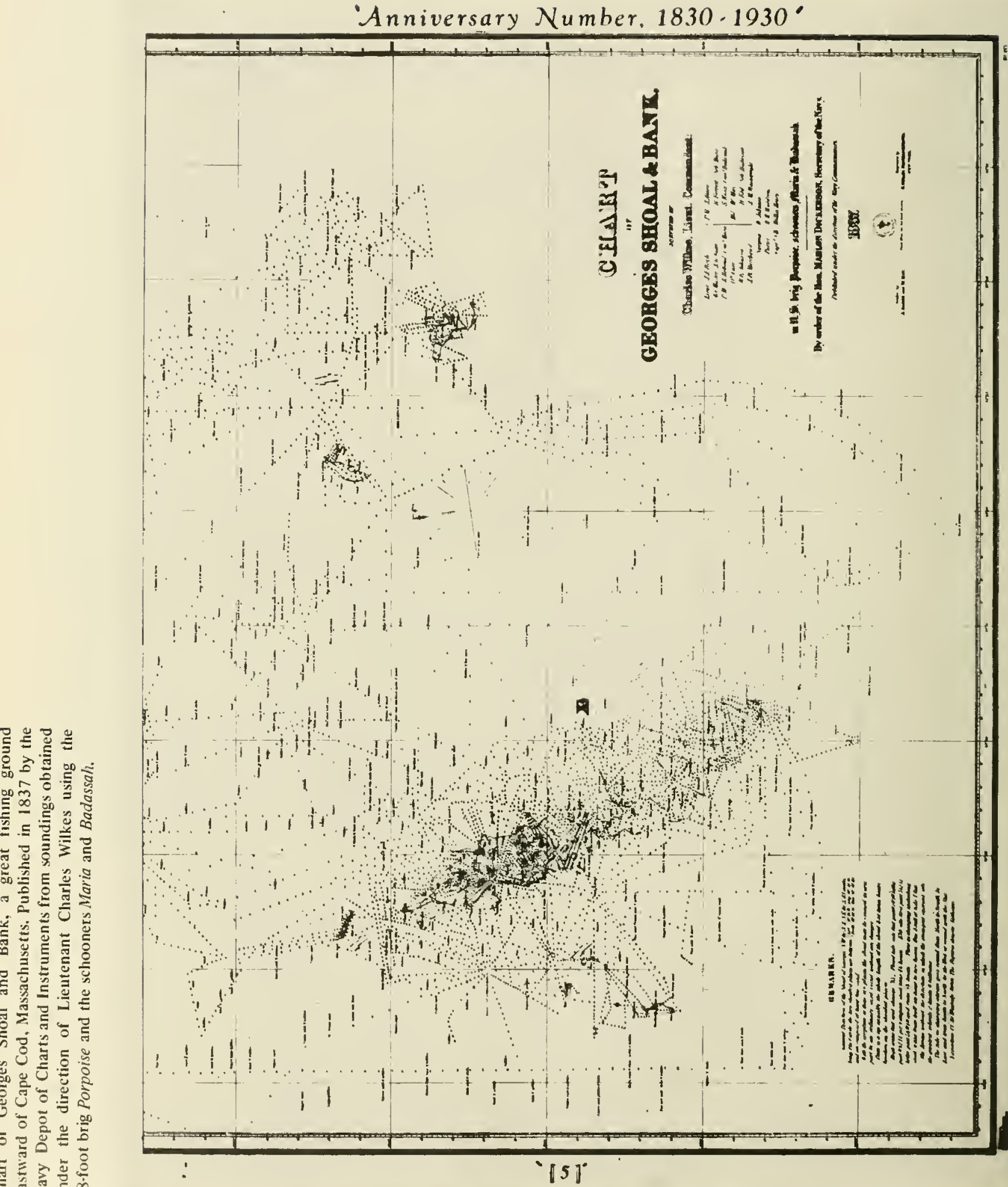

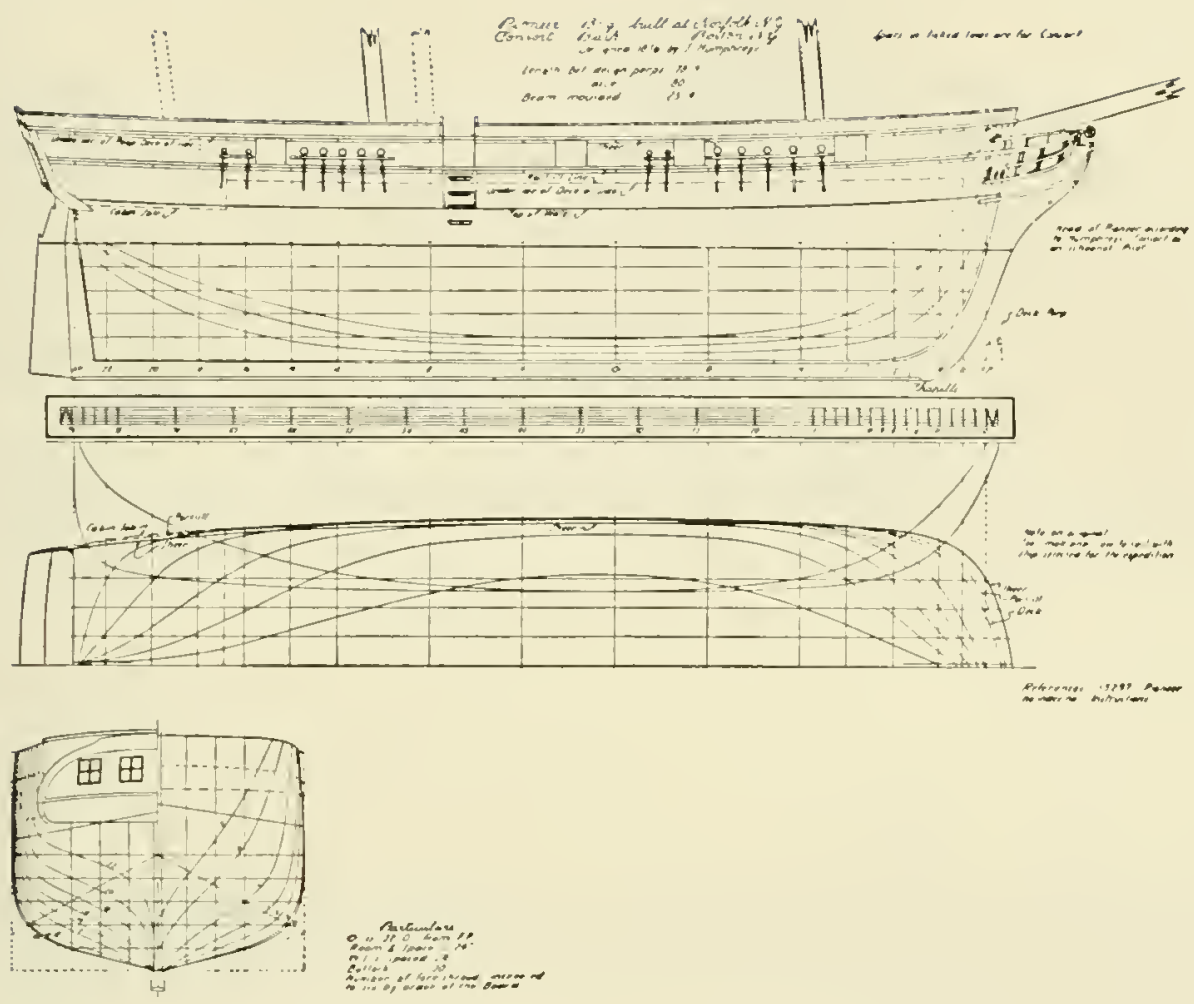

The brigs Consort and Pioneer were built in 1837 by Boston Navy Yard and Norfolk Navy Yard, respectively, especially foi Wilkes" Exploring Expedition. Tested in 1837, they were found to be too slow for participating in the expedition. Until their Jisposal in 1844, they were assigned routine duties and botl! slips were used for a while making surveys along the U.S. coasts.

Length: $78^{\prime} y^{\prime \prime}$ (between perpendiculars)

Displacement: 230 tons 


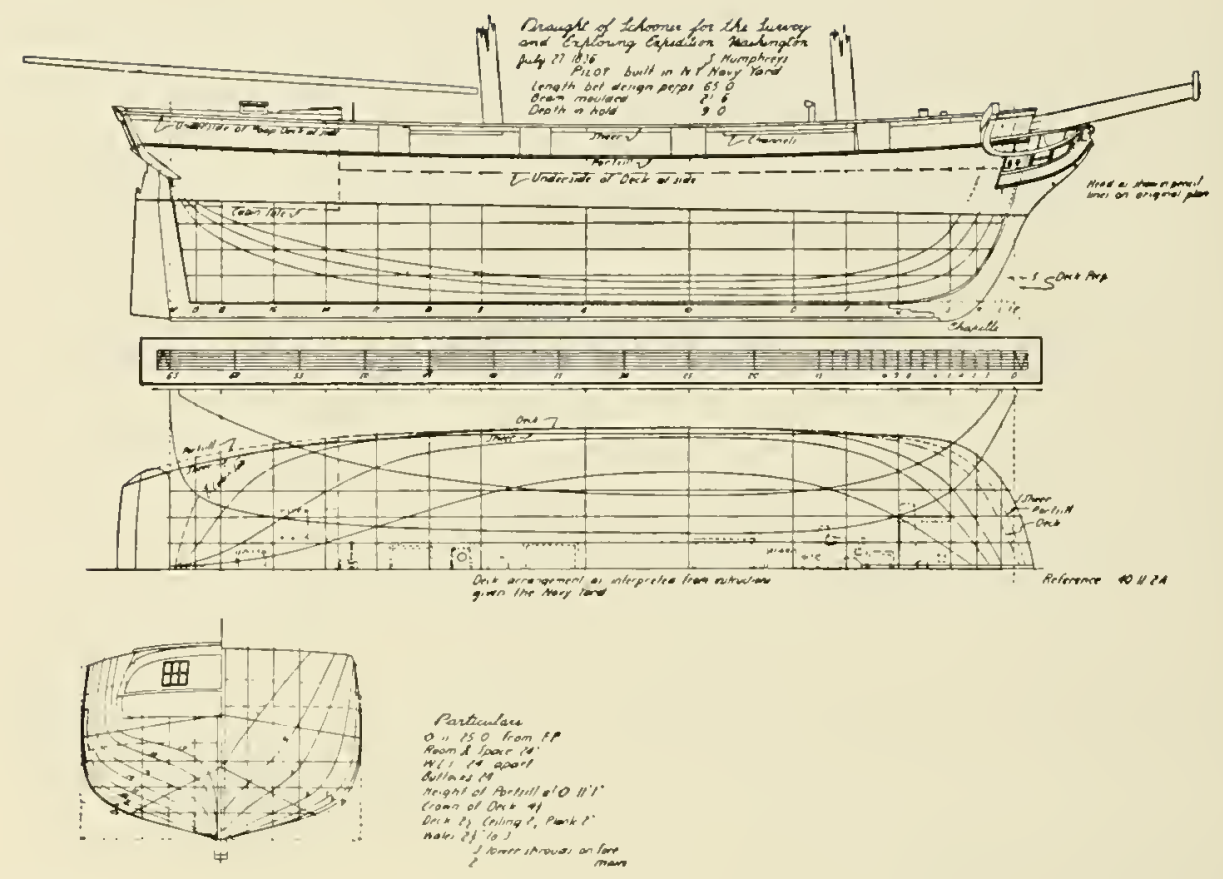

\section{U.S. Schooner Pilot}

The Pilot was built by New York Navy Yard in 1837 especially lor the Wilkes" Exploring Expedition. Found to be too slow to participate in the expedition. she was sold the following year.

Length: $65^{\circ}$ (between perpendiculars) Displacement: 120 tons 


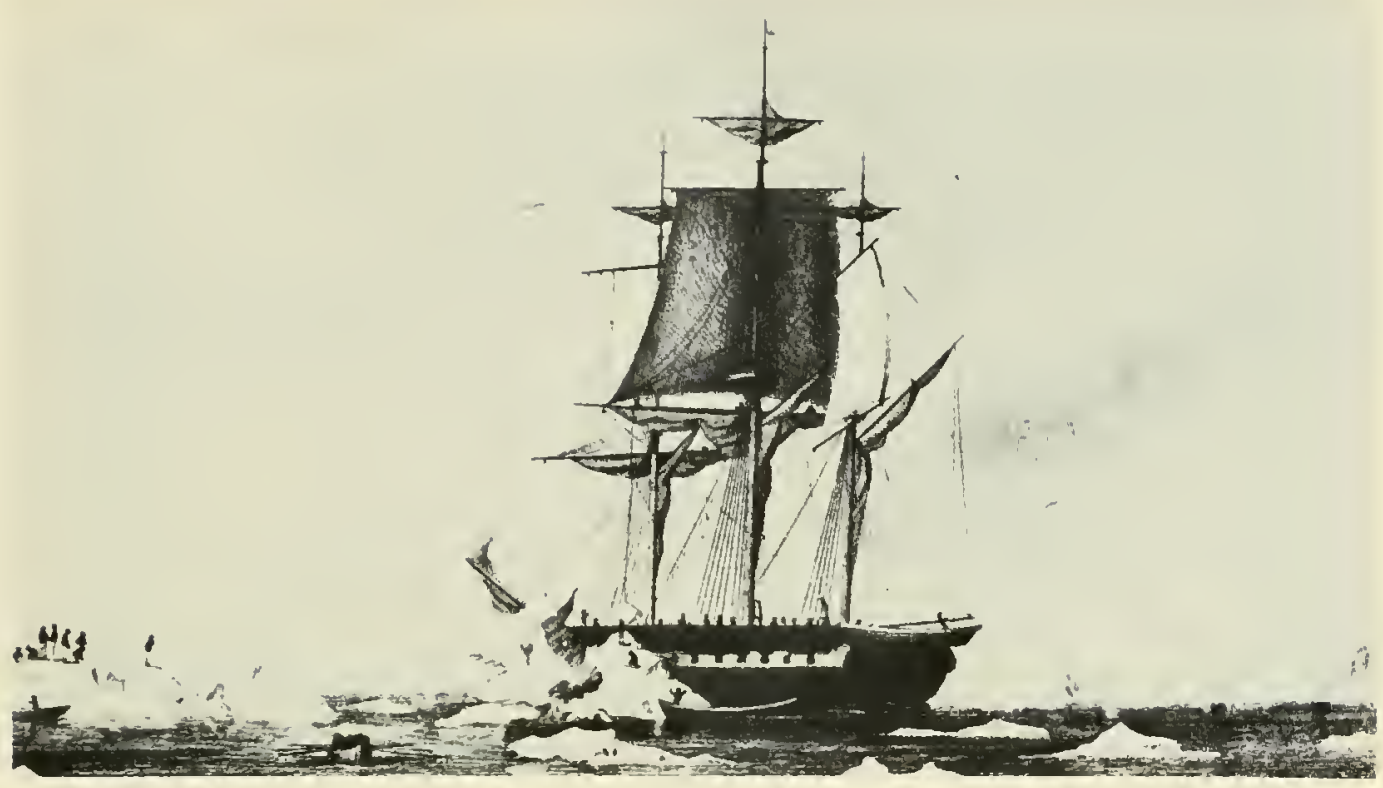

U.S. Sloop-of-War Vincennes

Built in 1826 by Brooklyn Navy Yard, flagship for both Lieutenant Charles Wilkes' U.S. Exploring Expedition (1838 1842) and Commodore Cadwalader Ringgold's Northern Pacific and Arctic Surveying Expedition (1853 - 1856). Laid-up at
Boston Navy Yard in 1865, Vincennes was sold for $\$ 8.600$ in 1867 at public sale.

Length: 127' Displacement: 780 tons

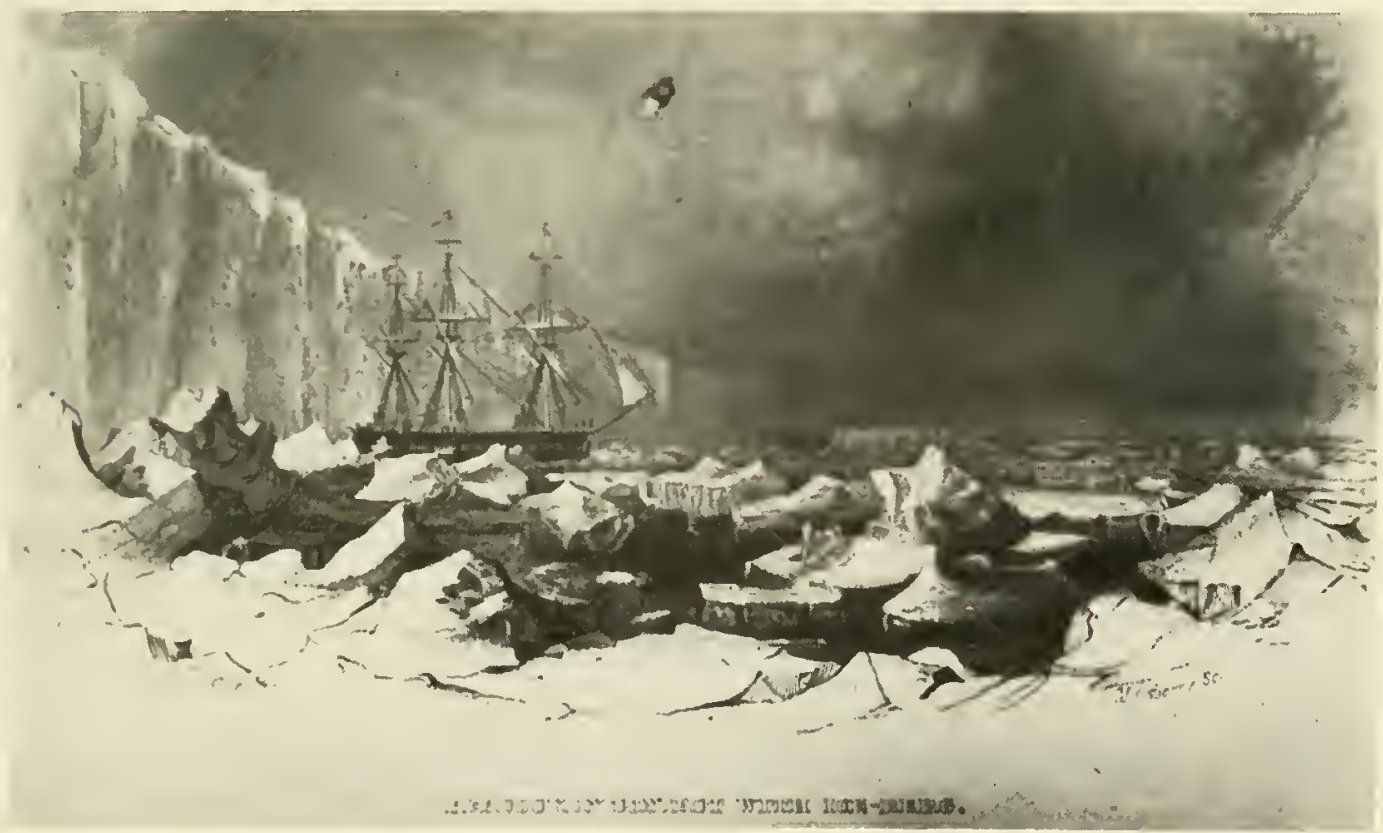

\section{U.S. Sloop-of-War Peacock}

Built in 1814 by New York Navy Yard. Peacock was assigned to the Wilkes' Exploring Expedition and while attempting to cross the bar at the mouth of the Columbia River in July 1841, slie grounded. Abandoned by her crew, Peacock pounded herself to pieces.

Length: 117' 1]" Displacement: 650 tons 


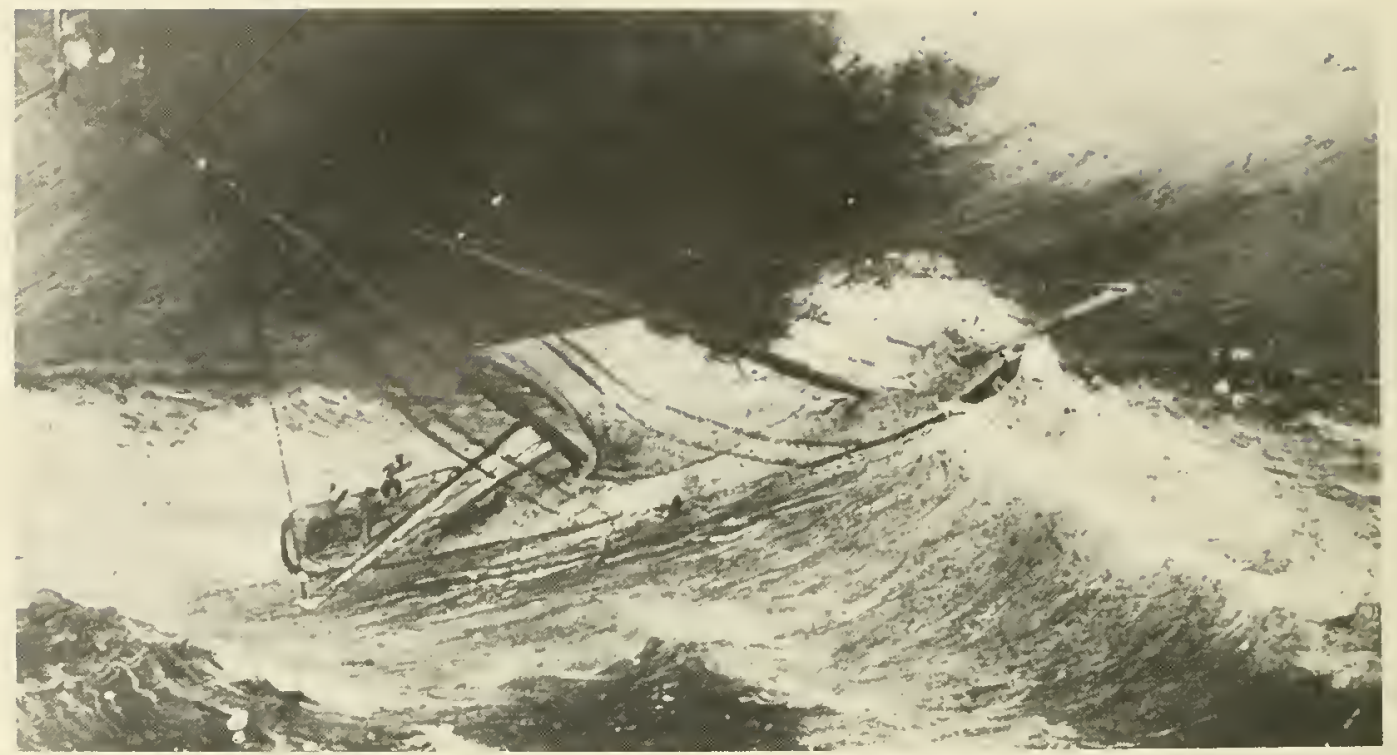

\section{U.S. Schooner Sea Gull}

Originally the New York pilot boat New Jersey. Purchased by the Navy in 1838 for $\$ 11,000$ to serve with the Wilkes Exploring Expedition (1838 - 1842). A small vessel of shallow Iraft, the Sea Gull was purchased (along with another New York pilot boat, renamed the Flying Fish) for eonducting inshore surveys and approaching the ice barrier. Sea Gull was lost without a trace in May 1839 off the coast of Chile.

Length: $96^{\circ}$ Displacement: 110 tons

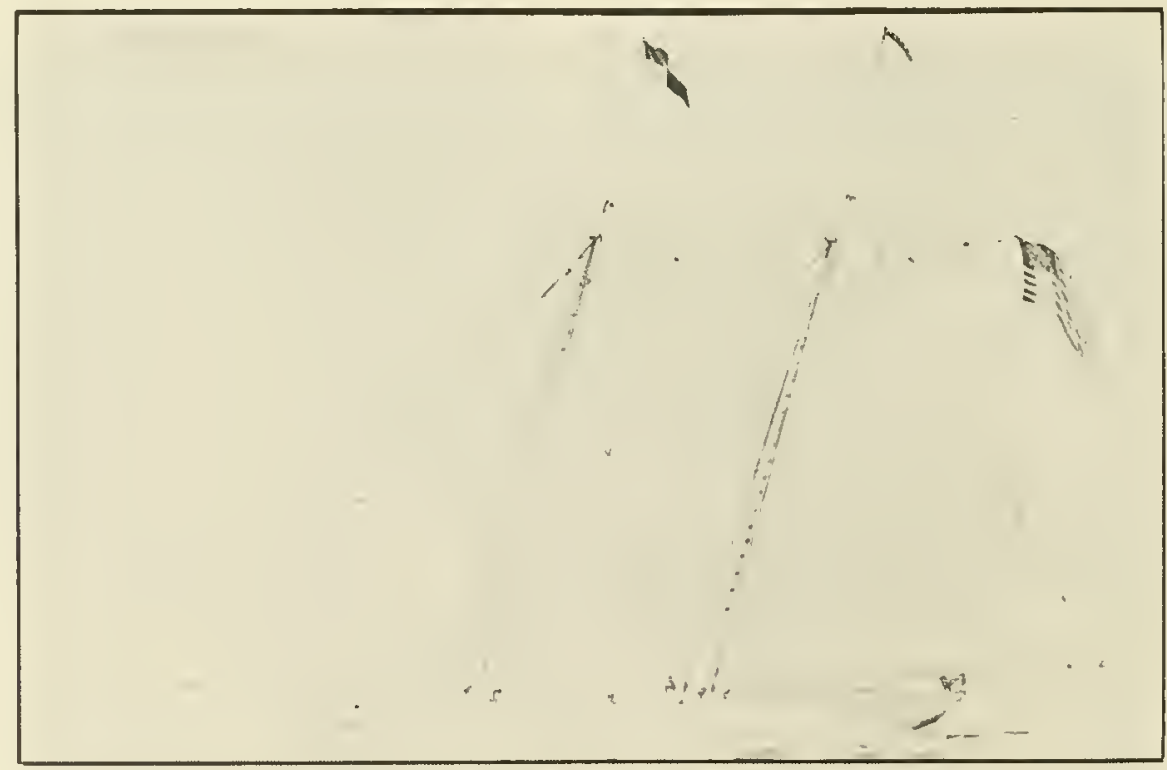

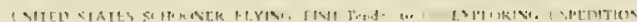

\section{U.S. Schooner Flying Fish}

Formerly the New Yurk pilot boat Independence which was employed on the Sandy Hlook run. Purchased by the Navy for $\$ 10,000$ and renamed Flying Fish, she joined Lieutenant Charles Wilkes" U.S. Exploring Expedition (1838-1842). Because of her poor condition she was sold in February 1842 at public auction in Singapore for $\$ 3,700$ and, under the name Spee, became an opium smuggler.

Length: $85^{\prime} 6^{\prime \prime}$ Displacement: 96 tons 


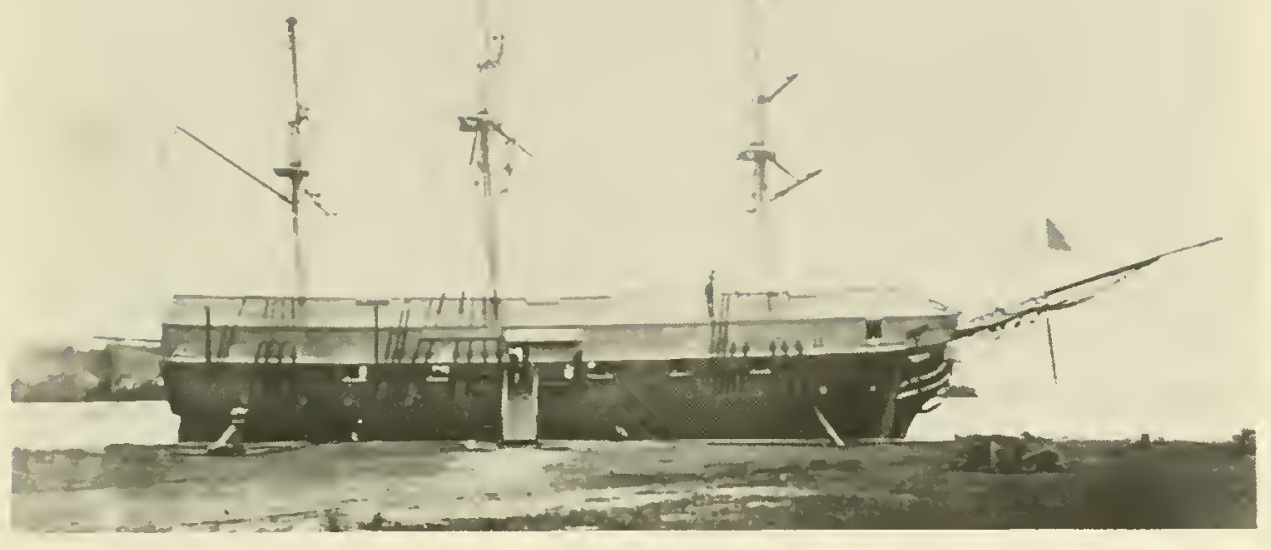

\section{U.S. Storeship Relief}

Built in 1836 by Philadelphia Navy Yard especially for the U.S. Exploring Expedition (1838 - 1842). Lieutenant Charles Wilkes, leader of the expedition, ordered the Relief home in 1839 from Callao, Peru since he felt her slowness, retarded all his operations and made her a constant source ol anxiety. She sailed for home after being "smoked" to destroy the rats with which she was infested and having taken aboard, as Wilkes described them, "all invalids and idlers". After calling at Honolulu and Sydney she arrived in New York in March 1840. The following years were spent on routine service and in 1878 slue was laid-up at Washington Navy Yard until her sale in 1883.

Lengtls: 109' Displacement: 468 tons

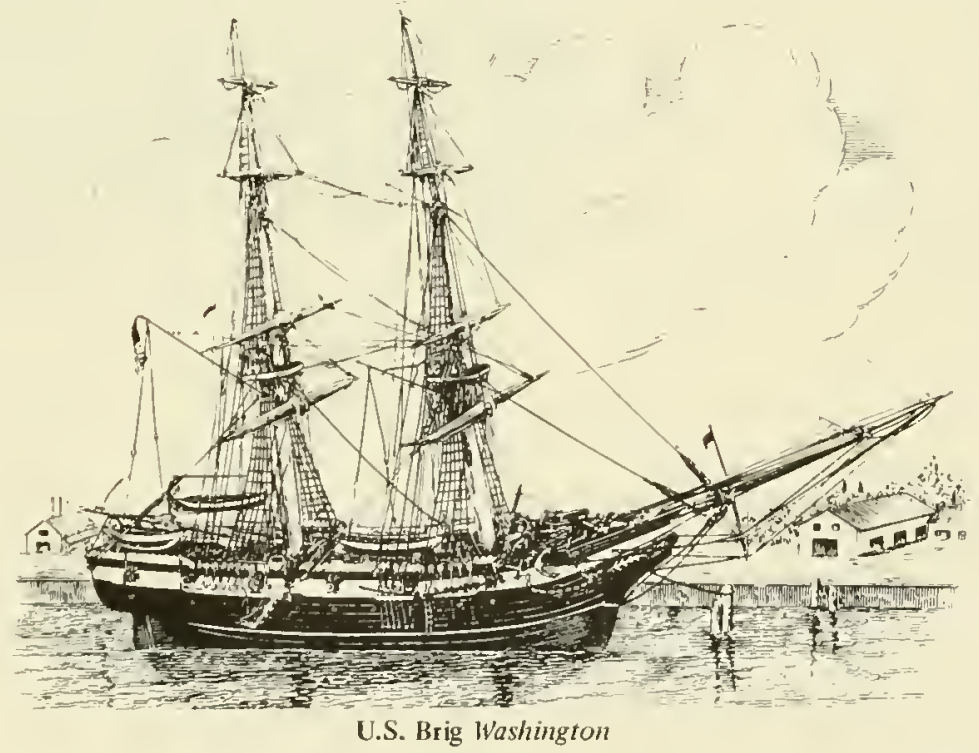

A 94-foot schooner built in 1837 for the U.S. Revenue Cutter Service. Re-rigged the following year as a brig, she spent the winter months as a Revenue Cutter and the summer months as a survey ship for the Coast Survey. From 1840 to 1852 she served exclusively as a Coast Survey brig. Returned to the Revenue Cutter Service in 1852, she was seized by the authorities at New Orleans when Louisiana seceded on 31 January 1861 and saw service as the Confederate States Ship Washington. 


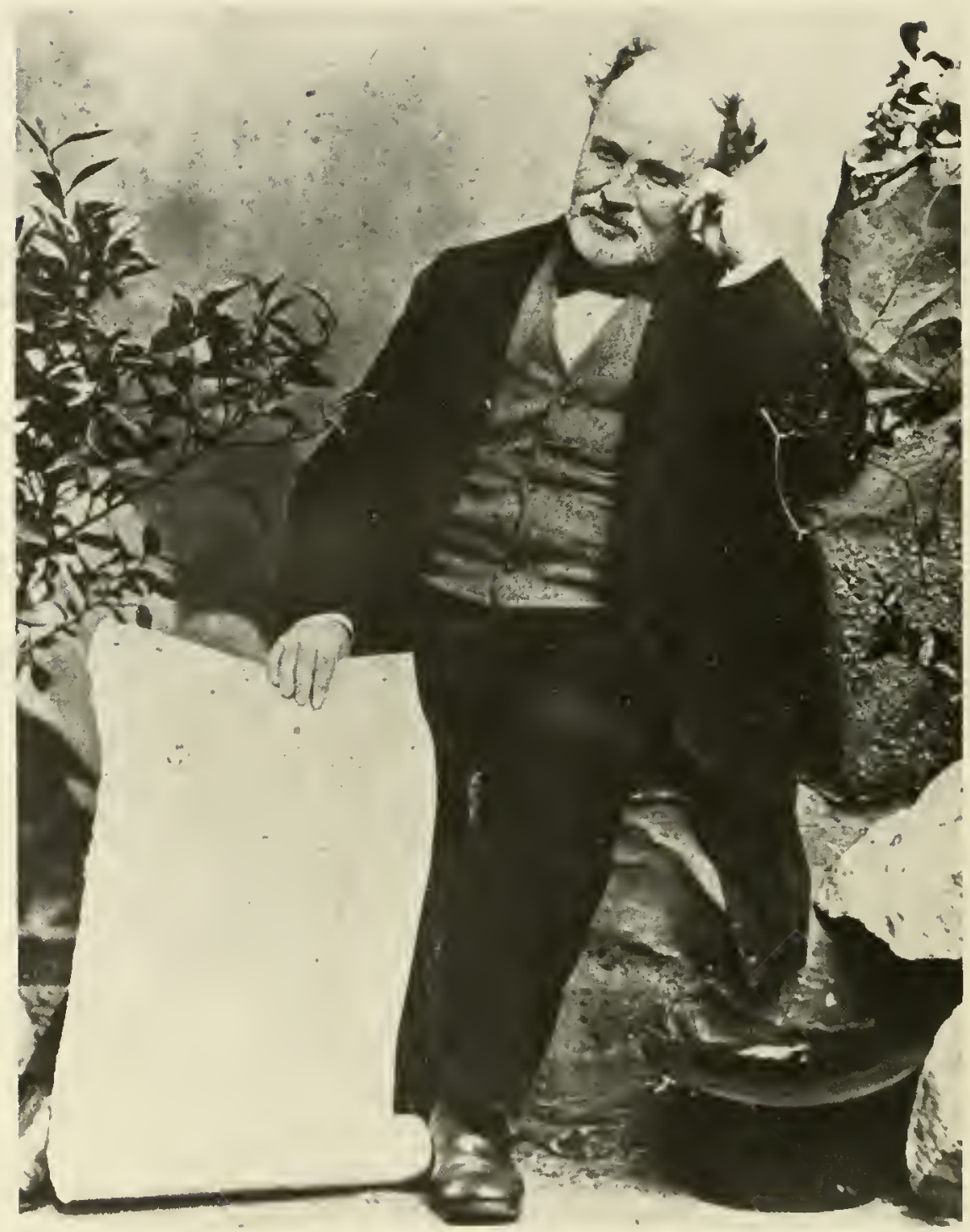

Commander Matthew Fontaine Maury,

U. S. Navy (1806-1873)

An astronomer and hydrographer, Maury was appointed in $\mathbf{1 8 4 2}$ Officer-in-Charge of the Depot of Charts and Instruments out of which grew, a short time later, the U. S. Naval Observatory and Hydrographic Office (the Hydrographic Office was not established as a separate institution until 1866). Until his resignation in April 1861 Maury published many acclaimed scientific works. He became world famous as "Patlifinder of the Seas". Following his resignation at the outbreak of the Civil War. he joined the Confederate Navy, attaining the rank of Commodore. At the end of the war, following an unsuccessful attempt to form a colony of Confederate expatriates in Mexico, he accepted the professorship of metcorology at the Virginia Military Institute. 


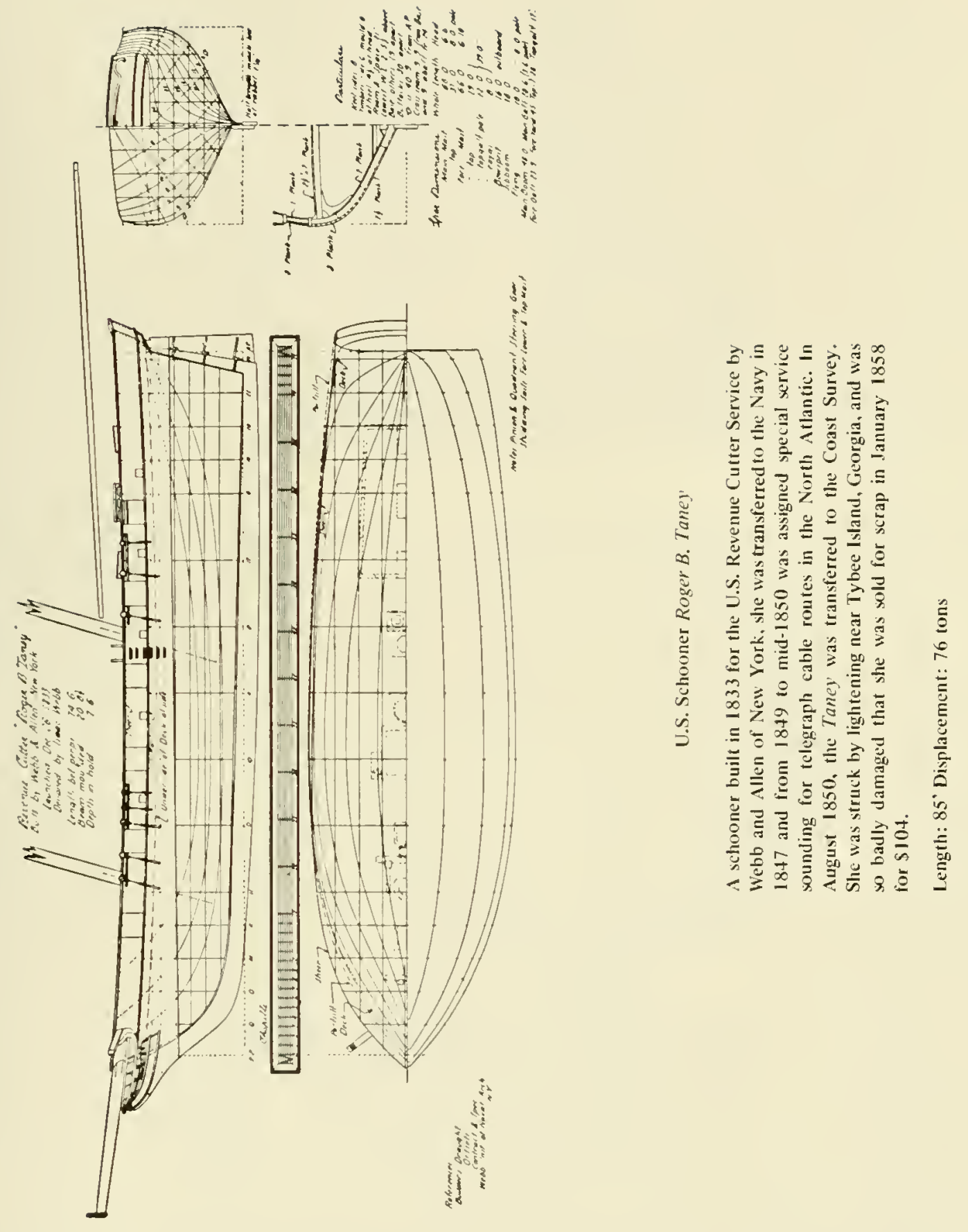




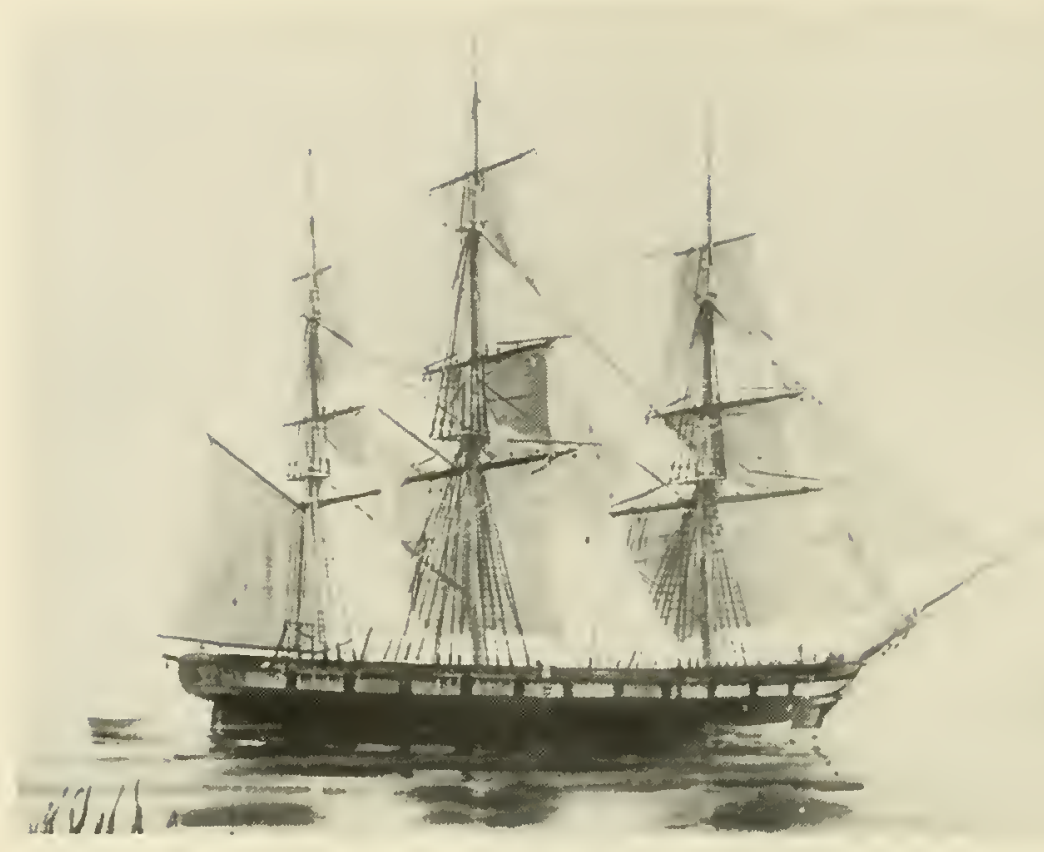

USS Albany

A first-class sloop-of-war built in 1846 by New York Navy Yard. 1854 she sailed from Aspinwall, Panama enroute to New York She was assigned special survey duty in 1852 in the North and was never heard from again.

Atlantic under the direction of Matthew Maury, In September Length: 163' 6"' Displacement: 1,064 tons

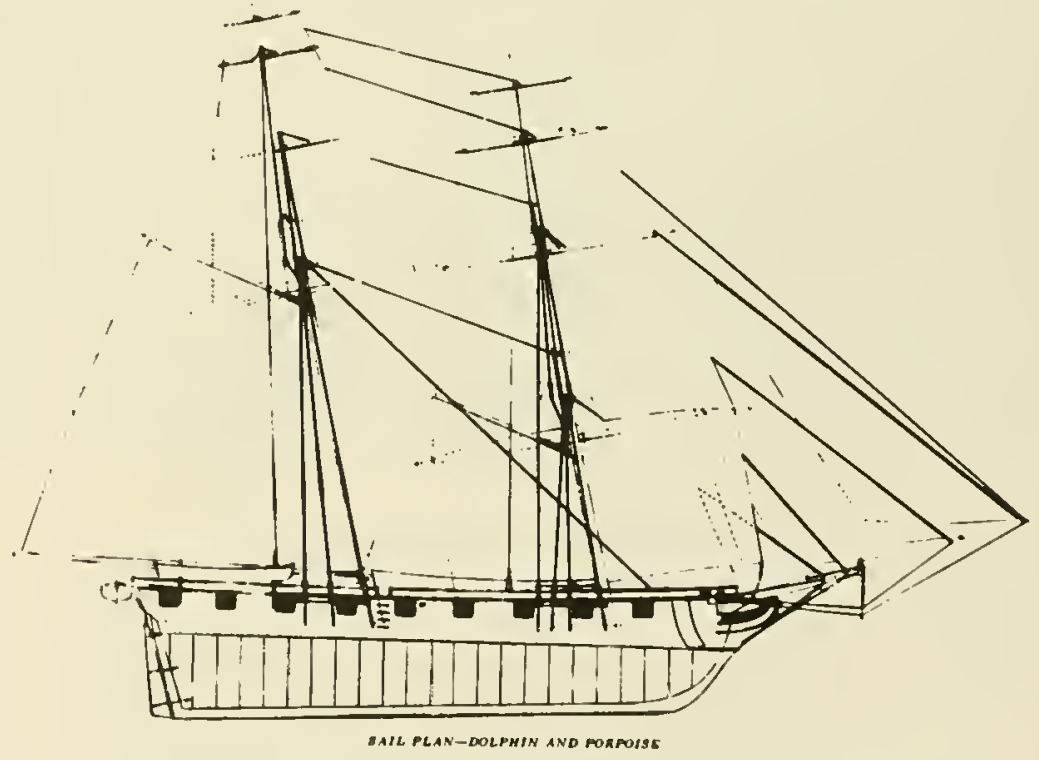

\section{USS Dolphin}

A brig built in 1836 by the New York Navy Yard. Dolphin was one of the three ships (Taney and Albany the other two) assigned to Maury as authorized by Congress "for testing new rontes, and perfecting the discoveries made by Maury in the course of his investigations of winds and currents of the oceans."
This special duty, concentrated in the North Atlantic, commenced in 1852 and ended in 1854. Dolphin's career ended at Norfolk Navy Yard in April 1961 when she was burned by Union forces to prevent her falling into Confederate hands.

Leng th: $88^{\prime}$ Displacement: 224 tons 


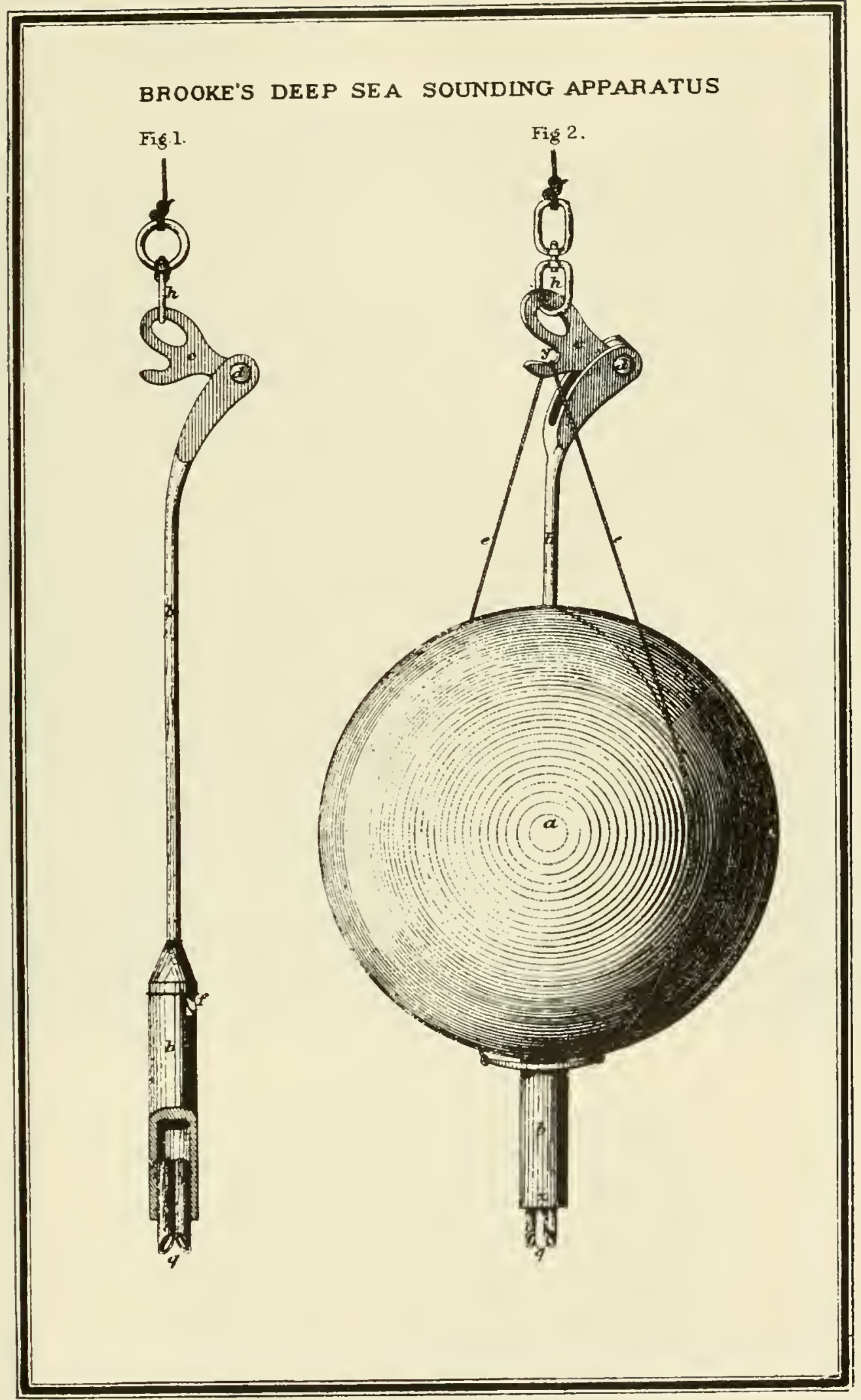

The deep-sea sounding devices devised in 1852 by Midshipman John Mercer Brooke, a protege of Matthew Maury. 


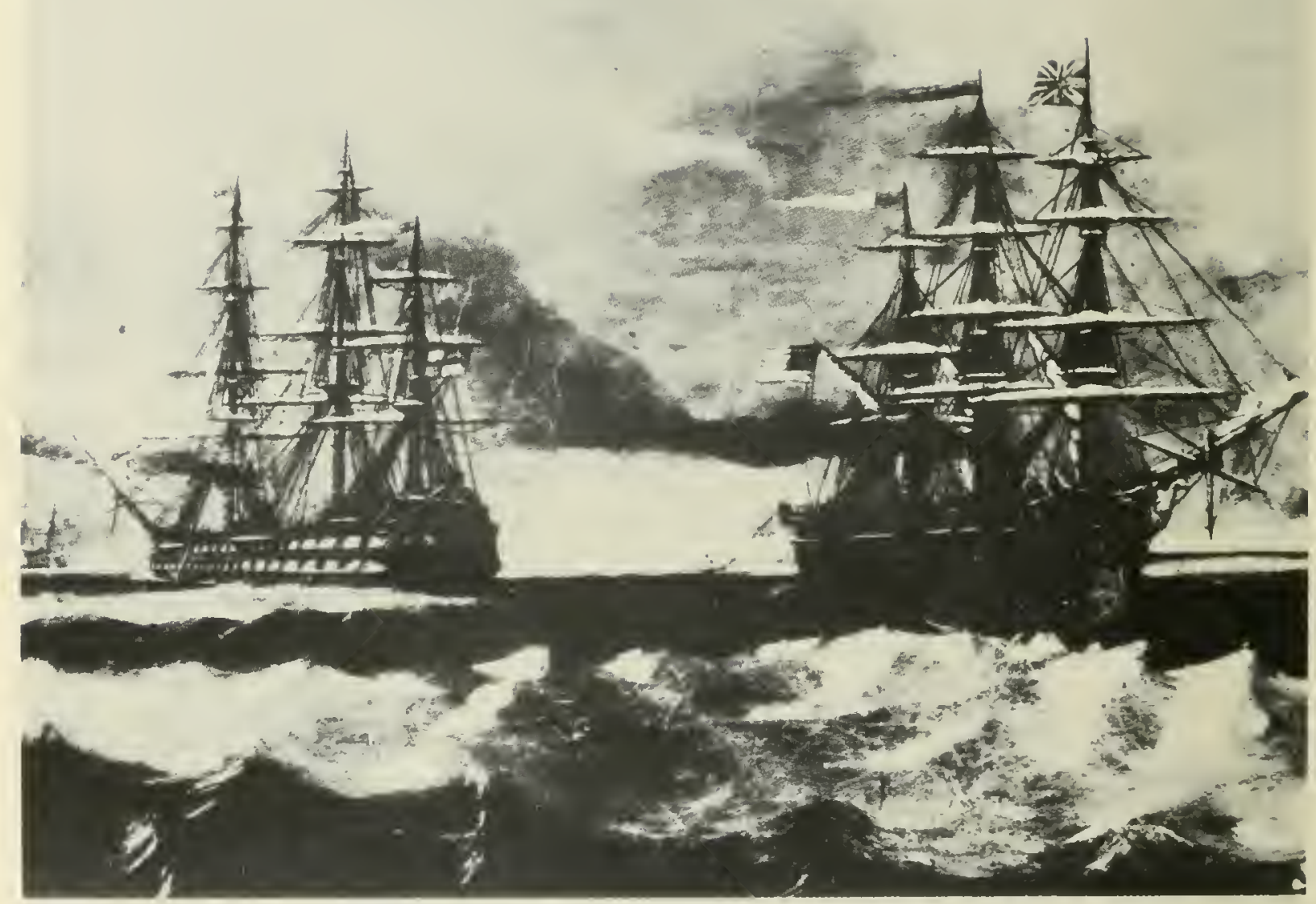

(4)

USS Niagara

A steam frigate built in 1857 by New York Navy Yard. Niagara's first service was laying the first trans-Atlantic telegraph cable. This venture was promoted by Cyrus W. Field, a New England mercliant. The British government assisted by lending the battleship Agamemnon, shown here at the right, to help lay the cable. After several mishaps the project was completed one year later (August 1858) and a copper wire 1,950 miles long connected Trinity Bay, Newfoundland with Valentia, Ireland. Niagara was disposed of in $\mathbf{1 8 6 5 .}$

Length: $328^{\prime} 10^{\prime \prime}$ Displacement: 5,540 tons 


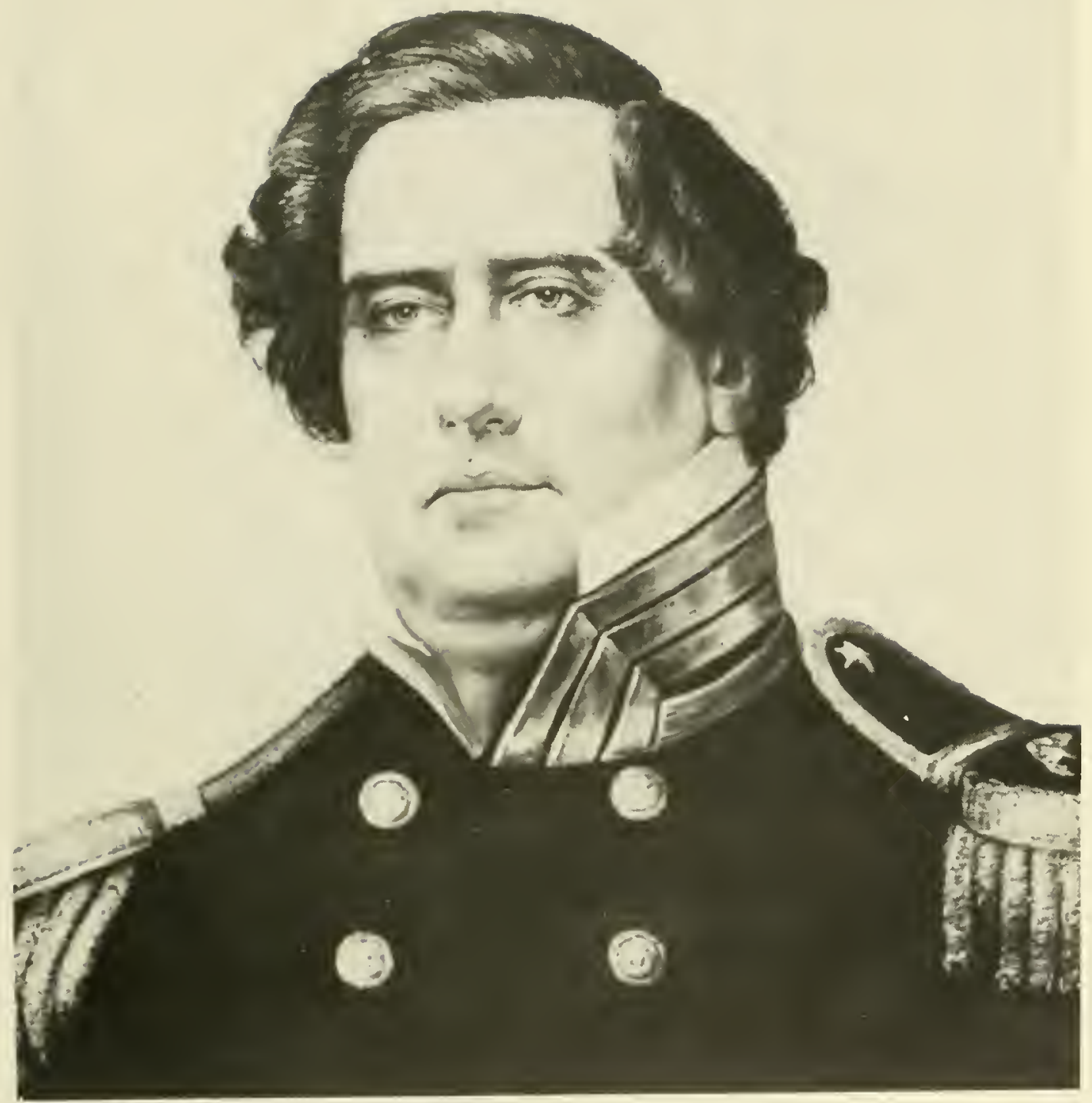

Commodore Matthew Catbraith Perry,

U.S. Navy (1794 - 1858)

In 1852 Perry was appointed commander of a naval expedition sent to Japan to induce the government to establish diplomatic relations with the United States. His decision "to demand as a right, and not to solicit as a favor, those acts of courtesy which are due from one civilized country to another ..." resulted in the first treaty between the U.S. and Japan recognizing however that Japan's acceptance of the treaty documents could be attributed to Perry's proclamation to "go on shore with a suitable force and deliver them personally, be the consequences what they might." Although the expedition was primarily a diplomatic mission, hydrographic surveys were made which included Tokyo Bay, and the first definitive study was made of the Kuroshio, the "Gulf Stream" of the Pacific. 


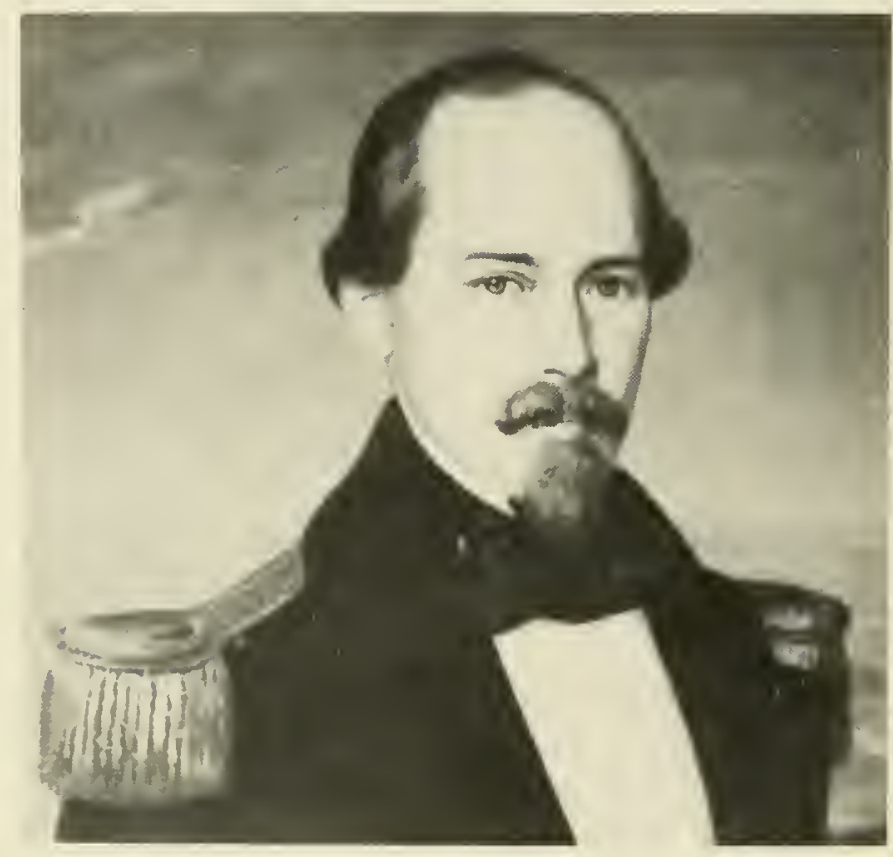

Lieutenant Silas Bent, U.S. Navy (1820 - 1887)

Bent served under Commodore Matthew C. Perry on his expedition to Japan, 1852 - 1854. He was placed in charge of conducting hydrographic surveys and his excellent work became the basis for surveys undertaken later by the Japanese government. His most important work was to delineate and scientifically describe the Kuroshio, or Black Tide, the great northern stream of the Pacific which resembles the Gulf Stream. His study was printed in Perry's official report of the Japan Expedition. In 1860 Bent was detailed to the Coast Survey but the following year he resigned his commission because of his sympathies for the South and assumed the management of his wife's family estate in Louisville, Kentucky. In 1868, he published his work, THE THERMOMETRIC GATEWAYS TO THE POLE, postulating that the Gulf Stream from the Atlantic and the Kuroshio from the Pacific maintained an open sea about the North Pole. 


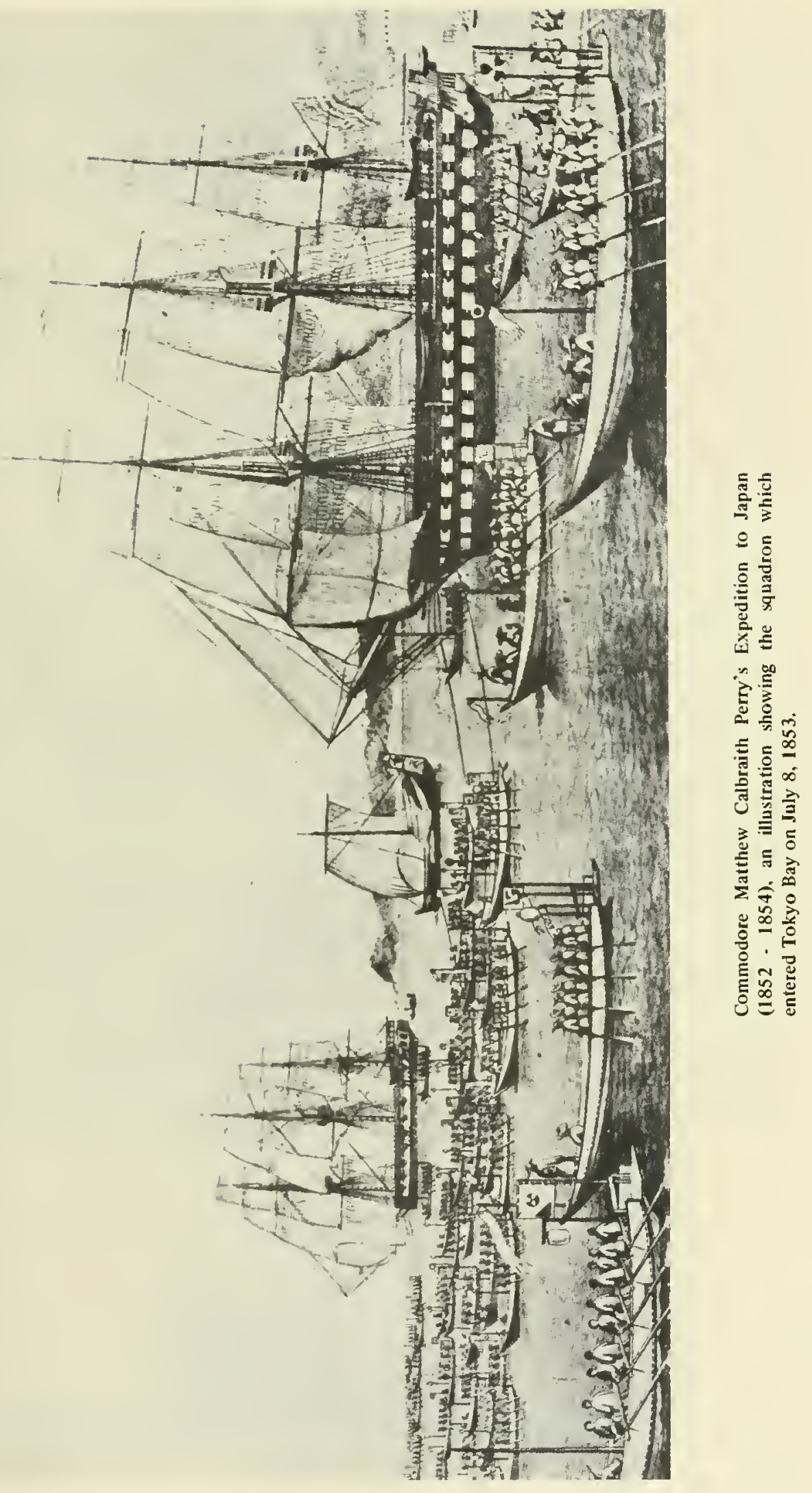




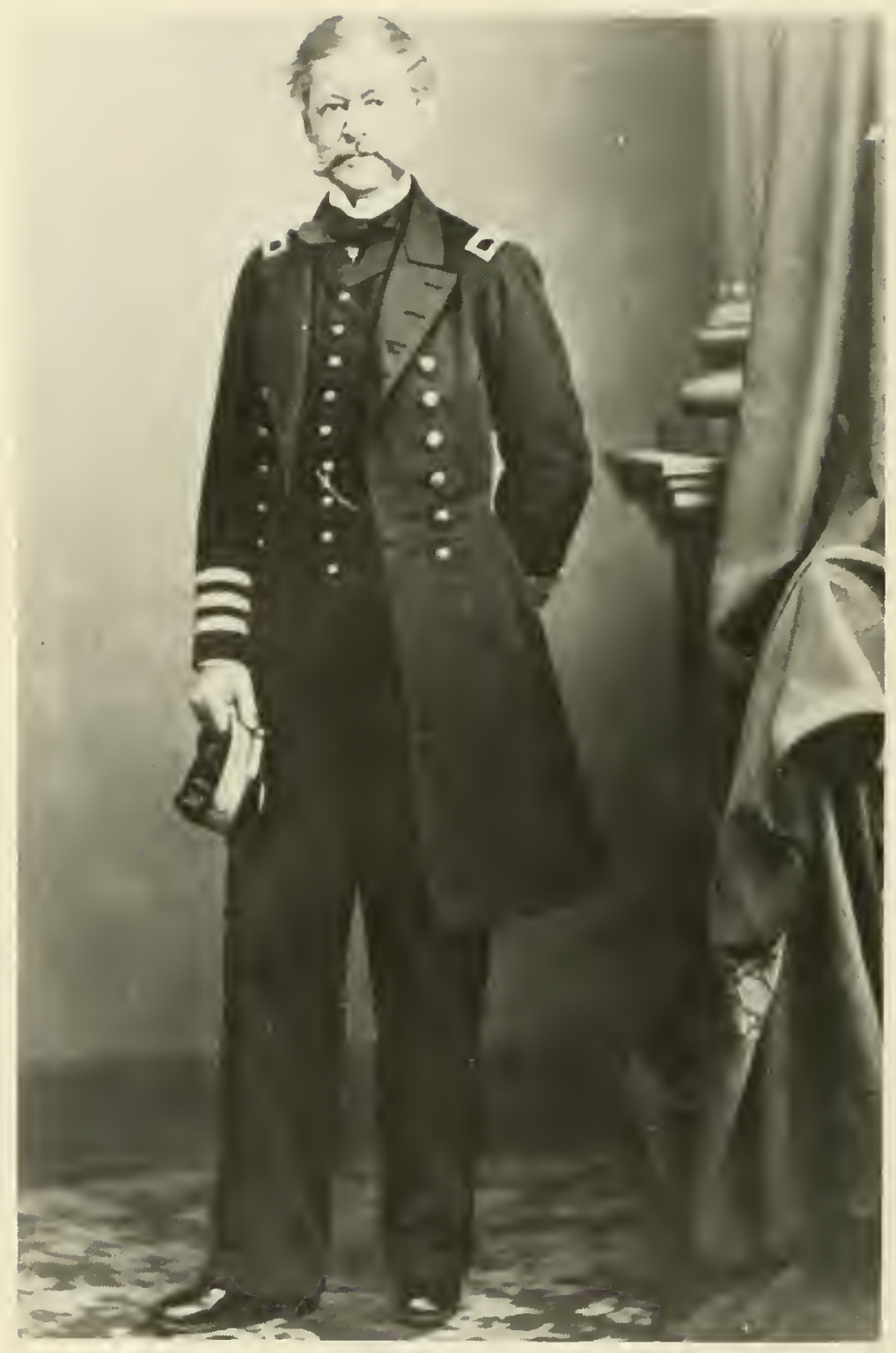

Rear Admiral Cadwalader Ringgold,

U.S. Navy (1802 - 1867)

Commander of the Porpoise in the Wilkes' U. S. Exploring Expedition (1838-1842). In 1853 he was placed in command of the Northern Pacific and Arctic Surveying Expedition. However, the following year while the Expedition was in China he suffered severe attacks of intermittent fever which weakened him both physically and mentally. A medical examination was ordered by Commodore Matthew PeIry with the resulting pronouncement that Ringgold was insane. Relieved of command, Ringgold was sent home on the Susquehanna. In 1857, Ringgold underwent another medical review and was declared fully recovered and returned to active duty. He was promoted to Rear Admiral on the setired list in 1866 . 


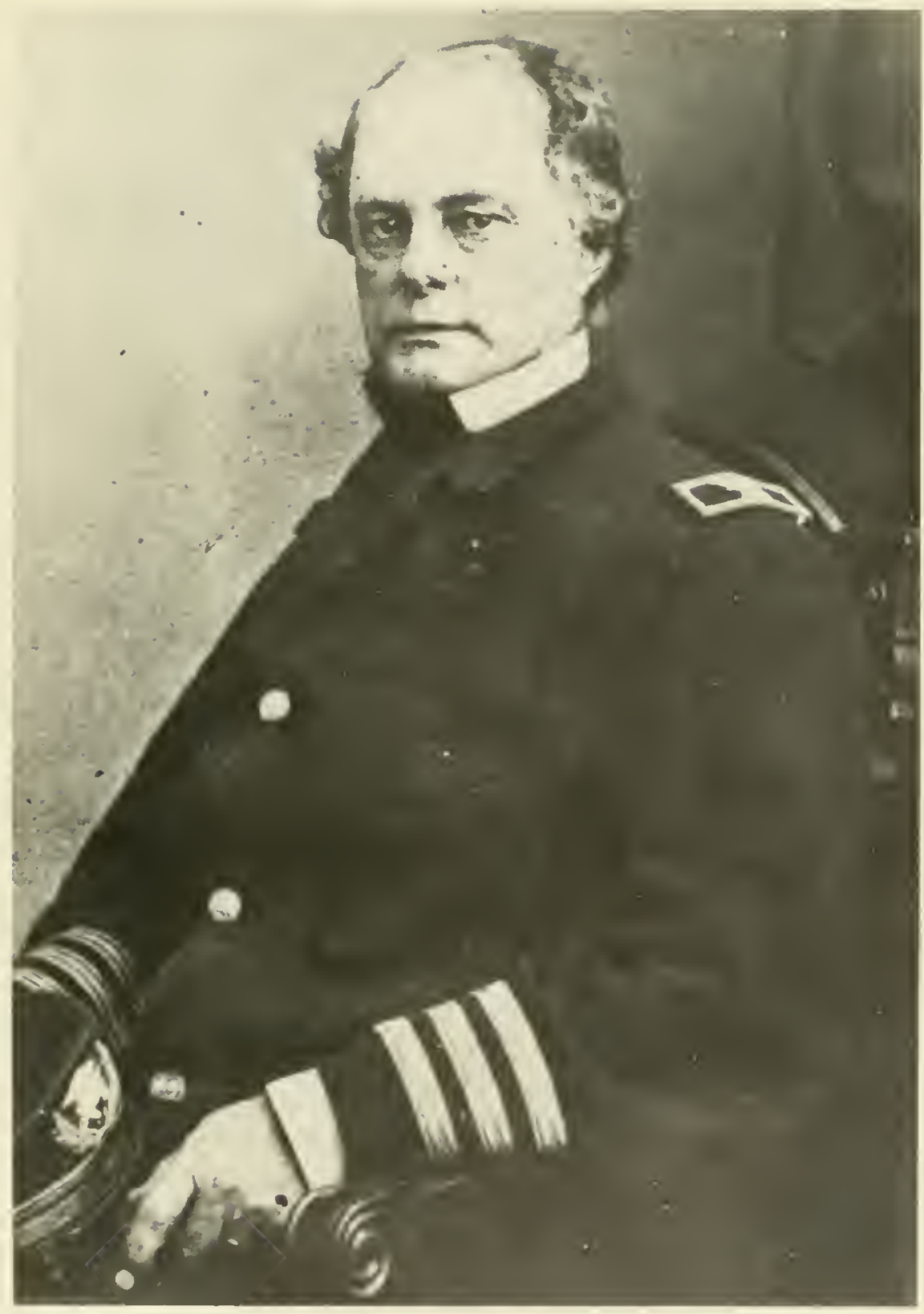

Rear Admiral John Rodgers,

U.S. Navy (1812 - J882)

Son of Commodore John Rodgers, he entered the Navy as a midshipman in 1828. In 1853 he was placed in command of the USS John Hancock and joined Commodore Cadwalader Ringgold's Northern Pacific and Arctic Surveying Expedition (1853 - 1856). In 1854 serious illness compelled Commodore Ringgold to relinquish command of the expedition to Rodgers, then a Lieutenant. Promoted to Rear Admiral in 1869, Rodgers also saw duty as Commander of the Naval Observatory. 


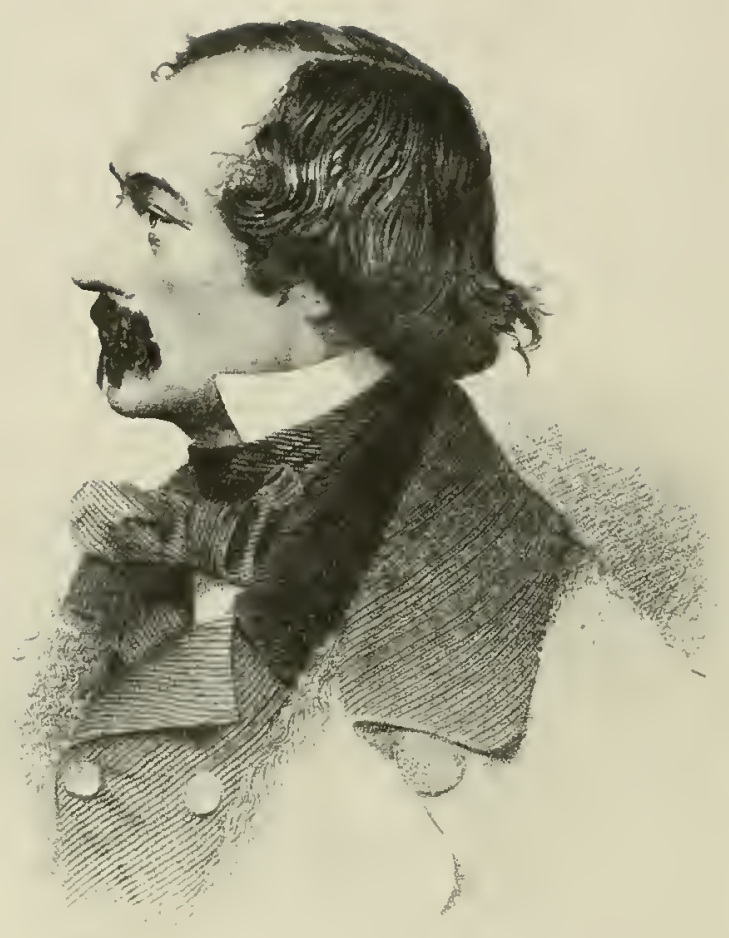

Passed Assistant Surgeon Elisha Kent Kane, U.S. Navy (1820 - 1857)

Graduated from the University of Pennsylvania Nedieal School in 1842, he became an Assistant Surgeon in the Navy the following year. In 1850, after serving in China, Africa and Mexico, he was assigned to the Coast Survey. However, in that same year he sought and obtained the position of senior medical officer of the unsuccessful Grinnell Arctie Expedition searching for explorer Sir John Franklin, lost since 1845. Kane organized and headed a second rescue expedition (Second Grinnell Expedition) which sailed from New York in 1853. Though scurvy-ridden and at times near death Kane pressed on. He charted Smith Sound (now called Kane Basin) and penetrated fartler nortl than any other explorer had done up to that time. At Cape Constitution he discovered ice-free Kennedy Channel, later followed by Ilayes, Hall, Greeley, and Peary in turn as they drove toward the North Pole. Kane finally had to abandon his icebound brig Adrance in May of 1855 and undertake an overland march of 83 days to reach safety. Kane returned to New York in October I855 and the following year he published lis two-volume ARCTIC EXPlEDITIONS. After visiting lingland, he sailed to Havana where he died on 16 February 1857, at the age of 37 . 


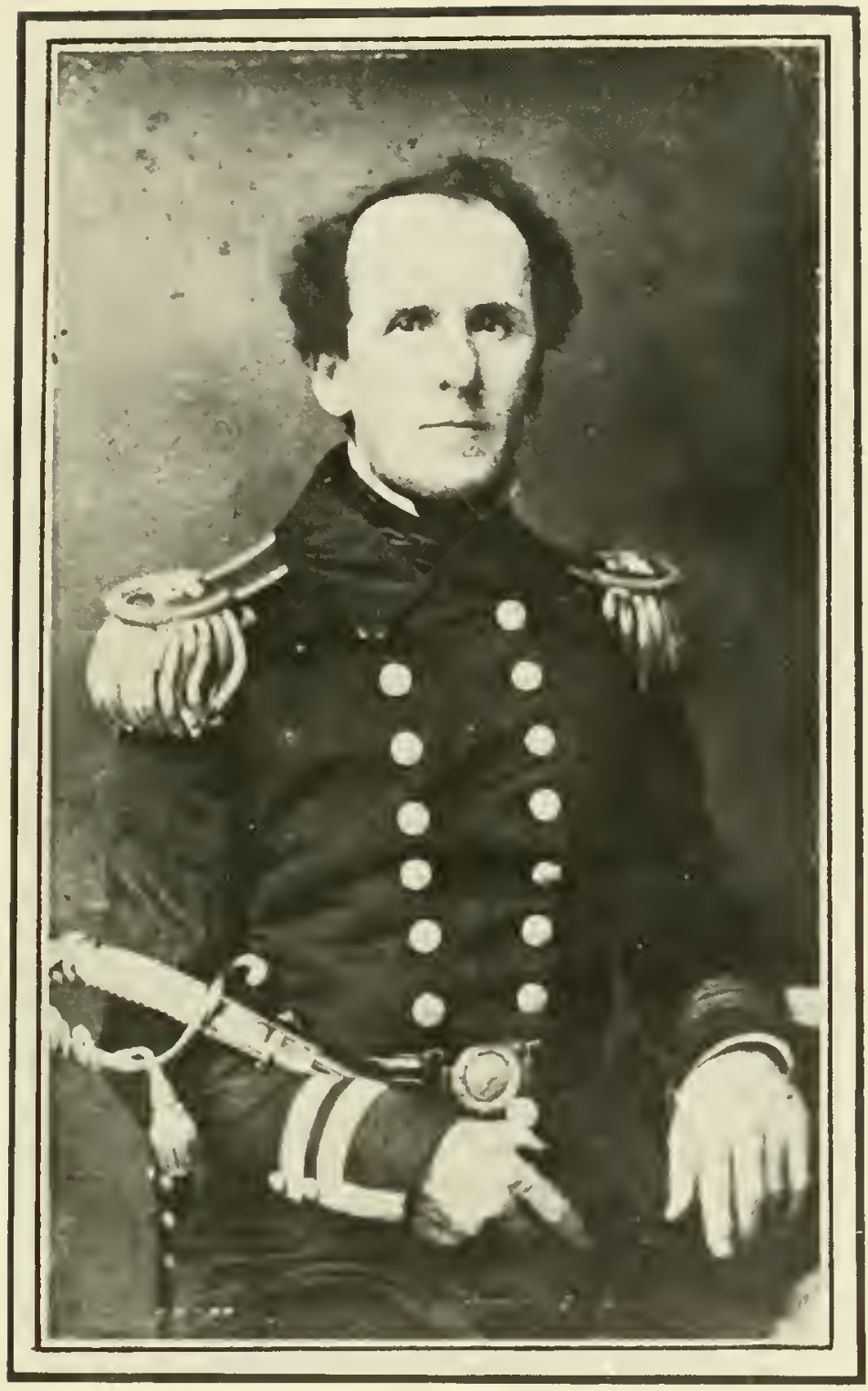

Captain William Francis Lynch, U.S. Navy (1801 - 1865)

In 1847 Lynch, tlien a Lieutenant, led an expedition to survey and explore the Dead Sea. Taking command of the storeship Supply, he sailed from New York to Acre carrying two metallic boats, one of copper and one of galvanized iron. From Acre he proceeded overland to the Sea of Galilee using camels to haul the hoats. After a 200-mile trip down the winding Jordan River, the Dead Sea was reached and three weeks were spent in charting and exploring its waters. In 1852, Lynch, now a Captain, explored the interior of Africa for purposes of possible colonization. Lynch resigned from the U.S. Navy in 1861 to cast his lot with the Confederacy. The oceanographic research ship T-AGOR 7 built in 1965 is named in his lionor. 


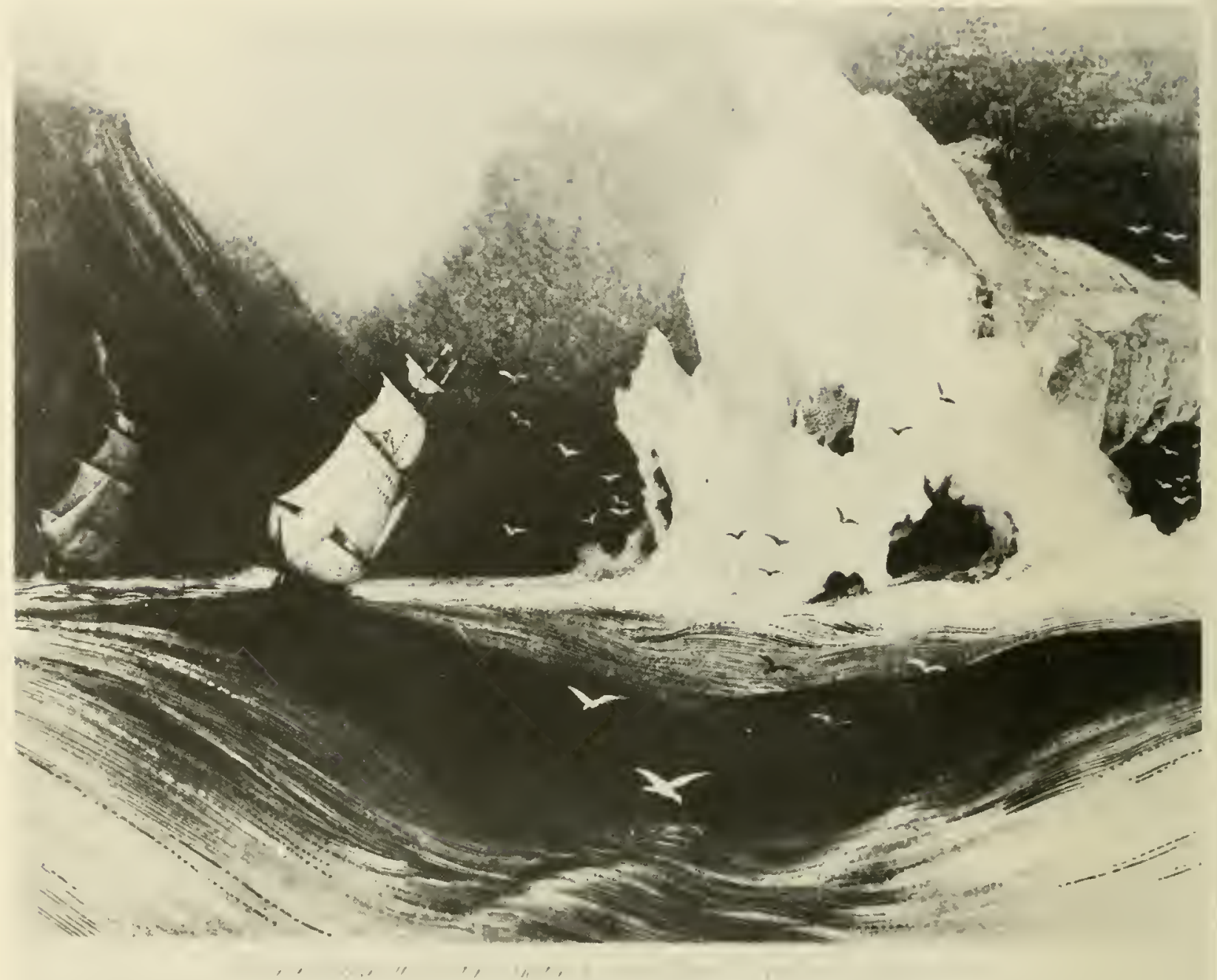

\section{U.S. Brig Advance}

The 140-ton brig Advance was loaned to the Navy by Henry Grinnell in 1850 as part of the First Grinnell Arctic Expedition to search for the explorer Sir John Franklin, missing since 1845. The expedition returned in 1851 without having found Franklin. In 1853, Grinnell again donated the Advance for the Second Grinnell Expedition under the command of Passed Assistant Surgeon Elisha Kent Kane, U.S. Navy. In 1855 the icebound Adrance was abandoned and his party undertook an overland trek of 83 days to safety. The Advance is shown here accompanied by the 90 -ton brig Rescue entering Lancaster Sound during the First Grinnell Expedition in 1850. 


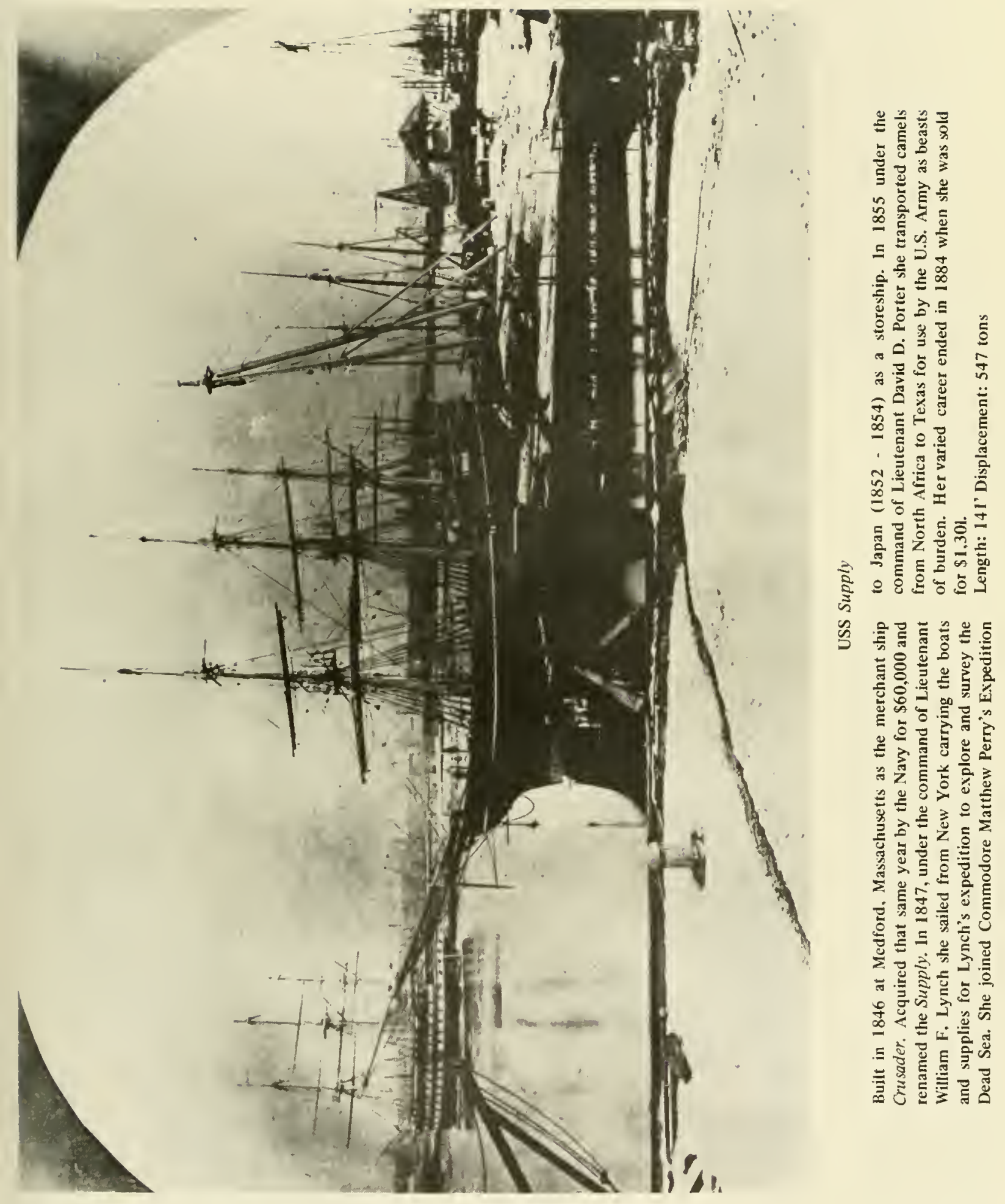




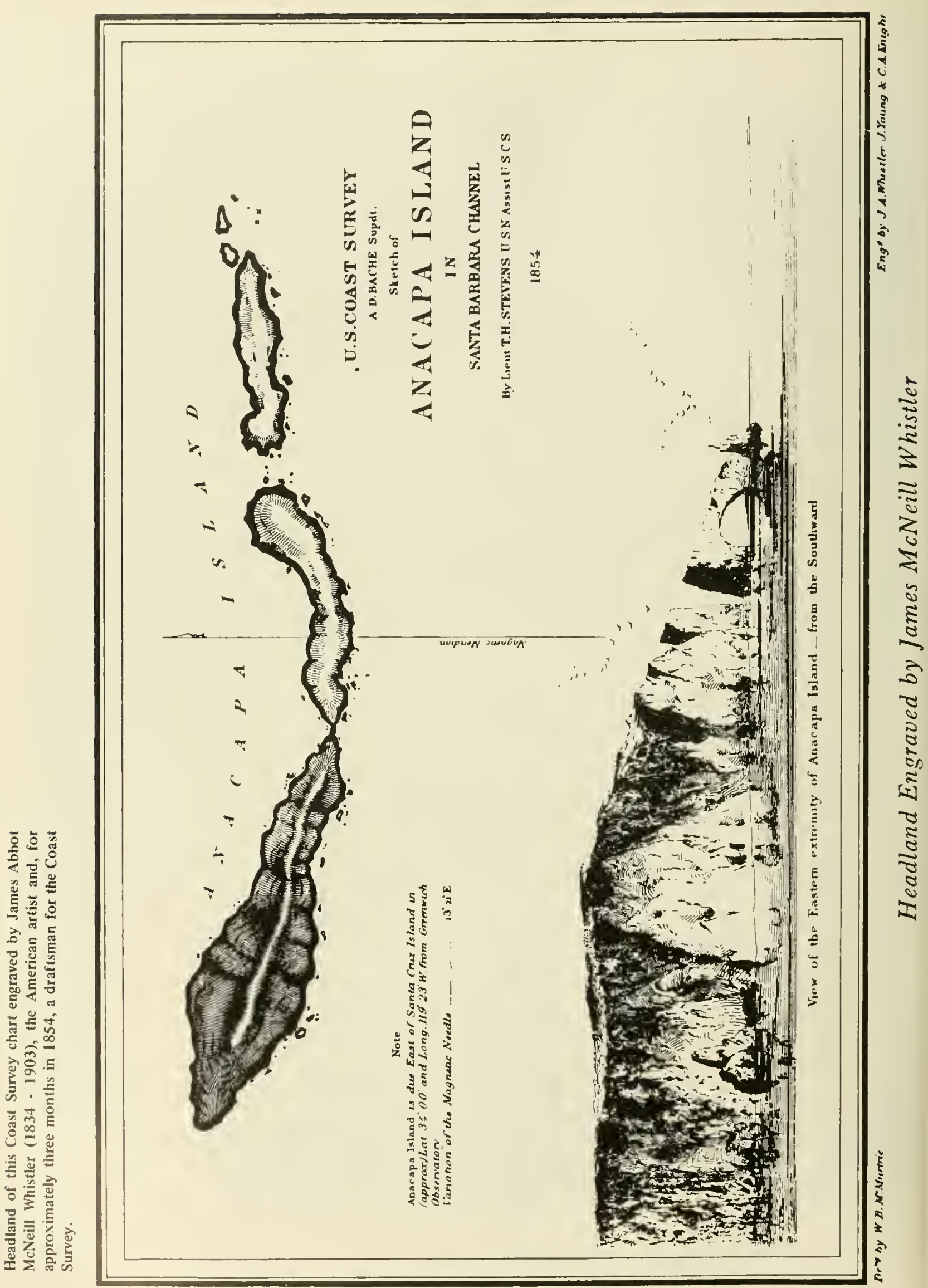




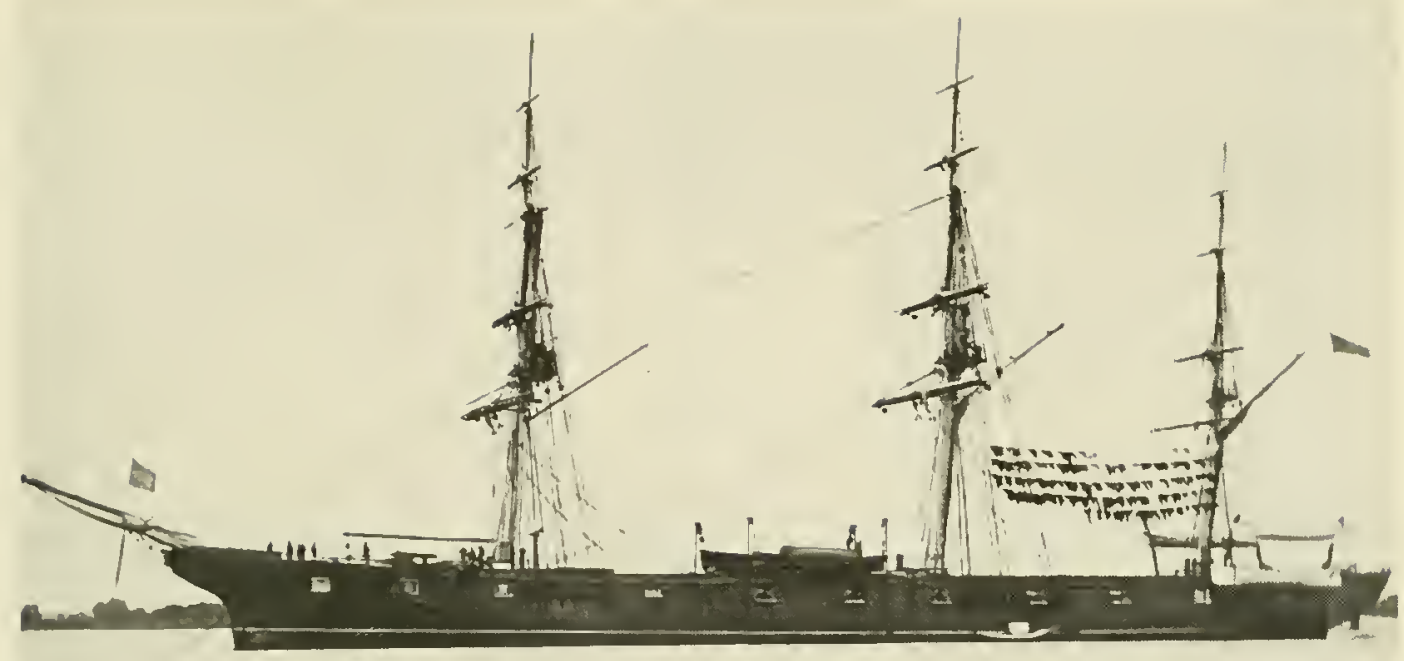

USS Alaska

A wooden screw gunboat built in 1869 by Boston Navy Yard. She was often assigned to survey duty, primarily in the Pacific. She also participated in Rear Admiral John Roger's Korean
Expedition in 1871. Alaska was disposed of in 1883. Her crew's laundry is shown drying out in her rigging.

Length: $250^{\circ} 6^{\prime \prime}$ Displacement: 2,400 tons

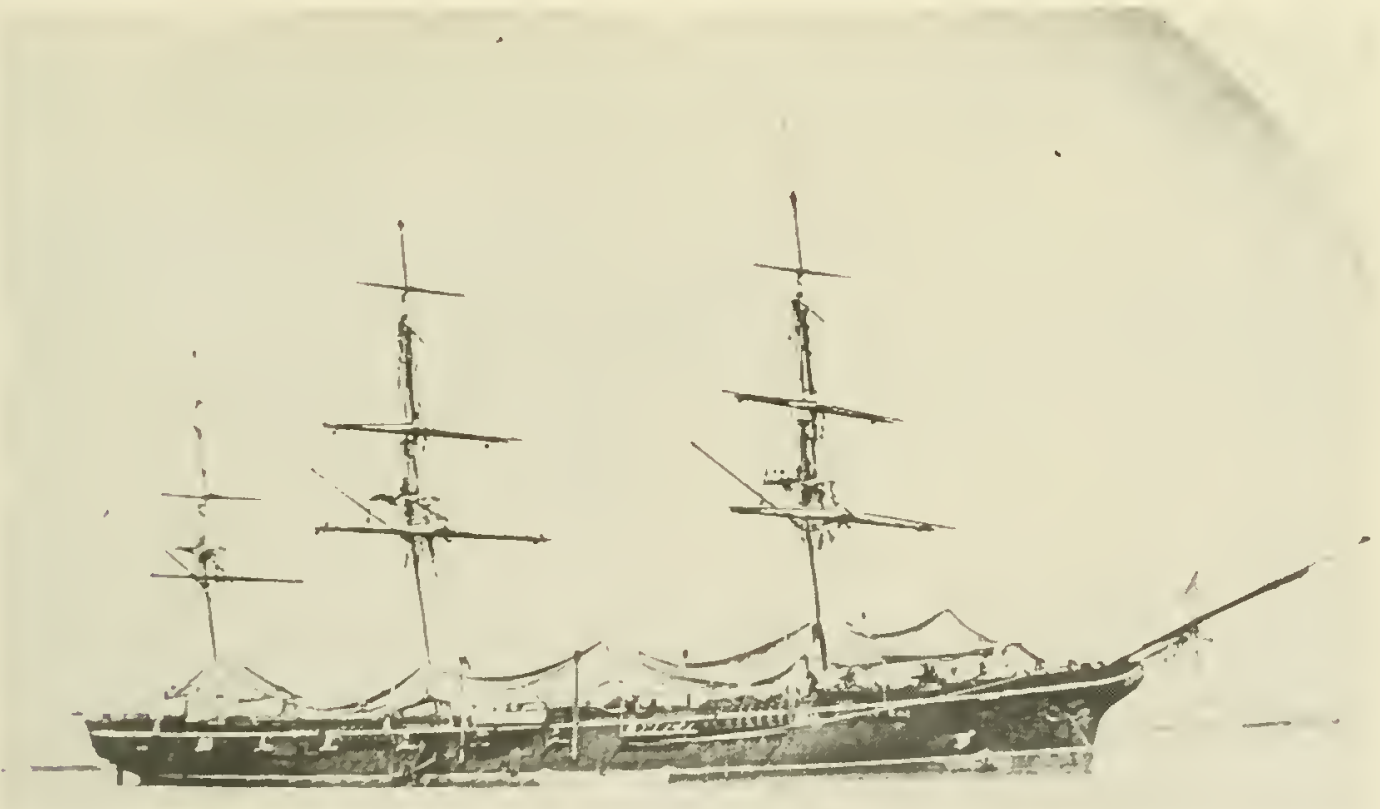

USS Benicia

A steam sloop-of-war huilt in 1869 hy Portsmouth Navy Yard. Her career, albeit short, was active.'Benicia operated with the Asiatic Fleet, sailed with Rear Admiral John Rodger's Korean Expedition in 1871 where she conducted surveys of Korcan waters, operated with the North Pacific squadron and in the
Ilawaian Islands. In 1874 she carried Ilis Majesty King Kalakaua and his suite from Honolulu to San Francisco. Laid-up at Mare Island Navy Yard in 1875, Benicia was finally sold in 1884 at public auction.

Length: 250" 6" Displacement: 2,400 tons 


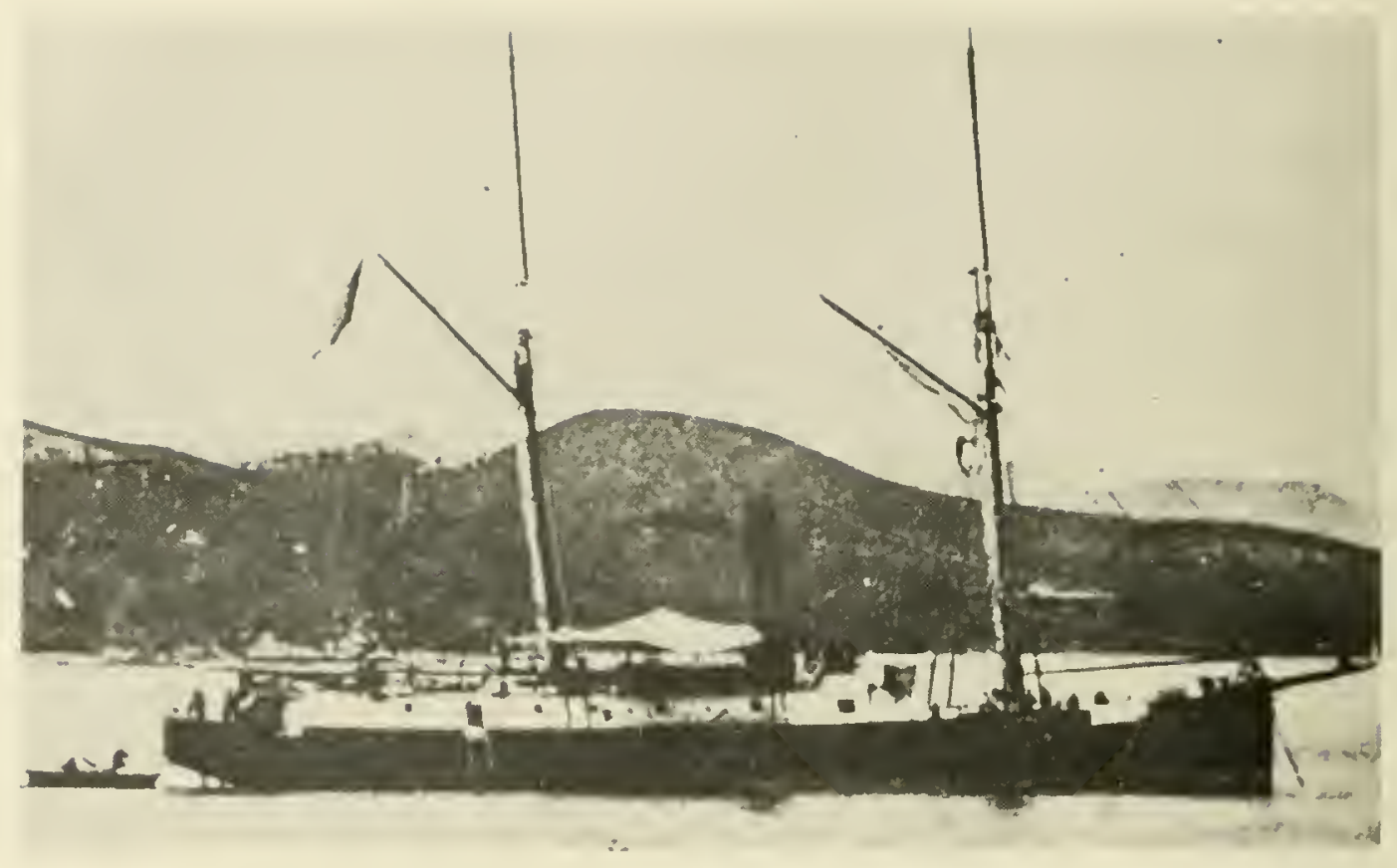

USS Palos

An iron hull, screw gunboat built in 1866 by James Tetlow of Boston, originally as a screw tug. She served as a yard tug at Boston Navy yard until 1870 when she was reclassified as a gunboat and sailed for Asiatic duty via the Suez Canal where she became the first U. S. ship of war to pass through the Canal. Palos was sold in 1893 at auction in Nagasaki.

Length: 137' Displacement: 420 tons

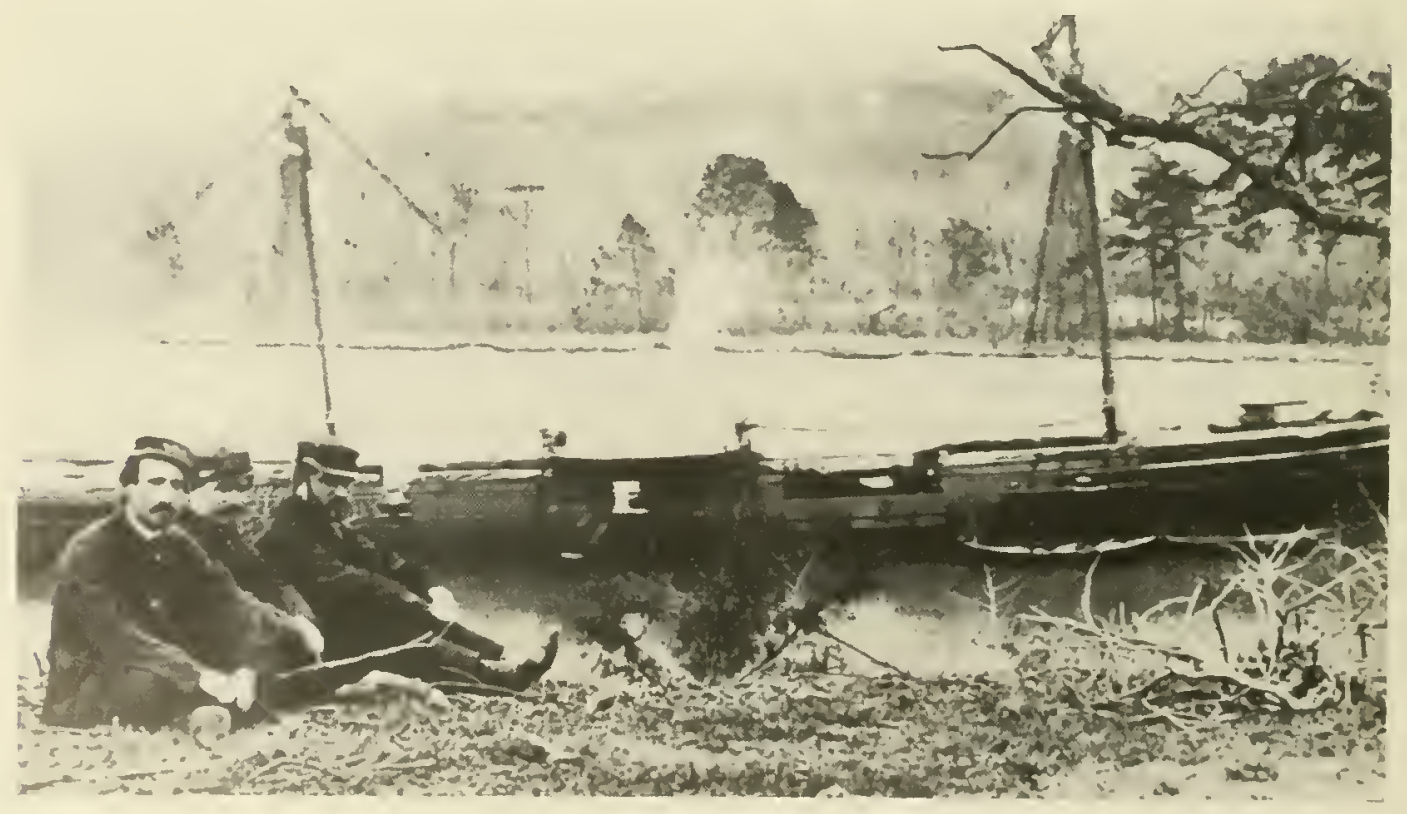

\section{USS Kansas}

A steam gunboat built in 1863 by Philadelphia Navy Yard. A veteran of the Civil War, Kansas made several surveying expeditions to Central America for potential inter-oceanic canal routes. Laid-up at Portsmouth Navy Yard in 1875. she was finally sold in 1883 .

Length: $129^{\prime}$ 6" Displacement: 625 tons 


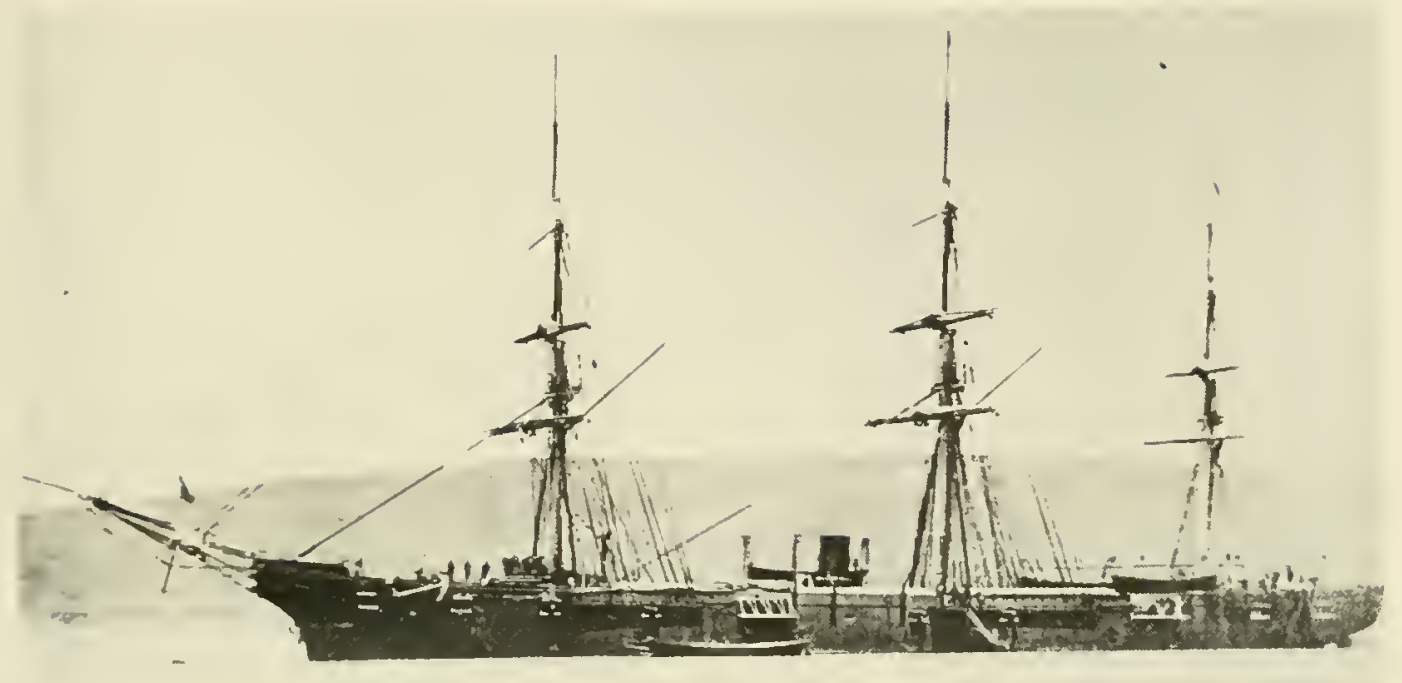

USS Lackawanna

A wooden hull, steam sloop-of-war built in 1863 by New York Navy Yard. Operating primarily in the Pacific, she was often assigned to survey duty. Decommissioned in 1885 , she was sold in 1887 at Mare lsland.

Length: $237^{\circ}$ Displacement: 2,526 tons

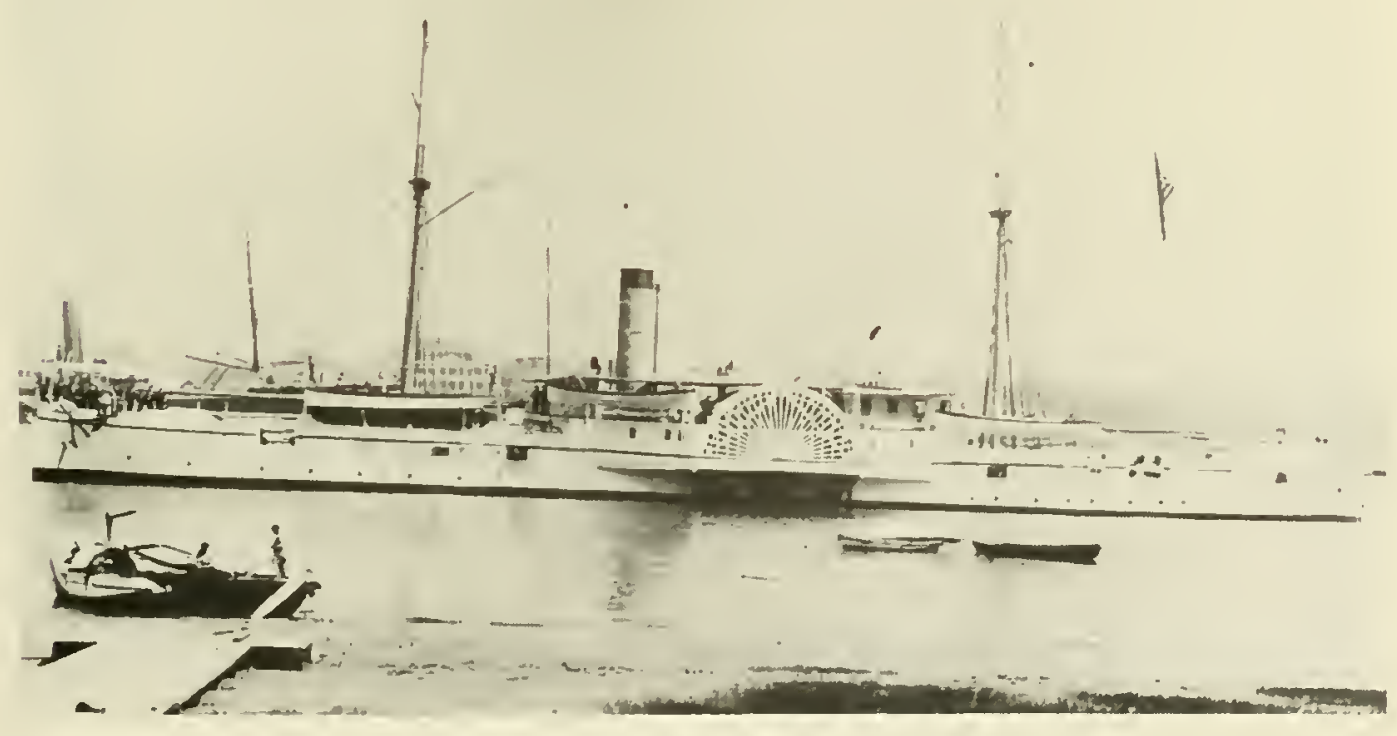

\section{USS Monocacy}

A sidewheel gunboat built in 1866 by A. \& W. Denmead and Son of Baltimore. Assigned to the Asiatic Station, Monocecy remained there until decommissioned in 1903, a period of service so long that the light-draft gunboat was given the nick-name "Jinrikisha of the Navy". Surveying the waters of Japan, Korea and China occupied much of her time. Monocacy was sold in 1903 at Nagasaki.

Length: 265' Displacement: 1,370 tons 


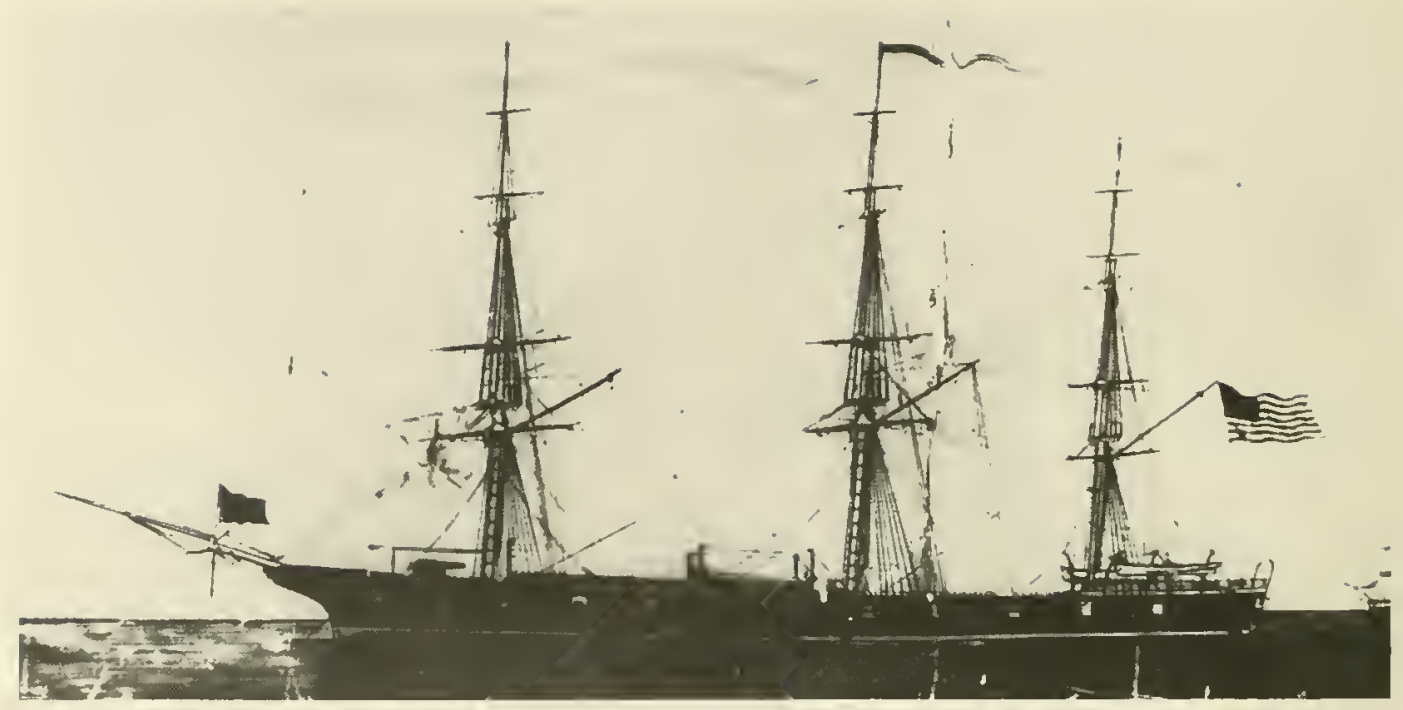

USS N'achusent

A screw sloop of war built in 1862 by Boston Navy Yard. Conducted routine survey operations, primarily in the Pacific. She was disposed of in 1887.

Length: 201' 4" Displacement: 1.488 tons

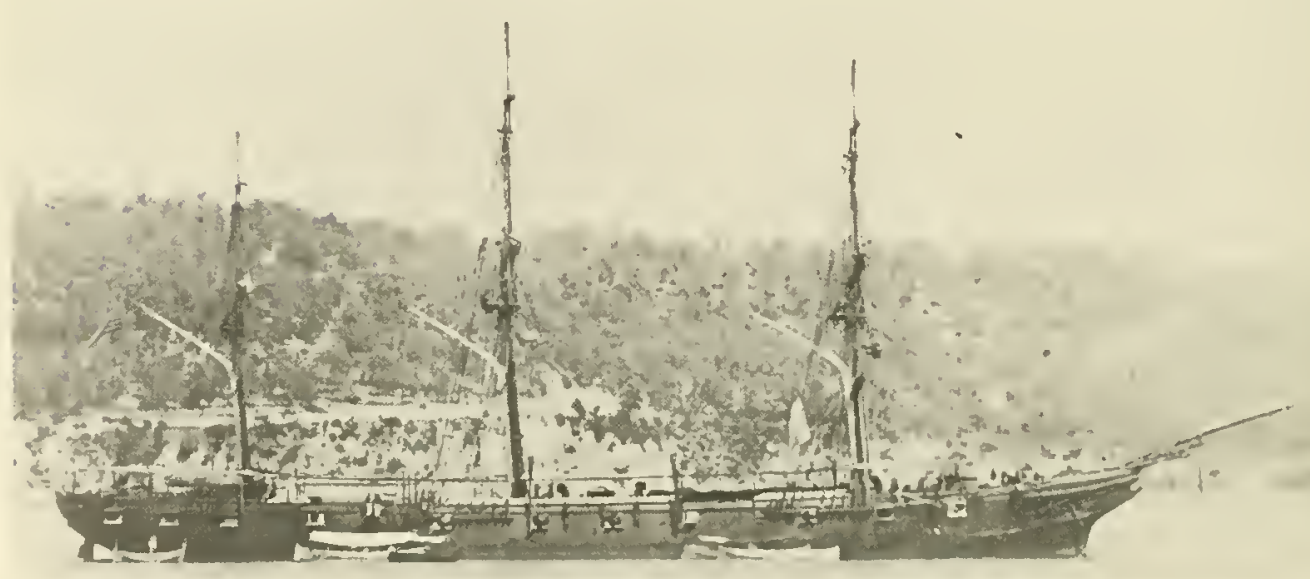

USS Shenandoah

A steam sloop-of-war built in 1863 by Philadelphia Navy Yard. Between 1866 and 1869, conducted many harbor and river surveys in Japan and Korea. Sle was disposed of in 1886.

Length: $237^{\circ}$ Displacement: 2,030 tons 


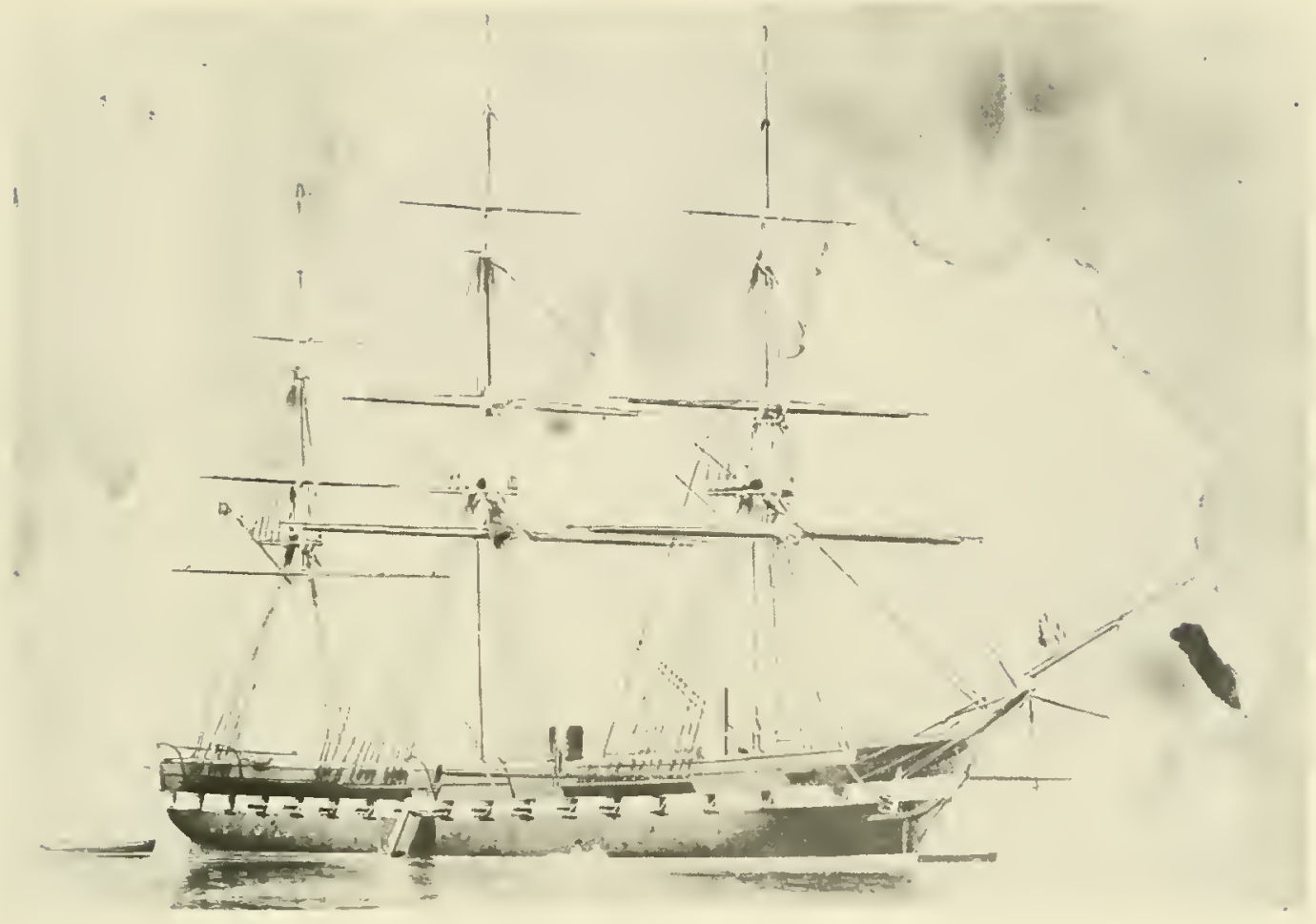

USS Narragansett

A second class, wooden hull, screw sloop built in 1859 by Boston Navy Yard. From 1873 to 1875 , under the command of Commander George Dewey, she surveyed trade routes in the
Pacific. She was laid up in 1875 at Mare Island Navy Yard until sold in 1883.

Length: 186 Displacement: 804 tons

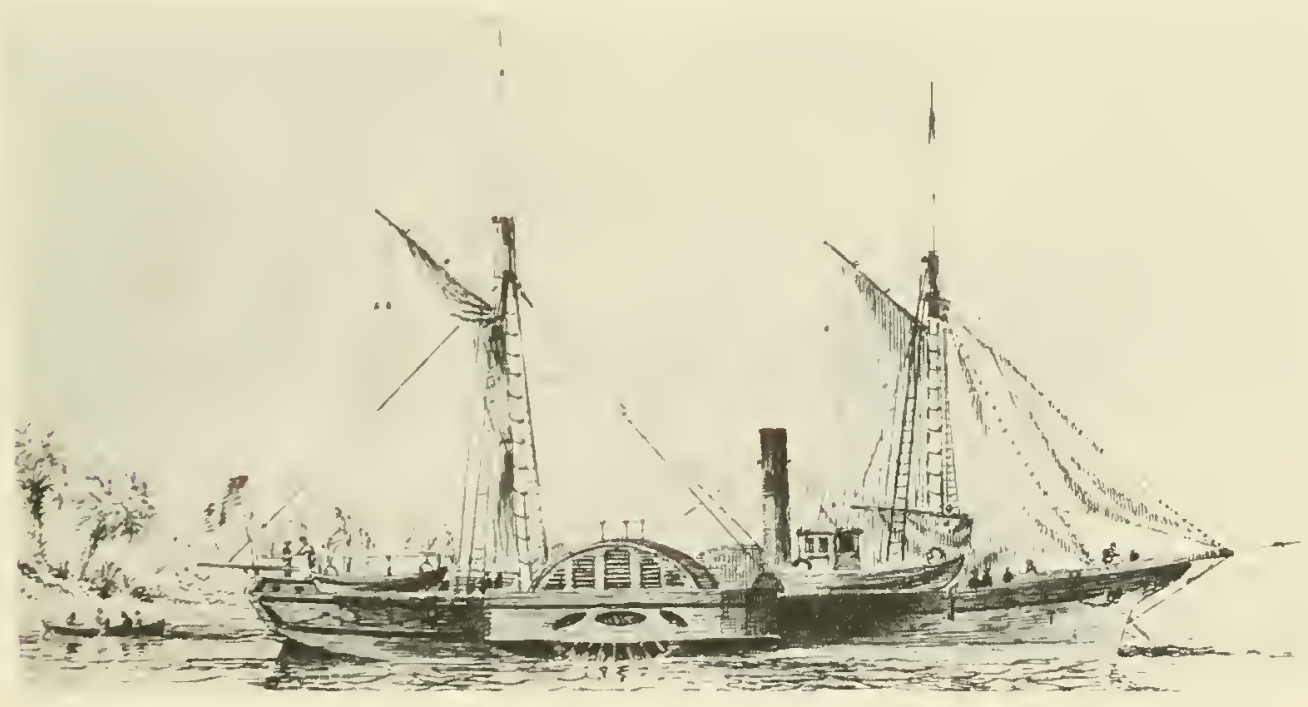

Coast Survey Steamer Bibb

A 150-foot sidewheel steamer used by the Survey from 1853 to 1873 . 


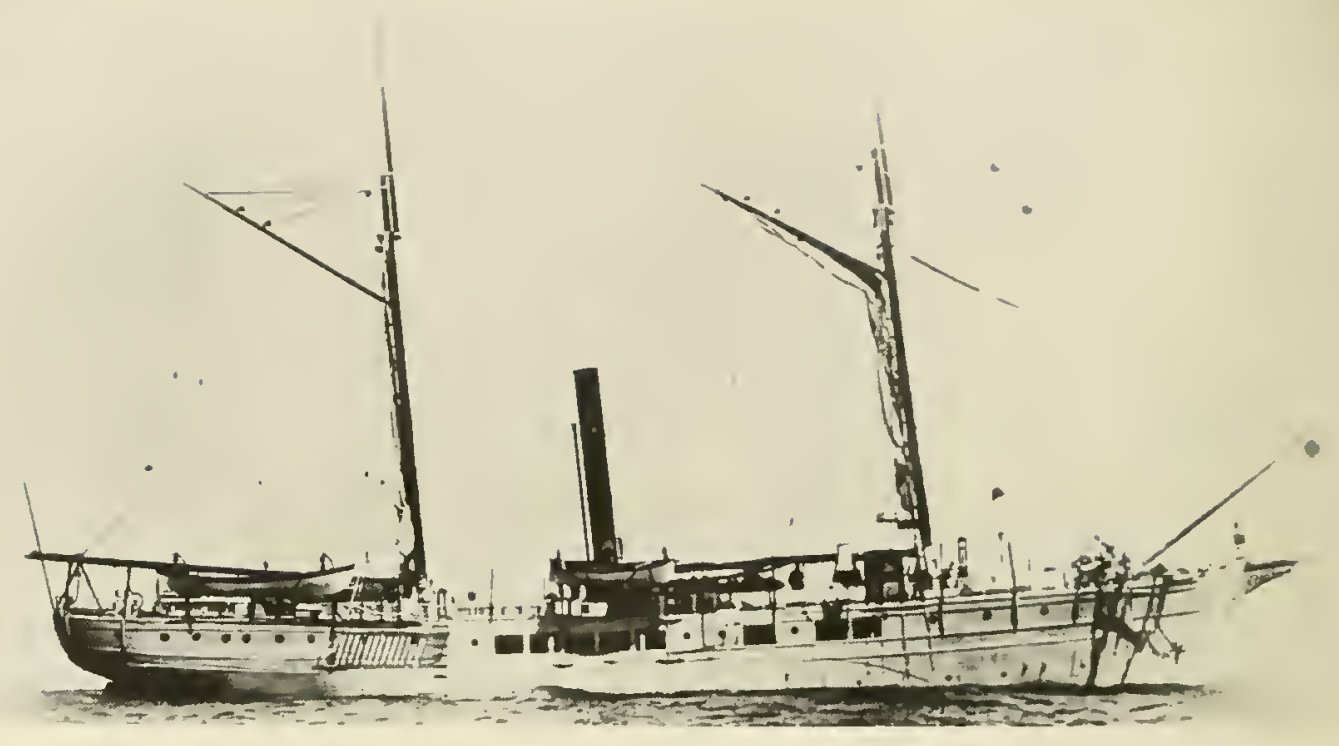

Coast Survey Steamer Blake

A 148-foot steamer built in 1874 for the Coast Survey and in service until 1905 .

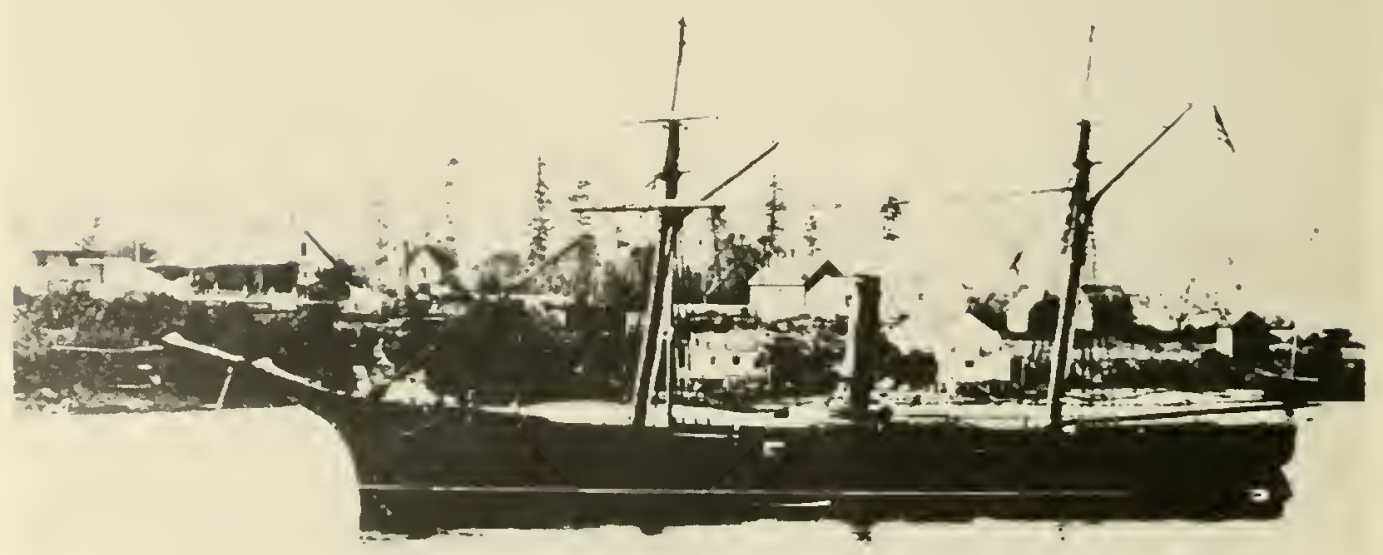

U.S. Revenue Cutter Lincoln

In 1867, Lincoln was dispatched to work with the Coast Survey on the first official United States exploration of Alaskan waters after the Territory was acquired from Imperial Russia. 


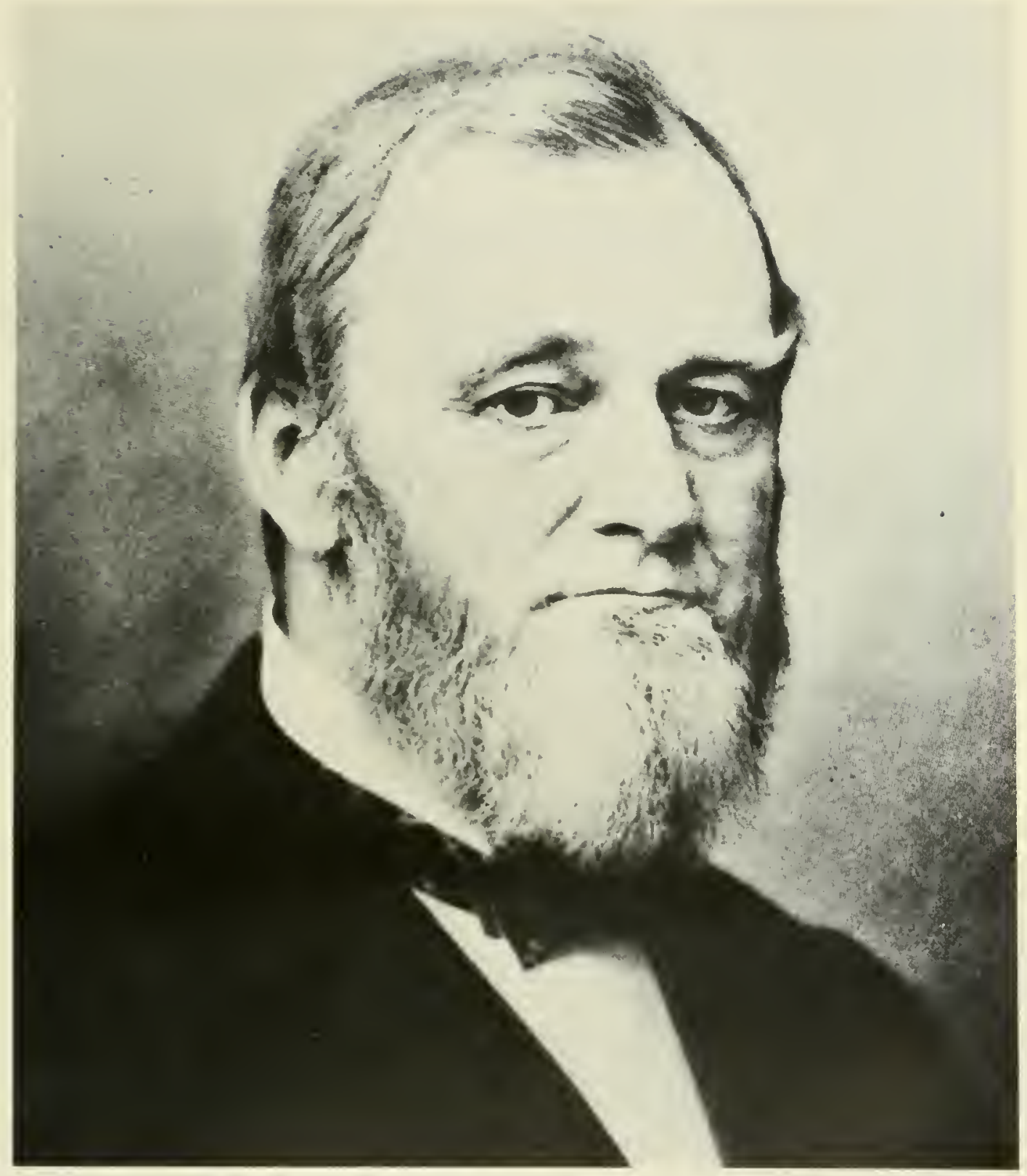

Spencer Fullerton Baird (1823 - 1887)

Secretary of the Smithsonian institution and, concurrently, first Commissioner of the U.S. Fish Commission from 1871 until his death in 1887 at Woods Hole, Massachusetts. 


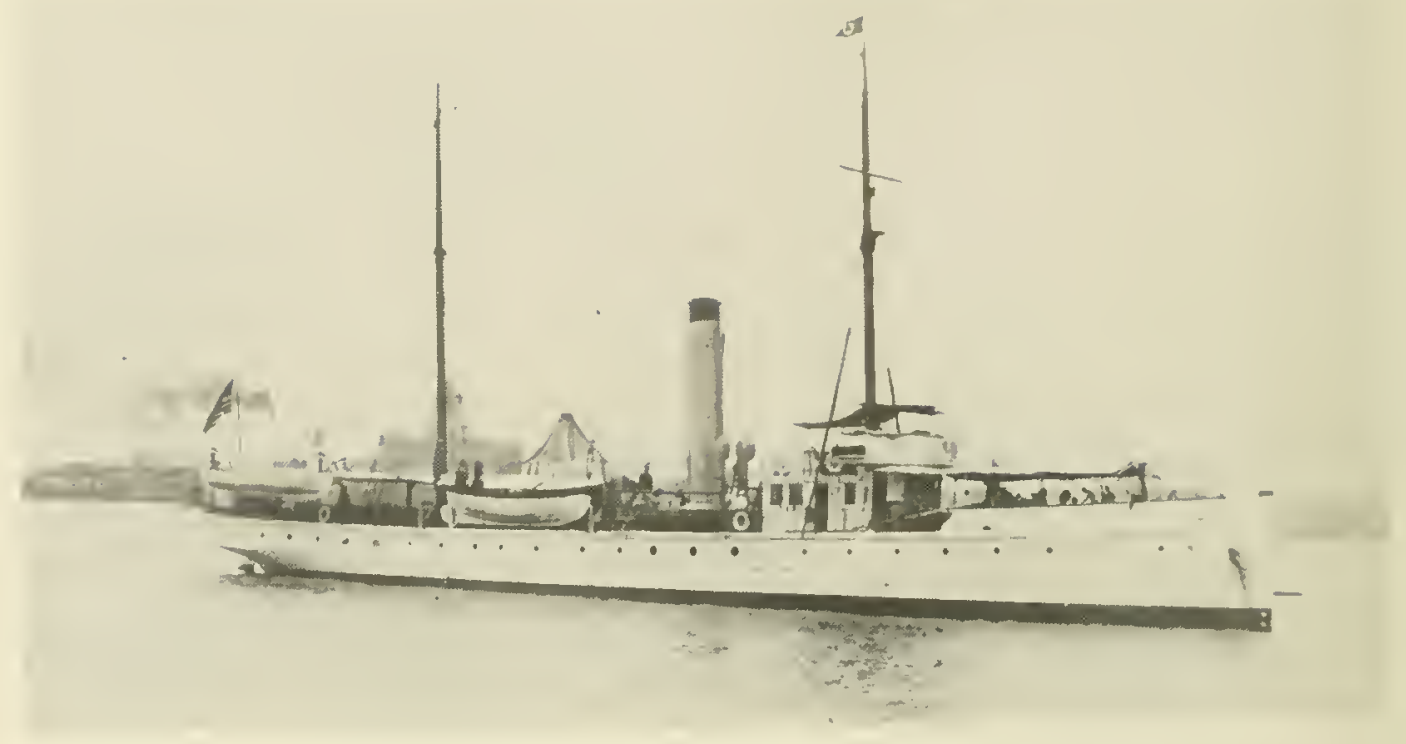

Coast Survey Steamer Bache

A 145-foot steamer huilt in 1872 by the Coast Survey and in service until 1901 .

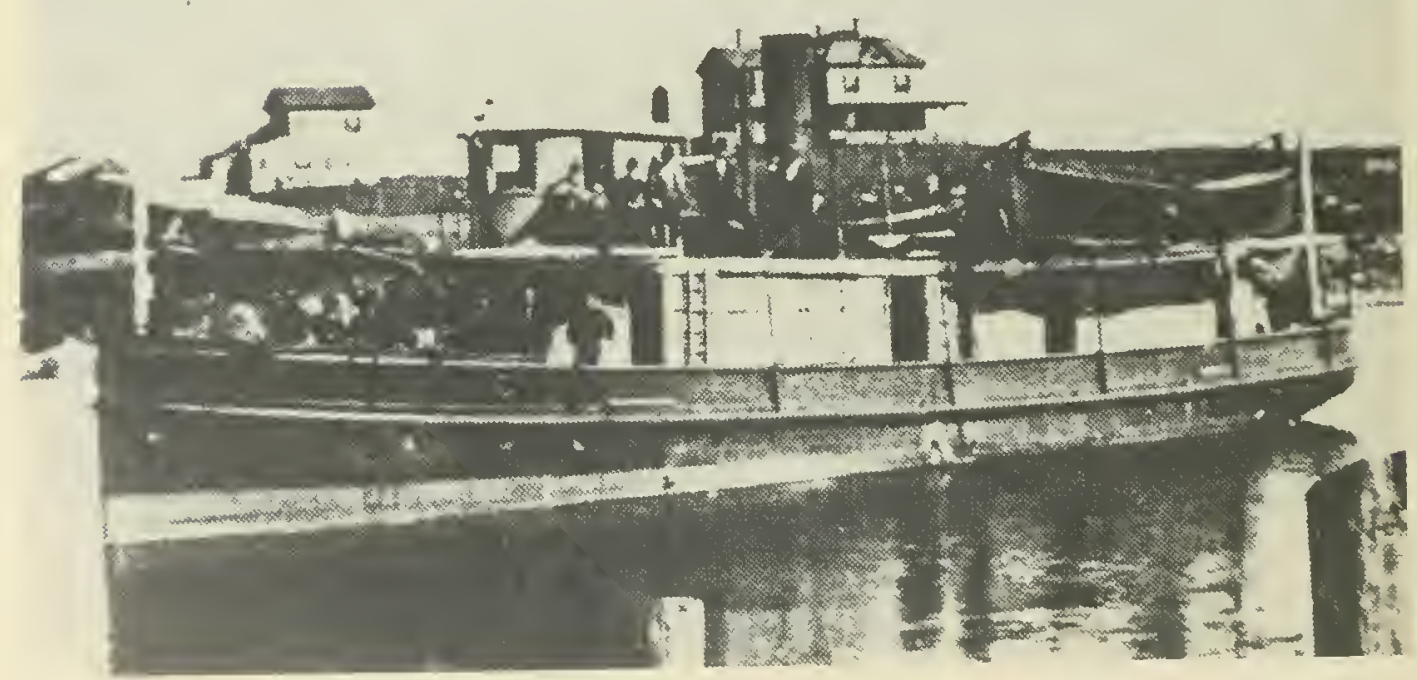

\section{USS Bluclight}

A steam screw tug built in 1864 by Portsmouth Navy Yard. Her inglorious career as a yard tug was temporarily interrupted when in 1873, she was assigned to the Fish Commission's laboratory at Woods Hole, Massachusett. Sle was disposed of in 1883.

Lengtls: $100^{\circ}$ Displacement: 100 tons 


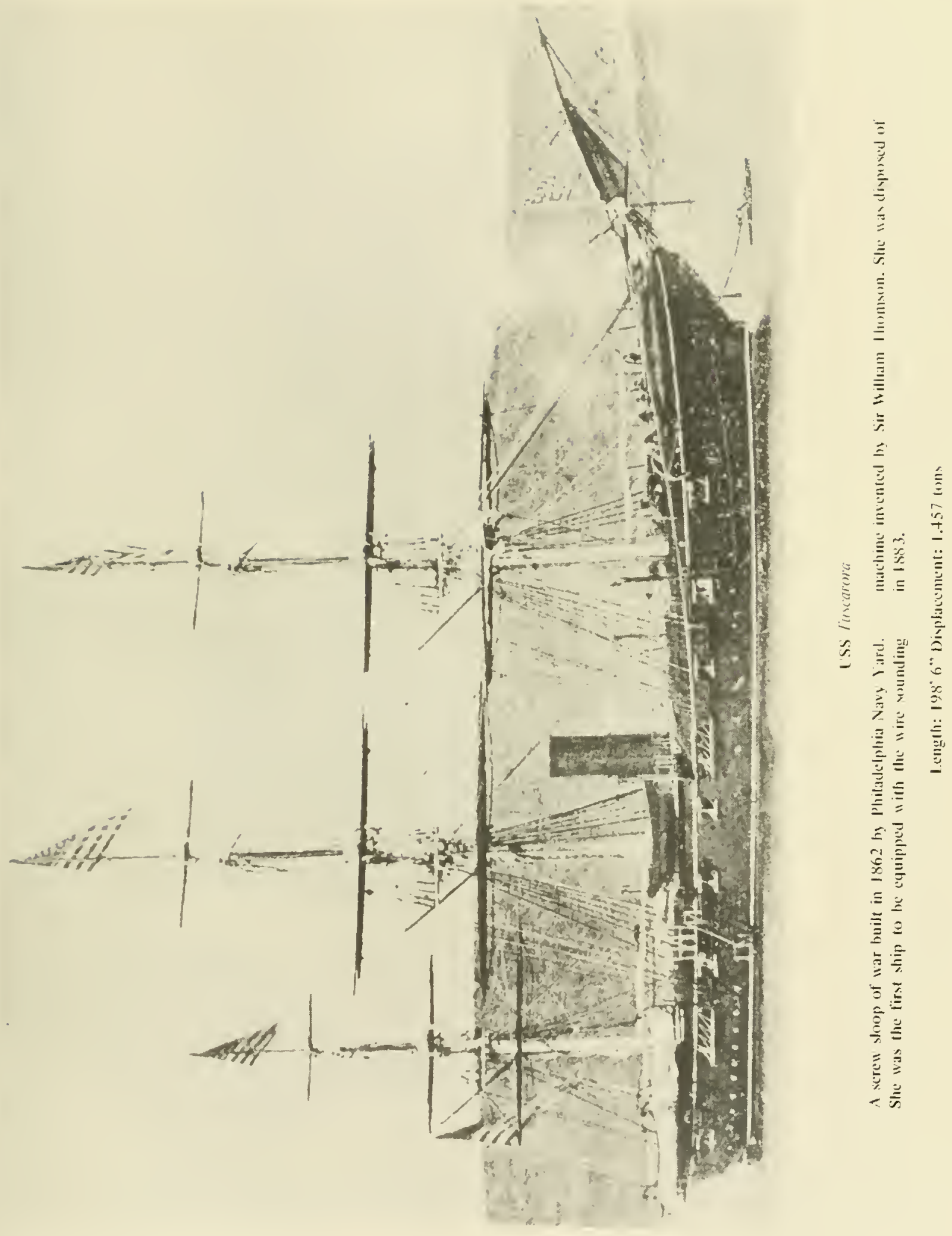




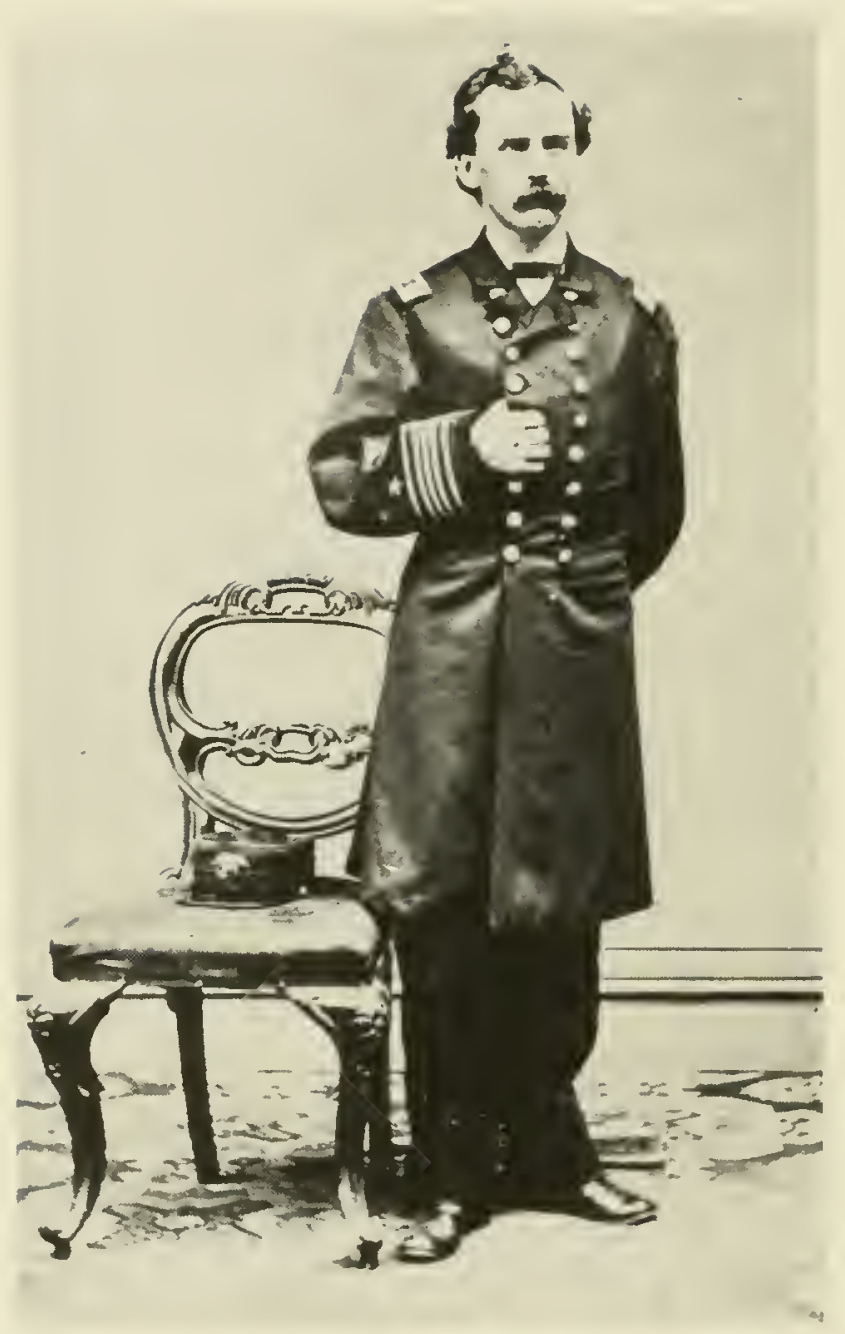

Rear Admiral George Eugene Belknap U.S. Navy (1832-1903)

Belknap perfected the piano-wirc sounding machine invented by Sir William Thomson. The sloop Tirscarora. under Belknaps command, was assigned a two year mission (1873 - 1874) to survey a cable route from the United Stales to lapan. The lirst ship to be equipped with a Thomson Sounding Machine, the Tuscarora successfully demonstrated the use of wire over rope for taking soundings. 


\section{SOUNDING OUTFIT \\ OF \\ USS TUSCARORA \\ FOR THE \\ NORTH PACIFIC OCEAN SURVEY \\ (1873 - 1874)}

1 Sir William Thomson's sounding-machine for piano-wire, loriginal pattern), with spare drum.

1 sounding-machine for rope, with steam-reel, and a dynamometer designed by Passed Assistant Engineer T. W. Rae, loriginally fitted for the Juniatal.

10 Brooke's sounding-rods.

6 Brooke's sounding rods, (long).

15 Brooke's modified attachment and sinkers.

210 slings for Brooke's sounding-apparatus.

11 Sands' cups for sounding-purposes.

1 spare spring for sounding-purposes.

6 Fitzgerald's sounding-apparatus.

8 sounding-cylinders.

100 copper sleeves for sounding-rods.

1 Massey's registering-apparatus.

1 Trowbridge's registering-apparatus.

600 bored shot, VIII-inch, for sinkers.

50 bored shot, 32-pounder, for sinkers.

25 bored shot, XV-inch, for sinkers.

Square sinkers, 18 to 30 pounds, for the Fitzgerald apparatus.

Split sinkers, from 20 to 300 pounds.

1200 -pound sounding-lead.

2 150-pound sounding-lead.

2 100-pound sounding-lead.

6 90-pound sounding-lead.

180 -pound sounding-lead.

1 50-pound sounding-lead.

180 pounds piano-wire, Birmingham gauge No. 22.

950 pounds Albacore line, 13/4 inch untarred hemp, 9 thread).

2,270 pounds $11 / 4$ inch Manilla whale-line.

1,700 pounds $21 / 2$ inch Manilla carbolized line.

3,750 pounds $11 / 4$ inch carbolized line.

2,800 pounds $11 / 2$ inch carbolized line.

1,575 pounds $13 / 4$ inch carbolized line.

665 pounds $11 / 4$ inch lead-line.

590 pounds $11 / 2$ inch lead-line.

9 dozen cod-line.

1 Burt's buoy and nipper.

3 accumulators.

3 iron dredge-frames.

22 surivels

1 galvanized-iron tub.

12 Miller-Cassella thermometers.

6 self-registering thermometers, (Saxton's).

1 standard thermometer.

1 photographic apparatus.

1 microscope.

100 glass bottles for specimens of the bottom.

4 cans of caustic soda for preserving the wire.

Drawing-instruments and materials.

Surveying-instruments. 


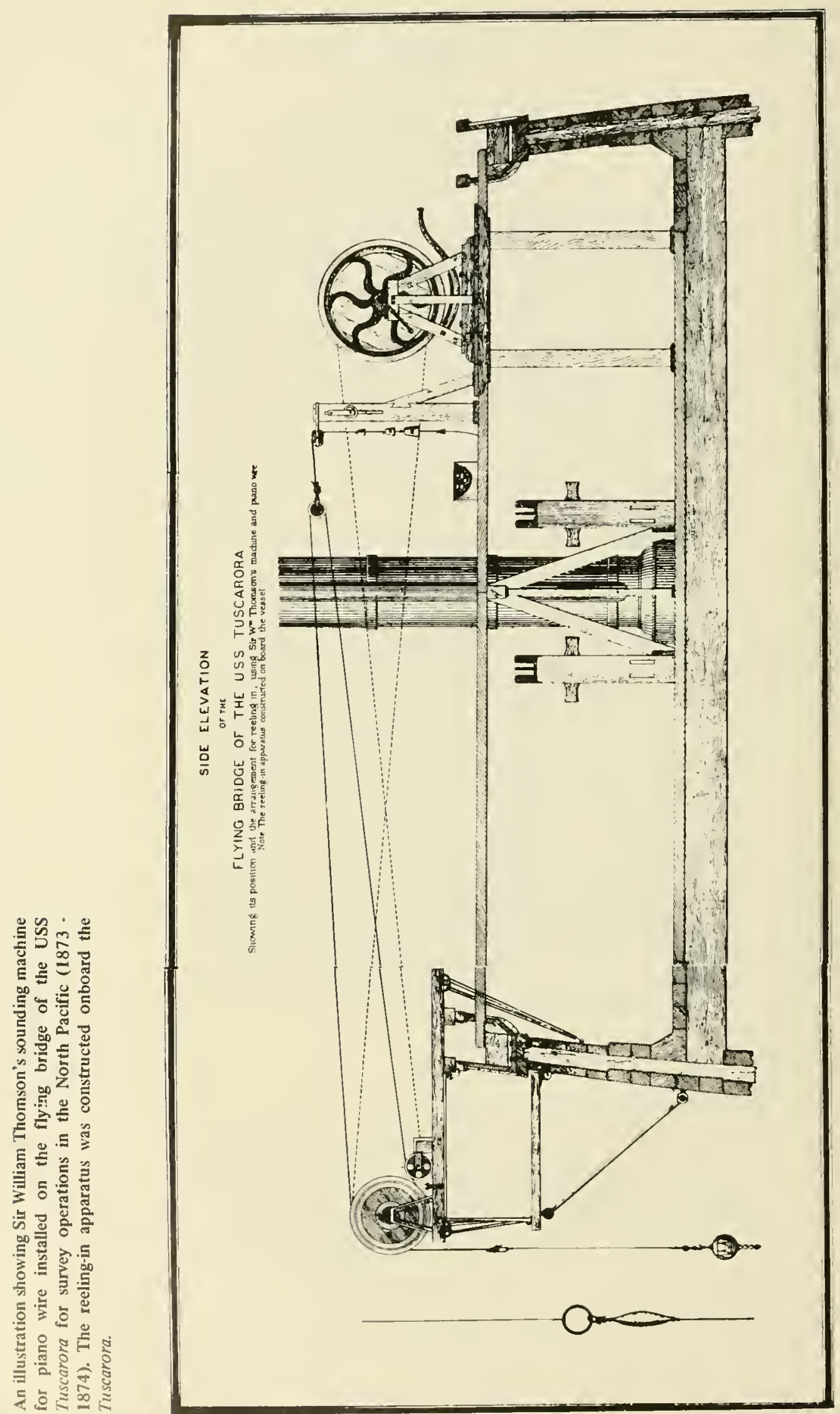




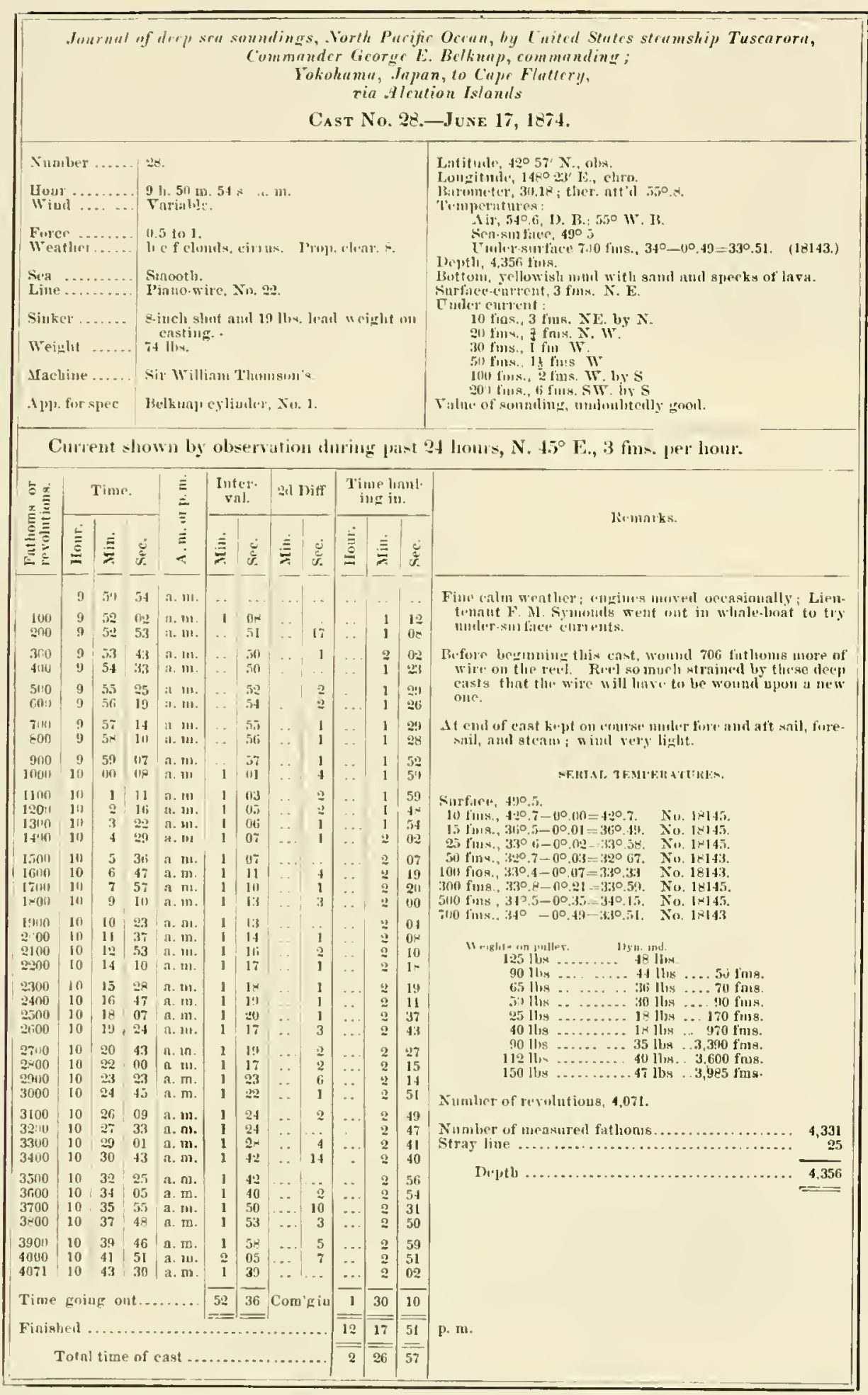

An extract from the official journal of the USS Tuscarora recording the deepest bottom specimen obtained with a sound- ing cast (Cast No. 28 - June 17, 1874) using the Thomson sounding machine for piano wire. 


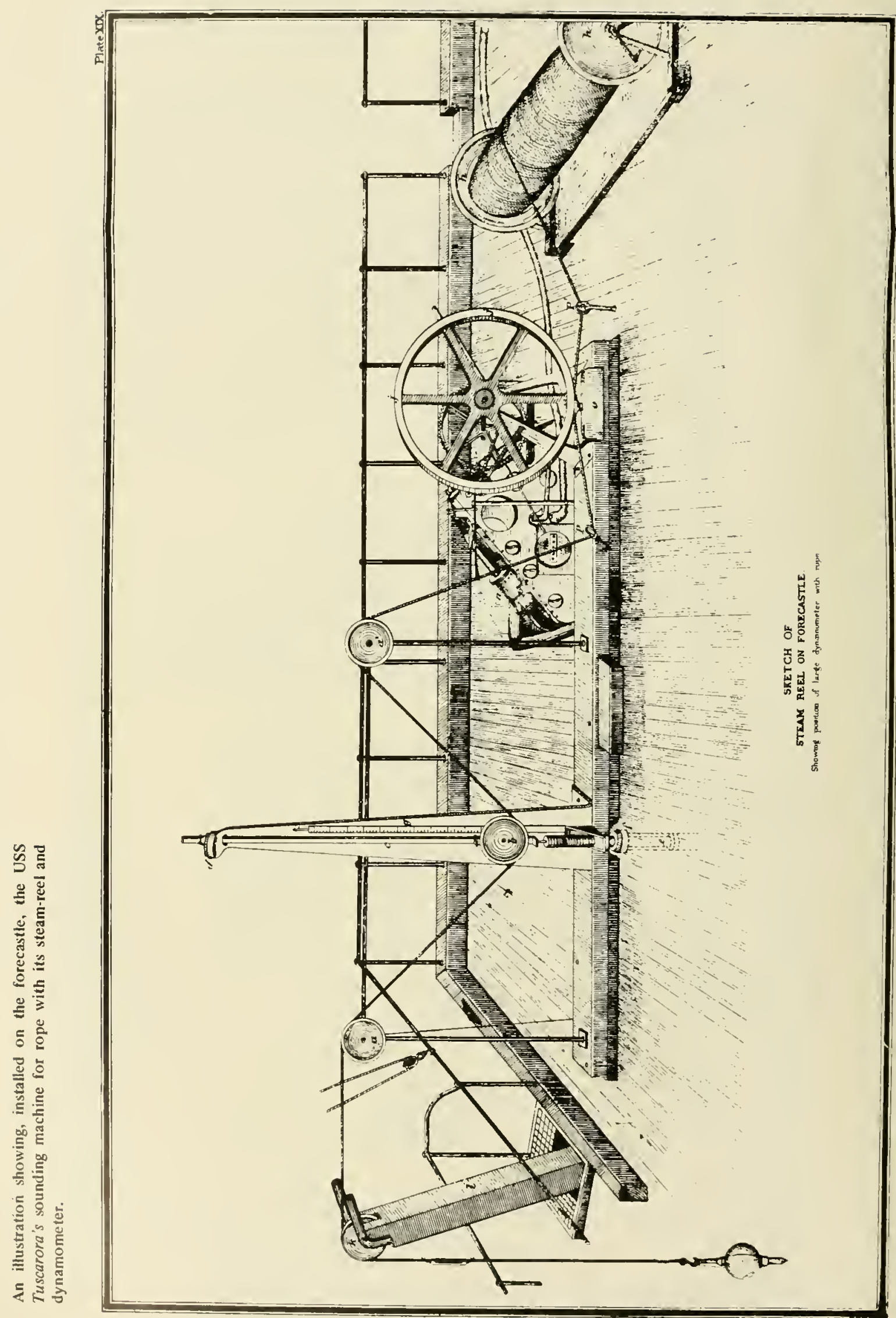




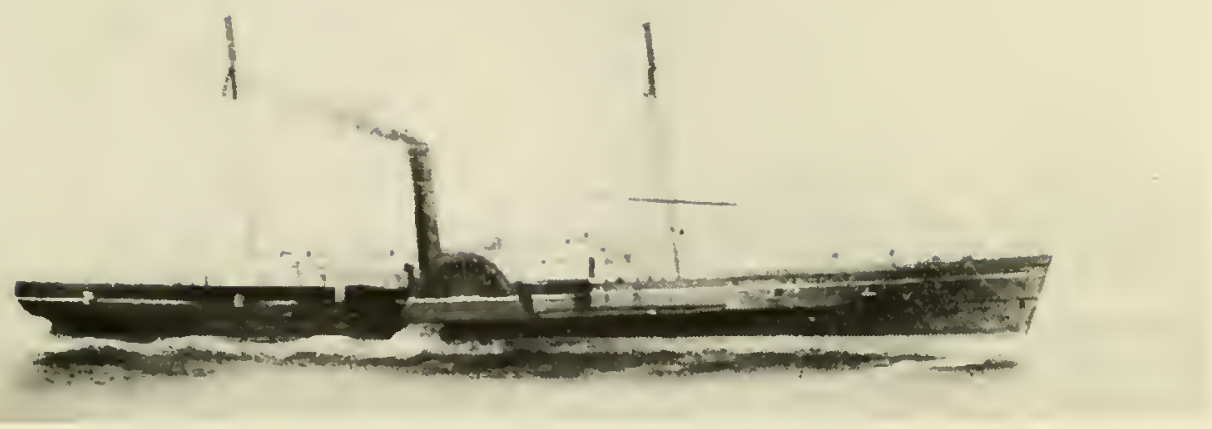

USS Gettysburg

An iron-hulled, screw, steamer built in 1858 at Glasgow, Scotland and originally named Dougiass, then Margaret and Jessie. She was captured as a blockade runner in 1863 and purchased the following year by the Navy from the New York Prize Court and renamed Gettysburg. Following her service in the Civil War, she assisted in the laying of a telegraph cable from Key West to Havana in 1868 . Between 1873 and 1875 she supported the survey teams and engineers engaged in seeking routes for an inter-oceanic canal. In 1876 she conducted surveys for the Hydrographic Office in the Caribbean and from 1877 to 1879 she was assigned special duty to the Mediterranean to obtain navigational information about coasts and islands of the area. Following her two year Mediterranean survey expedition, Gettysburg was sold in 1879.

Length: 221' Displacement: 950 tons

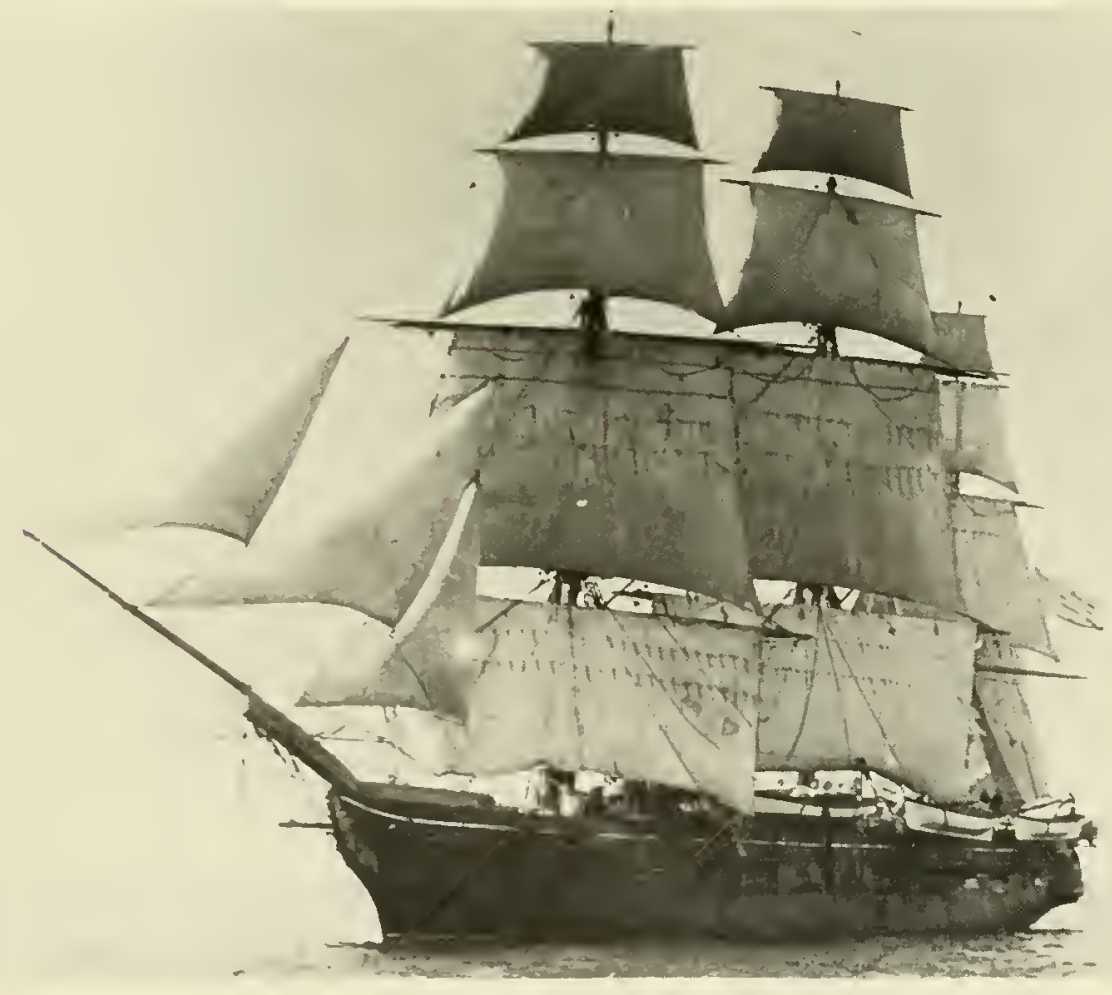

USS Jamestown

A sloop-of-war built in $\mathbf{1 8 4 4}$ at Gosport, Virginia. From 1876 to 1879, she operated in the Hawaiian Islands as a State Public Marine School. Returned to the Navy in 1879, Jamestown was assigned to survey the harbor of Sitka, Alaska. She was destroyed by fire at Norfolk Navy Yard in January 1913.

Length: 163' 6" Displacement: 1,150 tons 


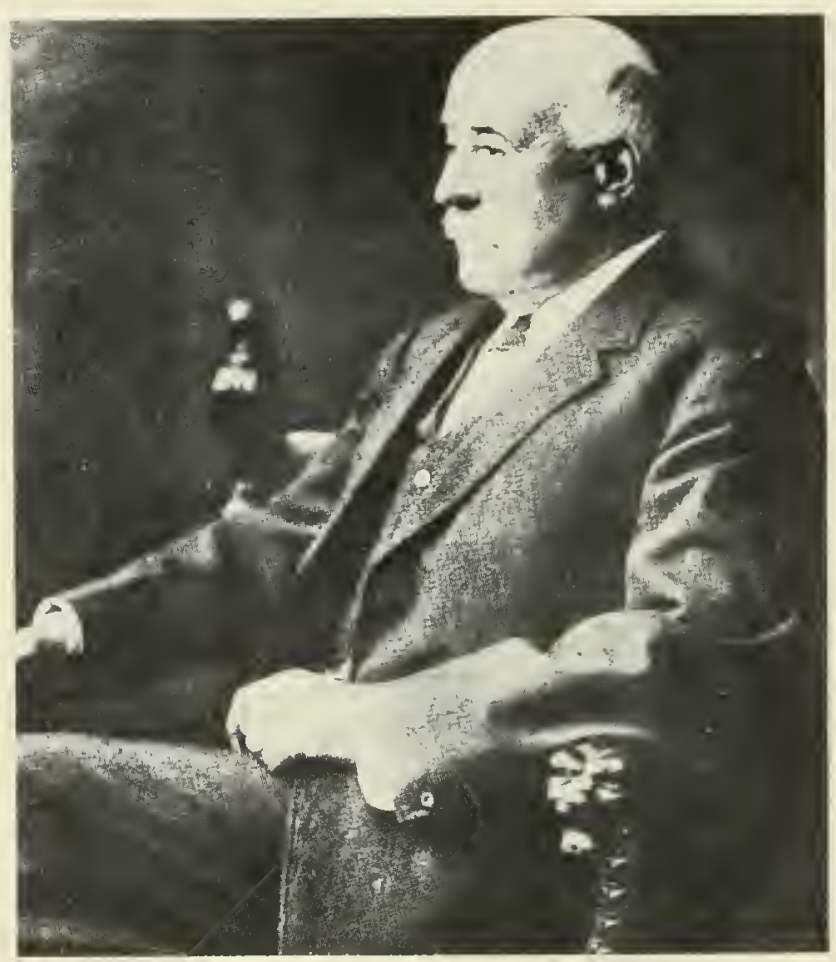

Alexander Agassiz (1835 - 1910)

Born in Neuchatel, Switzerland, he emigrated to the United States in 1849 witl his father, Jean Louis Randolphe Agassiz, later the famed Harvard University naturalist. Alexander was a specialist in marine ichthyology assisting Sir Wyville Thomson in the examination and classification of the examination and classification of the collections of England's Challenger Exploring Expedition. He also conducted sevcral scientific expeditions for the Coast Survey and U.S. Fish Commission. Throughout his active career he remained associated with Harvard's Museum of Comparative Zoology. 


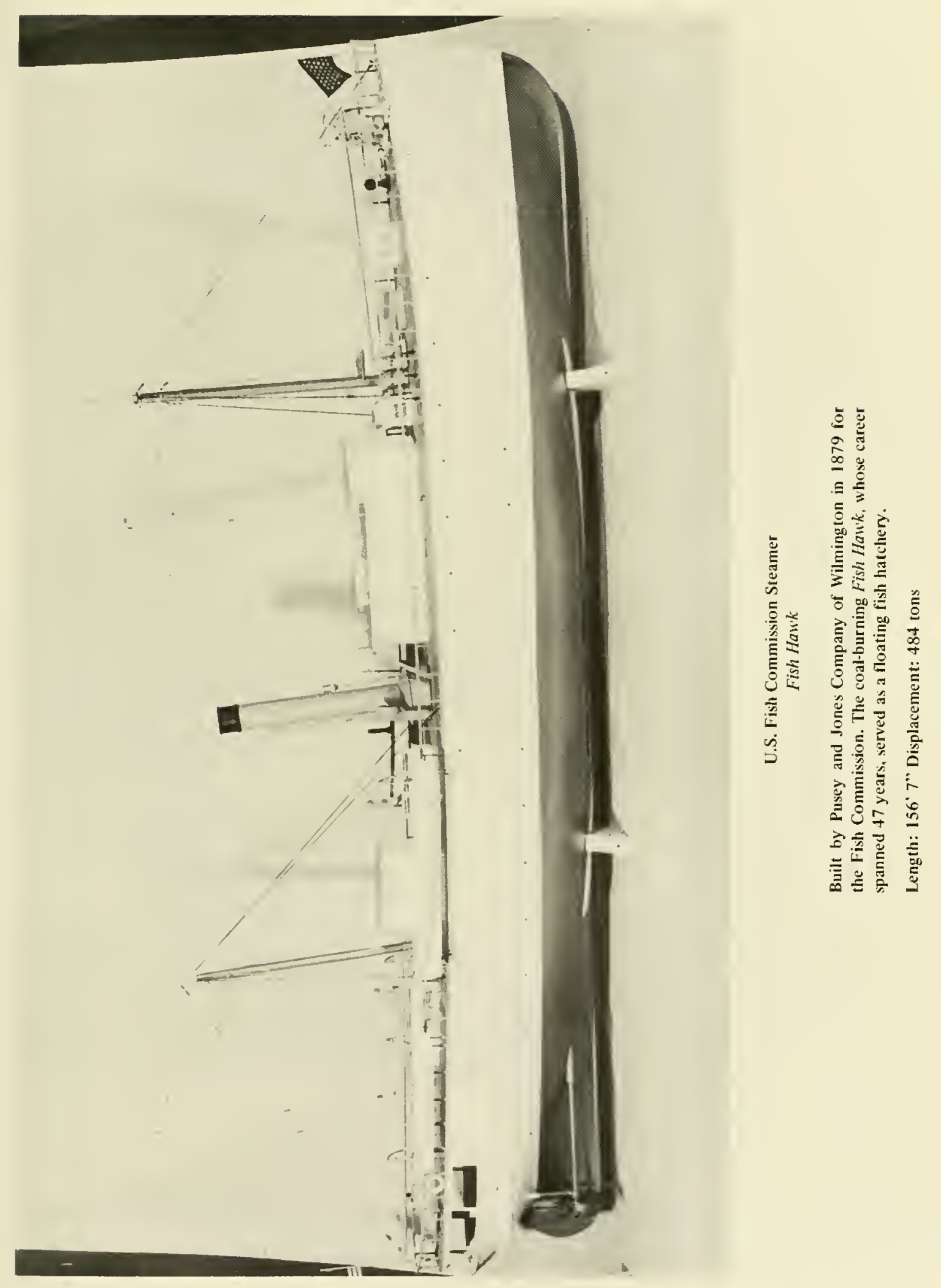




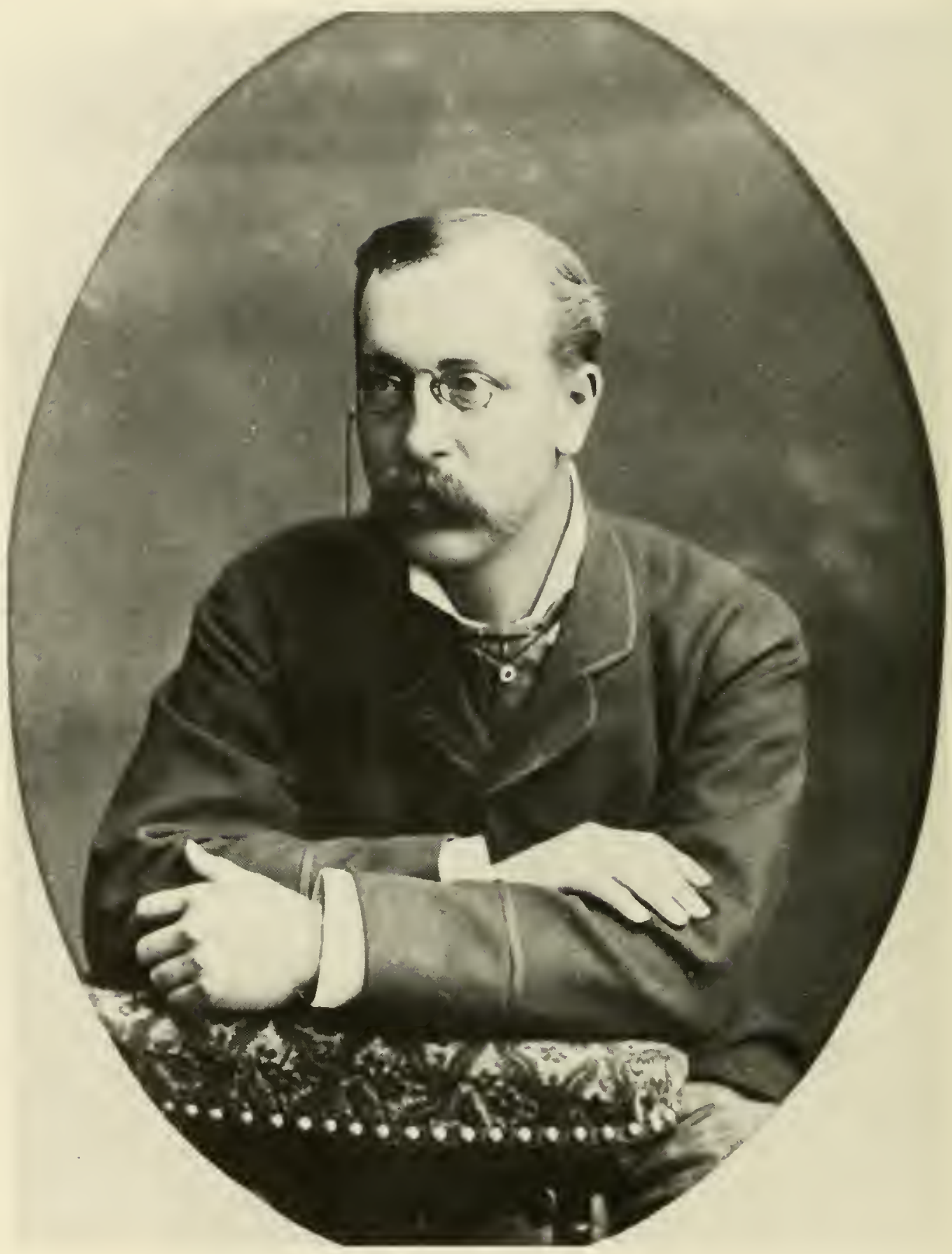

Lieutenant Commander George Washington DeLong

U.S. Navy (1844 - 1881)

DeLong was selected to lead the Arctic Expedition being fitted out by James Gordon Bennett, owner of the New York Herald and an Arctic enthusiast. DeLong sailed from San Francisco in July 1879 in command of the Jeannette, a 142-foot steam bark owned by Bennett. Jeannette became embedded in the polar ice pack from which she never escaped. The long trek to the Siberian coast claimed the lives of Delong and part of his crew. 


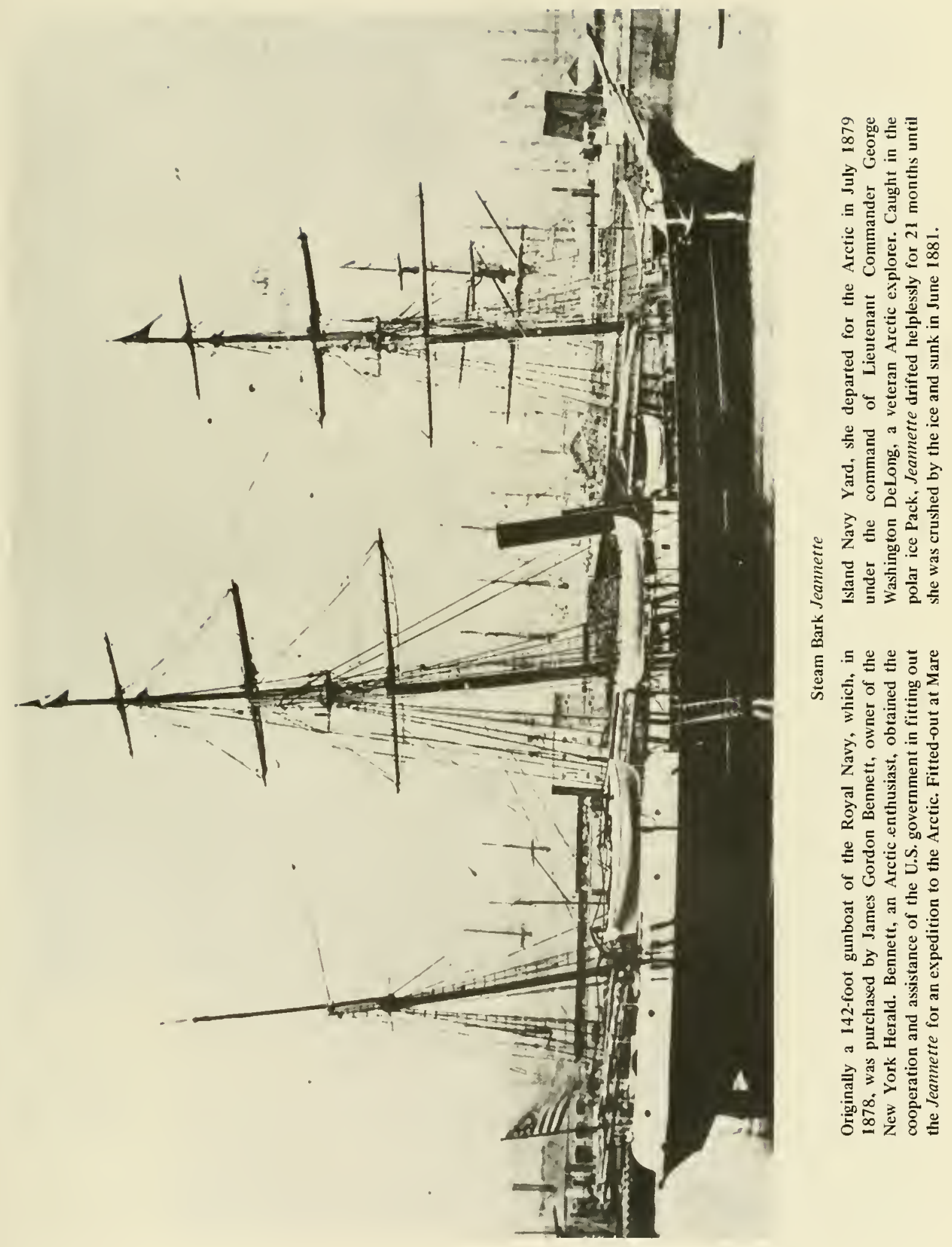




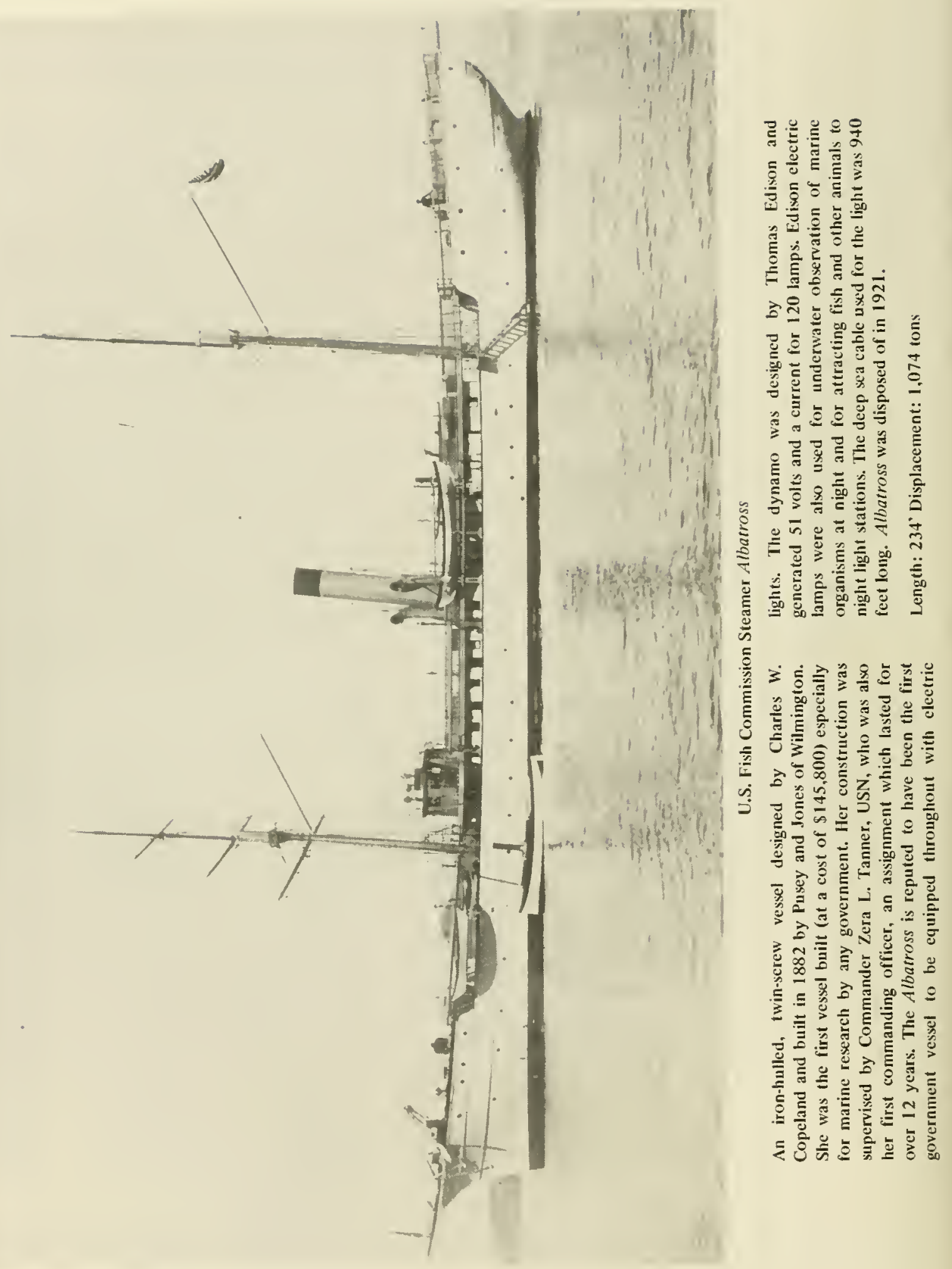




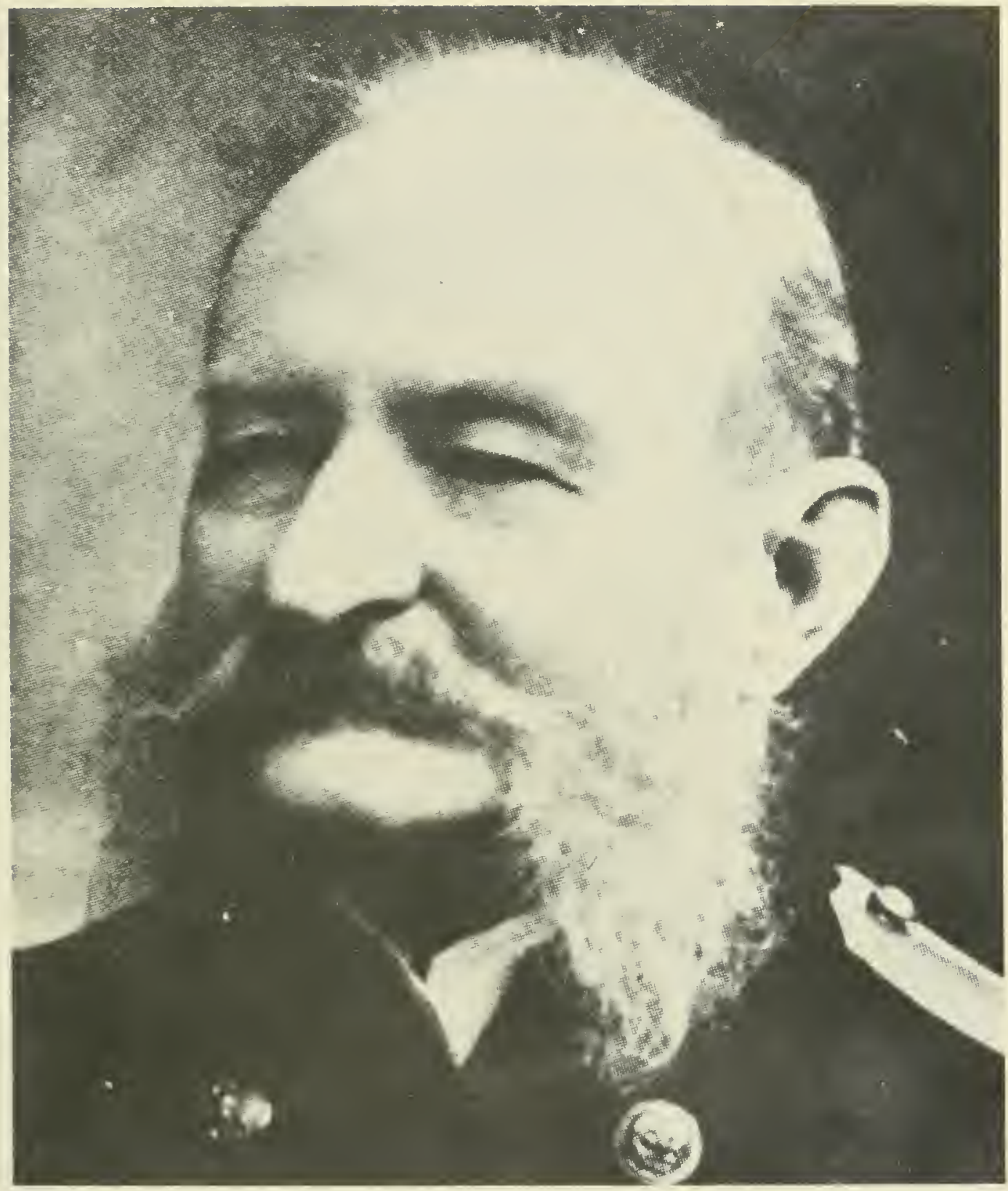

Captain Zera Luther Tanner,

U.S. Navy (1835 - 1906)

Entered the Navy in 1862 and saw service in the Civil War. Following the War and a one ycar lurlough for study abroad, he was ordered to the Iydrographic Office. Ile was assigned to supervise the construction of the steamer Albatross for the U.S. Fish Commission. Completed in 1882, Alhatross was commanded by Tanner for over $\mathbf{1 2}$ years. In 1897 he was placed on the retired list and in 1906 advanced to the rank of Captain. 


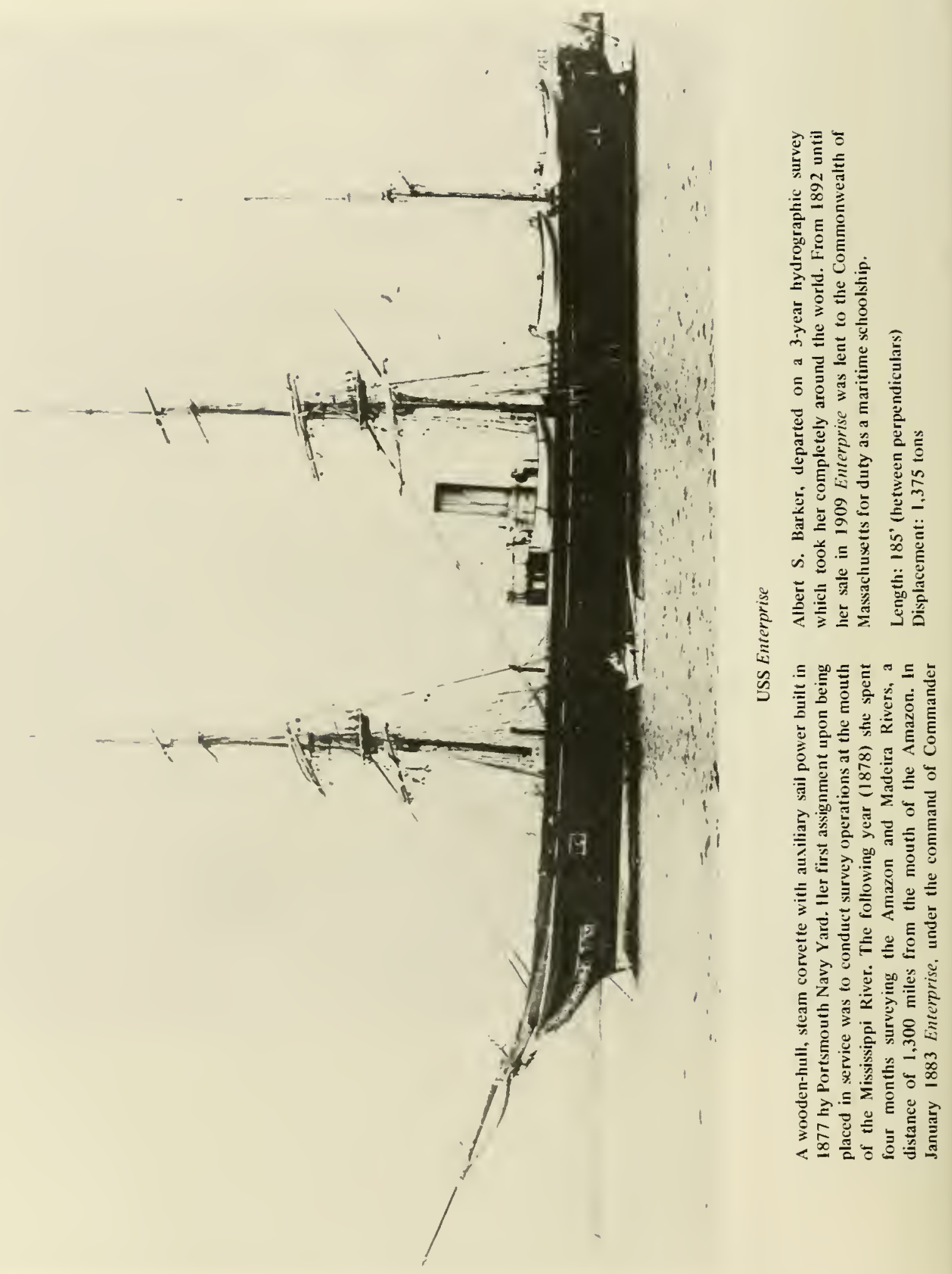




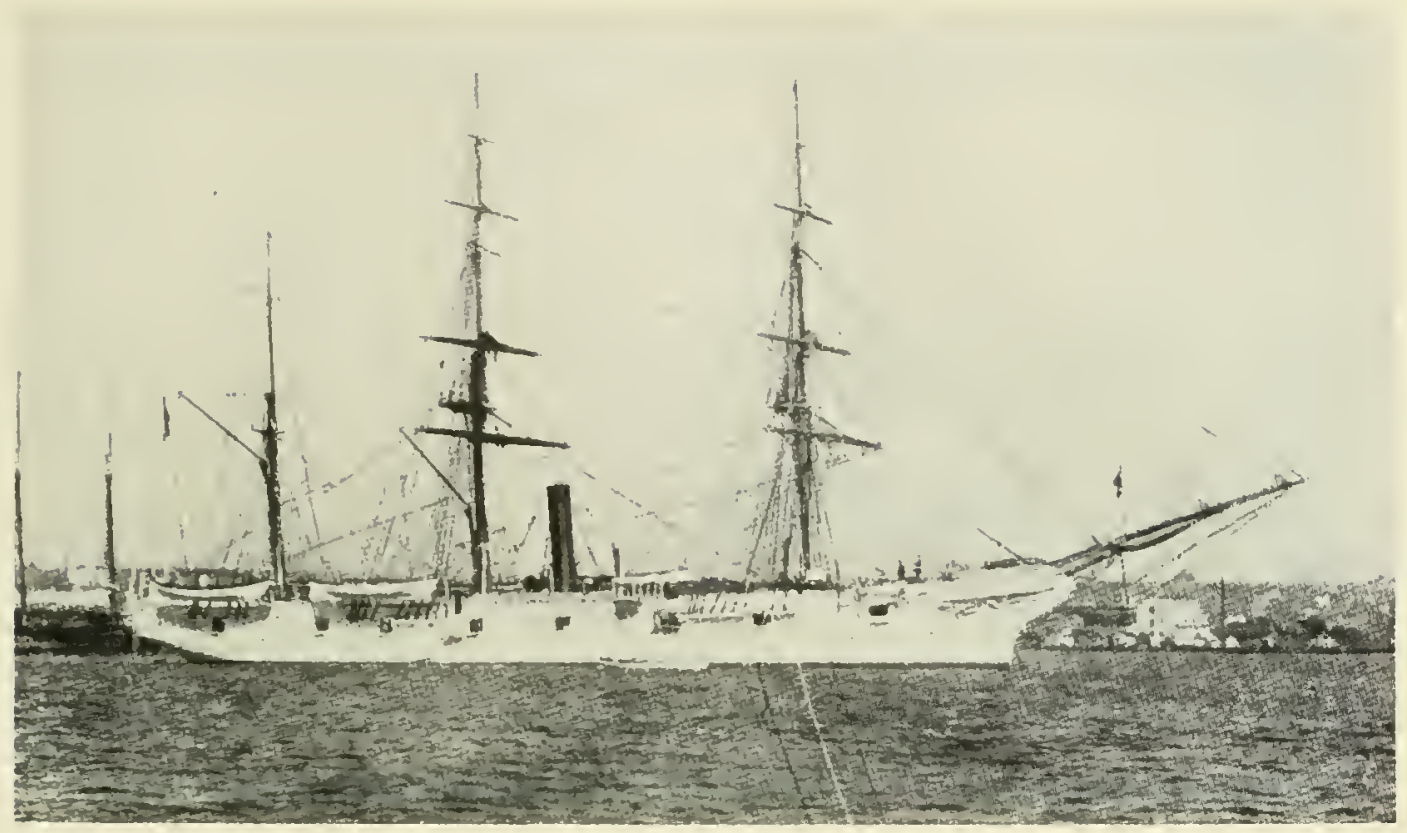

USS Ranger

A full rigged, iron vessel with auxiliary steam power built in 1876 by Harlan and Hollingsworth of Wilmington. Ranger saw service in the North Atlantic, Asiatic and Pacific waters with 12 years spent on surveying duty. In 1909 she was loaned to the state of Massachusetts as a nautical school. Her name was changed to Rockport in 1917 and the following year to Nontucket. The Ranger's long career ended when she was towed to a Baltimore scrap yard in 1959.

Length: 199" 9" Displacement: 1,300 tons

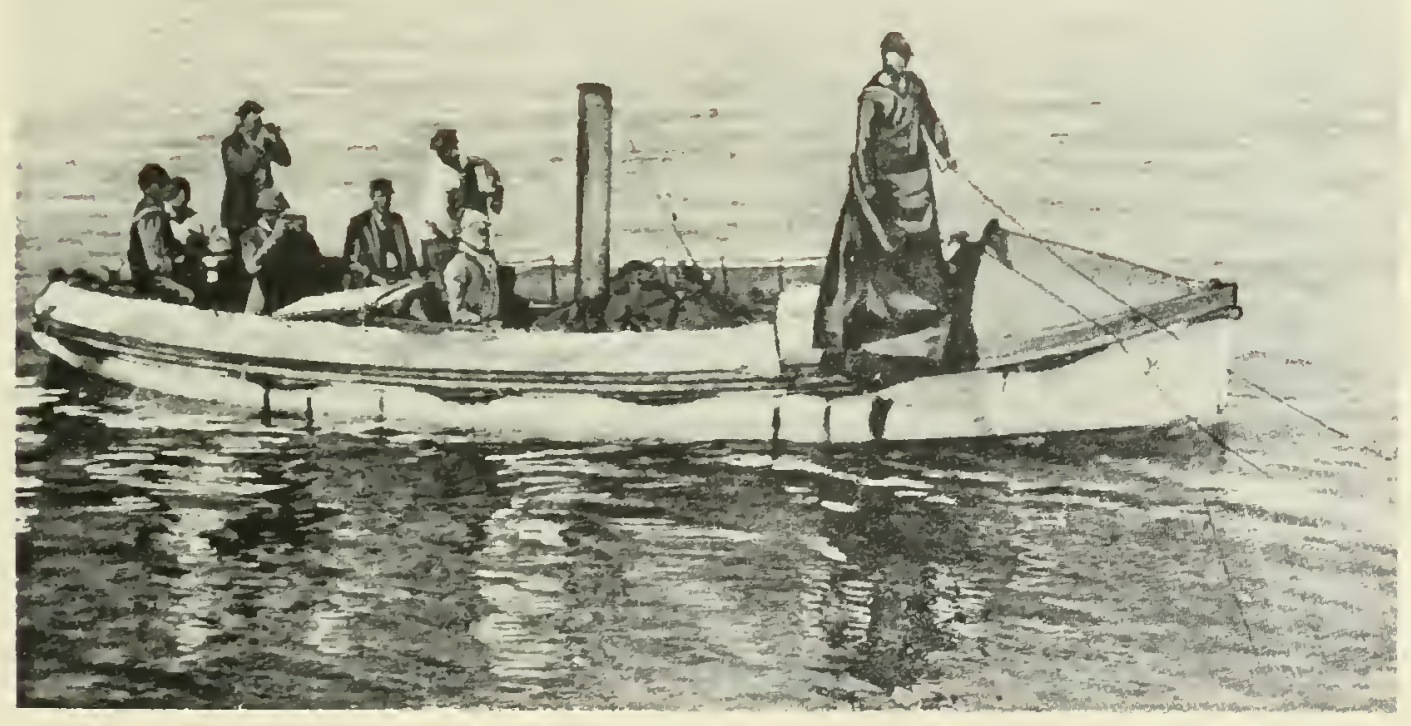

USS Ranger's Steam Launch conducting sounding operations off the west coast of Mexico (1899-1890) 


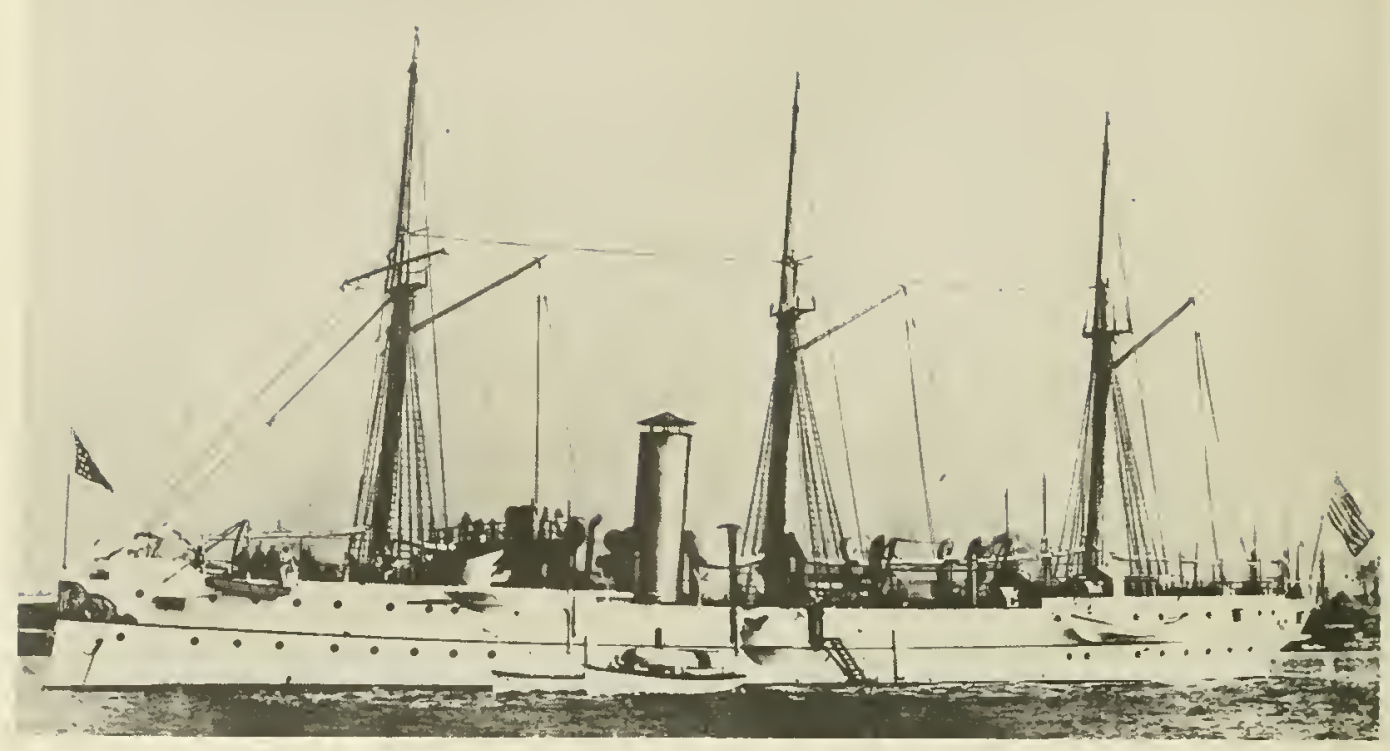

USS Concord

A twin-screw gunboat built in 1891 by Delaware River Iron Works. In 1894 Concord cruised the North Pacific to carry out the provisions of the treaty between the United States and Great Britian which empowered her to seize all vessels violating the laws protecting the valuable fur seal. She gathered hydrographic information to correct Bering Sea charts and conducted scientific observations of the fur seal. Concord was disposed of in 1929.

Length: $244^{\prime} 5^{\prime \prime}$ Displacement: 1,710 tons

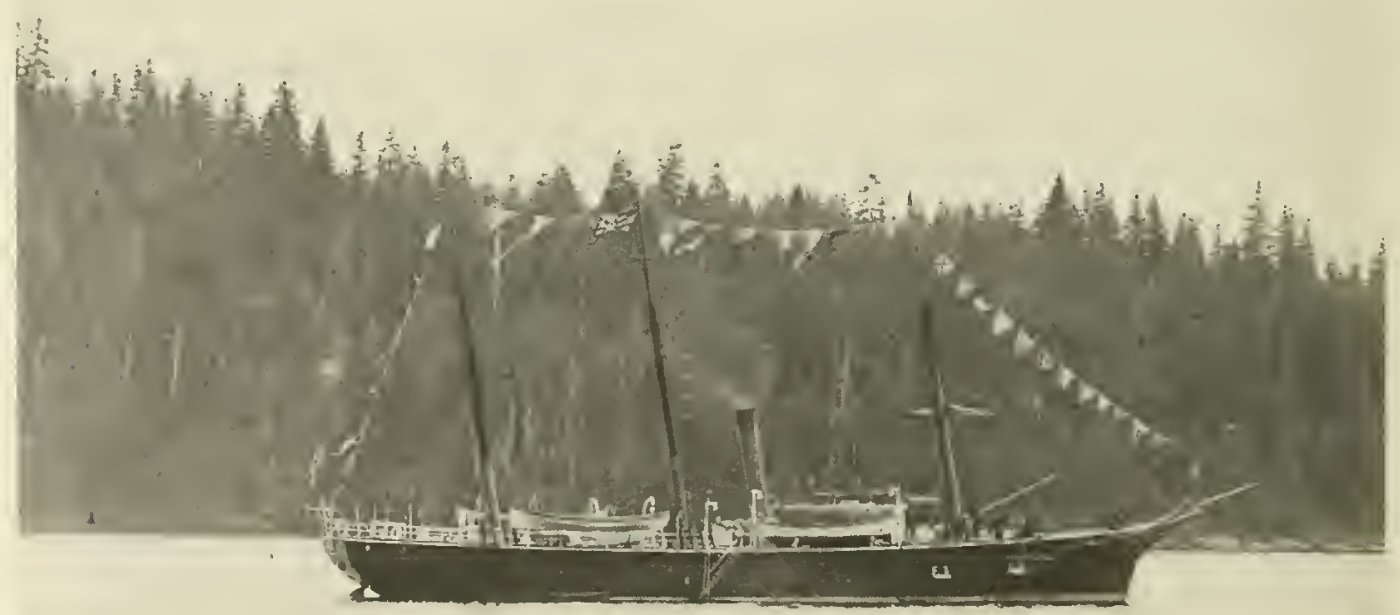

Coast Survey Steamer Hassler

A $159^{\circ} 6^{\prime \prime}$ steamer built in 1872 by the Coast Survey and in xervice until 1895. 


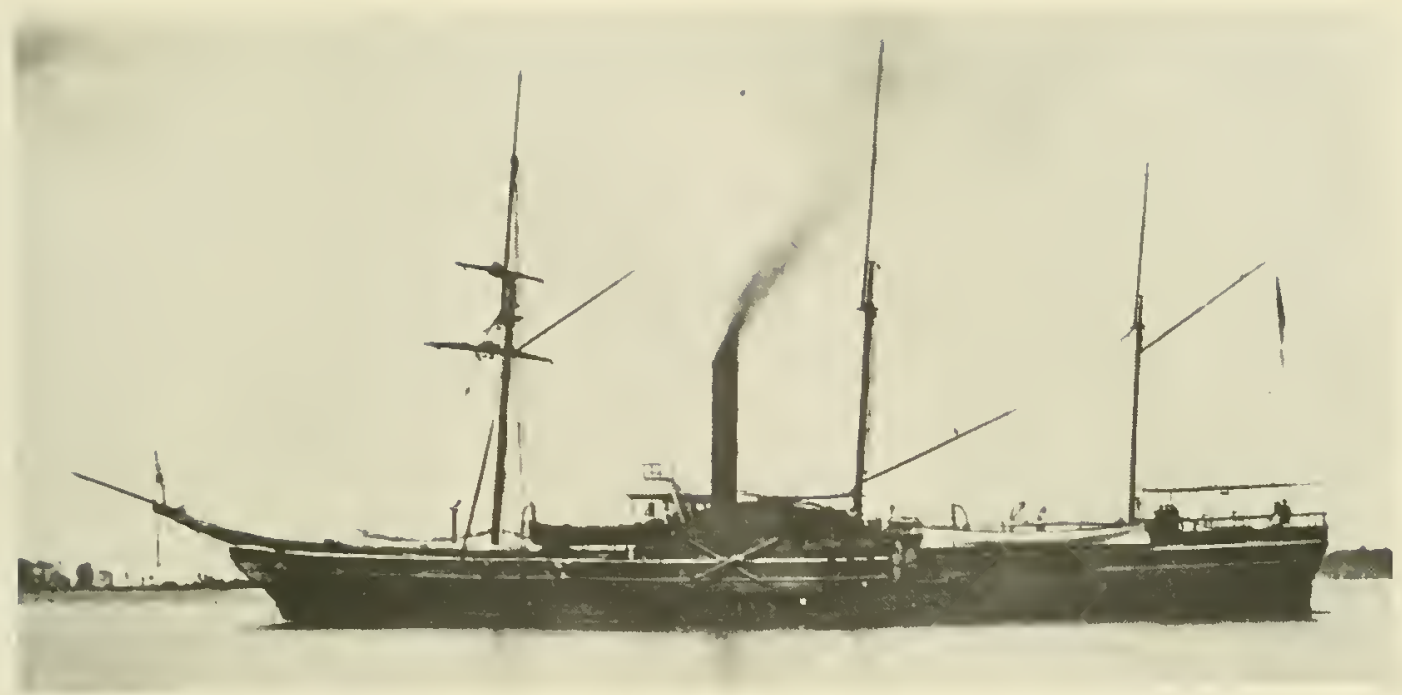

USS Michigan

The Navy's first iron-hulled warship. She was fabricated in parts by Stackhouse and Tombinson of Pittsburgh in 1842 and carried overland to Erie where whe was assembled. Secretary of the Navy A. P. Upshur had selected iron for her hull "to use the immense resource of our country in that most valuable metal" and "to ascertain the practicability and utility of building vessels, at least for harbor defense, of so cheap and indestructible a material." Michigan operated on the Great Lakes out of Erie, $\mathrm{Pa}$. throughout her career. In 1889 she commenced a 12-year intermittent survey of the Great Lakes. Renamed Wollerine in 1905, sle was retired from active service in 1923 following a casualty to her machinery plant. In 1927, she was pushed up on a sandbank in Erie Harbor and loaned to the city of Eric as a relic. When a fund-raising drive failed to acquire sufficient funds for her restoration and preservation, she was cut up and sold for scrap in 1949. In 1950 a monument to the "Iron Steamer" was erected in Erie featuring her actual bow and cutwater.

Length: 163' 3" Displacement: 685 tons

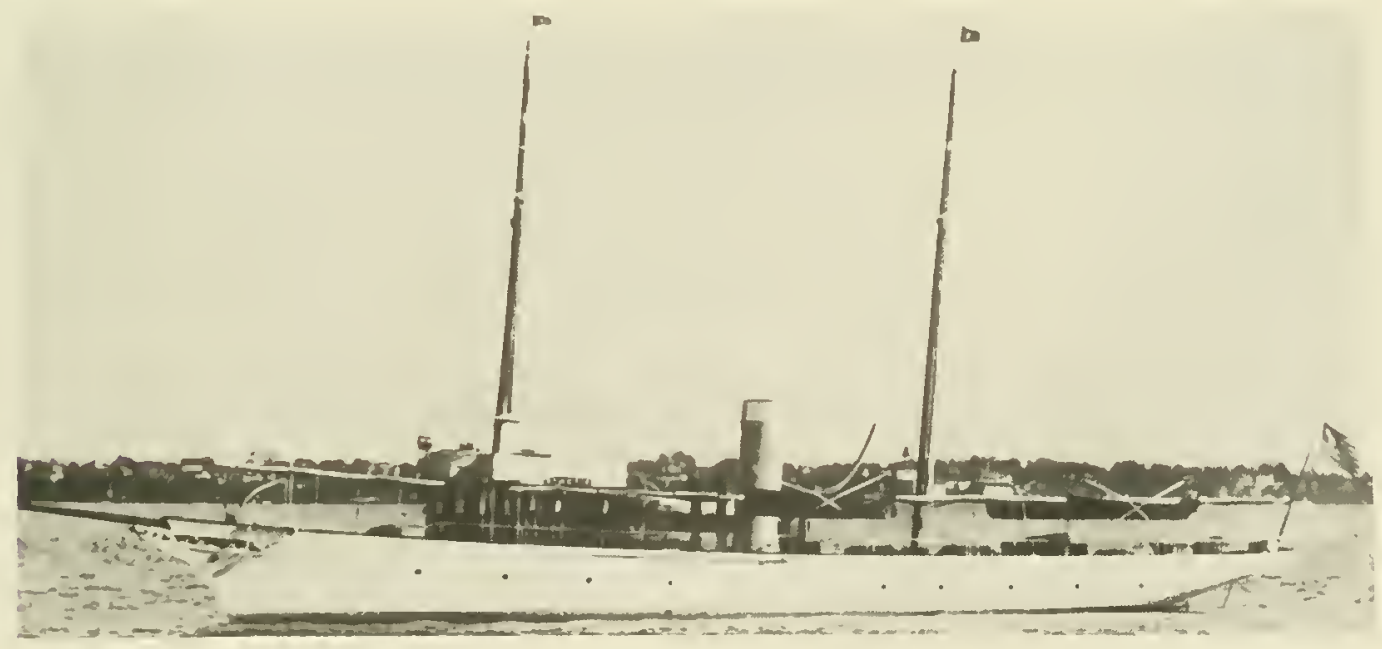

USS Thetis

A 1,250 ton steam whaler built by Alexander Stephen and Sons of Scotland and purchased by the Navy in 1884 to search for the survivors of Licutenant Adolphus W. Greeley's Arctic Expedition. In 1887 she was fitted-out as a gunboat and was engaged primarily in survey operations off the waters of Hawaii and
California. Thetis was transferred to the Tieasury Department in 1899 for revenue cutter service. Sold in 1916, she operated with a sealing fleet out of Newfoundland until broken up in 1950. ller figurehead is retained in St. Johns, Newfoundland. 


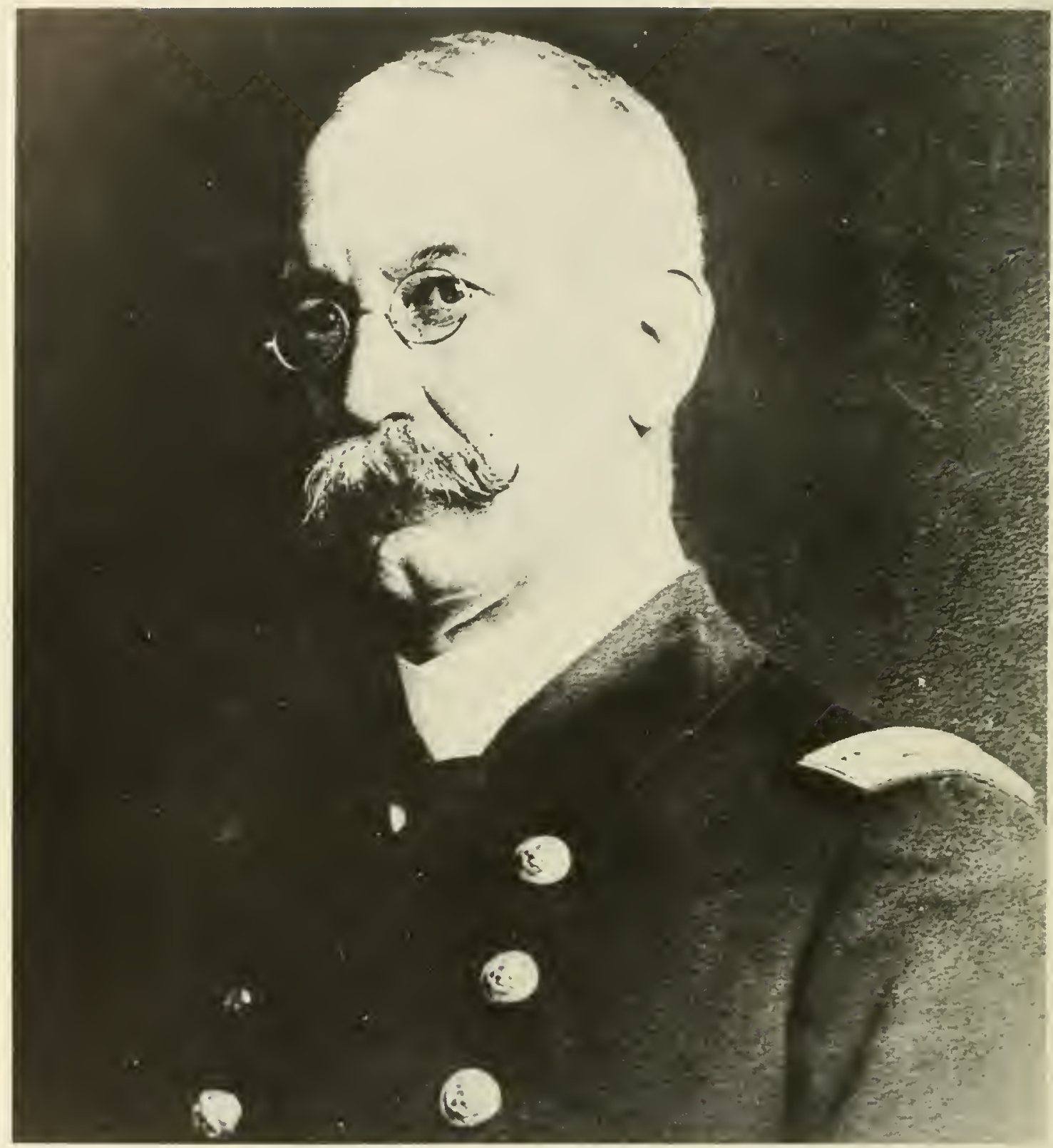

Rear Admiral Charles Dwight Sigsbee U.S. Navy (1845 - I923)

A veteran of two wars, the Civil War and the Spanish-American War, he achicved greater distinction for his services as an inventor and scientist than as a warrior. From 1875 - 1878, he was in command of the Coast Survey Steamer Blake where he was associated with Alexander Agassiz in deep-sea surveys and explorations, principally in the Gulf of Mexico. In recognition of this work, the Gulfs deepest area was named Sigsbee Deep. Many oceanograplic devices were invented or perfected by Sigsbee particularly in the field of deep-sea sounding and dredging. For his contributions to the advance of scientific exploration Emperor William I of Germany bestowed upon him the decoration of the Red Eagle of Prussia and at the International Fisheries Exhibition of London he was awarded a gold medal. He spent a total of ten years in the Navy's Hydrographic Office and from I893 to 1897 was the Hydro. grapher of the Navy. In $\mathbf{1 8 9 7}$ he was advanced to the rank of Captain and was in command of the battleship Maine when, the following year, she was blown up and destroyed in Havana Harbor. He was commissioned Rear Admiral in 1903 and retired in 1907 . 


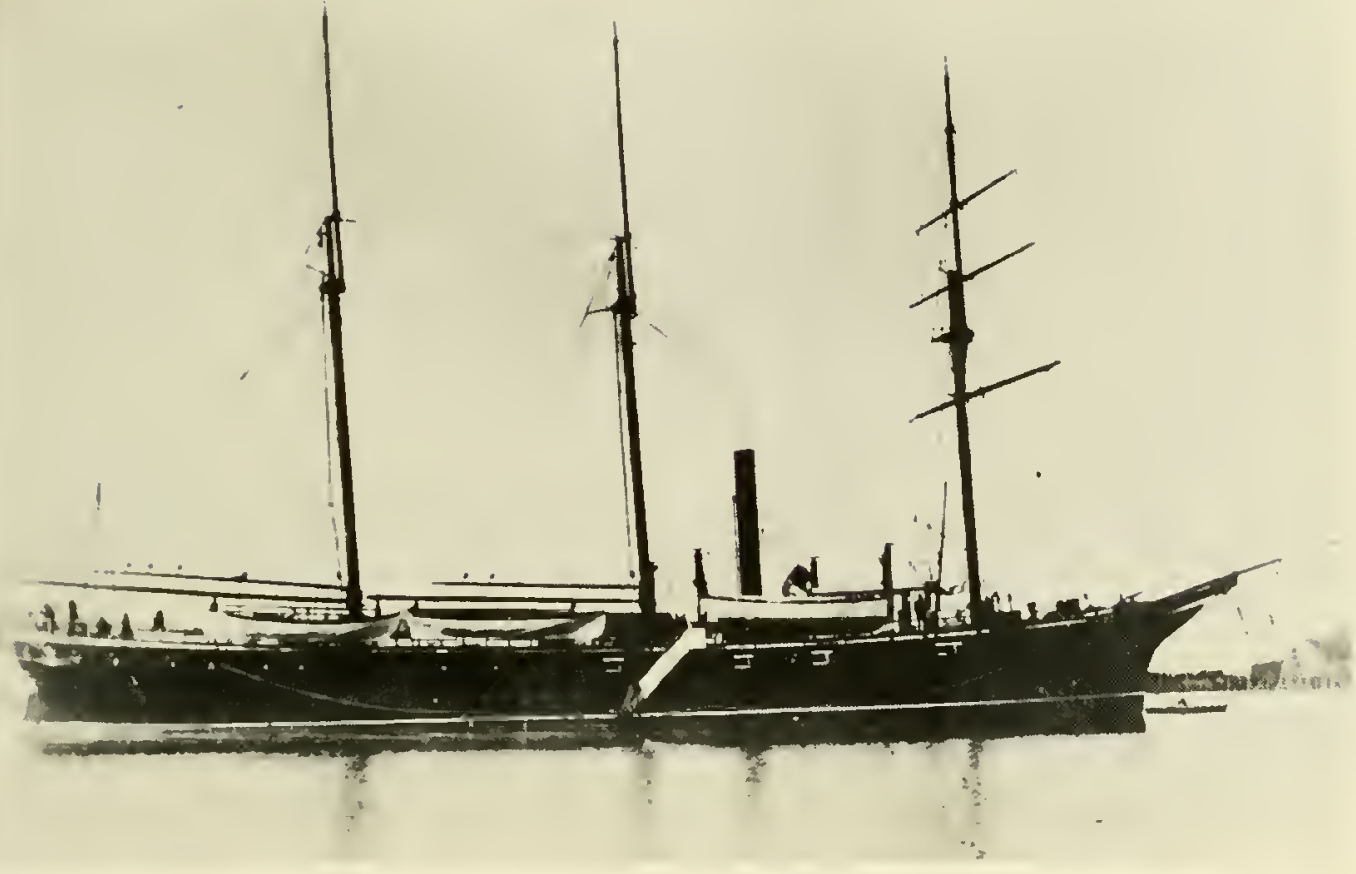

Coast Survey Stcamer Patterson

Built in 1882 at Brooklyn for the Coast Survey. In 1918 she was transferred to the Navy, renamed the Forward, and assigned survey and patrol duty in Alaskan waters. The following year she conducted surveys along the Mexican coast and in that same year returned to the Coast and Geodetic Survey and placed out of service.

Length: 163* Displacement: 719 tons

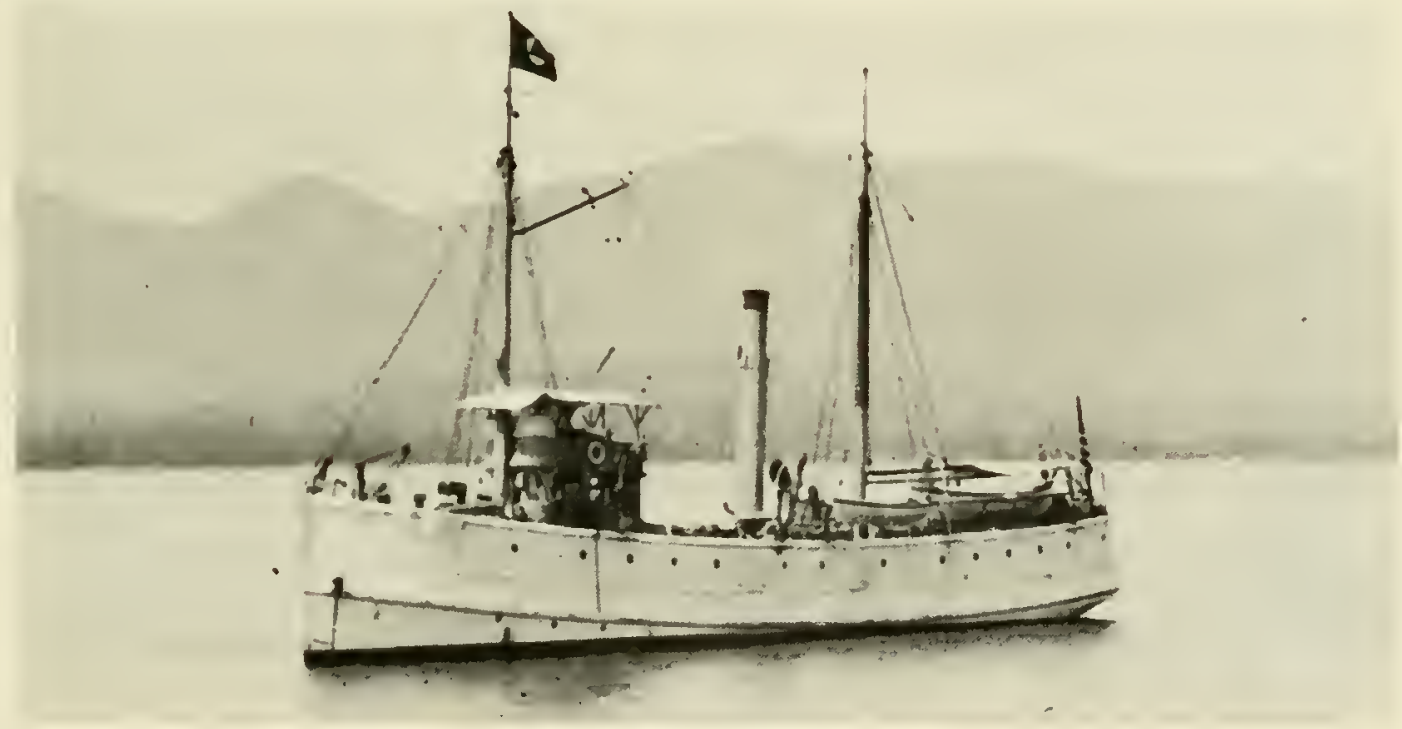

Coast and Geodetic Survey
Steamer McArthur

A 115-foot steamer built in 1877 for the Survey and in service until 1917. 


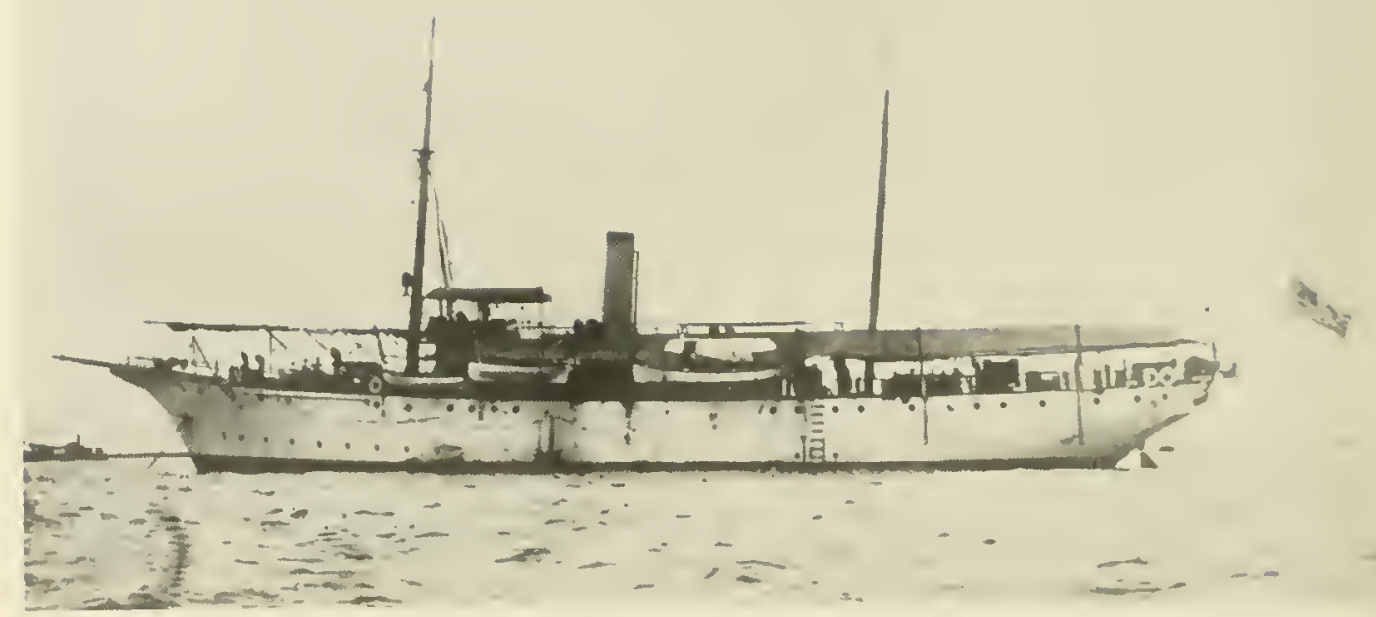

Coast and Geodetic Survey

Steamer Pathfinder

A 168-foot steamer built in 1899 for the Survey. In 1940 she was renamed the Research and during World War II beached in a sinking condition at Bataan.

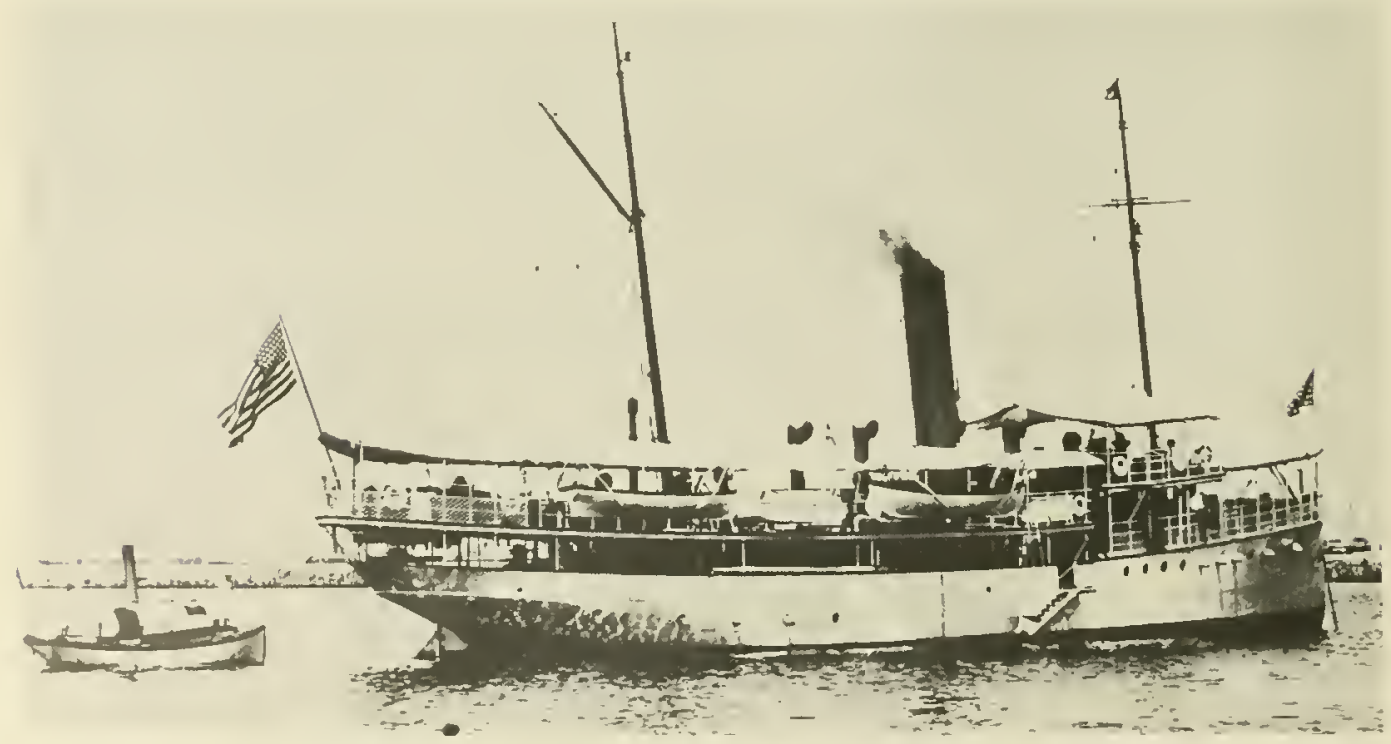

Fathomer

A 144-foot steamer owned by the Philippine Insular Government and placed under the command of the U.S. Coast and Geodetic Survey officers for survey work in the Philippines. The Fathomer was captured by the Japanese with the fall of Bataan and put to use as a transport. She was destroyed by American bombs during the recapture of the Islands. 


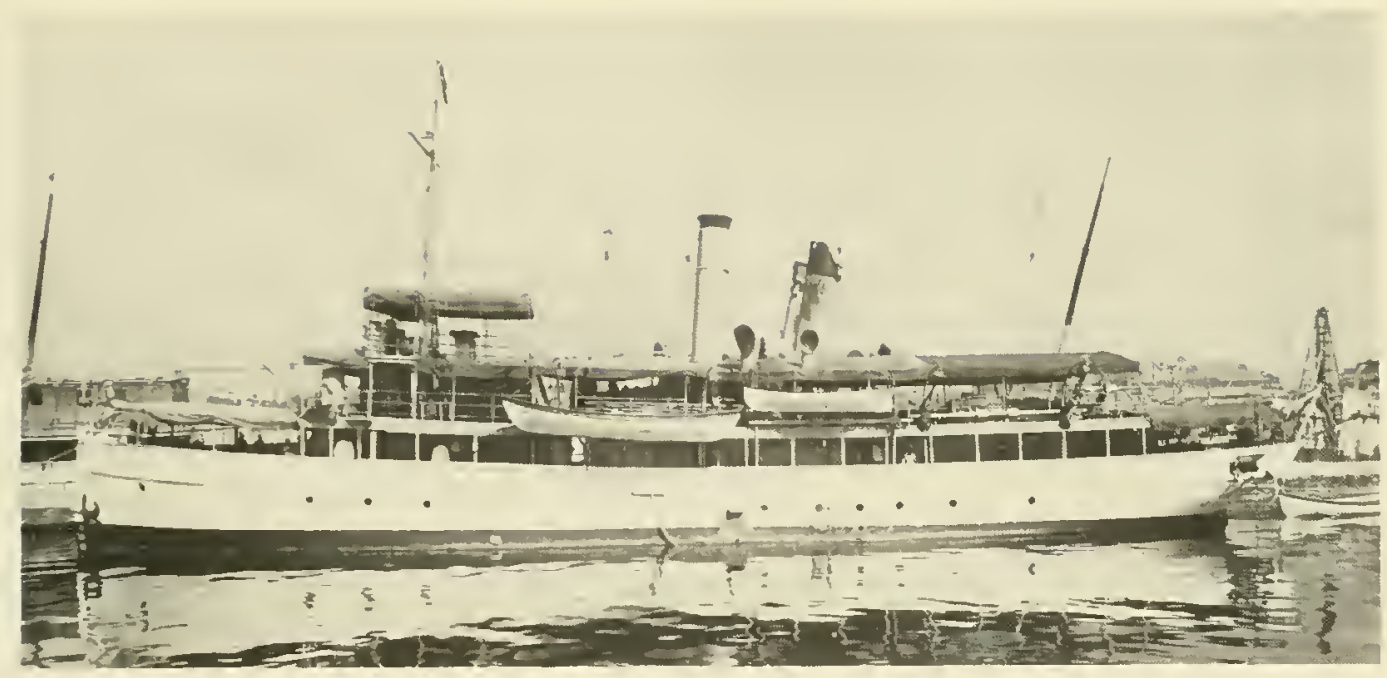

Marinduque

A 132-foot steamer owned by the Philippine Insular Government and, in the early 1900's, placed under the command of U.S. Coast and Geodetic Survey officers for survey work in the Philippines.

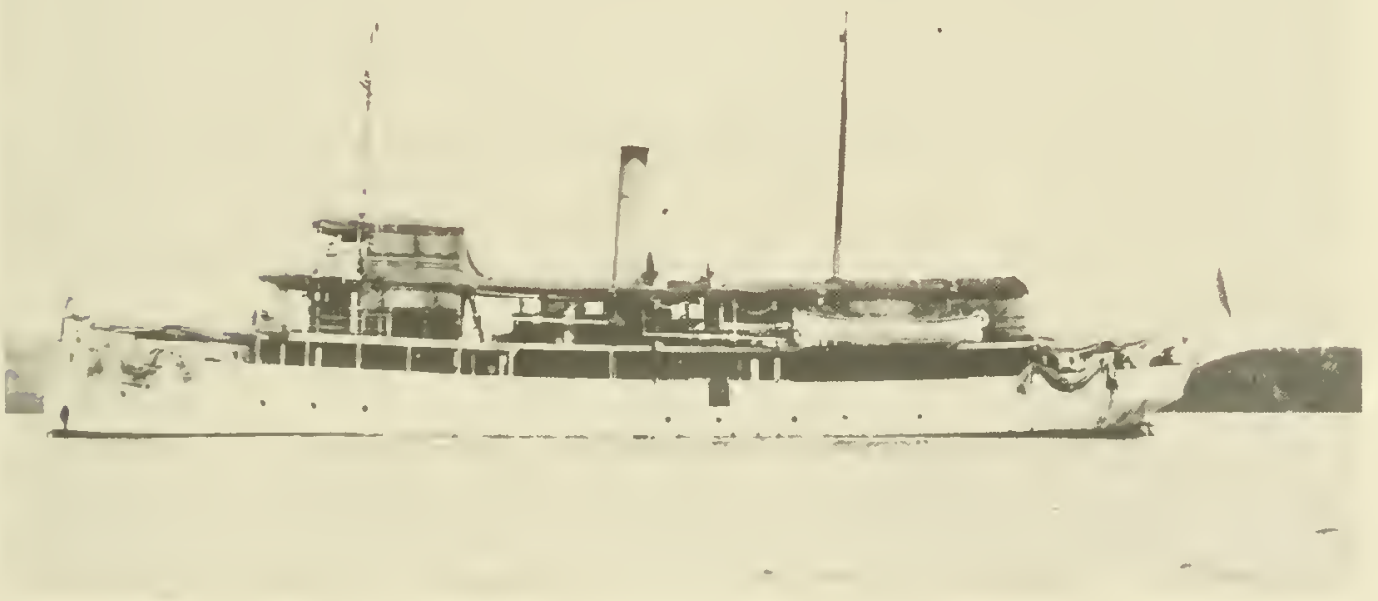

Romblon

A 132-foot steamer owned by the Philippine Insular Government and, in the early 1900s, placed under the command of U.S. Coast and Geodetic Survey officers for survey work in the Philippines. 



\section{CHAPTER III.}

\section{TO PEARL HARBOR}




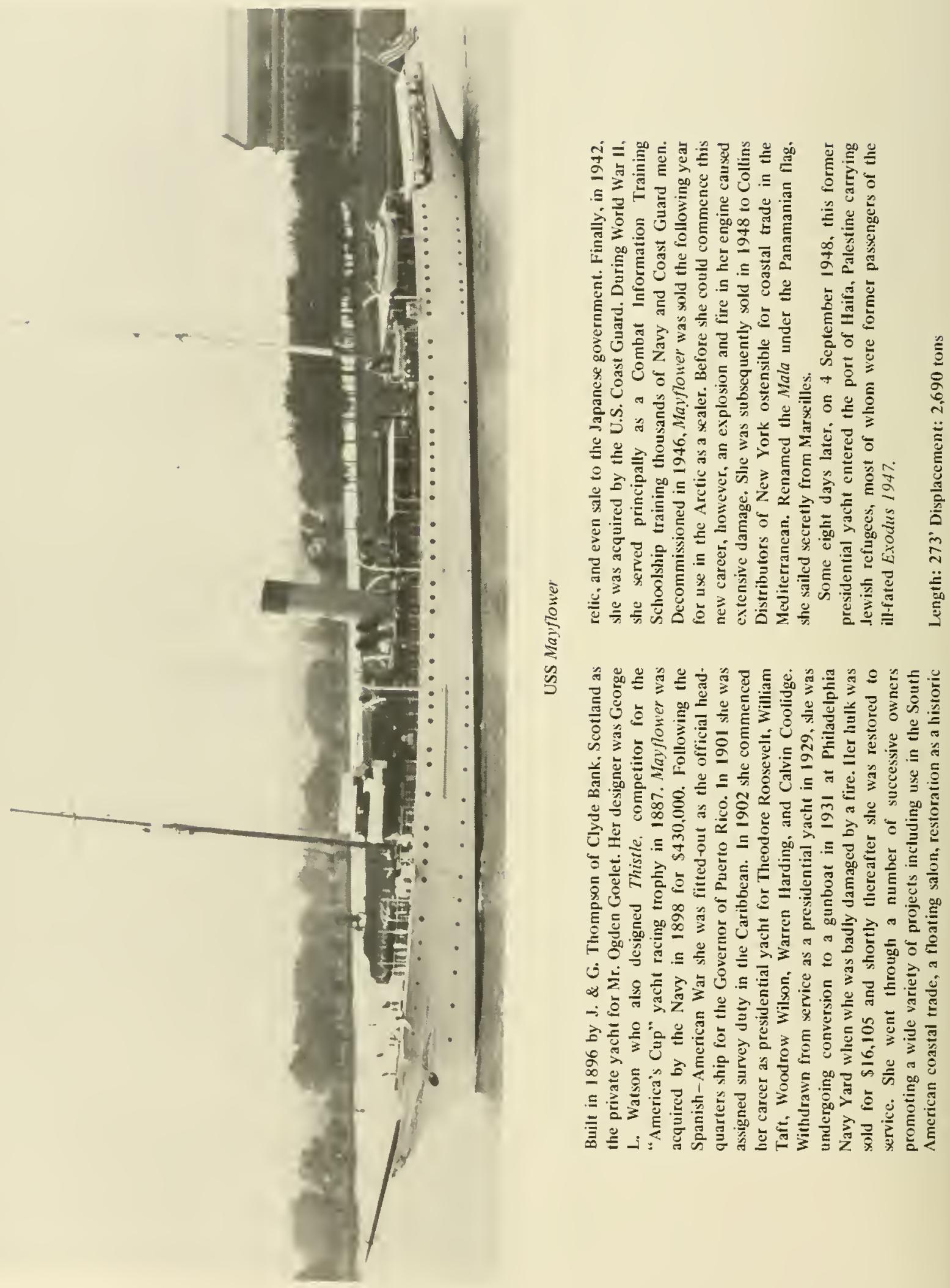


During the early 1900 s the Navy was concentrating on acquiring hydrographic data needed for nautical charts of strategic areas in the Caribbean, Central America and the Pacific. The principal ships were the converted yachts Mayflower, Eagle and Yankton, the former colliers Hannibal and Leonidas (both converted steamers built in Sunderland, England and acquired by the Navy in 1898), the gunboat Paducal, the gunboat Dolphin, and the cruiser Olympia, which in 1898 carried Admiral Dewey's flag at the battle of Manila Bay and was the podium for his: "You may fire when you are ready, Gridley."

In 1901, the Mayflower, a ship whose history is as proud as its name, sounded and charted approaches into various bays and sounds of Puerto Rico and the waters ranging to the coast of La Guiard, Venezuela. Originally, the private yacht of Mr. Ogden Goelet, the Mayflower was built in 1896 by J. and G. Thompson, Clyde Bank, Scotland. Her designer was George L. Watson who also designed Thistle. competitor for the America's Cup yaclit racing trophy in 1887. Acquired by the Navy in 1889 for $\$ 430,000$, following the death of Mr. Goelet, the Mayflower's career included service in the Spanish-American War, as presidential yacht for Theodore Roosevelt, Willian Howard Taft, Woodrow Wilson, Warren Harding, and Calvin Coolidge, and as a U.S. Coast Guard training ship. After sale by the government, she was acquired by Collins Distributors of New York, renamed the Mala and registered under the Panamanian flag supposedly for short haul cargo duty in the Mediterranean. On 4 September 1948, this former presidential yacht, having sailed from Marseilles, France some 8 days previous, entered the port of Haifa, Palestine carrying a group of Jewish refugees singing the Israeli national anthem. These refugees were all from Europe, most of them from the illfated Exodus 1947 which had been turned back from Palestine in the summer of 1947.

In 1902 the Carnegie Institution of Washington was founded and endowed by Andrew Carnegie with an original endowment of $\$ 10$ million to "encourage, in the broadest and liberal manner, investigation, research, discovery and the application of knowledge to the improvement of mankind ..."In 1905 it began a comprehensive world wide study of the magnetic, electric and chemical properties of the oceans using the ship Galilee. The Galilee was a 132-foot, 600-ton, wooden sailing vessel built in 1891 by Matthew Turner of California for hauling freight in the Pacific. She was chartered by the Carnegie Institution for a three year period (1905 - 1908). The year 1909 saw the construction of the nonmagnetic ship Camegie. The Camegie was the second U.S. ship (preceded 27 years earlier by the Albatross) to be built especially for ocean research. She was active from 1909 until her loss in 1929 at Apia, Samoa from a gasoline explosion.

There was increasing interest in the broad physical aspects of deep ocean circulation stimulated primarily from the sinking of the Titanic in 1912 in the North Atlantic. One of the direct results of this disaster was the Navy's detailing (at the recommendation of the Hydrographic Office) of the cruisers Birmingham and Chester to patrol in the iceberg region near the tail of the Grand Banks of Newfoundland as an ice patrol for passing vessels. This particular service was the forenuner of what is now the International lce Patrol.

World War 1 saw ships diverted to support the war effort, and, once again, oceanography was placed in limbo. By legislative order, five ships of the Survey, the Surveyor, Isis, Bache, Patterson and Explorer, with their officer complements, were assigned to the Navy, where they participated primarily in troop and cargo convoy duty, seeing little combat. The Surveyor, however, was later cited and decorated for disabling, by use of depth charges, the German submarine $U$-39, which had sunk the Lusitania. This action occurred during an attack on a ship convoy and resulted in the internment of the damaged $U$-39 in Spain. Other Survey ships were placed under Navy jurisdiction, sucl as the 101-foot wooden steam launch Hydrographer, performing surveying and coastal patrol duties. 
After the war, the Navy resumed its surveying efforts using primarily the Hannibal, the 243-foot Nokomis (the former yacht of Horace E. Dodge, which was purchased by the Navy for $\$ 510,000$ in 1917) and the converted 250 -foot steam yacht Niagara, all operating under the direction of the Hydrographic Office.

In 1921 a major development in oceanographic instrumentation heralded a new dimension of oceanography. Dr. Harvey C. Hayes, a scientist with the U. S. Naval Experimental Station at Fort Trumbull, New London, Connecticut. and later Superintendent of the Sound Division at the Naval Research Laboratory (a position he held for 25 years), developed the sonic-depth finder. Hayes' depth finder was first.used successfully in 1922 by the destroyer Stewart, which took over 900 deep soundings enroute from Newport, Rhode 1sland to Gibraltar. The following year sonic depth finders were installed on the destroyers Hull and Corry to obtain profiles of the Pacific continental shelf in support of investigations being carried out by the Carnegie Institution in determining the cause of earthquakes. This effort resulted in the publication, in 1923, by the Navy Hydrographic Office of the first bathymetric chart compiled from sonic soundings. In 1925 the Coast and Geodetic Survey ship Lydonia, a 181-foot converted yacht, had installed a sonic-depth finder called "Fathometer" which had been developed by the Submarine Signal Company of Boston and adopted in preference to Hayes' unit. The first bathymetric chart published by the Coast and Geodetic Survey based on sonic soundings was in 1939; it covered the coastal waters between San Diego and Santa Rosa Island, California. It is interesting to note that prior to the development of the sonic depth finder the total recorded soundings greater than 550 fathoms that had been taken from all the ocean basins of the world totaled only about 15,000: an average of only one sounding for each 5,500 square miles in the Atlantic, one for each 10,000 square miles in the Pacific and one for each 10,500 square miles in the Indian Ocean.

Though progress was being made, the United States' overall efforts in oceanography lagged far behind those of other countries. The 1920s saw a series of extensive government sponsored expeditions being carried out by Germany, Holland, Denmark and England.

In 1925 the Germans made the first determined effort to extract minerals from the oceans. Fritz Haber, the 1918 Nobel Prize winner in chemistry, conceived the idea of extracting enough gold from the sea to pay the German war debt. With optimism running high, the German South Atlantic Expedition was sponsored using the converted 200-foot gunboat Meteor to cross and recross the Atlantic, sampling the water. The venture was abandoned in 1927 when the yield was less than expected and the cost of extraction far greater than the value of the gold obtained.

1n July 1924, at the invitation of the Secretary of the Navy to consider all matters pertaining to a proposed United States Naval expedition for research in oceanography, the first General Conference on Oceanography was held at the Hydrographic Office. Participating in this conference were representatives from the State, Treasury and War Departments and the Carnegie Institution of Washington. Included in the official report of this conference were the following items:

"It is recommended that a naval vessel or vessels be permanently assigned to oceanographic work. Such vessels should, if practicable, have twin screws and low freeboard and must have a large cruising range. They should have laboratories and sufficient living quarters and cabins comfortably to accommodate the personnel.

While the above requirements are preferred, the conference desires to state that any suitable vesscl or vessels that the Navy Department can assign for this purpose will be acceptable... 
The conference recommends that this oceanographic undertaking be known as the Maury United States Naval Oceanographic Research, in honor of Lieutenant Mat thew Fontaine Maury, United States Navy, whose pioneer work in practically all branches of oceanography entitles him to this distinction. It is further recommended that the major ship that is assigned to this work be named the USS Tamner, in honor of Commander Zera L. Tanner United States Navy, whose long-continued oceanographic work has contributed much to the advance of this science."

Although the importance of initiating a national cooperative program was recognized, no positive steps were taken.

Recognizing this lack of scientific leadership, the National Research Council of the National Academy of Sciences established its first Committee on Oceanography (NASCO) in 1927, to consider the role of the United States in a worldwide program of oceanographic research. The results of the NASCO recommendations led to a serjes of grants from the Rockefeller Foundation which were used to establish the Woods Hole Oceanographic Institution, the Oceanographic Laboratory at the University of Washington.and additional facilities at the Scripps Institution of Oceanography.

For the Woods Hole Oceanographic Institution, the Rockefeller Foundation provided $\$ 2.5$ million for endowment. a ship and buildings. The Carnegie Corporation supplied the funds to purchase the land. In 1930 the Trustees of this newly founded institution "appreciated that one of the most important things it could do would be to operate a seagoing ship of moderate size with convenient living quarters, and equipped to carry on investigations at all depths of the various lines of sea science." By the end of 1930, the 142-foot steel ketcl1, Atlantis, was launched in Copenhagen. Much of the oceanographic equipment was purchased abroad. A fathometer and a radio for sending messages were installed when the Atlantis arrived in the United States in the Fall of 1931. The Atlantis thus became the third U. S. ship built especially for oceanography, but the first specifically designed for multi-discipline research. For a period of about 20 years after her delivery, the Atlantis was really the only United States representative in basic deep sea researcl. Prior to her sale to Argentina in 1964, the venerable Atlantis had logged more than a million miles at sea and made more than 5,000 oceanographic stations.

As Woods Hole was a single-ship institution in the 1930s with its Atlantis, so also were the University of Washington with the 75-foot vessel Catalyst and Scripps with the 104-foot schooner E.W. Scripps. The Bureau of Fisheries (formerly the Fish Commission) was also reduced to a single-ship activity. The Albatross had been sold in 1921 and the Fish /lawk was disposed of in 1926. As a replacement for the Fish Hawk the Navy transferred the 150-foot. two-masted, steel-hulled ocean tug Patnxent which was renamed the Albatross It.

Another recommendation of the NASCO in 1927 was that occanographic research be undertaken by a Navy vessel specially fitted for the work. This recommendation enabled the Hydrographic Office to acquire in 1931 its first suite of oceanographic equipment which was used only incidentially onboard the hydrographic survey ship Hamibal.

In 1929 the Secretary of the Navy convened a special board under the chairmanship of Rear Admiral Frank H. Schofield to review the Navy's role in future oceanographic programs. The recommendations of the Schofield Board for the expansion of Navy oceanographic programs resulted in the establishment of a Section of Oceanography in the Hydrographic Office (1933) and increased cooperation with private and academic occanographic institutions. Throughout the 
1930s, these institutions, primarily Woods Hole, Scripps and the University of Washington, were able to expand their oceanographic efforts through the utilization of Navy vessels assigned to survey duty. These included the Oglala (originally the S. S. Massachusetts of the Fall River Line) which conducted the Aleutian Islands Survey Expedition (1934 - 1936), the minesweeper Gannet on summer-month survey expeditions to Alaska and the Aleutian Islands, the Nokomis, the Hannibal, and the former World War l submarine tender Bushnell.

The installation of sonic echo sounders onboard Navy vessels resulted in a staggering collection of dynamic soundings. One ship, the Ramapo, acquired over 37,000 soundings during 51 crossings of the North Pacific in a nine year period (1929-1938). The Ramapo also acquired a degree of renown when in February 1933, while preceding from Manila to San Diego, she recorded a giant wave the height of which was 112 feet.

In 1932 the Navy's Gravity-at-Sea Expedition. in cooperation with the Princeton University sponsored International Scientific Expedition to the West Indies, assigned the submarine $S$ - 48 and the submarine rescue ship Chewink the task of conducting gravity measurements. The members of the Gravity-at-Sea Expedition included Dr. F. A. Vening Meinesz, of the Netherlands Geodetic Commission, who brought with him from Holland his Multipendułum instrument for installation onboard the S-48, Dr. H. H. Hess from Princeton University, Lieutenant Commander A. H. Gosnell, U. S. Naval Reserve, historian, and Mr. Townsend Brown, Naval Research Laboratory. Gravity-at-Sea measurements were taken in conjunction with measurements taken ashore by members of Coast and Geodetic Survey, the entire expedition being directed by Professor Richard M. Field of Princeton's Department of Geology.

The Navy's survey efforts during the 1930s were, as before, being concentrated primarily along trade routes. By the end of the decade only two ships were conducting surveys on what could be considered a full-time basis; the slow ( 7 knot), coal burning Hannibal and the former submarine tender Bushnell. 


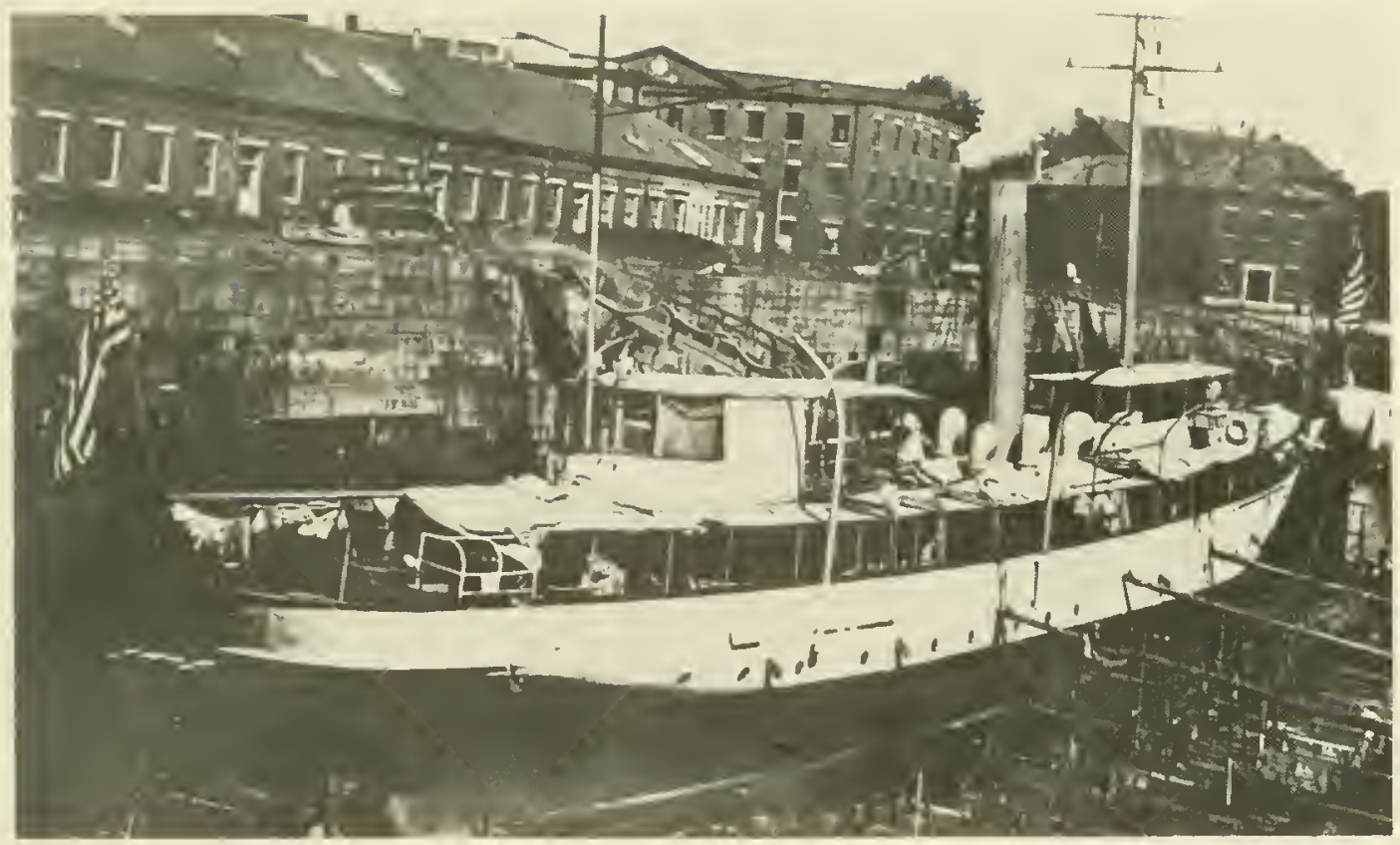

USS Eagle

Formerly the yacht Almy built in 1890 by Harlan and tions mainly in the Caribbean area. Decommissioned in 1919 , Hollingsworth of Wilmington. Purchased in 1898 by the Navy, she was sold the following year. She is shown here in Jrydock at Eagle was fitted out as a survey vessel, her principal employment Portsmouth Navy Yard (1916).

throughout her naval service. She conducted her survey opera- Lengtlı: 155' 6" Displacement: 434 tons

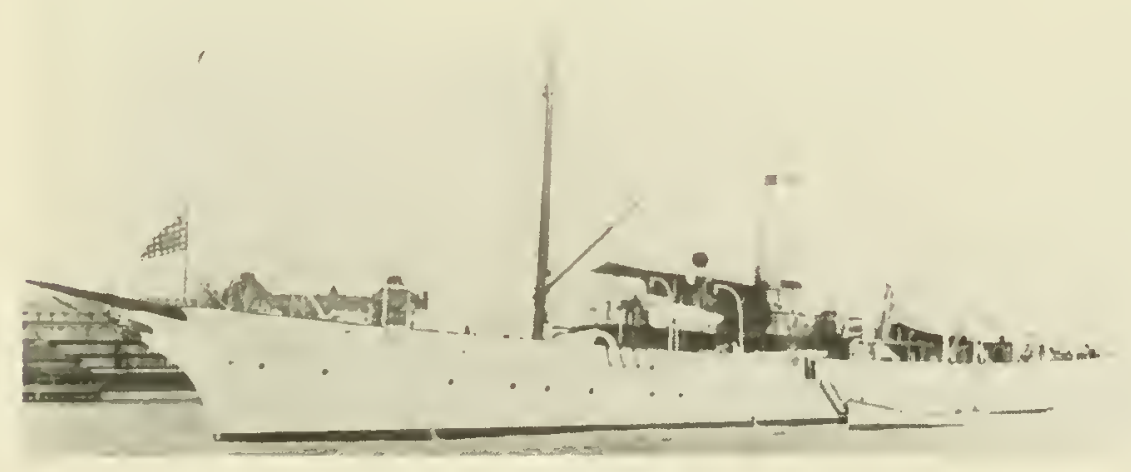

\section{USS Yankton}

Built by Ramage and Ferguson of Leith, Scotland in 1893 as the private yacht Penelope for Prince Edward V1l of England. Acquired by Sarah Bernhardt the yacht became the Cleopatra. Later purchased by an American, the yacht, was renamed the Sapphire. In 1898 the yacht was purchased by the Navy, converted to a gunboat, and renamed the Yankton. Following her participation in the Spanish - American War, Yankton was assigned survey duty in Cuban waters. During World War I she served primarily on coastal and anti-submarine patrols with one submarine sinking to her credit. Sold in 1921, the Yankton was seized two years later as a rum runner. After a brief period engaged in honest commerce, she was scrapped in 1930.

Length: 185' Displacement: 975 tons 


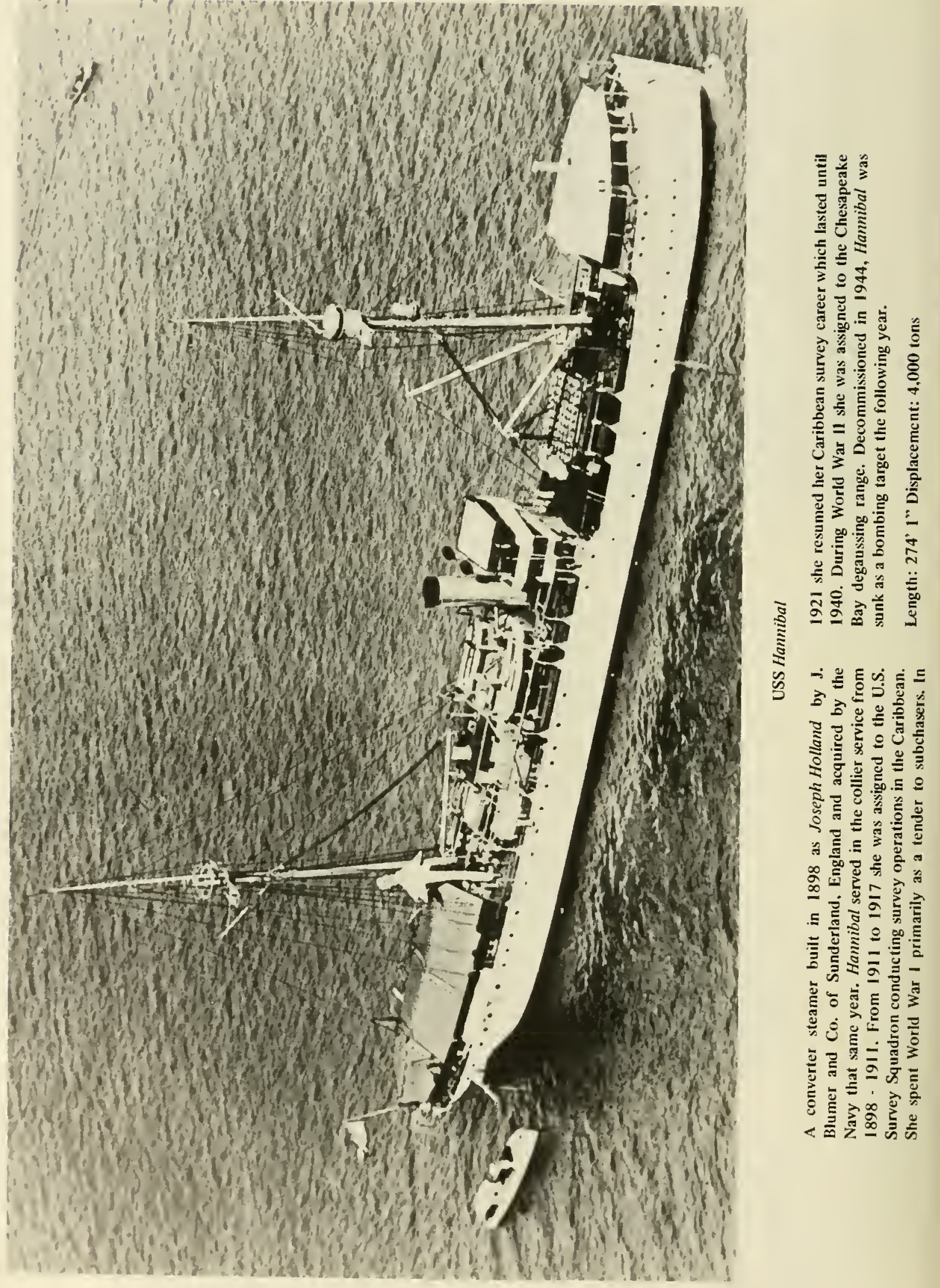




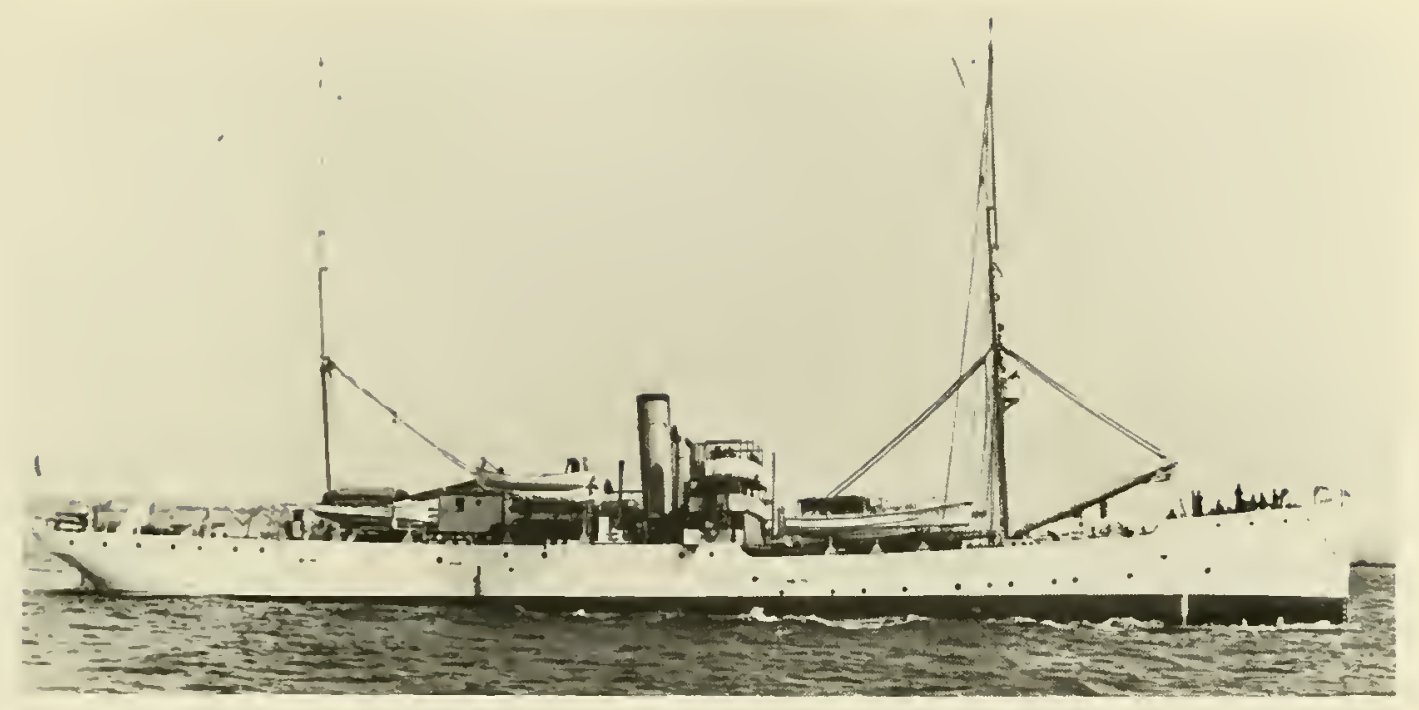

USS Leonidas

Originally the Elizabeth Holland built in 1898 by S. P. Austin and Son, Lid., of Sunderland. England. Purchased that same year by the Navy she was fitted-out as a collier. In 1914 she was converted to a survey ship, but with the outbreak of World War 1 she was assigned patrol duty. At war's end she was converted again, this time to a tender for submarine chasers. In 1922 she was sold to Ammunitions Products Corporation of Washington, D.C. Photographed here as a survey ship in 1914.

Length: 264' 3" Displacement: 4,264 tons

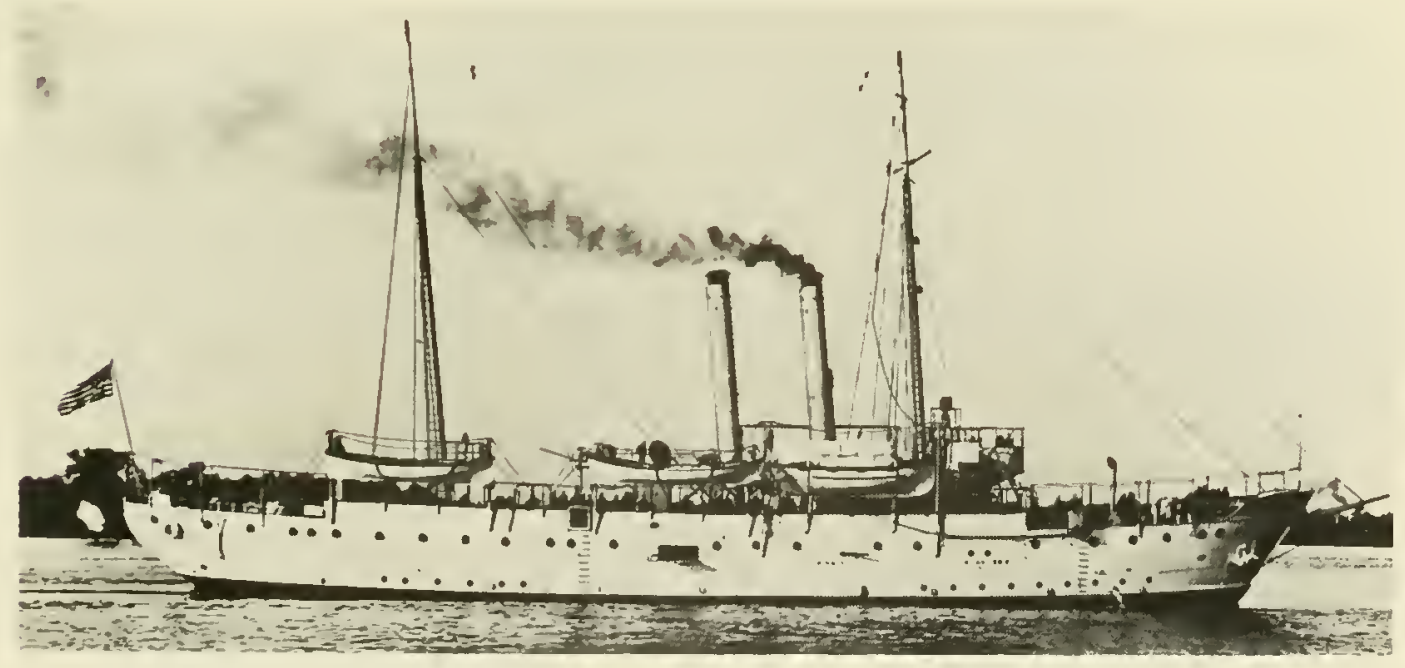

\section{USS Paducah}

A gunboat built in 1905 by the Gas Engine and Power Company and C. L. Seabury Company of Morris Heights, New York. She conducted routine survey operations during the course of her naval service. Sold to private interests in 1945, the Paducah in
1948 was renamed the Geula and was one of the Exodus ships carrying Jewish refugees to Palestine.

Length: 200' Displacement: 940 tons 


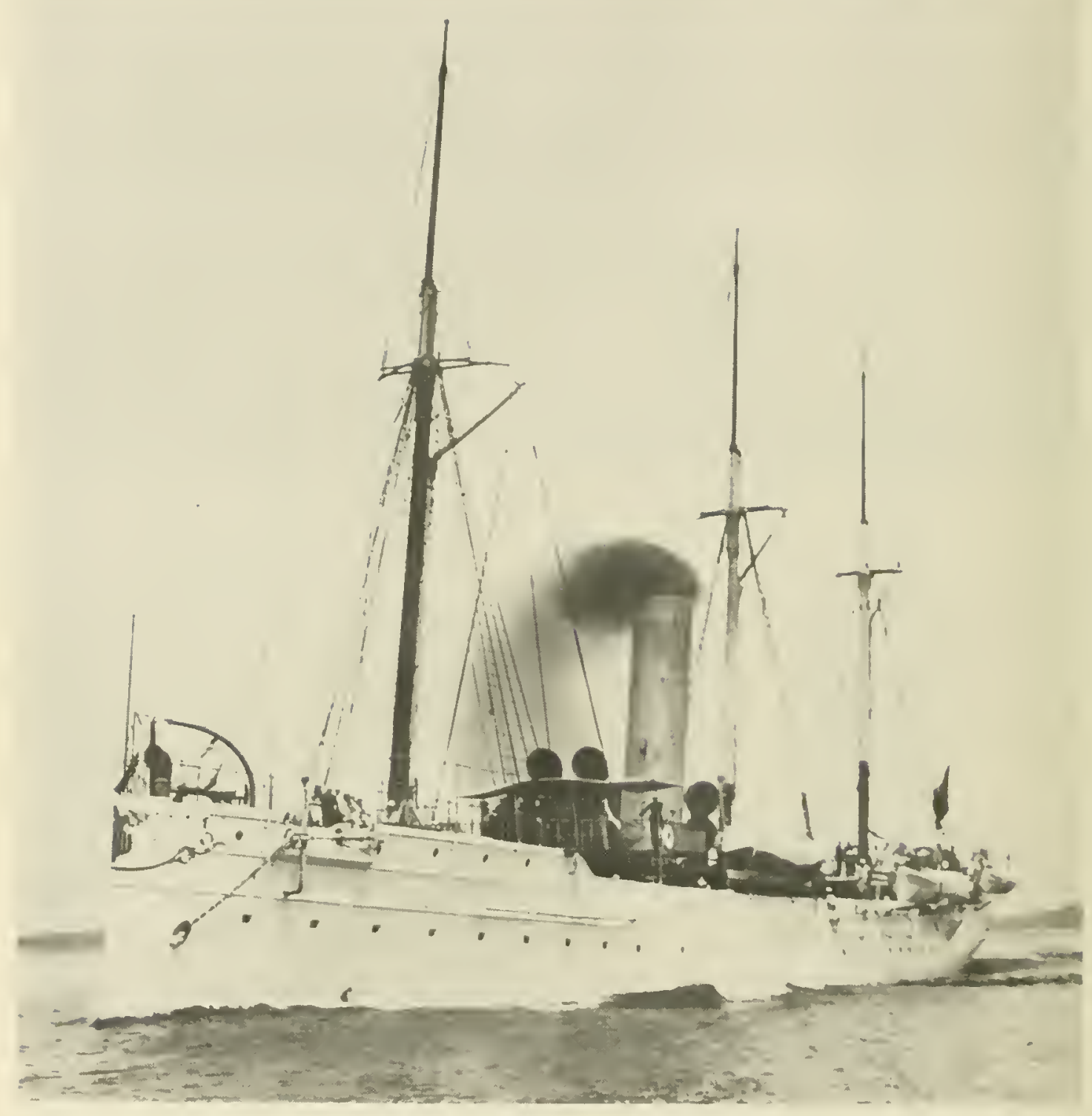

\section{USS Dolphin}

A gunboat built in 1885 by John Roach and Sons of Chester, Pennsylvania. The first of the ships of the "New Navy" to be completed, Dolphin deployed on an around-the-world cruise which ended at New York in September 1889. Assigned to the Special Service Squadron, she made surveying expeditions to Guatemala (1896), Venezuela (1899 - 1900), and Santo Domingo (1902). The following years were occupied on patrol and dispatch duty and protection of American interests. Decom. missioned in 1921, Dolphin was sold the following year.

Length: $256^{\circ} 6^{\prime \prime}$ Displacement: 1,486 tons 


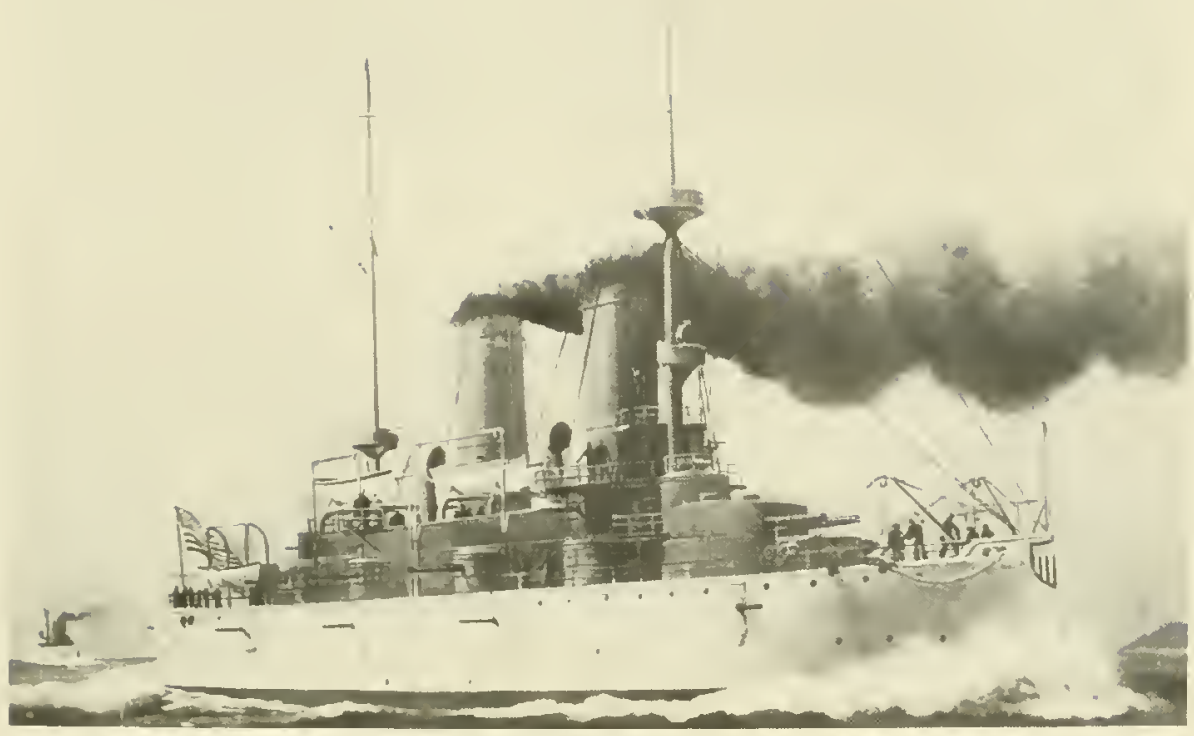

USS Olympia

A cruiser built in $\mathbf{1 8 9 5}$ by Union Iron Works of San Francisco, The oldest existing steel ship of the Navy, she now houses many this famous flagship of Admiral George Dewey at the battle of relics of the Spanish-American War.

Manila ("You may fire when you are ready, Gridley") is maintained by the Cruiser Olympia Association of Philadelphia.

Length: 344' l" Displacement: 5,870 tons

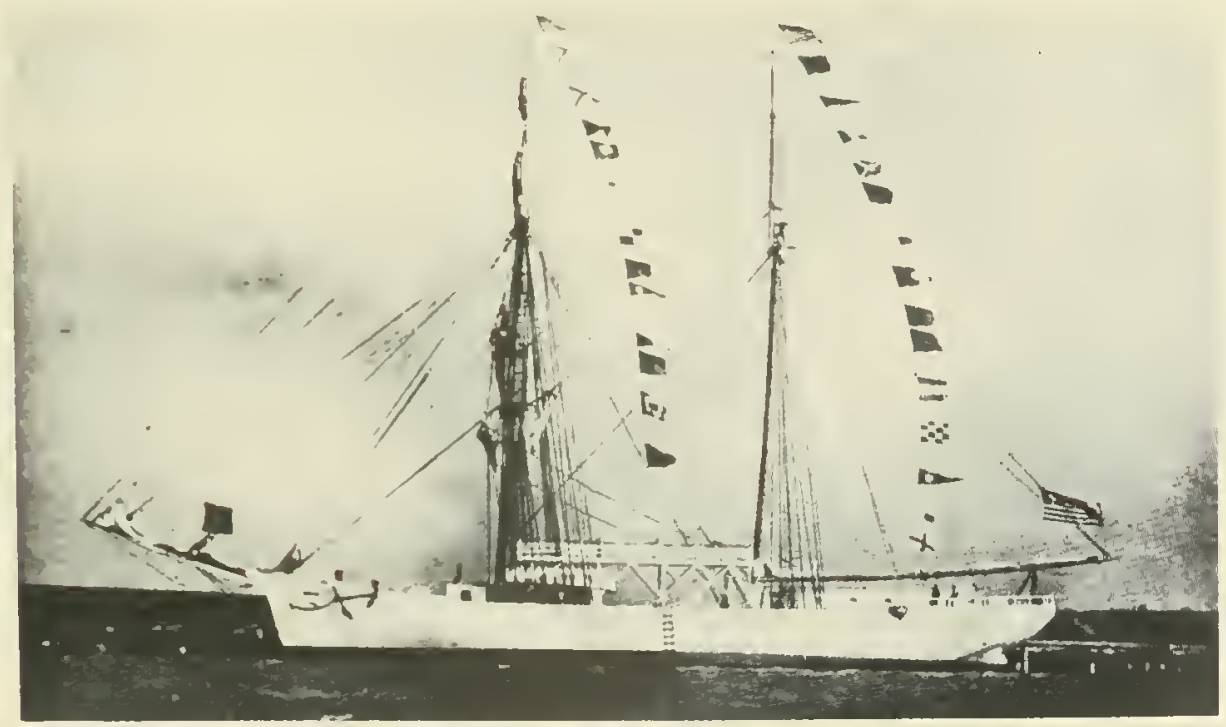

The Schooner Galilee

A wooden sailing ship built by Matthew Turner of California in 1891 for hauling freight. Chartered by the Carnegie Institution of Washington for the three-year period 1905 to $\mathrm{J} 908$ for use as a magnetic survey vessel. In her day Galilee was one of the fastest sailing vessels of her size in the Pacific Ocean.

Length: 132' Displacement: 600 tons 


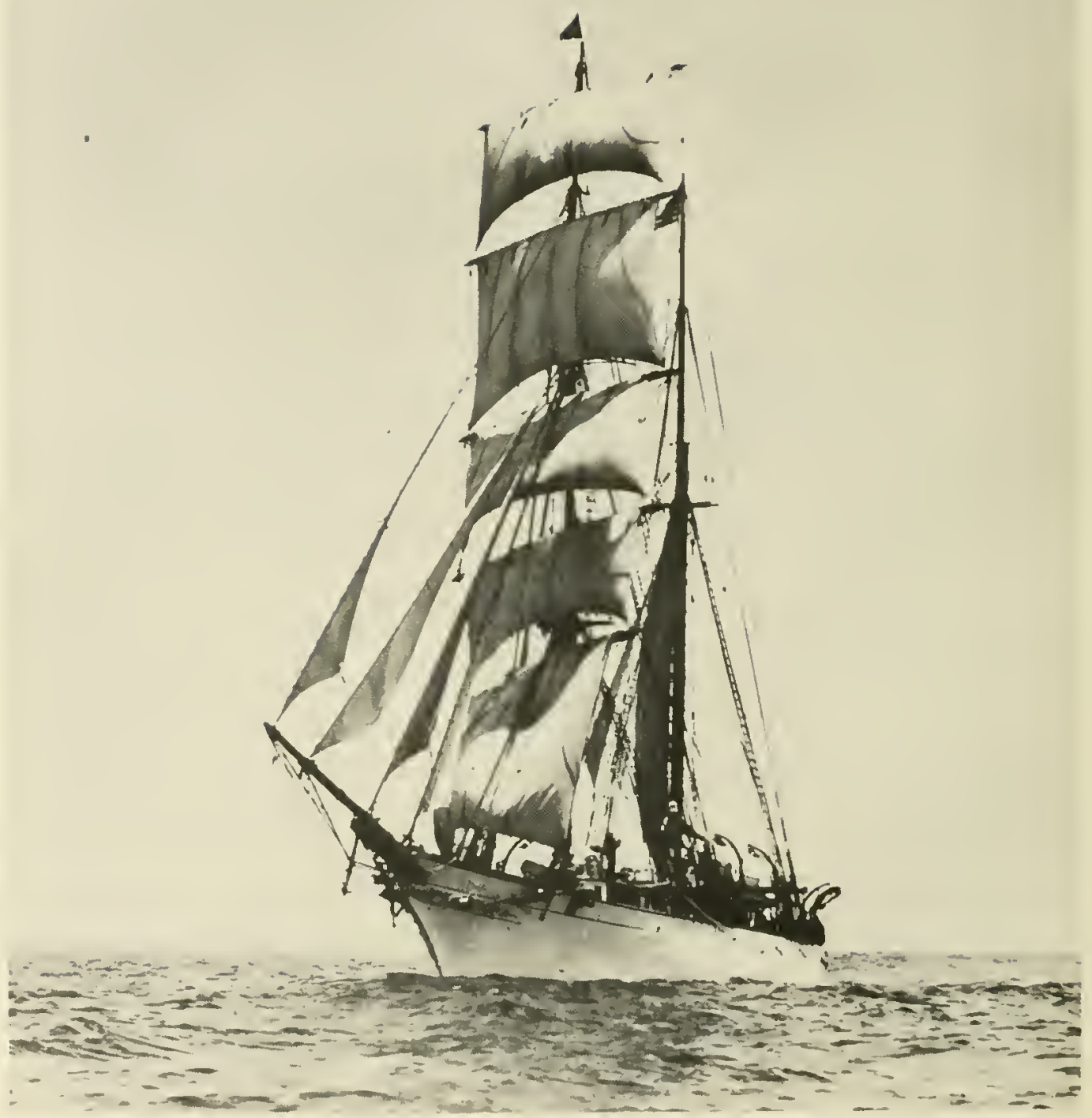

The Non-Magnetic Yacht Carnegie

Designed by $\mathbf{H}$. J. Gielow and built by Tebo Yacht Basin Company of New York in 1909, the Carnegie was the first specifically constructed non-magnetic vessel in which every effort was made to avoid the use of steel. She was also the first sea-going vessel equipped with a producer gas engine. IIer mission was mapping out the magnetic forces as they prevail over the oceans. She was active in this role until her tragic loss in 1929 at Apia, Samoa from a gasoline explosion.

Length: $155^{\circ} 6$ "Displacement: 568 tons 


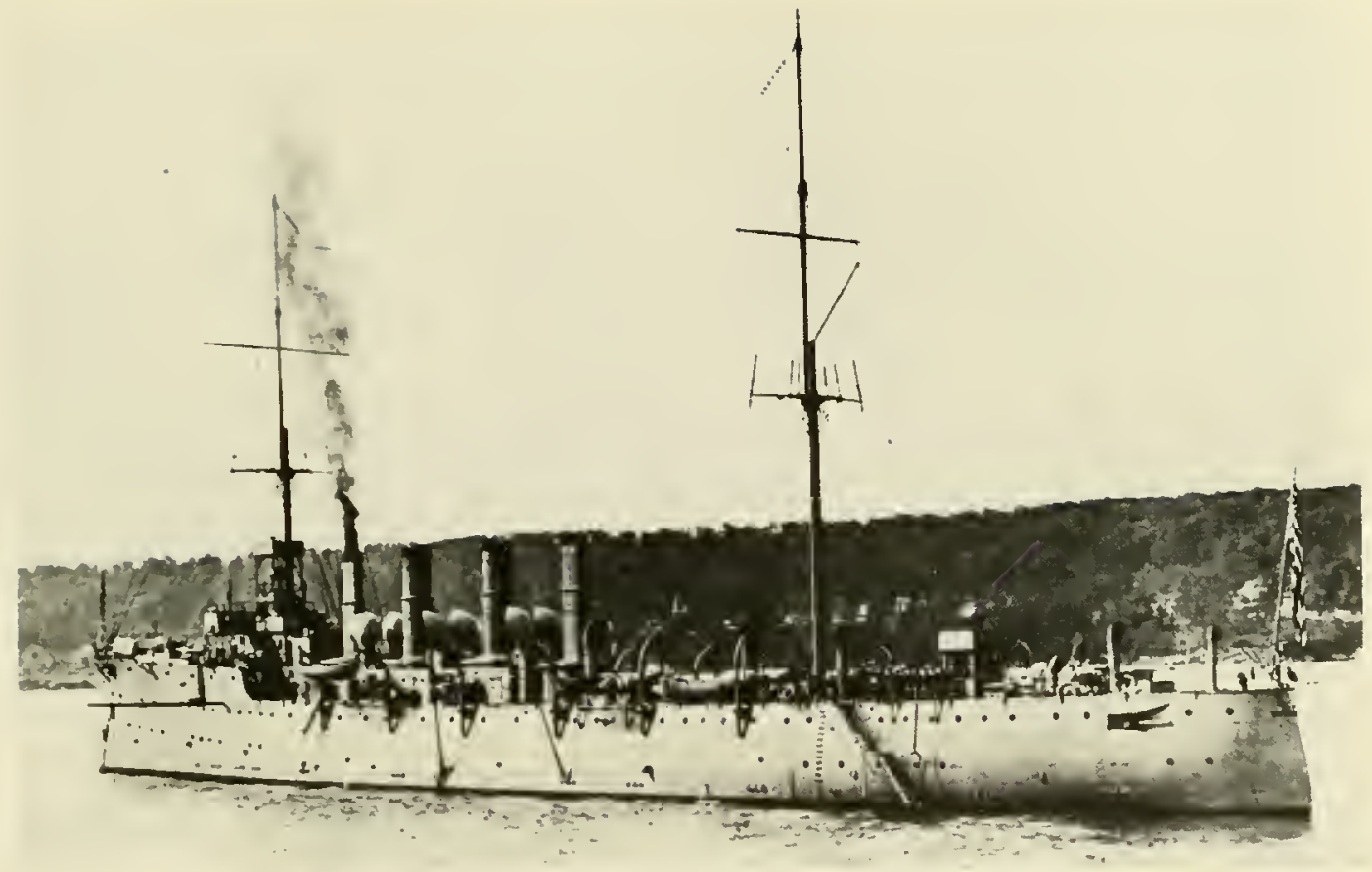

USS Birmingham

A cruiser built in 1908 by Fore River Shipbuilding Company of Quincy, Massachusetts. Following the sinking of the Titanic in 1912, the cruisers Birmingham and Chester were assigned at the recommendation of the Hydrographic Office to ice patrol duty, a forerunner of what is now the International Ice Patrol. She was disposed of in 1923.

Length: $423^{\prime \prime}$ I" Displacement: 3,750 tons

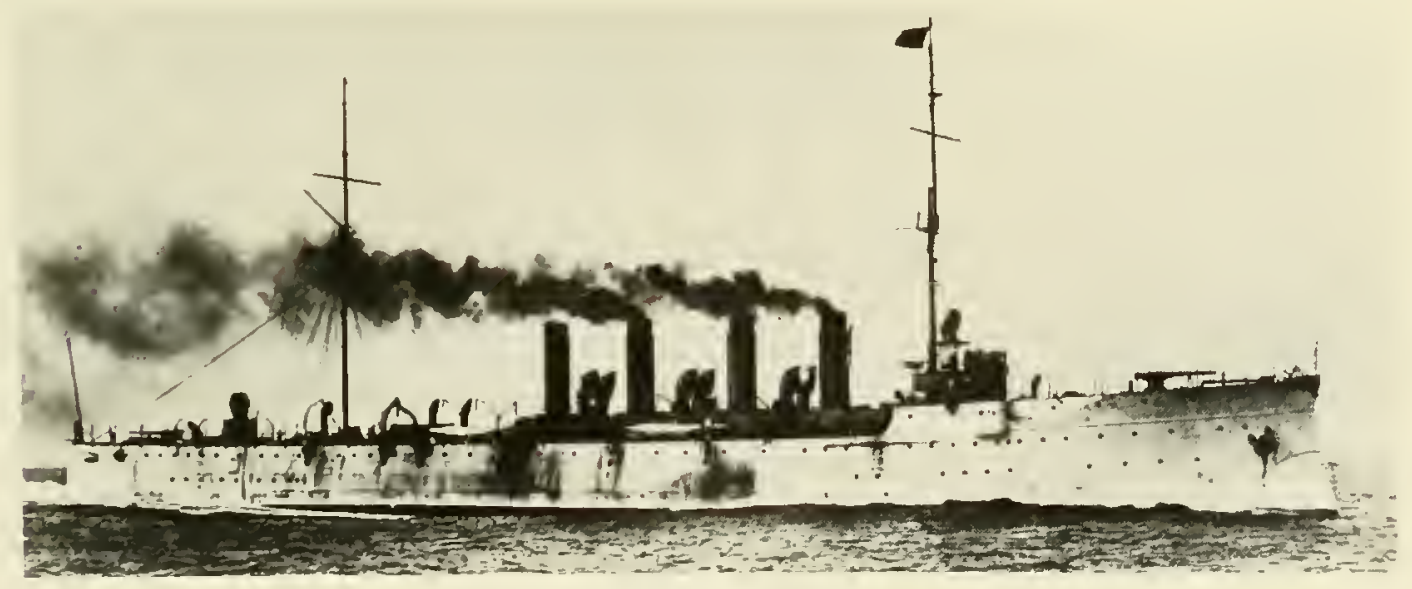

USS Chester

A cruiser built in 1908 by Bath Iron Works of Bath, Maine. Following the sinking of the Titanic in 1912, Chester and her sister ship Birmingham were assigned at the recommendation of the Hydrographic Office to ice patrol duty, a forerunnes of what is now the International Ice Patrol. The Chester was sold in 1921.

Length: 423' I" Displacement: 3.750 tons 


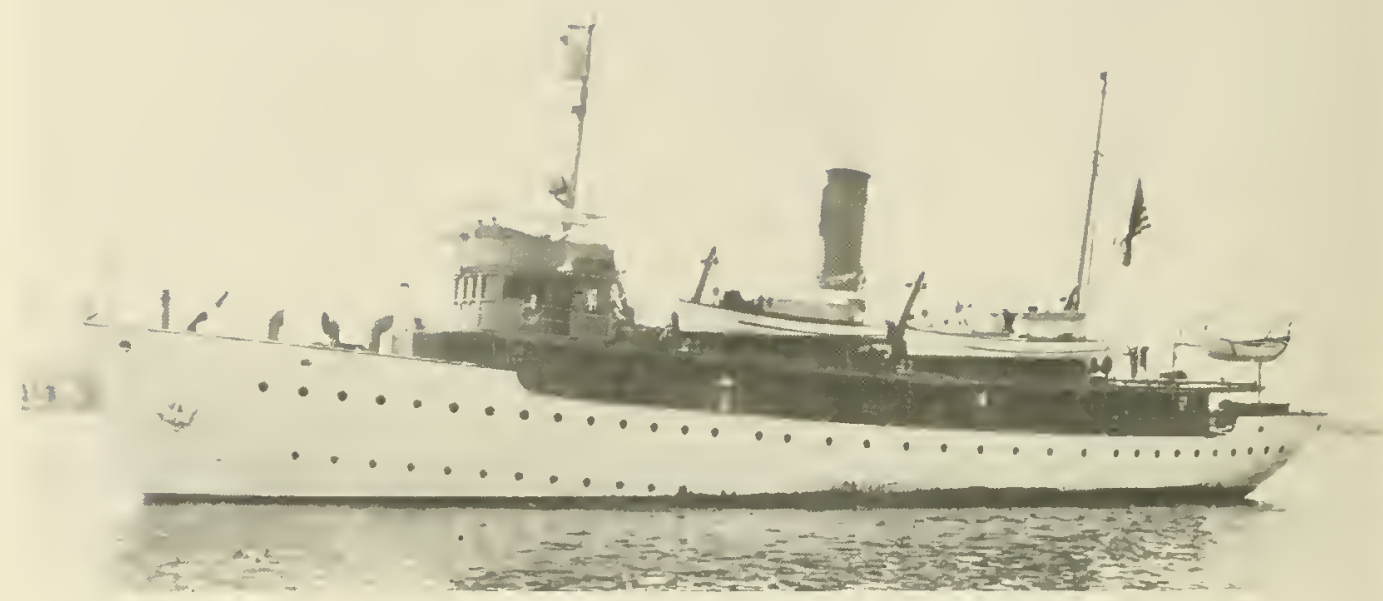

USC \& GSS Surveyor

Built in 1917 for the Coast and Geodetic Survey. Surveyor was a veteran of both World War 1 and II. During World War I, she was cited and decorated for disabling, by use of depth charges, the German submarine $U-39$, which had sunk the Lusitania. She was sold in 1950 .

Length: 186' Displacement: 1,150 tons

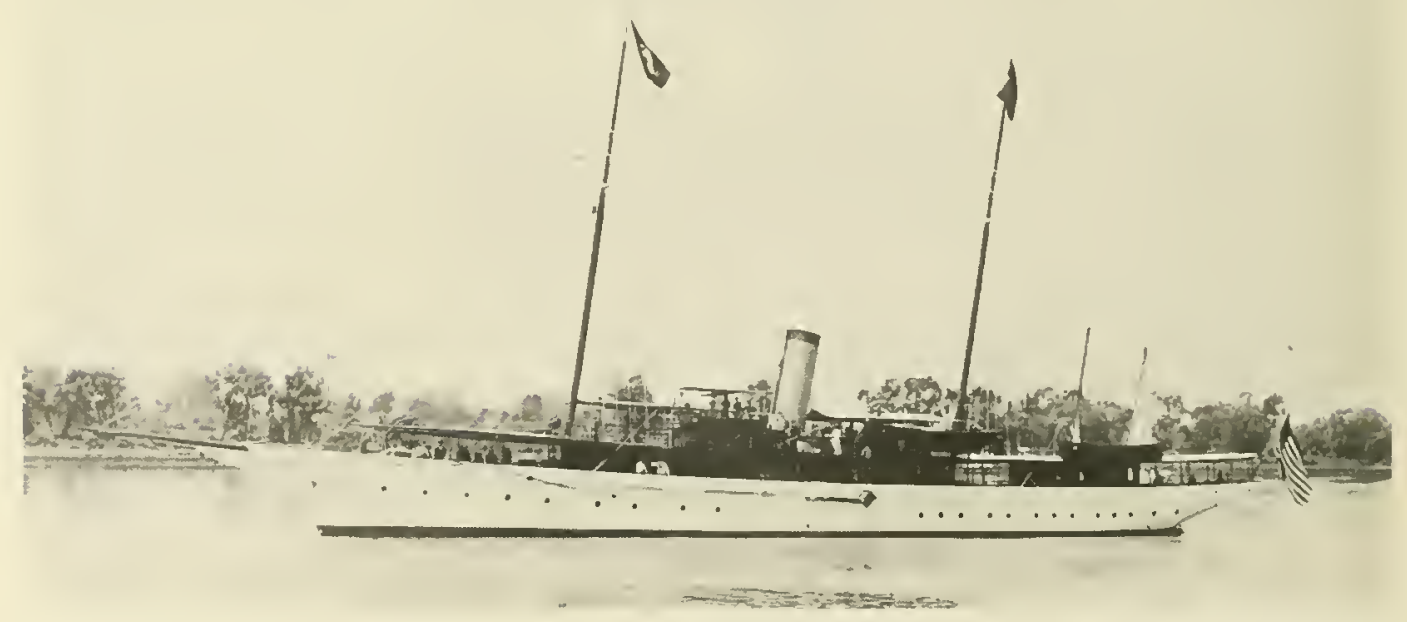

USC \& GSS / sis

A screw steamer built in 1902 for the Coast and Geodetic Survey. Isis was taken over by the Navy during World War I and operated out of New York and then Norfolk. She was returned to the Survey in 1919.

Length: 199' Displacement: 555 tons 


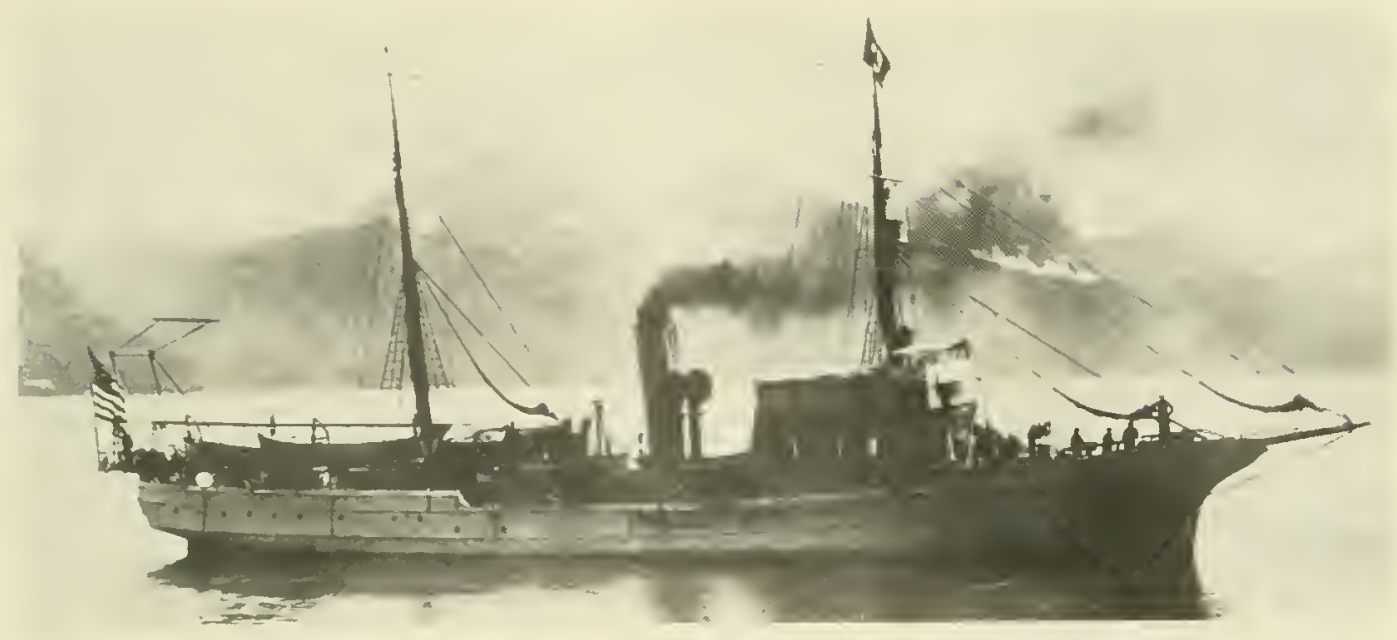

USC \& GSS Explorer

Built in 1904 for the Coast and Geodetic Survey at Wilmington. Transferred to the Navy in 1918, the Explorer was assigned to patrol duty off Alaska during World War I. She was returned to the Survey in 1919 and retired from service in 1939.

Length: 135' Displacement: 450 tons

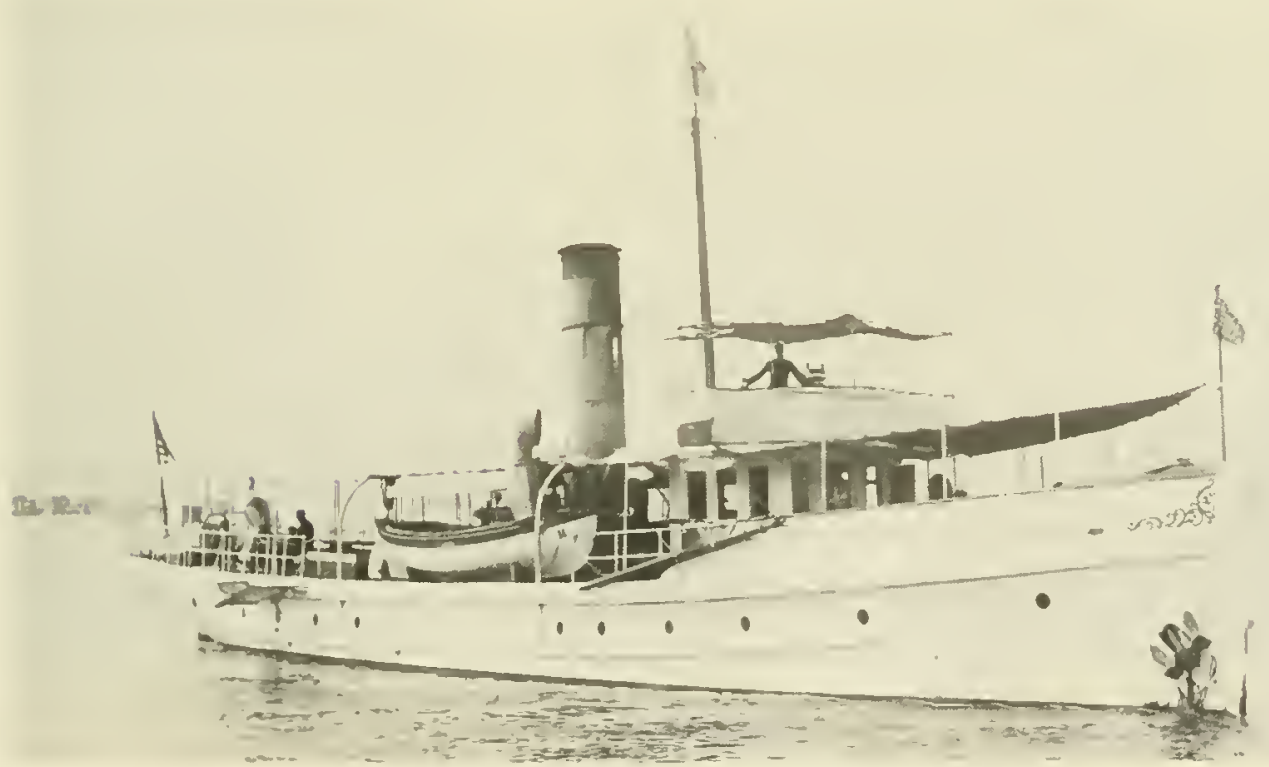

USC \& GSS Hydrugrapher

A wooden-hull steam vessel built in 1901 at Port Jefferson, New York for the Coast and Geodetic Survey. The first Survey ship to bear the name Hydrographer.

Length: 101' Displacement: 146 tons 


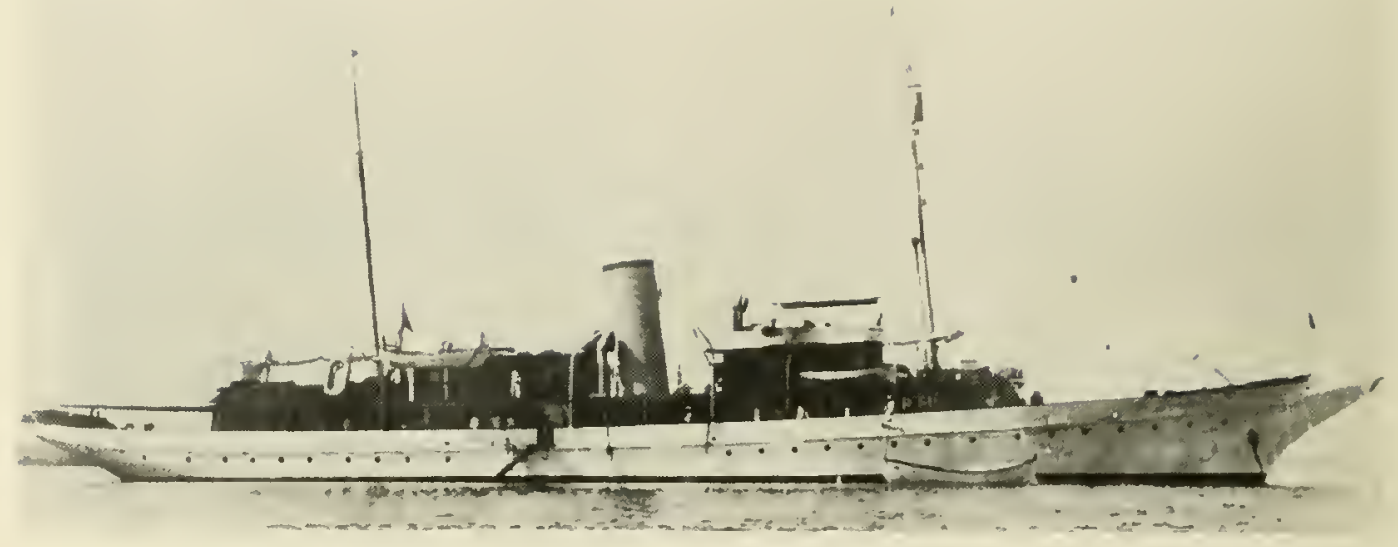

USS Nokomis

Built by Pusey and Jones of Wilmington in 1917 as the 243-foot steam yacht Kwaswind for Horace $\mathbf{E}$. Dodge. Purchased by the Navy that same year for $\$ 510,000$. From 1919 to 1934 she was assigned surveying duty in Mexican and Caribbean waters.

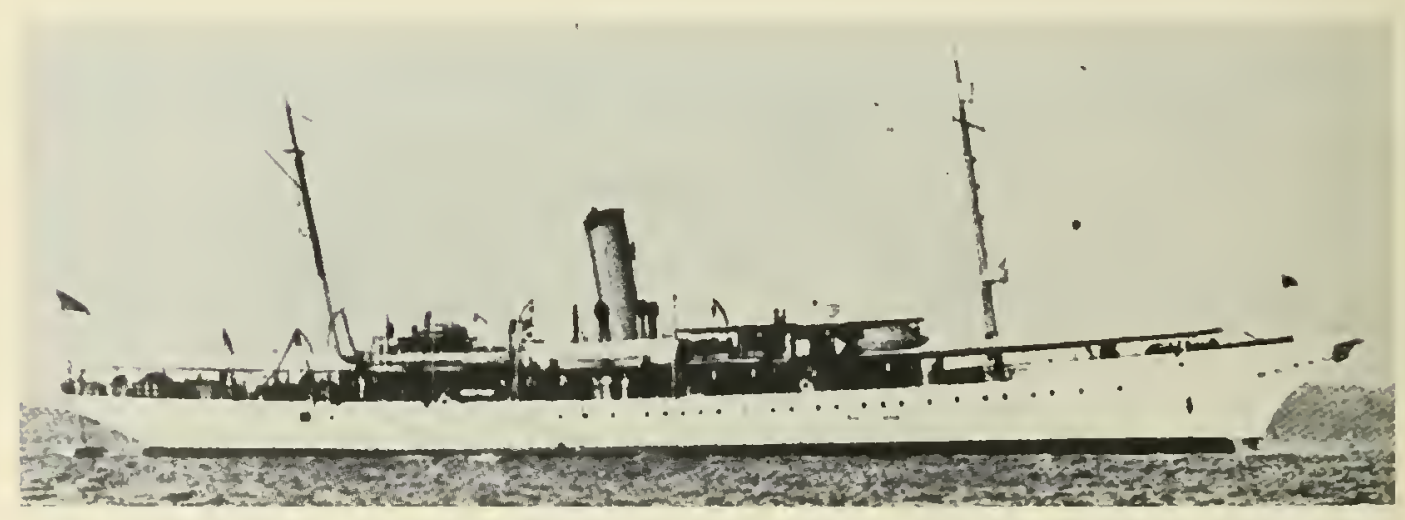

\section{USS Niagara}

A private steam yacht built in $\mathbf{1 8 9 8}$ by Harlan and Hollingsworth of Wilmington. She was purchased by the Navy in 1917, converted to an armed patrol yacht, and placed in commission the following year. Between 1924 and 1930 Niagara was engaged in surveying duty in Caribbean waters. Decommissioned in 1930 , she was sold for scrap the following year.

Length: $250^{*}$ Displacement: 2,600 tons 


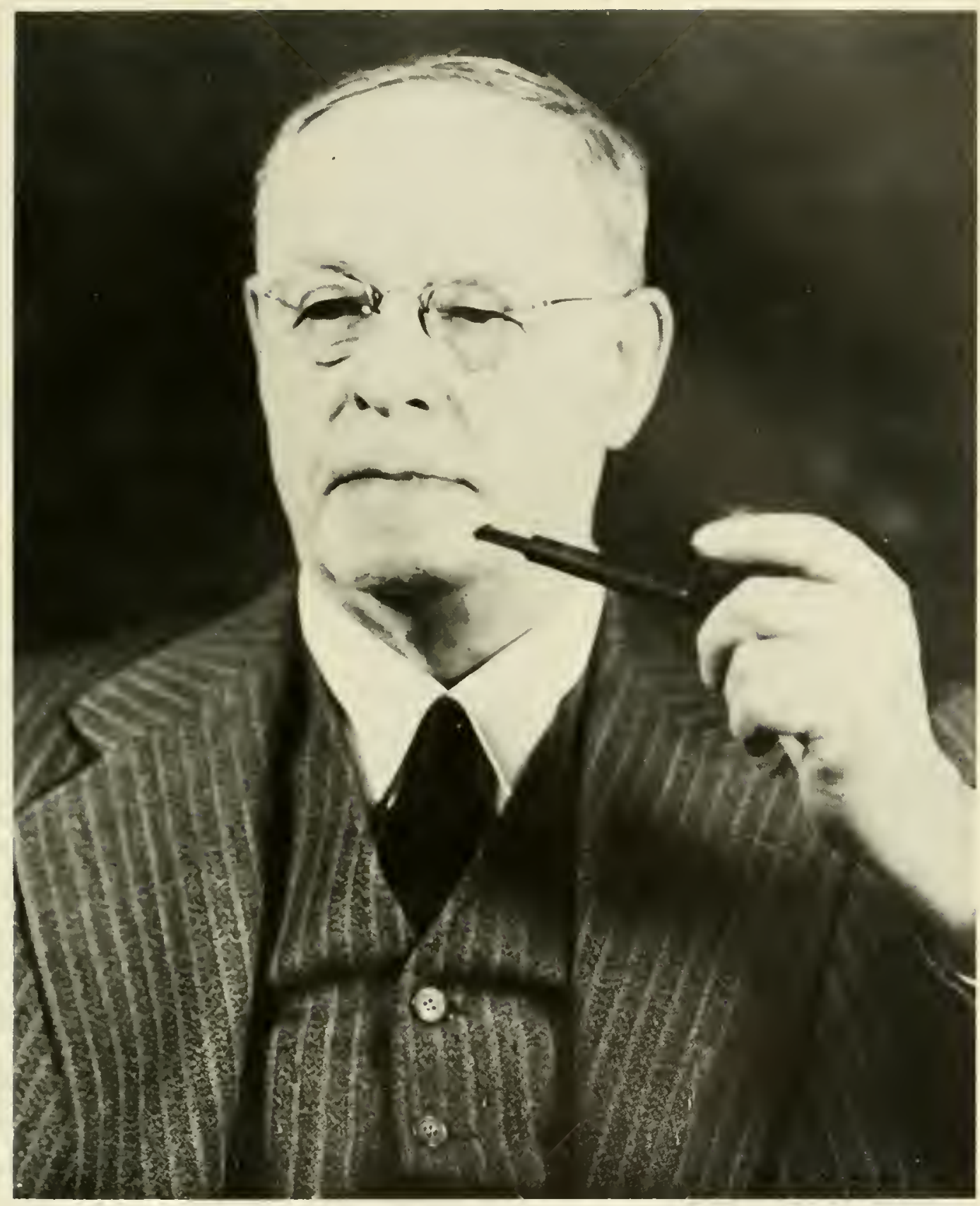

Harvey Cornelius Hayes

(1878-1968)

Developed the sonic depth finder in 1921 at the Naval Experimental Station at Fort Trumbell, New London, Connecticut. From 1923 - 1947 Hayes was Superintendent of the Sound Division at the Naval Research Laboratory. The Navy's first catamaran-hull oceanographic research ship, the T-AGOR 16, is named in his honor. 


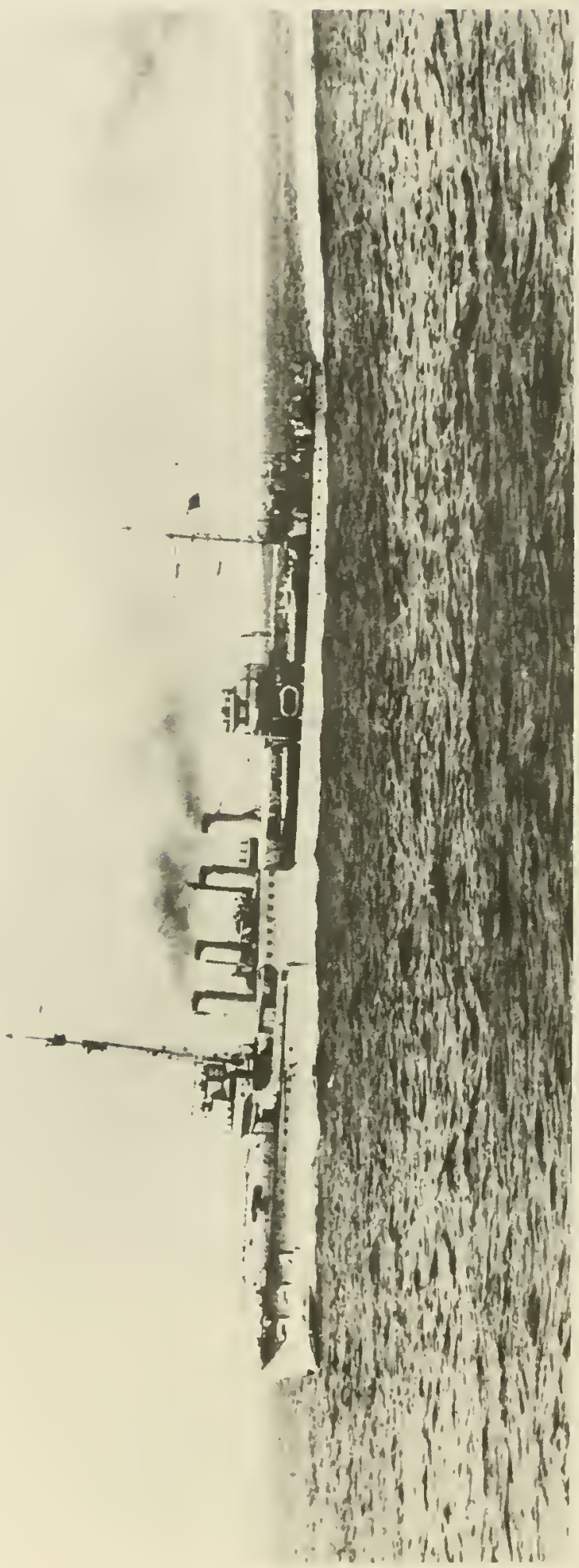

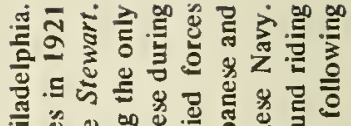

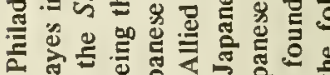

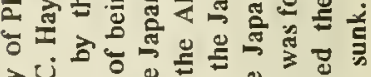

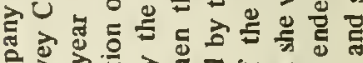

岕

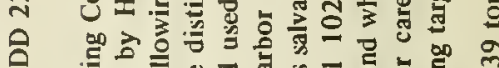

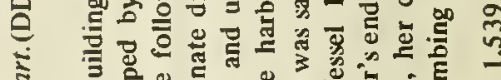

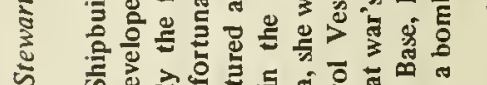

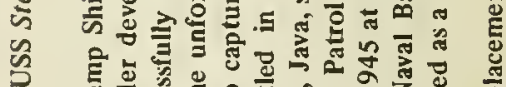

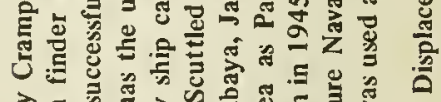

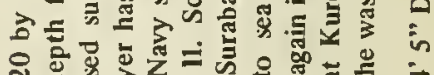

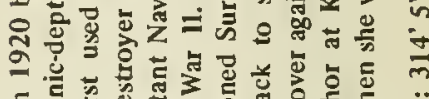

. 


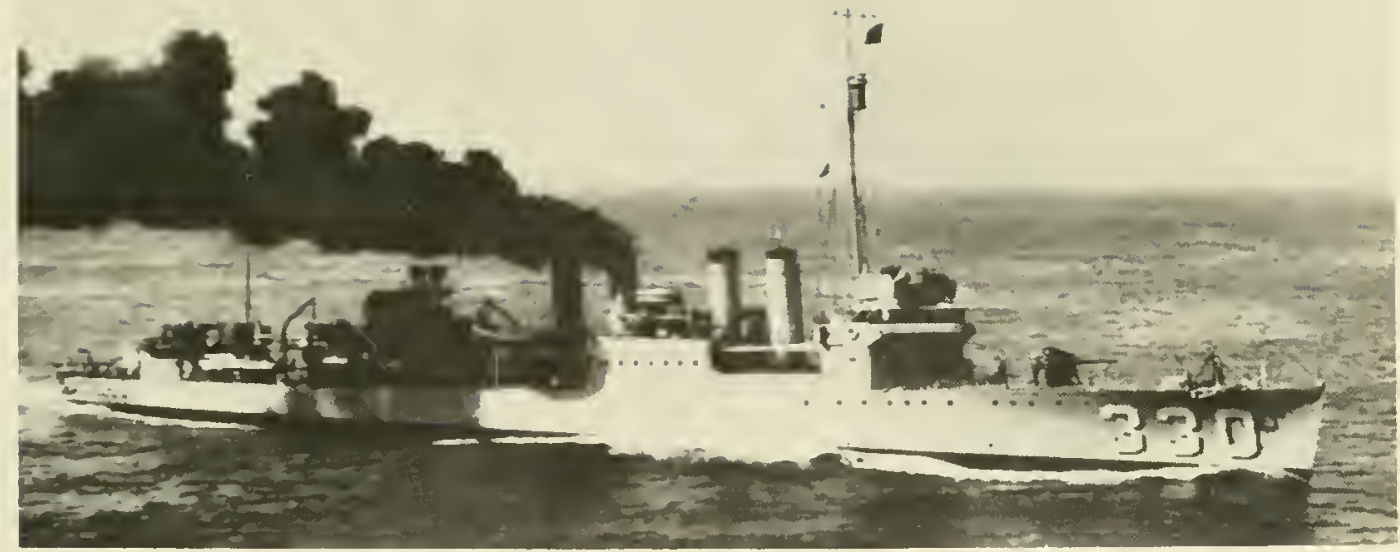

USS Hull (DD 330)

Built in 1921 by Bethlehem Shipbuilding Corporation of San Francisco. In 1922 Hull conducted sounding operations along the coast of southern California using the newly developed sonic depth sounder. This project was sponsored by the Carnegie Institution of Washington in determining the cause of earthquakes. In $1924 \mathrm{Hull}$ was assigned to take soundings between
Seattle, Washington and Seward, Alaska in preparation for laying an Alaska communications cable. Decommissioned in 1930, she was sold for scrap in 1931 in accordance with the London Treaty of 1930 for the limitation of naval armament.

Length: 314" 4" Displacement: 1,308 tons

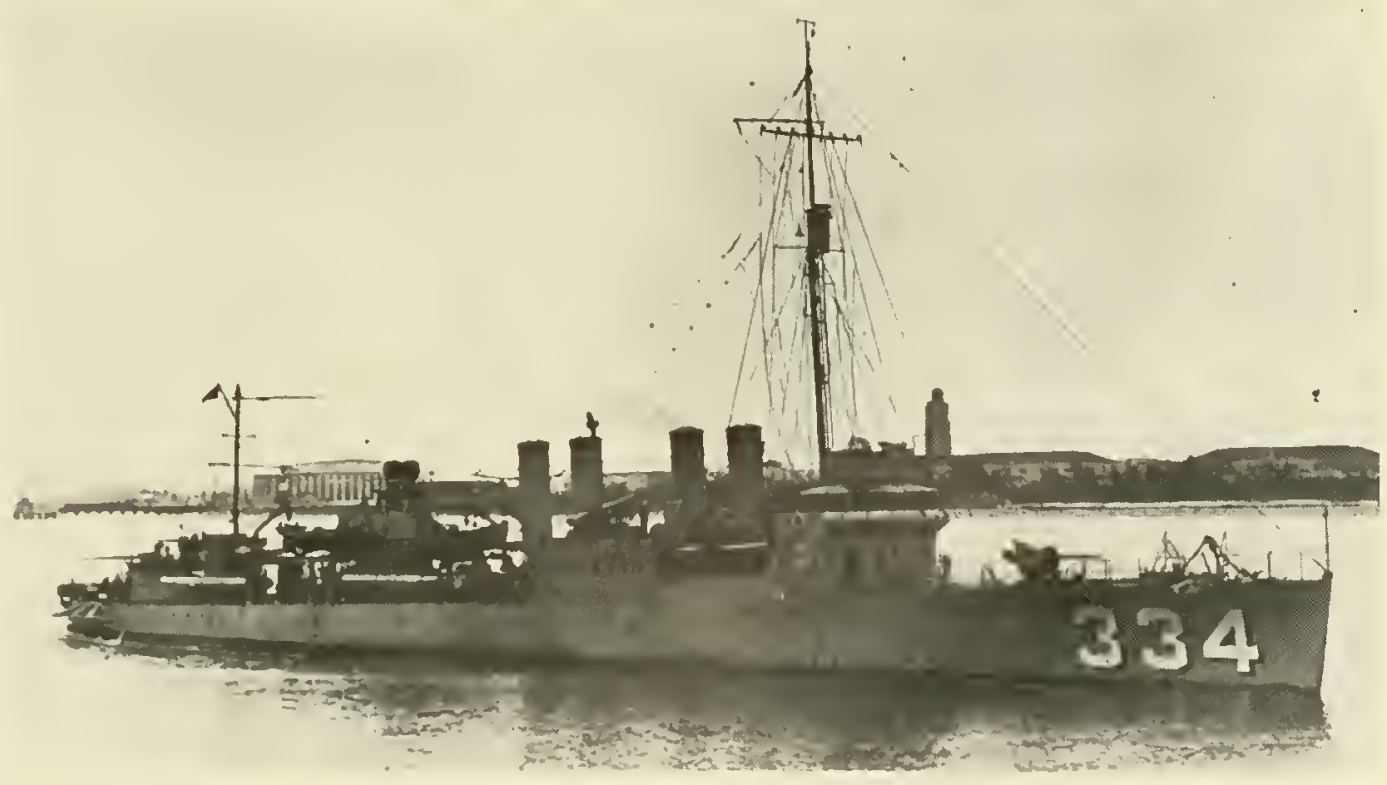

USS Corry (DD 334)

Built in 1921 by Bethlehem Shipbuilding Corporation of San Francisco. In 1923 the Corry, together with her sister ship Hull (DD 330), had the newly developed sonic depth finders installed and conducted sounding operations of the Pacific continental shelf in support of earthquake investigations being carried out by the Carnegie Institution of Washington. Corry was stripped and sold for scrap in 1930 in accordance with the terms of the London Treaty.

Length: 314'5" Displacement: 1,190 tons. 


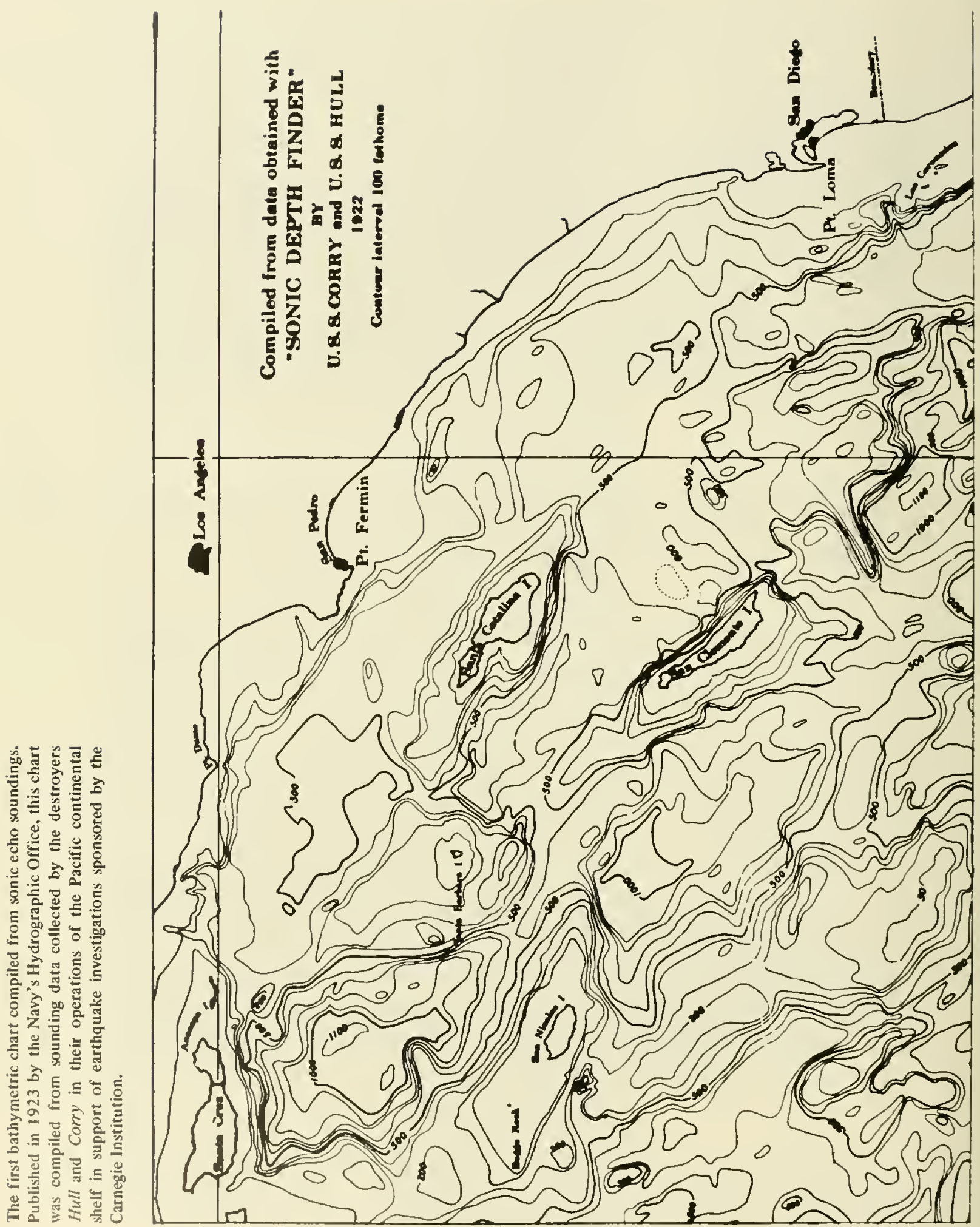




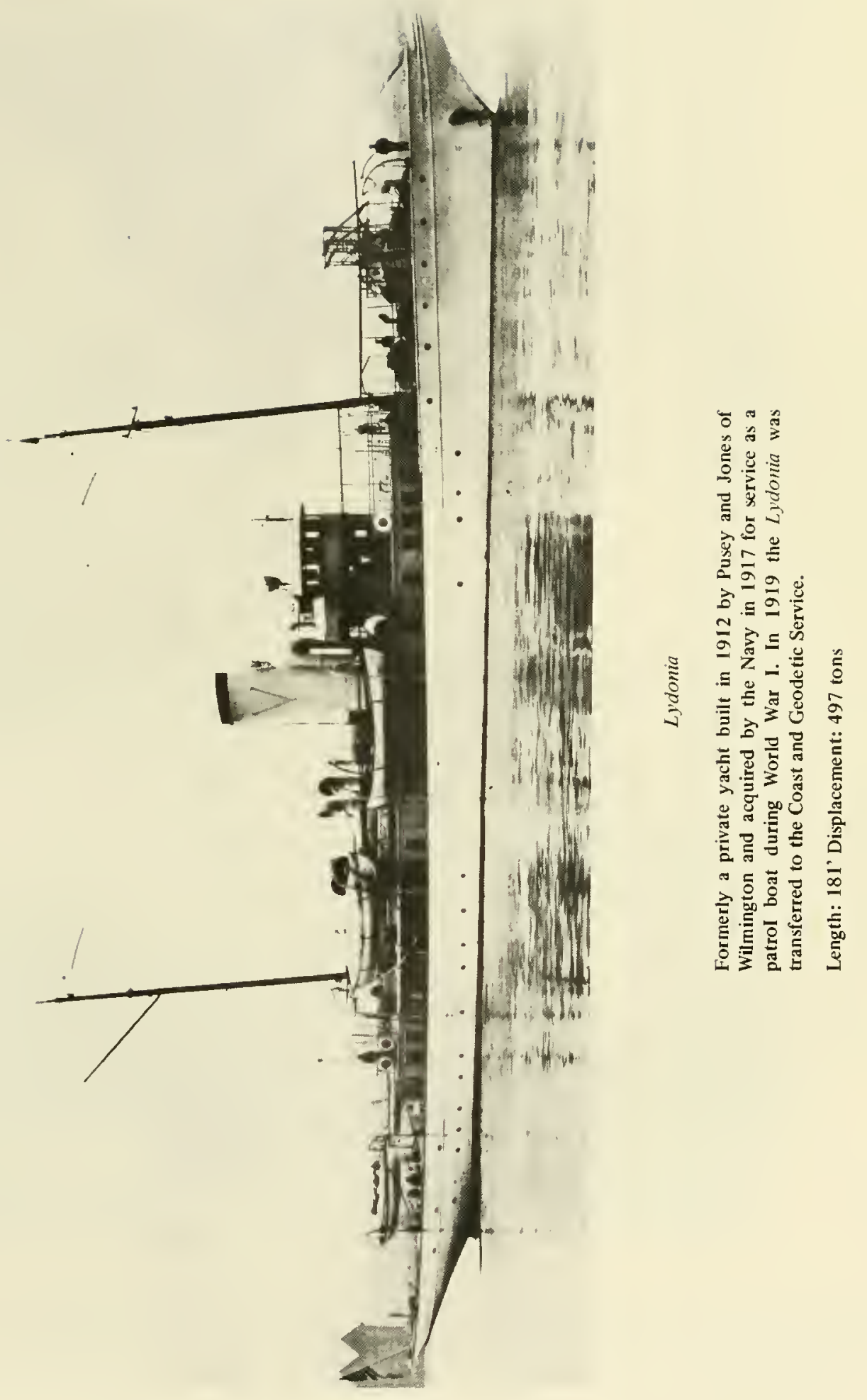




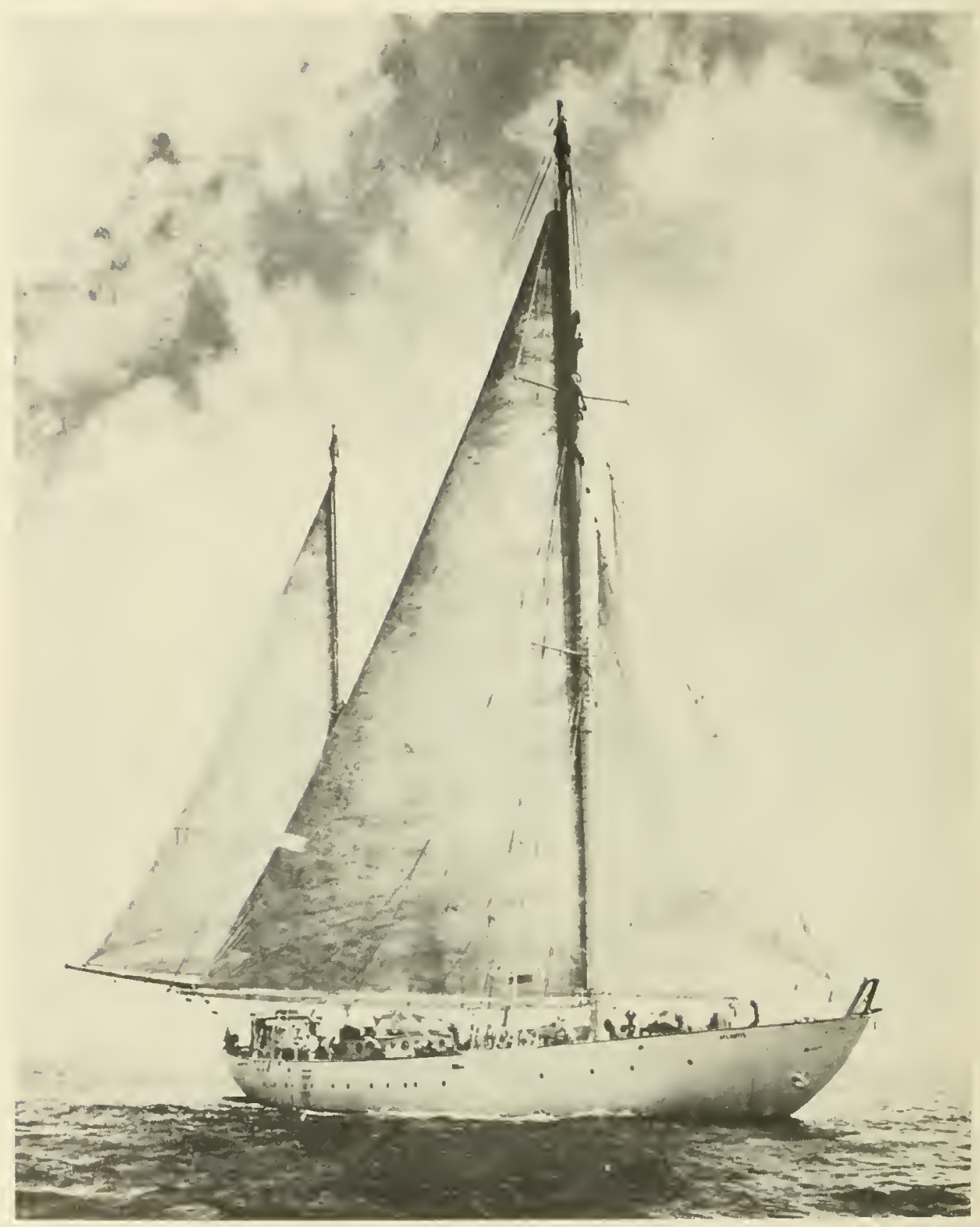

R/V Allantis I

A 142-foot steel ketch built in Copenhagen in 1931 for Woods Hole Oceanographic Institution. In 1964 Atlantis was sold to the Consejo Nacional de Investigaciones Cientificas y Technicas, Buenos Aires, Repulica de Argentina, where she was renamed El Austral. 


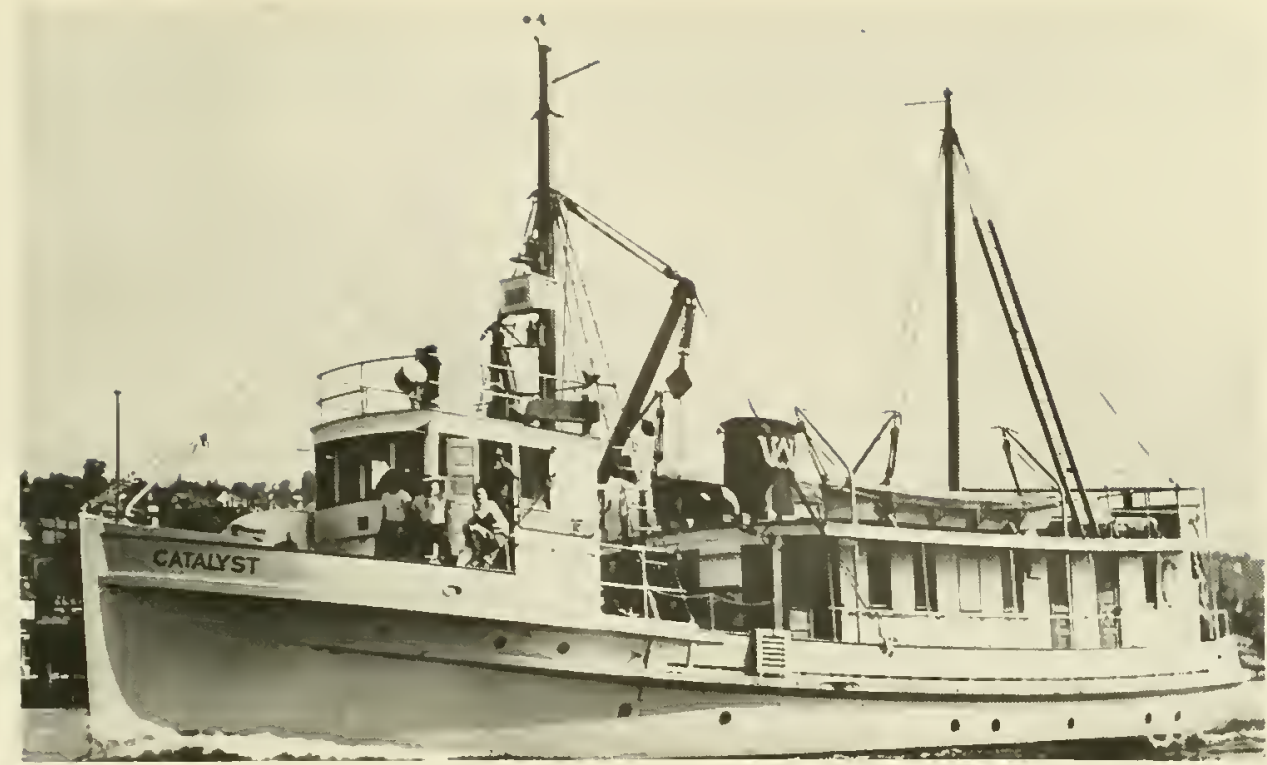

Courtesy of Marine Photo Shop, Joe D. Williamson, 285 Shannon Drive S.E., Winslow, Washington

R/V Catalyst

A 75 -foot converted vessel used for oceanographic research in the 1930s by the University of Washington.

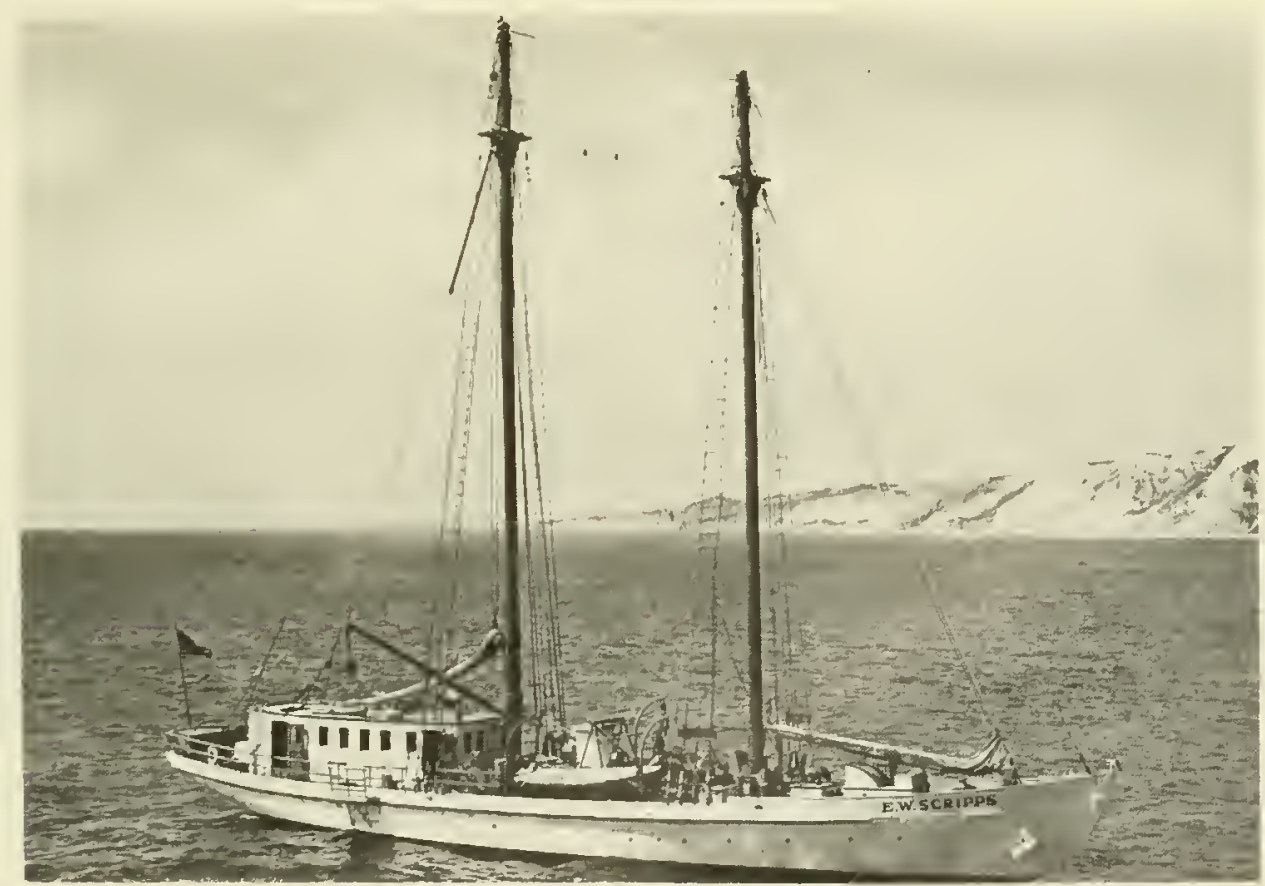

R/V E.W. Scripps

Originally the 104-foot luxury yacht Serena of Hollywood actor Lewis Stone. In 1937 she was purchased by Mr. Robert P. Scripps and presented to Scripps for use as a research ship. Disposed of in 1955 she was used for the movie "Around the
World in Eighty Days" and later became a South Seas island schooner. The E. IV. Scripps now rests on the bottom of the Papeete Harbor in Tahiti. 


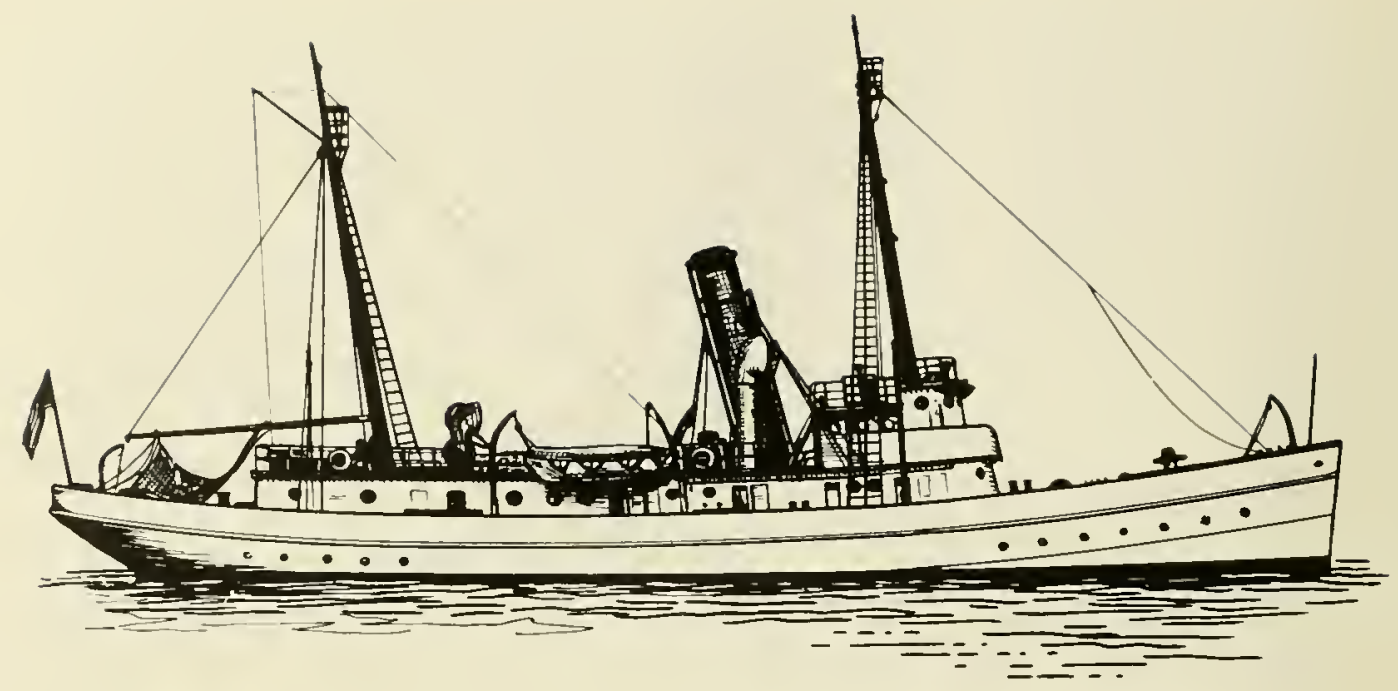

Albatross II

The former 150-foot, two-masted, steel-hulled, Navy sea going Tug Number 11 built in 1911 by Norfolk Navy Yard. In 1926 she was transferred to the Bureau of Fisheries and renamed the
Albatross II. Plagued by mechanical troubles, she was finally disposed of in 1934.

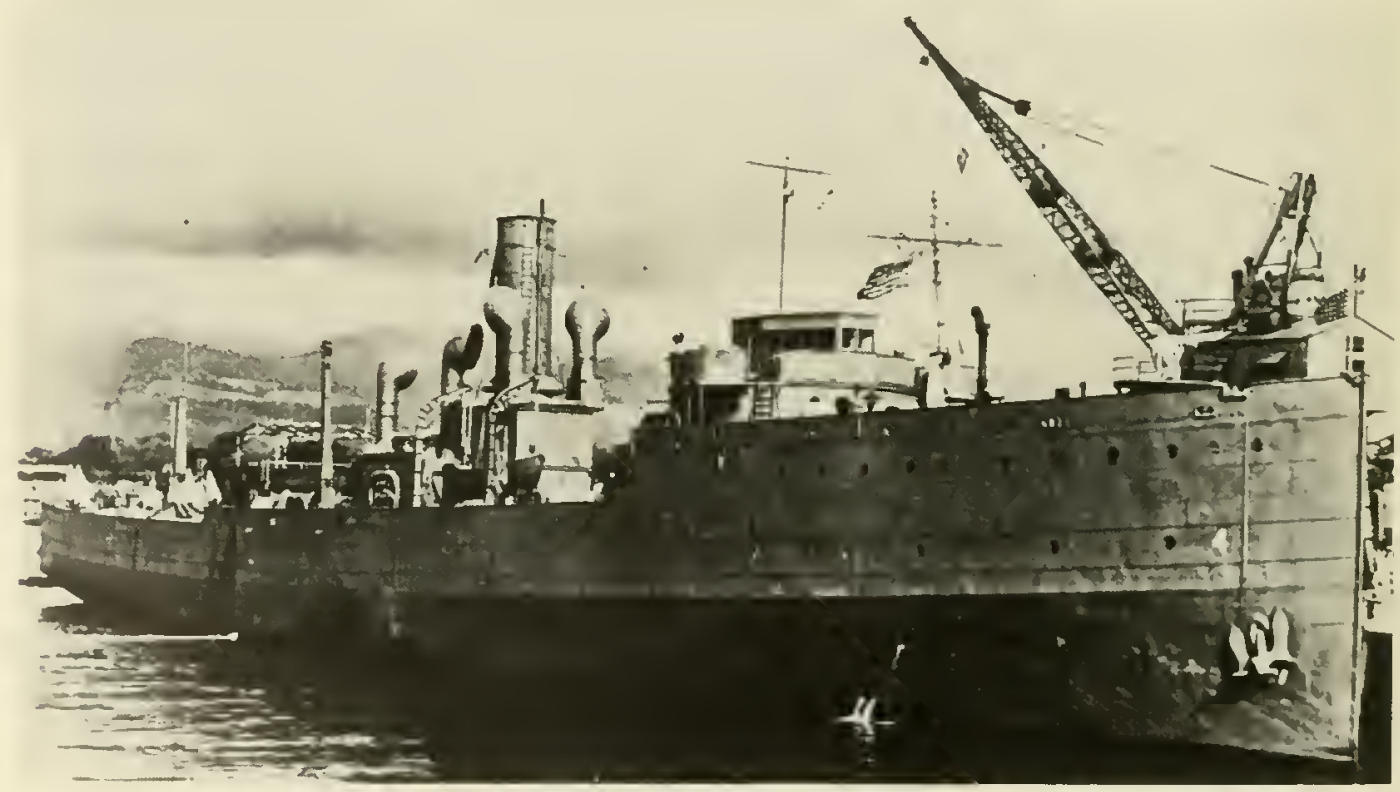

USS Oglala

Built by William Cramp and Sons of Philadelphia in 1907 as the SS Massachusetts for the Fall River Line. Acquired by the Navy in 1918 and converted to a minelayer, she was renamed USS Shawmut (CM 4). Later, refitted as an aircraft tender, she operated witl the fledgling naval air arm in the early 1920s. In 1928 her name was changed to USS Oglala and she was assigned duty as Flagship of Mine Division One. Oglala was sunk by a torpedo hit while berthed at Pearl Harbor when the Japanese launched their attack. Later salvaged, the Oglala provided repair to landing and patrol craft for the rest of the war. She was disposed of in 1947.

Length: $386^{\circ}$ Displacement: 3,746 tons 


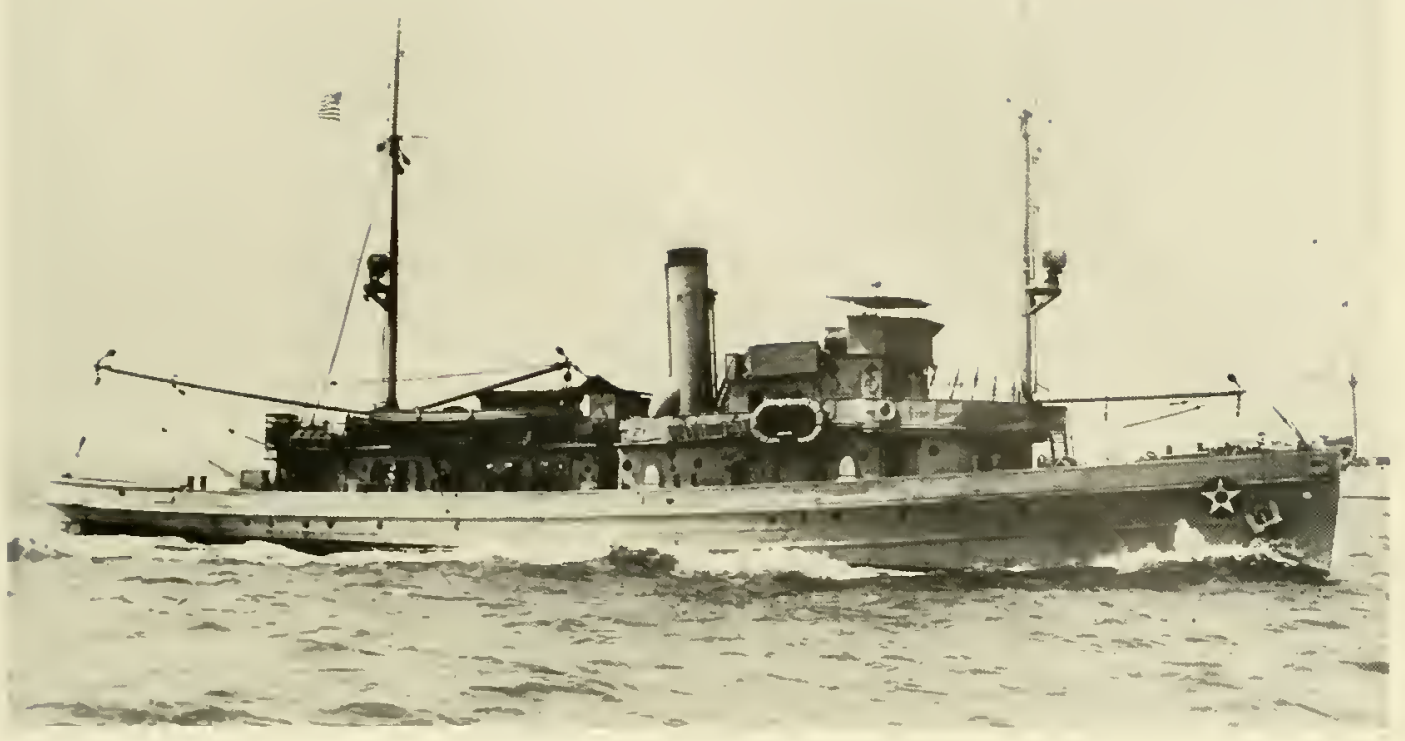

USS Gannel (AM-21)

Built in 1919 by Todd Shipyard Corporation of New York. During the summers of 1926, 1929, and 1932 through 1935, she acted as an aircraft tender accompanying survcy expeditions (which included aerial surveys) to Alaska and the Aleutian lslands. Participating in these summer expeditions were eivilian scientists from academic and private oceanographic institutions. In June, 1942 while operating northwest of Bermuda, Gannet was hit by torpedoes and sunk.

Length: 187'10" Displacement: 950 tons

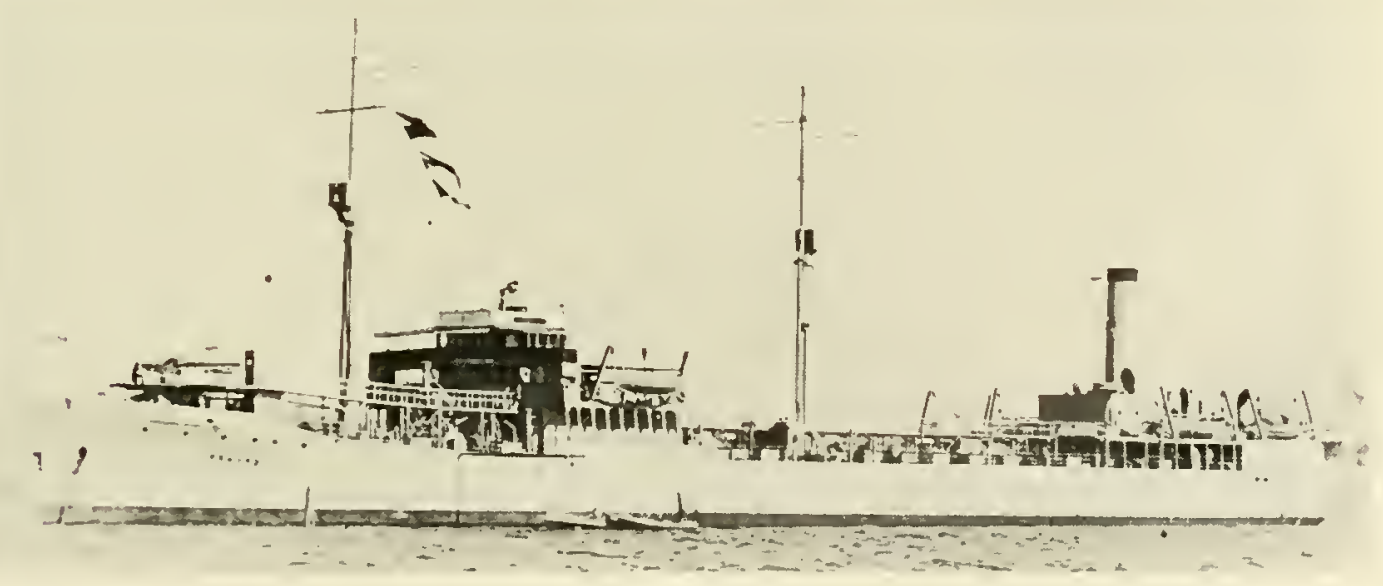

\section{USS Ramapo}

A single screw, commercial type oil tanker built in 1919 by 51 crossings of the North Pacific from 1929 to 1938 coinciNewport News Shiphuilding and Drydock Company of Newport dental with her tanker duties. She was disposed of in 1946. News, Virginia. She gathered extensive sounding data during her Lengtlı: $477^{\circ} 10^{\prime \prime}$ Displacement: 19,189 tons 



\section{CHAPTER IV.}

\section{THE WAR YEARS}




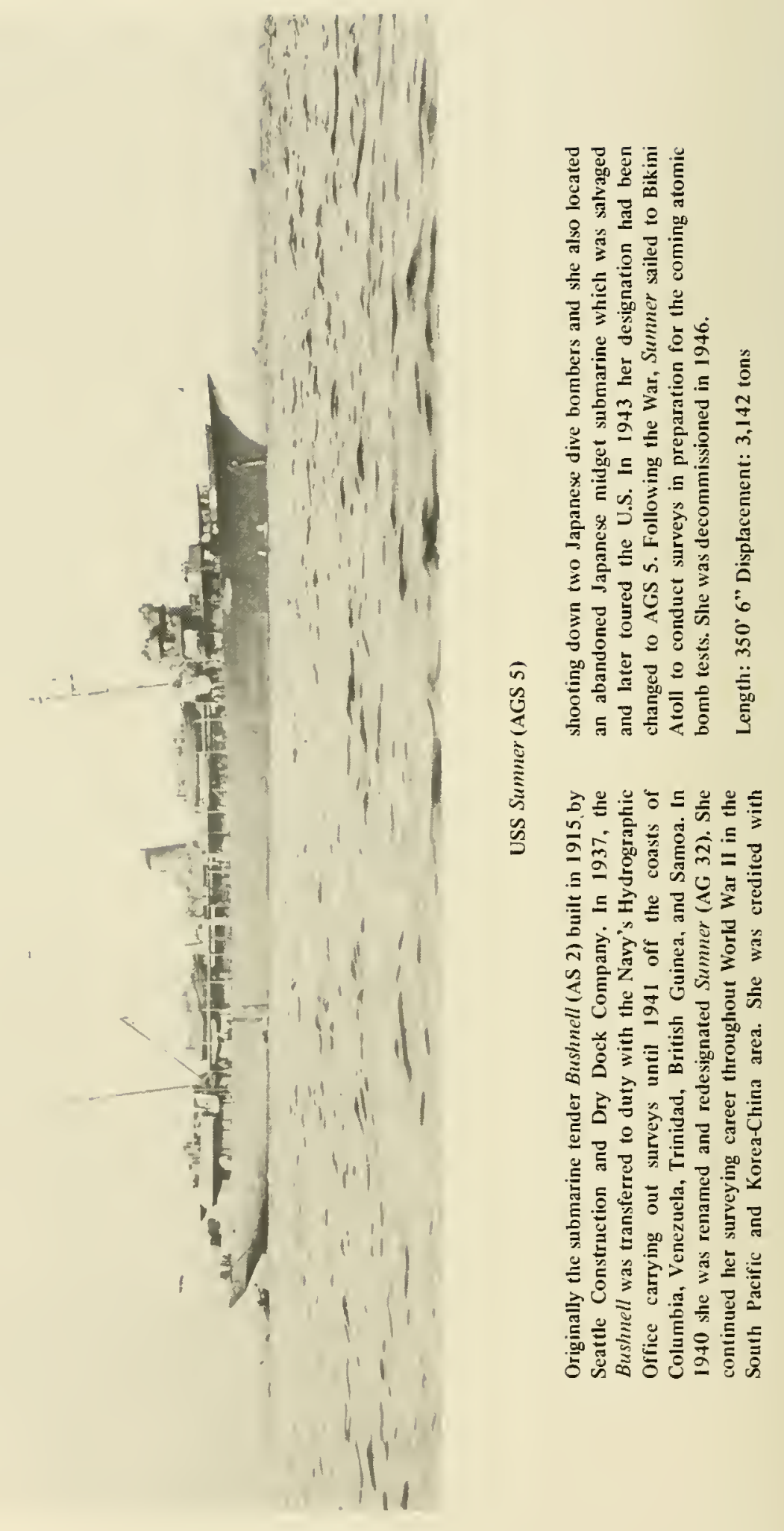


During World War II the Navy vigorously pursued oceanographlic research to meet vital defense needs. Turning to the private and academic institutions for the scientific expertise required, the significant contrihutions resulting were to include improved oceanographic instruments, bottom sediment charts, studies that improved the maintenance of trim on submarines, long-range weather forecasts, evaluation of beach information for amphibious landings. development of submarine detection equipment and sonar operators manuals for the Fleet, indentification of the deep seattering layer. and underwater sound and explosive phenomena.

The urgent need for extensive hydrographic surveys, especially in the Pacific, saw the enlistment of a varied lot of converted ships: the old subtender Bushnell (renamed Summer); the Grace Lines eargo-passenger ship $S . S$. Santa lnez (renamed Bowdith) which replaced the Ilamibal; the private schooners tiffic M. Morrissey and Bowdoin: the famed 199-loot sailing ship Bear, of the Greeley Relief Expedition and Rear Admiral Byrd's Antarctic Expeditions; the 136-foot motor minesweepers Chawenet. Ilarkness, James M. Gilliss and Simon Neweomb; the 136-foot subchasers Jo/m Blish, Armistead Rust, Littchales and Duthom, and the three 98-foot, steel-hull. auxiliary patrol craft YP 41.42 and 50 which operated with the Boweditch. Six of the Coast and Geodetic Survey's major ships were ordered to duty with the Navy: lhe Guide. Discoverer, and Pioncer Which were former Navy minesweepers transferred to the Survey after World War 1, the Oceanographer which was the former $\$ 3.0$ million luxury yacht Corsair $/ /$ built in 1897 for J. P. Morgan and acyuired by the Survey in 1930: and the Mydrographer and the Pallinder which were built by the Survey in 1931 and 1942, respectively. These ships had their days in battle. often under fire acquiring the data needed to take our fighting ships deeper into enemy-held waters. At Tarawa, the Summer was under Japanese air attack for 26 out of 30 ditys as she struggled to update the only available charts of that island, which were nearly loo years old. Ar Iwo Jima, the Sumner again was under attick when sle added a nearly forgotten hydrographic footnote to history. As the fighting raged on and the enemy lobbed shells at the Summer, the hydrographers went about their jobs of surveying settung up one of their triangulation markers alongside the now famous flag raised hy the Marines on Mount Suribachi! At Okinawa, the Bowdich conducted survey operations hand-inthand with fighting. Almost daily the guns of the Bowditch answered the allacks by enemy planes and in all, some $20+$ general cuaters were sounded and lour Japanese planes downed, one by he YP H. The IIydrographer operated with Army assault forces in the Aleutians soumding out safe anchorages and ship lanes for attack Iansports and other auxiliaries. Also assigned in survey operations in the western Pacific, the Ily drographer fought off frequent raids by the enemy while operating in the Palaus and one night destroyed a three-man assault team which sought to blow-up the ship while it lay at anchor in the harhor. The Palhfinder was also attacked by Kanikaze planes at Okinawa, one of which erashed in(1) a gun platlorm, killing one man and setting a fire which was extinguished without serious damage to the vessel.

The Coast and Geodetic Survey retained jurisdiction over their remaining ships, all of which participated in the war effort. The ships - Surveyer and Explorer, built for the Survey in 1917 and (939, respectively: Derickson, a former Navy patrol craft; Lester Jones and Patton, two 88-foot liydrographic survey and wire drag vesscls; and the 77-foot survey launch IVestdahl - were engaged primarily in surveys of the Aleutian Islands and of the Alaska Peninsula. These surveys, aceomplished at the request of various branches of the Army and Navy, included wire dragging of areas for deep submergence tests of submarines, hydrographic surveys of special anchorages for naval use, and surveys used for laying of submarine nets. Several of these ships were provided with armament lurnished and installed by the Navy and in many instances these ships were used for emergency convoy duty. 


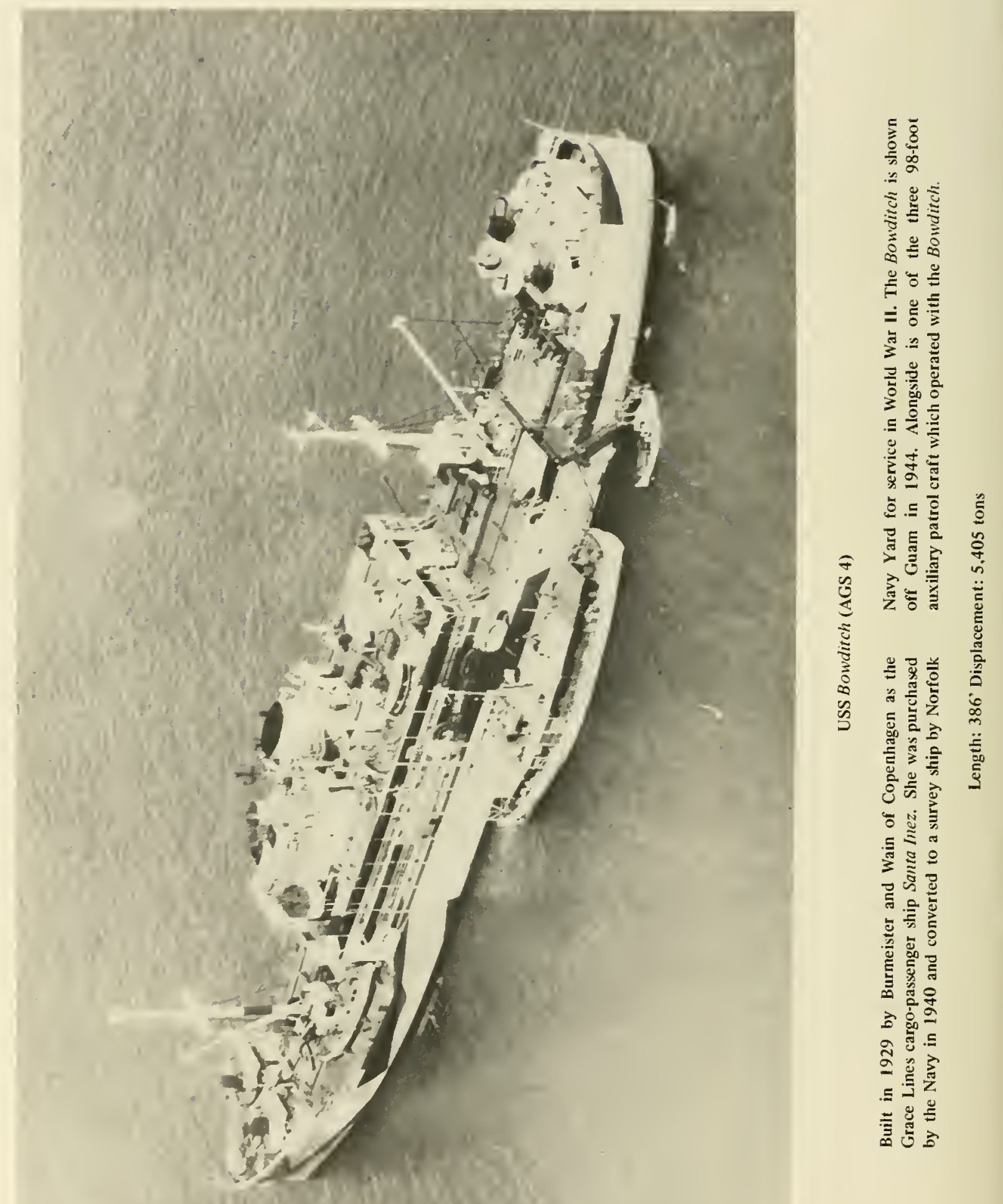


The Survey also conducted surveys, at the request of the Navy, in the British West Indies at sites of proposed naval bases, and in Casco Bay, Maine and adjacent waters which were used extensively as anchorages for naval vessels and particularly for ships engaged in convoy duty The Survey ships Ll'donia and Gilbert were engaged primarily in these surveys.

The hundreds of wrecks along the Atlantic coast caused by enemy submarine action constituted dangers to navigation. Concentrating in areas of immediate concern, the Survey's two small (66-foot), wooden hulled, wiredragging vessels Wainwright and Hilgard searched for underwater hazards off Delaware and Chesapeake Bays and along the coast of Florida. Several Navy and Coast Guard ships to which Coast and Geodetic Survey Officers were assigned also participated in these essential surveys.

Before the war, surveying and charting of the Philippine Islands were being carried on under a cooperative agreement with the Insular Government. Two ships were engaged in this effort, the Fathomer which was owned by the Insular Government but under the command of Survey officers and the Survey's Research which was the original Pathfinder built in 1899 and renamed in 1940. At the outbreak of the war these two ships were engaged in surveys requested by the Navy in Coron Passage, north of Palawan and off Bataan. The Research was damaged by a bombing attack on Manila and later both ships proceeded to Corregidor where they suffered further damage from bombs. The Research, which also served temporarily as a hospital ship, was finally beached in a sinking condition at Bataan. The Fathomer was captured by the Japanese with the fall of Bataan and put to use as a transport. She was destroyed by American bombing during the recapture of the Islands.

The valiant surveying efforts of this astonishing variety of ships are best attested to by the over 43 million charts which were printed and issued by the Hydrographic Office in the peak year 1944. 


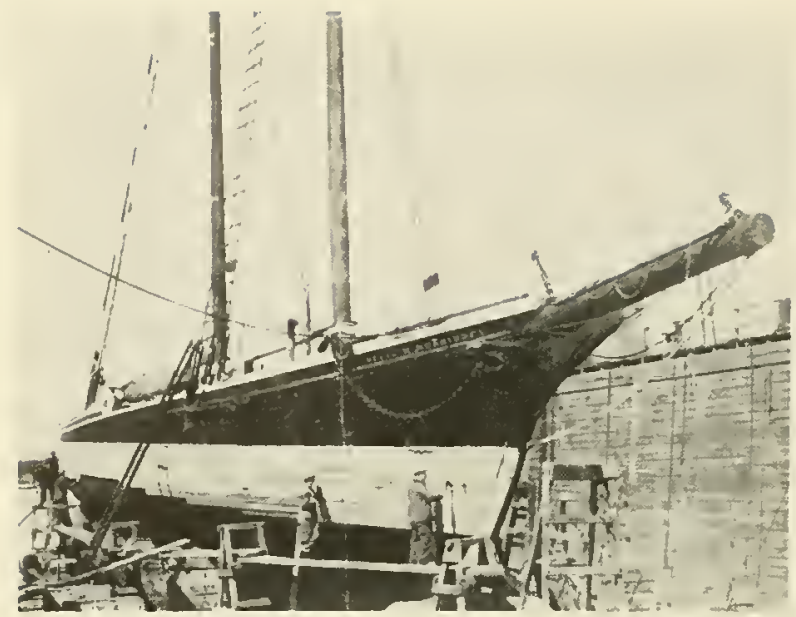

\section{Effie M. Morrissey}

A 93-foot schooner built in 1894 by James and Tart of Essex, Mass. for Robert Bartlett. The Effie M. Morrissey was loaned to the Navy during World War $\|$ and used briefly for Greenland survey operations. Returned to her owner by the Navy after her military service, she was sold in the 1960s to Portuguese interests. She is shown here in drydock being sheathed with Greenheart.

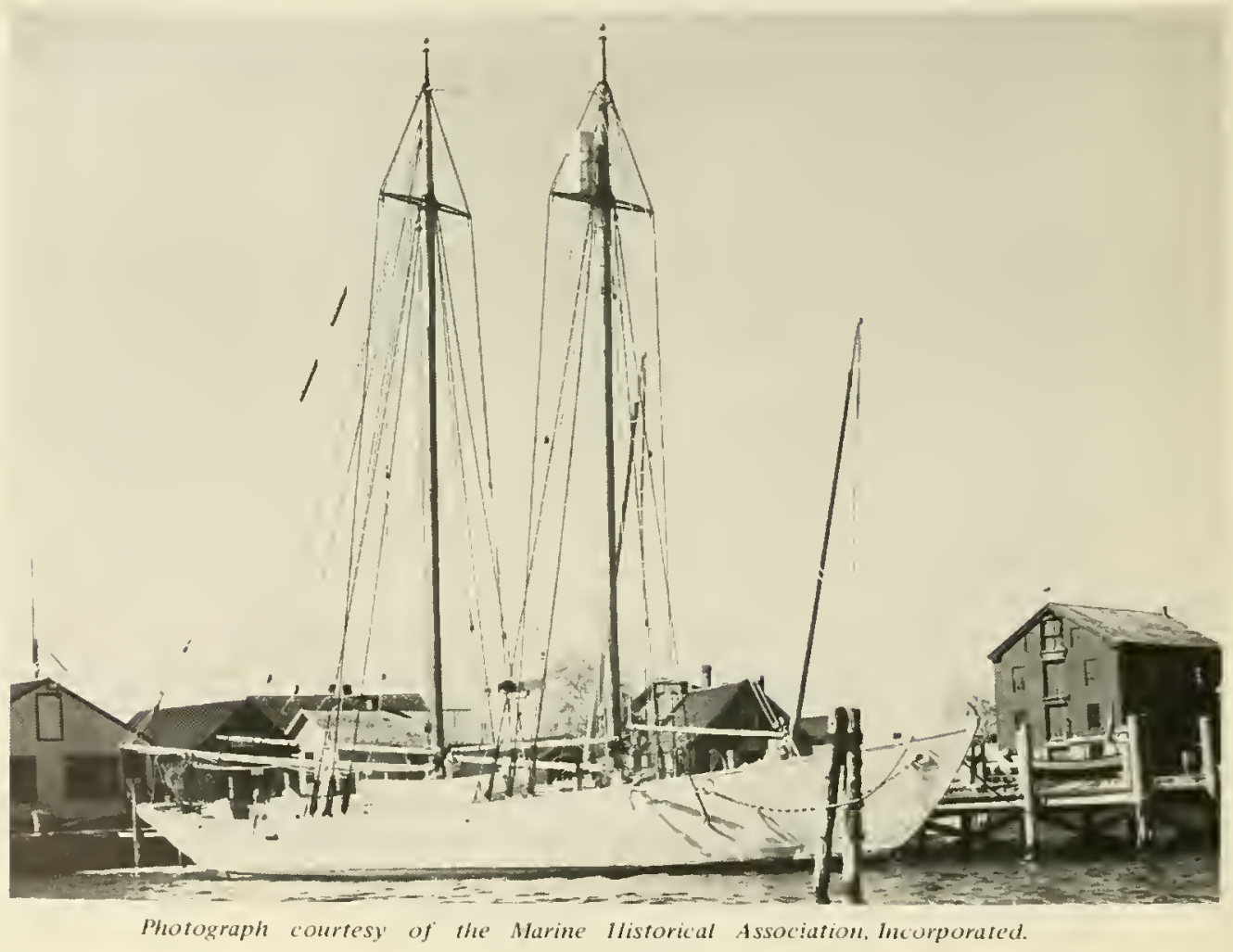

Bowdoin

An auxiliary knockabout schooner designed by William H. Hand and built in 1921 by Hodgdon Brothers of East Boothbay. Maine. She was built to the order of Admiral Donald D. MacMillan who had been a member of the Peary polar expedition and who later undertook a series of scientific expeditions in the Bowdoin to Greenland and the Far North. In 1941 , sle was purchased by the Navy for $\$ 35,000$, given the hull designation $1 X-50$, and assigned to the South Greenland Patrol where one of her duties was conducting hydrographic surveys. She was disposed of in 1945 atter being deelared unfit for further Naval service. Still in existence the schooner Bow doin is shown liere as she appeared as an exhibit vestel at Mystic Seaport from 1959 to 1968 .

Length: $87^{\circ}$ Displacement: 110 tons 


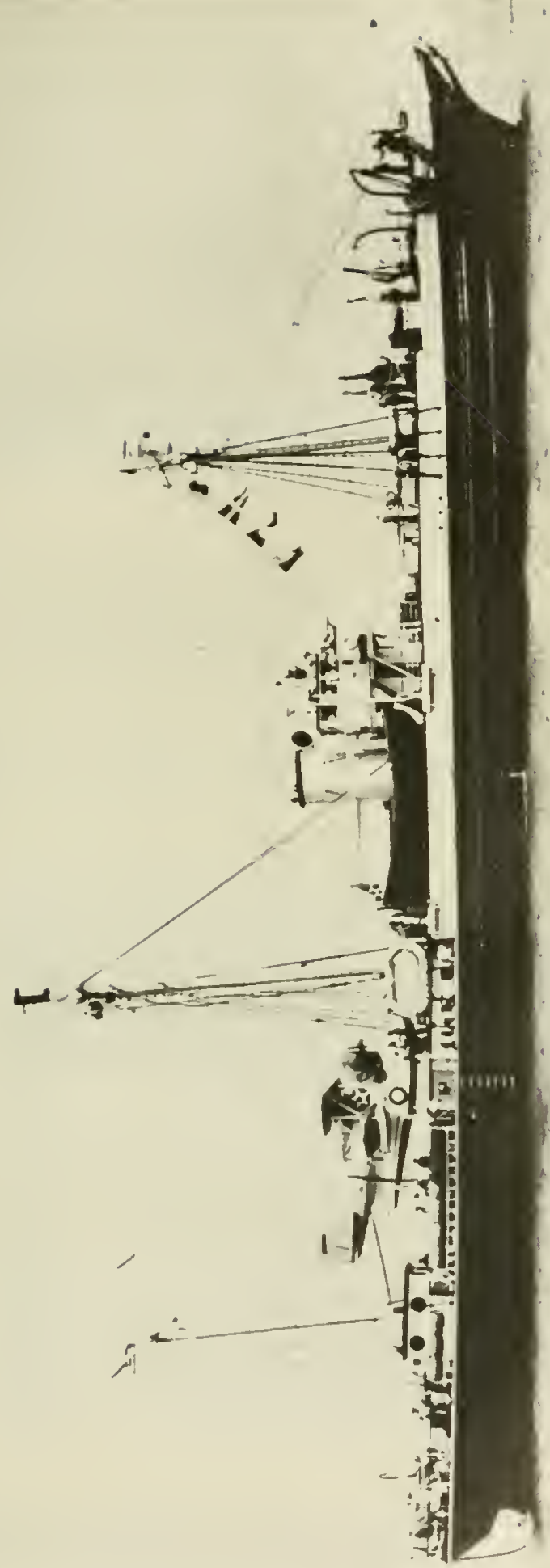

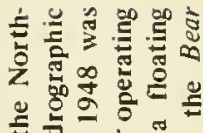

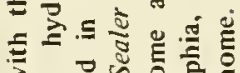

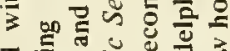

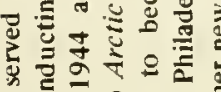

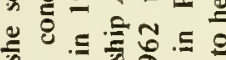

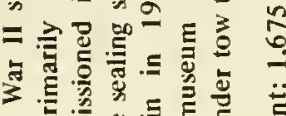

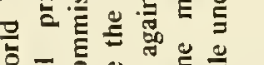

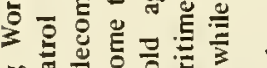

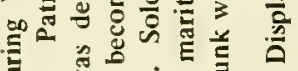

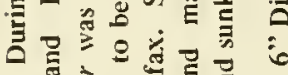

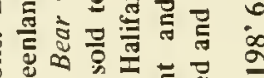

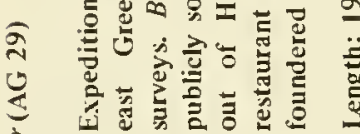

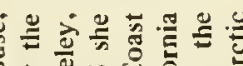

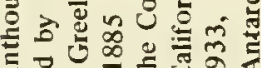

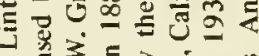

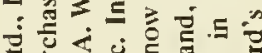

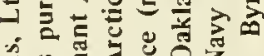

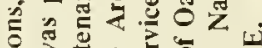

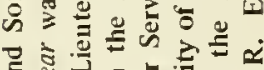

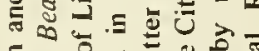

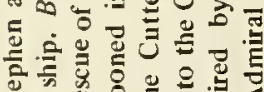

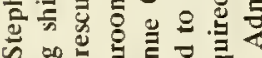

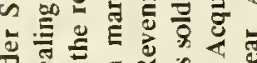

ซै

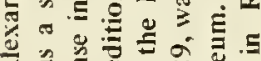

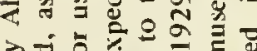

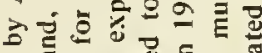

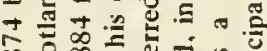

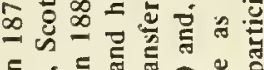

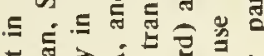

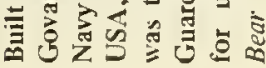




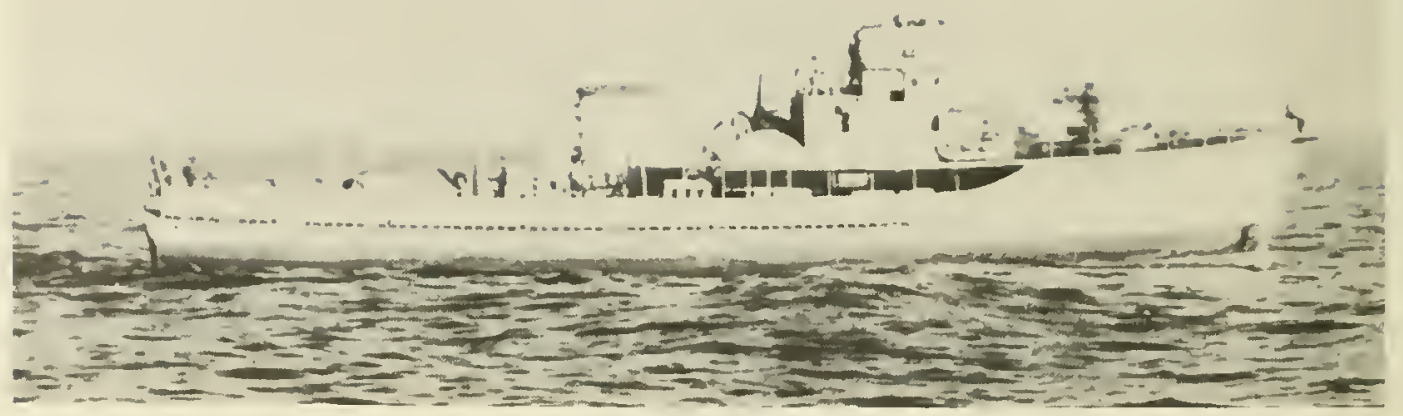

Courlesy of $T . F$. Gundlach; Belleville, Illinois

\section{USS Chauvenet (AGS 11)}

Originally built as a motor minesweeper (YMS 195) in 1943 by C. Hiltebrant Drydock Company of Kingston, New York, she underwent conversion to a surveying ship in 1945 receiving the name Chauvent and the designation AGS 11 and departed for duty in the Pacific. Decommissioned in 1946 she was sold the following year and became the British mercantile Zipper. In 1963 she foundered 100 miles off Georgetown, British Guinea. Length: 136' Displacement: 215 tons

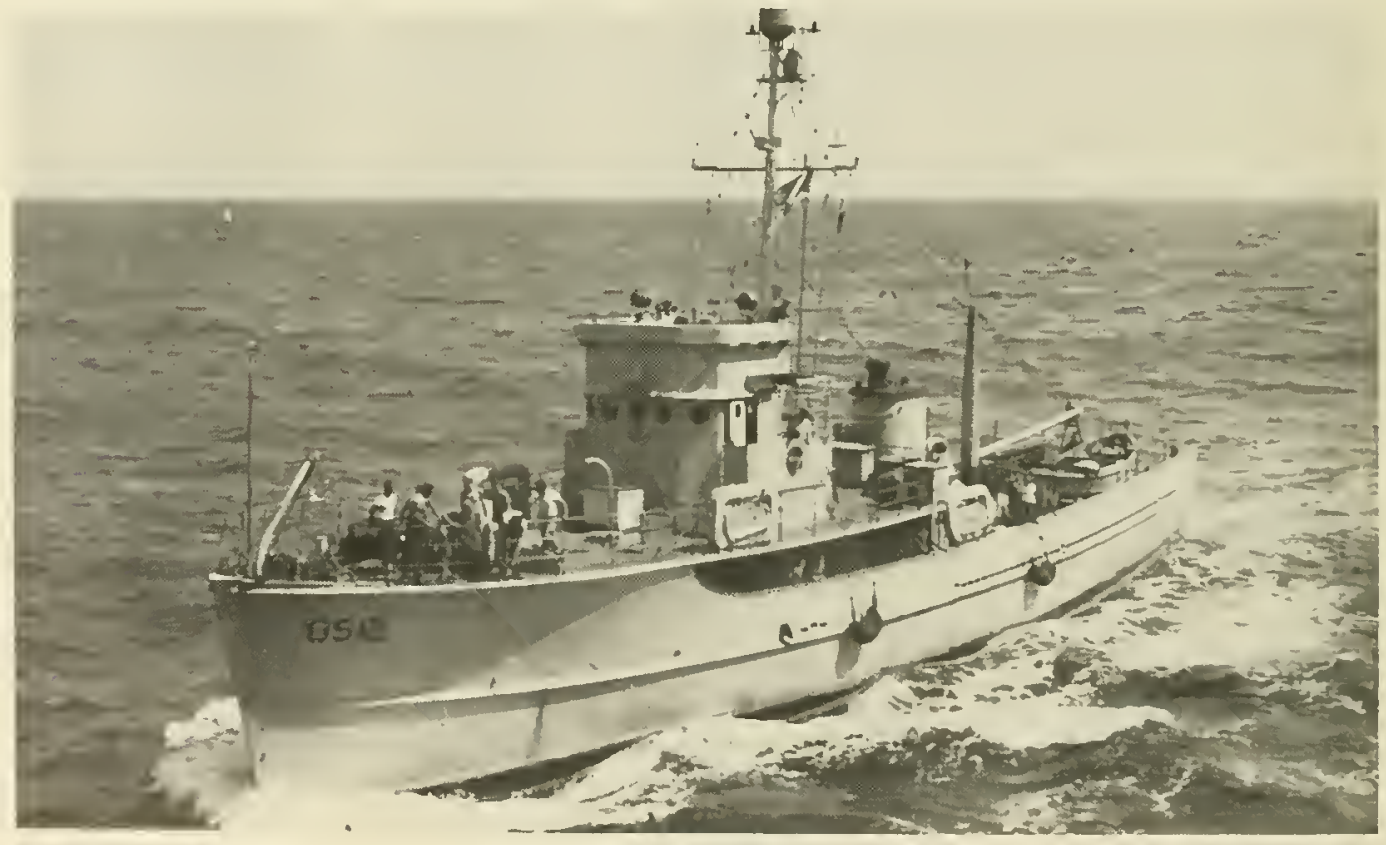

USS Harkness (AGS 12)

Originally the motor minesweeper YMS 242 built in 1943 by Tacoma Boat Building Company. Converted to a surveying ship in 1945 and redesignated the Harkness (AGS 12), she deployed to the Western Pacilic where she conducted survey operations in the Marshalls and at Okinawa and, following the war, at Japan.
Redesignated a coastal surveying ship (AGSC 12) in 19.46, she operated along the Atlantic Coast for over three years. In 1951 Harkness" survey career ended and she was converted to a mine hunter. Slic was sold at public auction in 1960.

Length: $136^{\circ}$ Displacement: 245 tons 


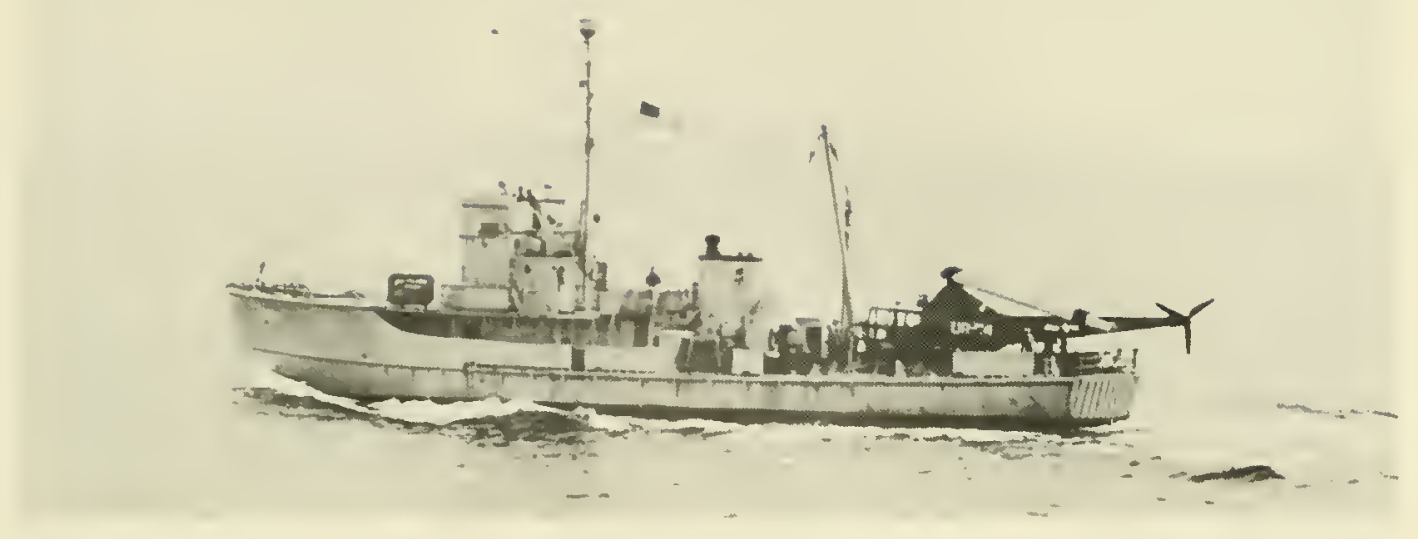

USS James M. Gilliss (AGS 13)

Originally the motor minesweeper YMS 262 built in 1943 by the South Coast Company of Newport Beach, California. In 1945 she was converted to a survey ship at California Shipbuilding Corporation, Wilmington, California and redesignated the James M. Gilliss (AGS 13). She conducted surveys at Okinawa and then at Nagoya, Japan in support of occupation operations. In 1946 she operated between Bikini and Eniwetok conducting hydrographic and oceanographic surveys to support Operation "Crosiroads", the atomic bomb tests. Later that same year she was classified as a coastal survey ship, AGSC 13, and assigned coastal survey operations from the North Atlantic to the Caribbean. In 1950 she ended her survey career and was converted to a minehunter, $A M C U 13$. Inactivated in 1958, she was sold in 1960. The Gilliss is shown off the coast of Labrador in 1949. On her fantail is the helicopter from the USS Tanner (AGS 15) being taken to Goose Bay for repairs.

Length: 136' Displacement: 265 tons

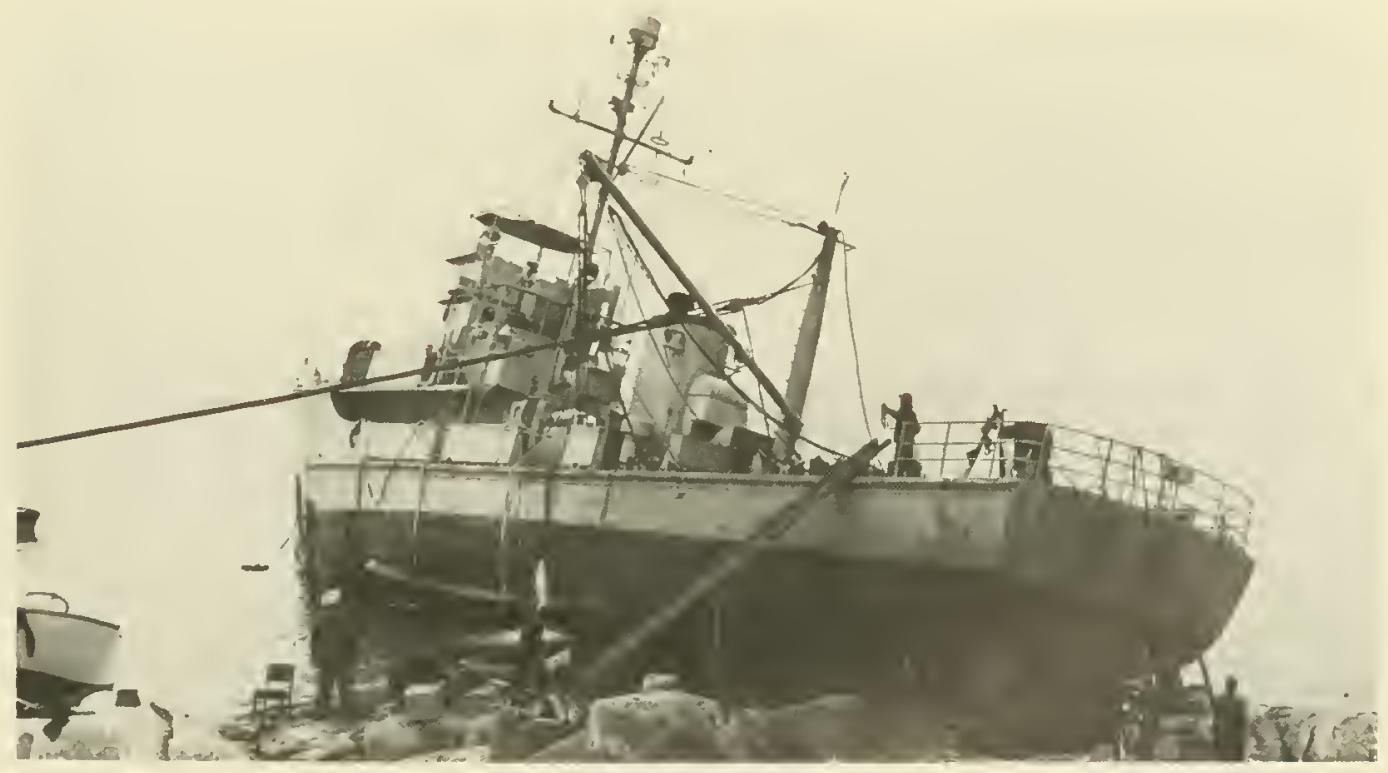

USS Simon Newcomb (AGS 14)

Originally the motor minesweeper YMS 263 built in 1943 by the South Coast Company, Newport Beach, California. Active in the South Pacific, she was assigned after the war to survey operations along the Atlantic Coast. In 1949 she was blown aground on Mother Burns Cove, Labrador. Shown here personnel are unloading all removable gear and ballast prior to salvage attempt. Although successfully salvaged by the USS Hoist (ARS 40 ), the Newcomb was disposed of later that year.

Length: $136^{\circ}$ Displacement: 265 tons 


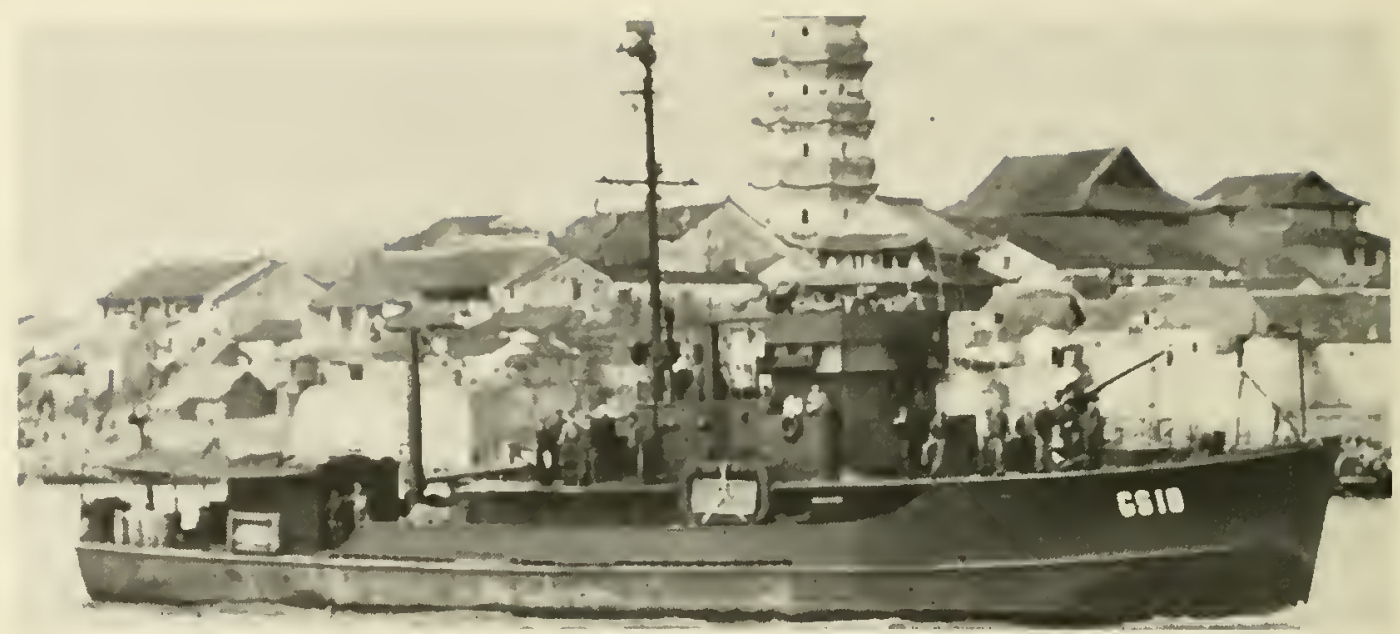

USS John Blish (AGS 10)

The formes subchaser PCS 1457 built in 1944 by Ballard Marinc Railway Company of Seattle. In 1945 she was reclassified as the survey ship AGS 10 and named John Blish. Throughout the remaining months of the war she provided hydrographic information for the Allied efforts in the Pacific and actively participated in the invasion of Okinawa. In 1946 she was reclassified as a coastal survey ship, the AGSC 10, and operated off the West Coast. The John Blish also participated in Operation
"Crossroads", the atomic weapons tests at Bikini in 1946. Decommissioned in 1949, she was sold for scrapping the following year. John Blish is shown passing the oldest pagoda in China as slue steams pass the small town of Anking on a hydrographic survey of the Yangtze River, China in November 1945. This was the first official U.S. patrol up the Yangtze since 1937.

Length: 136" Displacement: 245 tons

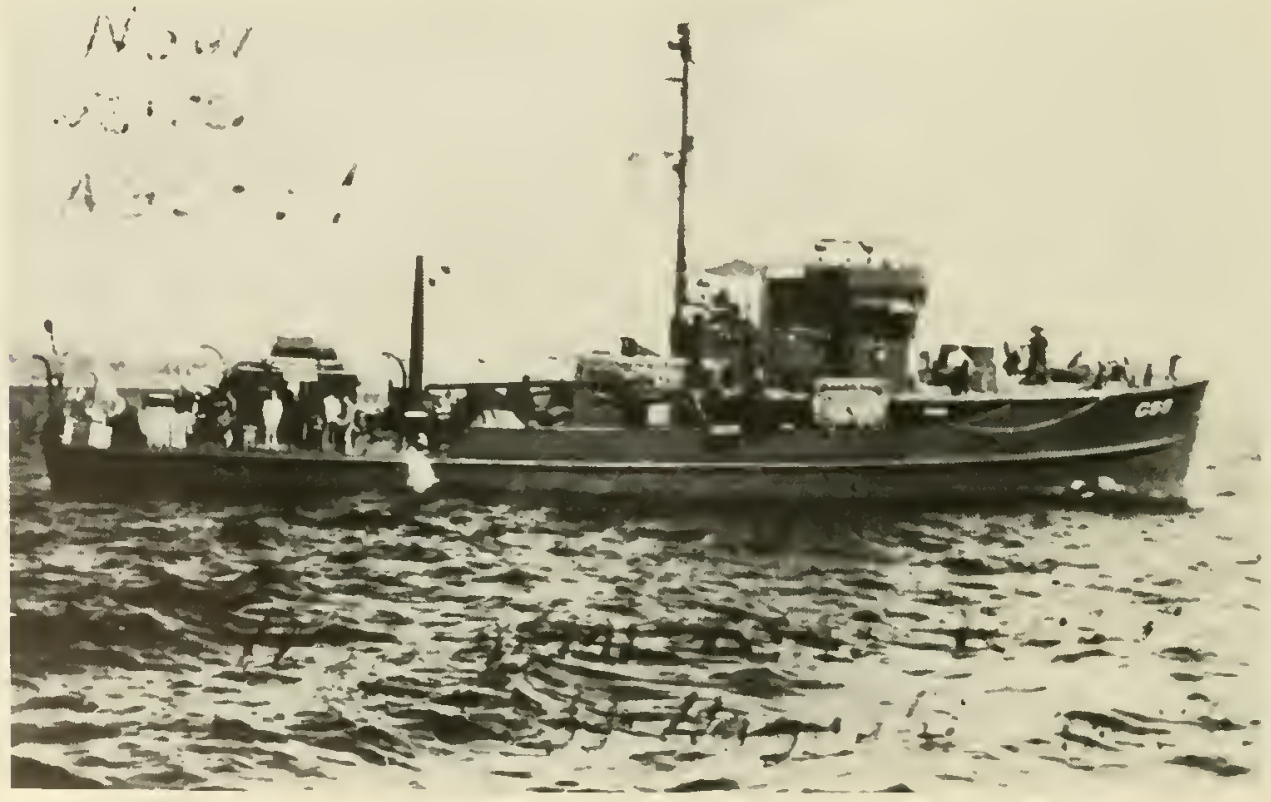

USS Armistead Rust (AGS 9)

Originally the subchaser PCS 1404 built in 1944 by Colbert Boat Works of Stockton, California. In 1945 she was renamed Armistead Rust and reclassified as the survey ship AGS 9. She conducted survey operations at Okinawa. the Philippines, Manila, and Subic Bay. Decommissioned in 1946, she was sold in 1948.

Length: 136' Displacement: 260 tons 


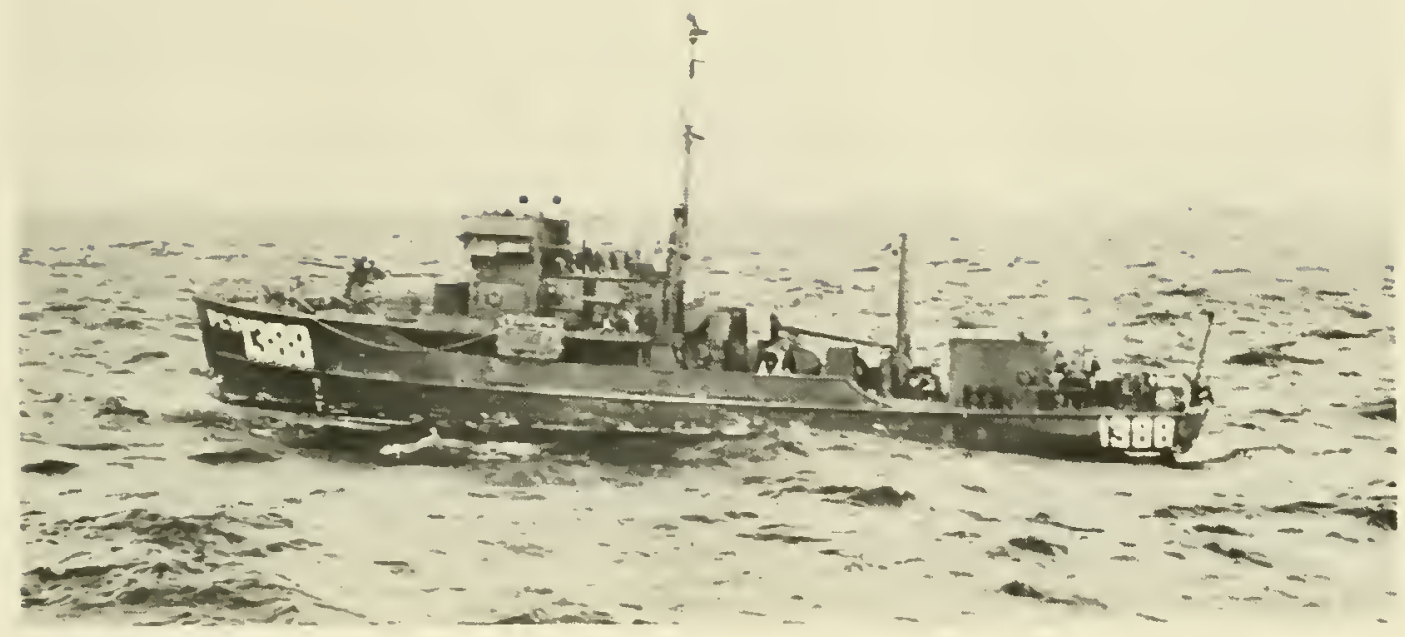

USS littlehales (AGS 7)

Originally the subchaser PCS 1388 built in 1943 by Robert Jacob, Inc. of City Island, New York. Redesignated as a survey ship in 1945 and named Littlehales (the first ship to bear that name), she actively participated in Pacific operations. After the war Litllehales conducted far-flung hydrographic operations until decommissioned in 1949. The following year she was sold to Haylew Fisheries, Inc. of Reedville, Virginia.

Length: 136" Displacement: 245 tons

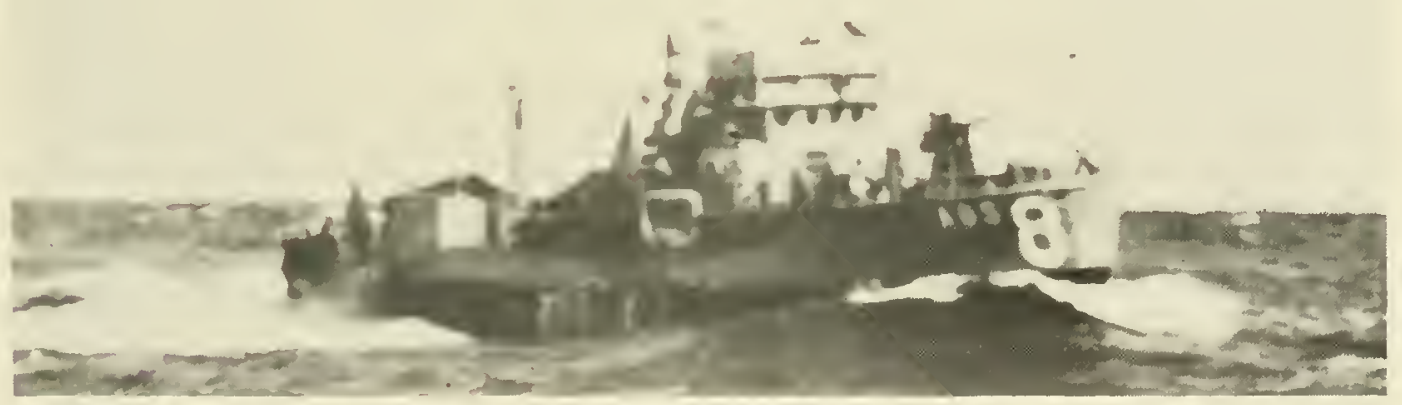

USS Dution (AGS 8)

Originally the subchaser PCS 1396 built in 1944 by South Coast Company of Newport Beach, California. In 1945 she was reclassified as a survey ship, AGS 8 , and assigned the name Dutton. During the battle of Okinawa the Dutton conducted surveys to determine suitable landing beaches for amphibious craft. At Okinawa a Japanese plane crashed into her, carrying away part of the bridge, blowing one of her crew overboard, and holing her, fortunately only above the water line. The Dutton continued her survey career after the war, including participation in Operation "Crossroads", until her decommissioning in 1949. She was sold the following year.

Length: I 36' Displacement: 240 tons 


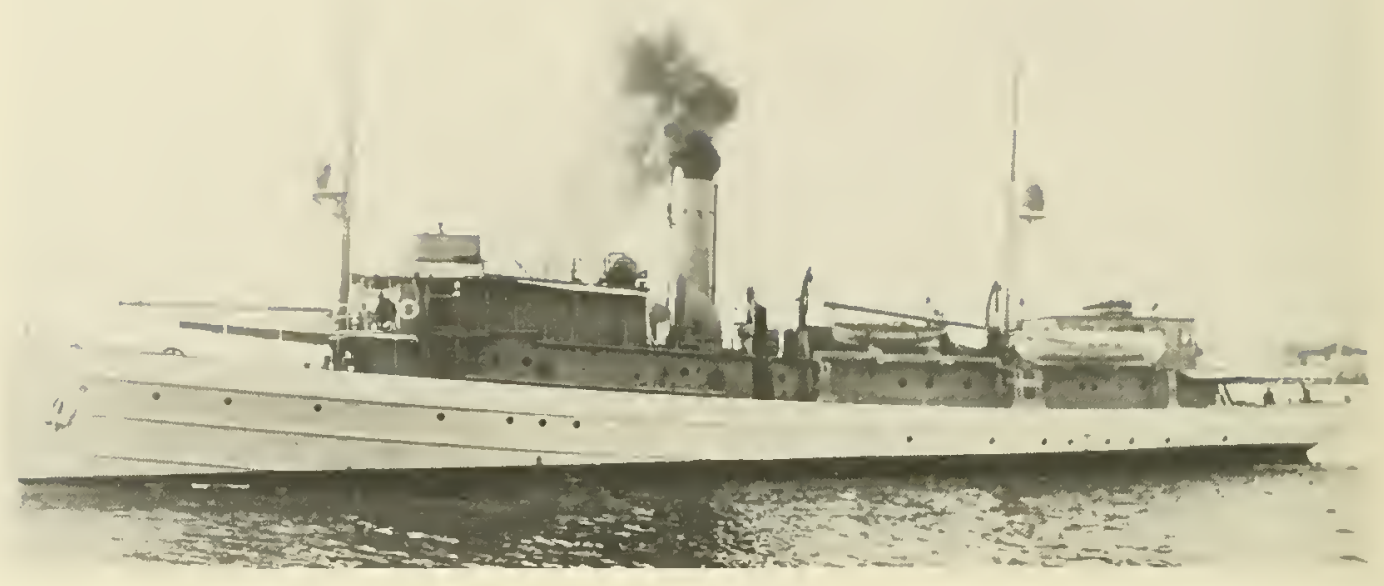

USC \& GSS Guide

Formerly the Navy minesweeper Flamingo (AM 32) built in 1919 by New Jersey Drydock and Transportation Co. of Elizabethport, New Jersey. She was transferred to the Coast and Geodetic Survey in 1923 and renamed the Guide. In 1941 she was recalled by the Navy for service in World War 11 and converted to a salvage ship with the name and classification of Viking (ARS 1). Viking was sold in 1953.

Lengtlı: 187' 10" Displacement: 950 tons

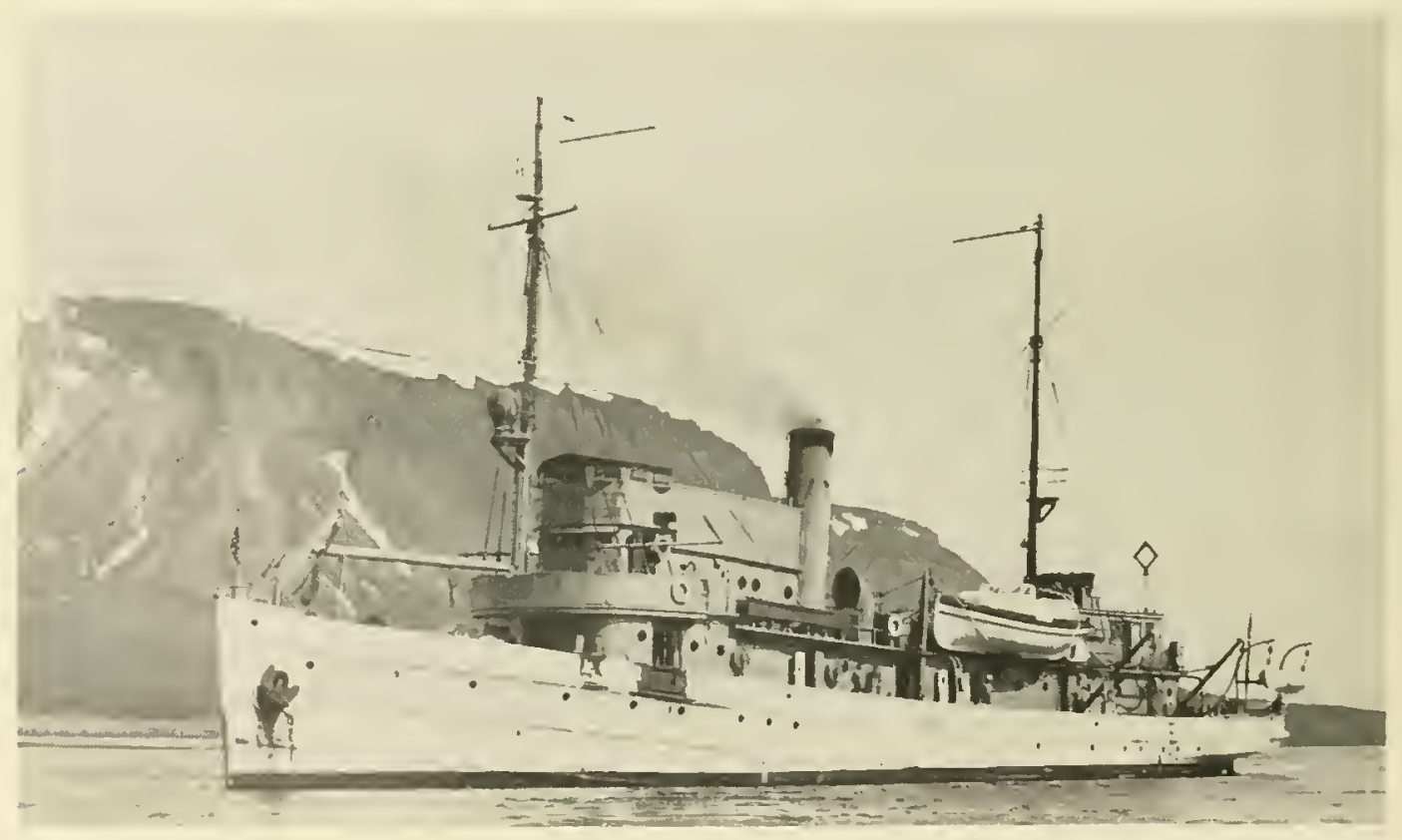

USC \& GSS Discoverer

Originally the Navy minesweeper Auk (All 38) built in 1919 by Todd Shipyard Corporation of Brooklyn, New York. In 1922 whe was transferred to the Coast and Geodetic Survey and renamed Discolerer. She was returned to the Navy in 1941 and underwent conversion to a salvage ship (ARS 3), retaining the name Discolerer. She was disposed of in 1947.

Length: 187' 10" Displacement: 950 tons 


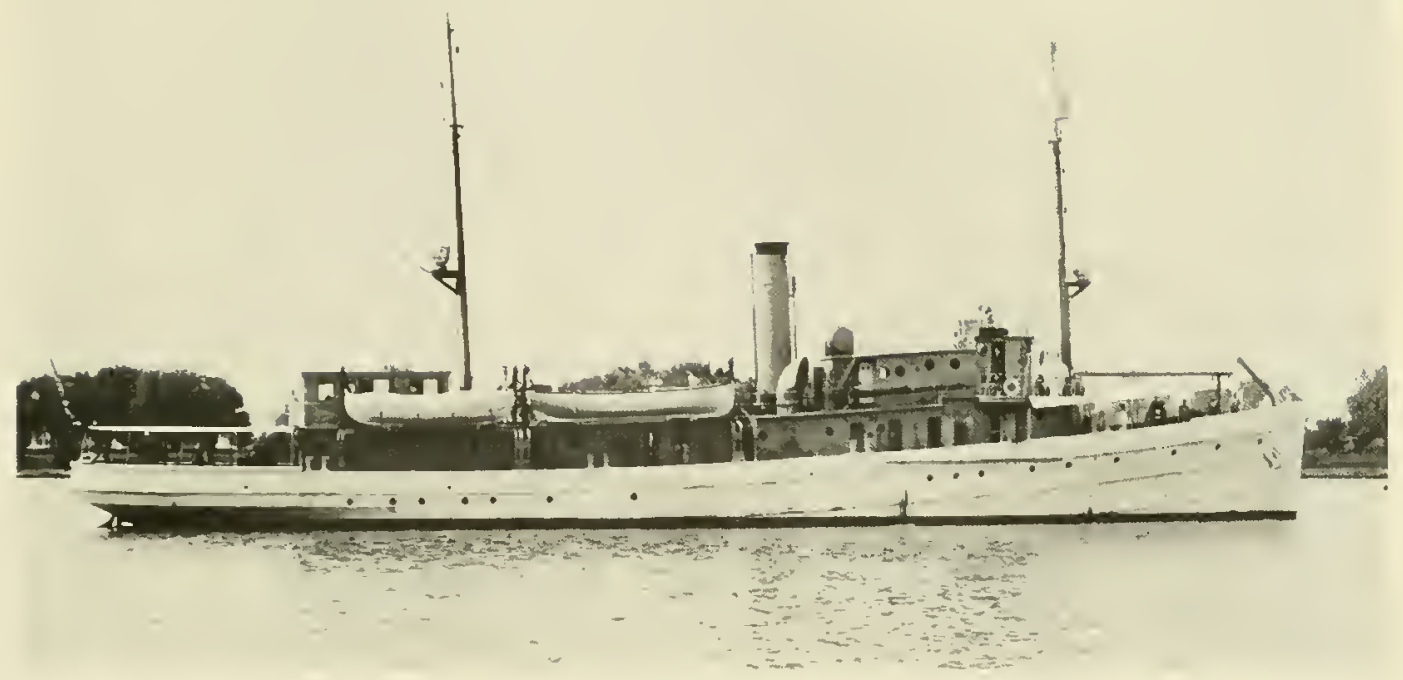

USC \& GSS Pioneer

Formerly the Navy minesweeper Osprey (AM 29) built in 1918 World War 11 service, she was converted to a salvage ship and by the Gas Engine and Power Company of Morris Heights, New York. In 1922 she was transferred to the Coast and Geodetic Survey and renamed Pioncer. Recalled by the Navy in 1941 for Length: 187 10" Displacement: 950 tons

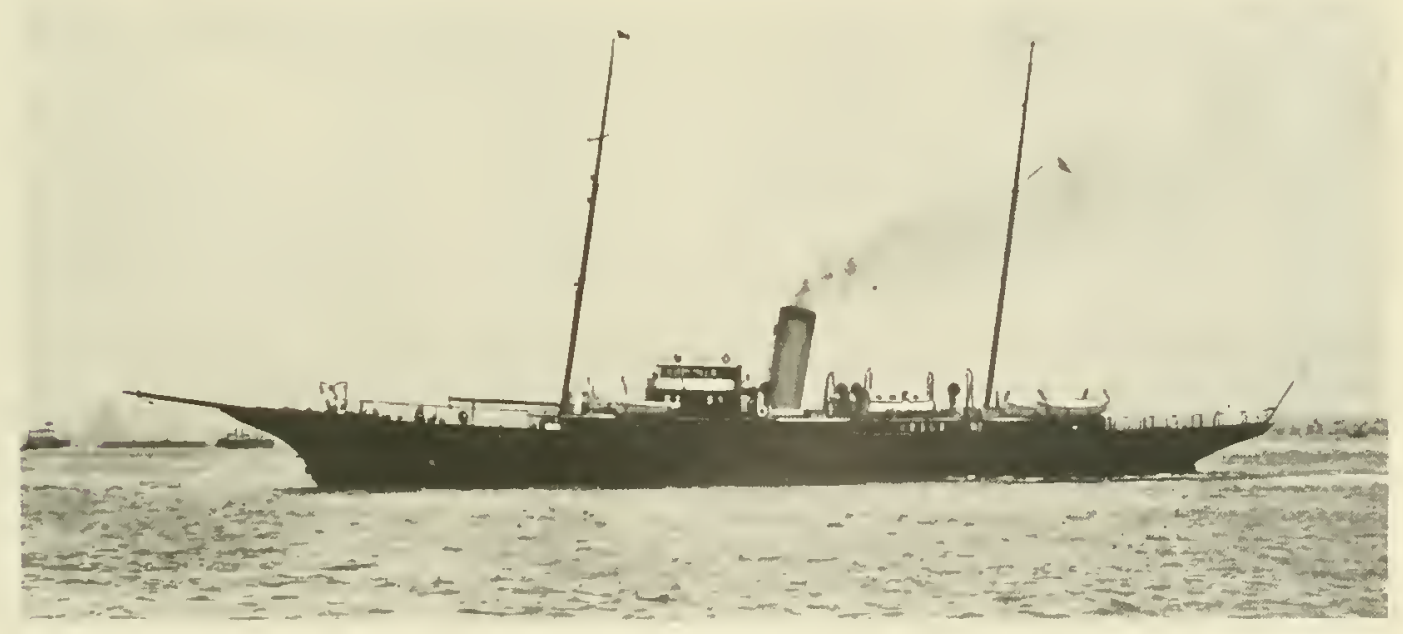

Oceanographer

Originally the $\$ 3$ million luxury yacht Corsair /I of J.P. Morgan, rapher (OSS 26). With the outbreak of World War 11, she was Sr., built in 1897 by W. \& A. Fletcher Company of lloboken, again commissioned by the Navy (this time with the designation New Jersey. She served as Morgan's pleasure craft until 1930, AGS 3). She conducted survey and charting operations off except for a bricf period during World War I when she was commissioned by the Navy (designated the PY 159). Corsair II was credited with sinking a German U-boat. She was acquired by the Coast and Geodetic Survey in 1930 and renamed Oceanog. Alaska and in the South Pacific. Tired and worn, Occanographer was decommissioned in September 1944 and a few months later scrapped.

Length: 304' Displacement: 1,600 tons 


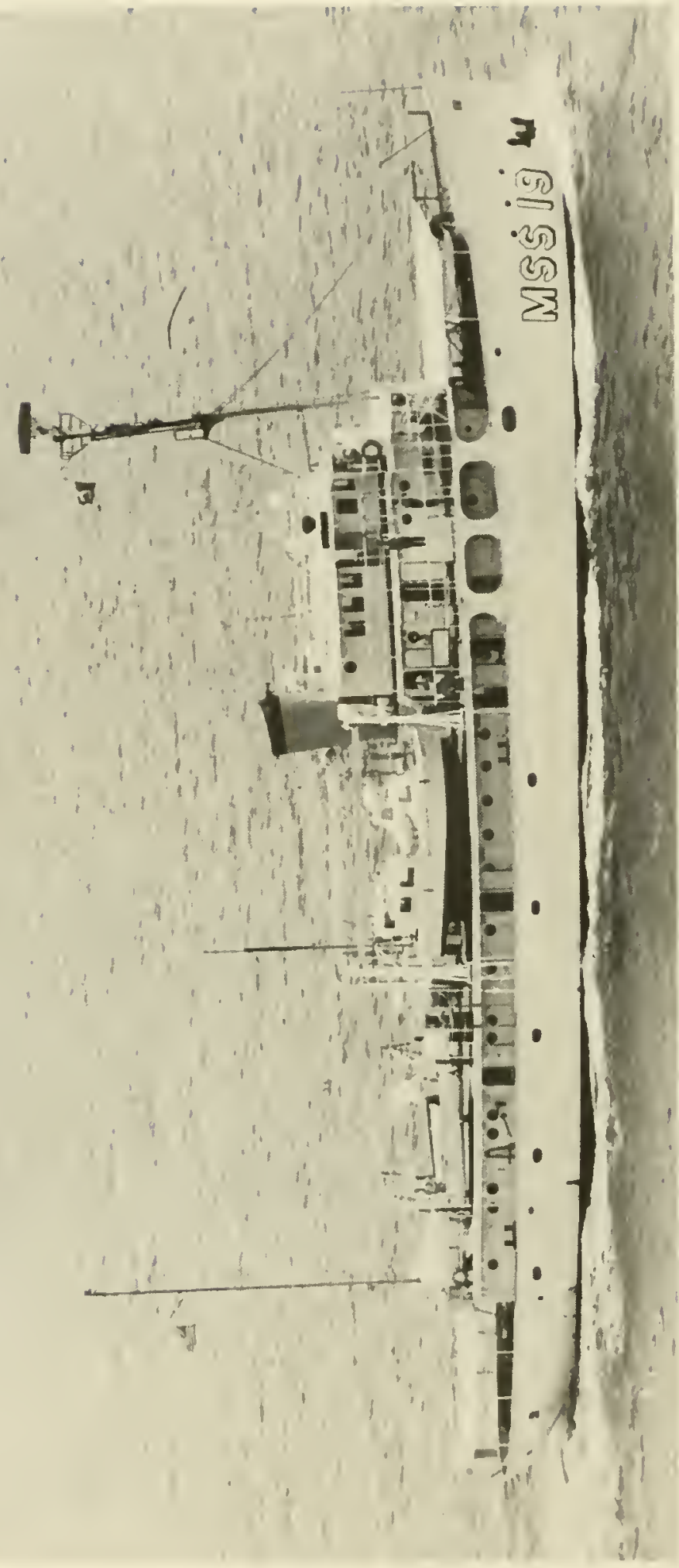

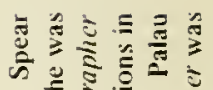
ว

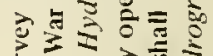

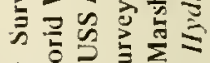

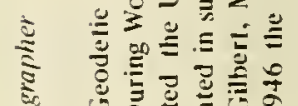

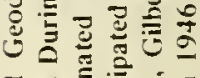

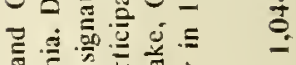

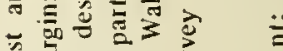

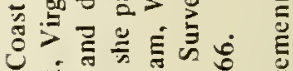

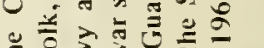

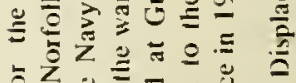

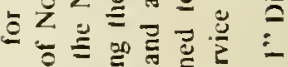
-

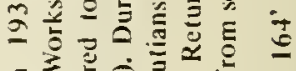

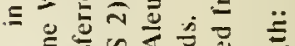

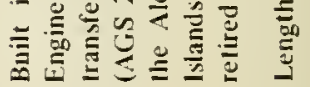




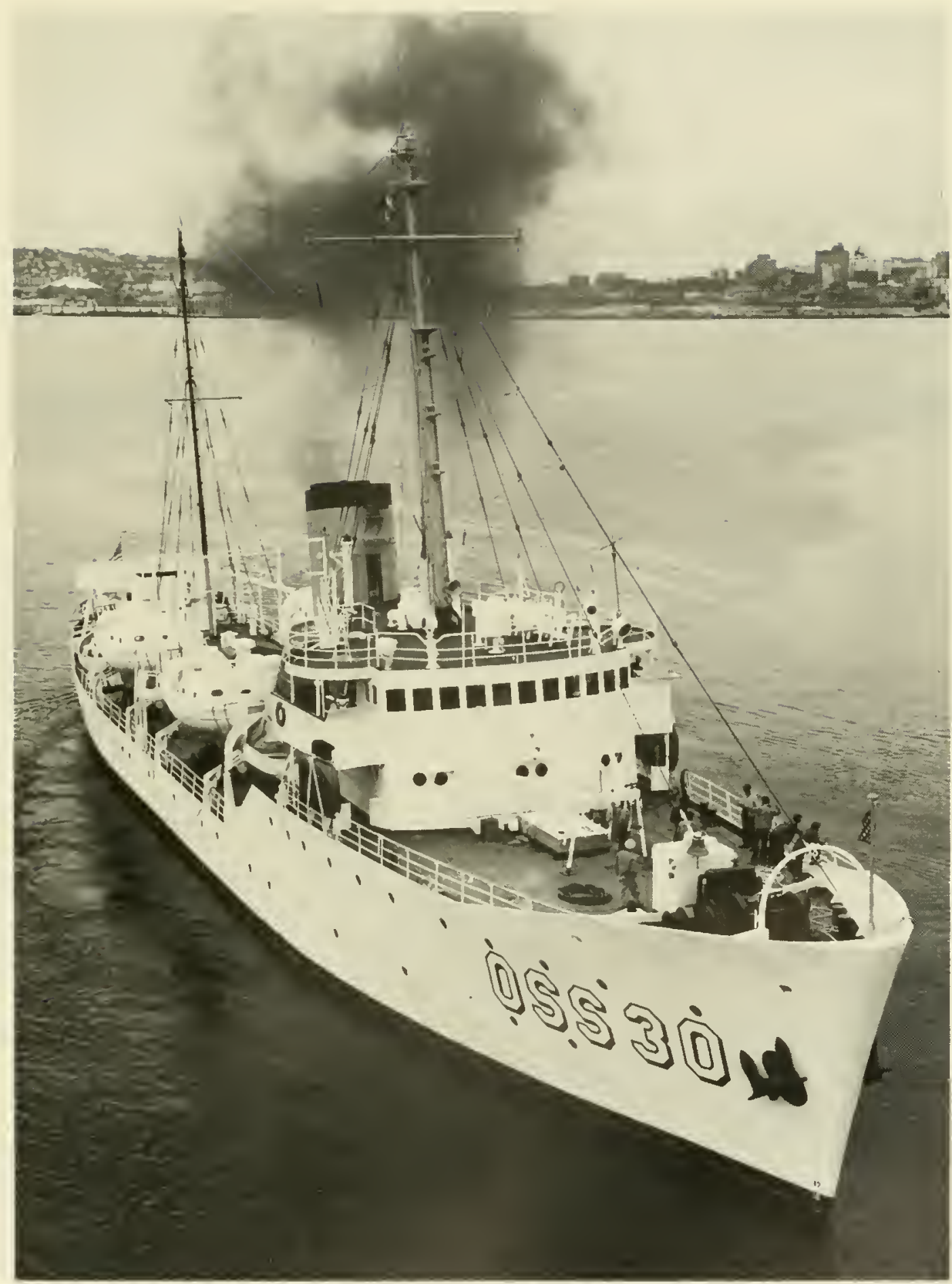

USC \& GSS Pathfinder (OSS 30)

Built in 1942 for the Coast and Geodetic Survey by Lake Washington Shipyards of Hougliton, Washington. During World War II Pathfinder was transferred to the Navy for hydrographic operations near New Caledonia, Guam, Guadalcanal and other South Pacific areas. She was damaged off Okinawa when a
Kamikaze crashed into the stern gun platform. Her wartime performance was sufficiently extensive for Tokyo Rose to report Pathfinder destroyed on six occasions.

Length: 229' Displacement: 2,000 tons 


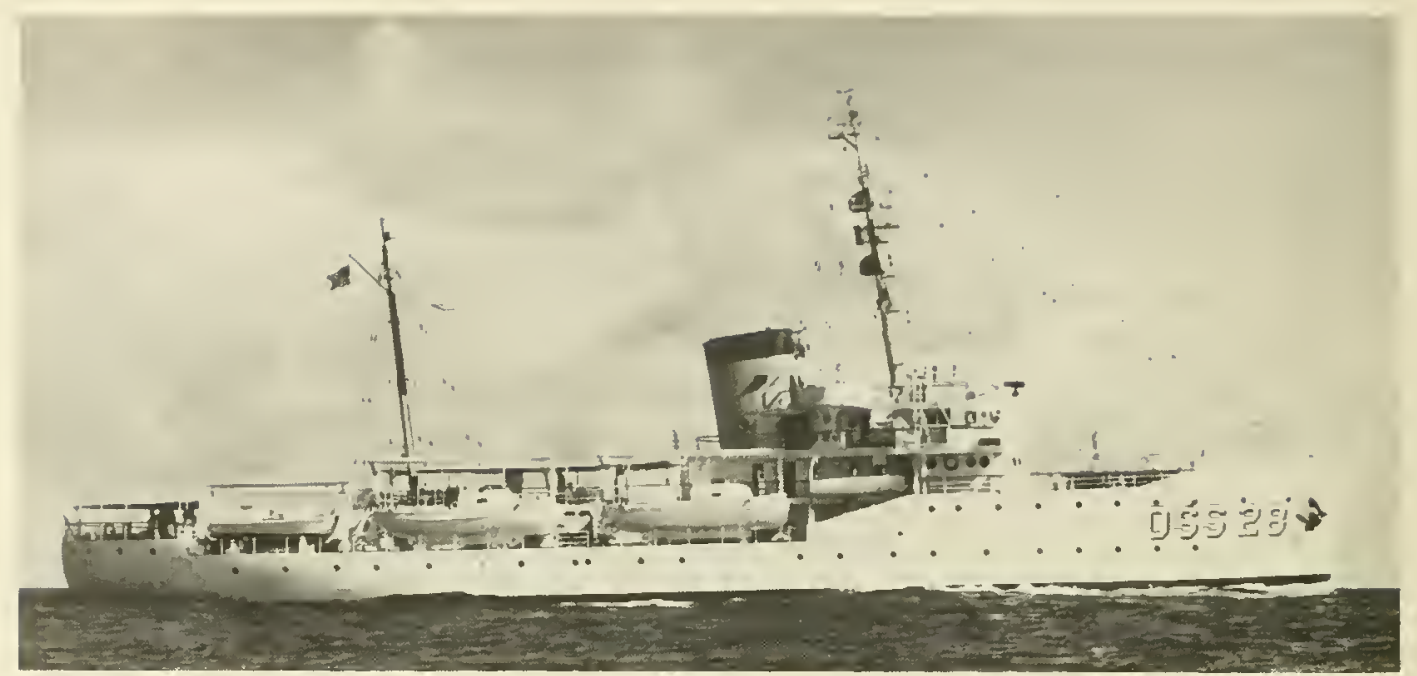

USC \& GSS Explorer

Built in 1939 for the Coast and Geodetic Survey by Lake Washington Shipyards of Houghton, Washington. During World War 11 the Explorer, which remained under the Survey's jurisdiction, participated in hydrographic surveys in the Aleutians and the South Pacific in support of U.S. military operations. Decommissioned in 1968, the Explorer, which was transferred to the Department of Labor, is now permanently berthed at the Washington Navy Yard and serves as a floating classroom for training oceanographic aides.

Length: $219^{\circ} 6^{\prime \prime}$ Displacement: 1,900 tons

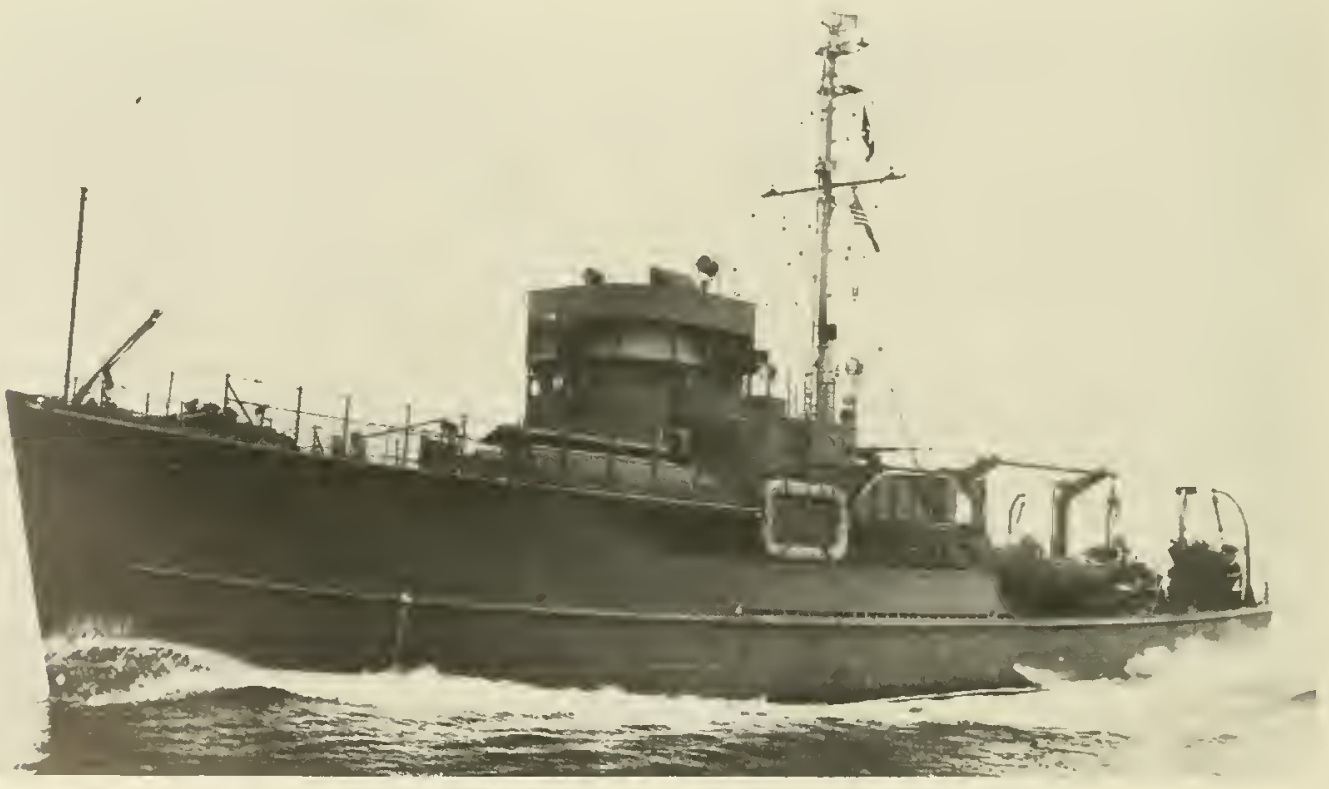

USC \& GSS Derickson

Originally the Navy subchawer PCS 1458 built in 1944 by IBallard Marine Railway Company of Seatlle. She was loaned to the Coast and cieodetic Survey upon completion of her construction, and renamed and reclassified USS Derickson (AGS 6), but operated during World War II under the Survey's jurisdiction. In 19.48 she was permanently transferred to the Survey.

Length: 136' Displacement: 267 tons 

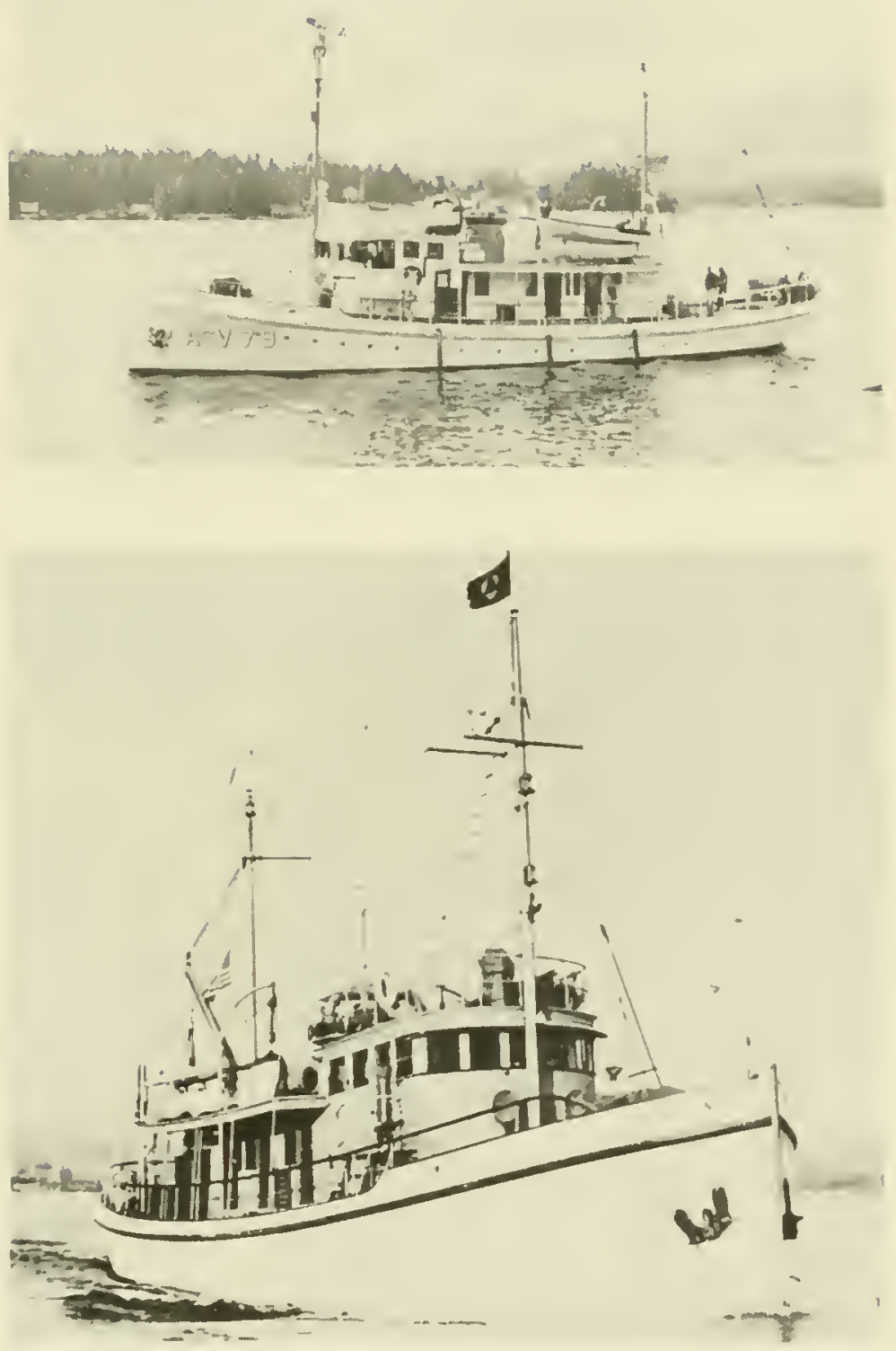

\section{USC \& GSS Lester Jones and \\ USC \& GSS Patton}

Two hydrographic survey and wire drag vessels built in 1940 and 1941. respectively, for the Coast and Geodetic Survey and in service on the West Coast until 1968.

Length: 88' Displacement: 150 tons 


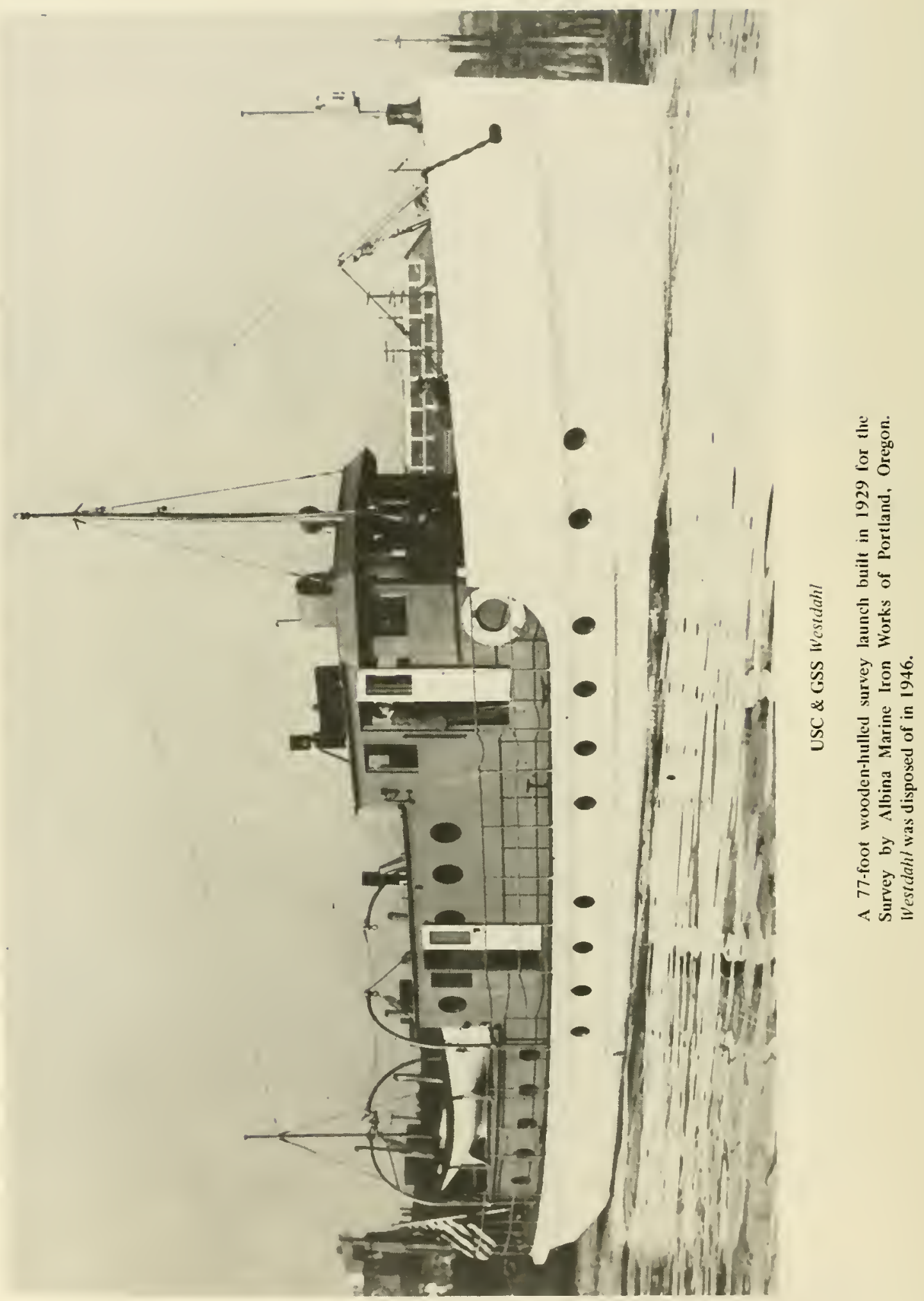




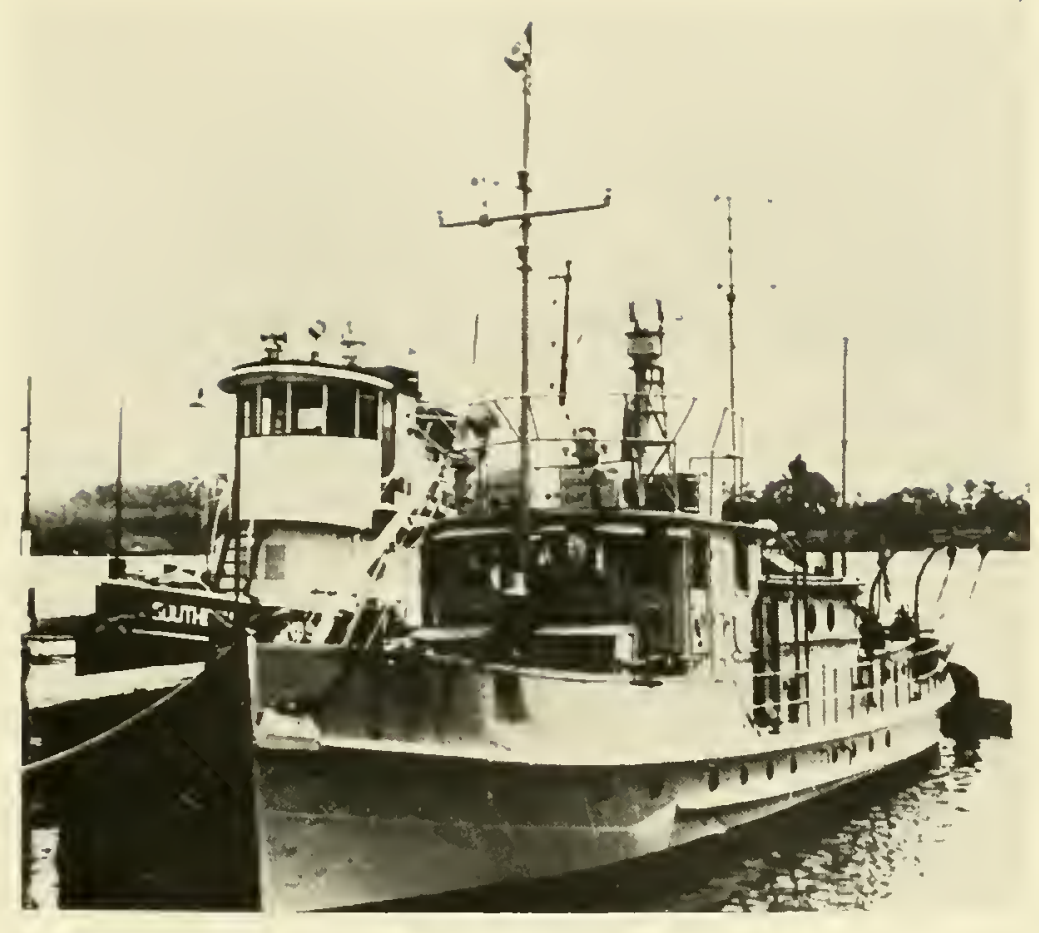

USC \& GSS Gilbert

A small hydrographic survey launch built in 1930 for the Survey and in use until the early 1960s.

Length: $77^{\prime} 8^{\prime \prime}$ Displacement: 95 tons

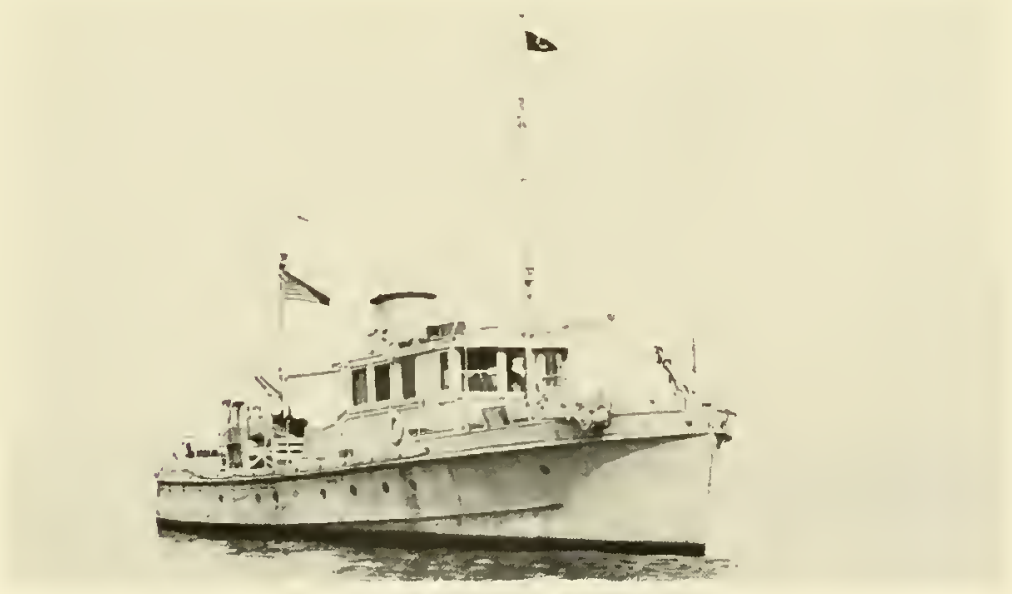

USC \& CSS Waimuright

The wooden hull liamright and her sister slip Hhlgard were hult in 1942 at Benton IIarbor, Michigan for the Coast and Cieodetic Survey. They were the first ships to be bult specifically for wire dragging aperations. By virtue of their mission they were "inseparable" ships, joined together by a quarter-inch
Saintess steel wire that was dragged between them as they noved slowly at distances a half-mile to two miles apart. These ships-disposed of in 1966 -had the unique distinction of sloaring one captain for hoth sips.

Length: 66' Displacesment: 48 tons 



\section{CHAPTER V.}

THE POSTWAR YEARS (1946-1956) 


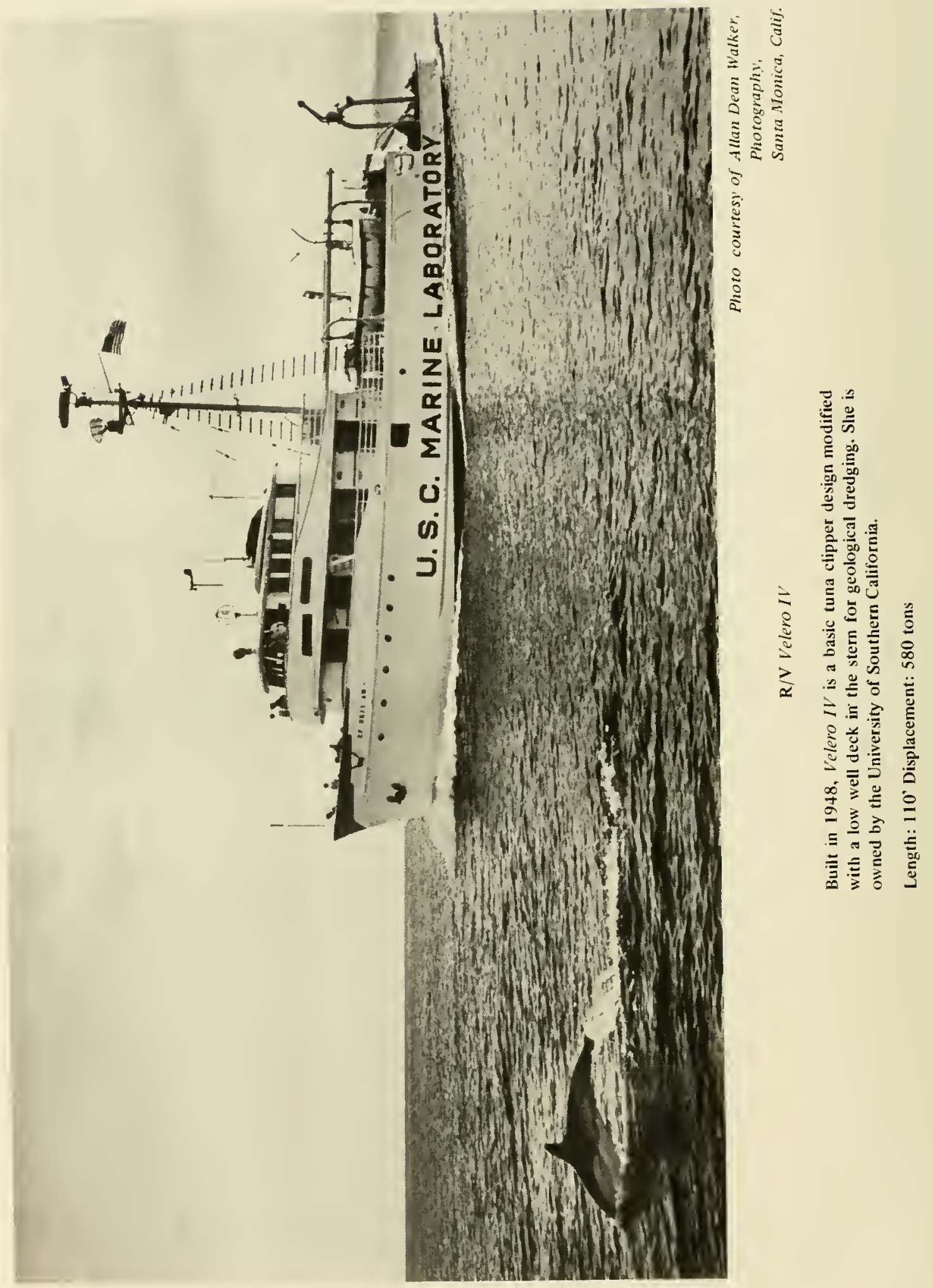


Following World War Il, the government, stimulated by the techniques and programs evolved during the war, continued 10 support oceanographic research at universities and institutions through such agencies as the Office of Naval Research (created in 1946), the Navy Hydrographic Office (now the Naval Oceanographic Office), the Bureau of Ships (now the Naval Ship Systems Command), the Atomic Energy Commission (established in 1946) and the National Science Foundation (established in 1950). Numerous ocean-oriented educational and research programs were launched at such universities as Columbia, Johns Hopkins, Rhode Island, New York, Oregon State, Miami, and Texas A\&M. At the same time, applied ocean research directly related to defense problems was being expanded in the Navy's own laboratories such as the Naval Research Laboratory, Navy Underwater Sound Laboratory, Naval Electronics Laboratory and Naval Ordnance Laboratory.

During this postwar period the oceanographic research fleet consisted wholly of converted ships with two exceptions, the Atlantis of Woods Hole and the Velero $I V$ of the University of Southern California. Unlike the Atlantis though, which was specifically designed and built for research, the Velero IV, which was presented to the University in 1948 by Captain Allan Hancock, was basically a tuna clipper design modified with a low well deck in the stern for geological dredging. Included in this collection of institution conversion were the tugs Spencer Baird and Horizon at Scripps; the Navy harbor minesweeper Crest (Scripps); the yachts Stranger (Scripps), Vema (Lamont Geological Observatory), Action (New York University); the fishing vessels Paolina-T (Scripps), Hugh M. Smith (Scripps), Gerda (University of Miami), Oncorhynchus (University of Miami); the Coast Guard boats Orca (Scripps) and Crawford (Woods Hole); and the coastal freighters Bear (Woods Hole) and Brown Bear (University of Washington). Correspondingly, ocean going support for the Navy laboratories was provided by the converted 185-foot escort craft Marysville, Rockville, Rexburg, Brattleboro, Somersworth, Fairview, Whitehall, and the converted 173-foot subchaser Weatherford.

For fisheries research a "new" conversion was acquired in 1948 to replace the "old" conversion Albatross II. This ship, the former 179-foot steam trawler Hanarl built in 1926, had actually been acquired in 1939 and was undergoing conversion to a fishery research vessel when War erupted. She was immediately requisitioned by the Navy lor the Coast Guard and renamed Bellefonte. The ship was returned in 1944, funds were finally allocated in 1948 to reconvert her back to a fishery research vessel and she was renamed the Albatross III.

The Navy's hydrographic surveying ship capability, proven essential in World War II, continued to be a game of musical conversions. In 1947, the Bowditch and Summer, which had participated in Operation Crossroads at Bikini Atoll, were replaced with (wo converted 426-foot attack-cargo ships renamed Tamer and Maury. These ships eventually carried four 52-foot survey boats, a Marine Corps coastal survey team, a helicopter, and chart compilation and production facilities. They were the largest and best equipped ships of their time and they pioneered the use of helicopters for support of coastal surveying operations. The Tanner was assigned to the Atlantic area and mothered a survey group consisting of the former minesweepers Ilarkness, Gilliss and Newcomb. A similar Pacific survey group was made up of Maury and the former subchasers Blish, Dutton and Littlehales which in 1948 were replaced by the two 180-foot auxiliary ocean-going tugs, Allegheny and Stallion, they in turn were replaced in 1952 by the minesweepers Sheldrake and Prevail. The Newcomb was blown aground on the Labrador coast in 1949 and, although successfully salvaged, was stricken from the active list later that year. In 1950 the Gilliss and IIarkness were replaced by the 220-foot, steel-hulled, lleet minesweepers Pursuit and Requisite which were later to be replaced by the fleet tug Serrano and the minesweeper Towhee in 1960 and 1964, respectively. 
In 1949 an additional capability was provided to the Navy's survey fleet with the introduction of the converted seaplane tenders San Pablo and Rehoboth. These were the first ships specifically designated to conduct deep ocean oceanographic surveys for the Hydrographic Office. The 132-foot freight lighter YF-854 was acquired in 1952 and used for conducting harbor surveys which ranged from Alaska to Panama on the West Coast and from Florida to Newfoundland on the East Coast. Renamed the Littlehales (the second ship to bear that name) she was assigned to Project AUTEC (Atlantic Underwater Test and Evaluation Center) from 1962 until her disposal in 1968. Also in the early 1950s, the 204-foot landing ship LSM-398 was converted to support testing of experimental sonar equipment for the Naval Research Laboratory. Designated the Hunting (EAG-398), she was plagued by mechanical problems and finally placed out of service in 1962.

Recognizing that, since the Atlantis in 1931, no American oceanographic research ship had been specifically designed and built, and concerned with the present hodge-podge of jury-rigs, the Office of Naval Research established a ship panel at the June 1952 symposium on Oceanographic Instrumentation in Rancho Santa Fe, California. This panel stimulated the oceanographic community's interest in ship design, and many concepts and recommendations were made which were representative of the highly individualistic and motivated personages in attendance. Consequently, in that same year, ONR provided funds to Woods Hole to conduct a predesign engineering study of oceanographic vessels reflecting existing ideas and exploring further the most logical choices of power plant, ship size and outfitting. The study was directed by an Advisory Cornmittee consisting of Mr. Francis Minot, Chairman, who was the Woods Hole naval architect: Dr. Columbus O’D. Iselin, then Director of Woods Hole; Professor Emeritus H. L. Seward of Yale University; Dr. K. S. M. Davidson, then Director of the Experimental Towing Tank at Stevens Institute of Technology; and Mr. Mandel Rosenblatt, naval architect. This was the most comprehensive study at that time to describe the general requirements of oceanographic vessels.

Shortly after the study became available, the Office of Naval Research, in October 1953 , sponsored a conference in Washington, D. C. on oceanographic slips. It was attended by over 50 representatives of academic and private institutions, Navy laboratories, the Hydrographic Office and the Bureau of Ships. General ship characteristics for an oceanographic vessel were evolved, but it was the consensus that a steering committee be established for further definition. This steering committee was composed of representatives of each of several institutions and Navy activities. However, the ship characteristics adopted were those proposed by the Scripps Institution representative, Rear Admiral C. D. Wheelock, USN (Retired), formerly professor of Naval Construction at Massachusetts Institute of Technology and Deputy Chief of the Navy's Bureau of Ships.

In 1955 the Bureau of Ships undertook and completed a preliminary design study investigating the feasibility of these characteristics. The project, which eventually resulted in the basic design for the AGOR 3 Class research vessels, was to remain dormant, however, for more than three years while awaiting the appropriation of funds for construction of an especially designed oceanographic ship. 


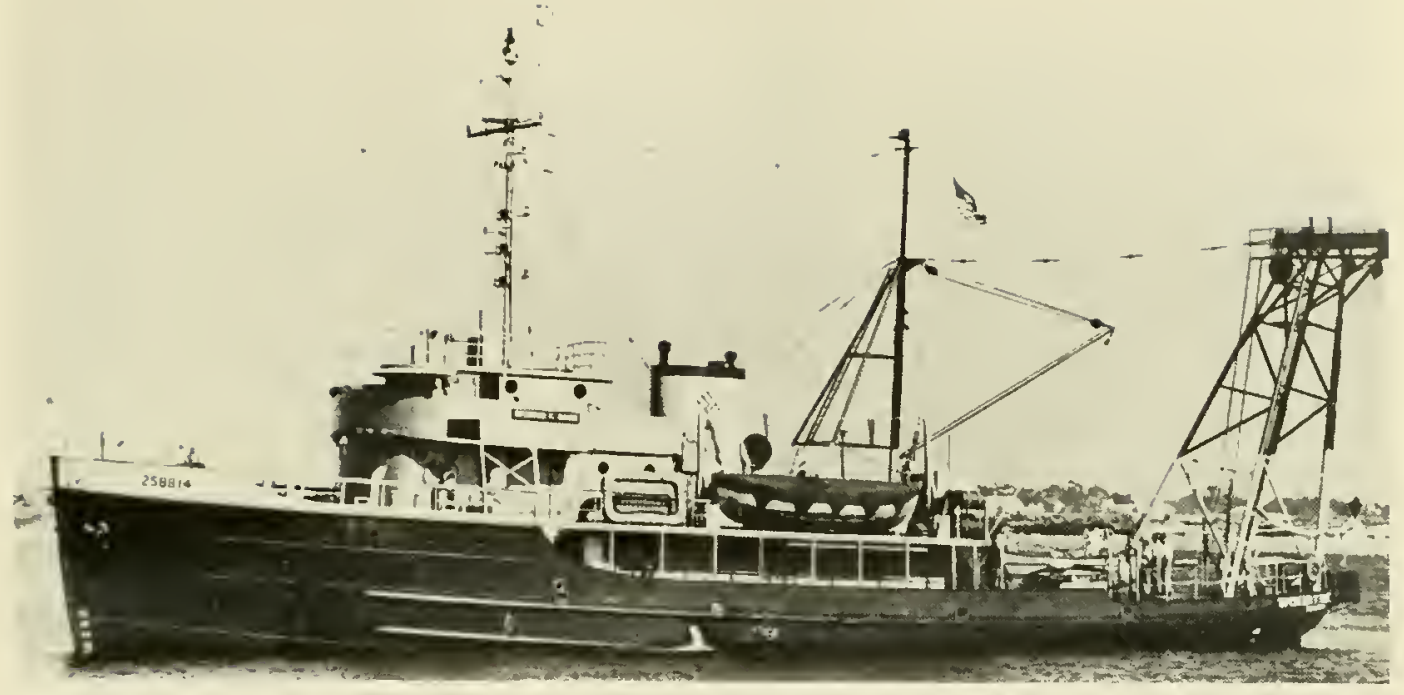

R/V Spencer Baird

Originally the U.S. Army sea-going tug, LT 581. Acquired by Scripps Institution of Oceanography in 1952 for use as an oceanographic research ship. In 1965, she was transferred to the Vietnamese government and renamed Tien $\mathrm{Sa}$.

Length: 145' Displacement: 997 tons

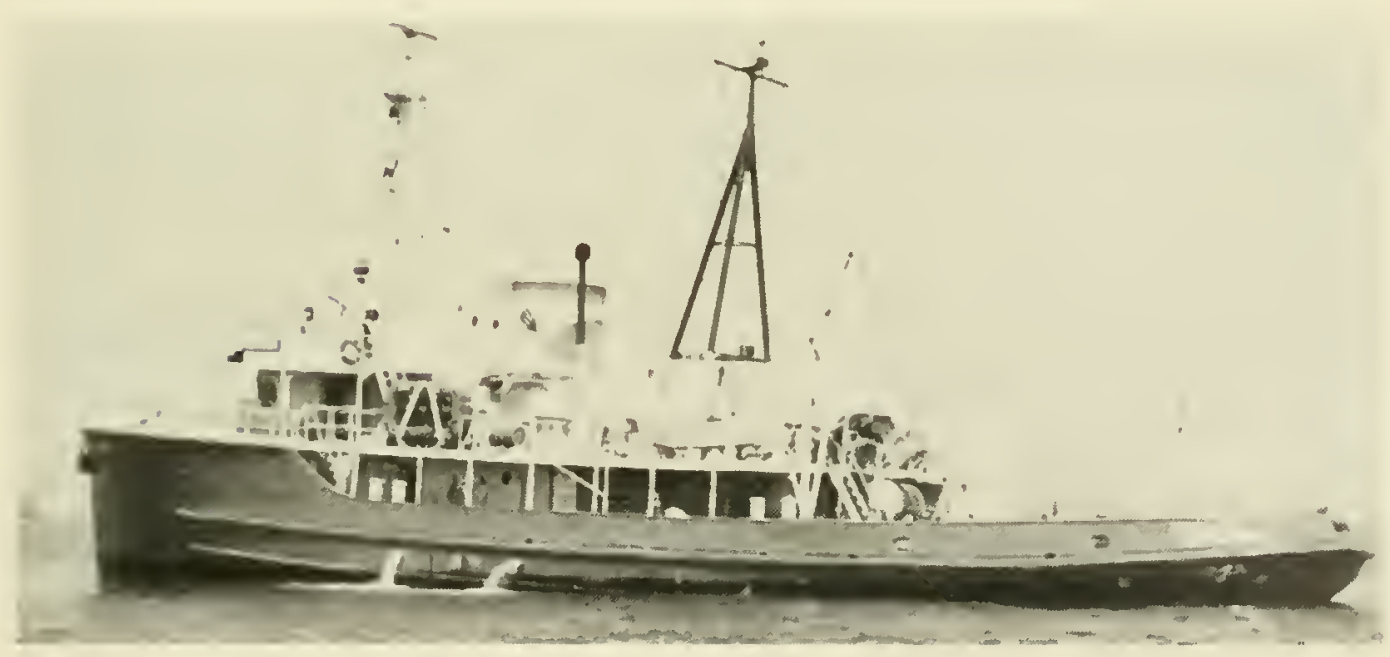

R/V Horizon

The former Navy sea-going tug $A T A 180$ built in 1944. Acquired by Scripps in 1948 and converted to an oceanographic research ship. Horizon was disposed of in 1969.

Length: 143' Displacement: 900 tons 


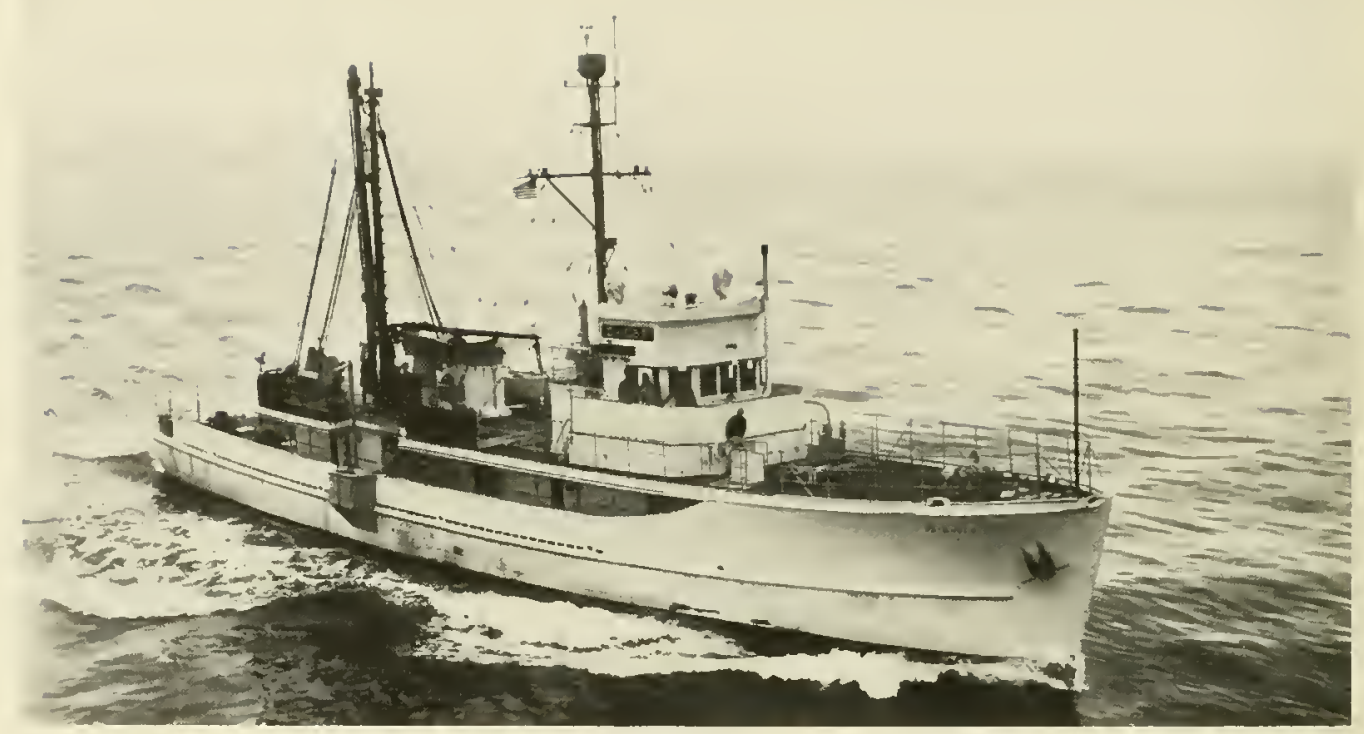

R/V Crest

A former 136-foot Navy minesweeper built in 1944 and provided to Scripps Institution of Oceanography in 1948 for use as a research ship. Renamed the Crest by Scripps, she was disposed of in 1956.

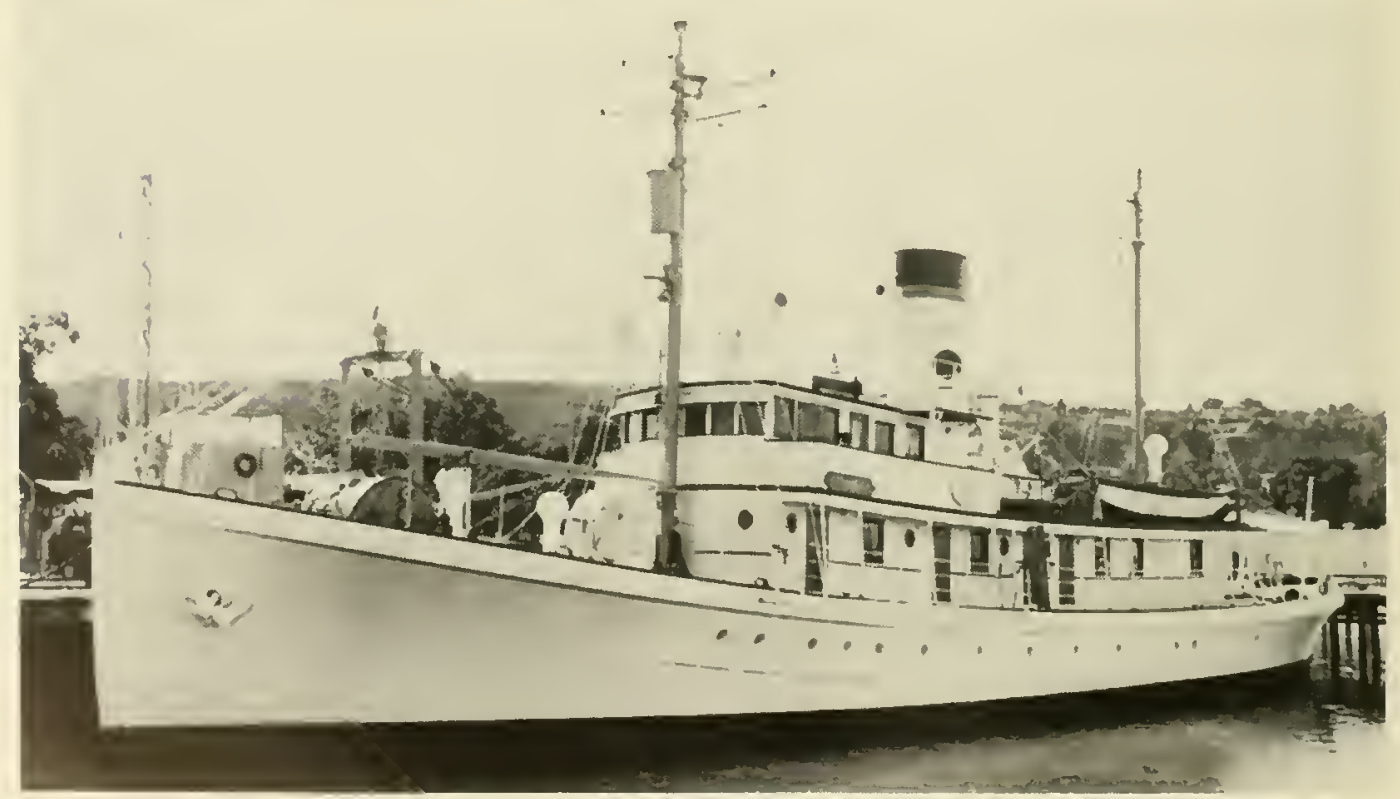

R/V Siranger

A wooden hulled yacht built in 1938 and acquired by Scripps Institution of Oceanography in 1955 for use as an oceanographic research ship. Stranger was disposed of in $\mathbf{1 9 6 2 .}$

Length: I 34' Displacement: 405 tons 


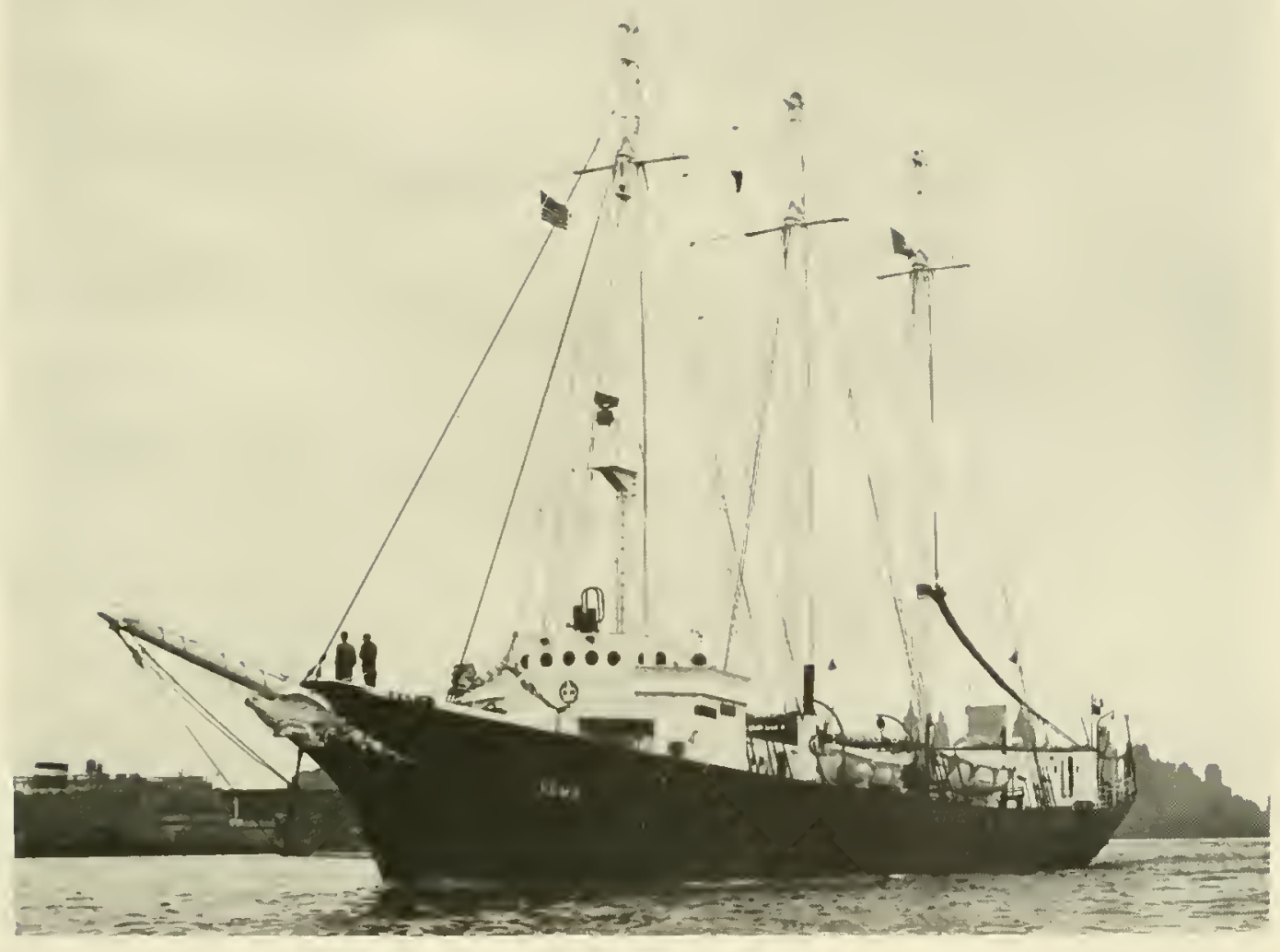

$\mathrm{R} / \mathrm{V}$ lema

An iron hulf scliooner built in 1923. Acquired in 1953 and converted to a research ship by Lamont-Doherty Geological Observatory, Columbia University.

Length: 202' Displacement: 743 tons 


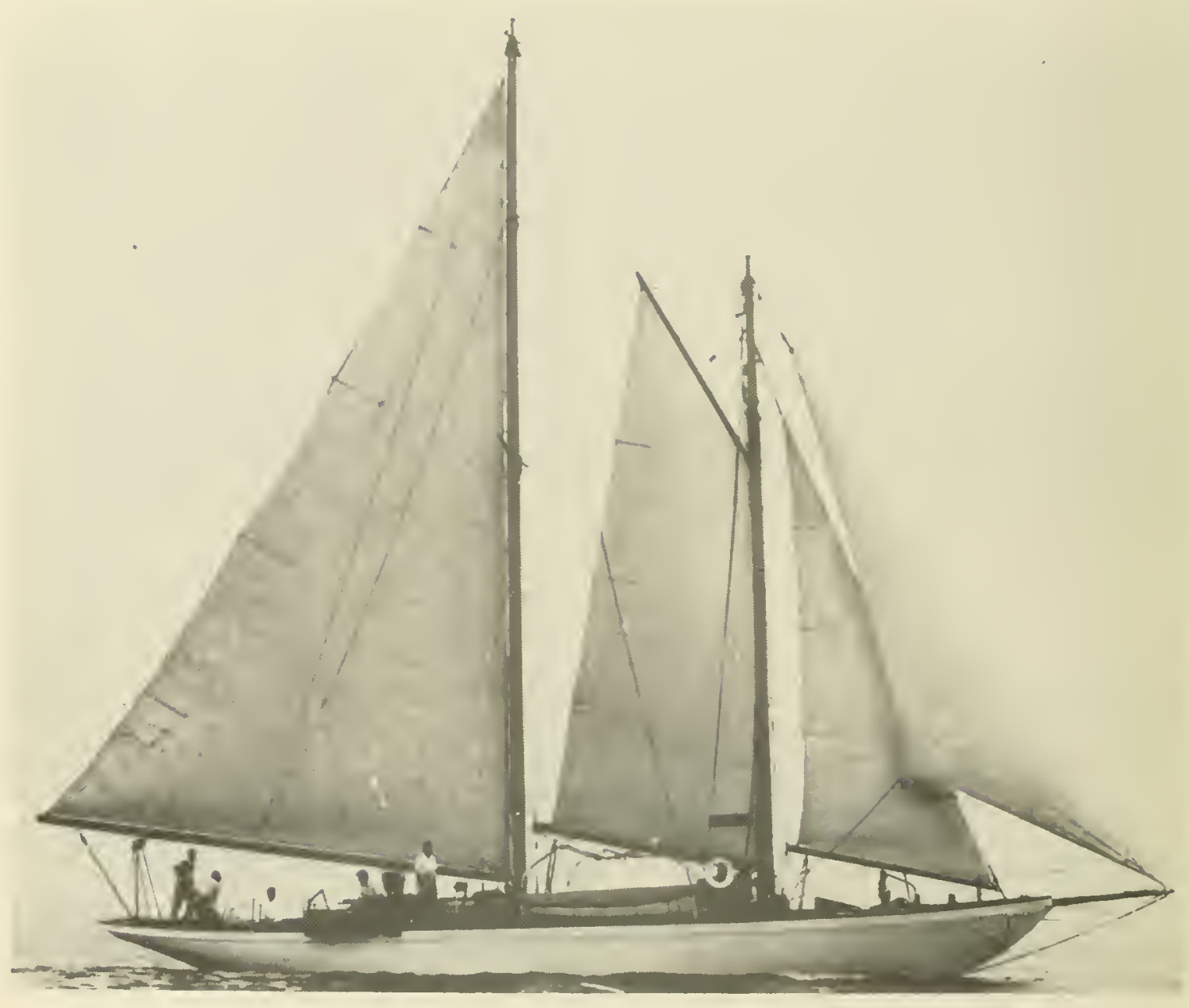

\section{R/V Action}

A 55-foot schooner built in 1931 and used during the period of 1956 to 1962 by the Department of Meteorology and Oceanography, New York University. 


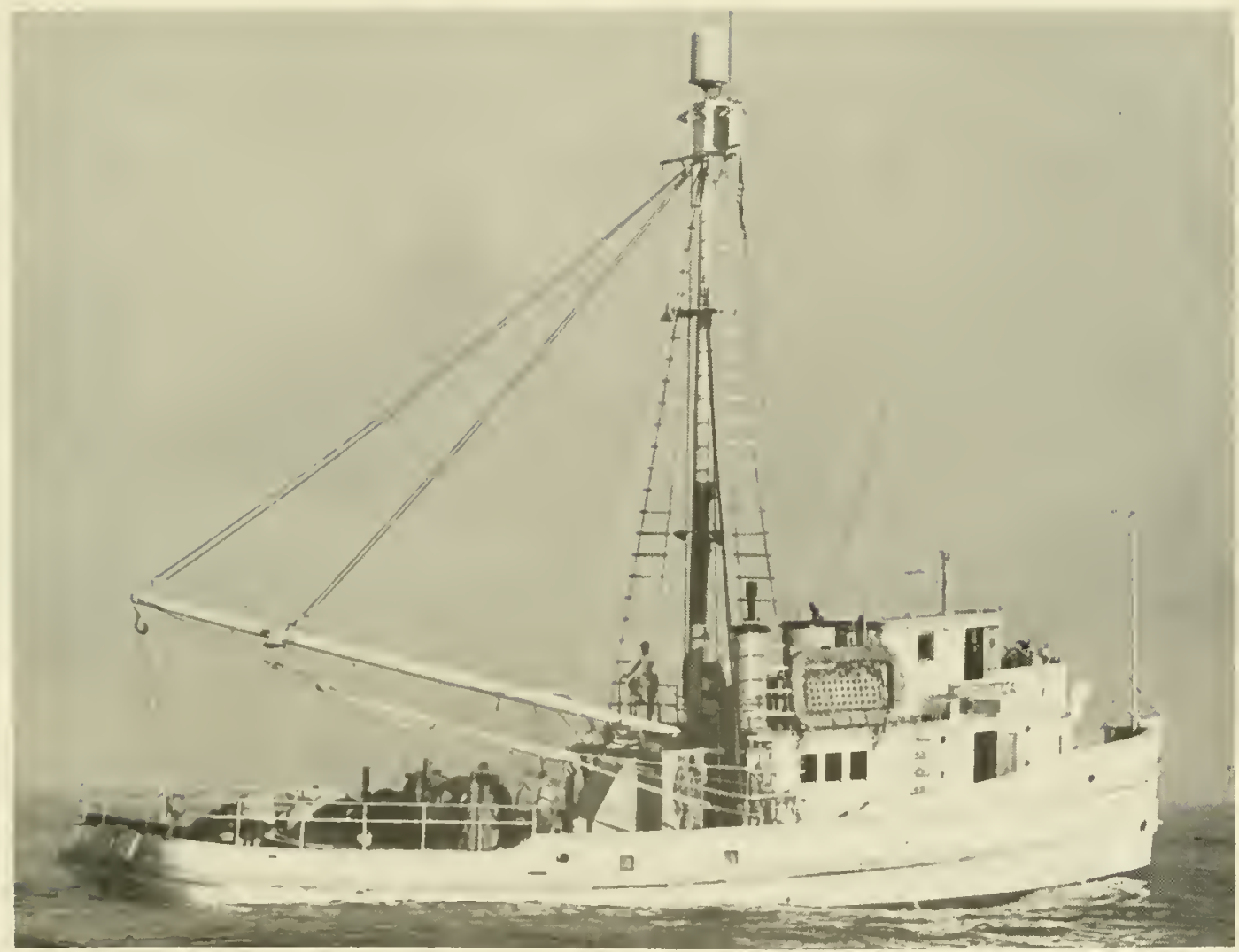

R/V Paolina-T

A wooden hulled purse seiner built in 1944. Acquired by Scripps Institution of Oceanography in 1948 for use as a research ship. She was disposed of in 1964.

Length: 80' 3" Displacement: 170 tons

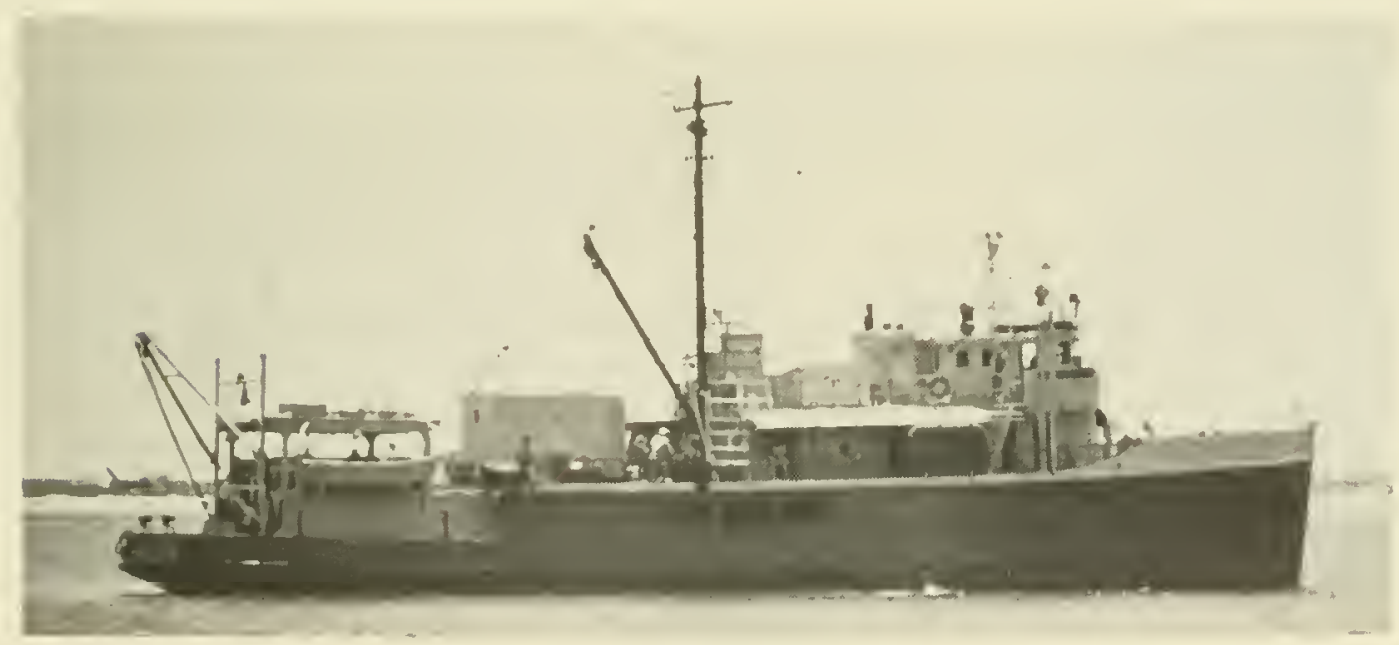

R/V Hugh M. Smith

A wooden hulled tuna clipper built in 1945. Owned by the U.S. tion of Oceanogiaphy from 1959 to 1963 on a loan basis. Fish and Wildlife Service, she was operated by Scripps InstituLength: $128^{\circ}$ Displacement: 561 tons 


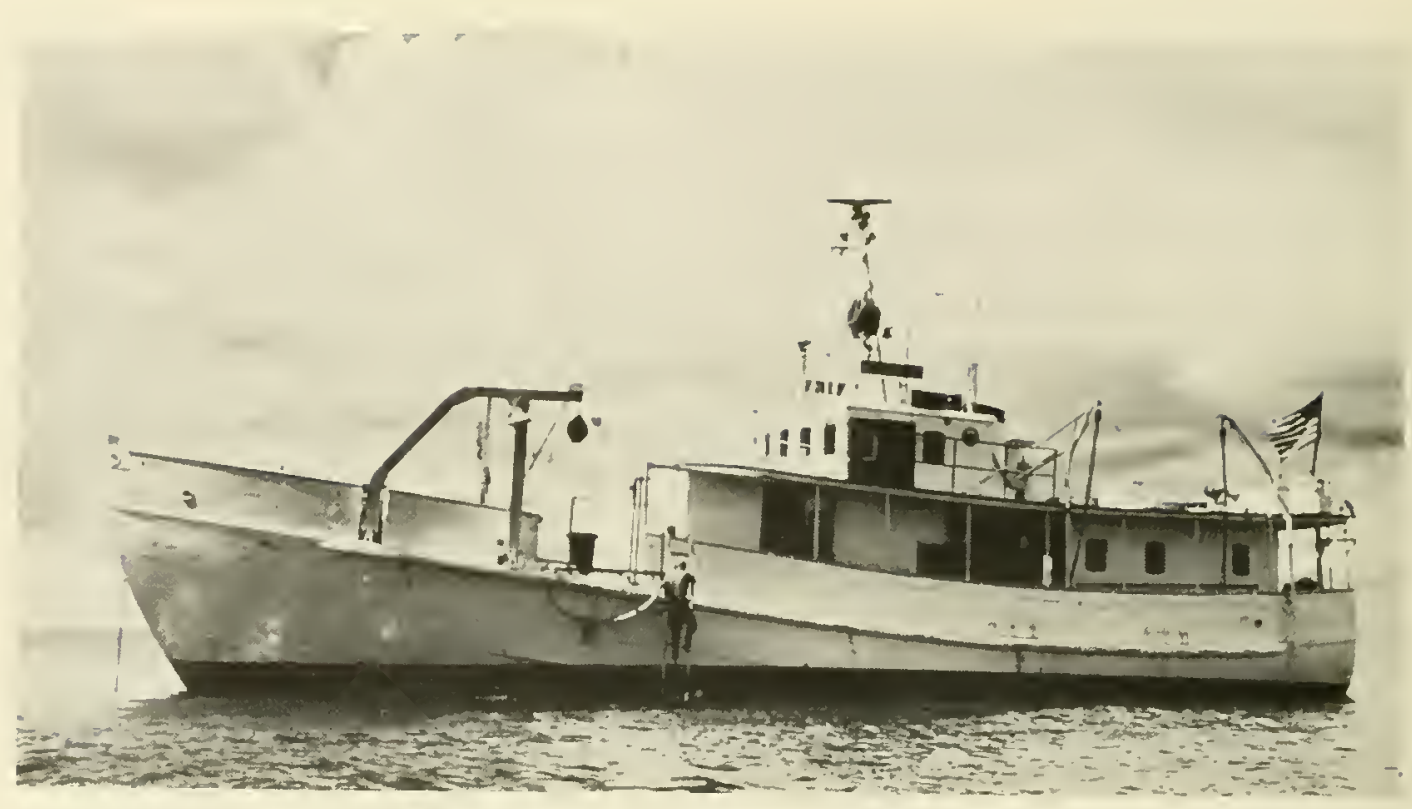

R/V Gerda

A wooden North Sea trawler design yacht built in 1947 in Denmark. Acquired by the University of Miami in 1954 for use as a research ship.

Length: $76^{\prime}$ 6" Displacement: 213 tons

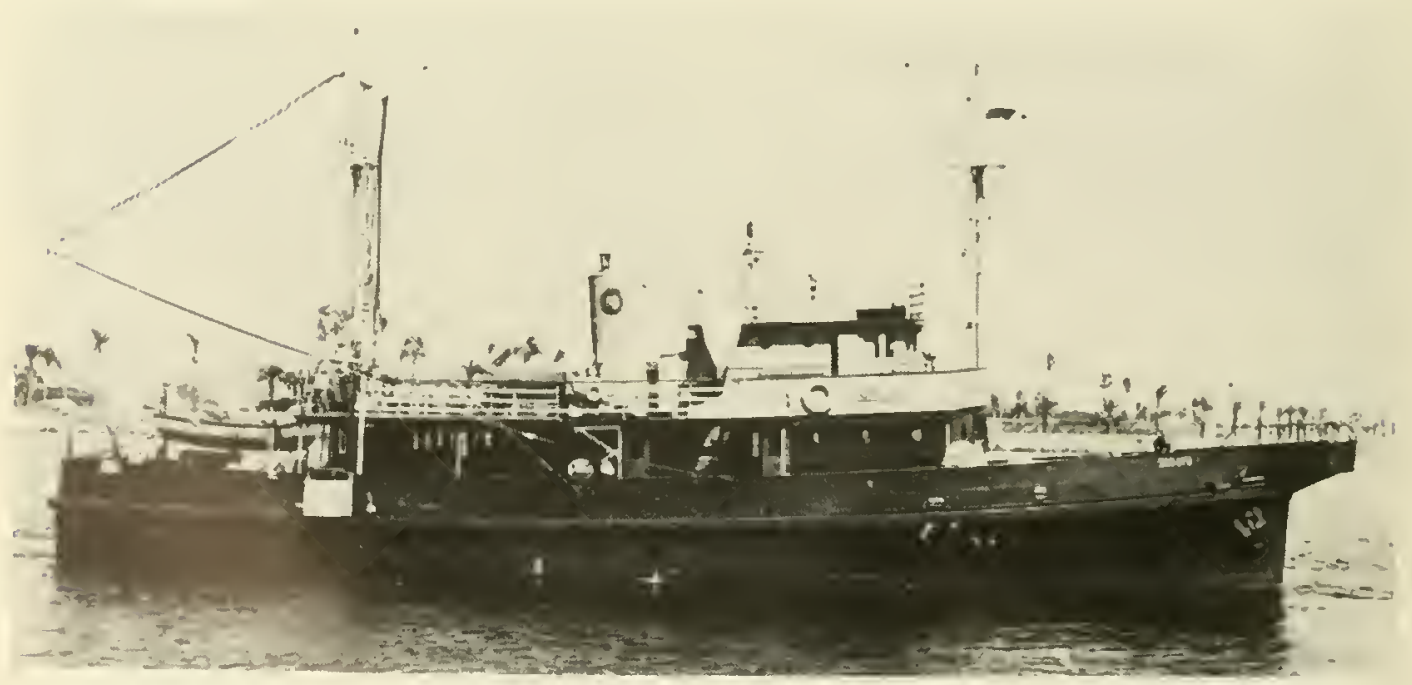

R/V Orca

A wrought-iron hulled former Coast Guard patrol vessel built in 1926. Slie was acquired by Scripps Institution of Oceanography in 1956 and converted to a research vessel. In 1961 the Orca was wold to Teledyne, Inc. and employed as a geophysical survey vessel in the Gulf of Mexico. In April 1970, Texas A\&M University obtained the Orca for use as a research vessel.

Length: 98' Displacenent: 205 tons 


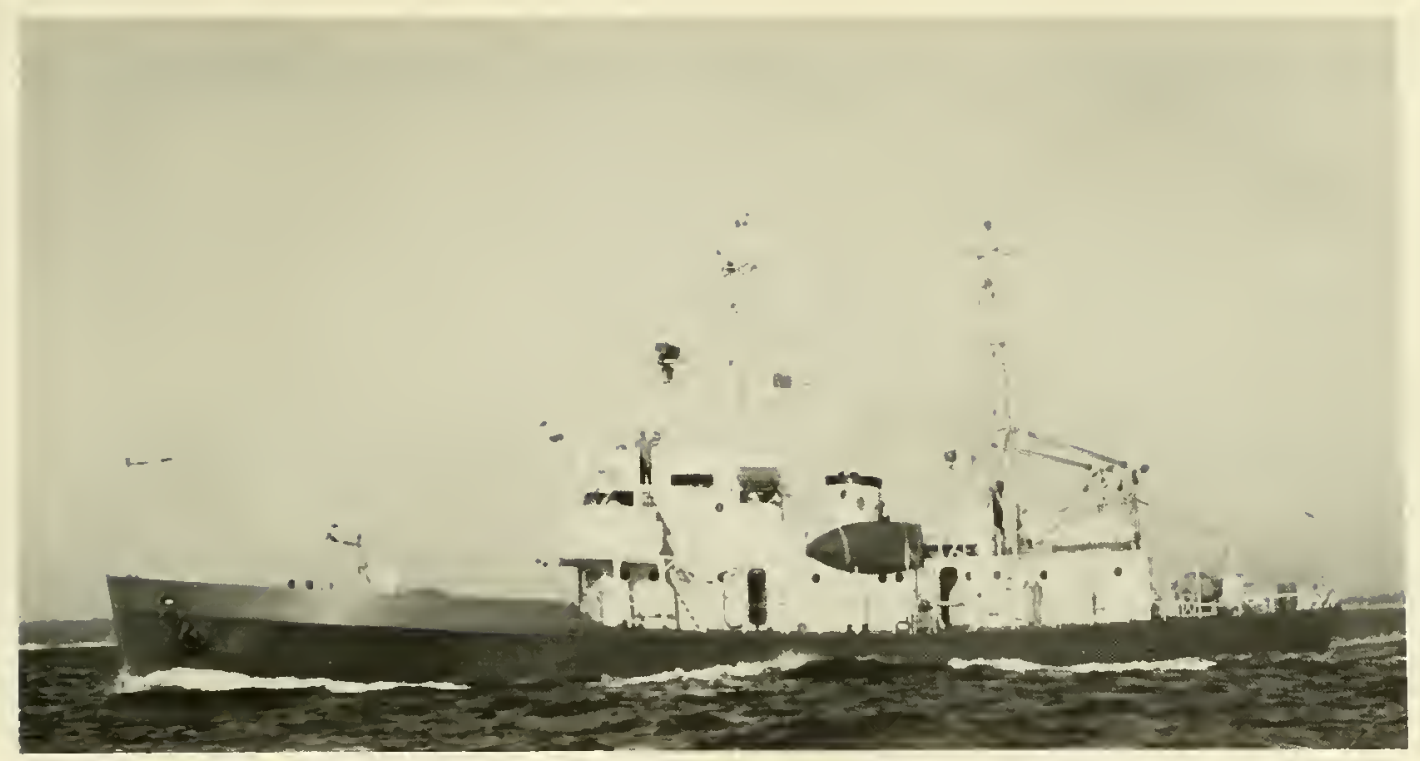

R/V Crawford

Formerly a Coast Guard cutter built in 1927. She was acquired by Woods Ilole in 1956 for use as an oceanographic rexearch veswel and, after 175 eruises, laid up in 1968. She was purchased in 1970 by the University of Puerto Rico.

Length: 125' Displacement: 304 tons

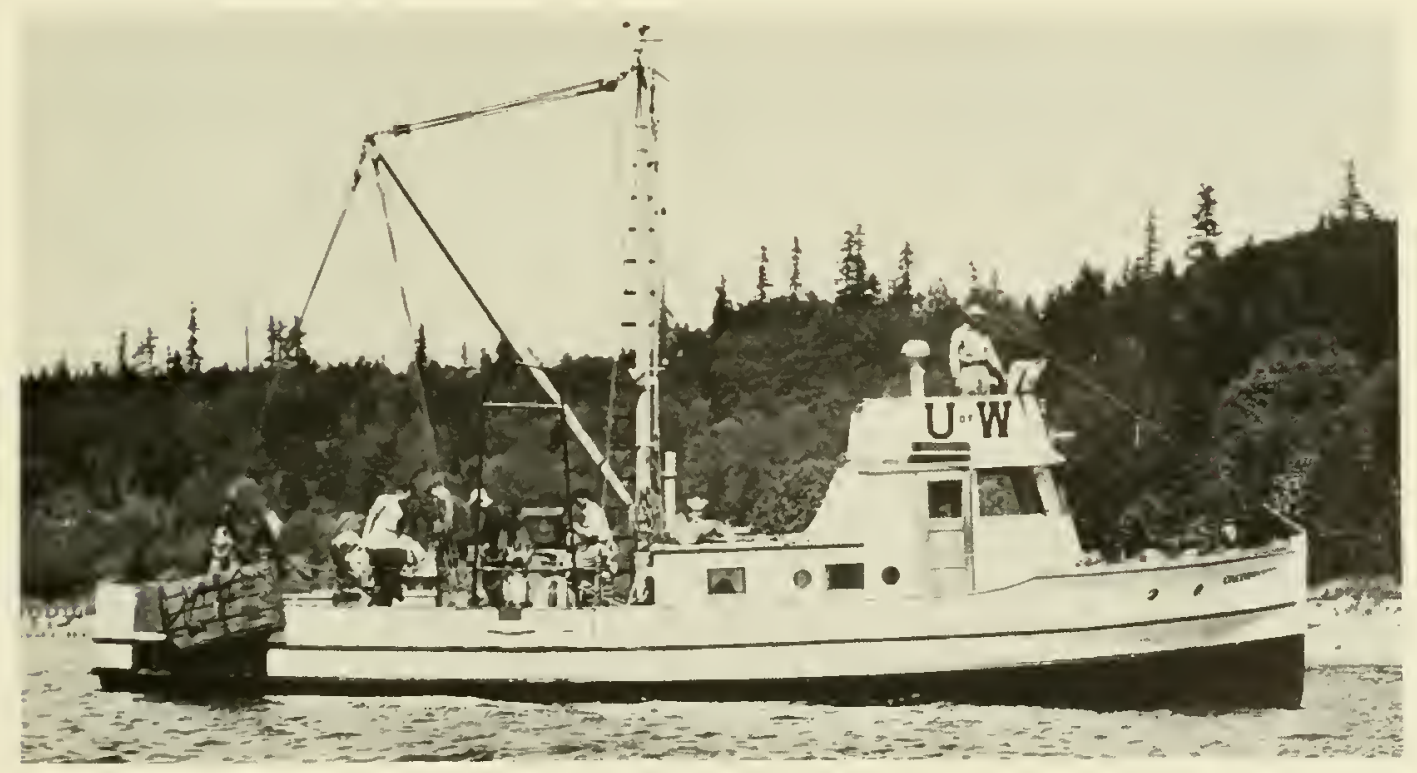

R/V Oncorkinchus

Jormerly a motor launch built in 1937 and aequired by the University of Washington in 1948 for use as a research vessel. She was disposed of in 1951.

Length: $50^{\circ}$ Displacement: 27 tons 


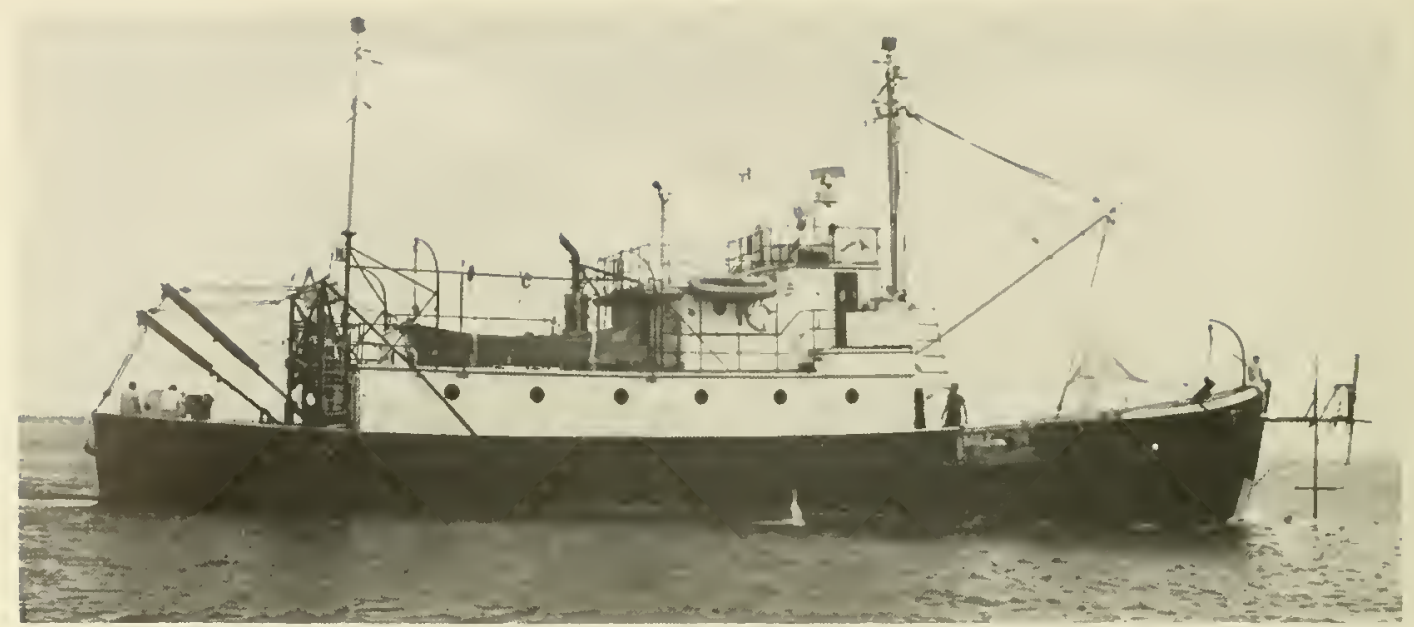

R/V Bear

A former coastal freighter built in 1943 and acquired by Woods Hole in 1957 for use as a research vessel. Bear was disposed of in 1965.

Length: $100^{\circ}$ Displacement: 260 tons

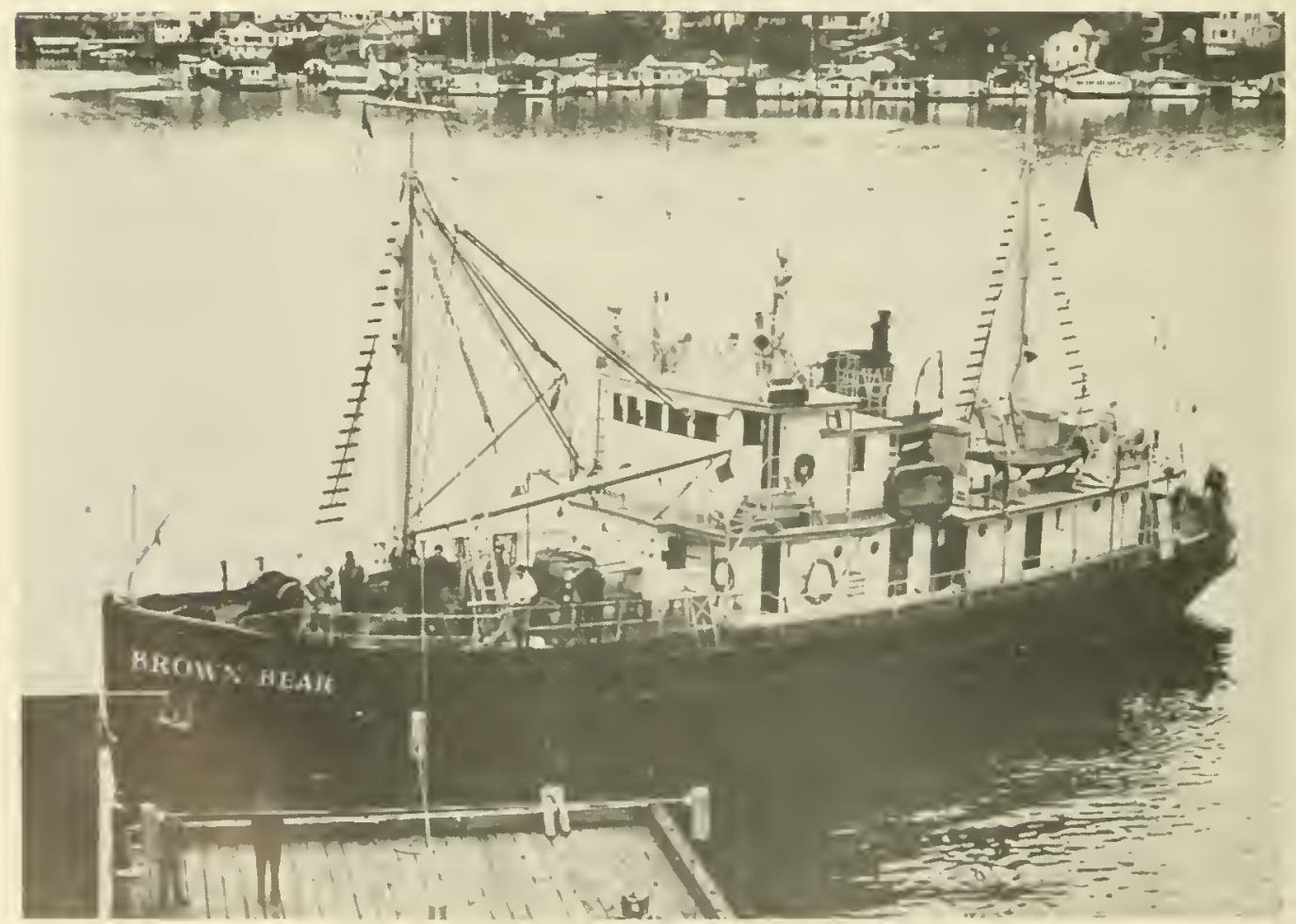

R/V Brown Bear

A wooden-hulled coastal freighter built in 1934. Acquired by the University of Washington in 1950 from the U.S. Fish and Wildlile Commission for use as a research ship. In 1965 the
Brown Bear was returned to the Fish and Wildlife Commission. Length: $114^{\prime}$ Displacement: 270 tons 


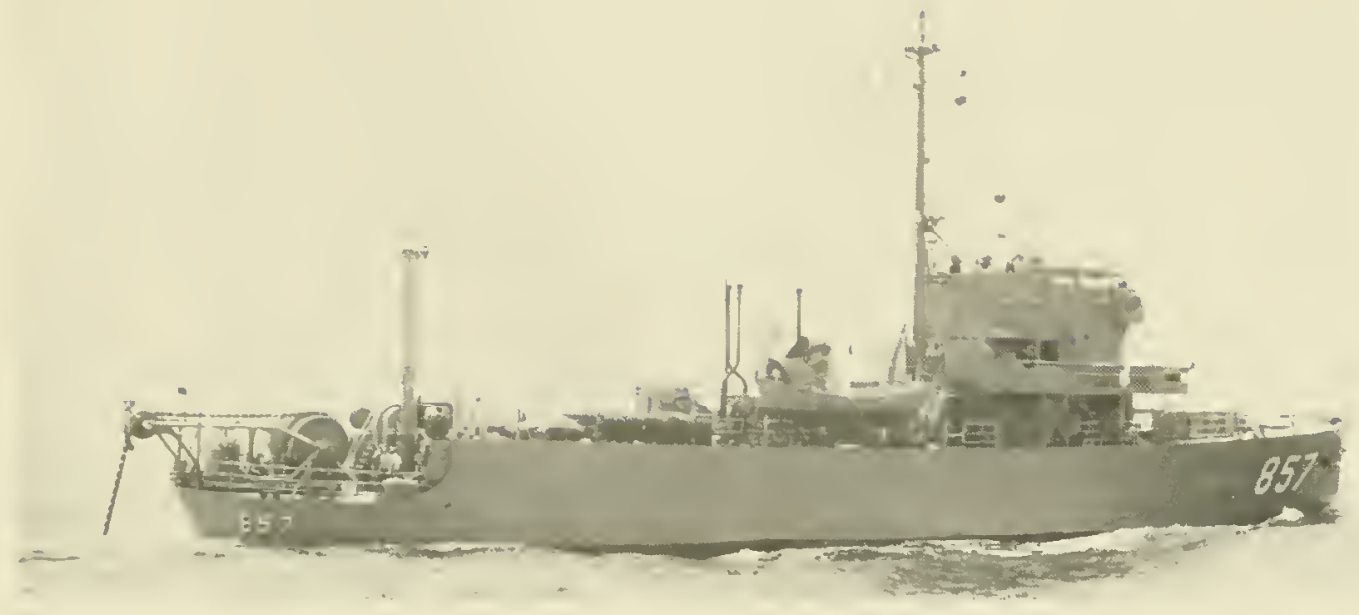

USS larysille (PCER 857)

A former escort craft built in 1944 and, in 1951, assigned to support research and development projects at West Coast Navy laboratories. Marysillc was inactivated in 1970.

Length: 185' Displacement: 900 tons

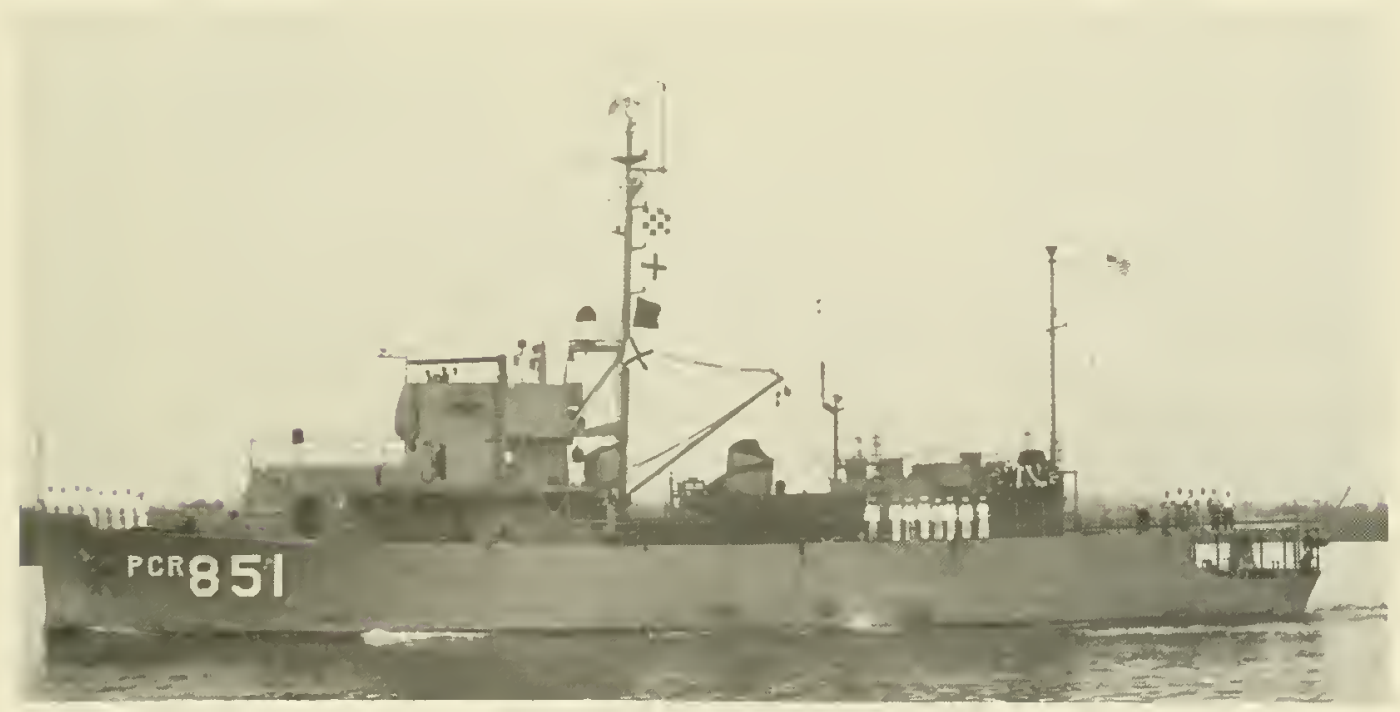

USS Rockville (PCER 851)

A former escort craft built in 1944 by Pullman Standard Car Manufacturing Company of Chicago. In 1953 she was assigned to support researcli and development projects at Navy laboratories, principally the Naval Rexearch Laboratory. Rocksille partic- ipated as part of the Task Group which conducted the first year search operations for the nuclear submarine Thresher. Rockville was disposed of in 1969.

Length: 185' Displacement: 900 tons 


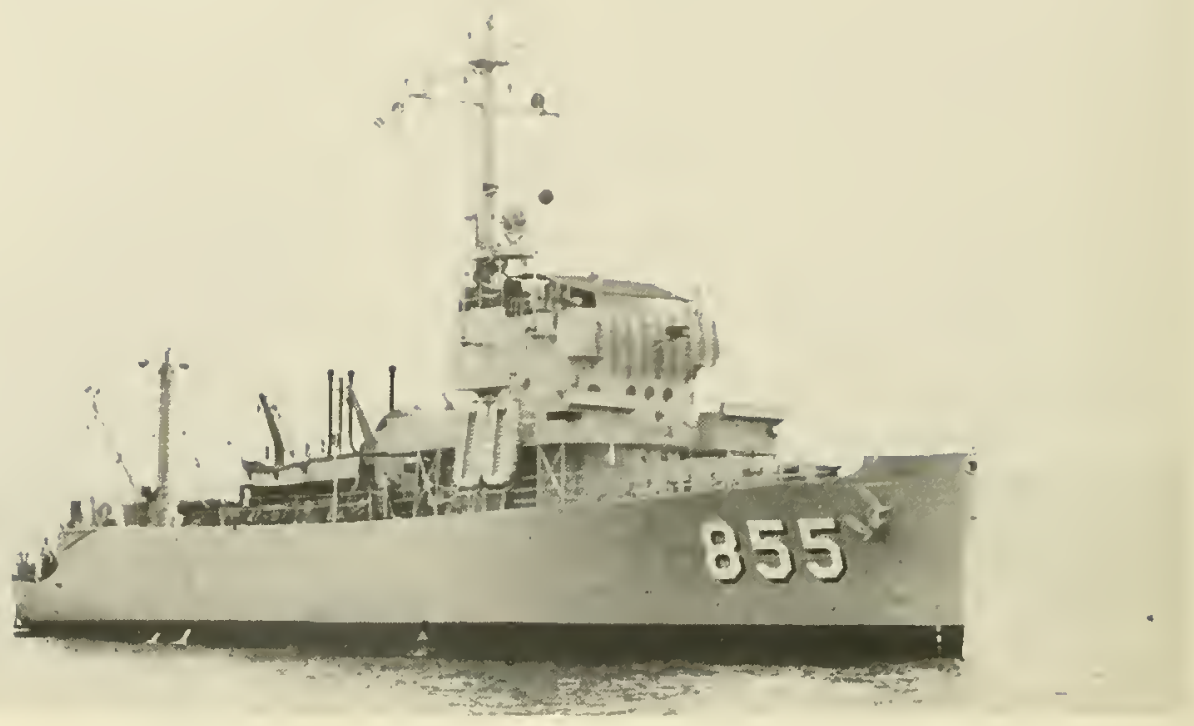

USS Rexburg (PCER 855)

A former 185-foot escort craft built in 1944 and, in 1951, assigned to support research and development projects at West Coast Navy laboratories. Rexburg was inactivated in 1970.

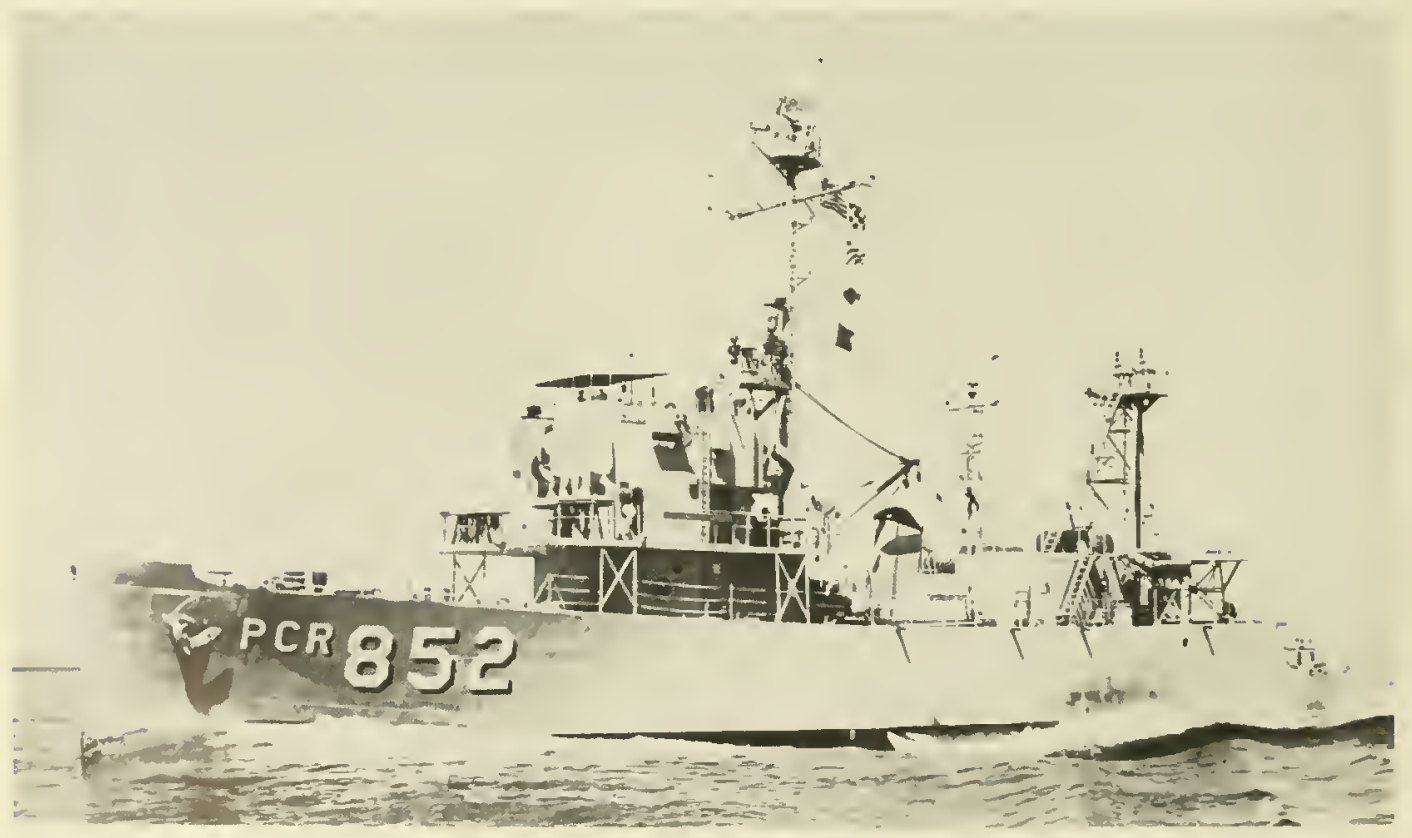

USS Bratleboro (PCER 852)

A former 185-foot escort craft built in 1944 and after the War assigned to support research and development projects at East Coast Navy laboratories. Brattleboro was disposed of in 1965. 


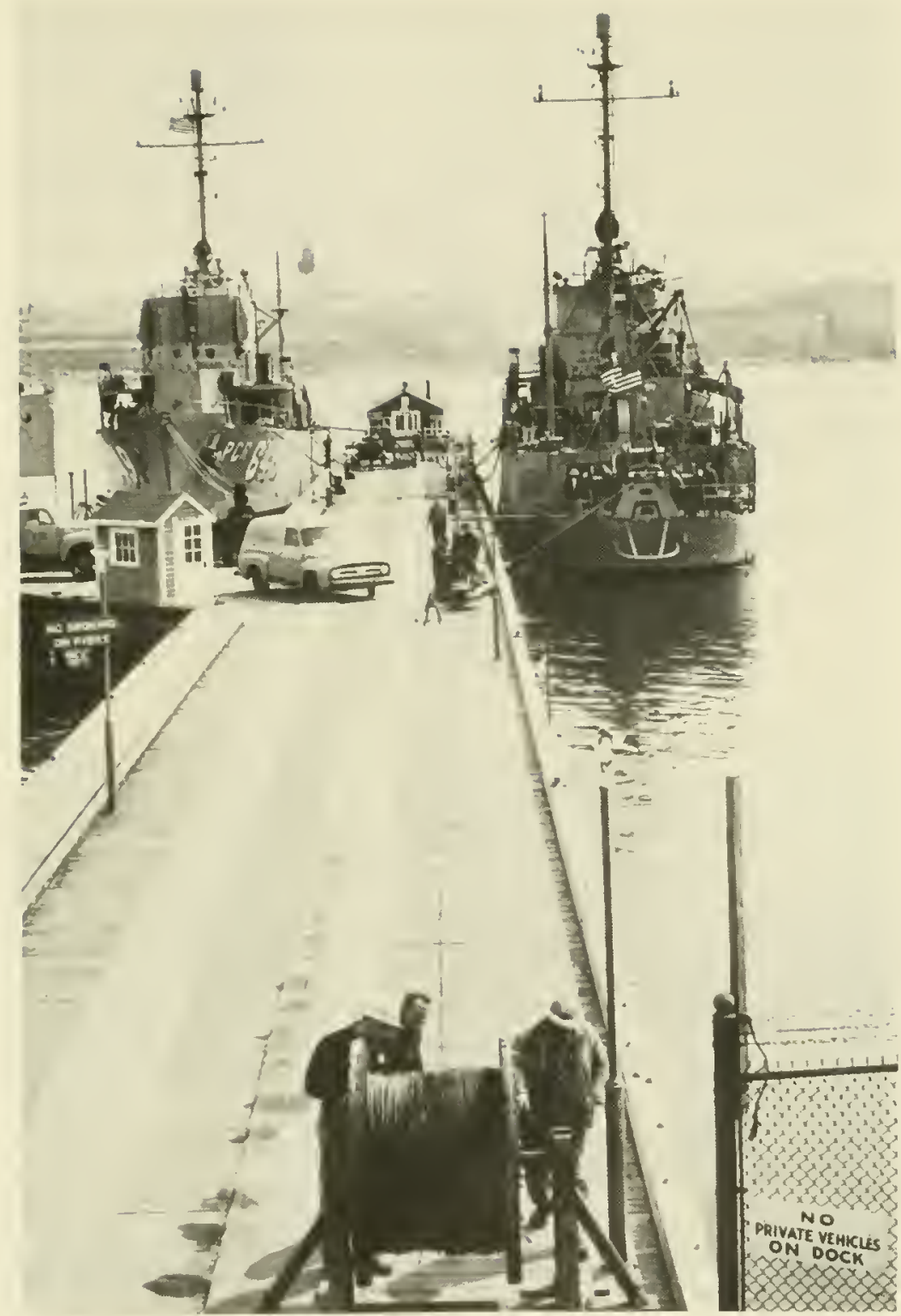

USS Somersworlh (PCER 849)
and

USS Fairview (PCER 850)

Former 185-foot escort craft built in 1944 by Pullman Standard Car Manufacturing Co. of Chicago. In 1947 they were assigned to support research and development projects at East Coast Navy laboratories. In this 1954 photograph Somersworth and Fairview are shown at the dock of the Navy's Underwater Sound Laboratory in New London, Connecticut. Wire rope $(5 / 8$ inch diameter) is being reeled on to the Farview's aft electrical winch. In the background is General Dynamics, Electric Boat Division Shipyard. Somersworth and Fairview were disposed of in 1965 and 1968 , respectively. 


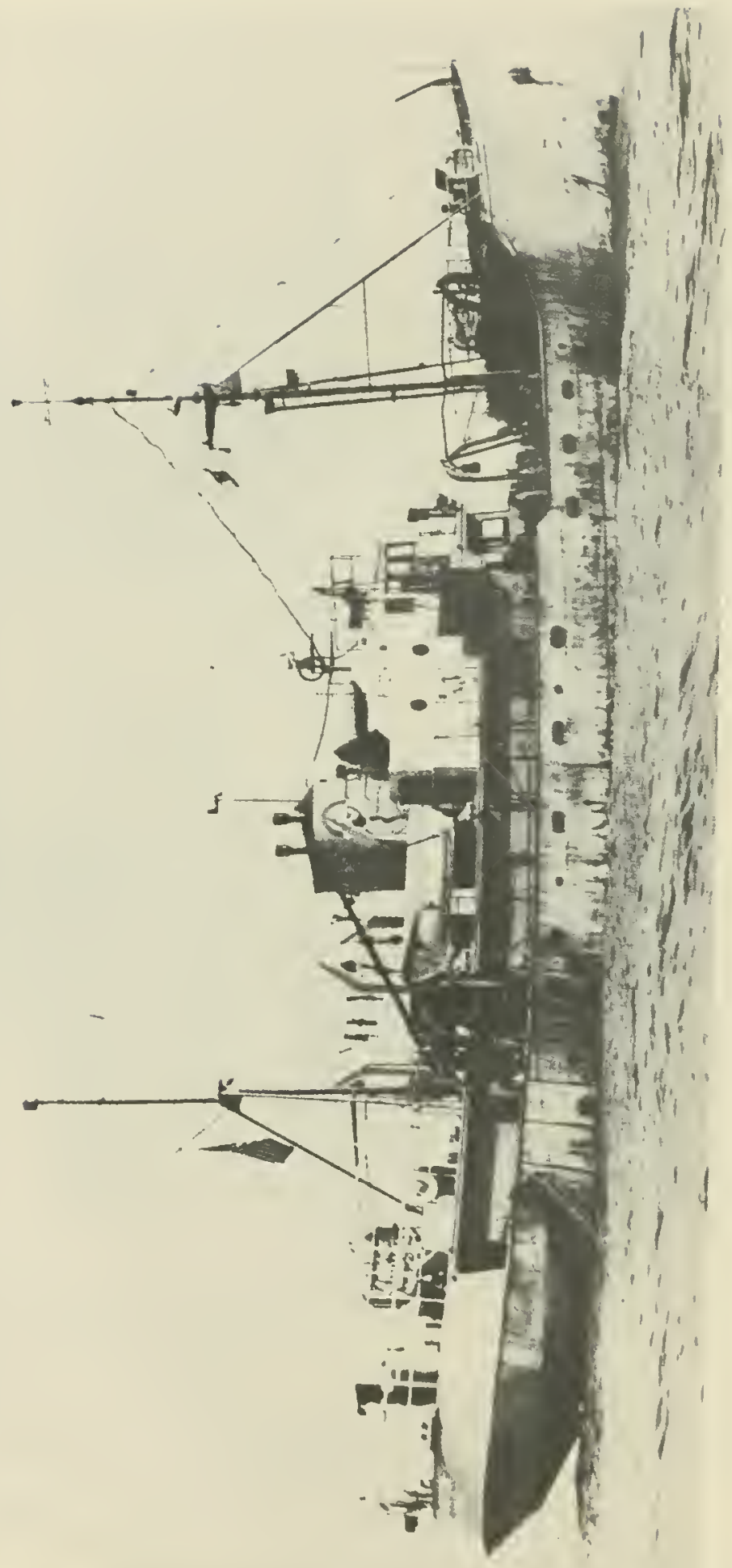

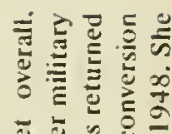

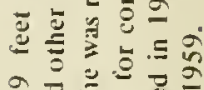

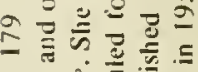

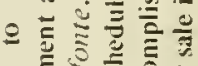

记

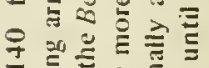

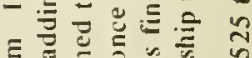

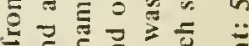

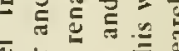

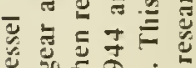

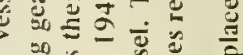

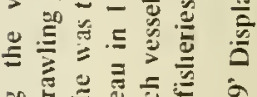

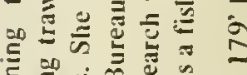

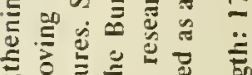

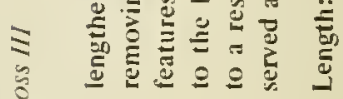

E

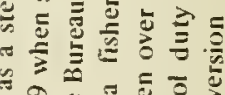

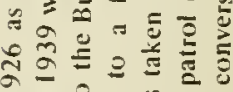

ธ

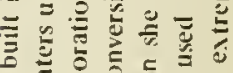

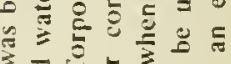

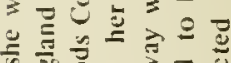

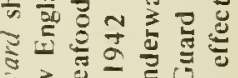

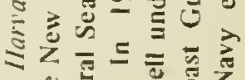

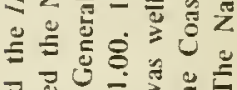

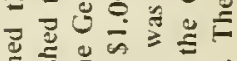

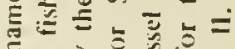

๖う气

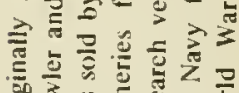

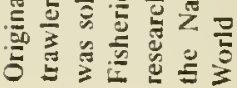



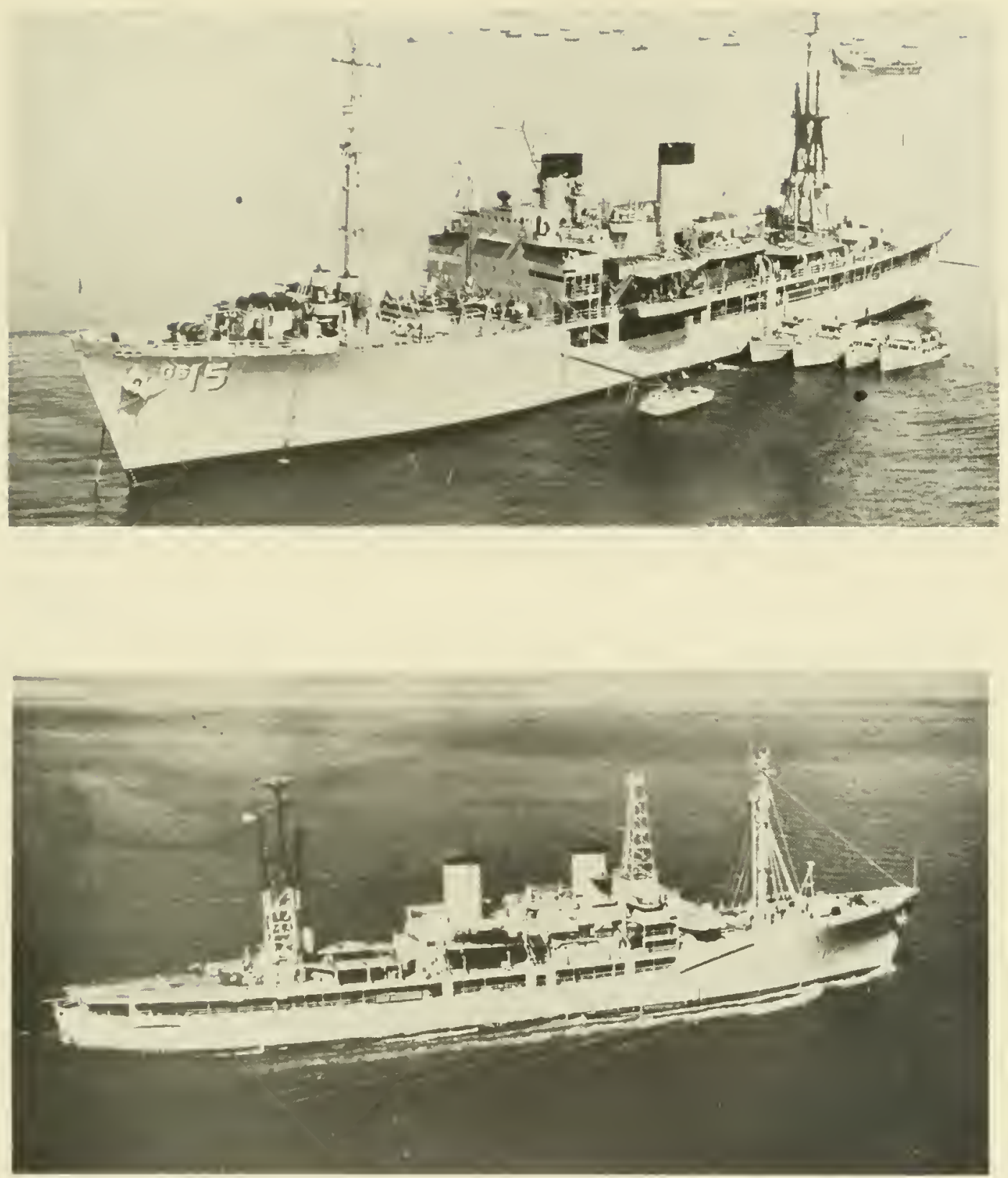

\section{USS Tanner (AGS 15) \\ and}

USS Maury' (AGS 16)

Originally the attack cargo ships USS Pamina (AKA 34) and USS Renate (AKA 36), respectively, built in 1945 by Walsh-Kaiser Shipyard of Providence, Rhode Island. The following year they were converted to hydrographic survey ships by Norfolk Navy Yard (Tanncr) and Portsmouth Navy Yard (Maury). Initially, they carried two 40-foot and two 50-foot sounding boats but later four 52-foot sounding boats were substituted. Also carried were six small landing crafts, two amphibious trucks (DUKWs), several jeeps and trucks, a portable electronic positioning system, and a small amphibian aircraft which was replaced by a hclicopter in 1948. Stricken from the list of active ships in 1969 , Tanner's and Maury's survey career spanned 23 years of continuous service for the Navy's Oceanographic Office.

Length: $426^{\prime}$ Displacement: 6,000 tons 


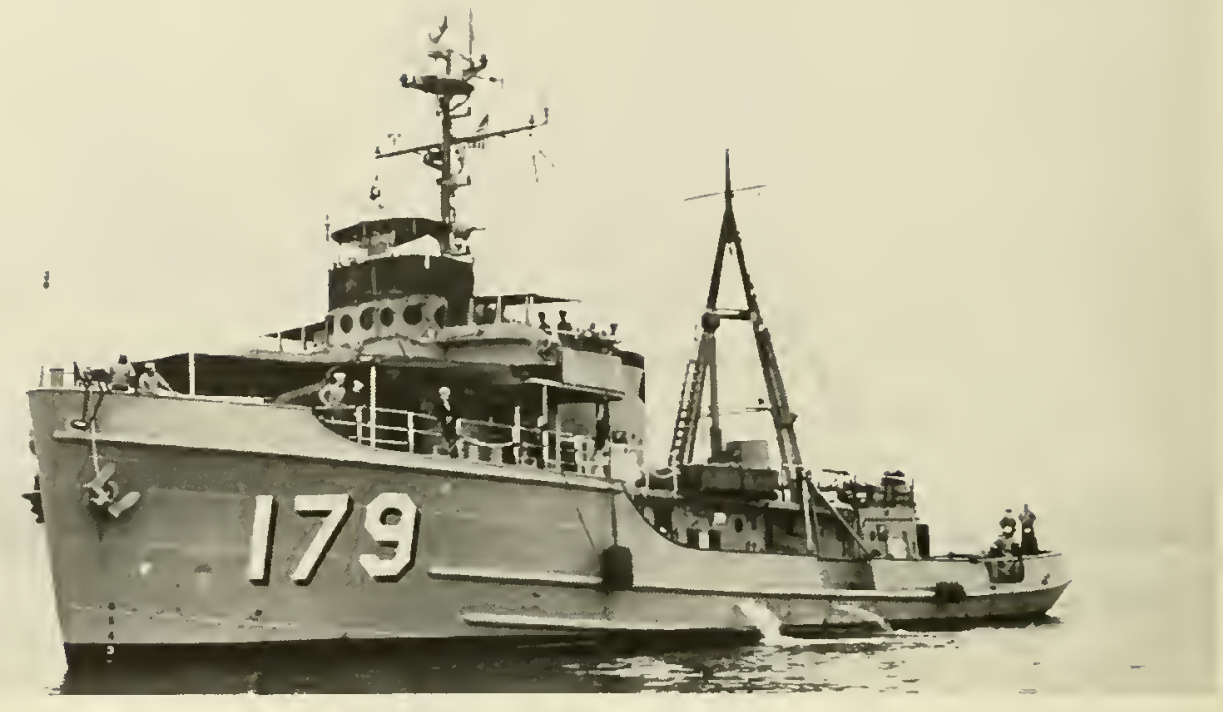

R/V Allegheny (ATA 179)

Built in 1944, this Navy auxiliary ocean tug was assigned to hydrographic survey duty from 1948 - 1952. Allegheny' was then made available (1952 - 1969) to support research projects at Hudson Laboratories of Columbia University. In 1969 the
Allegheny, declared excess to Navy needs, was acquired by Northwestern Michigan College.

Length: 143' Displacement: 860 tons

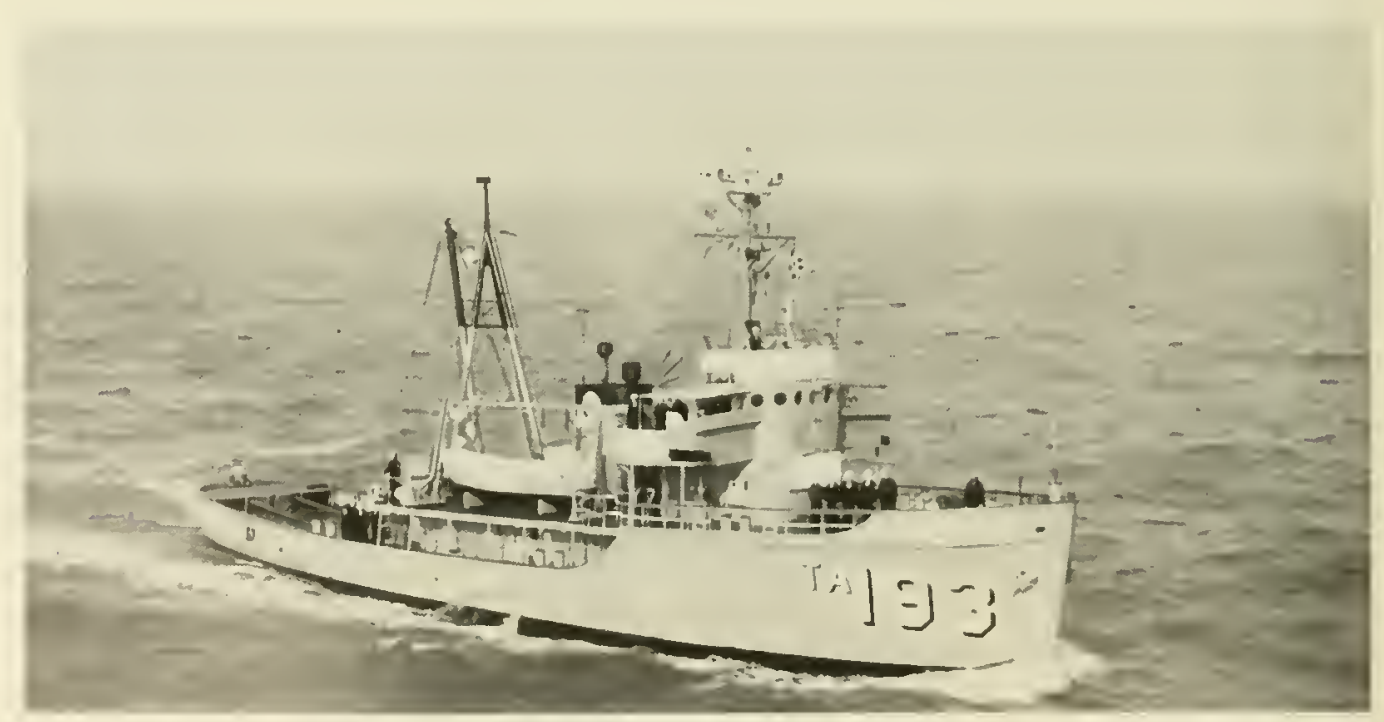

USS Stallion (ATA 193)

Built in 1945 by Livingstone Shipyard of Orange, Texas and placed in the Reserve Fleet the following year. In 1948 she was recommissioned and assigned to the Navy's Hydrographic Office for survey service in the Persian Gulf. In 1952 Stallion completed her tour in the Persian Gulf and was then assigned to the Naval Ordnance Laboratory until 1955 to assist in test and evaluation of new developments in underwater ordnance. Her next employment was primarily towing assignments operating out of Fort Landerdale, Florida.

Length: 143' Displacement: 860 tons 


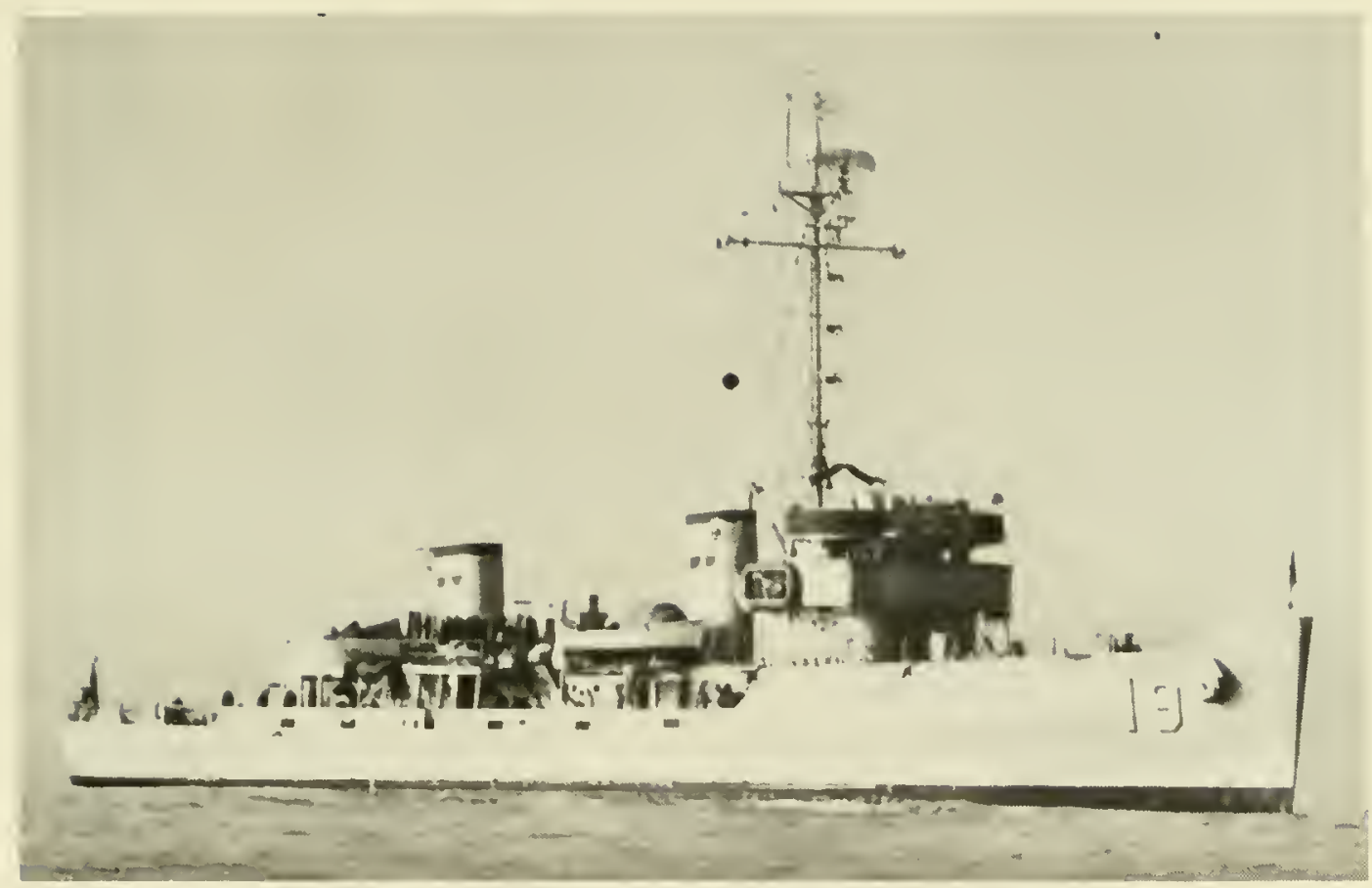

USS Sheldrake (AGS 19)

Originally the fleet minesweeper AM 62 buitt in 1942 by General converted to a hydrographic survey vessel in 1952 and redesig. Engine and Dry Dock Company of Alameda, California. She was nated the AGS 19. Shcldrake was disposed of in 1968.

Length: $221^{\prime}$ Displacement: 1,200 tons

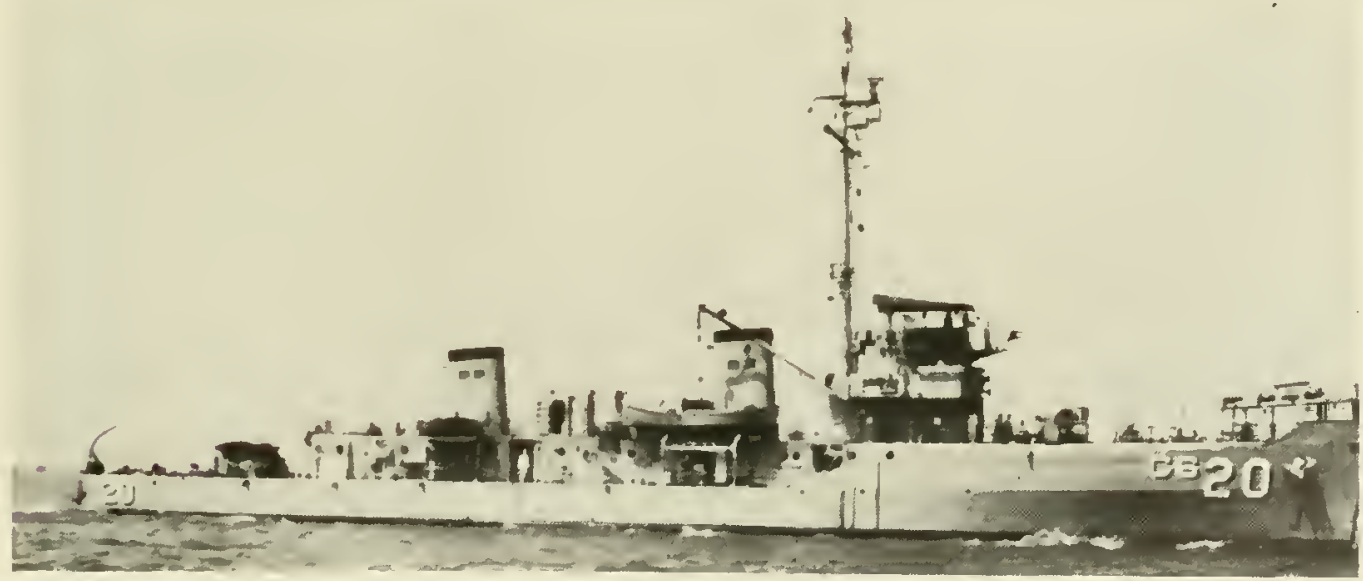

USS Prevall (AGS 20)

Originally the fleet minesweeper AM 107 buift in 1943 by hydrographic survey ship in 1952, Prevail was continuously Pennsylvania Shipyards of Beaumont, Texas. Converted to a employed in this service until her disposal in 1964.

Length: 221' Displacement: 1,200 tons 


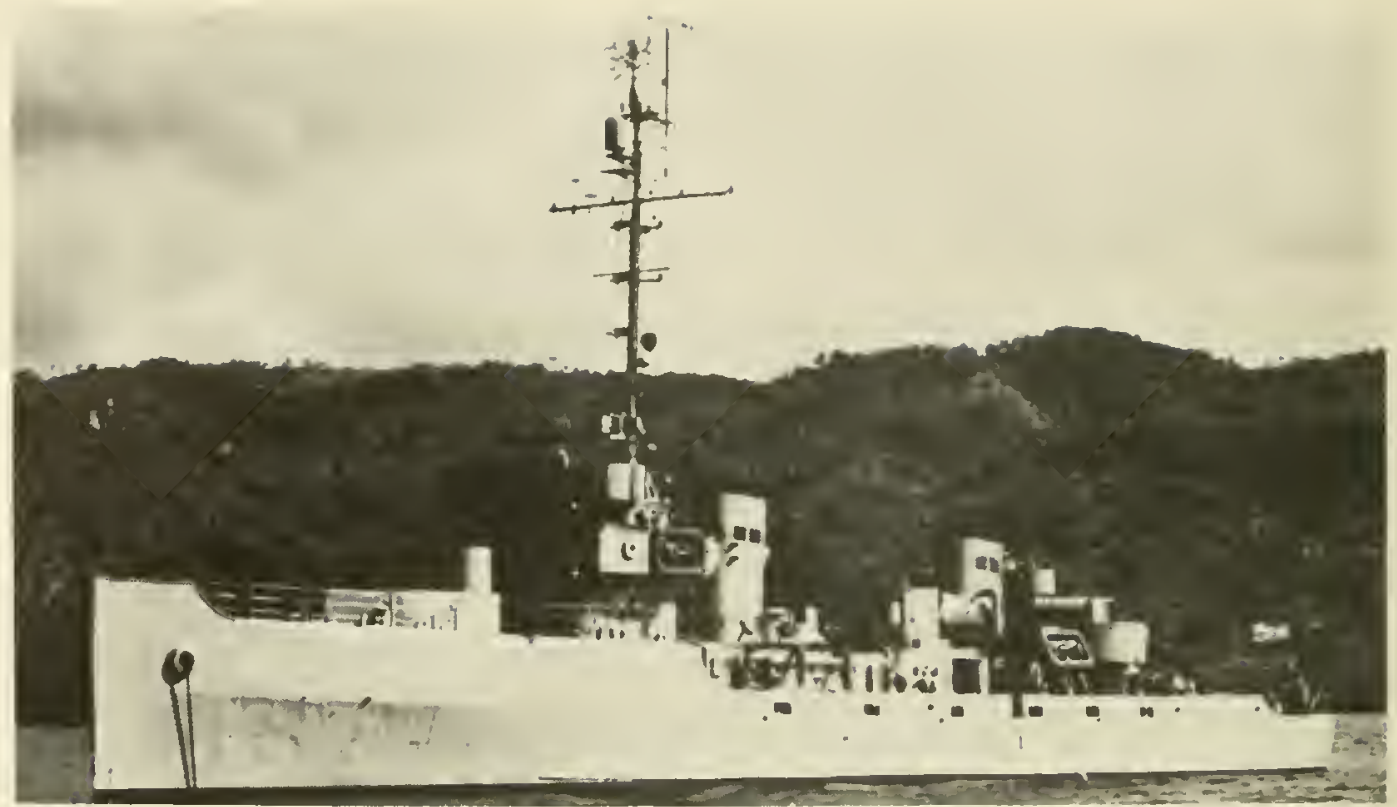

USS Pursuit (AGS 17)

Originally the fleet mineswecper AM 108 built in 1943 by Winslow Marine. Converted to a hydrographic survey ship in 1950 and in service until disposed of in 1960.

Length: 221' Displacement: 1,200 tons

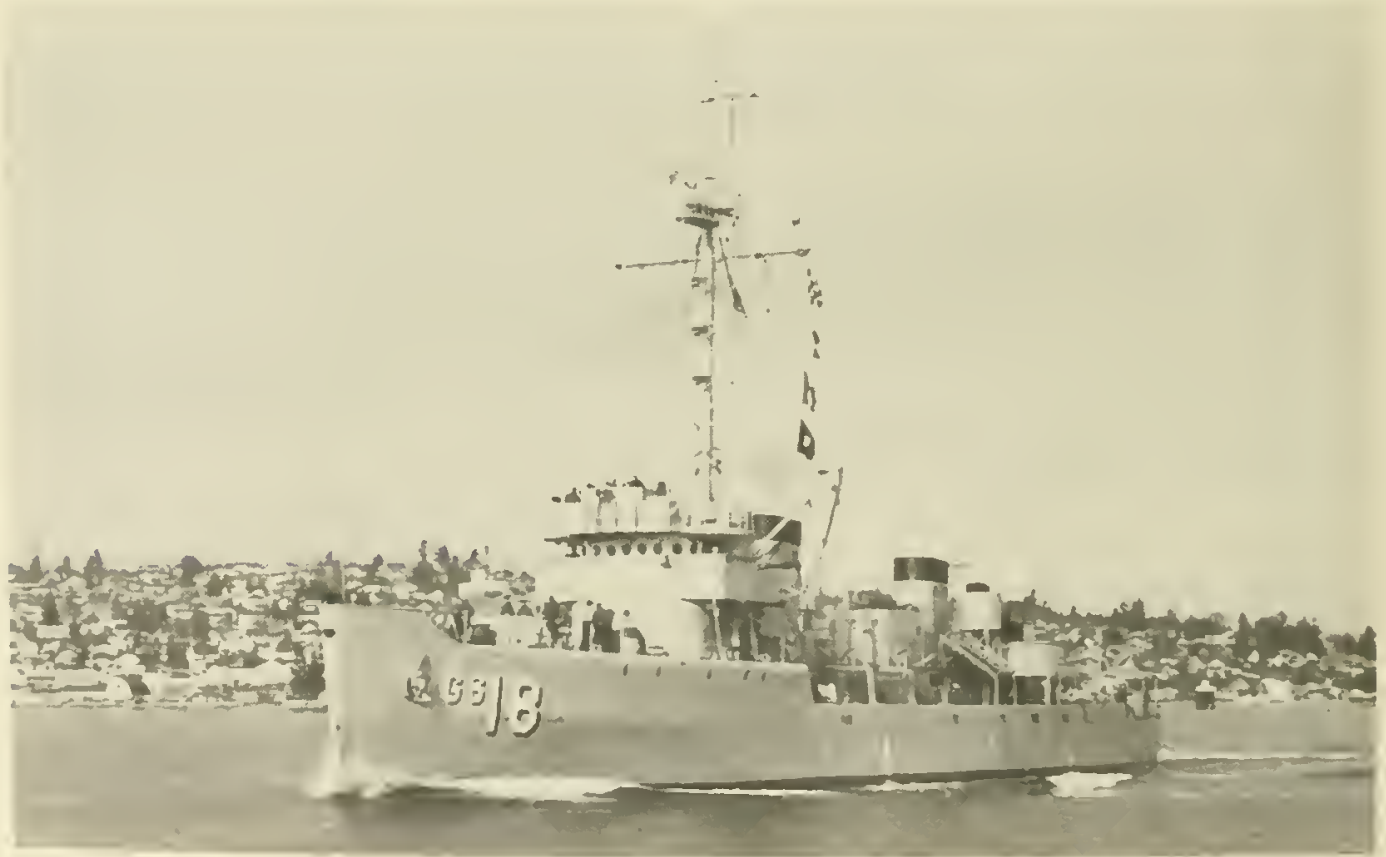

USS Requisite (AGS 18)

Originally the lleet minesweeper AM 109 built in 1943 by 1952 Requisite was continually employed in survey operations Winslow Marine. Converted to a hydrographic survey ship in until her disposal in 1964.

Length: 221’ Displacement: 1.200 tons 


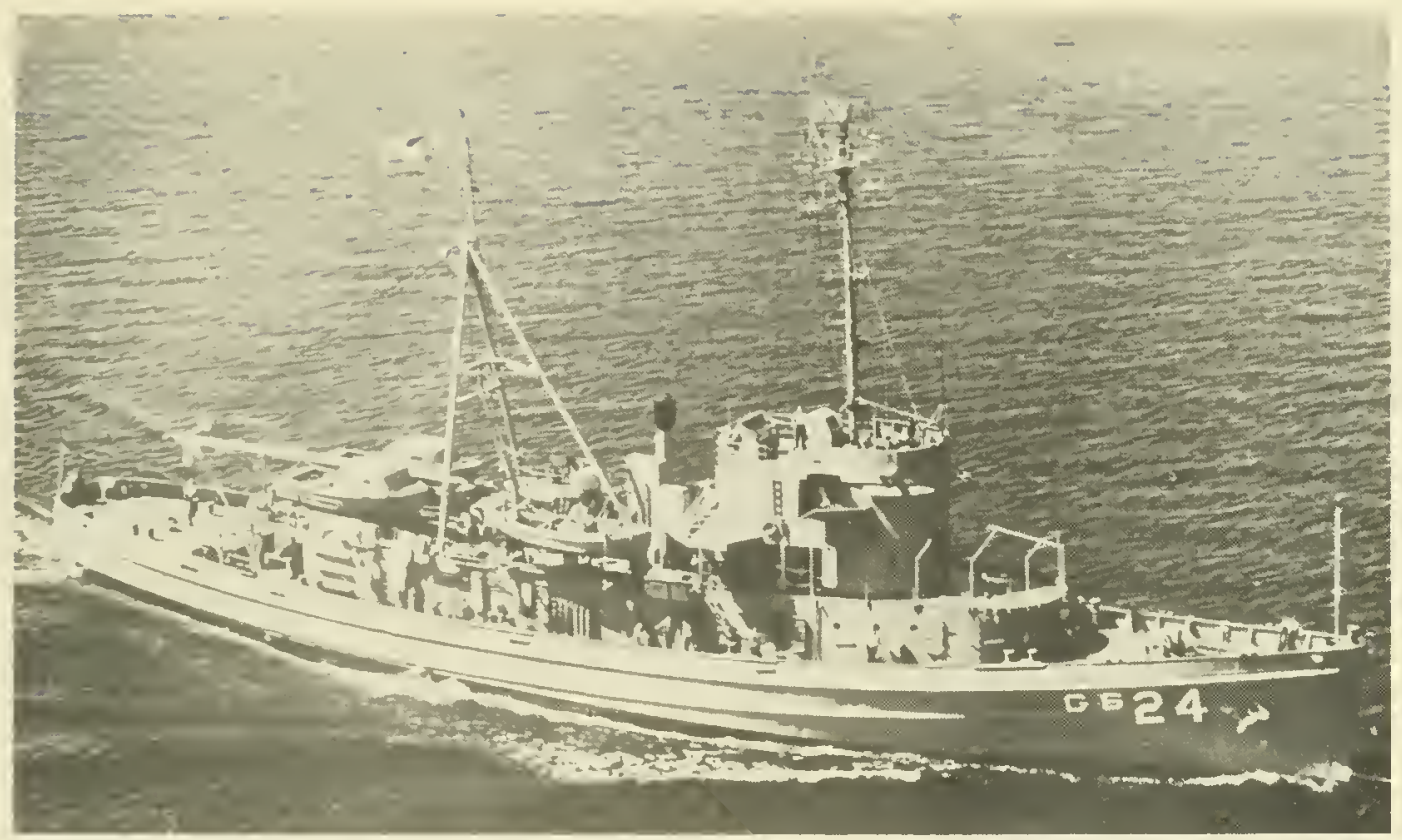

USS Serrano (AGS 24)

The former fleet ocean tug ATF 112 built in 1944 and converted to a hydrographic survey ship in 1960. Serrano was disposed of in 1970 .

Length: 205' Displacement: 1,680 tons

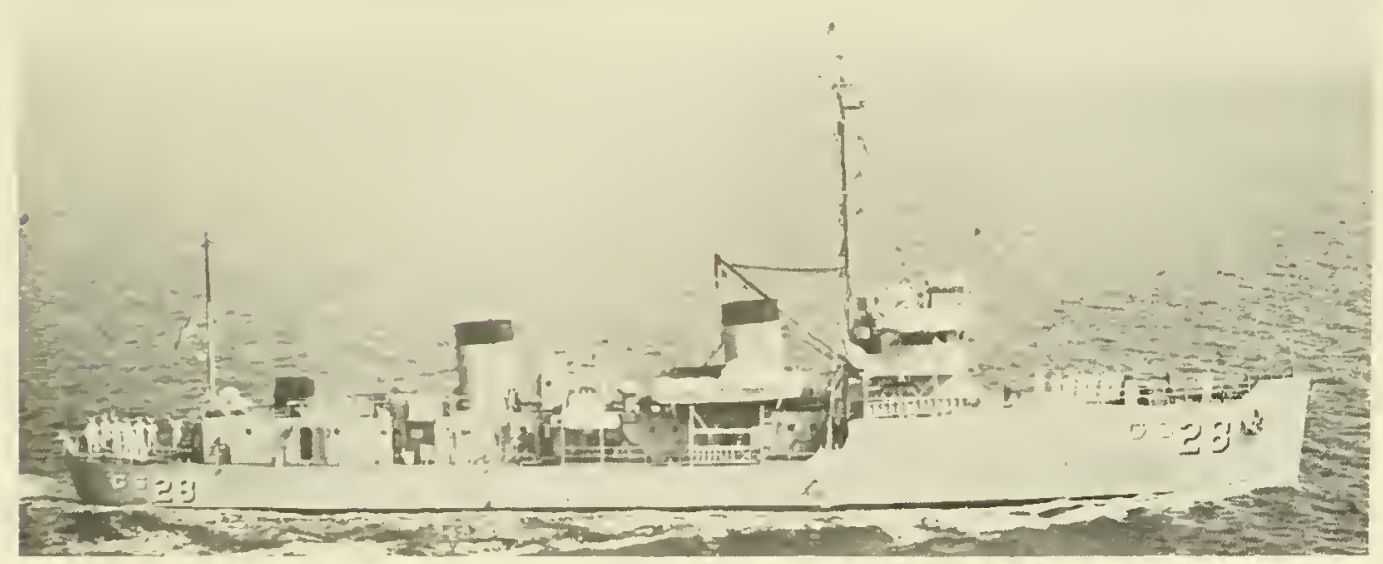

USS Towhec (AGS 28)

The former fleet minesweeper AM 388 built in 1945 by American Ship Building Company of Cleveland. In 1964, Towhee was converted to the lyydrographic survey ship (AGS 28 ) and engaged in survey operations until her disposal in 1969.

Lengtlı: 22 I' Displacement: 1,200 tons 


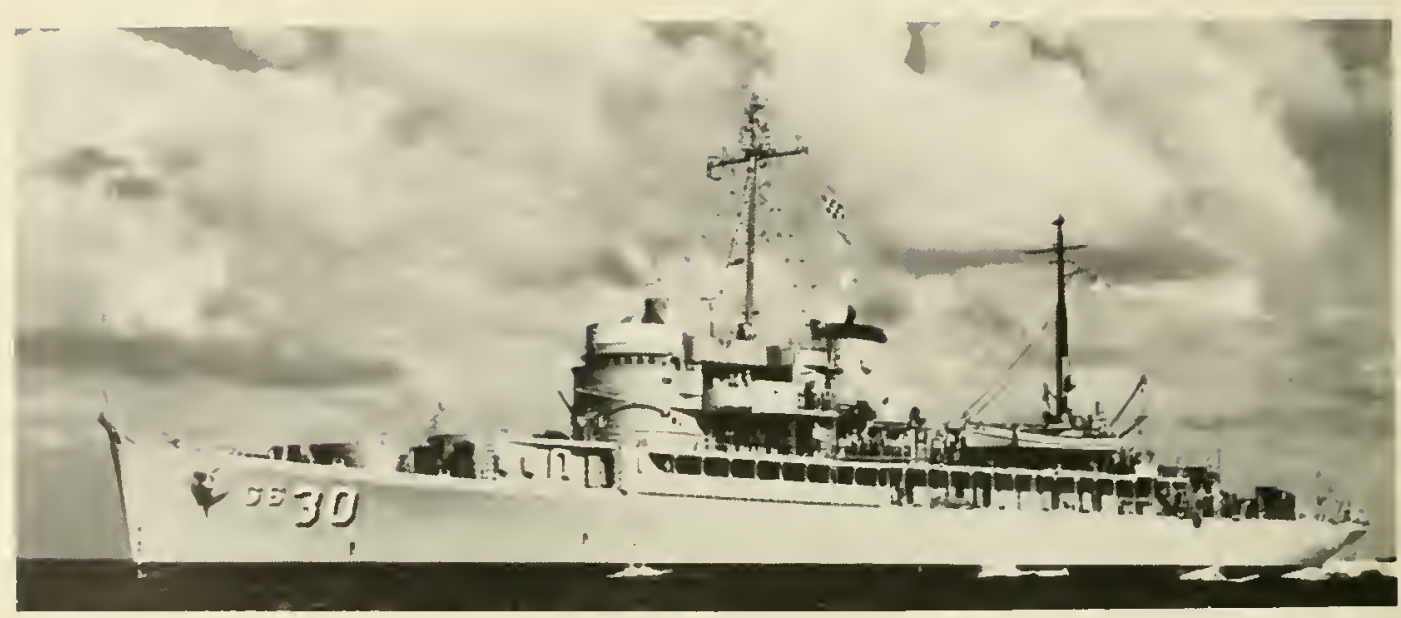

USS San Pablo (AGS 30)

The former seaplane tender AVP 30 built in 1943 by Associated Shipbuilding Company of Seattle. In 1949 the San Pablo was converted to a deep ocean oceanographic survey ship and assigned to the technical control of the Navy's Hydrographer. Her active career in furthering the frontiers of oceanography ended with her disposal in 1969.

Length: $311^{\prime}$ Displacement: 2,720 tons

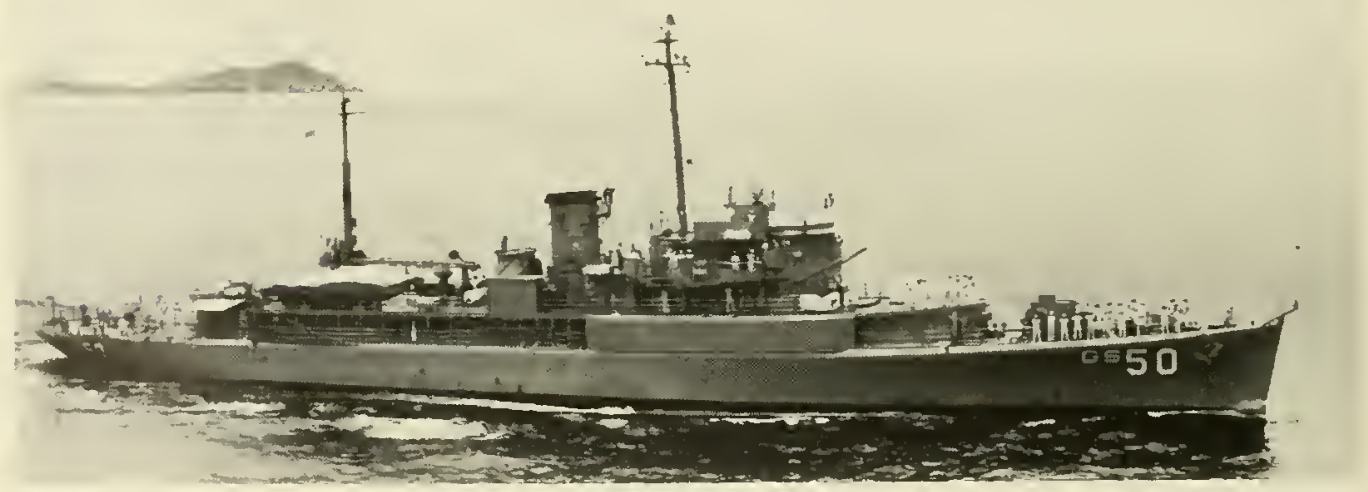

USS Roholwoth (ACS 50)

The former seaplane tender AVP 50 built in 1944 by Lake Washington Shipyard of Iloughton, Washington. In 1949, the Rehoholh was converted to a deep ocean oceanographic survey ship and assigned to the technital control of the Hydrograpler. Her active career in oceanography ended with her disposal in 1970. Rehohoth's demise also represented the last Navy-nanned survey ship since all Navy survey ships are now operated by civilians of the Military Sealift Command (formerly the Military Sea Transportation Service).

Length: $311^{\circ}$ Displacement: 2,720 tons 


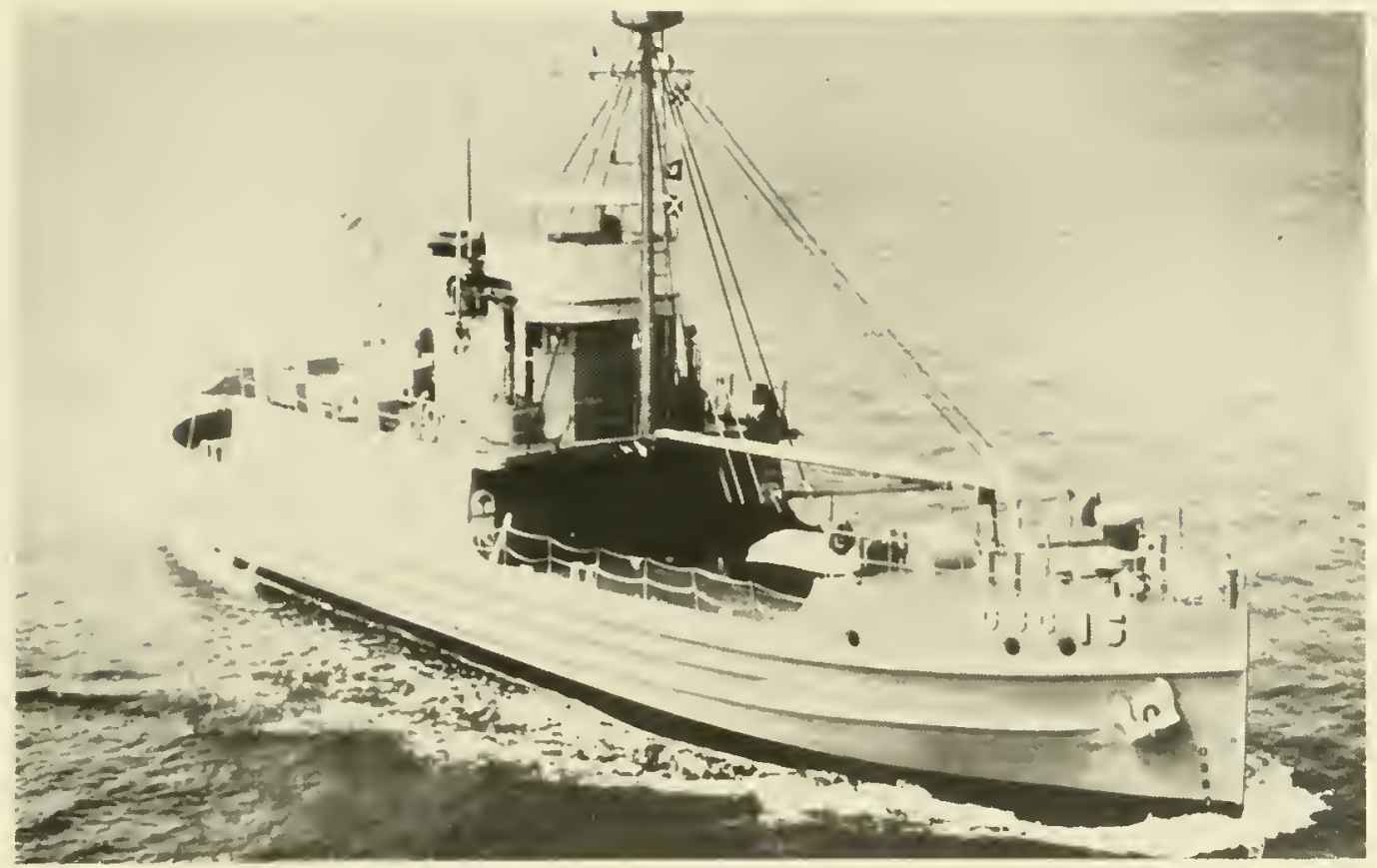

USS Litllehales (ACSC 15)

The second ship to bear the name Lithlclales was originally the Lithlehales and redesignated the AGSC 15 . From 1962 until lier 132-foot freight lighter YF 854 huilt in 1945 by liric Concrete disposal in 1968 the Litllehales was assigned to the Atlantic and Steel Company of Erie, Pennsylvania. Launched at the end Underwater Test and Evaluation Center conducting operations in of World War II the YF 854 remained inactive until 1952 when the Tongue of the Ocean off the Bahamas. she was utilized as a survey vessel. Ii 1959 she was named the

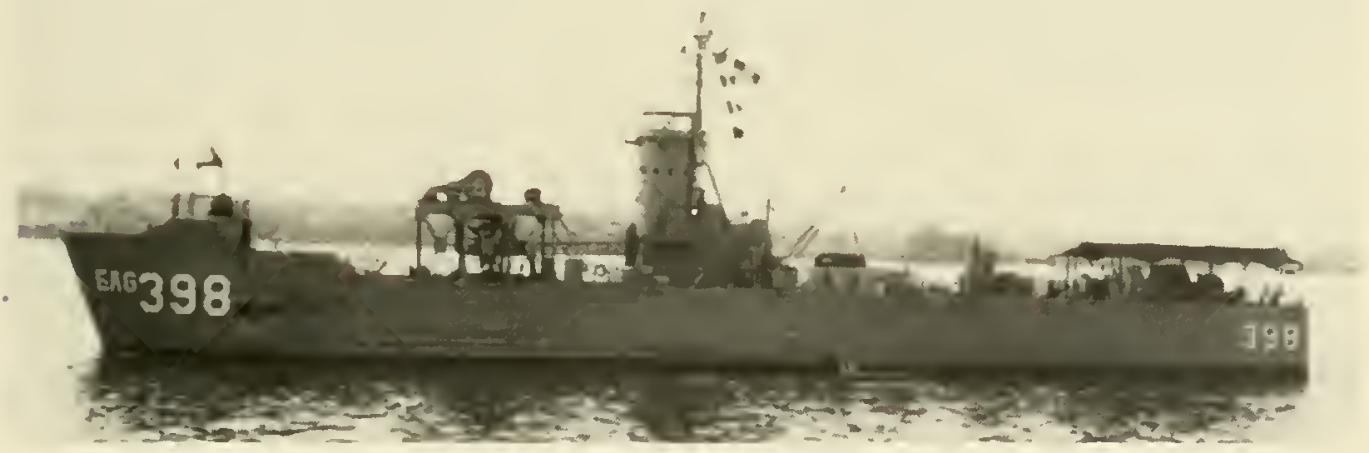

USS Hunting (EAG 398)

Originally the medium landing ship LSM 398 built in 1945 by Charleston Naval Shipyard. In 1954 she was converted to an experimental ship (redesignated the EAG 398) for testing advance sonar equipment for the Naval Research Laboratory. The name Hullting was assigned in 1957. During her conversion the Hunting had an internal well (30' $\left.\times 12^{\prime}\right)$ installed for handling scientific equipment through the center of the ship, a unique feature for U.S. research ships at that time. Huming had the distinction of being the first ship to tow the heaviest "fish" (28" long $\times 8^{\prime}$ wide $\times 1 l^{\prime}$ high, and 30,000 pounds) at a depth of 600 feet. Slie also made the first deep tow of a "fish" $\left(5^{\circ}\right.$ long $\times 2$ " wide $x$ 3' high and 6,000 pounds) at a depth of 16,000 feet. Her career unfortunately was plagued by mechanical problems and she was finally decommissioned in 1962 and sold the following year.

Length: 203" 6" Displacement: 1,095 tons 



\section{CHAP'TER VI.}

THE YEARS OF IMPETUS (1957-1959) 
In 1957 the third National Academy of Science's Committee on Oceanography (NASCO) was established. The second committee, established in 1949, produced a report OCEANOGRAPHY 195! which was overshadowed by the Korean War and thus received little attention. This report stressed the necessity of regaining the balanced program of basic research that had characterized oceanograplyy in the years before World War 11.

The third Oceanography Committee consisted of the following members: Maurice Ewing. Lamont Geological Observatory. Columbia University: Columbus O'D. Iselin, Woods Hole Oceanographic Institution: Fritz Koczy. Marine Laboratory, University of Miami; Sumner Pike, formerly with the Atomic Energy Commission; Collin Pittendrigh, Department of Biology. Princeton University; Roger Revelle. Director. Scripps Institution of Oceanography; Gorden Riley, Bingham Oceanographic Laboratory, Yale University: Milner R. Schaefer, Inter-American Tropical Tuna Commission: Athelstan Spilhalus, Institute of Technology, University of Minnesota; and Richard Vetter, Office of Naval Rescarch.

The creation of this committee was promoted by three Federal activities with oceanographic programs: The Office of Naval Research, the Bureau of Commercial Fisheries, and the Atomic Energy Commission. These activities, concerned that the Lnited States was spending less than one-half percent of the national basic research budget annually for studies of the ocean, requested NASCO to identify the national requirements for oceanography and to propose a ten-year program for their accomplislınents. The first task of NASCO was to make a thorough survey of U.S. marine research-the level of support, activities, manpower, facilities andproblems-and to evaluate the probable future needs for oceanographic information and understanding. Based upon the status and forecast of necds, NASCO prepared a set of recommendations for minimal strengthening of U.S. marine science over a ten-year period at a rate considered consistent with the requirements and limitations imposed by reasonable increases in shipbuilding, laboratory building, recruitment and training.

While NASCO labored to prepare a series of reports under the general title OCEANOGRAPHY 1960 - 1970, the excitement created over the launching of Russia's SPUTNIK in October 1957 and the attention being aroused by the significant oceanographic programs of the International Geophysical Year (1957 - 1958), had placed the U.S. on the verge of a scientific explusion.

The NASCO Report was released in 1959 with the conclusion that:

"Action on a scalc appreciably less than llat recommended will jeopardize the position of oceanography in the United States relative to the position of the sciences in other major nations, thereby accentuating serious military and political dangers and placing the nation at a disadvantage in the future use of the resources of the sea."

This awakening of national concern over the necd to expand the marine sciences necessitated the infusion of larger and more capable oceanographic ships. The Navy provided two 217-foot, 2.000-ton, ocean going salvage tugs, one to Woods Hole (R/V Chain) and the other to Scripps Institution (R/V Argo), and also a 3lo-foot seaplane tender (USNS Josiah Itillard Gibbs) to Hudson Laboratories of Columbia University. The Navy’s hydrographic survey lleet was enlanced by the addition of three 455-foot, 13,000-ton Victory slips for deep-ocean surveying, renamed USNS Bowdirch (T-AGS 21), USNS Dulon (T-AGS 22) and USNS Michelson (T-AGS 23). 


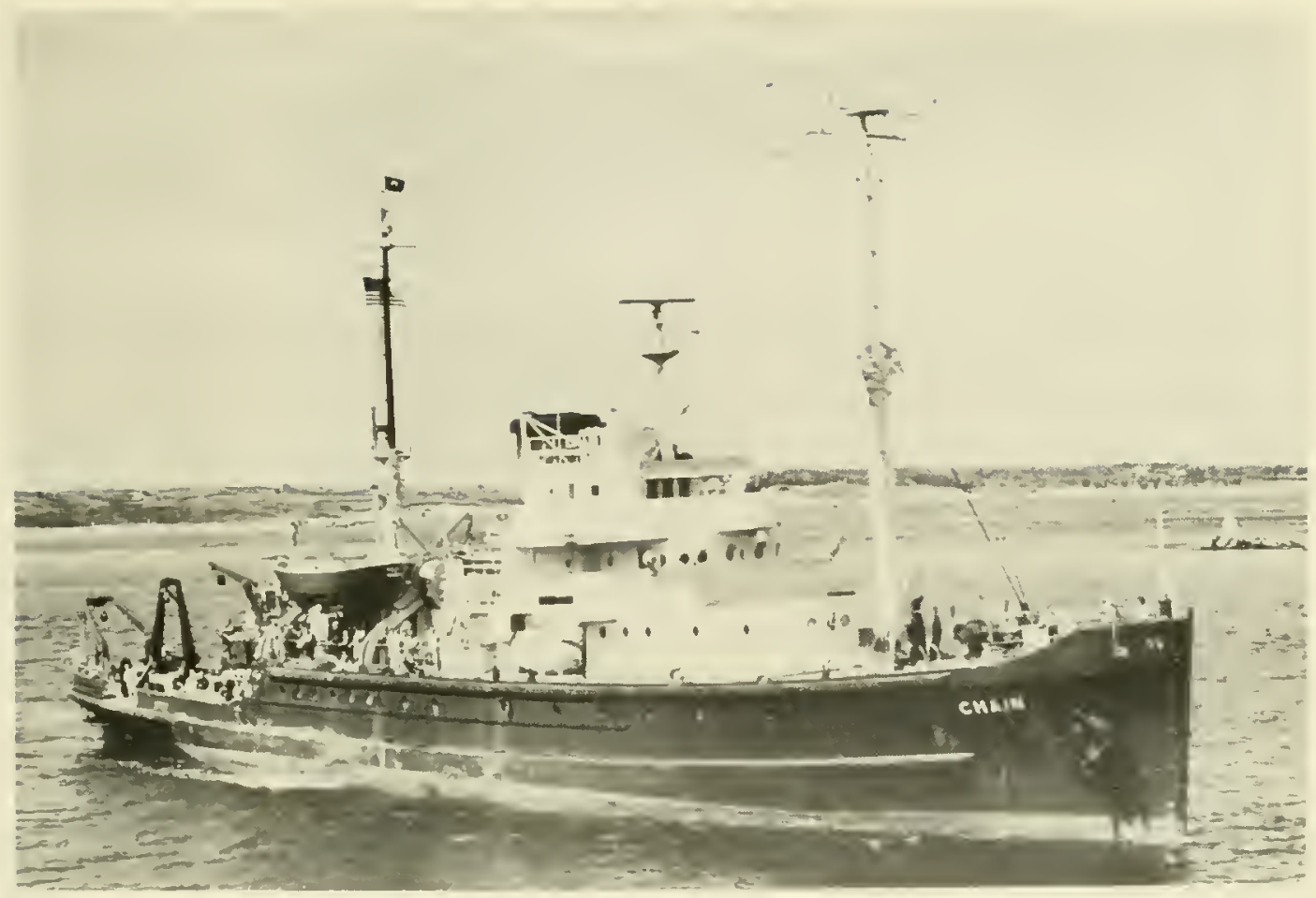

\section{R/V Chain (AGOR 17)}

The Navy-owned Chain was built in 1944 as a salvage ship. ARS 1958 and provided to Woods Hole Oceanographic Institution for 20. She was converted to an oceanographic research vessel in operation in support of Navy basic research projects.

Length: $213^{\prime}$ Displacement: 2,100 tons

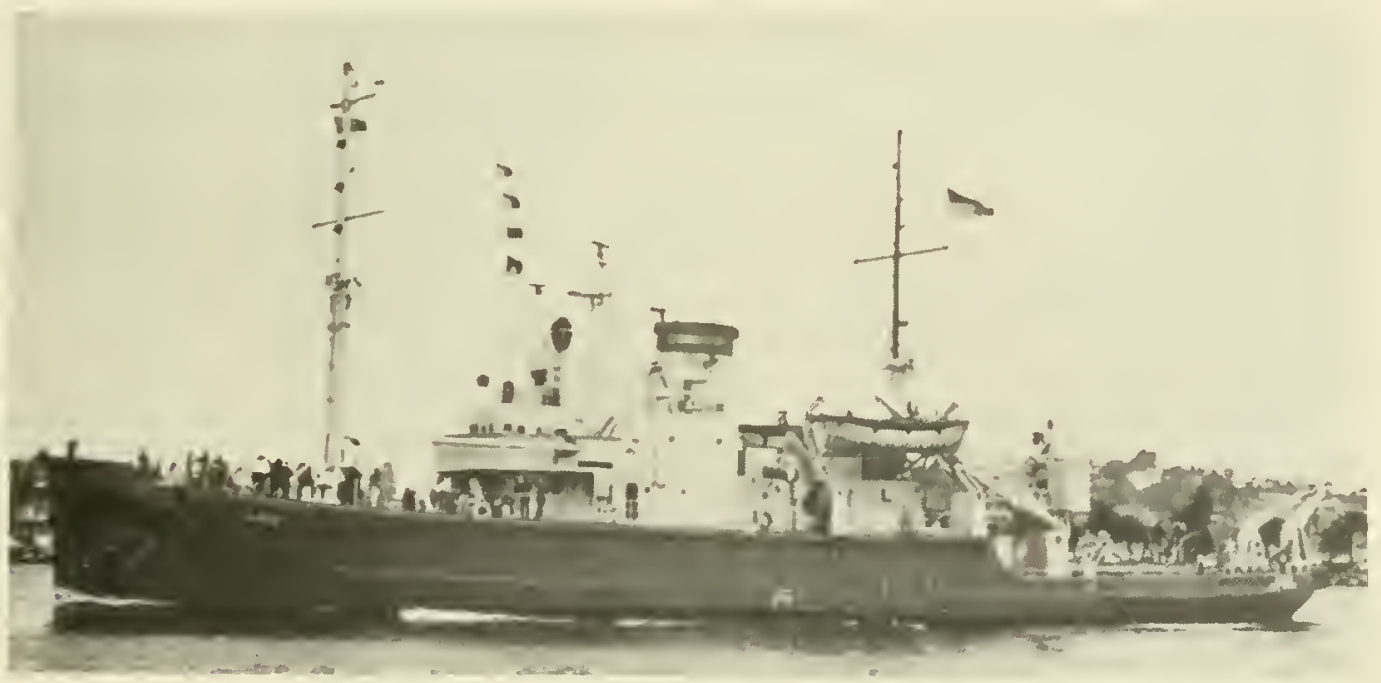

R/V Argo (AGOR 18)

This Navy-owned converted salvage ship, the ex-USS Snatch (ARS 27) built in 1944, was provided to Scripps in 1959 for operation as a research ship. Argo was placed out of service in
March 1970 after 10 years of research service totaling 446,906 miles of steaming.

Length: $213^{\prime}$ 'Displacement: 2,079 tons 


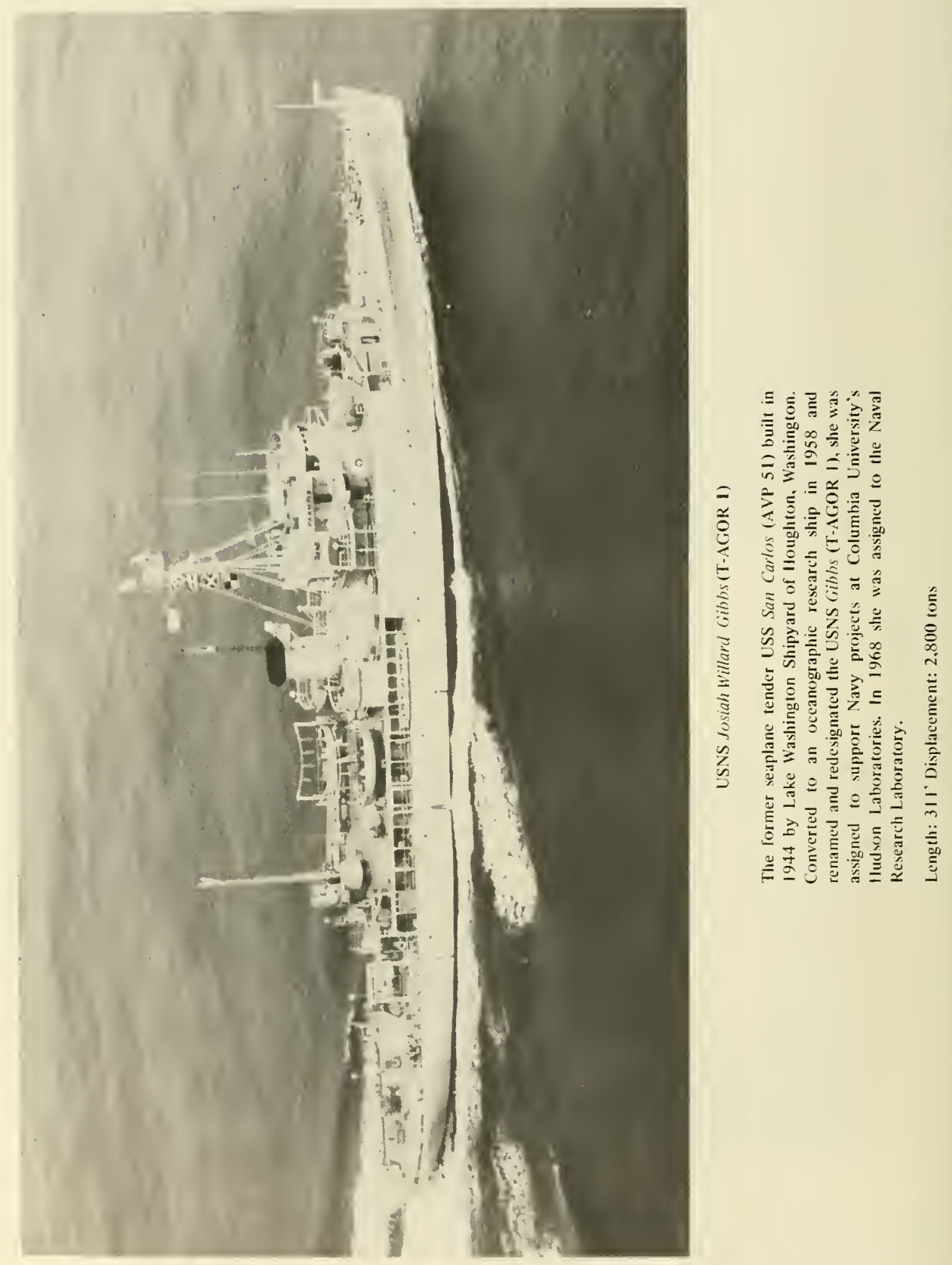




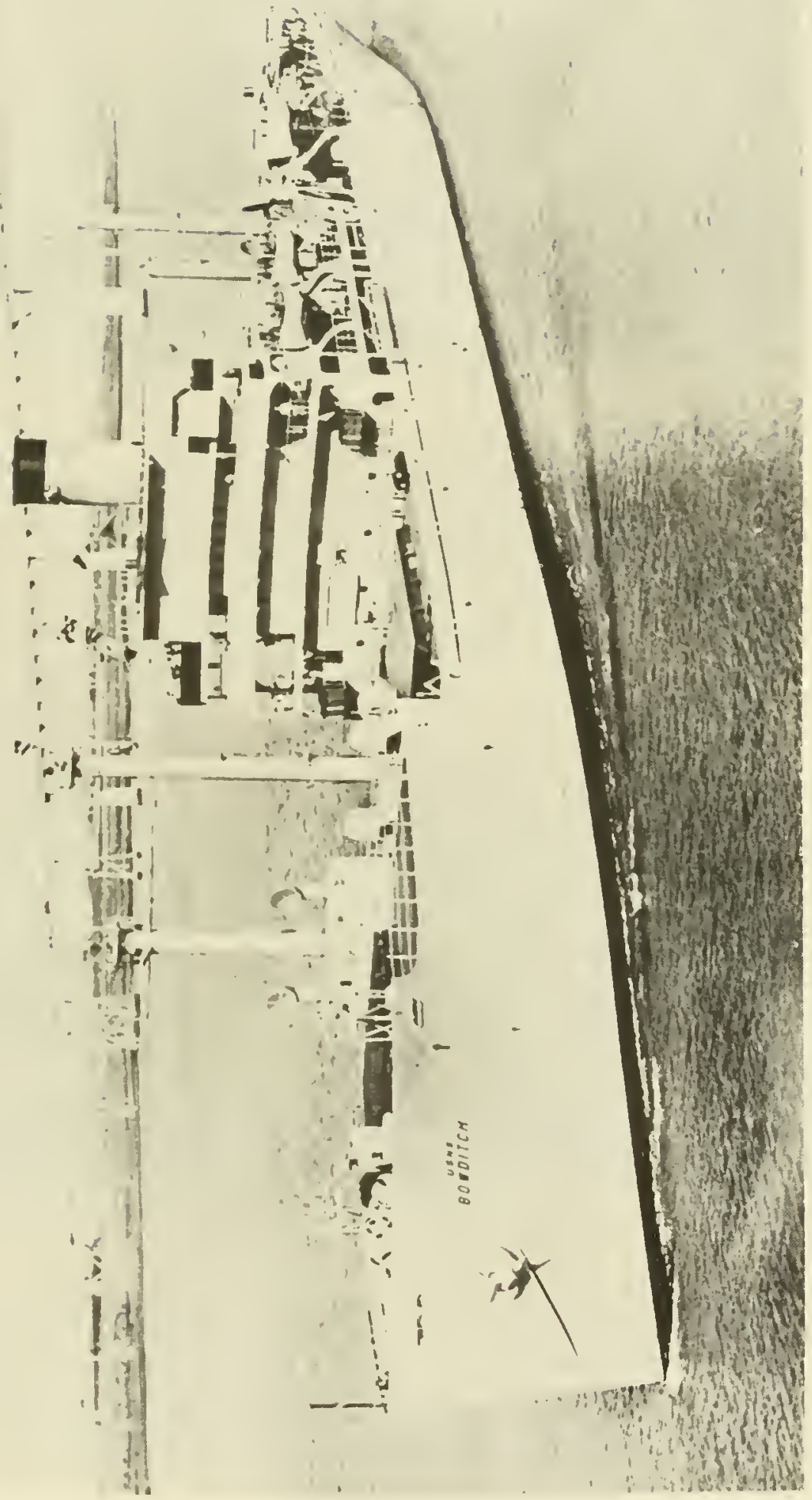

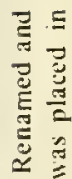

这

产

吾

焉

$\hat{\Xi}$

:

8

至

政

范

\& n

运至

$\overline{\bar{v}} \stackrel{2}{\Xi} \stackrel{2}{2}$

क כ 코

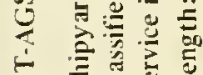

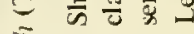

可 호을

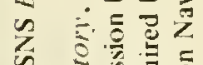

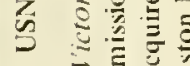

-

‡

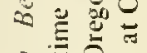

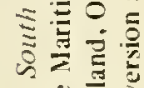

内

的苛

象告高焉

$:$ ธ

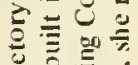

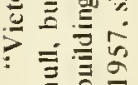

总育紊

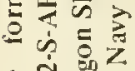

ڤบป 


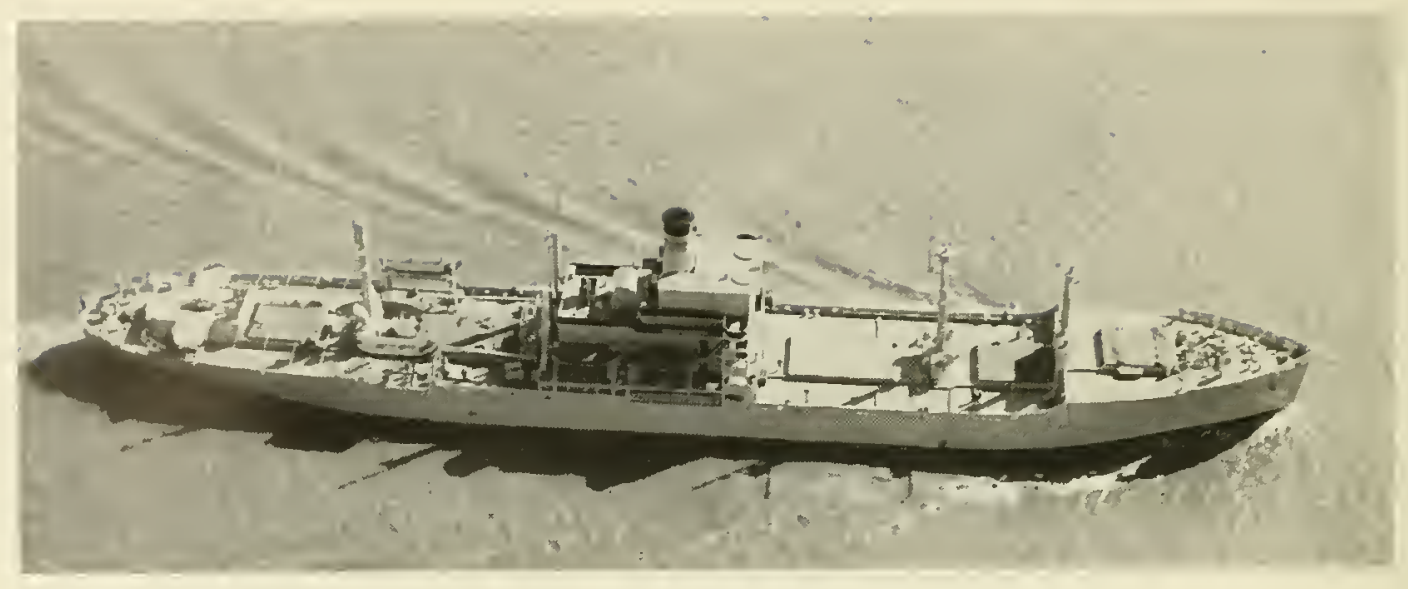

\section{USNS Dutton (T-AGS 22)}

The former "Victory" ship S.S. Tuskegee Victory, a VC2-S-AP3 hull, built in 1944 for the Maritime Commission by Oregon Shipbuilding Company of Portland, Oregon. Acquired by the Navy in 1957, she was converted to a deep ocean bathymetric survey ship by Philadelphia Naval Shipyard. She was placed in service in 1958 as the USNS Dutton (T-AGS 22).

Length: $455^{\prime}$ Displacement: 13,000 tons

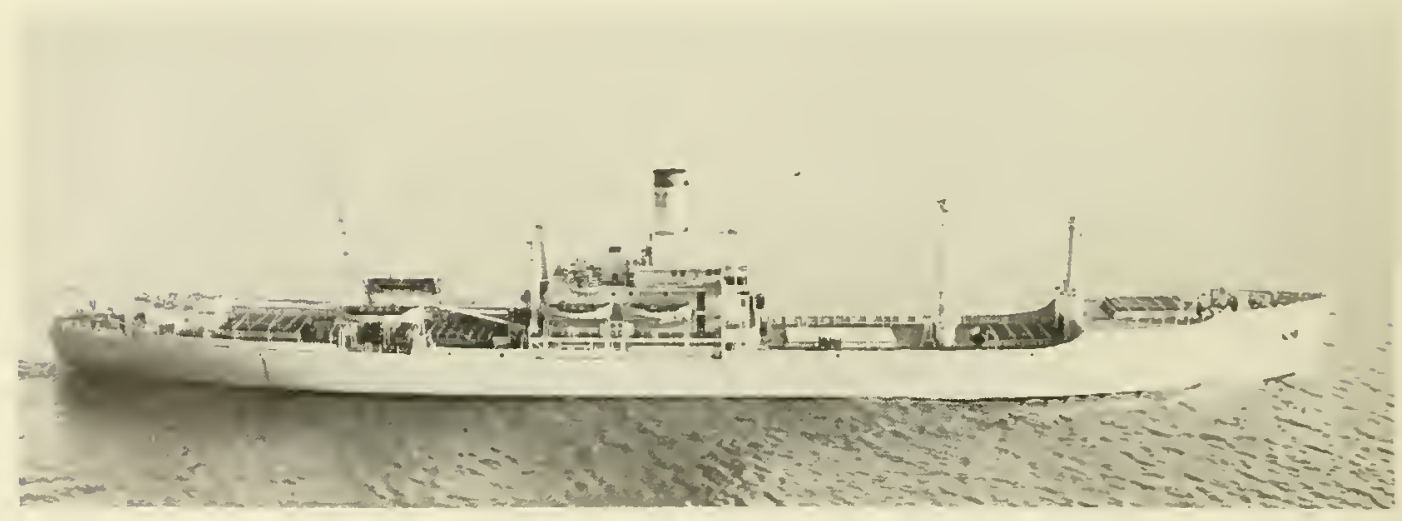

USNS Michelson (T-AGS 23)

The former "Victory" ship S. S. Jolict I'ictory, a VC2-S-AP3 hull, built in 1944 for the Maritime Commission by Oregon Shipbuilding Company of Portland, Oregon. Acquired by the Navy in 1958 she was converted to a deep ocean bathymetric survey ship by Philadelphia Naval Shipyard. Renamed and classified USNS Michelson (T-AGS 23), she was placed in service in December 1958.

Length: $455^{\circ}$ Displacement: 13,000 tons 


\section{CHAPTER VII.}

THE NEW EMERGENCE (1960-1967) 


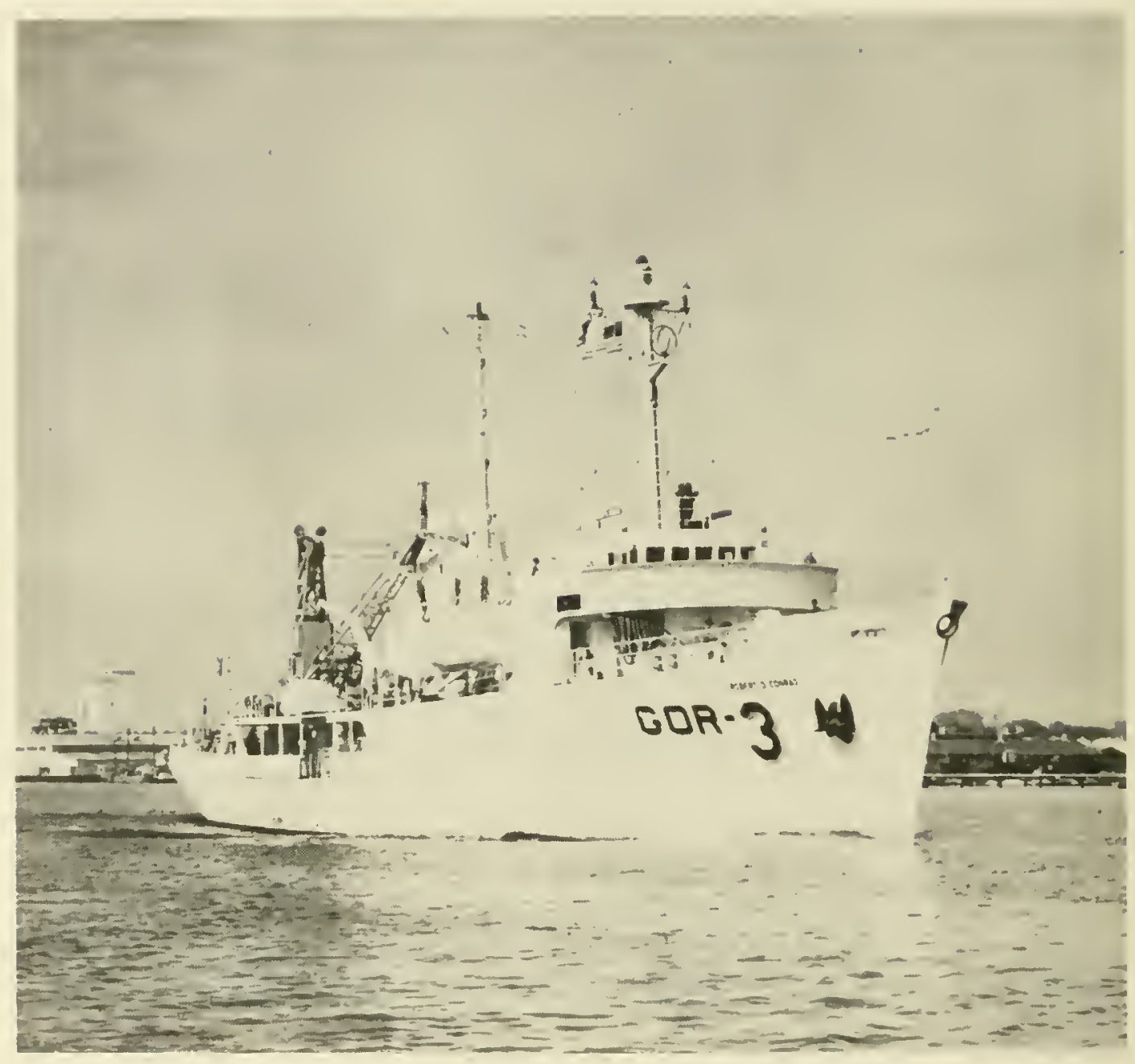

R/VRobert D. Conrad (AGOR 3)

Built in 1962 by Gibbs Corporation of Jacksonville, Florida, the Conrad was the first Navy ship especially designed for oceanographic research. She is assigned to and operated by Lamont-Doherty Geological Observatory, Columbia University.

Leng th: $208^{\prime} 4^{\prime \prime}$ Displacement: 1,370 tons 
The concepts and guidelines developed by the NASCO report provided the basis for long-range plans generated by the various Federal agencies. Of particular signilicance was the Navy's TEN YEAR PROGRAM IN OCEANOGRAPHY (TENOC). The ten-year ship construction program recommended by TENOC called for 20 research ships (including 12 for institutions), 9 oceanographic surveying ships, and 11 hydrographic surveying ships. This construction program began in 1960 when funds were appropriated for the Navy's first new-construction vessel, the 288-foot, 1,370-ton oceanographic research ship R/V Robert D. Conrad (AGOR 3), which, when completed in 1962, was to be operated by Lamont Geological Observatory. While the Bureau of Ships was dusting off its earlier preliminary design studies for the Comrad, a coincidental design effort was being undertaken by Woods Hole. With a grant provided by the National Science Foundation, they undertook the design and construction of their own research vessel. In collaboration with their design agent, M. Rosenblatt and Son, lnc.. they completed in 1959 an extensive study encompassing a series of research ship preliminary designs ranging in size from 400 to 3,000 tons. The ship which finally evolved was the 210-foot, 2,100-ton R/V Atlantis II, which was completed in 1963.

Generally speaking, Woods Hole's Atlantis II has proved to be a more viable platform than the Navy's Conrad (AGOR 3) class of ships. Maneuverability of the Atlantis II is more effective with the combination of twin screws and bow thruster than the AGOR 3 's single screw and bow thruster (the last two ships of the AGOR 3 class were also equipped with an active rudder). The Atlantis $I I^{\prime}$ 's accommodation for 25 scientists and laboratory space of approximately 2.500 square feet is almost double that of the AGOR 3 Class ships. The Atlantis II also features an internal well. bow observation chamber, a stern ramp, and an aloft observation tower (enclosed crow's nest). Over a five year. (1960 - 1965), eleven ships of the AGOR 3 type (including the Conrad) were funded. The disposition of these ships is as follows:

SHIP NAME

$\begin{array}{rll}\text { AGOR } & 3 & \text { (R/V Conrad) } \\ \text { T-AGOR } & 4 & \text { (USNS Gilliss) } \\ \text { T-AGOR } & 5 & \text { (USNS Davis) } \\ \text { T-AGOR } & 6 & \text { (USNS Sands) } \\ \text { T-AGOR } & 7 & \text { (USNS Linch) } \\ \text { AGOR } & 9 & \text { (R/N Thompsun) } \\ \text { AGOR } & 10 & \text { (R/V I'ashington) } \\ \text { T-AGOR } & 12 & \text { (USNS DeSteiguer) } \\ \text { T-AGOR } & 13 & \text { (USNS Bartlett) }\end{array}$

T-AGS 25 T-AGS

\author{
(USNS Kellar) \\ (USNS Lee)
}

USER

DELIVERED

Lamont-Doherty Geological Observatory

1962

Navy Lab East Coast Pool

1962

Navy Lab West Coast Pool

1963

Navy Lab East Coast Pool

1964

Navy Lab East Coast Pool

1965

University of Washington

1965

Scripps Institution

1965

Navy Lab West Coast Pool

1969

Navy Lab West Coast Pool

1969

Two ships of the AGOR 3 type, the USNS Kellar (T-AGS 25) and USNS Lee (T-AGS 31 ), were modified for hydrographic surveying. Basically, this surveying modilication included the addition of a 26-foot survey launch, multi-beam echo sounders, a side scanning sonar, a stabilized gyro compass, and an active rudder. If an award for notoriety is ever considered the poor Kellar 
will have to be the undisputed winner. The highlight of her unprecedented seven year construction period was her eapsizing when approximately 85 percent complete (between two sewer outlets!) at New Orleans in 1965 durmng Hurricane Bestsy.

The year 1960 also saw the introduction of the USNS Mission Capistrano a 524 -foot tanker, which was specifically converted to an experimental platiorm for research in underwater sound in support of new sonar systems.

In 1964 the Navy converted a 266-foot cargo ship, the USNS Mizar, for oceanographic research. Her scientific facilities include an internal well and an aloft observation tower. The Mizar, which is operated for the Naval Research Laboratory, has received wide acclaim for her successful role in three of the most widely publicized undersea searches of modern times - those for the ill-fated nuclear submarines Thresher and Scorpion and for the H-bomb lost off Palomares, Spain. Her most recent achievement was in the recovery of the Deep Research Vehicle Alvin from a depth of over 5,000 feet, which set a record for object size, depth and salvage time for deep ocean operations.

Many small converted ships were also provided by the Navy for use by the institutions. These conversions included the hasbor minesweeper Sir Horace Lamb for Lamont; the tugs Oconostota for Scripps and Hoh for the University of Washington (prior to her introduction to oceanography, the Hoh had served as the Alcatraz Prison ferry); the 65-foot Army cargo and passenger " $T$ " boats Onar for the University of Washington, Kyma for New York University, T-441 for Scripps (now operated by the University of Connecticut), Manning for Hudson Laboratories, Columbia University (now operated by Crumb School of Mines, Columbia University), T.426 for Bermuda Biological Station, Columbia University (now operated by Florida Institute of Technology), and Tursiops for the University of Miami (now assigned to Florida State University); and the supply boat Erline for Lamont.

During the 1960s, the National Science Foundation provided many institutional grants for ship conversions. Most notable of these were the 135-foot schooner Te Vega (Stanford University), which was sold in 1969 and replaced by the 100-foot fishing boat Proteus; the 96-foot yacht Teritu (University of Hawaii); the 114-foot Army island freighter Inland Seas (University of Michigan); and the 180-foot Army island freighters: Alaminos (Texas A\&M) which replaced the 136-foot subchaser Hidalgo, Trident (University of Rhode Island), Pillsbury (University of Miami), and Yaquina (Oregon State University) which replaced the Navy-owned 80-foot trawler type boat Acona that had been transferred to the University of Alaska. Oregon State University later received a grant to construct another 80 -foot boat, the Cayuse. The National Science Foundation also funded for the construction of the 118-foot Eastward for Duke University and the 133-foot Alpha Helix for Scripps. Both of these ships are employed as.national cooperative facilities for biological research. The 243-foot Williamsburg, former presidential yacht of Harry S. Truman, was acquired by NSF, renamed the Anton Bruun, and converted to a research vessel for participation in the four-year long International Indian Ocean Expedition. The 266-foot cargo ship USNS Eltanin was converted by NSF to support research in the Antarctic. Also for Antarctic research, NSF later constructed a 125-foot, wooden-hulled, trawler type vessel named the $\mathrm{R} / \mathrm{V}$ Hero. The diesel powered Hero is equipped with sails which provide propulsive power when ultra-quiet ship operations are required.

The institutions were also utilizing their own efforts to obtain such ships as Seripps' Agassiz, another 180-foot Army freighter, and Ellen B. Scripps, a 95-foot off-shore oil supply boat: Woods Hole's 99-foot Army freighter Gosnold, and the University of Georgia's 64-foot tug K'it Jones.

The 1960s have also seen the Navy's construction of a new class of 285-foot oceanographic surveying ships specifically designed for conducting systematic multi-disciplined surveys on a 
world-wide basis. Currently, two ships of this class, the USNS Bent (T-AGS 26) and USNS Kane (T-AGS 27) are operational and a third ship, the USNS Ivilkes (T-AGS 33) currently under construction in Bay City, Michigan, is scheduled for delivery in mid-1971.

Five new hydrographic surveving ships were also funded during this period. The aforementioned USNS Kellar (T-AGS 25) and USNS Lee (T-AGS 31) are operational and have replaced the Navy-manned conversions Sheldrake and Towhee. The new design 393-foot coastal survey ships USNS Chauvenet (T-AGS 29) and USNS Harkness (T-AGS 32), completing construction in Glasgow, Scotland, will replace the Navy-manned survey ships Tammer and Maury which were inactivated in 1969. The Chausenet and Harkness are designed to carry four 36-foot survey launches, two helicopters, a combined naval/civilian hydrographic survey detaclument, and a Marine Corps coastal survey team. The USNS Wyman (T-AGS 34) is also under construction in Bay City, Michigan, and, when delivered in late 1971 will replace the Serrano wlich was inactivated in January 1970. The 285.foot Wyman is the same class as the Bent (T-AGS 26) but modified for hydrographic surveying.

In addition to these ships, the Navy converted two cargo ships for ocean gravity surveys, the USNS Sgt. Curtis F. Shoup and USNS Sgt. George D. Keathley.

In 1966 the limitations of the AGOR 3 class research ships to meet changing oceanographic requirements were recognized and, primarily through the efforts of the Office of Naval Research, a new and novel design was conceived.

This new design was designated the AGOR 14 class. Among the number of new concepts which were incorporated was the utilization of cycloidal propellers, a major advancement in position keeping and maneuverability, and the capability to "customize" the basic design to meet the diversity of requirements among the prospective institutional and government users. This first two ships of this class, the R/V Melville (AGOR 14) delivered to the Navy in August 1969, and R/V Knorr (AGOR 15), delivered in January 1970 have been assigned to Scripps Institution and Woods Hole, respectively. These ships have an overall length of 245 feet, miximum beam of 46 feet, full load displacement of approximately 2,100 tons, 2,000 square feet of laboratory space and accommodations for 25 crew and 25 scientists. The customized features incorporated include a drill rig for the Mchille and submersible handling facilities on the Knorr.

Other new avenues in the design of research vessels were also being explored. In 1967, the catamaran-hull research vessel Ridgely Warficht was completed. This all aluminum 106 -foot catamaran was built by Johns Hopkins University through a grant provided by the National Science Foundation.

About the same time the AGOR 14 class design was being completed, the Navy was also investigating designs for a specialized platlorm capable of handling large deep sea velicles and acoustical arrays in open ocean and high sea states. The result of these investigations was the USNS Haves (T-AGOR 16) which features a catamaran hull. Funded in 1967, the Hayes (which is named for Harvey C. Hayes, developer of the sonic-depth finder) is now under construction in Seattle, Washington, and when delivered in mid-1971 will be used by the Naval Research Laboratory. This catamaran research ship provides a major improvement in stabllity witl increased deck area and laboratory space in contrast to a single-hull ship of the same displacement. The laboratory space, for instance, is more than double that of the Atlantis // or the AGOR 14 Class slips. The large separation between the controllable, reversible-pitch (CRP) propellers on eachi liull allows a high degree of maneuverability thereby eliminating the need for bow thrusters and active rudders used in previous ship designs. At slow speeds the Hayes will be able to turn almost within her own length. The principal characteristic of this first Navy catamaran* research ship are: 
THE NEW EMERGENCE (1960 - 1967) - (Cont'd)

Length overall

Beam maximum

Bearn, each hull

Draft, full load

Displacement, full load
246 feet

75 feet

24 feet

18 feet

3,100 tons
Sustained speed

Accommodations:

Civilian Crew

Scientists
15 knots

44

25

\begin{abstract}
*Historieally, the Navy's first experience with catamaran ships goes back 155 years when the U. S. Floating Battery Demologos was constructed. This twin hulled ship, designed by Robert fiulton, is reputed to have been the first steam warship in history. The War of 1812 was in progress at the time, but hostilities were suspended before it could be put to a practical test against the British fleet. Shortly after her launching on October 29, 1814, Fulton died and certain changes, notably the addition of sails which the designer had considered unnecessary, were made by Captain David Porter. Although her efficiency was somewhat reduced, the ship was
\end{abstract}

successful and was renamed the "Fulton" in honor of her inventor. She was 156 feet long with a beam of 56 fect including a 14 -foot separation between her hulls. A single paddlewheel of 16 -foot diameter, which was powered by a 120 hor sepower steam engine, was mounted between her hulls. On her original trials she attained a speed of five and a half knots although Fulton had promised the Government only three knots. Unfortunately, the Fulton has an ignoble career - she was used as a receiving ship in Brookly n and never left New York Harbor. Her demise was more spectacular though, when on 4 June 1829 her powder magazine exploded, and she was totally destroyed.

The 1960s also heralded in many new construction oceanographic ships for other agencies.

The National Ocean Survey (formerly the Coast and Geodetic Survey) had 16 new survey ships constructed during this decade. They include the 303-foot ships Oceanographer and Discoverer; the 292-foot Surveyor; the 278-fool Researcher; the 231-foot ships Fainveather, Mt. Mitchell, and Rainier; the 175-foot ships Davidson and McArthur; the 164-foot ships Pierce and Whiting; the 133-foot current survey ship Ferrel whose design is based upon the standard of fshore oil supply boat; the 90-foot wire drag ships Heck and Rude; and, finally, the 59-foot high-speed sounding boats 1255 and 1257 .

The National Marine Fisheries Service (formerly the Bureau of Commercial Fisheries) during the 1960s constructed six major fisheries research ships: the 216-foot Miller Freeman; the 187-foot Albatross IV; the 171-foot David Starr Jordan; the 170-foot Oregon II; the 158-foot Townsend Cromwell; and the 155-foot Delaware II.

The Federal Water Quality Administration (formerly the Federal Water Pollution Control Administration) also built, for estuarine monitoring, the boats Clean Waters (65-foot) and $\mathrm{H}$.W. Streeter (45-foot).

The Coast Guard in 1969 completed the design for a 388-foot, 3.950-ton research ship especially configured for near-polar operations. This new ship, whose construction is still unfunded, is intended to replace the 180-foot, 1,025-ton converted buoy tender Evergreen which in 1970 commenced her $24 \mathrm{th}$ year in support of the International Ice Patrol.

During the 1960s the Navy, starting with the Conrad (AGOR 3) and ending with the calamaran ship Hayes (T-AGOR 16), has funded for the construction of 20 new occanographic ships. Unfortunately, this number is only one half that recommended by TENOC for this decade, and the new additions have becn offset by an equivalent number of inactivations.

Witl the close of this decade the Navy has also experienced a major transition in the op:ration of its survey fleet. The Rehoboth, retired from the active list in April 1970, represented the last Navy-manned survey șip. Primarily as a resulı of manpower and budget constrainis, Navy crews no longer operate the Navy's survey ships. This function has been assumed by civilians of the Military Sealift Command (formerly the Military Sca Transportation Service). Although ending their role as operators of survey ships, Navy personnel will continue to be used to accomplish the actual hydrographic survey requirements. 


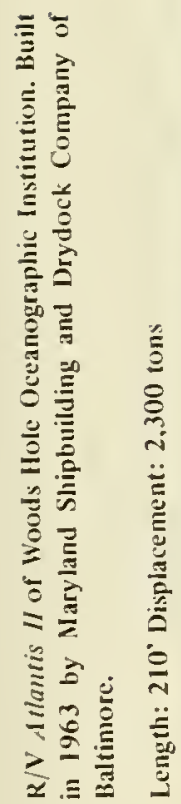

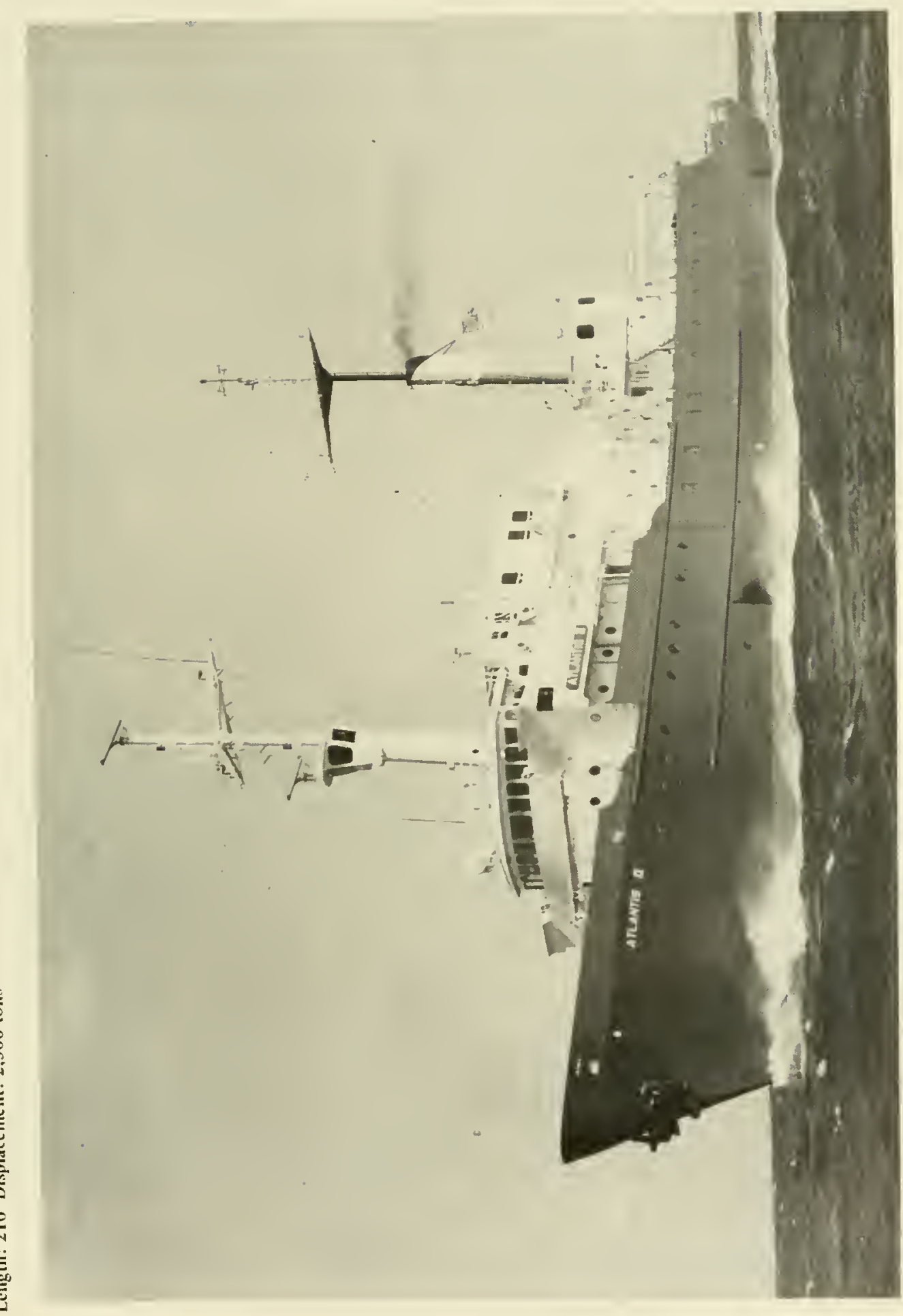




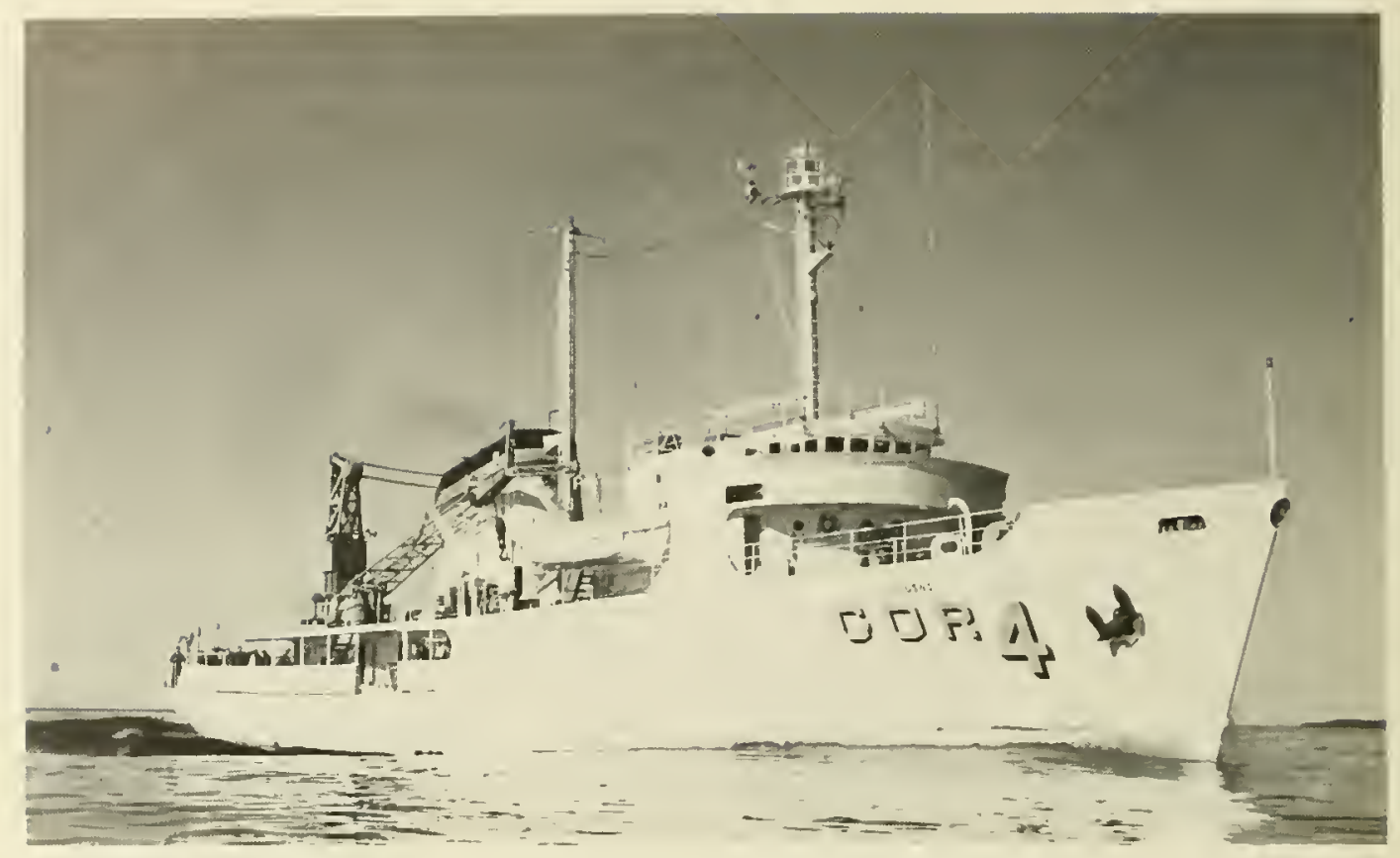

USNS James M. Gilliss (T-AGOR 4)

Built in 1962 by Christy Corporation of Sturgeon Bay. Wisconsin. Gilliss is operated by the Military Sealift Command as a "pool" research ship for East Coast Navy laboratories.

Length: 208' 4" Displacement: 1,370 tons

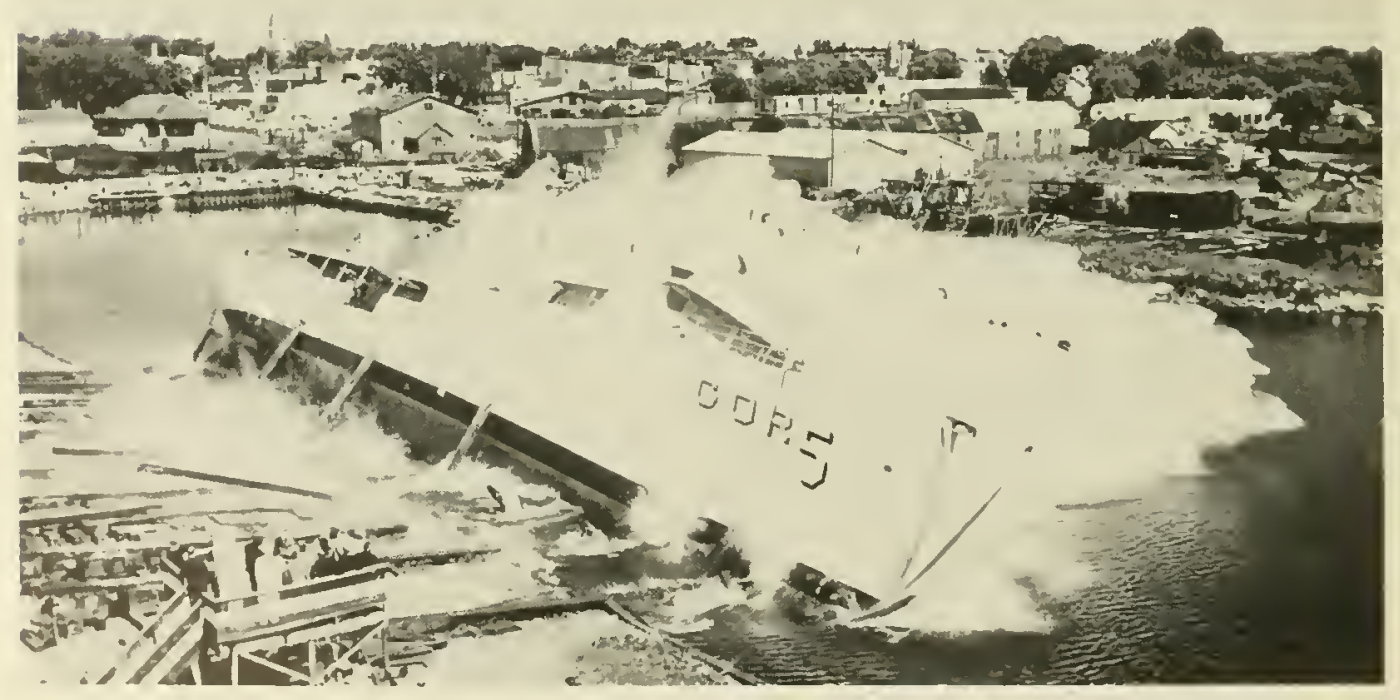

USNS Charles $/$. Davis (T-AGOR 5)

Built in 1963 by Christy Corporation of Sturgeon Bay, Wisconsin. Dovis is operated by the Military Sealift Command as a "pool" research ship for West Coast Navy laboratories.

Length: 208" 4" Displacement: 1,370 tons 


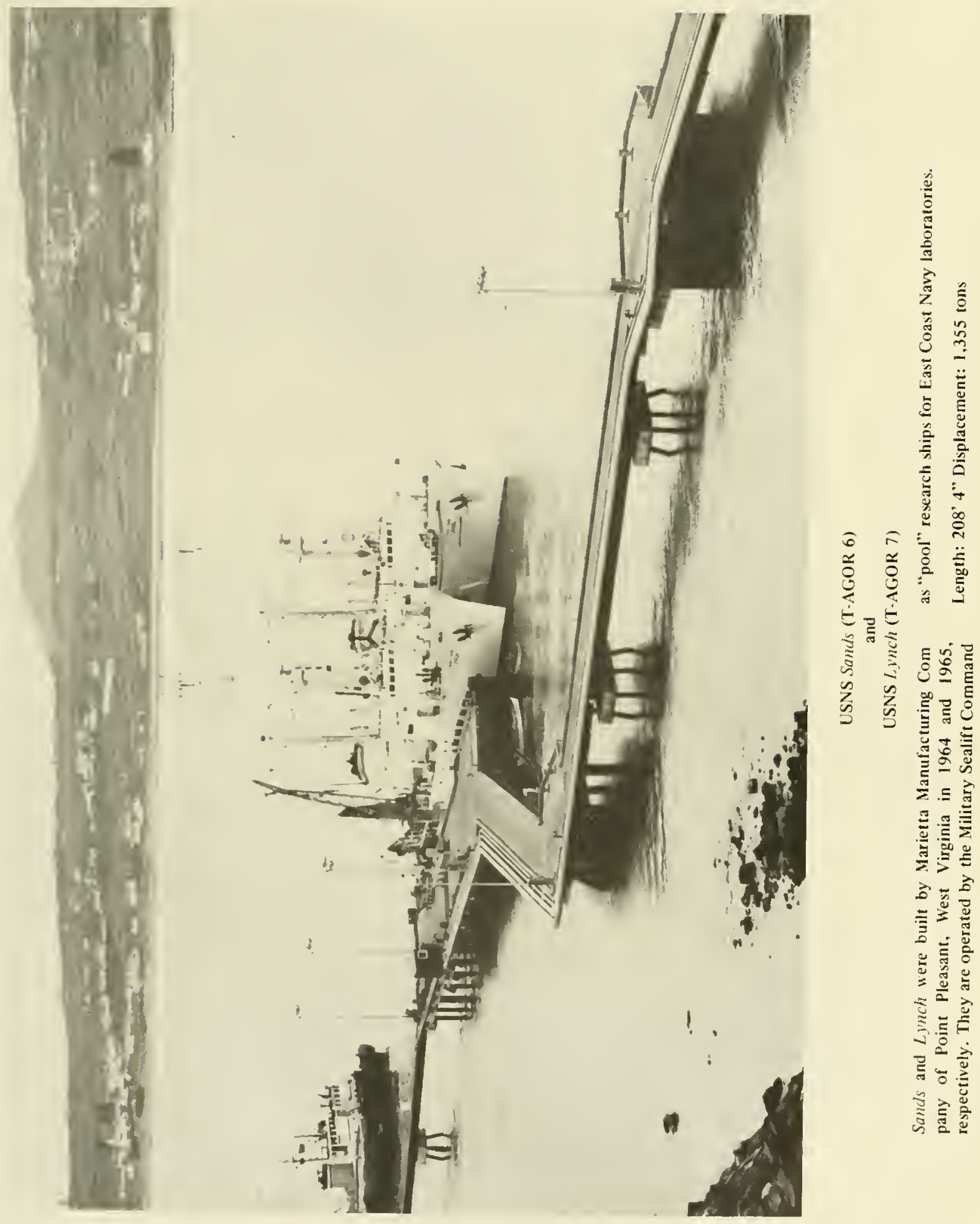




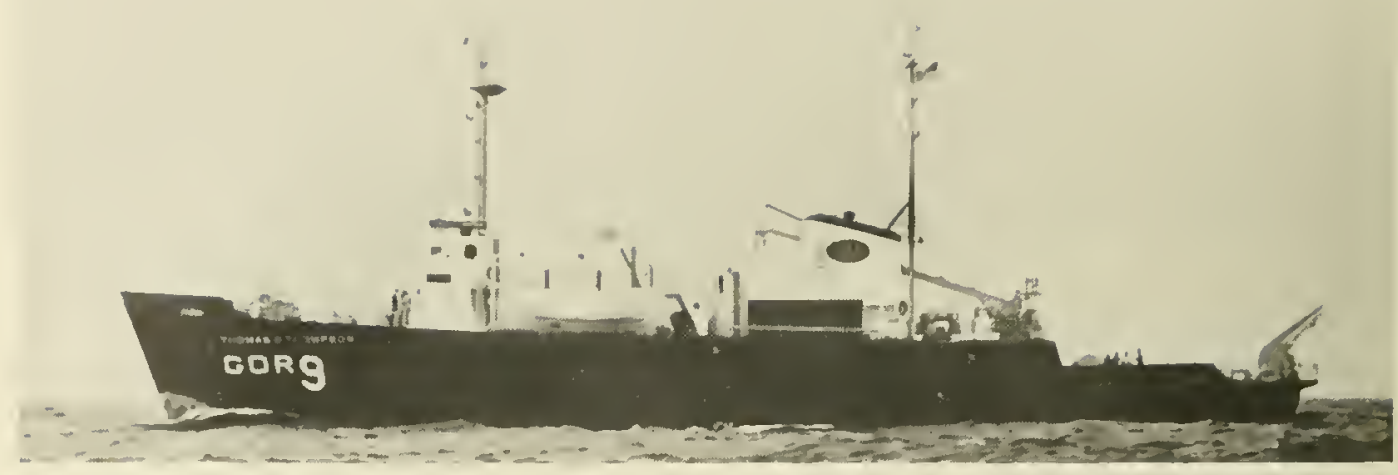

R/V Thomas G. Thompson (AGOR 9)

A Navy-owned oceanographic research ship built in 1965 by Marinette Marine Corporation, Marinette, Wisconsin and assigned to the University of Washington for operation.

Length: 208' 4" Displacement: 1,362 tons

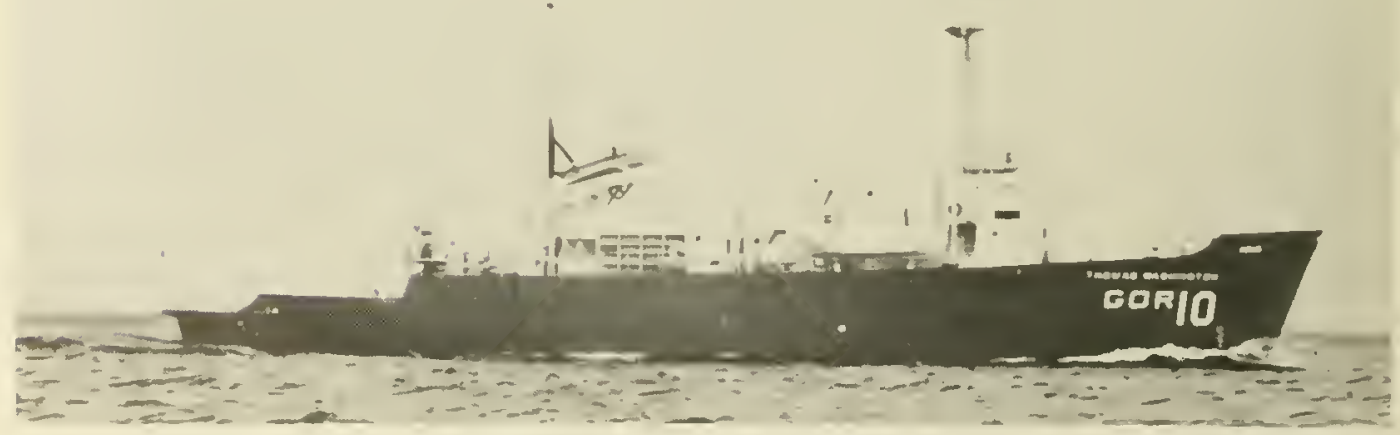

R/V Thomas Washington (AGOR 10)

Owned by the Navy and assigned to Scripps Institution for operation. The W'ashington was huilt in 1965 by Marinette Marine Corporation of Marinette, Wisconsin.

Length: $208^{\circ} 4^{\prime \prime}$ Displacement: 1,362 tons 


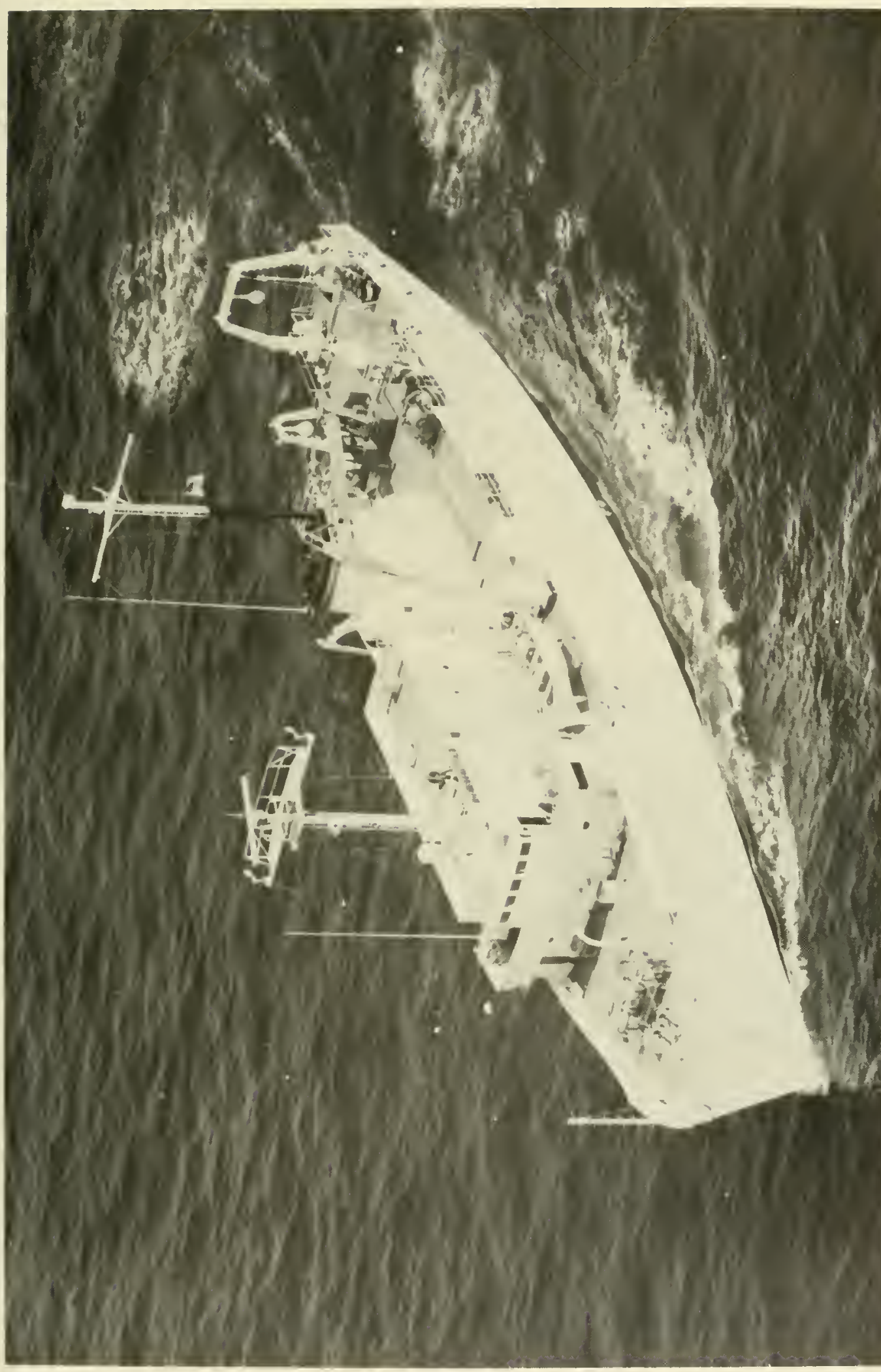

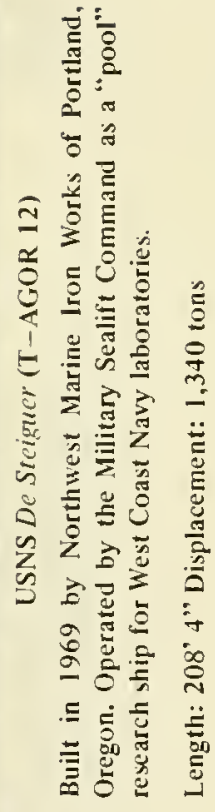




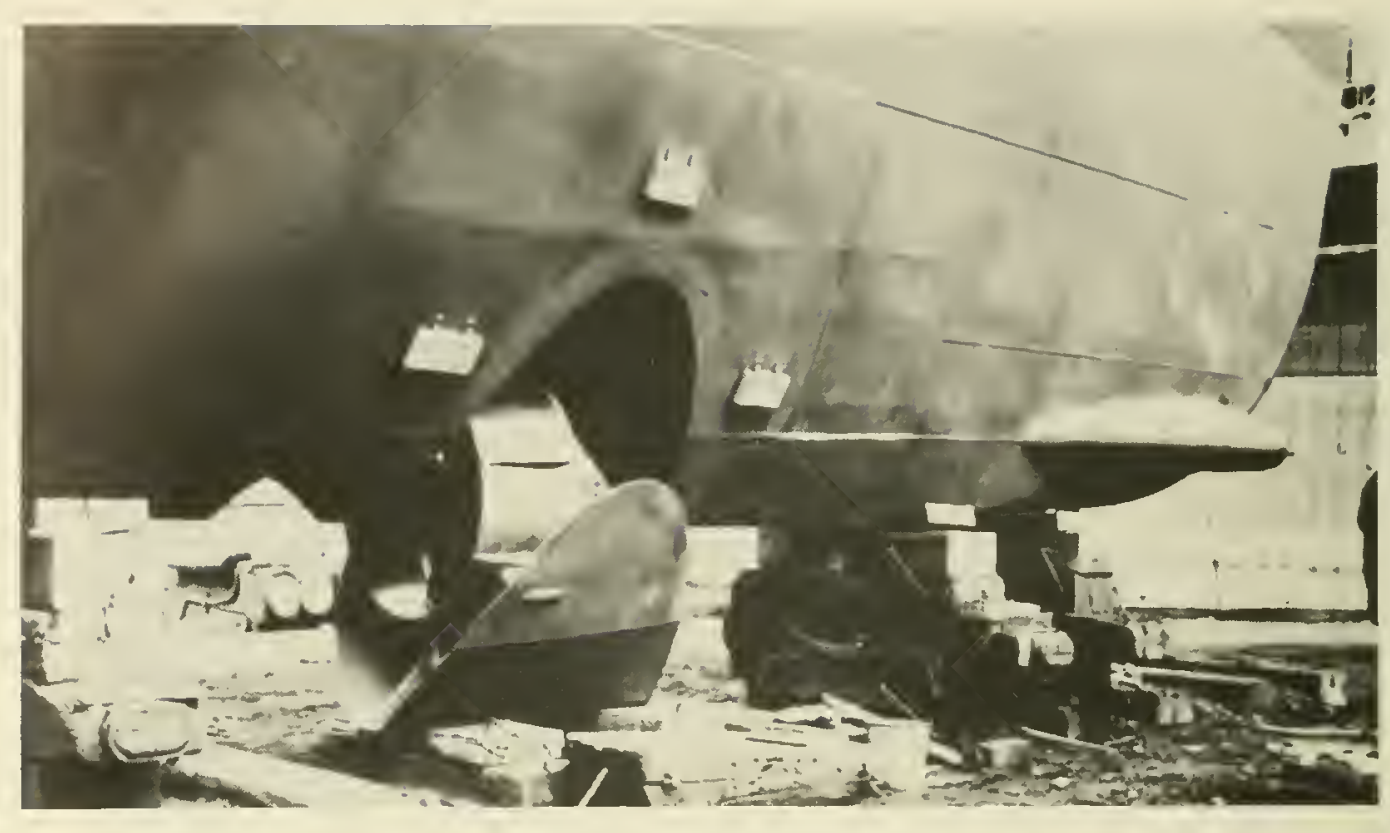

USNS De Steiguer (T-AGOR 12)

Bow Propulsion Unit in its extended position. (Shown also is the bow housing for echo sounder transducers).

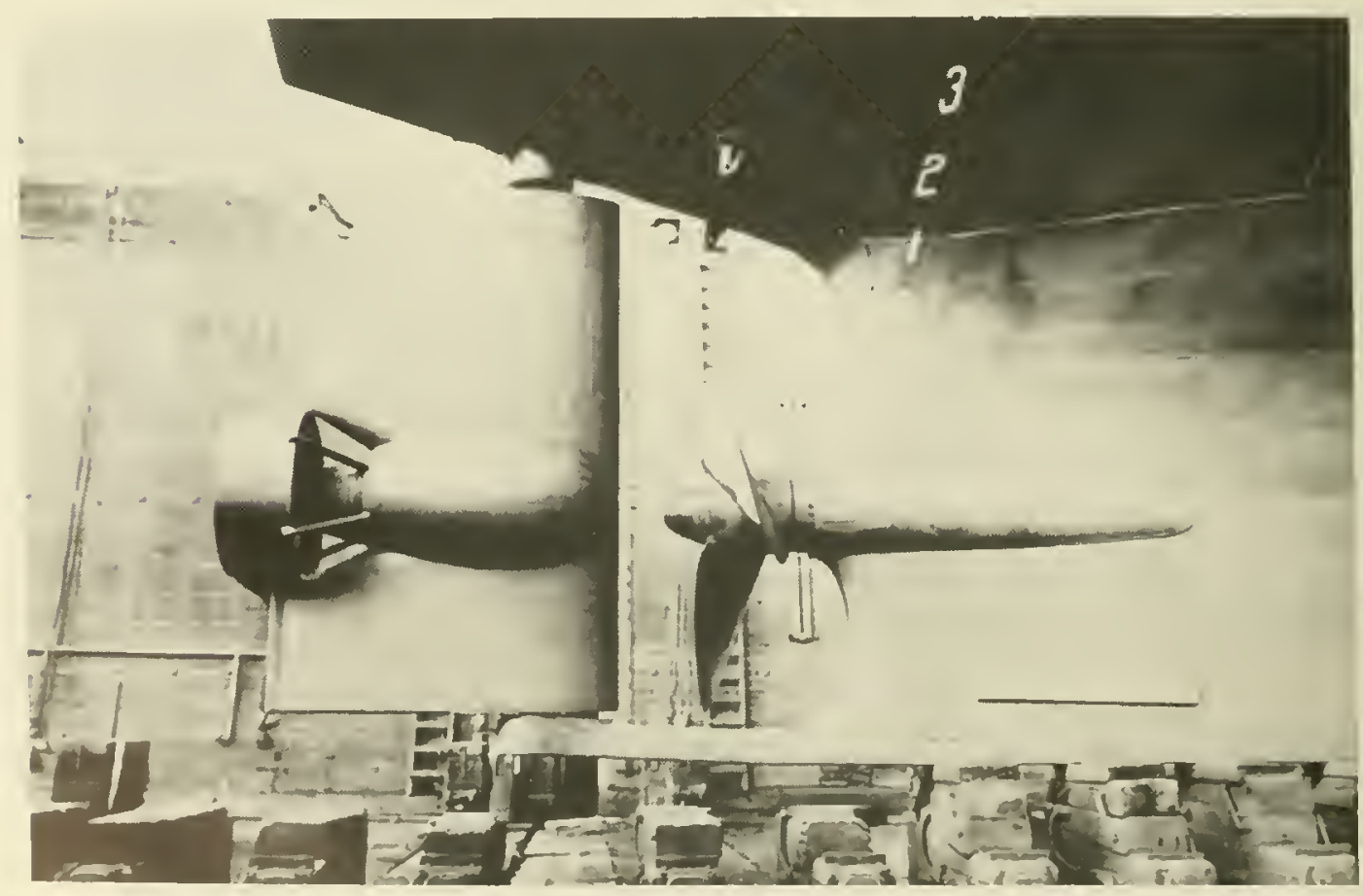

USNS De Steiguer (T-AGOR 12)

Propulsive Rudder Assembly, used for maneuvering and auxiliary proputsion. 


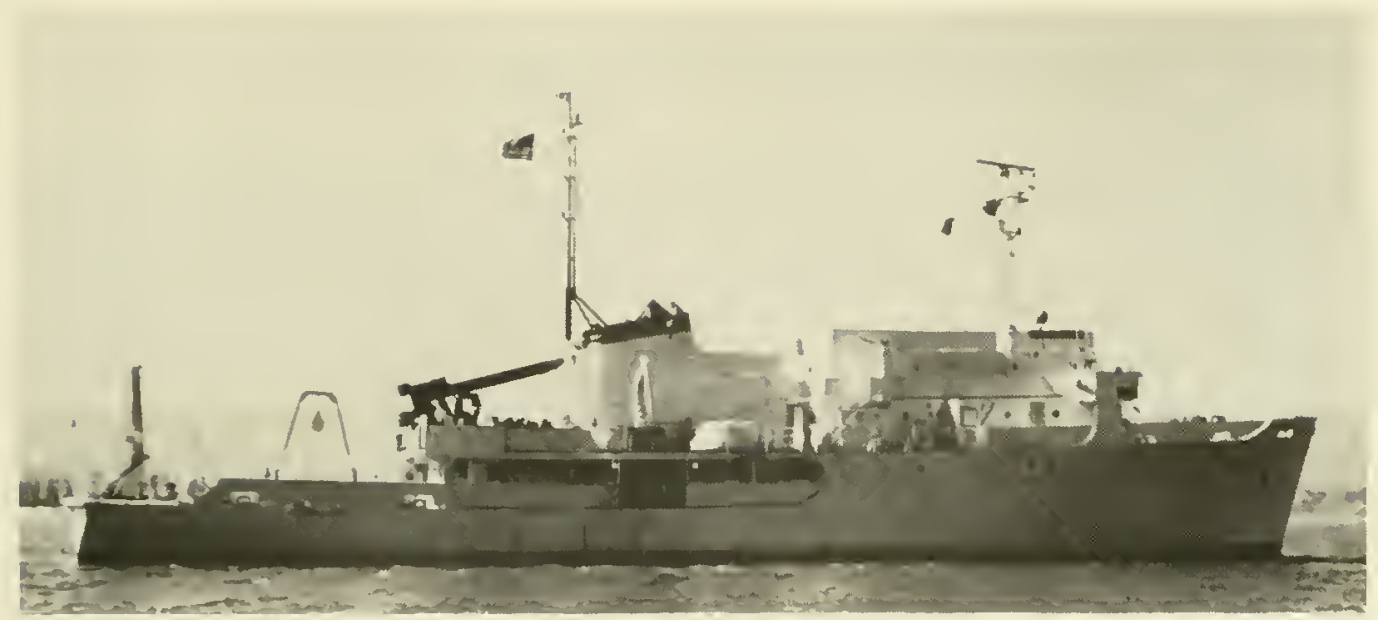

USNS Barlett (T-AGOR 13)

Built in 1969 by Northwest Marine Iron Works of Portland. Oregon. Bartlett is operated by the Military Sealift Command as a "pool" ship for West Coast Navy laboratories.

Length: $208^{\prime} 4$ "Displacement: 1,340 tons

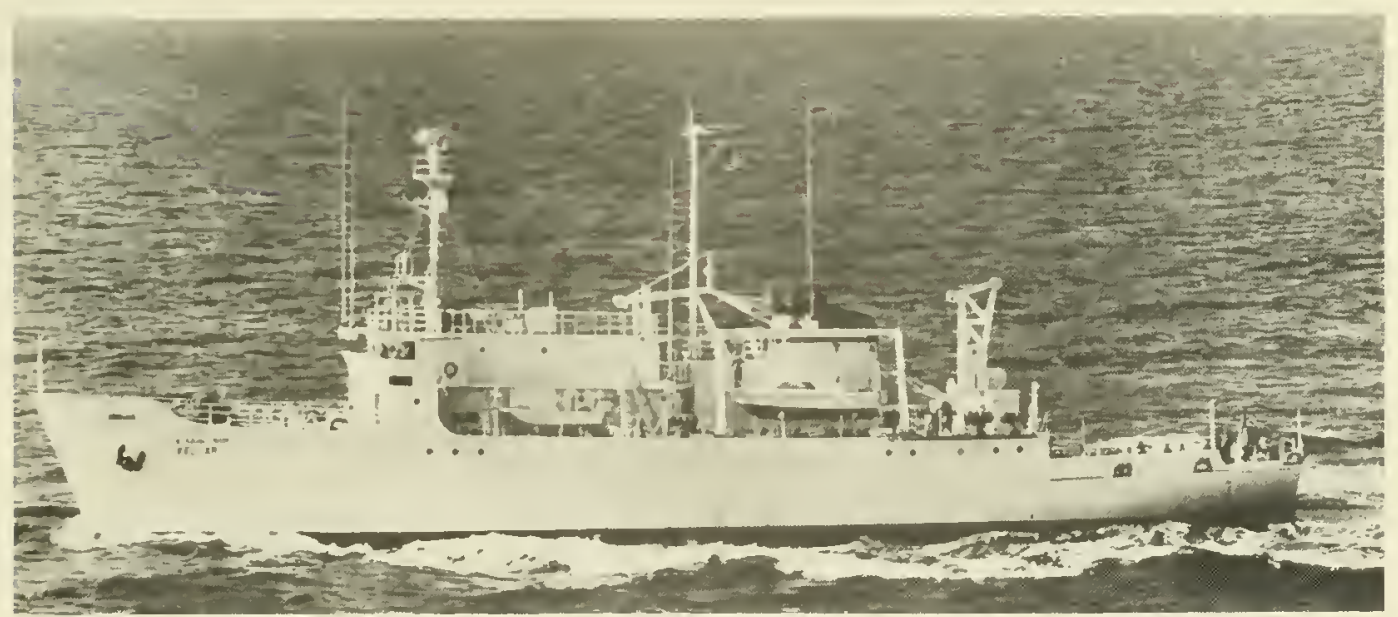

USNS Kellar (T-AGS 25)

A small, coastal hydrographic surveying ship, her construction was started in 1962 by Marietta Manufacturing Company of Point Pleasant, West Virginia. Witl her construction $85 \%$ complete, Kellar became a victim of llurricane Betsy (September $1965)$ and eapsized in the Mississippi River. Later salvaged, she was completed by Boland Machine and Manufacturing Company of New Orleans, Louisiana in January 1969.

Lengih: $208^{\circ} 4^{\prime \prime}$ Displacement: 1,334 tons 


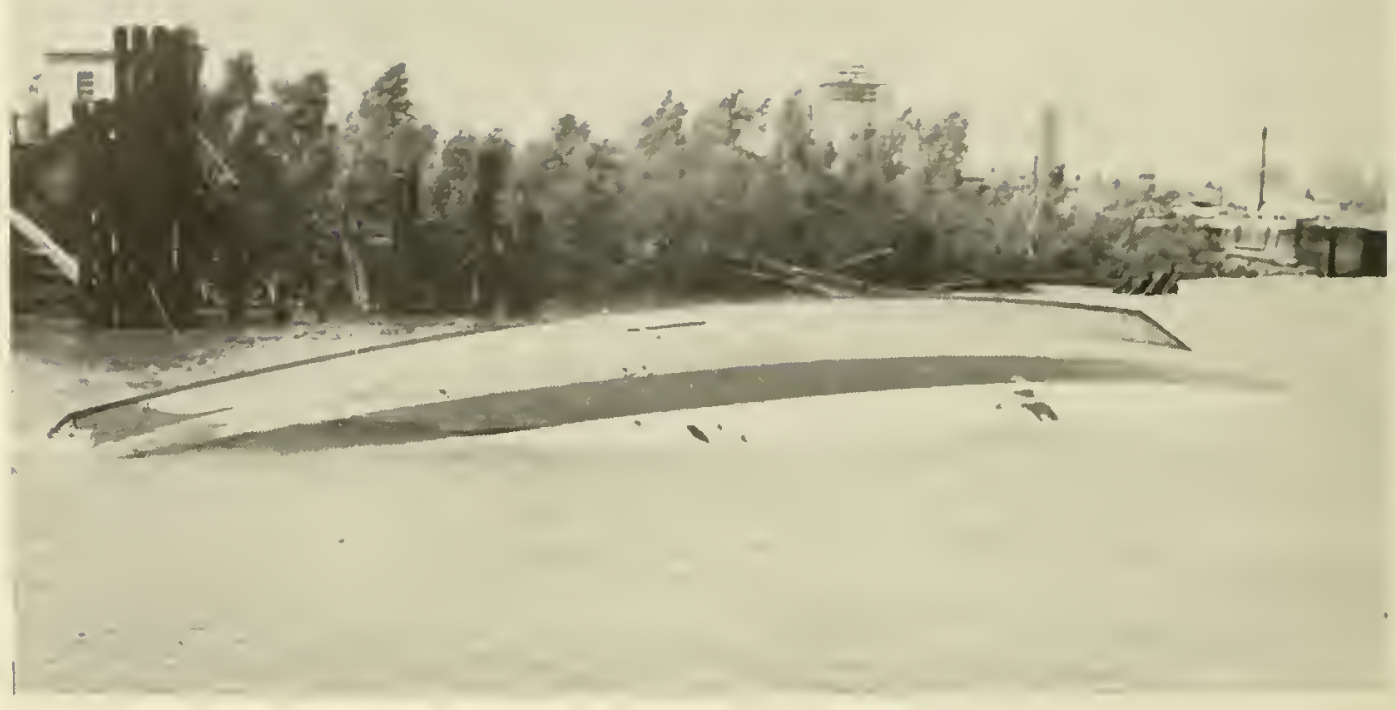

USNS Kellar (T-AGS 25) capsized in Mississippi River at New Orleans - a victim of Hurricane Betsy (September 1965).

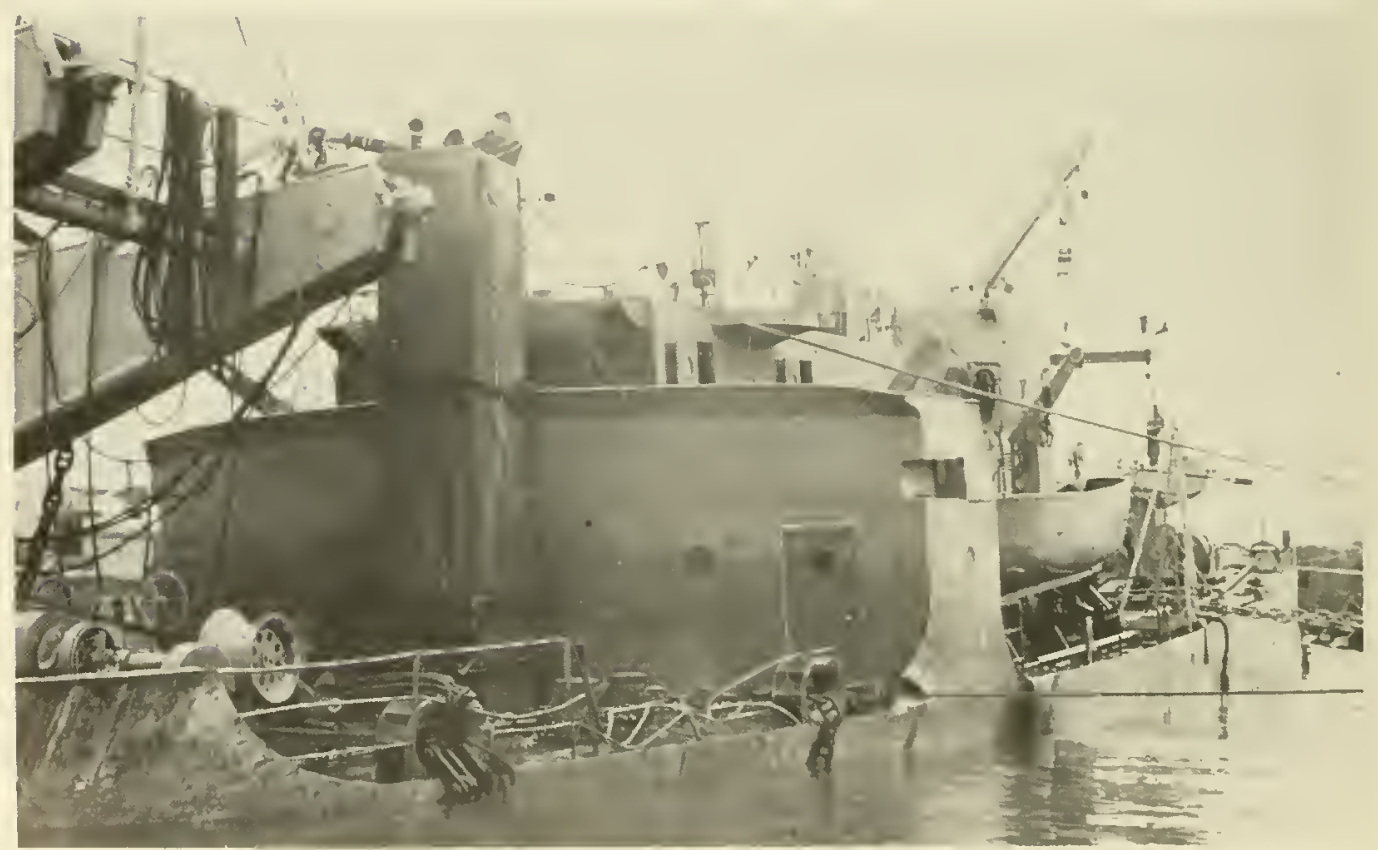

The USNS Kellar (T-AGS 25), a victim of Hurricane Betsy, is salvaged from the Mississippi River. 


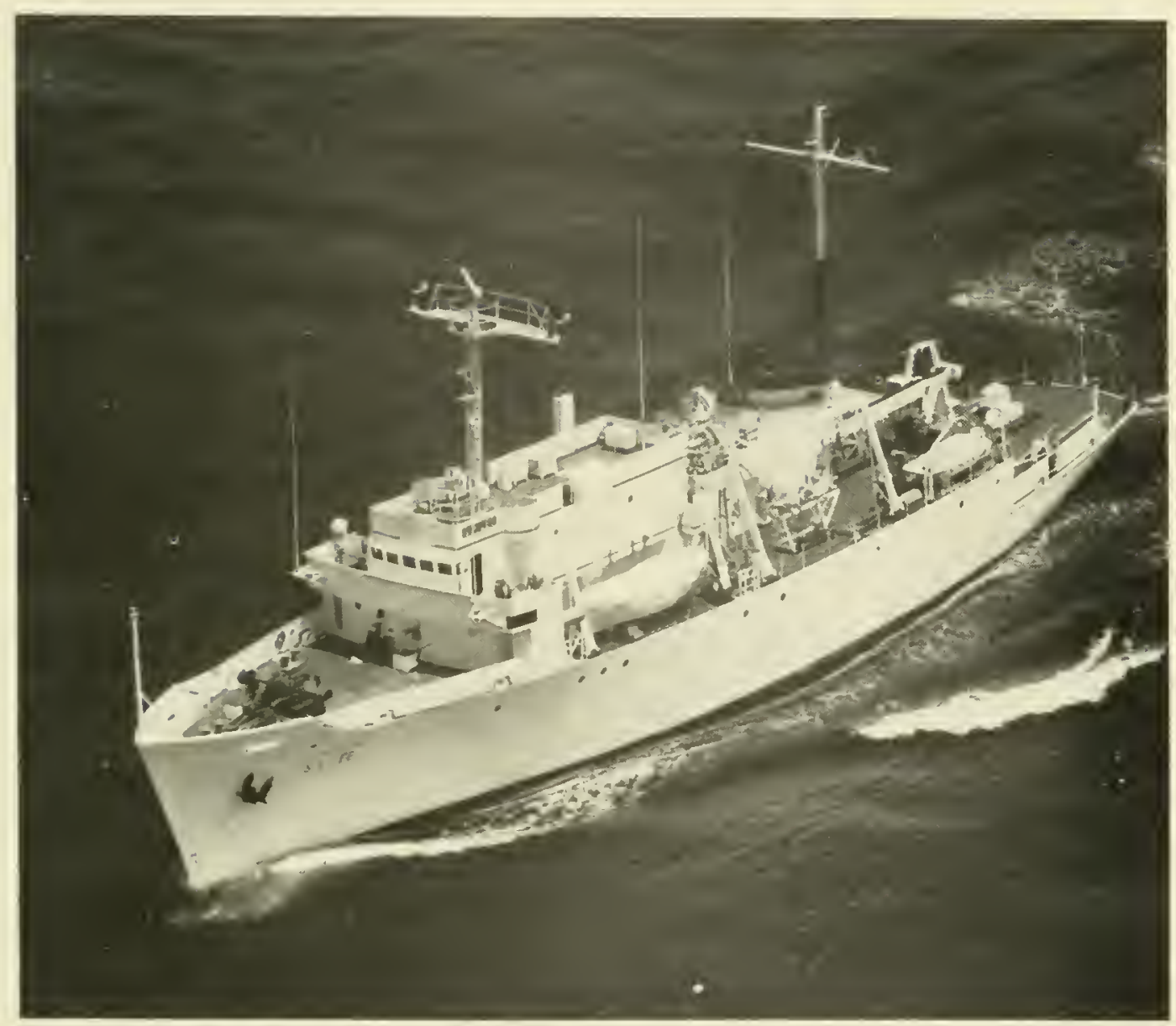

USNS S.P. Lee (T-AGS 31)

A small, coastal hydrographic surveying ship built in 1968 by Defoe Shipbuilding Company of Bay City, Michigan.

Length: 208`4" Displacement: 1,297 tons 

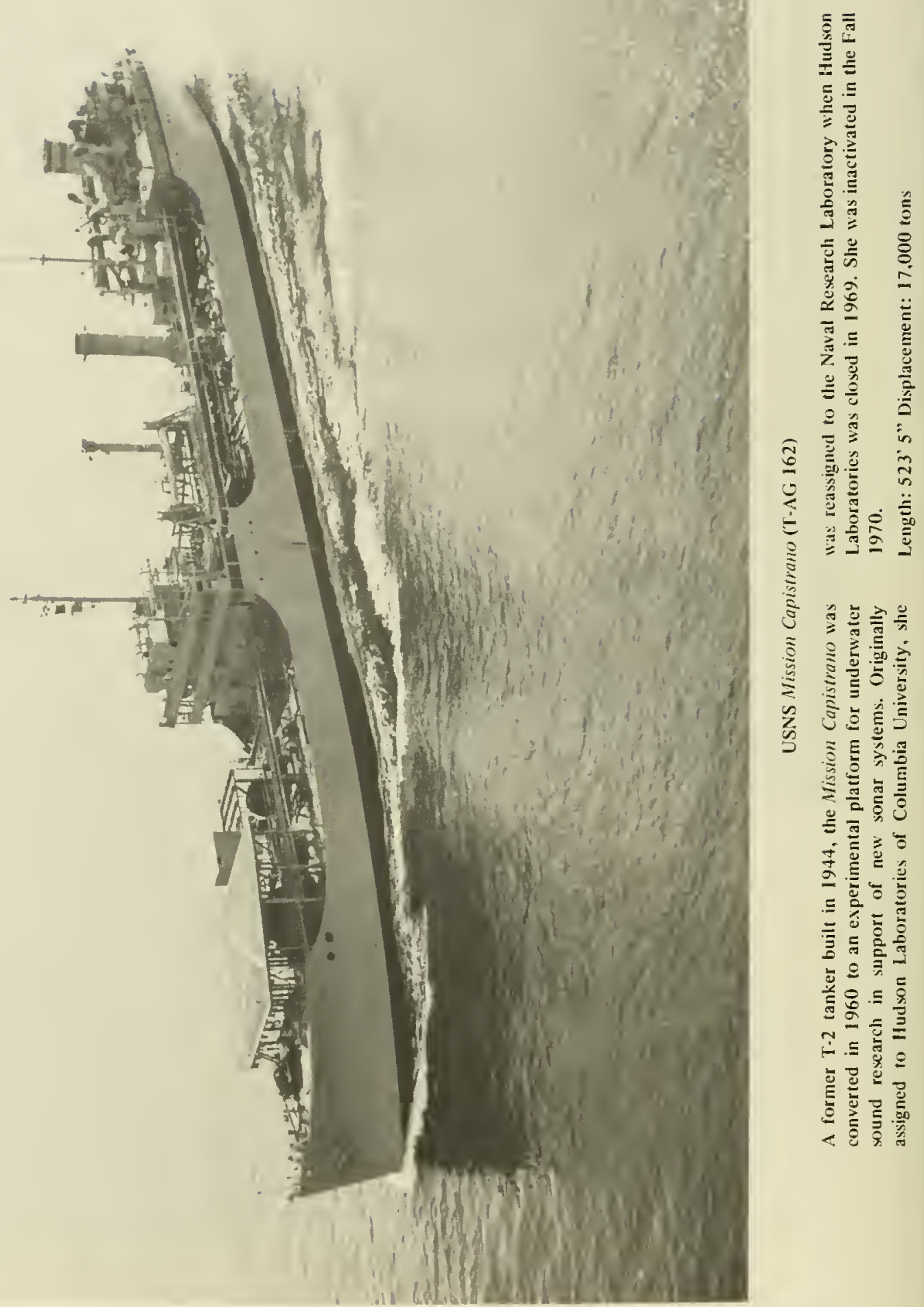


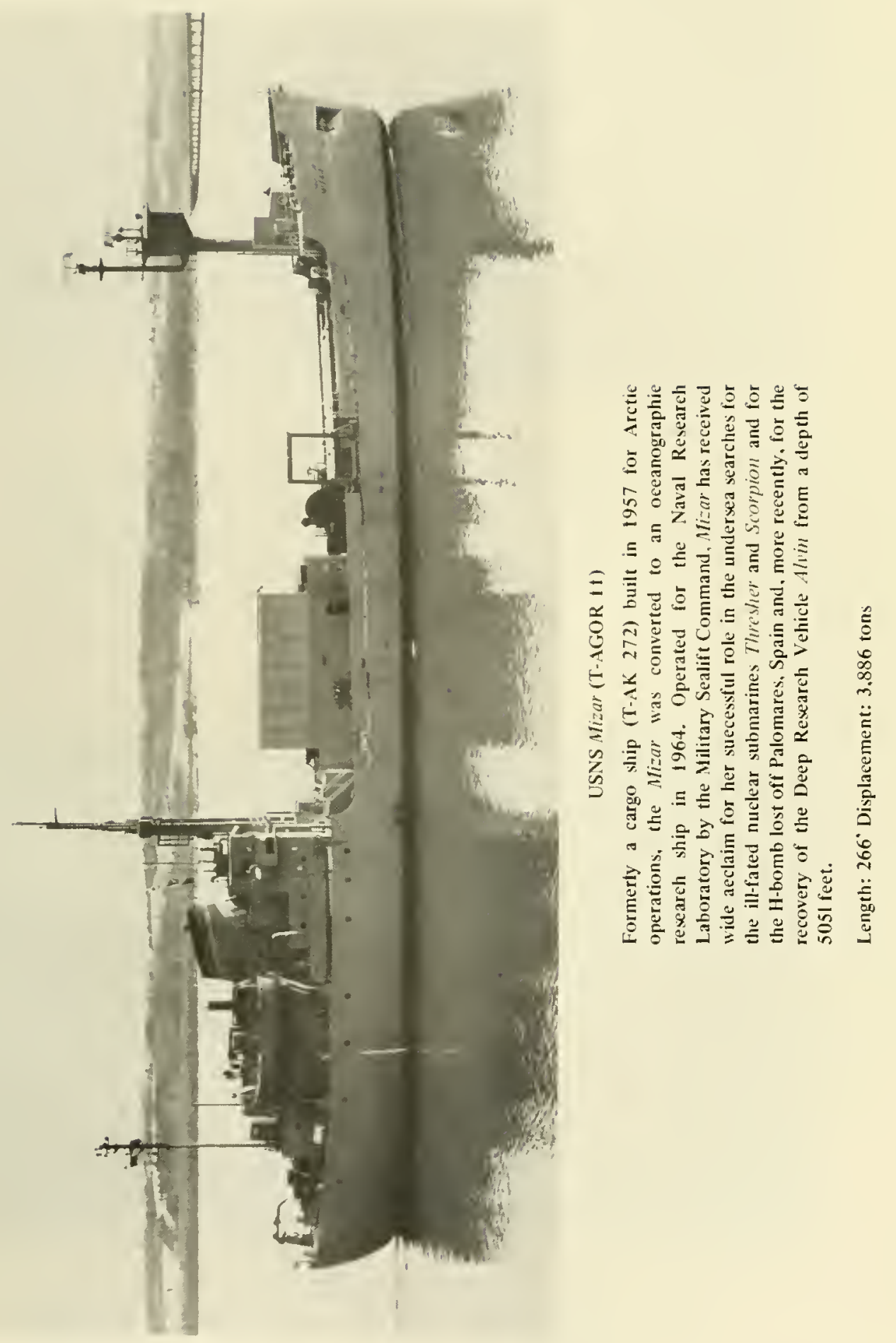




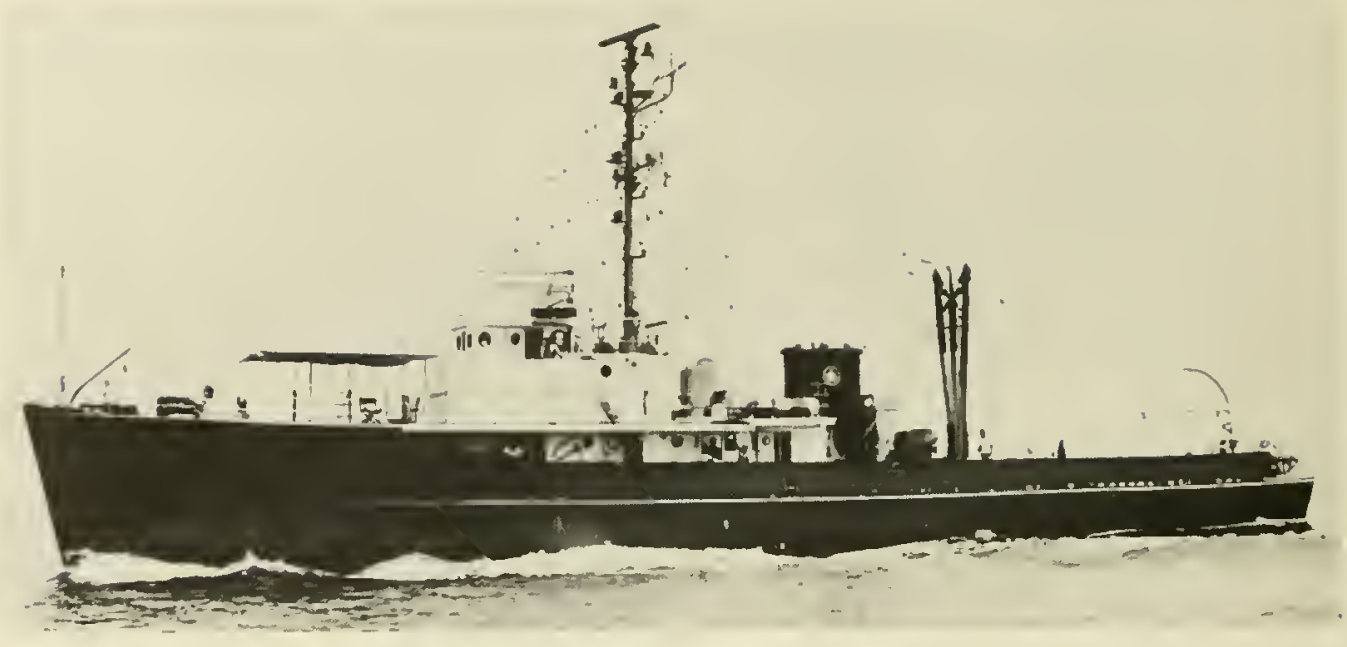

R/V Sir Horace Lamb

The former wooden-hulled auxiliary minesweeper USS Redpoll (YMS 57) built in 1942 by Gibbs Gas Engine Company of Jacksonville, Florida. Converted to an oceanographic research vessel in 1960 and renamed the $R / V$ Sir Horace Lamb, this Navy-owned ship is assigned to Columbia University's Geophysical Field Station in Bermuda.

Length: 136' Displacement: 320 tons

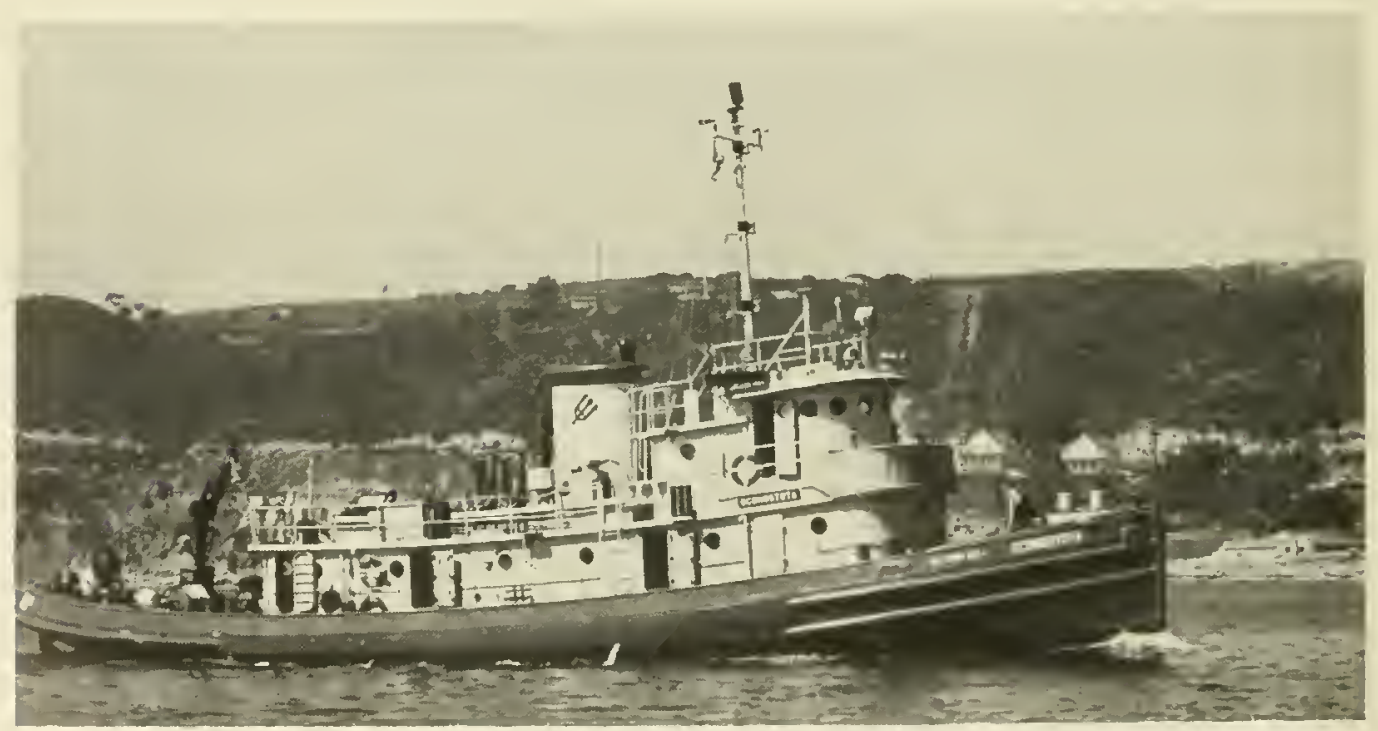

R/V Oconostota

A Navy-owned converted harbor tug (ex-YTM 375) built in 1944 and assigned to Scripps Institution of Oceanography in 1962 for operation as a research vessel.

Length: 102' Displacement: 328 tons 


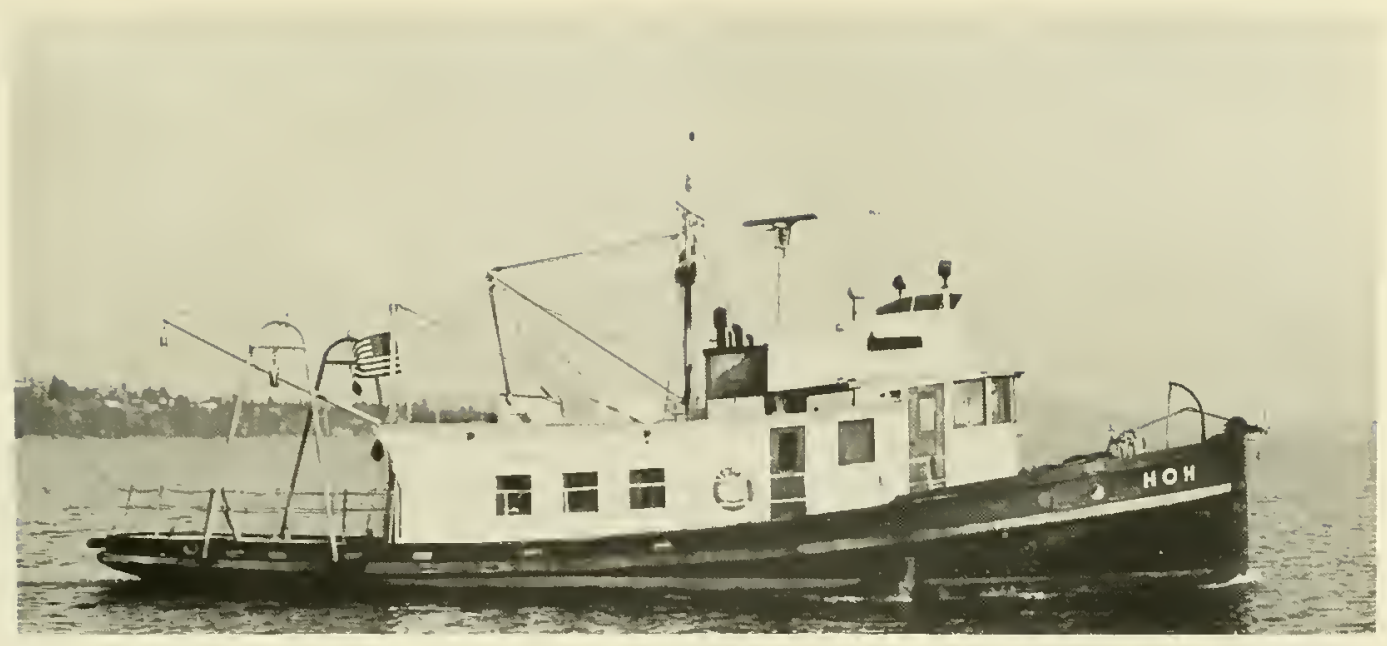

R/V Hoh

Navy-owned tug (YT 89), built in 1943, which saw service as the Alcatraz Prison ferry. Hoh was assigned to University of Washington in 1962 for oceanographic research.

Length: 64' 11" Displacement: 91 tons

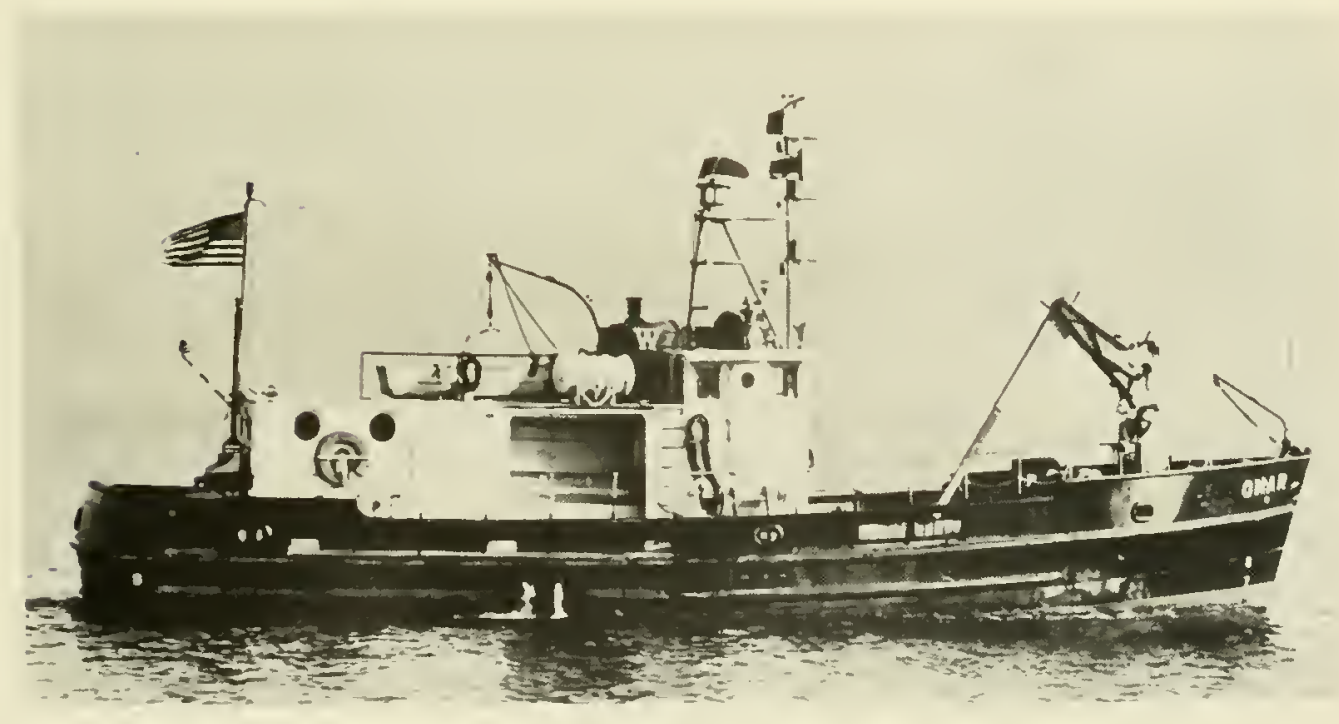

R/V Onar

Navy-owned former U.S. Army " $T$ " boat (T-480) built in 1954. In 1963 Onar was provided to the University of Washington for oceanographic research.

Length: $65^{\prime}$ Displacement: 95 tons 


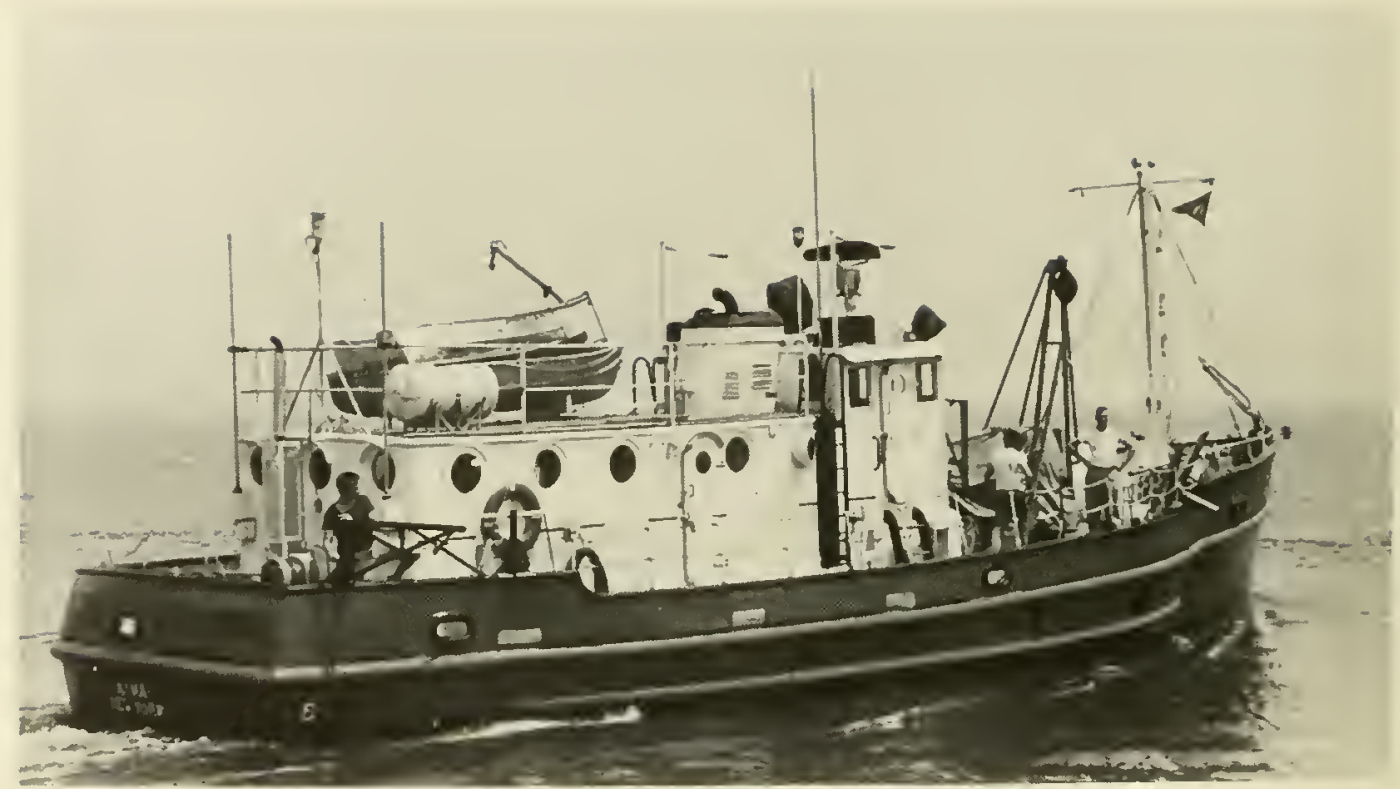

R/V Kyma

This Navy-owned former U. S. Army "T" boat, built in 1952 , was provided to New York University in 1962 for use as a research vessel.

Length: $65^{\prime}$ Displacement: 102 tons

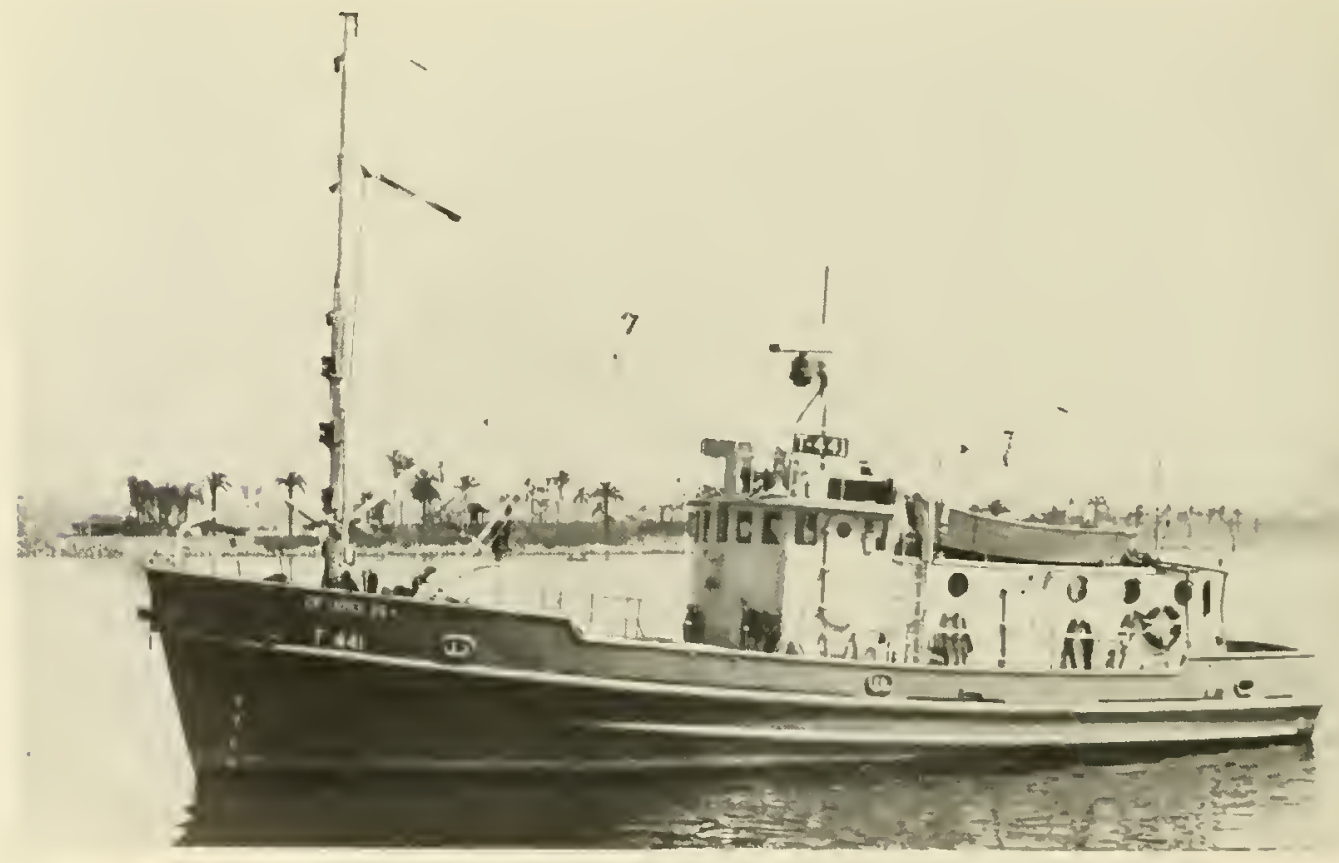

R/V T.4.1

Navy-owned, former U. S. Army "T" boat built in 1953, raphy during the period 1955 - 1969. In 1969, the vessei "Nas operated as a research vessul by Scripps Institution of Oceanogreassigned to the University of Connecticut.

Length: 65' Displacement: 99 tons 


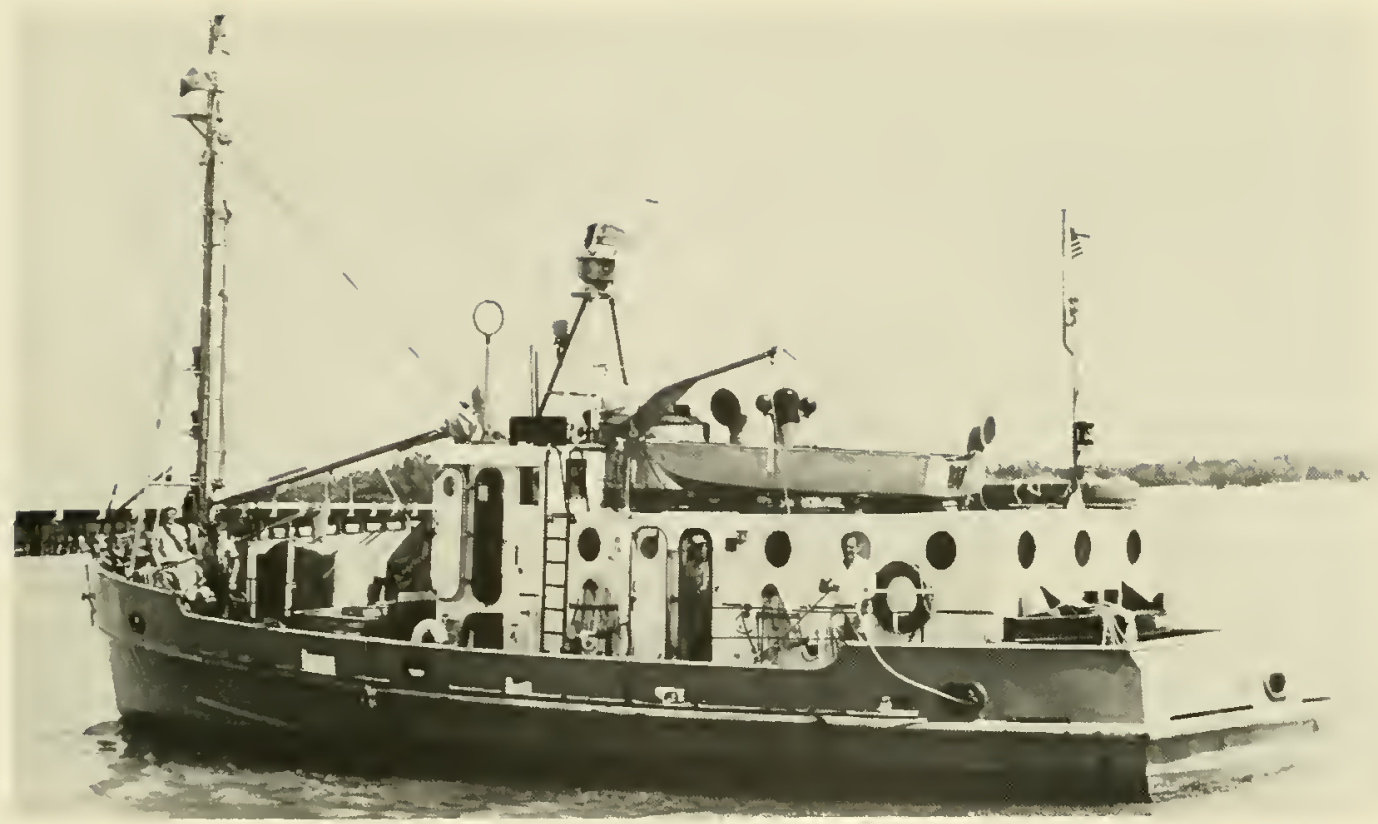

R/V Tursiops

This Navy-owned, former U.S. Army "T" boat, built in 1954, use as a research ship. The Tursiops was assigned to Florida State was originally provided to the University of Miami in 1964 for University in 1968.

Length: $65^{\circ}$ Displacement: 95 tons

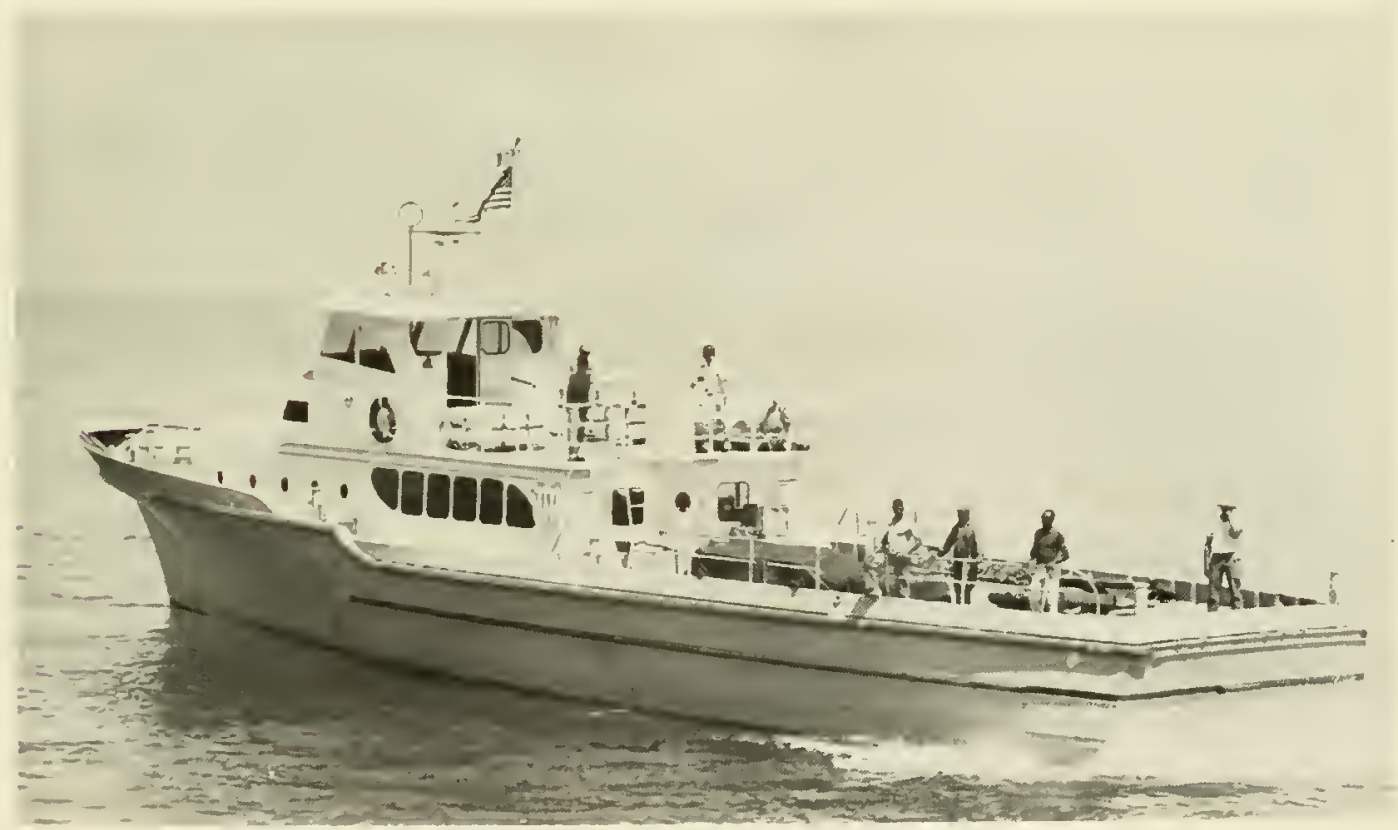

R/V Erline

The former commercial, off shore water "taxi" M/V Orrin built Acquired by the Navy in 1967, she is assigned to Columbia in 1965 by Equitable Equipment Company of New Orleans. University as a support boat for Argus 1sland.

Length: $100^{\prime}$ Displacement: 120 tons 


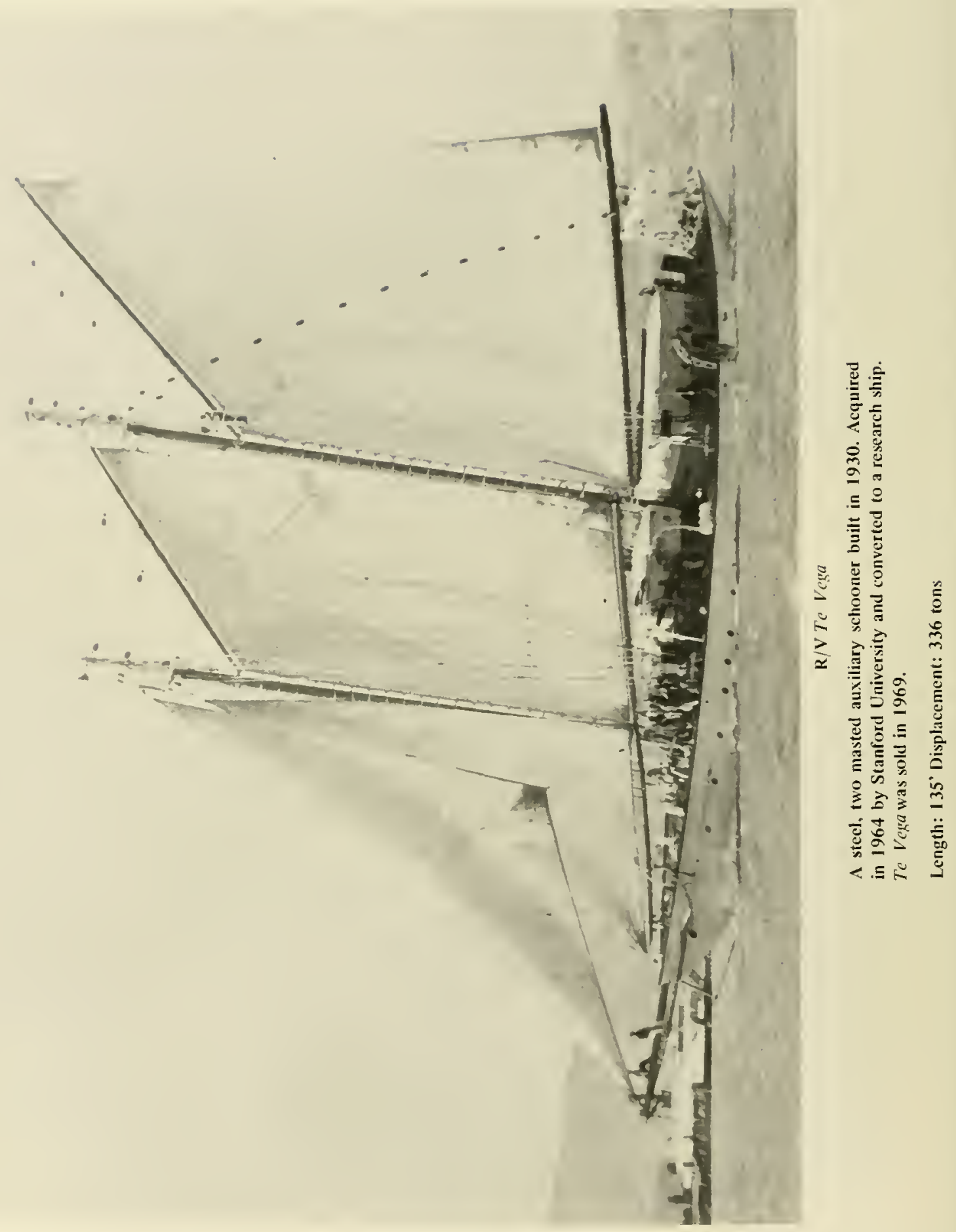




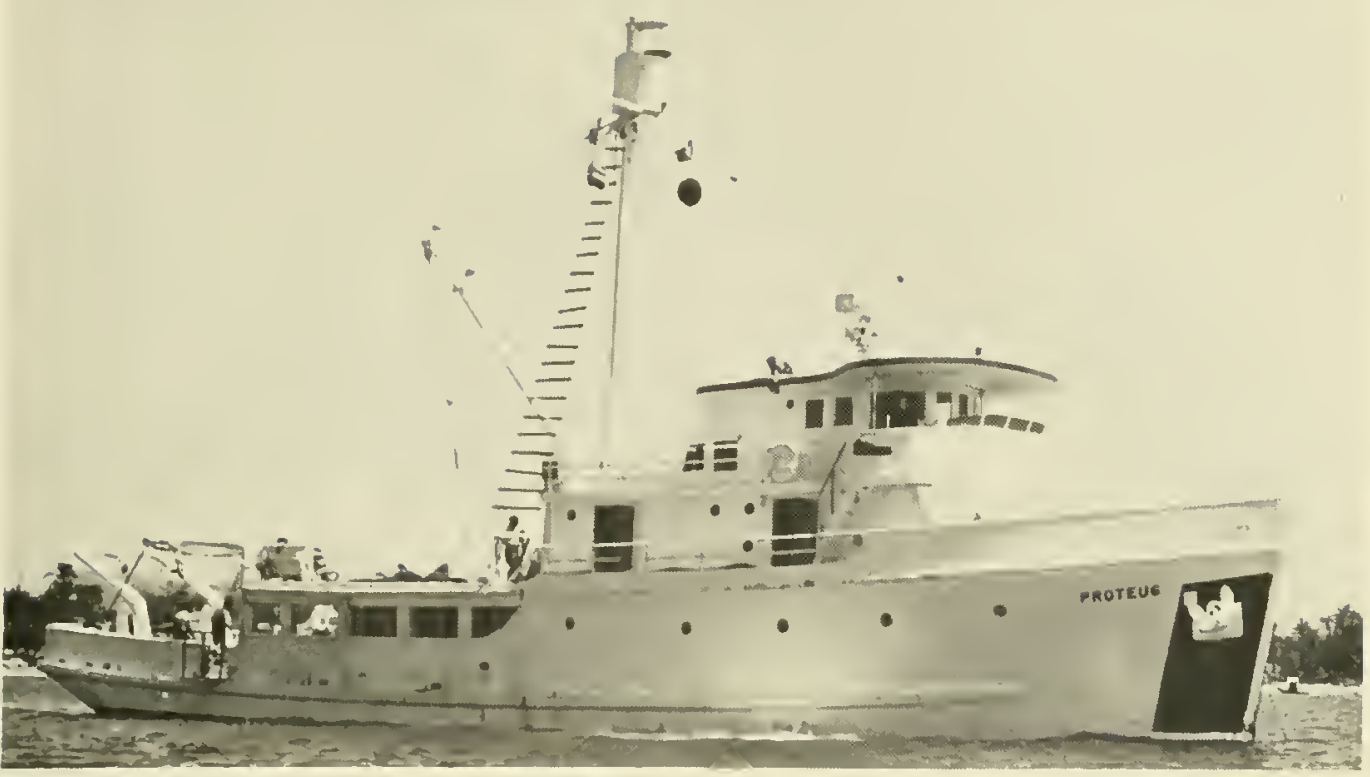

R/V Proteus

A former fishing vessel built in 1946 and acquired by Stanford University in 1969 for use as an oceanographic research vessel. Length: 100' Displacement: 186 tons

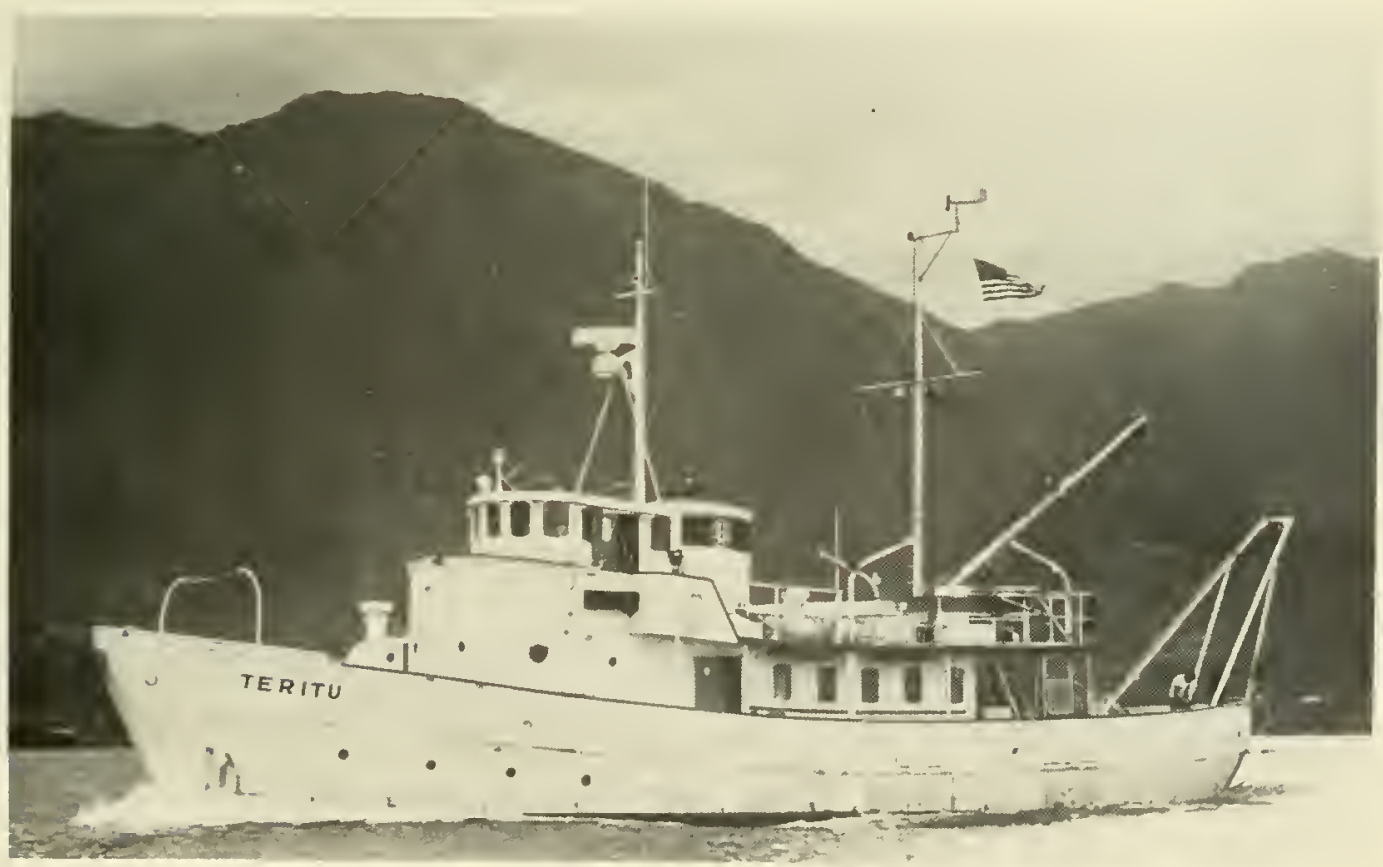

\section{R/V Tcritu}

The former yacht Cilenmore built in 1953 in Sanderborg, Denmark. Acquired by the University of Hawaii in 1964 and converted to a research ship.

Length: 90' Displacement: 136 tons 


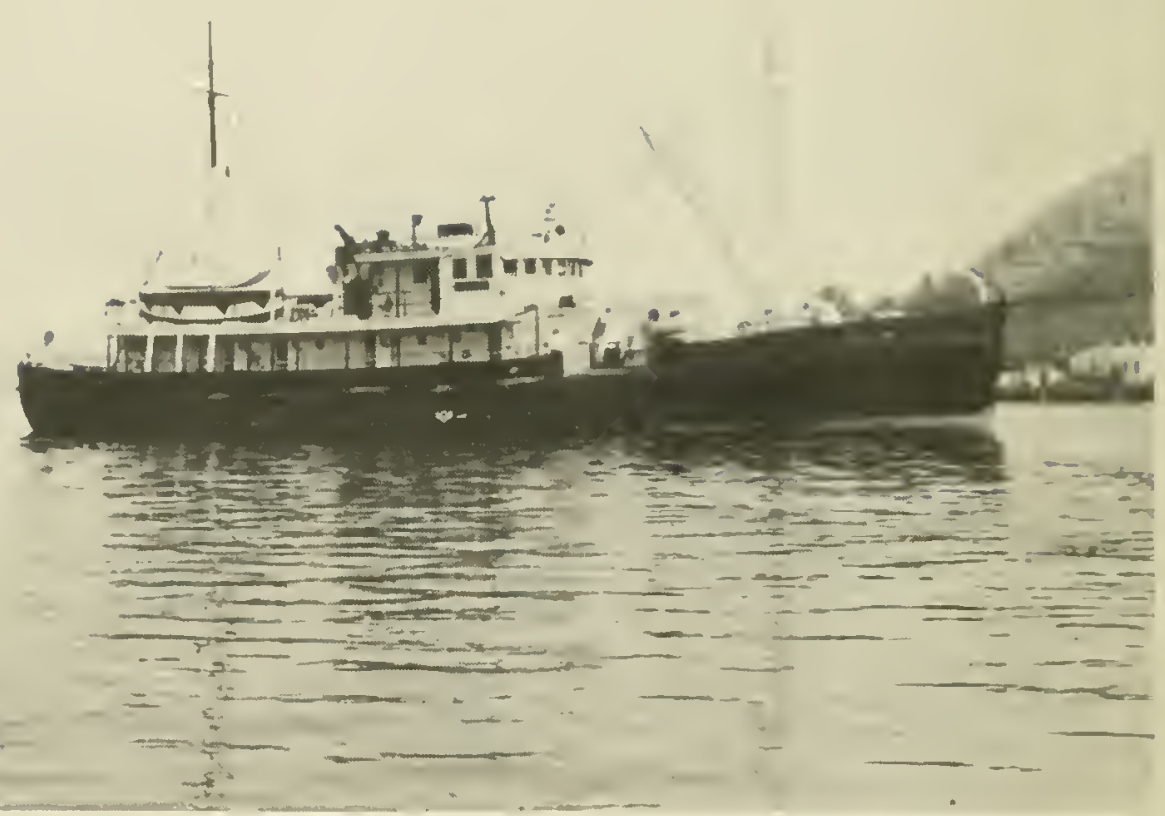

R/V Inland Seas

A former U. S. Army Frieght and Supply Vessel built in 1943 and converted in 1962 by the University of Michigan for oceanographic research.

Length: 114' Displacement: 500 tons 


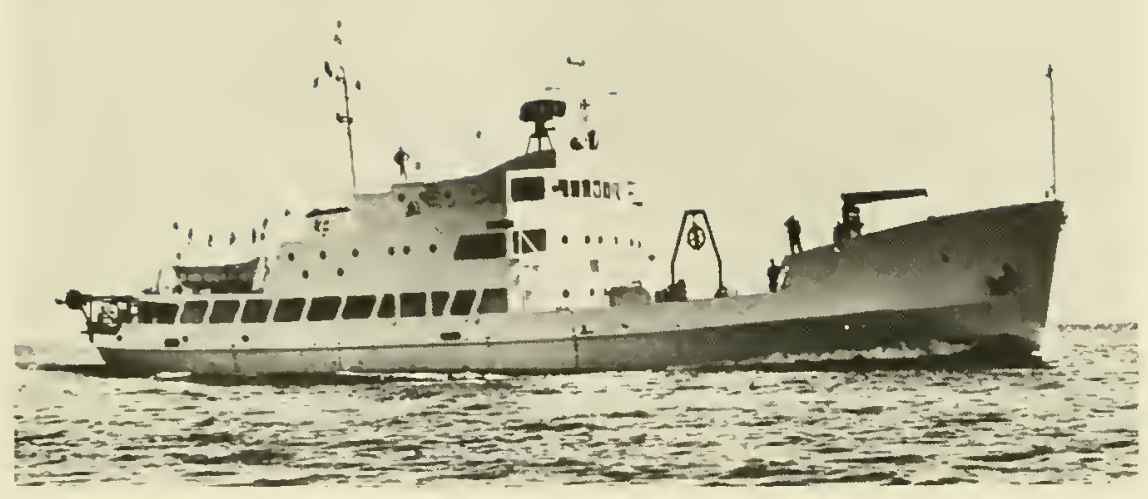

R/V Alaminos

Acquired and converted by Texas A\&M University for oceanographic research in 1963, the Alaminos is the former U. S. Army Freight and Supply Vessel FS-227 built in 1945.

Length: 180' Displacement: 850 tons

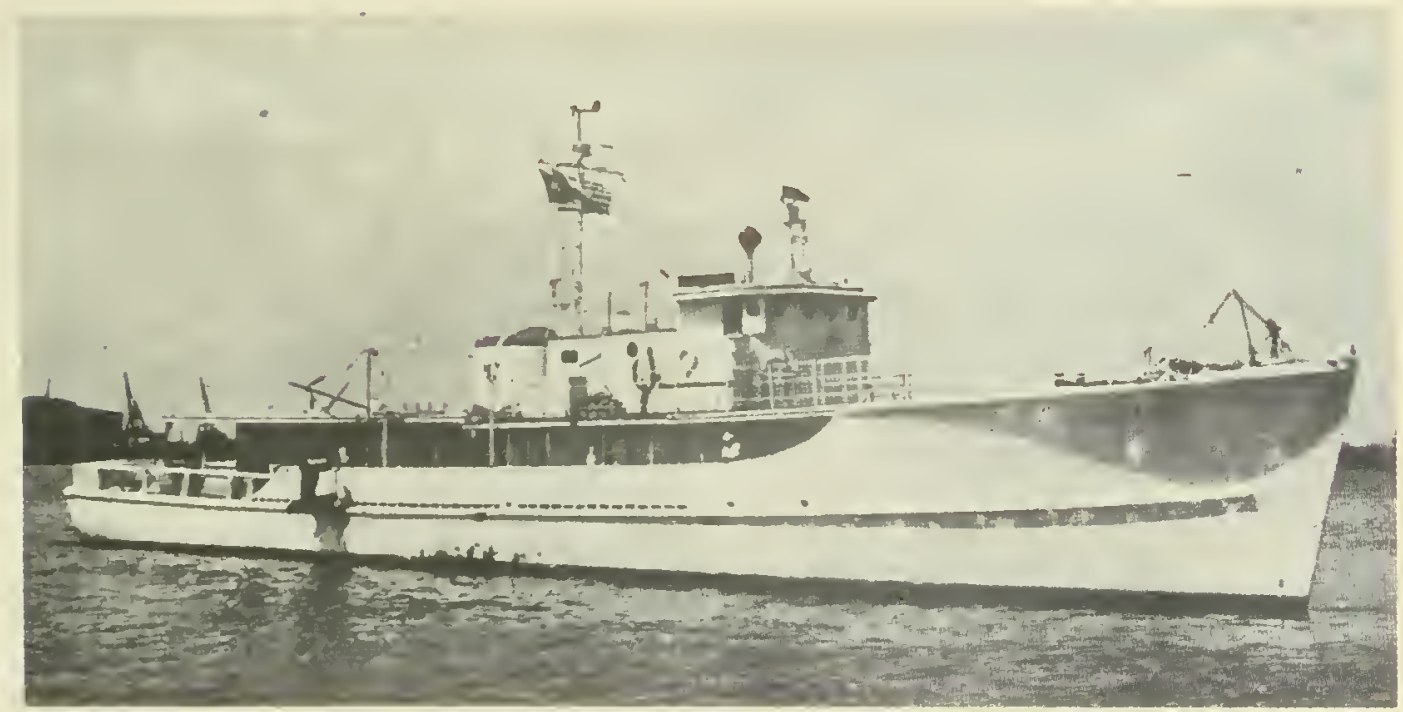

R/V Hidalgo

A former wooden hulled Navy subchaser built in 1944 and acquired by Texas A\&M University in 1957 for use as a research vessel. In 1963 the Hidalgo was replaced by the R/V Alaminos, a converted U. S. Army Freight and Supply Vessel.

Length: 136' Displacement: 410 tons 


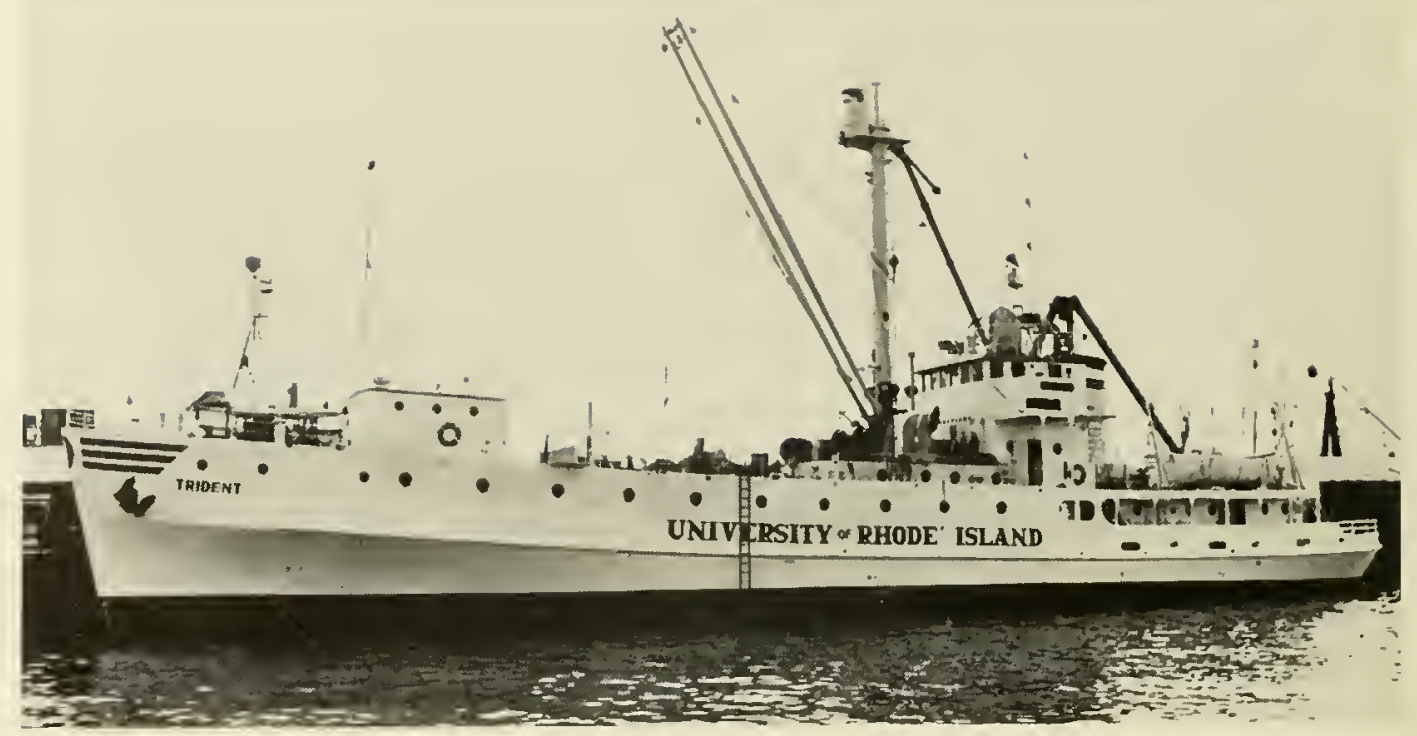

\section{R/V Trident}

The former U.S. Army Freight and Supply Vessel FS-206 built in 1944 and acquired by the University of Rhode Island in 1962 for use as an oceanographic research ship.

Length: 180' Displacement: 1,021 tons

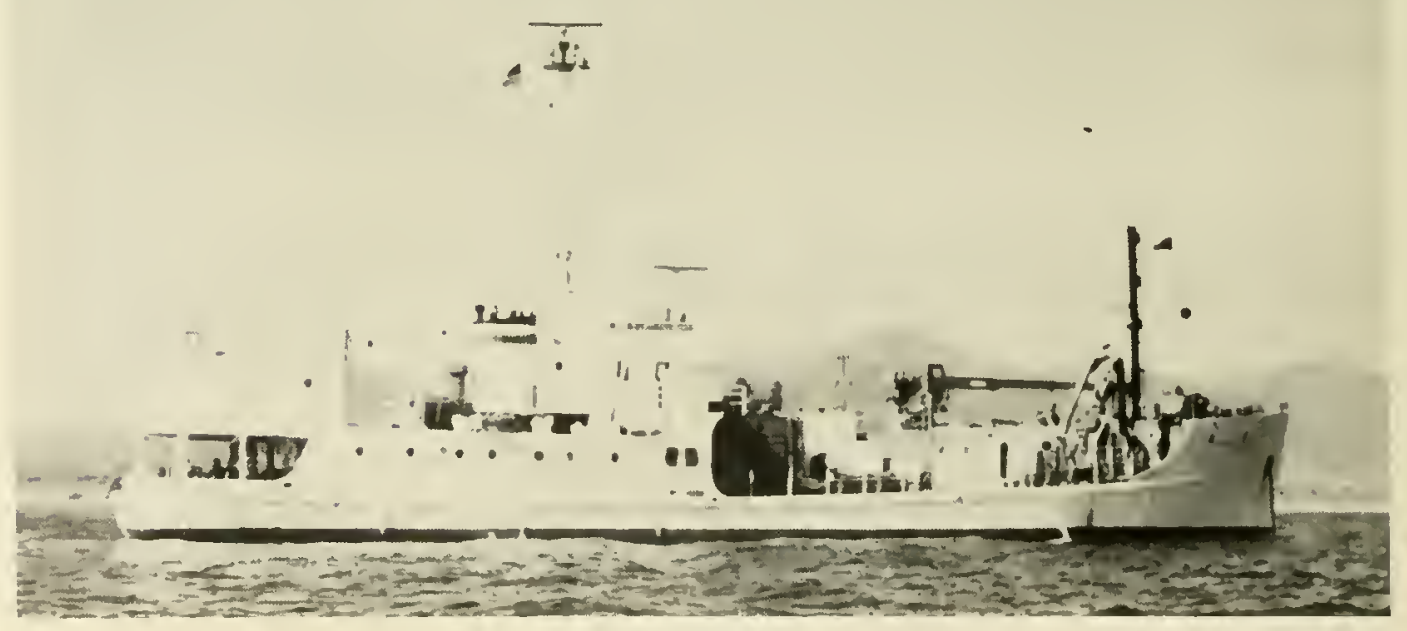

R/V Pillsbury

Formerly the U. S. Army Freight and Supply Vessel FS-539 built in 1944. Acquired by the University of Miami in 1963 for use as an oceanographic research vessel.

Length: 176' Displacement: 935 tons 


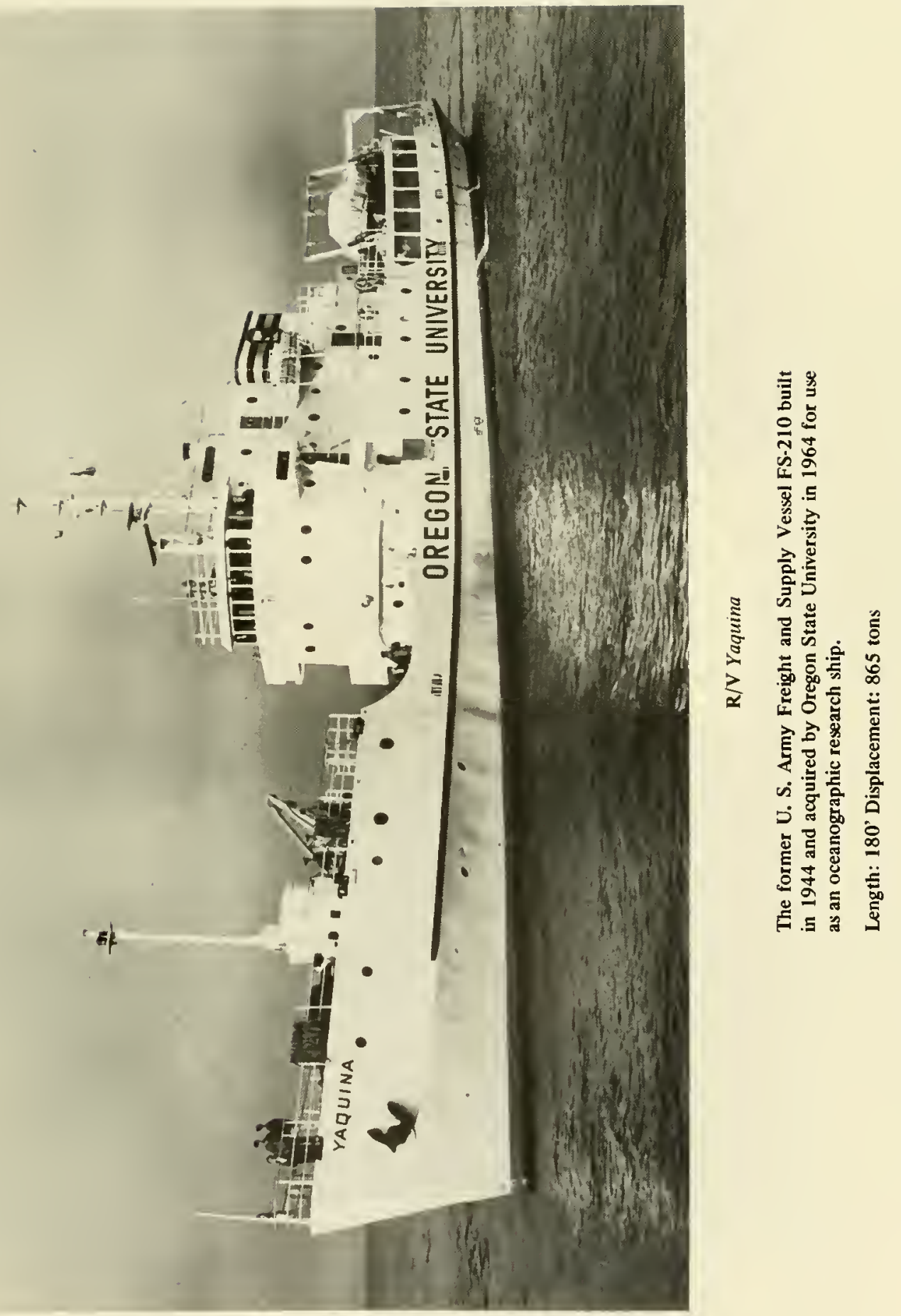




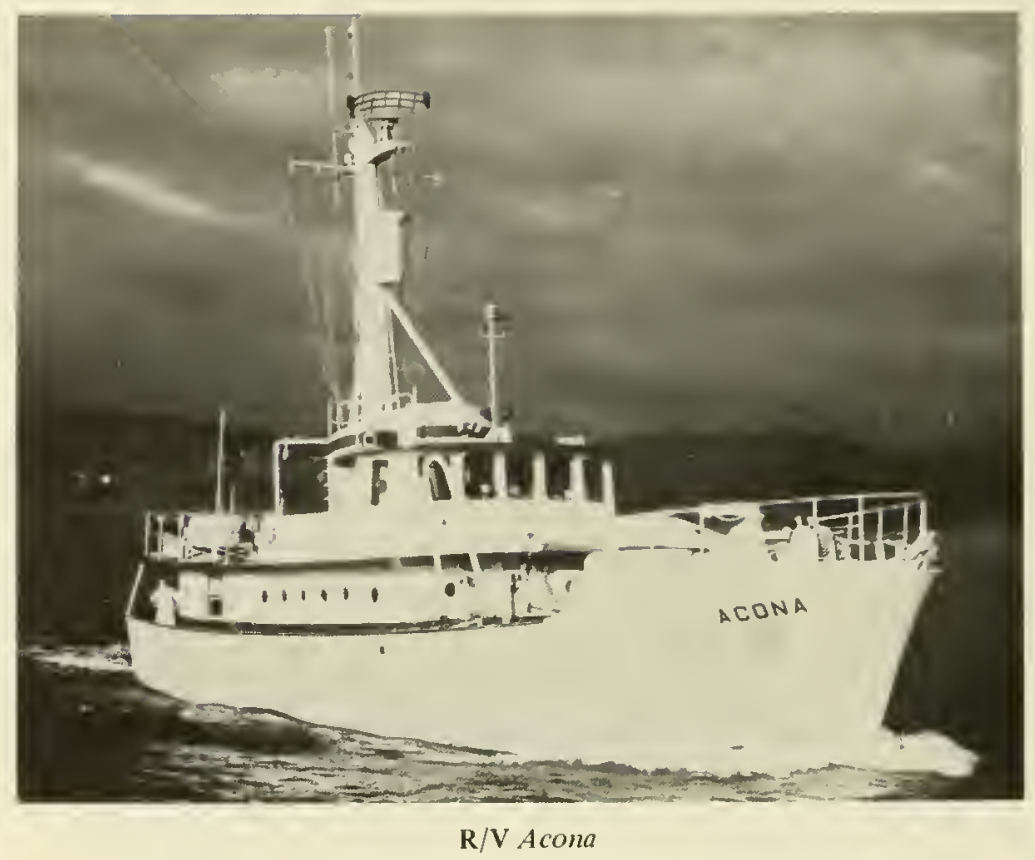

This Navy-owned ship was built in 1961 by L. S. Baier Company of Portland, Oregon for use by Oregon State University. In 1964 the Acong was transferred to the University of Alaska's Institute of Marine Science.

Length: 80 'Displacement: 154 tons

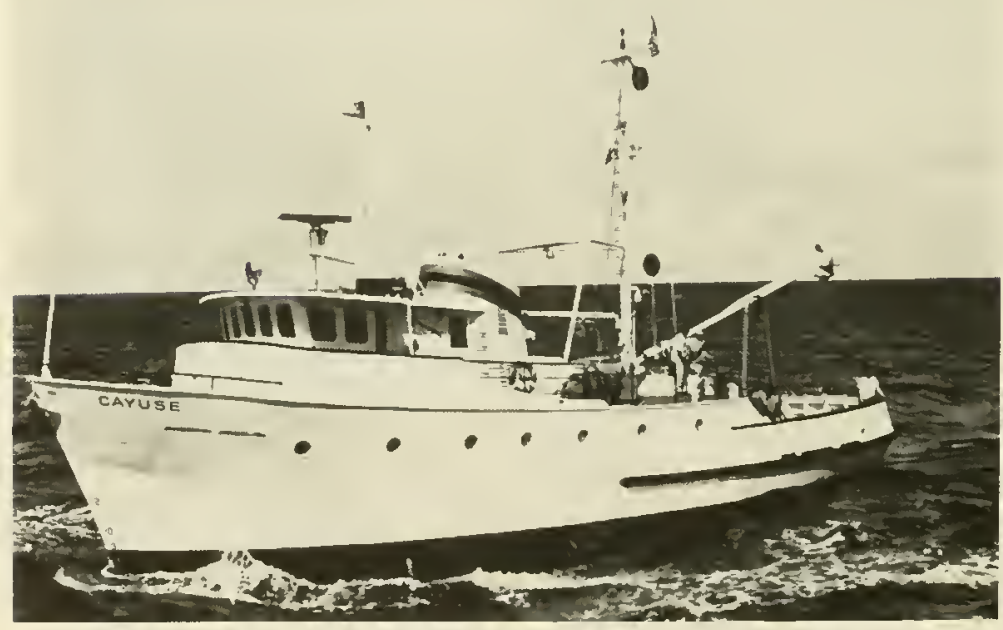

$\mathbf{R} / \mathbf{V}$ Cayuse

Built in 1968 for Oregon State University by Albina Engine and Machine Works of Portland, Oregon.

Length: 79' 10' Displacement: 173 


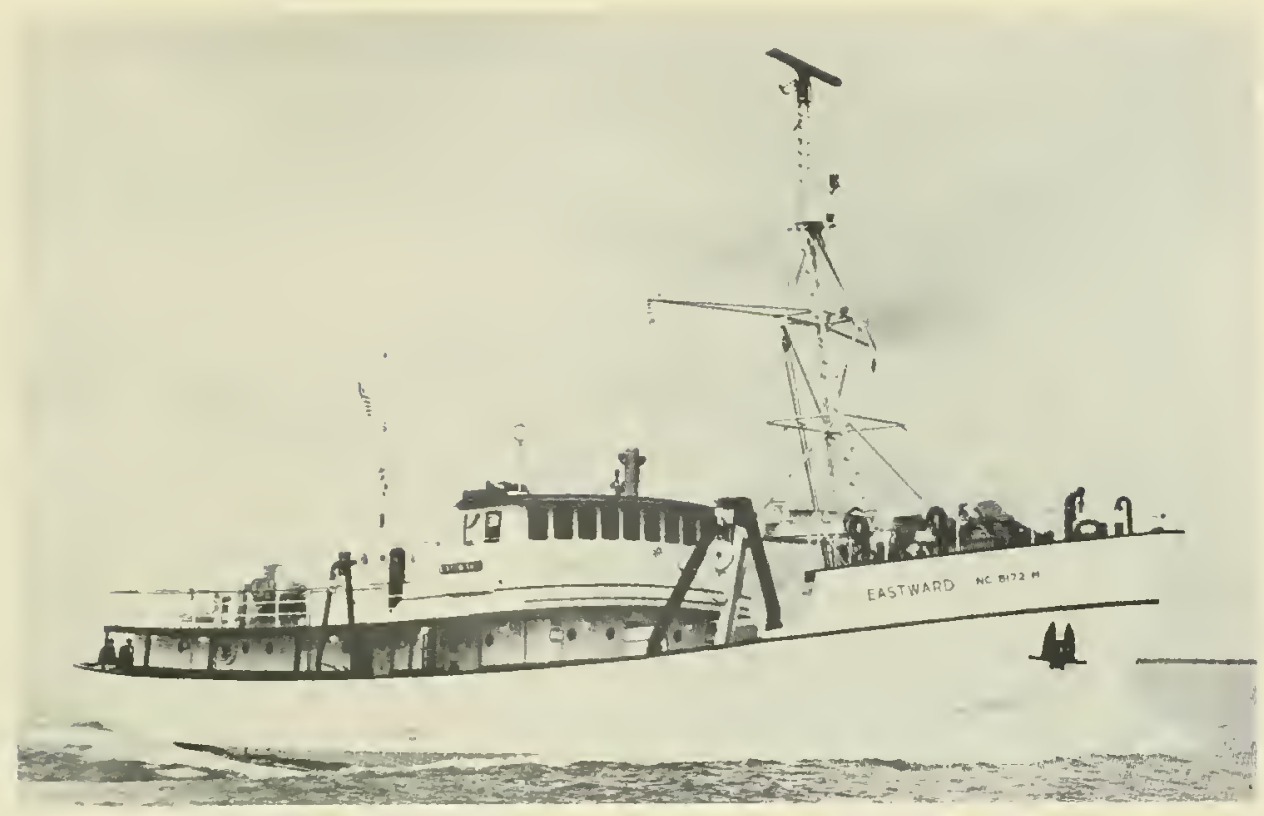

R/V Eastward

Built in 1964 at Sturgeon Bay, Wisconsin as a biological research ship. The Eastward is operated by Duke University as a national cooperative facility for the Cooperative Program of Research and Training in Biological Oceanography supported by the National Science Foundation.

Length: 117' 6" Displacement: 474 tons

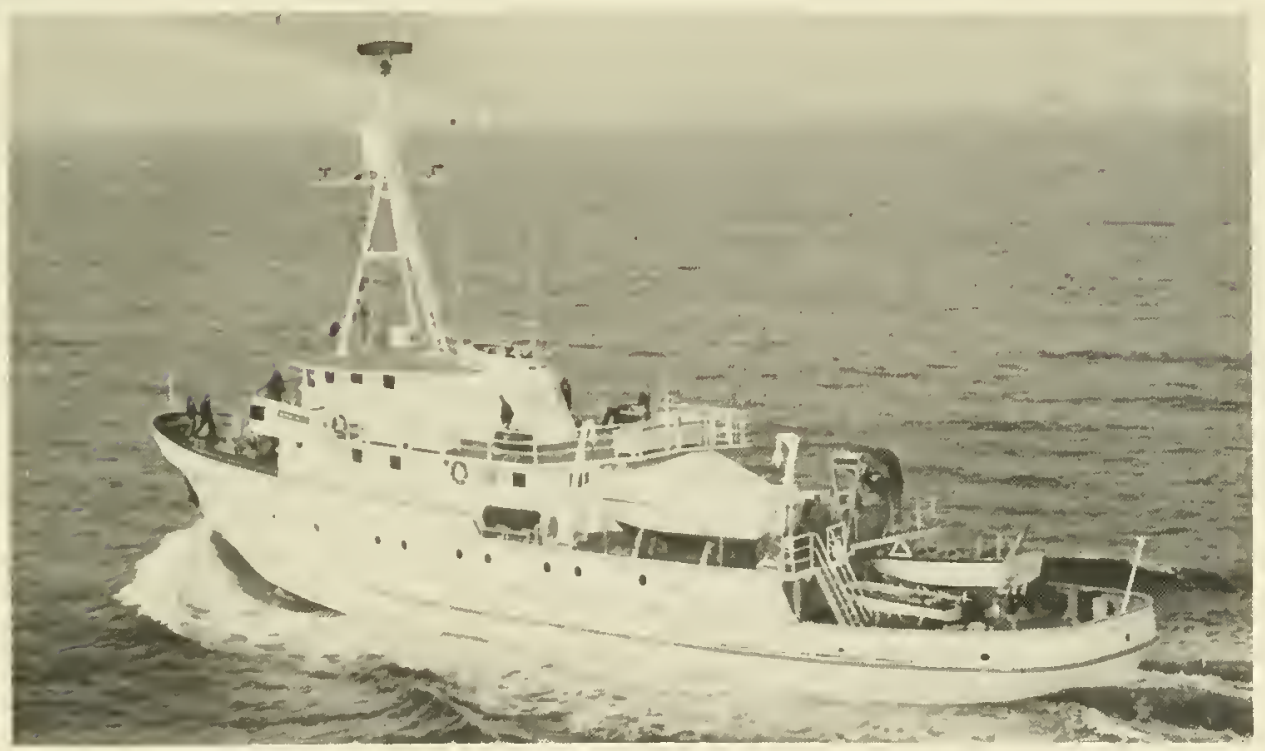

R/V Alphe Helix

Built in 1966 by J. M. Martinac Co. of Tacoma, Washington.

Operated by Scripps Institution of Oceanography as a national facility for biological research.

Length: 132' 9" Displacement: 512 tons 


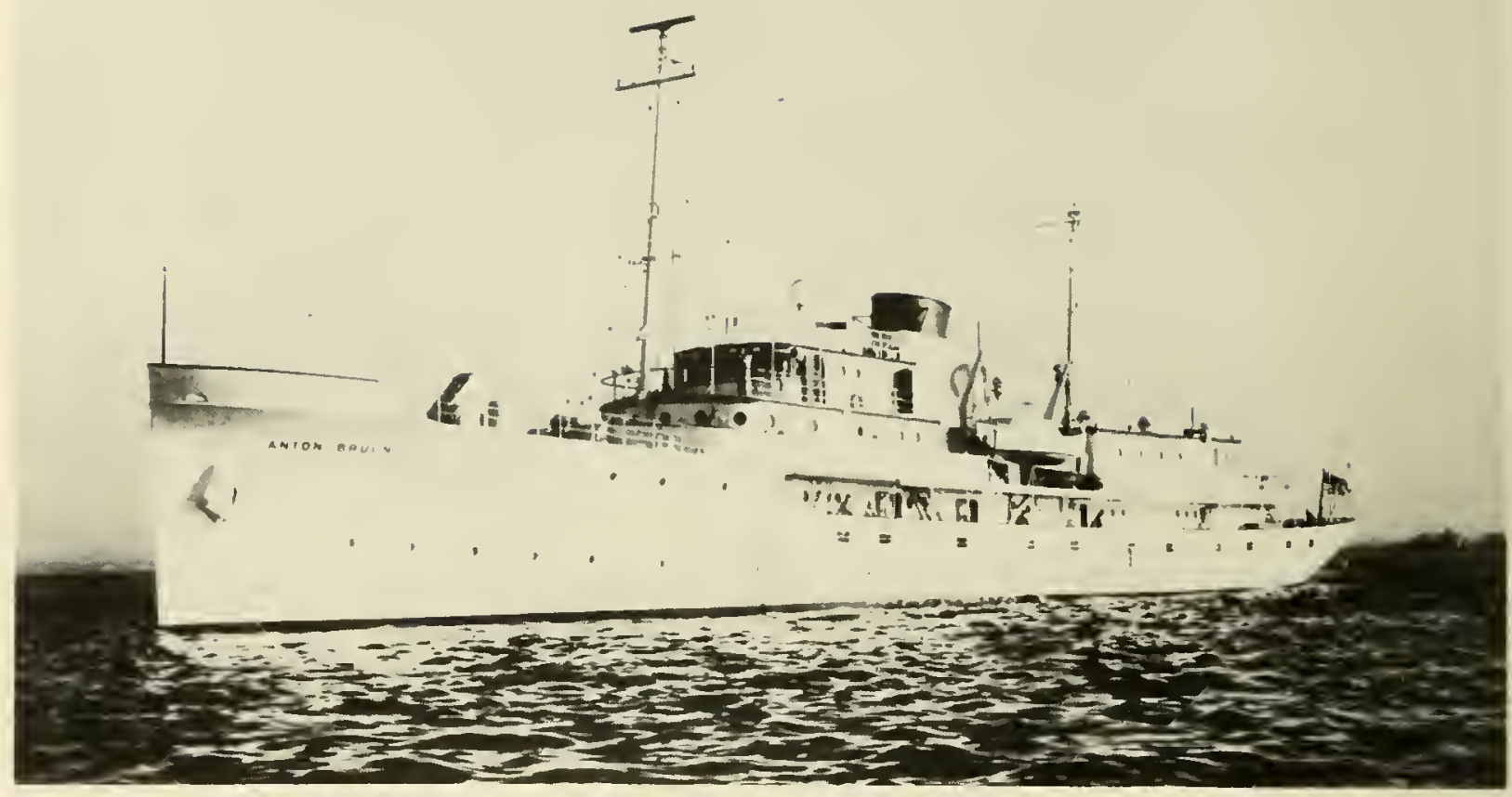

\section{R/V Anton Bruun}

Originally the private yacht Aras built in 1931 by Bath Iron Works of Bath, Maine. She was purchased by the Navy in 1941 for $\$ 250,000$ and converted to the gunboat USS Williamsburg (PG 56). After service in World War II she underwent conversion to an amphibious force flagship and her hull designation was changed to AGC 369. She then reported, in late 1945, to Washington, D.C. to serve as presidential yacht for Presidents Harry S. Truman and briefly, Dwight D. Eisenhower. Her presidential service ended in 1953 and she was laid-up until 1962 when she was then transferred to the National Science Foundation and renamed the R/V Anton Bruun. The Foundation contracted with Woods Hole Oceanographic Institution to undertake the conversion of the ship to a research vessel for participation in a 4 year Indian Ocean Expedition. In 1968, while final arrangements were being made to permanently transfer the Anton Bruun to India, a floating dry dock sunk, unfortunately, with the ship in it. Since restoration proved uneconomical, she was offered for sale by the Maritime Administration and purchased by a commercial concern with the intention of using her as a combination floating hotel-restaurant-museum on the Salem River in New Jersey.

Length: 243' 9" Displacement: 2,085 tons 


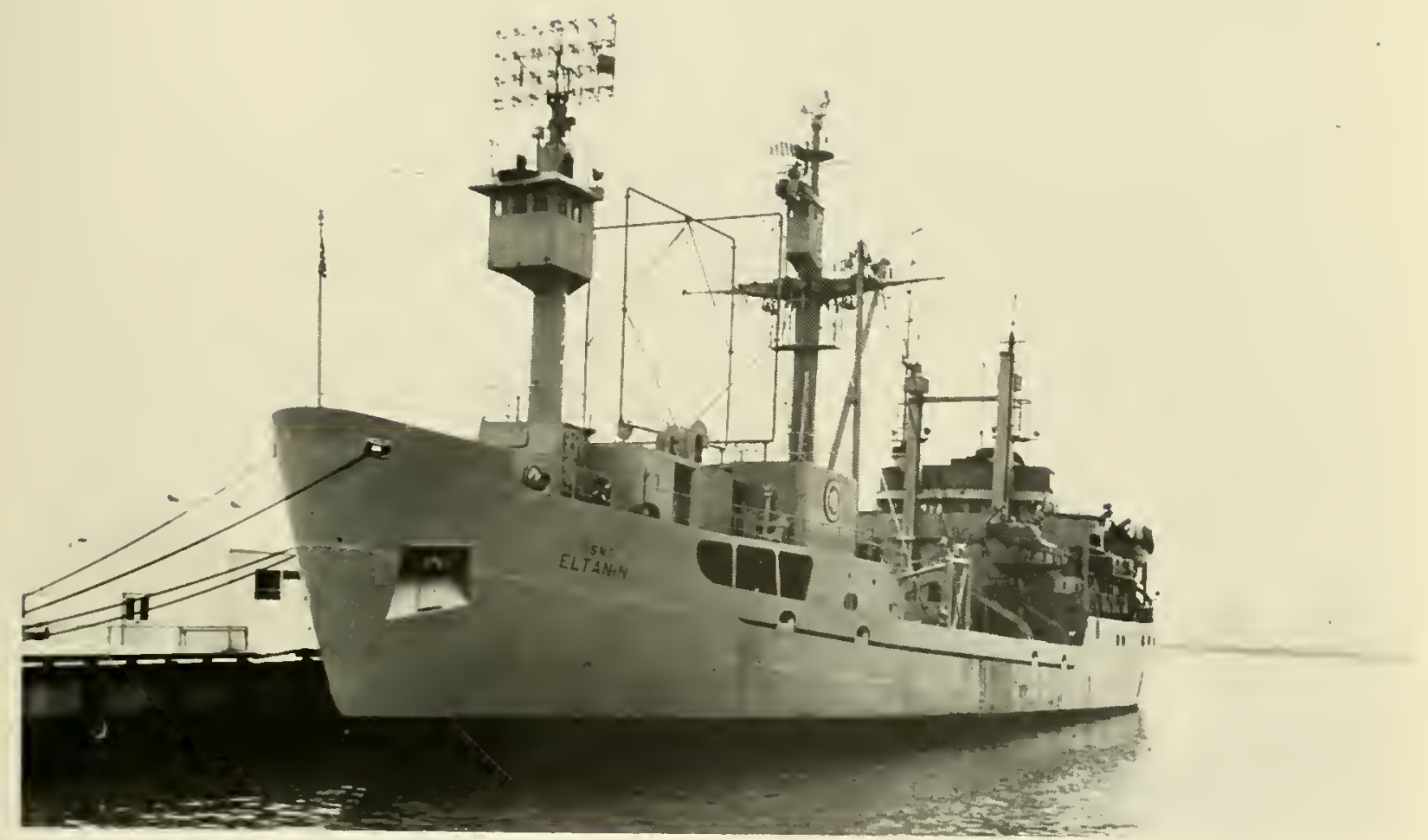

R/V Eltanin (T-AGOR 8)

Formerly the cargo ship T-AK 270 built in 1957 by Avondale Marine Ways, Inc. of Avondale, Louisiana and operated by the Military Sealift Command for Arctic supply operation. In 1962, the Eltanin was assigned to the National Science Foundation for use as a research ship in support of the Foundation's Antarctic Research Program.

Length: 266' Displacement: 3,886 tons 


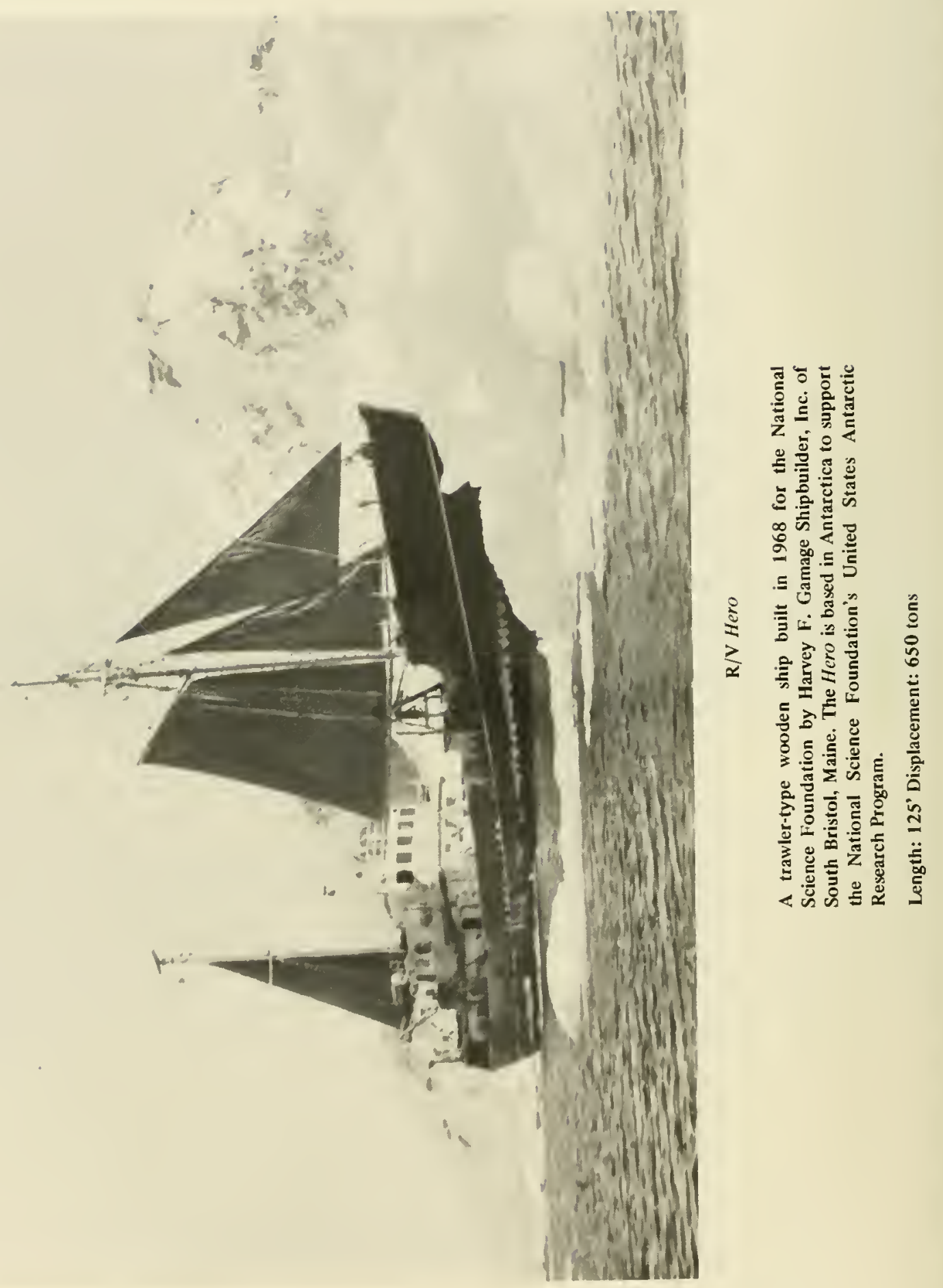




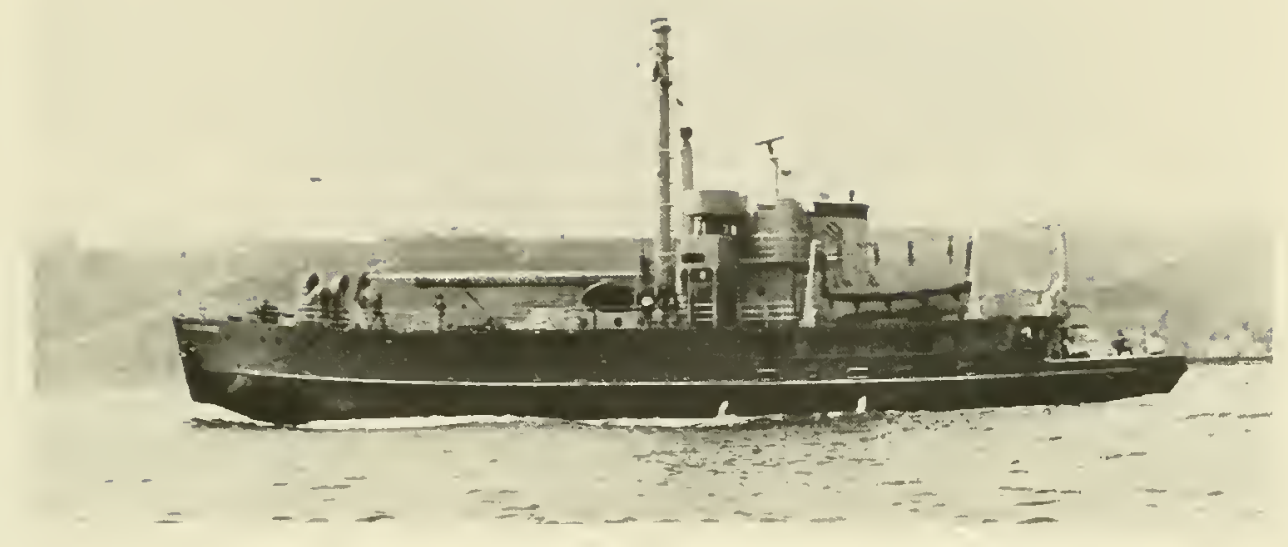

R/V Alexander Agassiz

The former U. S. Army Freight and Supply Vessel FS-208 built in 1944. Acquired by Scripps Institution of Oceanography in 1961 and converted for oceanographic research.

Length: $180^{\circ}$ Displacement: 866 tons

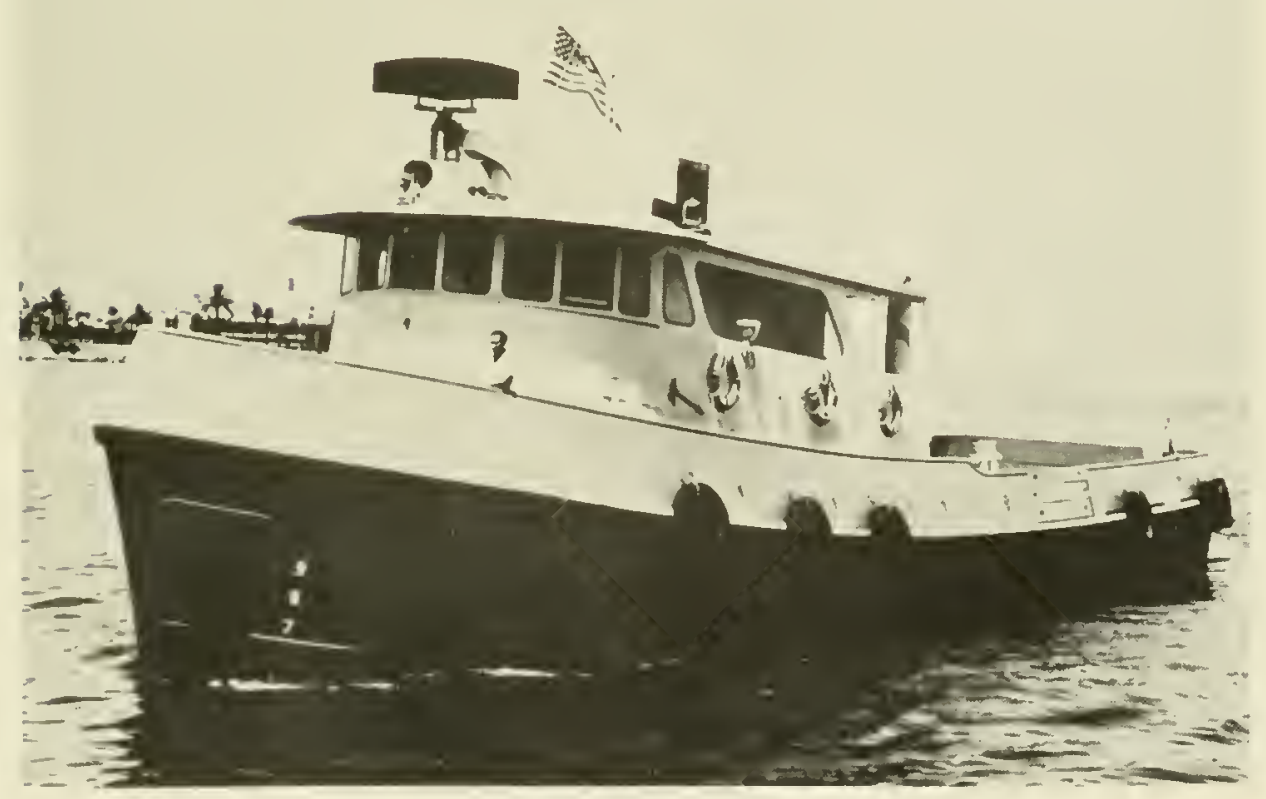

R/V Ellen B. Scripps

Built by Halter Marine Services, 1nc. of New Orleans in 1965 for offshore oil supply/work boat modified for oceanographic Scripps Institution of Oceanography. The R/V Scripps is an research.

Length: 95' Displacement: 234 tons 

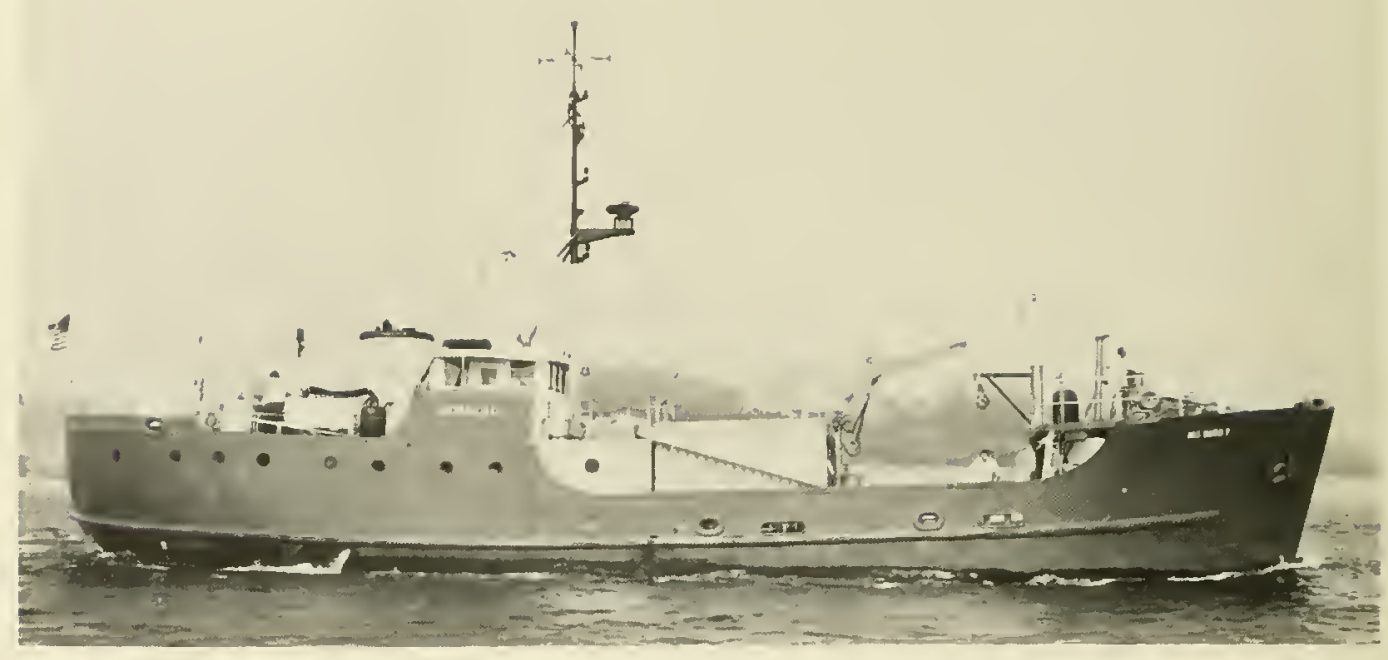

R/V Gosnold

Formerly an Army freight vessel built in 1944. Acquired by Woods Hole Oceanographic Institution in 1961 for use as an oceanographic research vessel.

Length: 99' Displacement: 300 tons

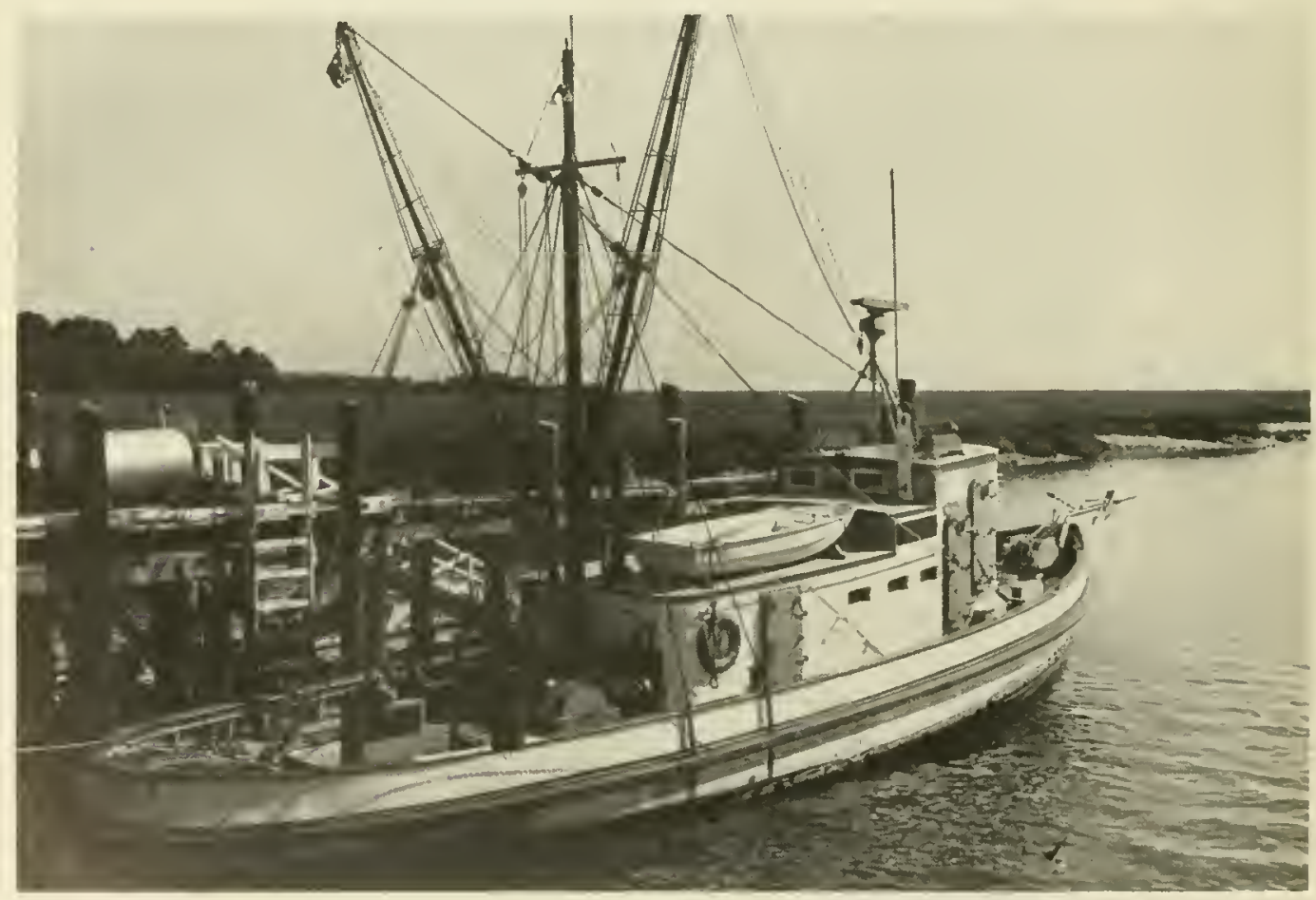

R/V Kit Jones

A former tug built in 1938 and donated to the University of Georgia in 1958 by R. J. Reynolds for use as an oceanographic research vessel.

Length: 63' 8" Displacement: 90 tons 


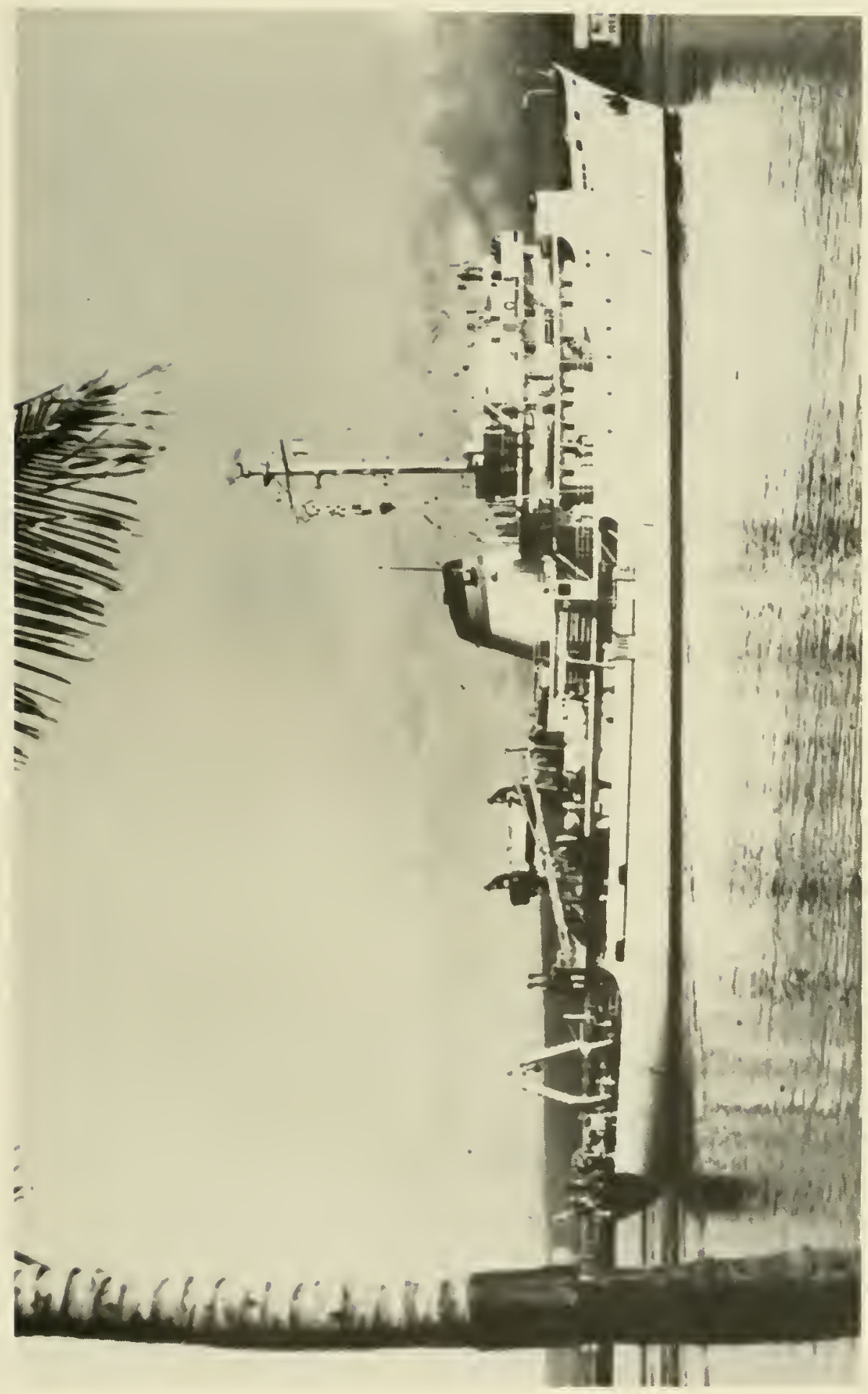

产

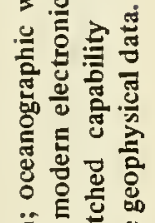

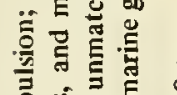

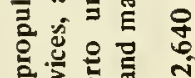

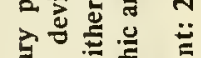

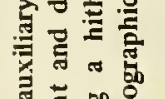

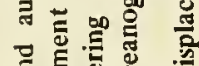

(2)

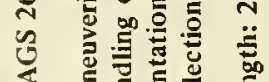

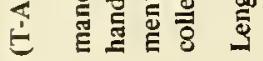

ह

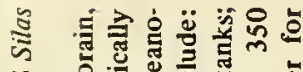

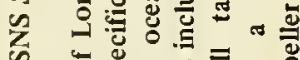

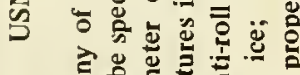

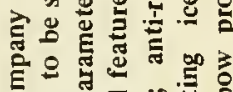

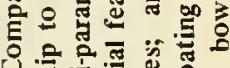

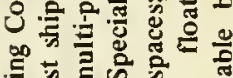

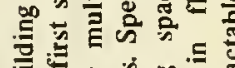

言

危药

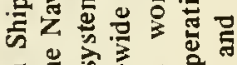

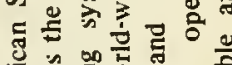

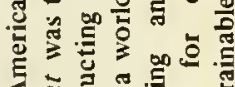

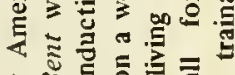

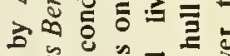

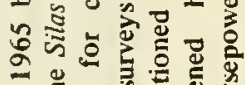

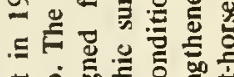

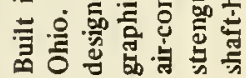




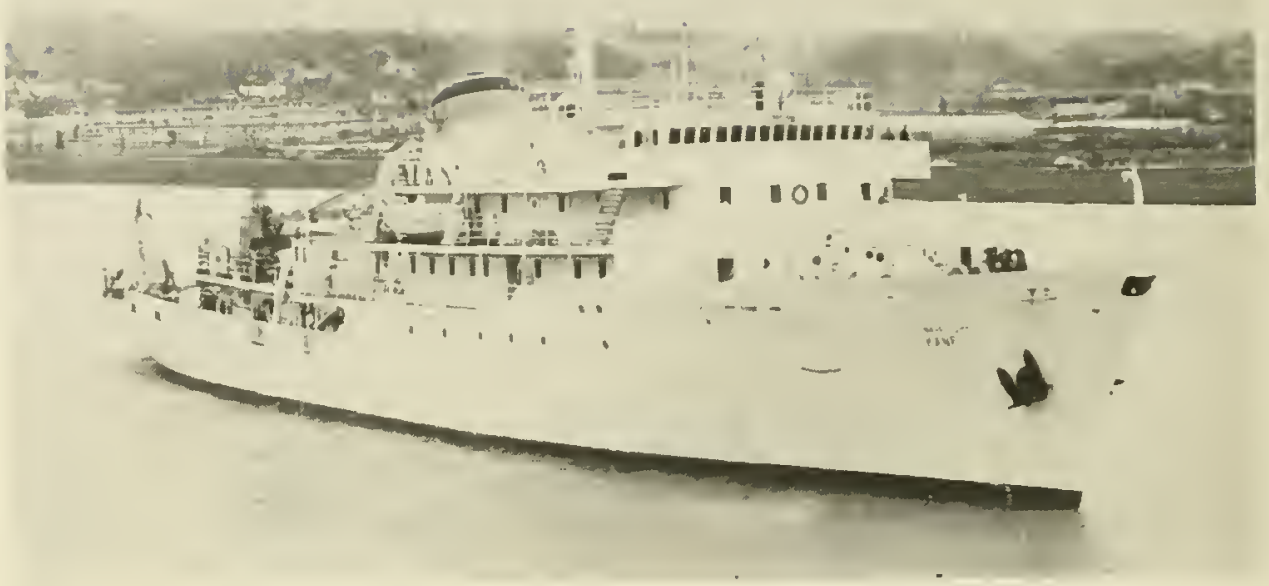

USNS Kane (T-AGS 27)

Built in 1967 by Christy Corporation of Sturgeon Bay, Wisconsin. Designed especially for oceanographic surveys, Kane is a sister ship of the USNS Silas Bent (T-AGS 26).

Length: $285^{\prime}$ Displacement: 2,640 tons

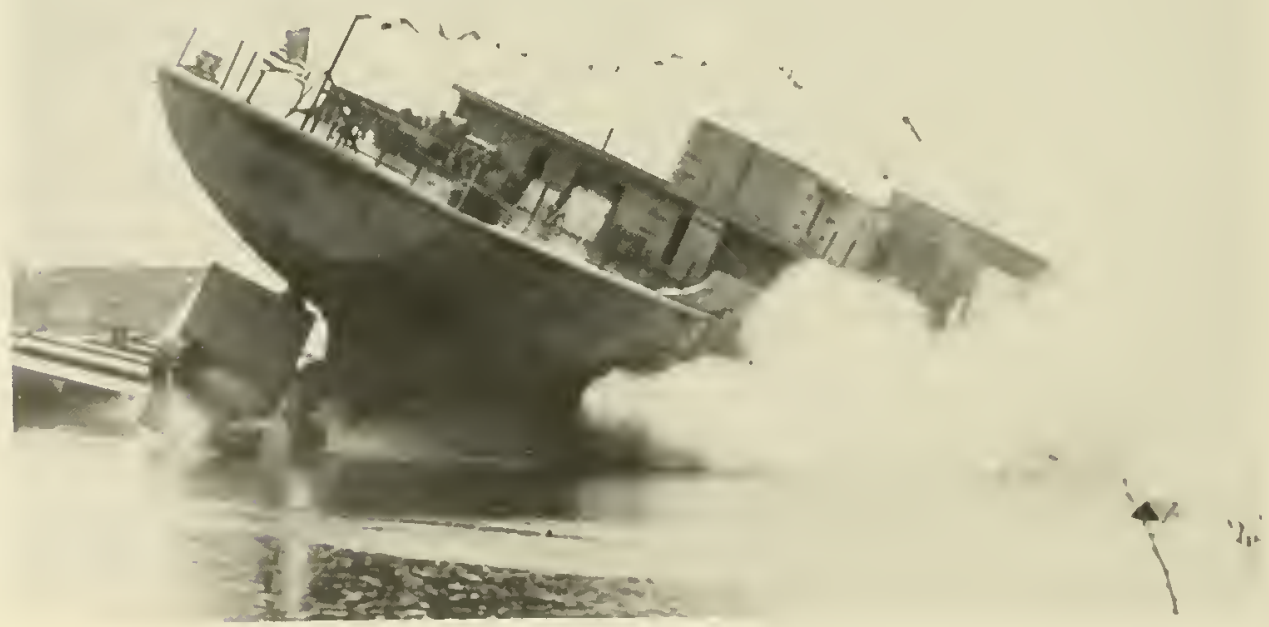

USNS wilkes (T-AGS 33)

Currently under construction by Defoe Shipbuilding Company Designed especially for oceanographic surveys, the Wilkes is a of Bay City, Michigan with delivery expected in Summer 1971. sister ship of the USNS Silas Bent (T-AGS 26).

Length: $285^{\prime}$ Displacement: 2,600 tons 


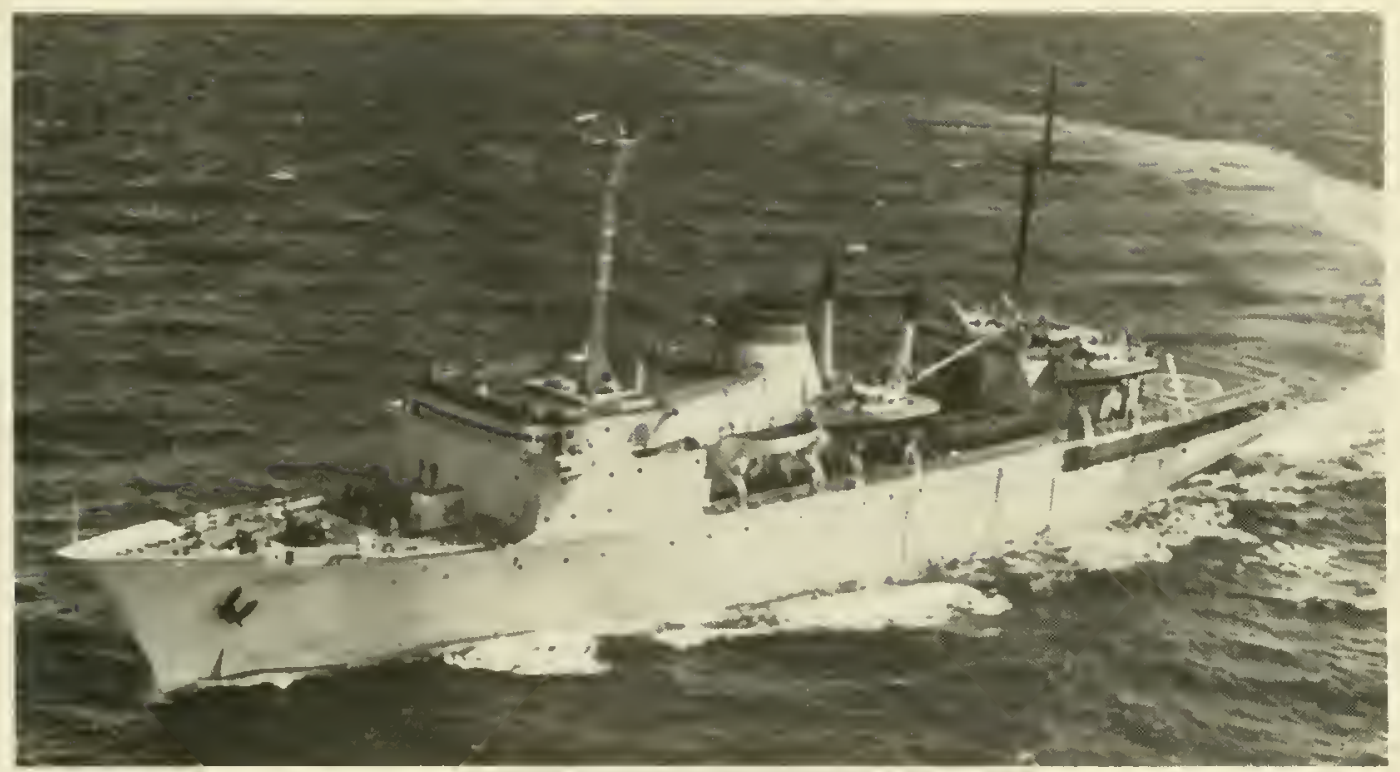

USNS Chauvenet (T-AGS 29)

Built in 1970 by Upper Clyde Shipbuilders of Glasgow, Scotland, the Chauvenet is the Navy's first ship especially designed to support coastal hydrographic surveys. Carried onboard are four 36-foot survey launches, two helicopters, a combined naval/civilian hydrographic survey detachment, chart production and printing facilities, and a Marine Corps coastal survey team complete with their landing vehicles, trucks and jeeps.

\section{Length: 393 Displacement: 4,200 tons}

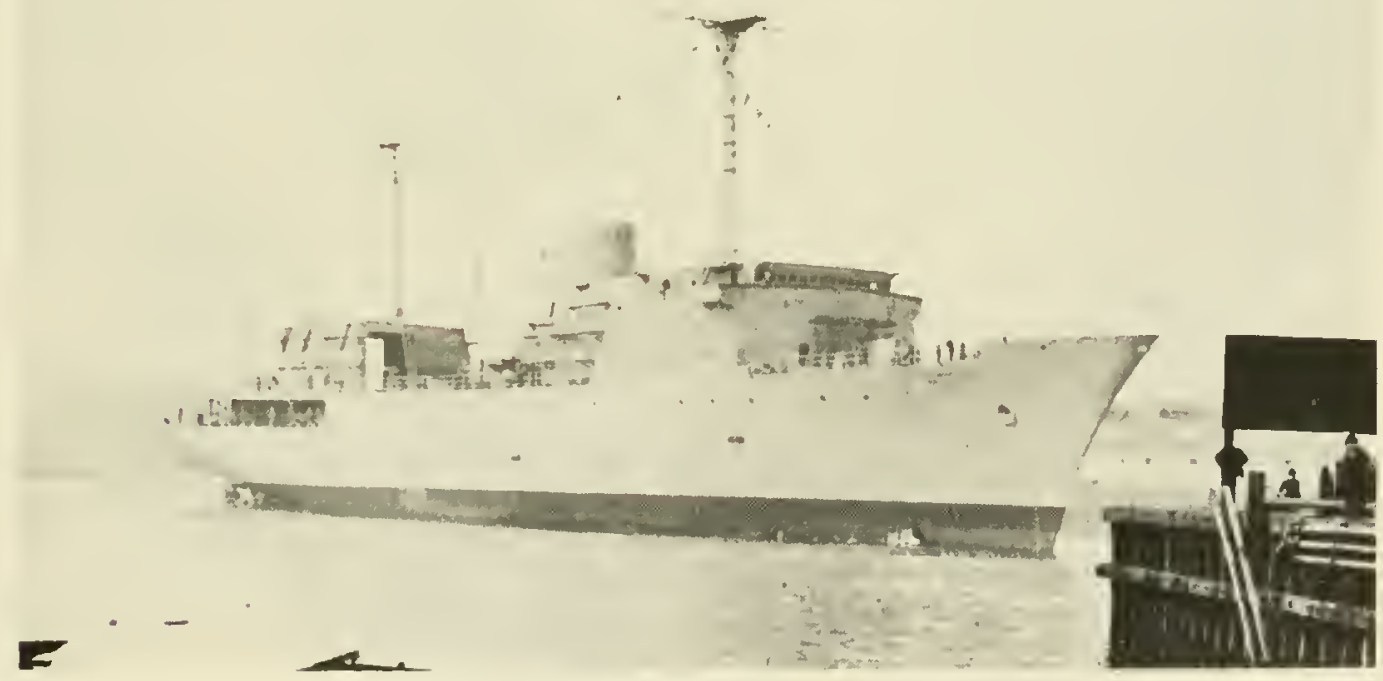

USNS Harkness (T-AGS 32)

Built in 1971 by Upper Clyde Shipbuilders of Glasgow, (T-AGS 29), was especially designed to support coastal hydro. Scotland, the Horkness, like her sister ship USNS Chauvenet graphic surveys. 


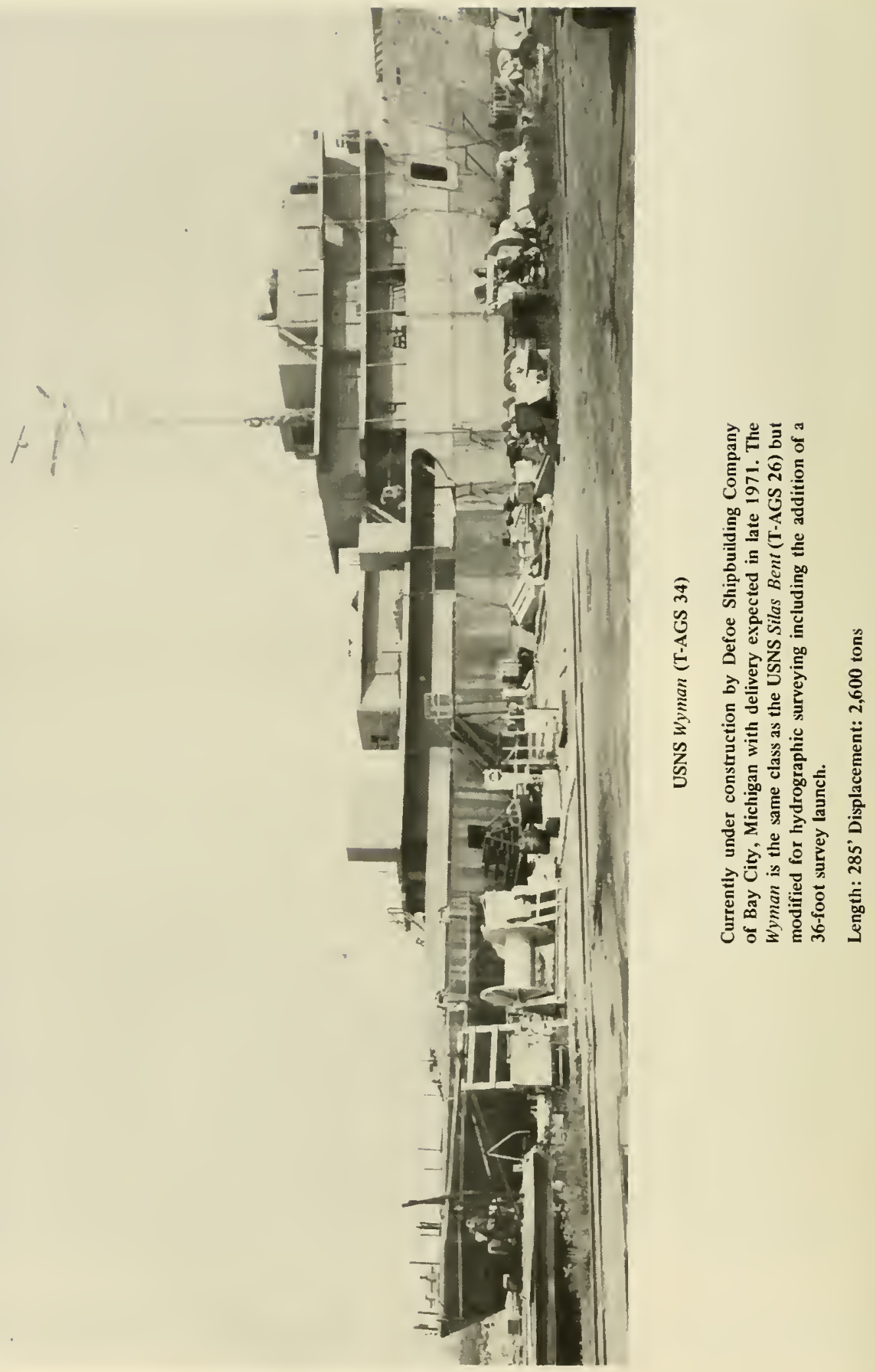




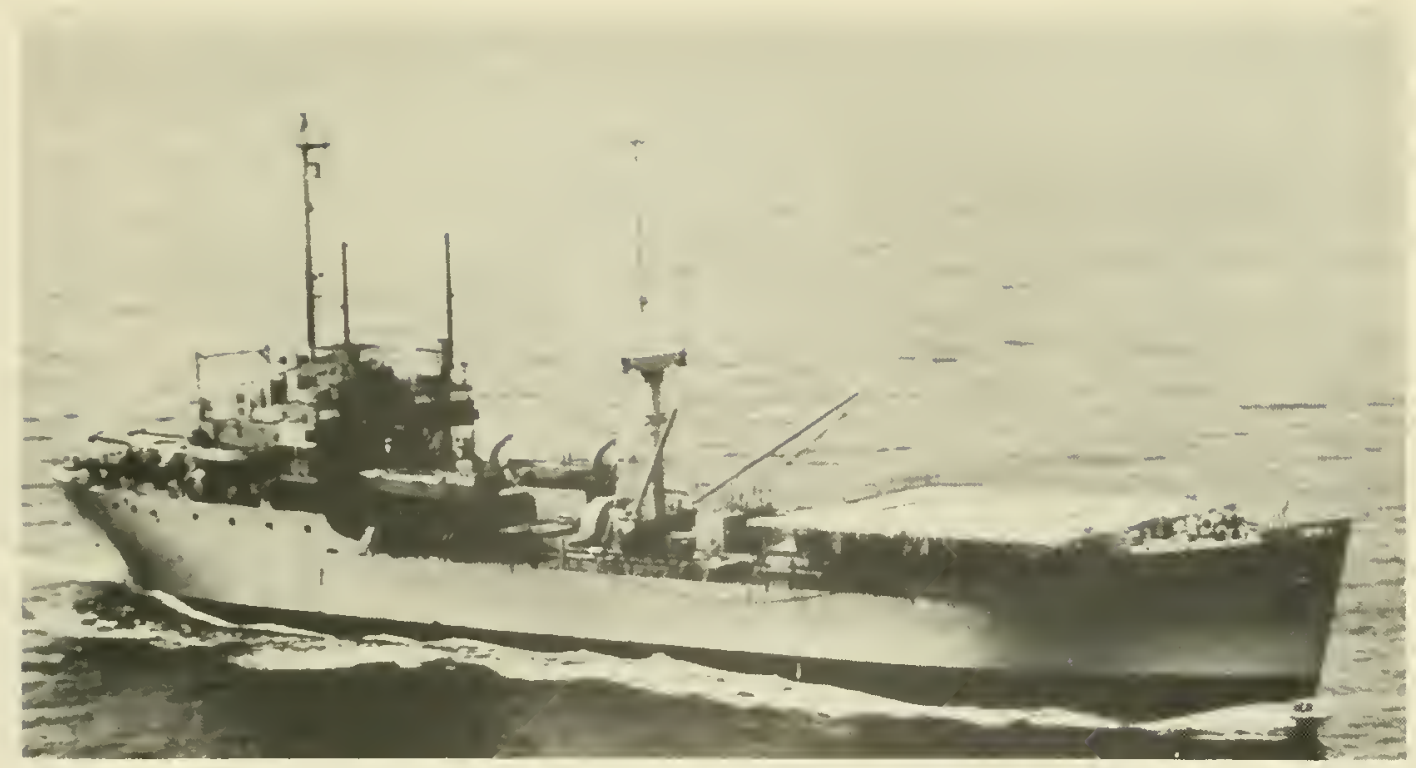

USNS Sgt. Curtis F. Shoup

(T-AG 175)

Originally a modified Cl-MA-VI cargo ship (named Spindle Eye) fleet. In 1963 Shoup was converted to an oceanographic ship at built in 1945 and configured to transport press correspondents covering World War Il. But the war ehded before she entered service and most of her early career was spent in the reserve

Williamette Iron and Steel Company of Portland, Oregon. Until she was stricken from the active ship list in January 1970, Shoup was engaged primarily in ocean gravity surveys

\section{Length: $338^{\prime} 8^{\prime \prime}$ Displacement: 5,835 tons}

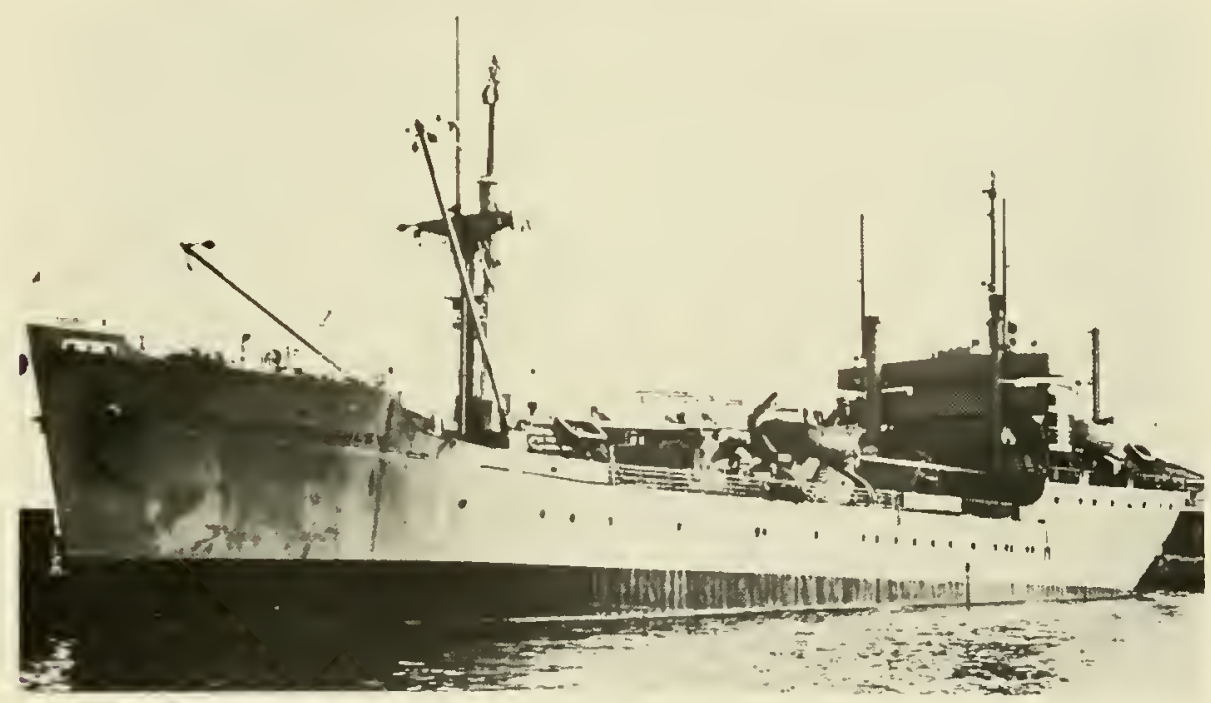

USNS Sgt. George D. Keathley

(T-AGS 35)

Formerly the transport ship APC-117 (Maritime Administration hull type C1-MA-V1) built in 1945. In 1967 she was converted to an ocean gravity survey ship and reclassified T-AGS 35 .

Length: $338^{\prime}$ Displacement: 6,090 tons 


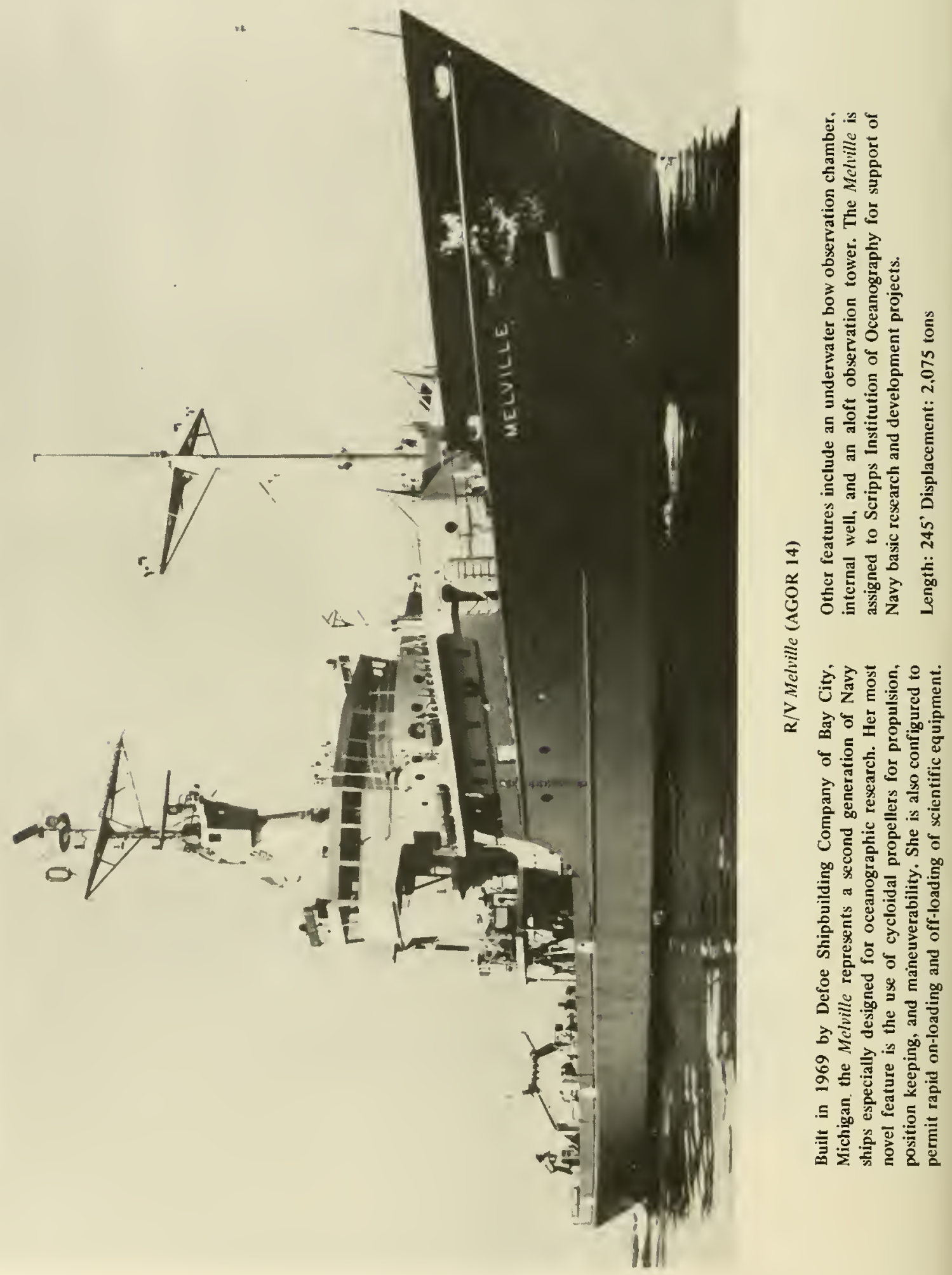




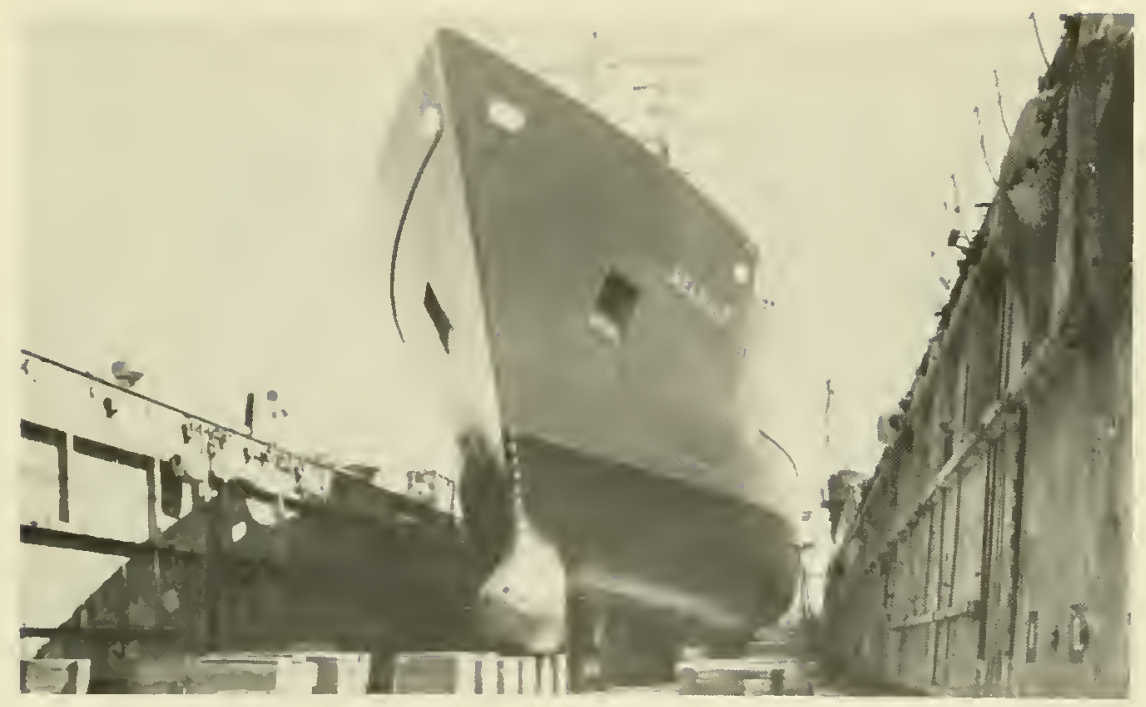

$\mathrm{R} / \mathrm{V}$ Melville (AGOR 14) in drydock - shown are the underwater bow observation chamber and forward cycloidal propeller.

Courtesy of James Pollack, Scripps Institution of Oceanography

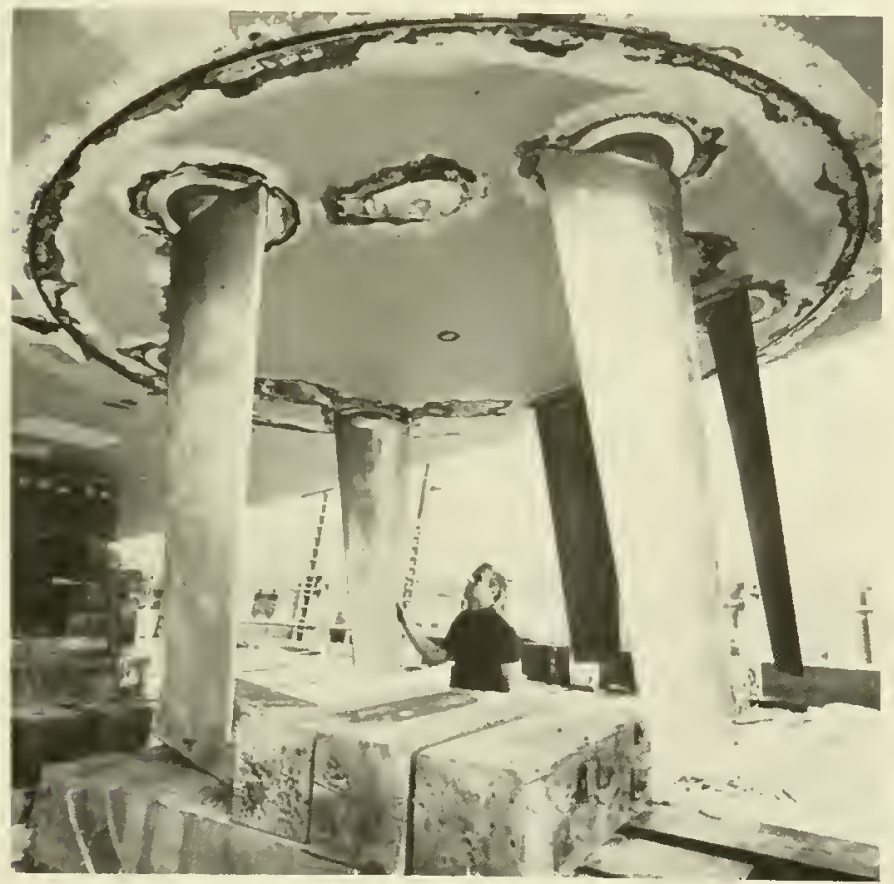

R/V Melville (AGOR 14) - Aft Cycloidal Propeller. To provide maximum directional control at zero speeds and lateral translation control in high sea states, a cycloidal propeller is provided at each end of the ship driven by a single 2,500 horsepower diesel engine located amidships. Essentially these propellers may bc compared to paddle wheels installed vertically rather than horizontally and which have feathering blades, similar to the feathering propellers of airplanes. This makes it possible to steer as well as propel the ship. By feathering the blades thrust can be delivered in any direction, thus the ship needs no rudder. Maneuverability is obtained through actual finger-tip control of both forward and aft cycloidal propellers giving control of both direction and magnitude of thrust.

Courtesy of James Pollack, Scripps Institution of Oceanography 

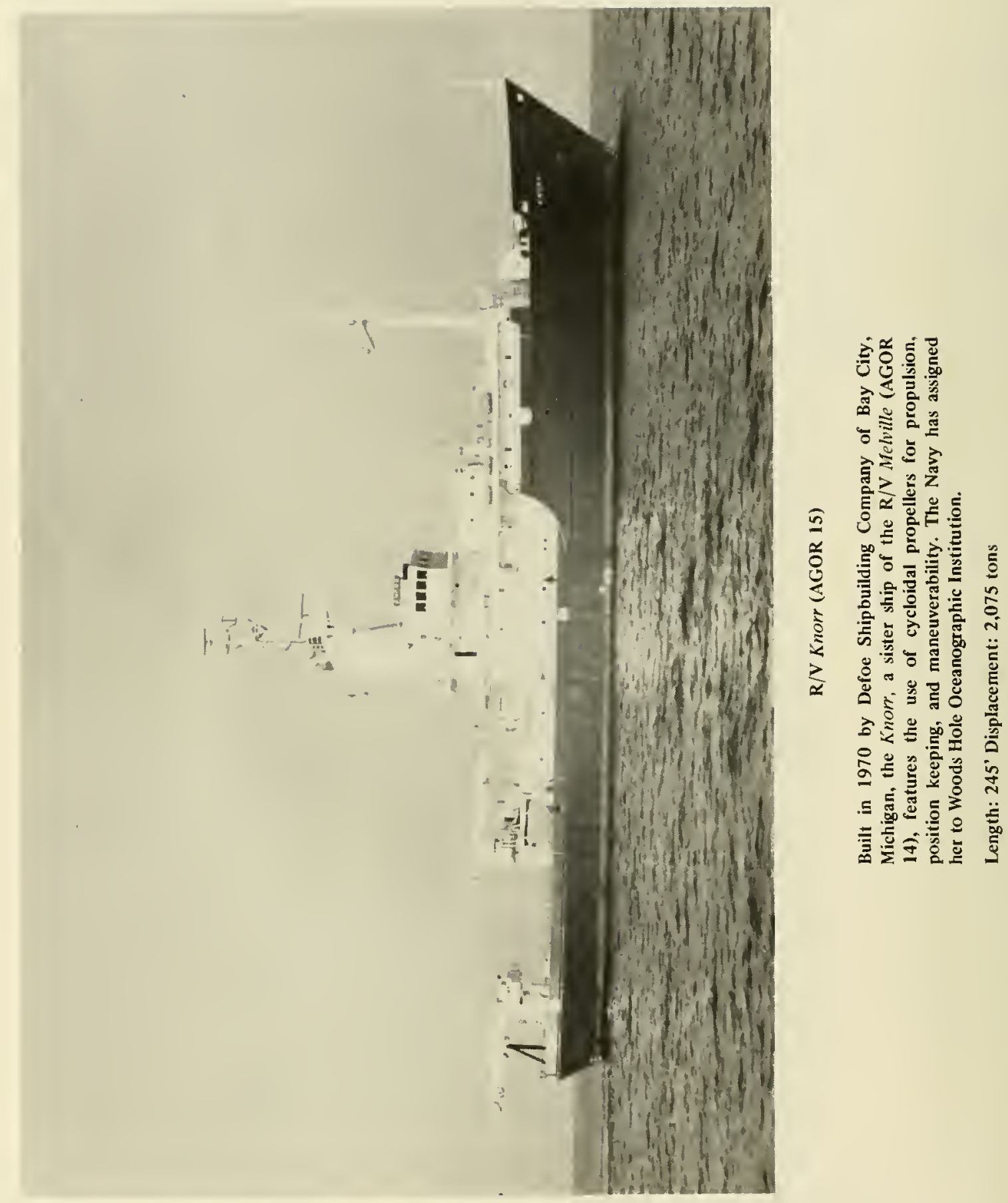


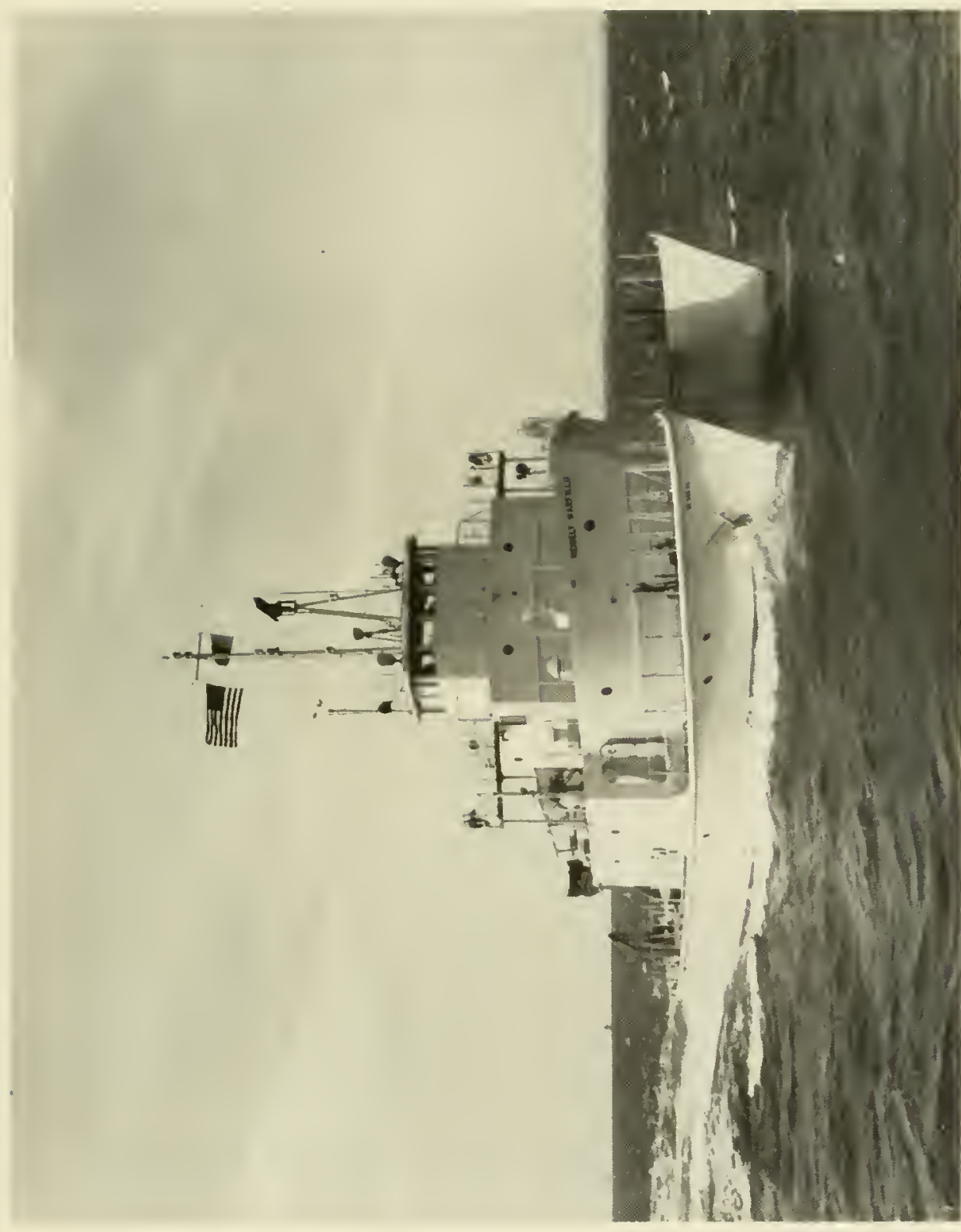

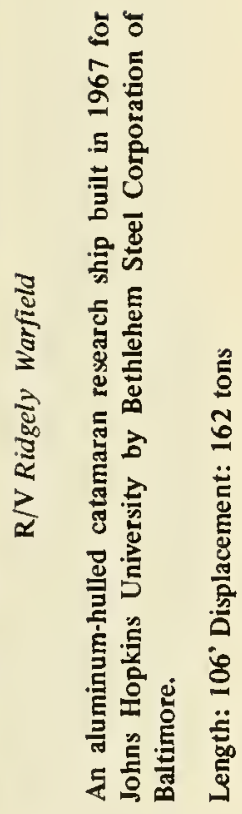



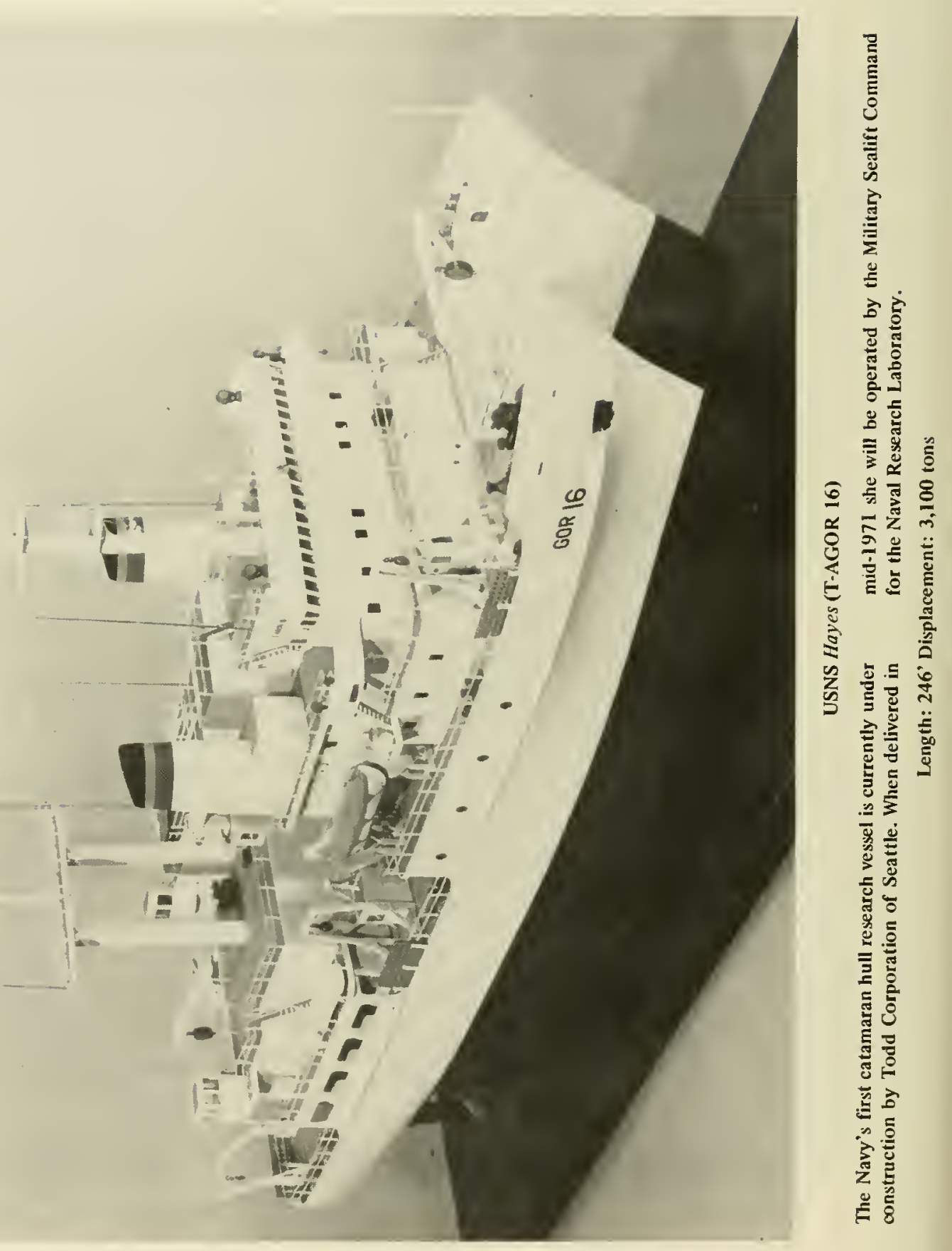


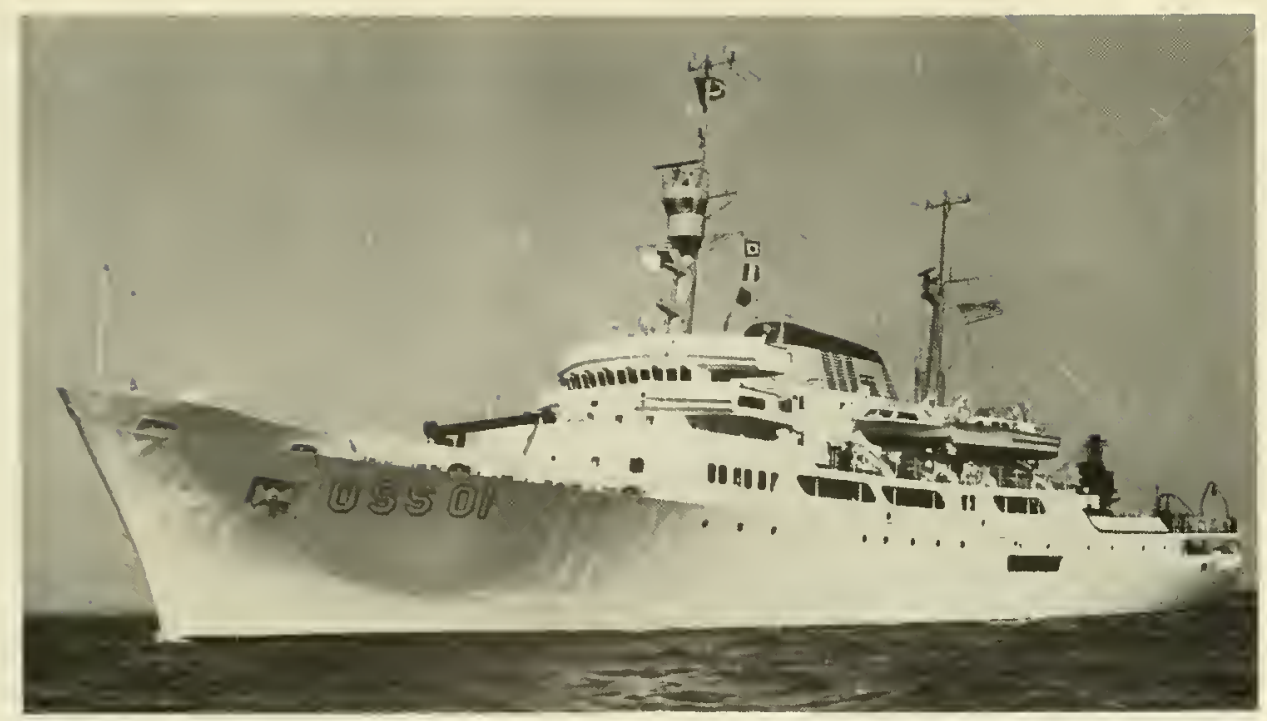

USNOSS Oceanographer (OSS 01)

An ocean survey ship built in 1966 for the National Ocean Survey by Aerojet-General Shipyard of Jacksonville, Florida. Oceanographer and her sister ship Discoverer (OSS 02) are the largest ships in the Survey's fleet.

Length: 303' Displacement: 3,959 tons

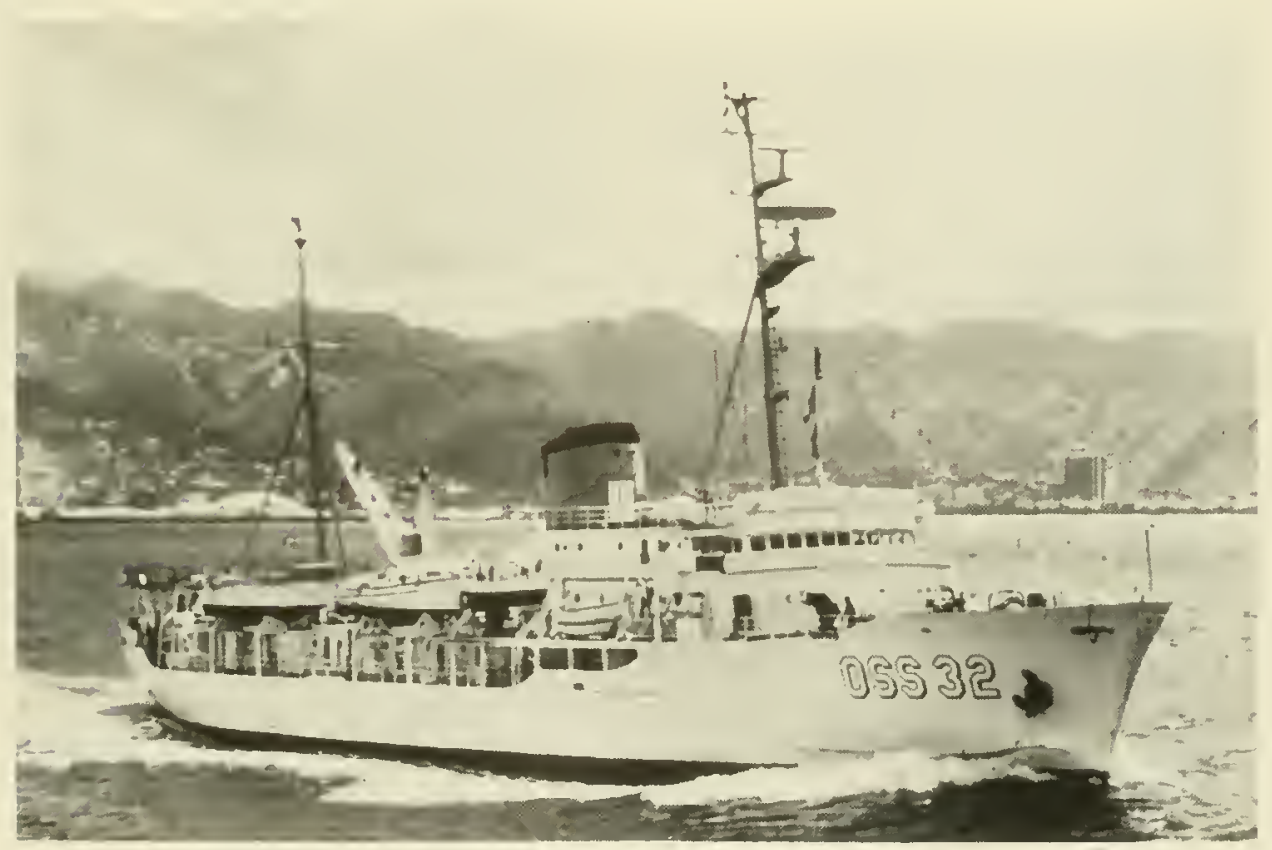

USNOSS Surveyor (OSS 32)

Built in 1960 by National Steel and Shipbuilding Corportion of San Diego for the National Ocean Survey. The Surveyor operates out of Seattle.

Length: 292' Displacement: 3,150 tons 


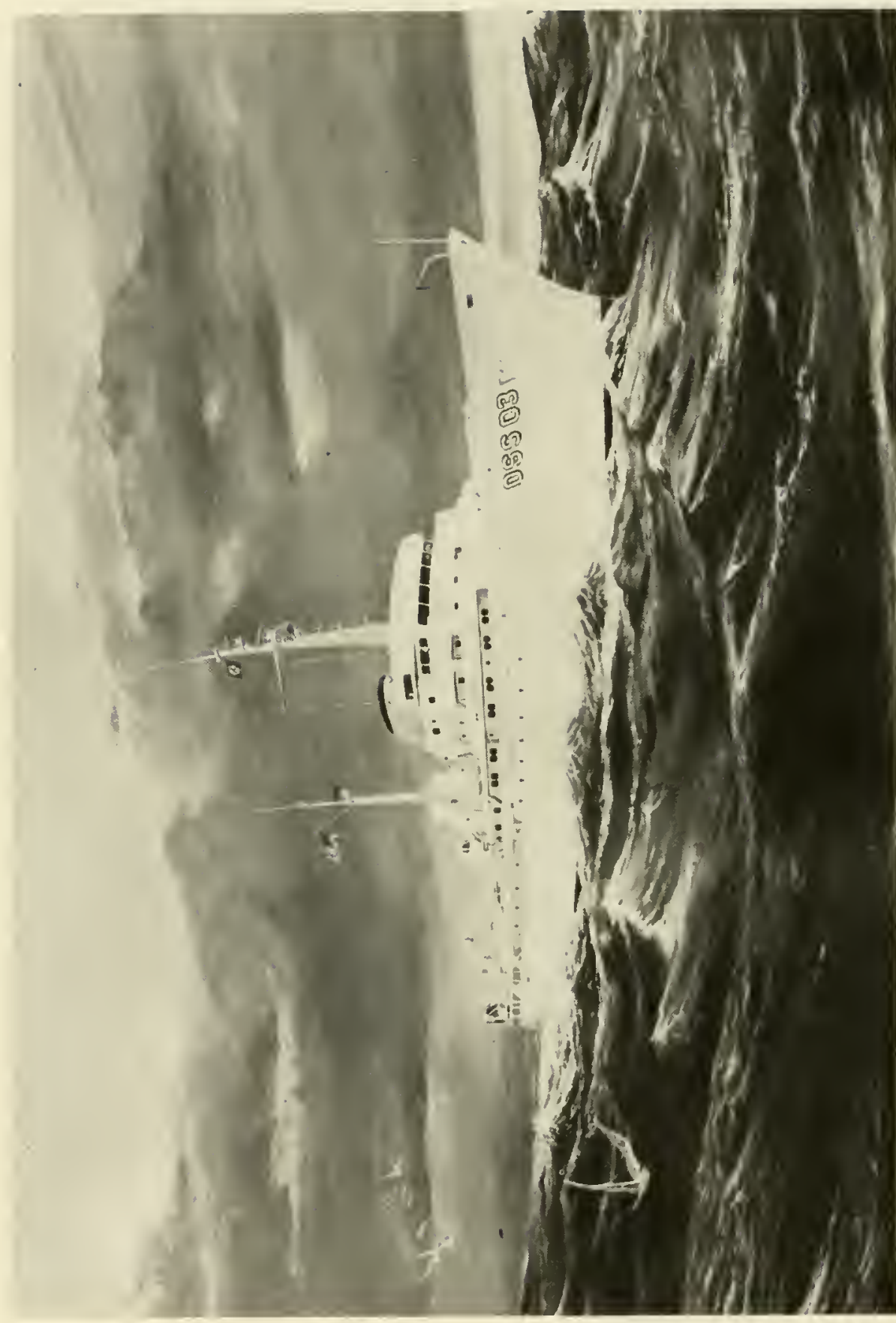

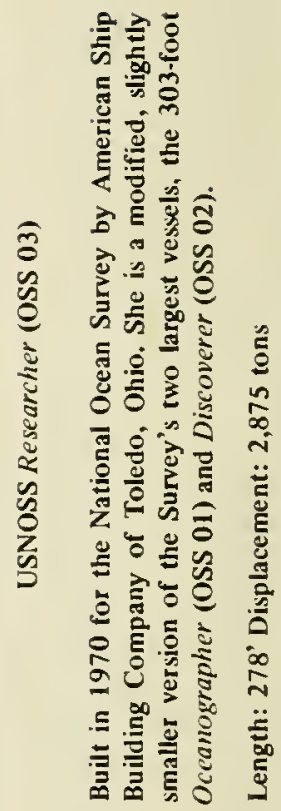




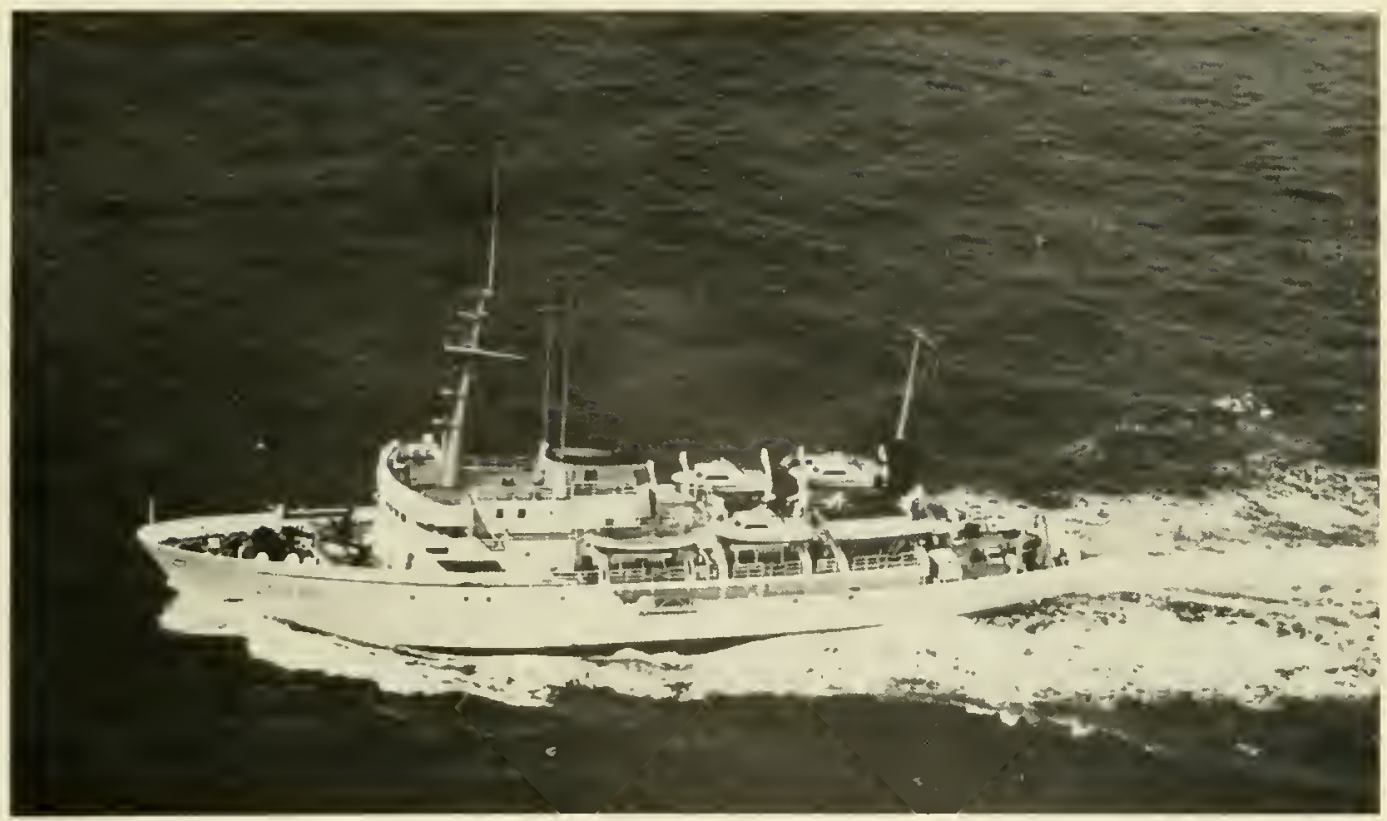

USNOSS Mt. Mitchell (MSS 22)

This medium class survey ship was built in 1967 for the National Norfolk, Virginia. Her sister ships, the Fairwcather (MSS 20) and Ocean Survey by Aerojet-General Shipyards of Jacksonville, Rainier (MSS 21), are based at the Survey's Pacific Marine Florida. Her home port is the Survey's Atlantic Marine Center in Center in Seattle.

Leng th: 231' Displacement: 1,798 tons

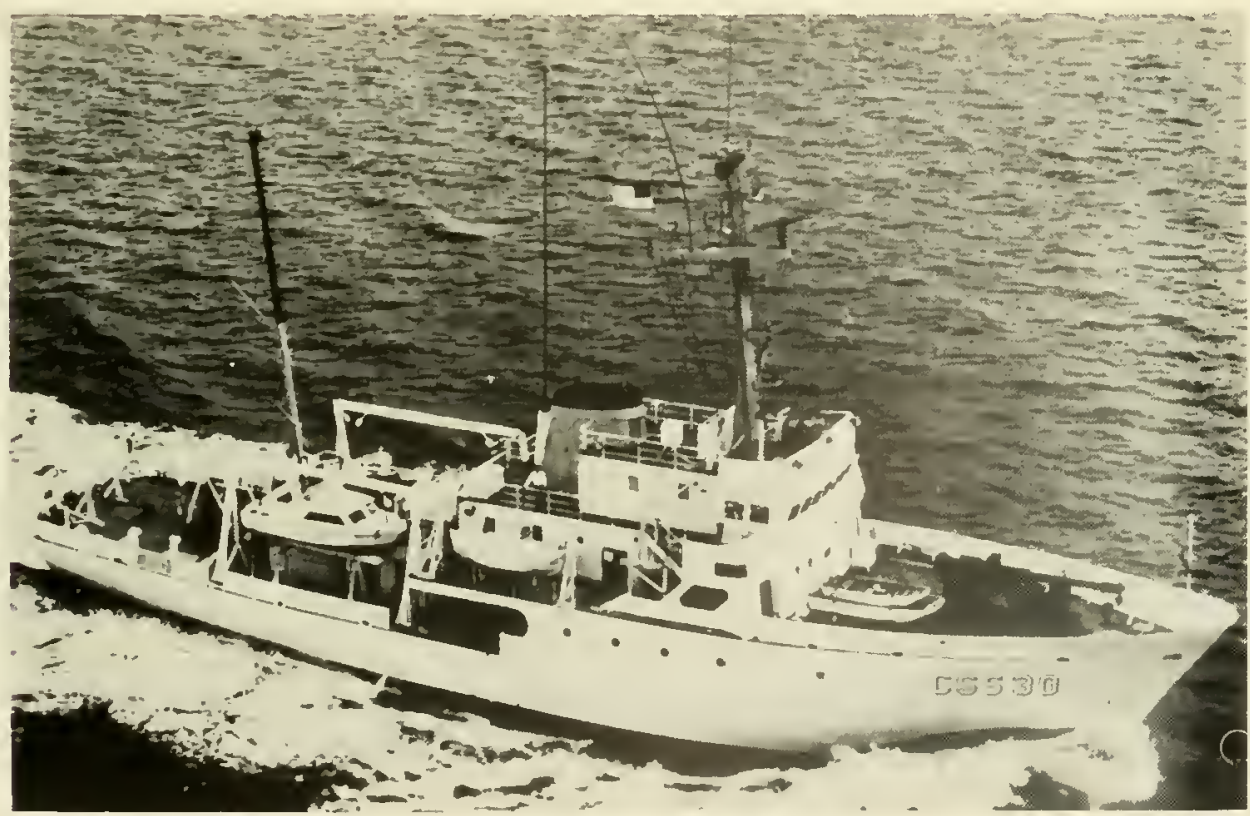

USNOSS M/CArlhur (CSS 30)

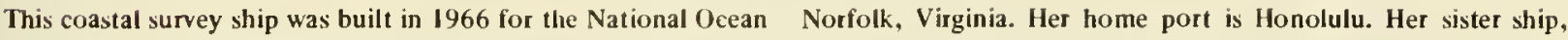
Survey by Norfolk Shipbuilding and Drydock Corporation of the Davidson (CSS 31), is based at Seattle.

Length: 175' Displacement: 995 tons 


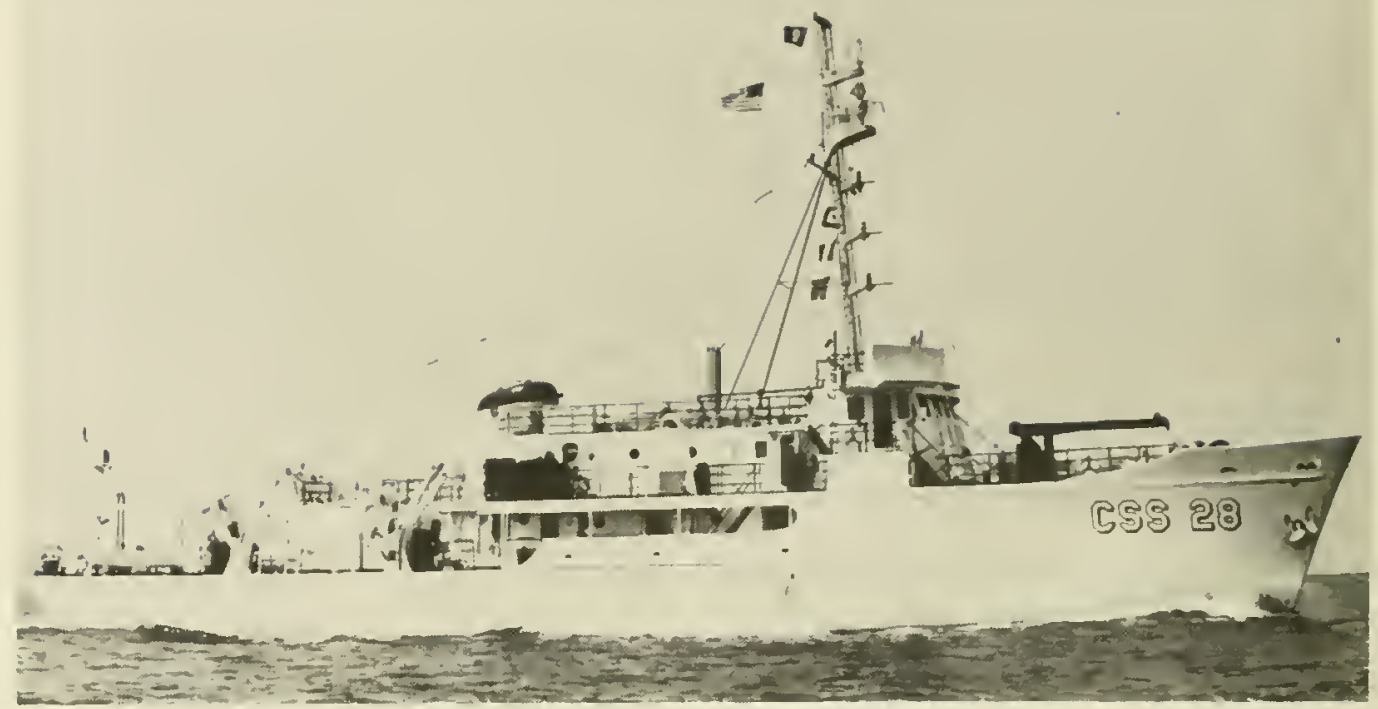

USNOSS Pierce (CSS 28)

The coastal survey ship Pierce was built for the Survey in 1963 Virginia. She and her sister ship, the Whiting (CSS 29), are based by Marietta Manufacturing Company of Point Pleasant, West at Norfolk, Virginia.

Length: 164' Displacement: 760 tons

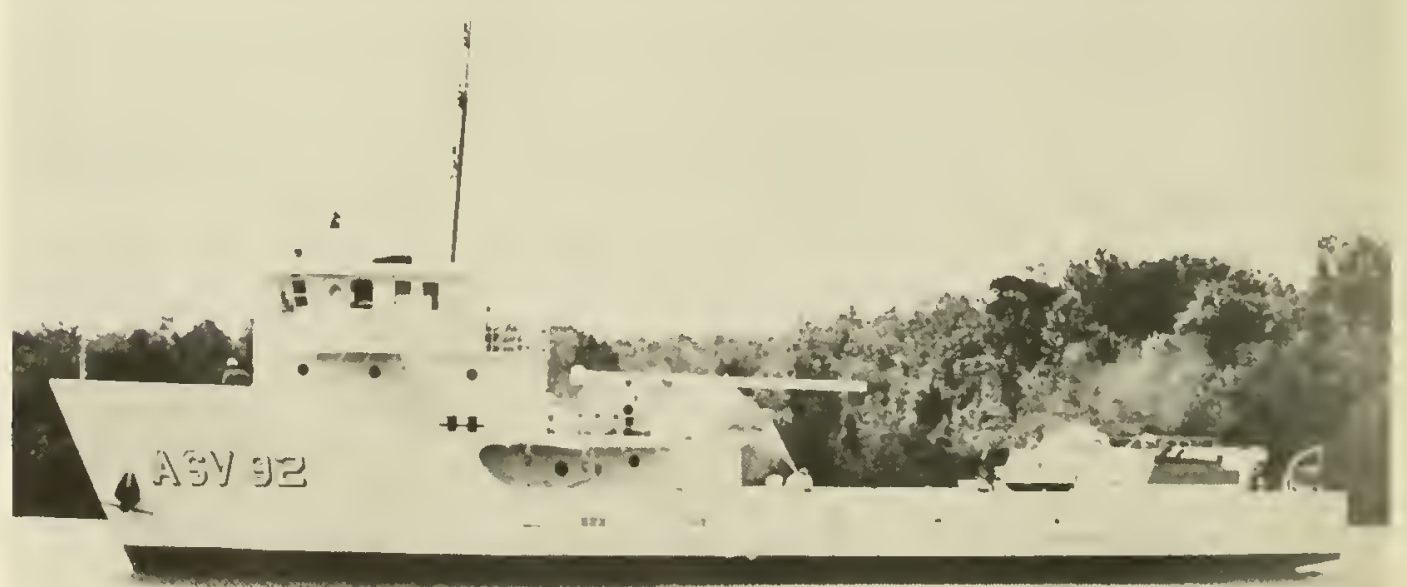

USNOSS Ferrel (ASV 92)

An auxiliary survey vessel built in 1968 for the National Ocean Survey by Zigler Shipyards of Jennings, Louisiana. Home-ported at the Survey's Atlantic Marine Center in Norfolk, Virginia, the
Ferrel is primarily used for measuring coastal and estuarine current.

Length: $133^{\circ} 3^{\prime \prime}$ Displacemcnt: 363 tons 


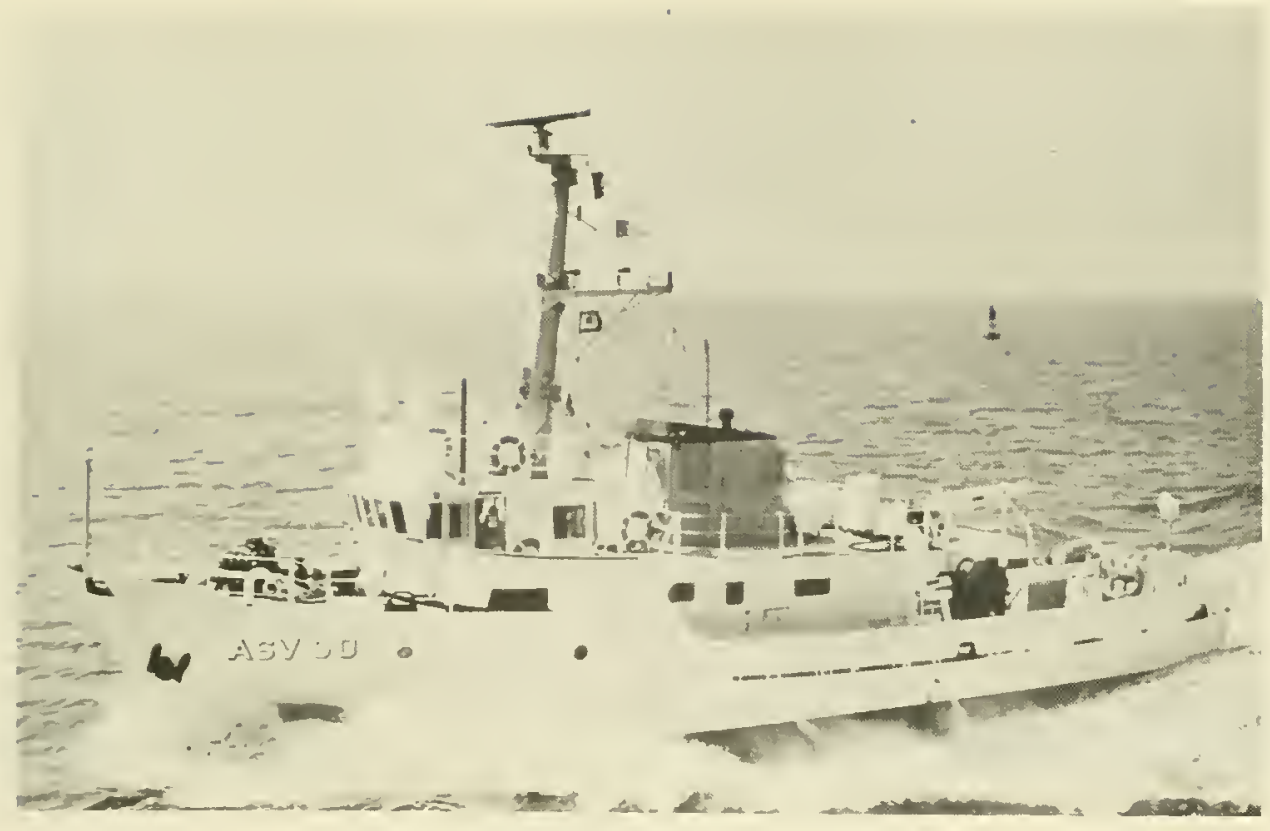

USNOSS Rude (ASV 90)

The Rude and her sister ship Heck (ASV 91) were built by these twin ships, like their predecessors the Wanwright and Jakobson Shipyard of Long 1sland in 1967 for the National Hilgard, share one commanding officer.

Ocean Survey. Specifically built for wire dragging operations, Length: 90 ' Displacement: 214 tons

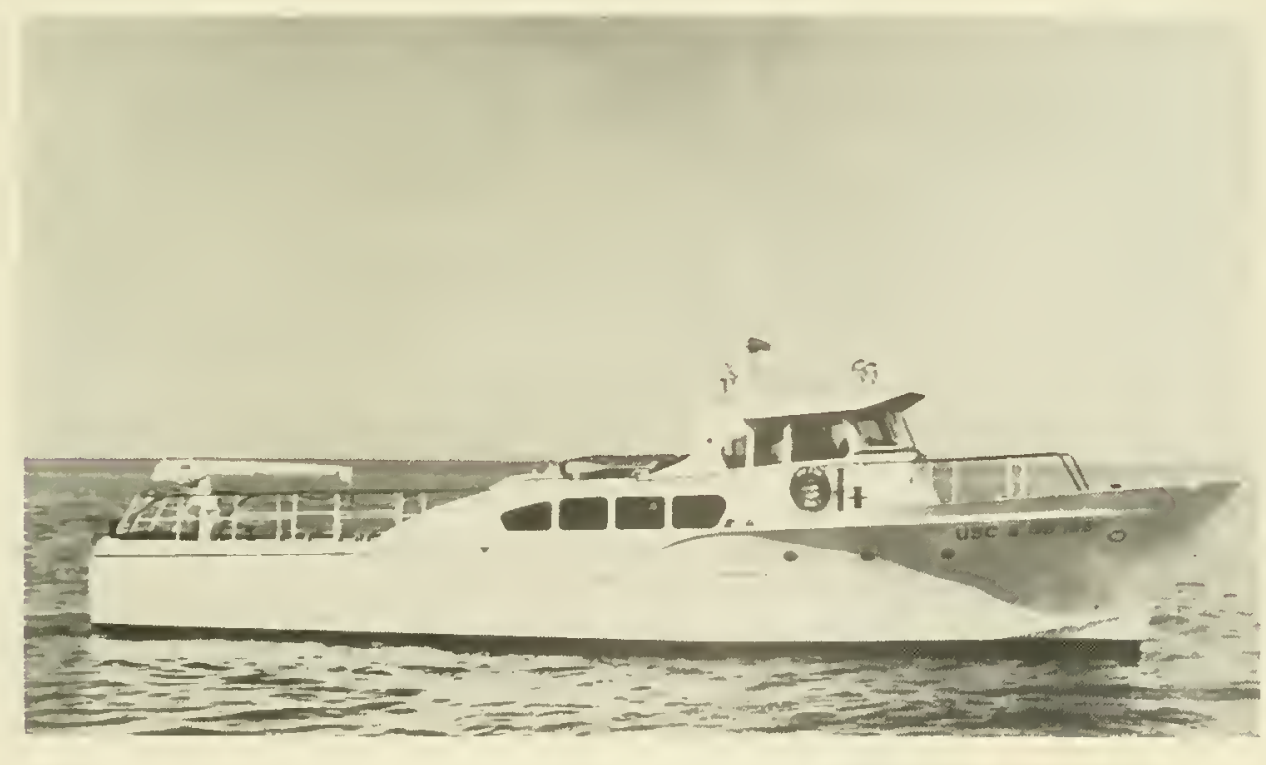

\section{NATIONAL OCEAN SURVEY LAUNCH \#1255}

Built in 1968, the Survey's Launch \#1255, and her sister launch $\# 1257$, are used for high-speed hydrographic sounding and buoy tending.

Length: 59' Displacement: 41 tons 


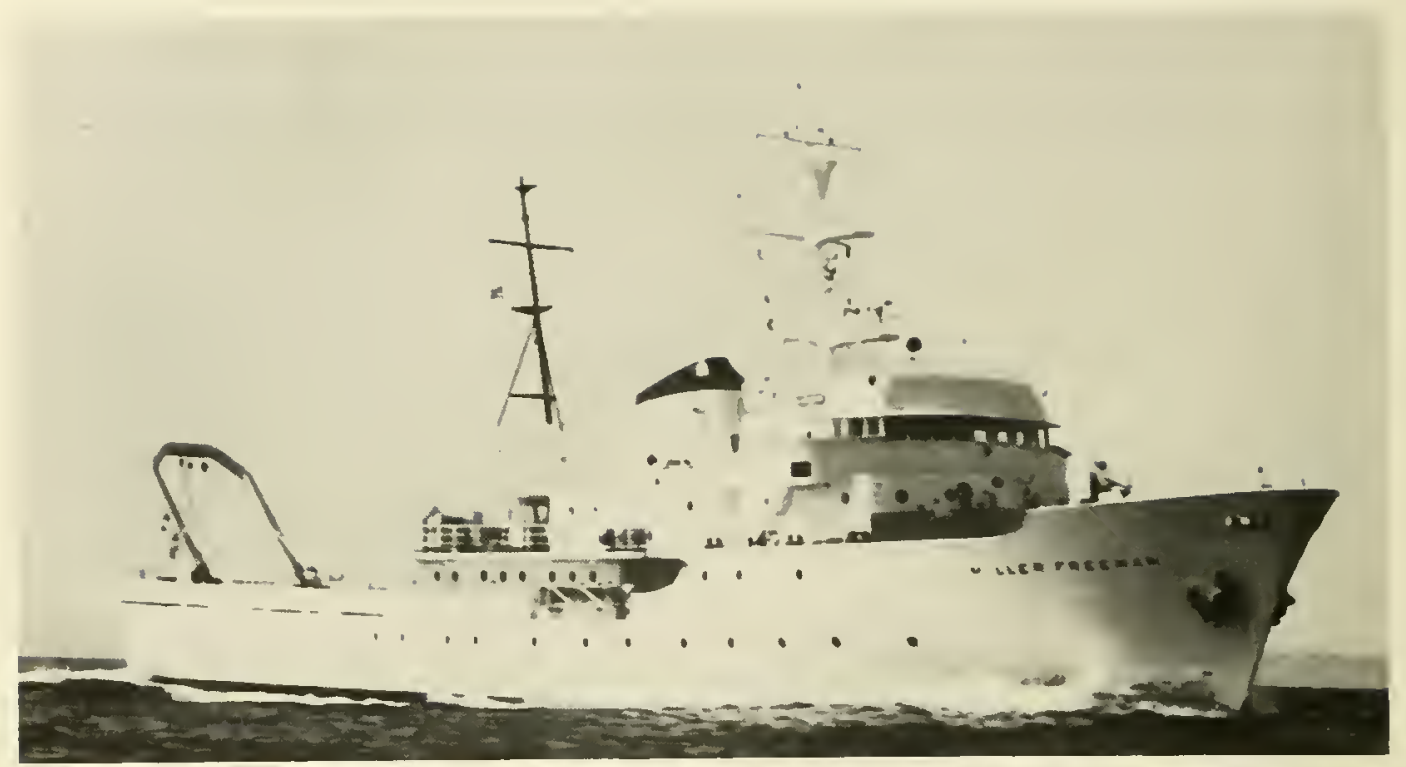

FR/V Miller Freeman

Built in 1967 by American Ship Building Company of Cleveland, Ohio for the National Marine Fisheries Service (formerly the Bureau of Commercial Fisheries).

Length: 216' Displacement: 1,782 tons

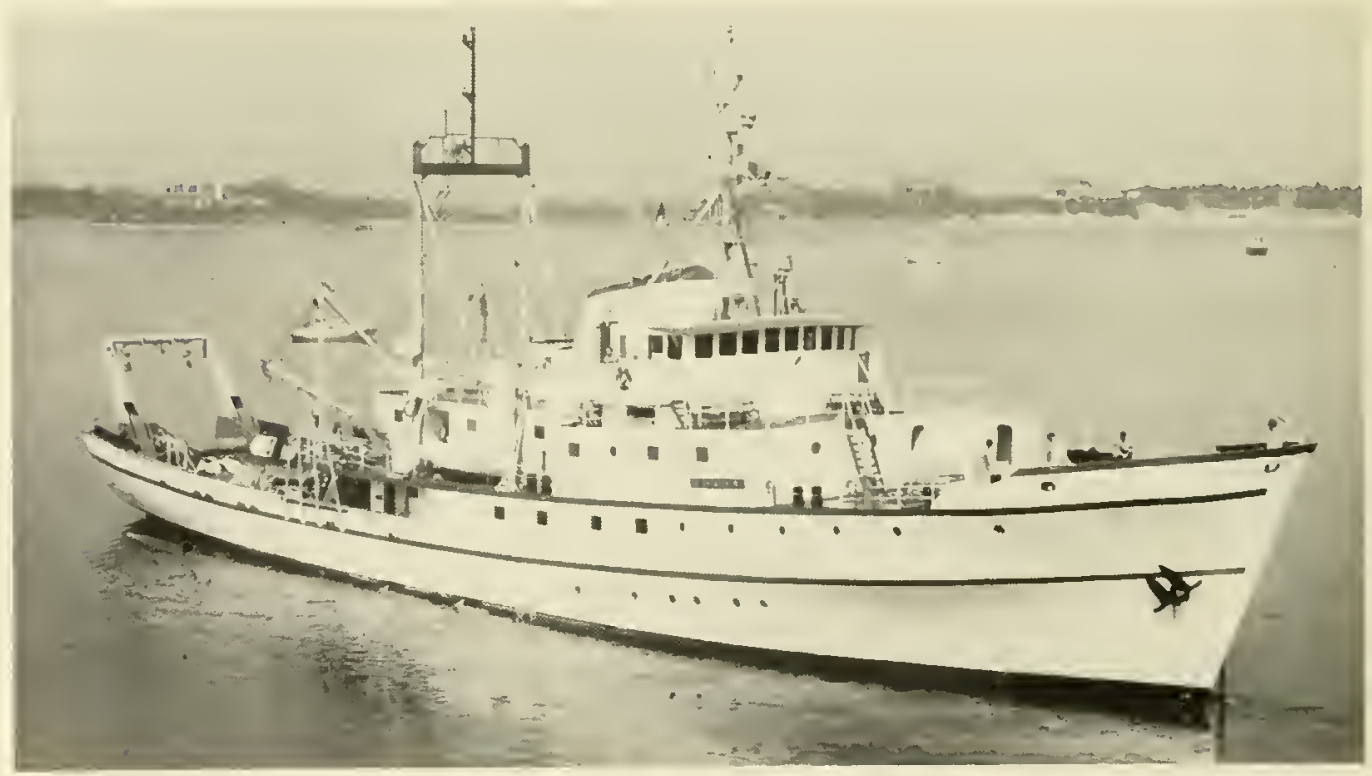

FR/V Albatross IV

The Albatross IV was built in 1963 for the National Marine Fisheries Service by Southern Shipbuilding Corporation of Slidell, Louisiana. Designed to conduct fisheries and oceano- graphic research in the Northwest Atlantic, the Albatross IV operates out of the Fisheries Service's Biological Laboratory in Woods Hole, Massachusetts.

Length: $187^{\prime}$ Displacement: 1,060 tons' 


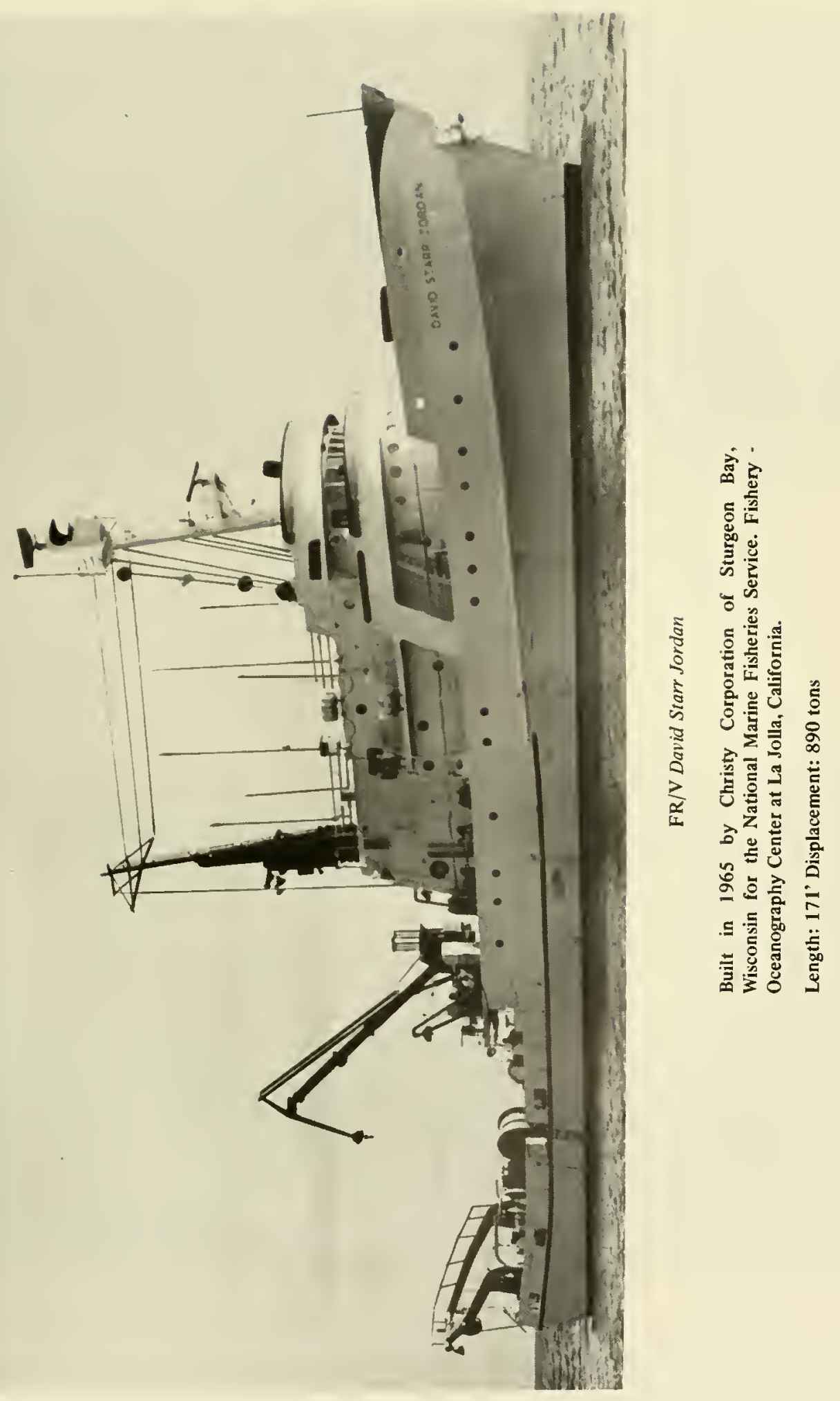




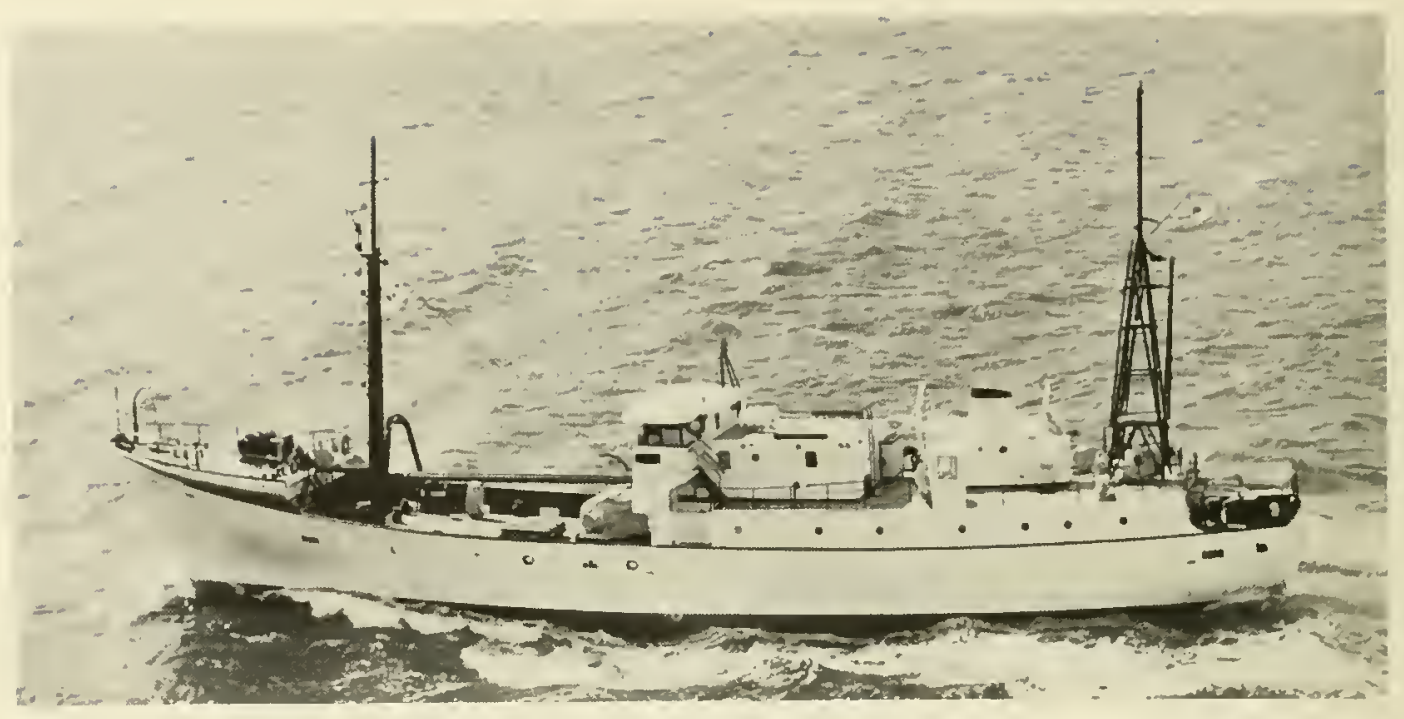

FR/V Townsend Cromwell

Built in 1963 for the National Marine Fisheries Service's Biological Laboratory in Honolulu.

Length: 158 ' 6" Displacement: 652 tons

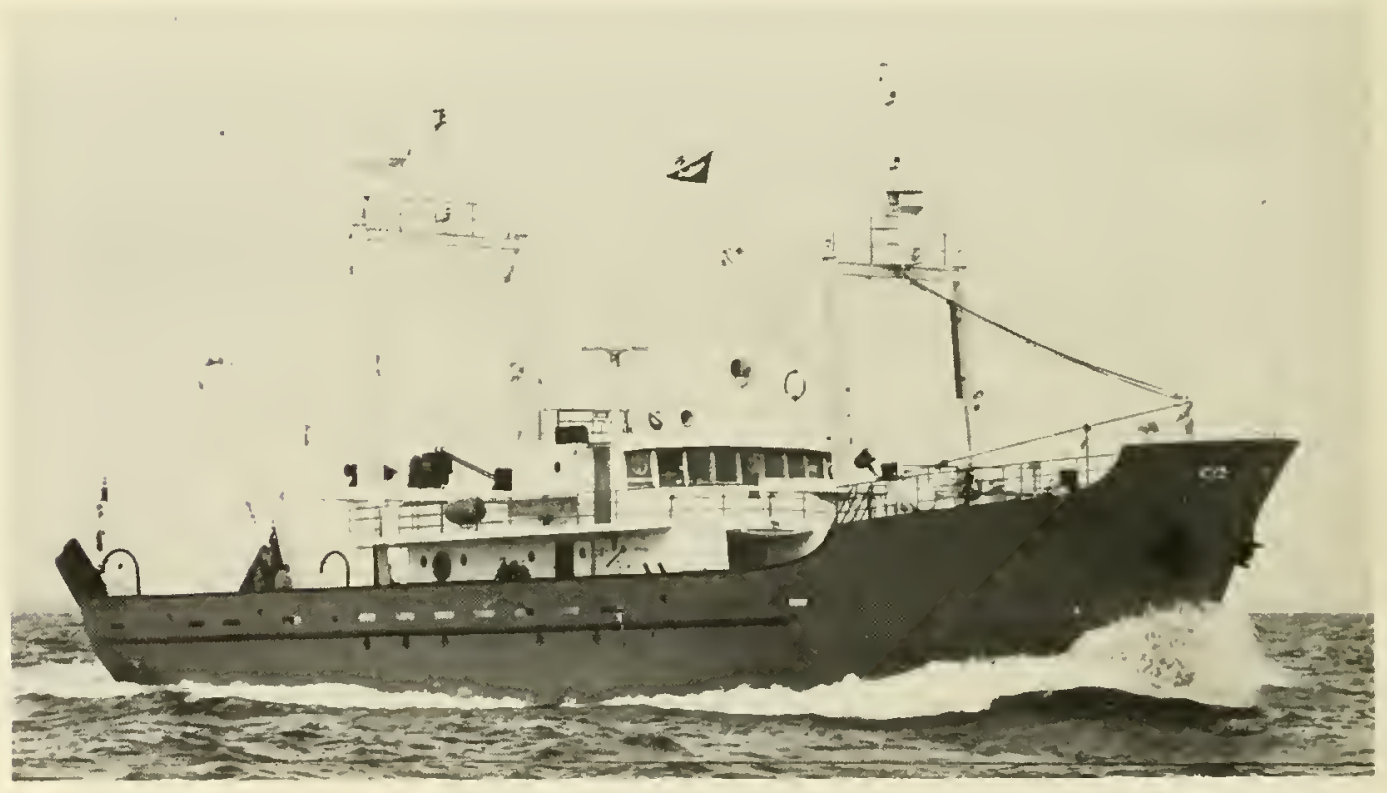

FR/V Delaware II

Built in 1968 for the National Marine Fisheries Service, Exploratory Fishing and Gear Research Base at Gloucester, Massachusetts.

Length: $155^{\prime}$ Displacement: 720 tons 


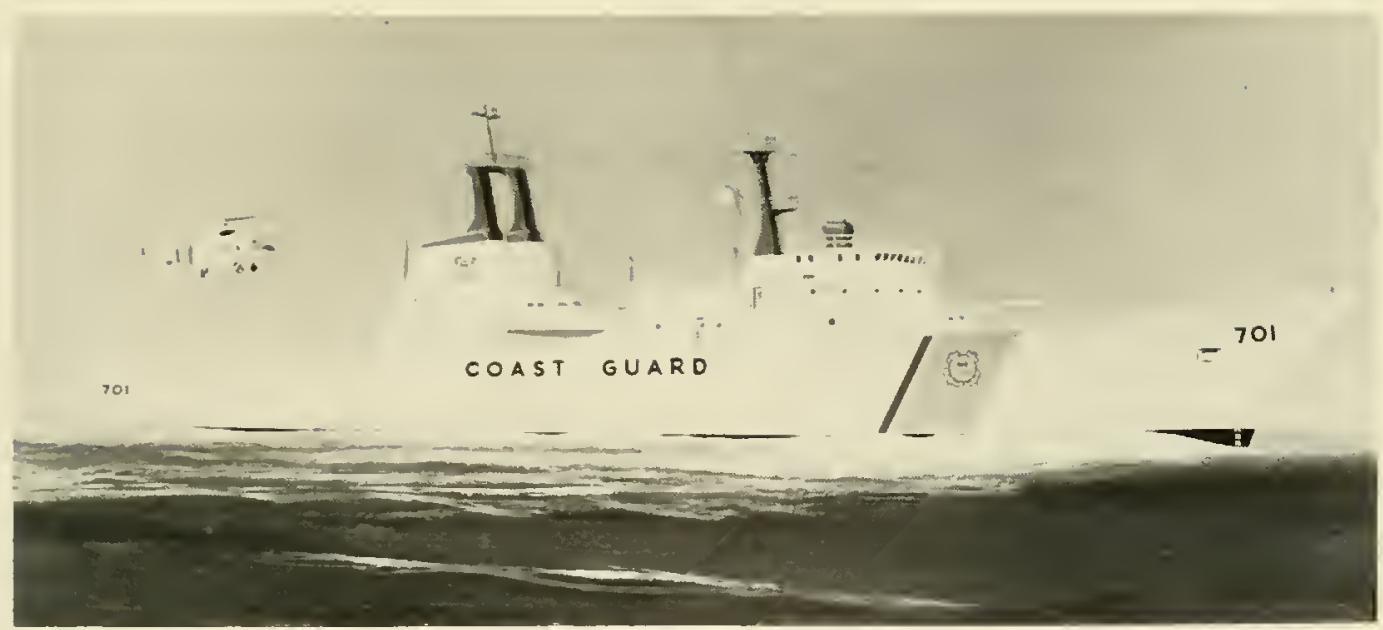

The proposed U.S. Coast Guard high endurance oceanographic cutter (WHEO 701). Designed for near-polar operations, primarily in support of the International Ice Patrol, the funds for her construction are still unappropriated.

Length: 388' Displacement: 3,950 tons

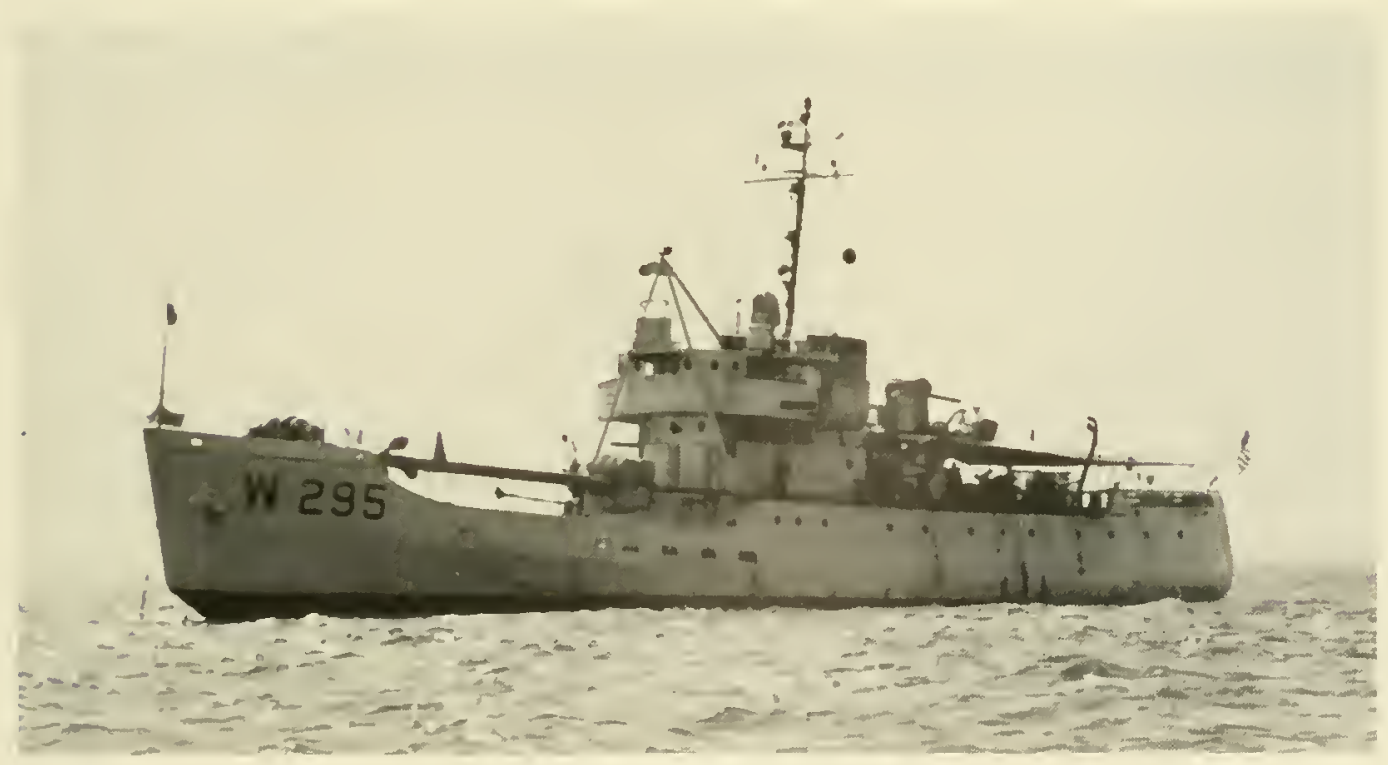

The U.S. Coast Guard ship Evergreen

Built in 1943 as a buoy tender, she was converted for ice patrol research and the year 1970 marks her 24 th year in support of the International lce Patrol.

Length: $180^{\prime}$ Displacement: 1,025 tons 



\section{CHAPTER VIII.}

A VIEW TOWARD THE FUTURE 
The progress made during the 1960s for expansion of the oceanographic fleet can best be summarized quantitatively as a giant step sideways.

The academic institutions supporting the Navy's oceanographic program are still plagued with old, inefficient and uneconomical conversions.

Coastal hydrographic surveys are conducted today at speeds about comparable with those of almost 50 years ago.

Synoptic observations employing a single ship are difficult, if not impossible, to accomplish when current ship speeds are limited to 10 to 15 knots.

The need to conduct all-weather operations is compromised by ship platforms limited in their seakeeping and seakindly capabilities.

The future, though, does offer solutions to these problems.

To supplement the large multi-discipline research ships and satisfy the need for replacement of small conversions, the Navy is planning to utilize small commercial designs such as off-shore oil supply boats to provide economical platforms capable of rapid interchange between oceanographic disciplines through the use of portable equipment and instrument vans. Using a basic hull design, these small AGOR ships, designated AGOR (UTILITY), can be configured to perform such specialized tasks as ocean drilling and submersible vehicle handling.

Currently under design is a new coastal hydrographic surveying ship class which will carry an advanced surveying system being developed to increase the rate of surveying at least ten-fold. The survey launches being evaluated include hydrofoils and captured-air-bubble (CAB) vehicles.

Concurrently, the use of hydrofoils and $\mathrm{CABs}$ are being considered for use in conducting synoptic observations. The increased use of aircraft to satisfy these requirements is also being reviewed.

Stable ocean platforms have received widespread attention, particularly from the oil industry. Platforms such as the Navy's Spar and Flip have greatly enhanced the capability to conduct research programs. Although no active programs have as yet been initiated, it is logical to assume that future Navy considerations for stable ocean platforms will be based upon the concepts embodied in Spar and Flip and the designs being pursued by the oil industry.

As our needs for knowledge and understanding of the ocean environment continue to be more demanding and more exacting, our ships must do more-but we are confronted with a paradox.

It is well recognized that continuing budget constraints have severely impacted upon the Navy. The oceanographic program has had to absorb its share of this impact and consequently with our existing ships we reach for tomorrow with yesterday's hands. There are, however, two cogent arguments which favor the maintenance and strengthening of the oceanographic program in spite of overall funding restrictions: first, the fact that our field experiments and the majority of surveys must be done in peacetime, when the operating areas are accessible; and secondly, the fact that, as the numbers of ships in the operating forces of the Navy are reduced, the remaining ships must increase their operational effectiveness. Such increased effectiveness will in large part be dependent upon a more thorough knowledge of the operating environment.

We look therefore to the future, remembering the words of Matthew Fontaine Maury:

"Navies are not all for war. Peace has its conquests, science its glories, and no Navy can boast of brighter chaplets than those gathered in the field of geophysical exploration and pliysical research." 

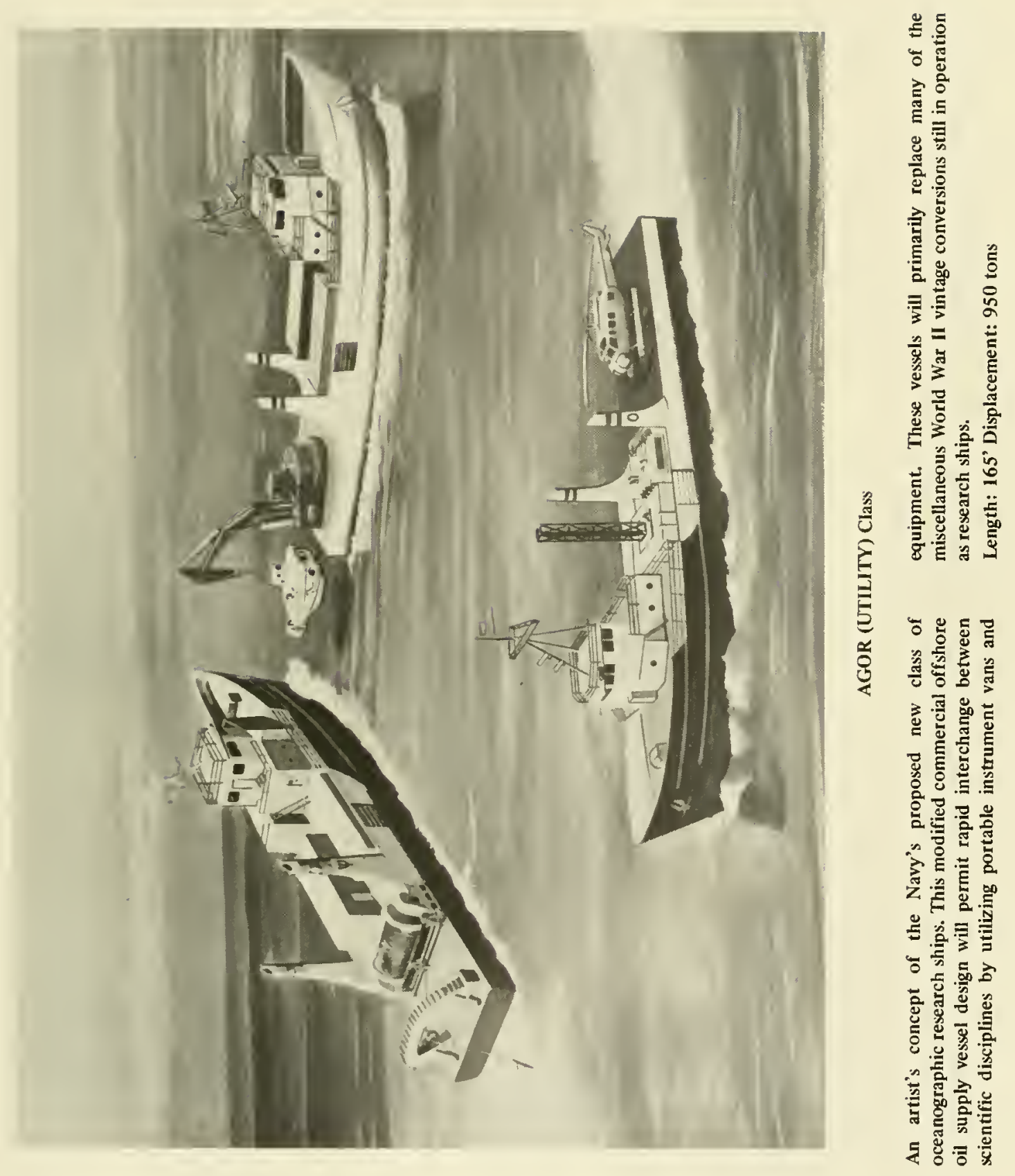


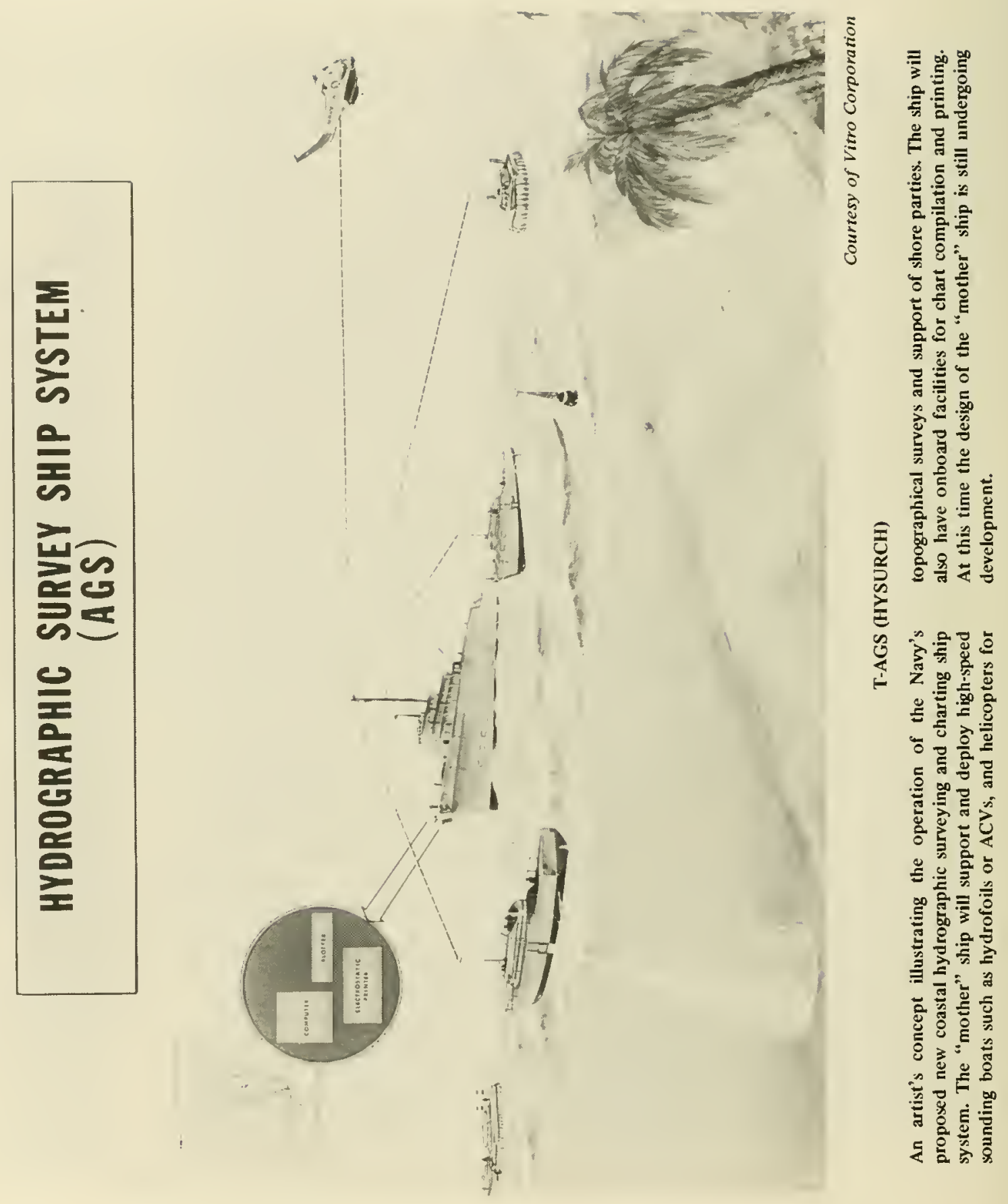



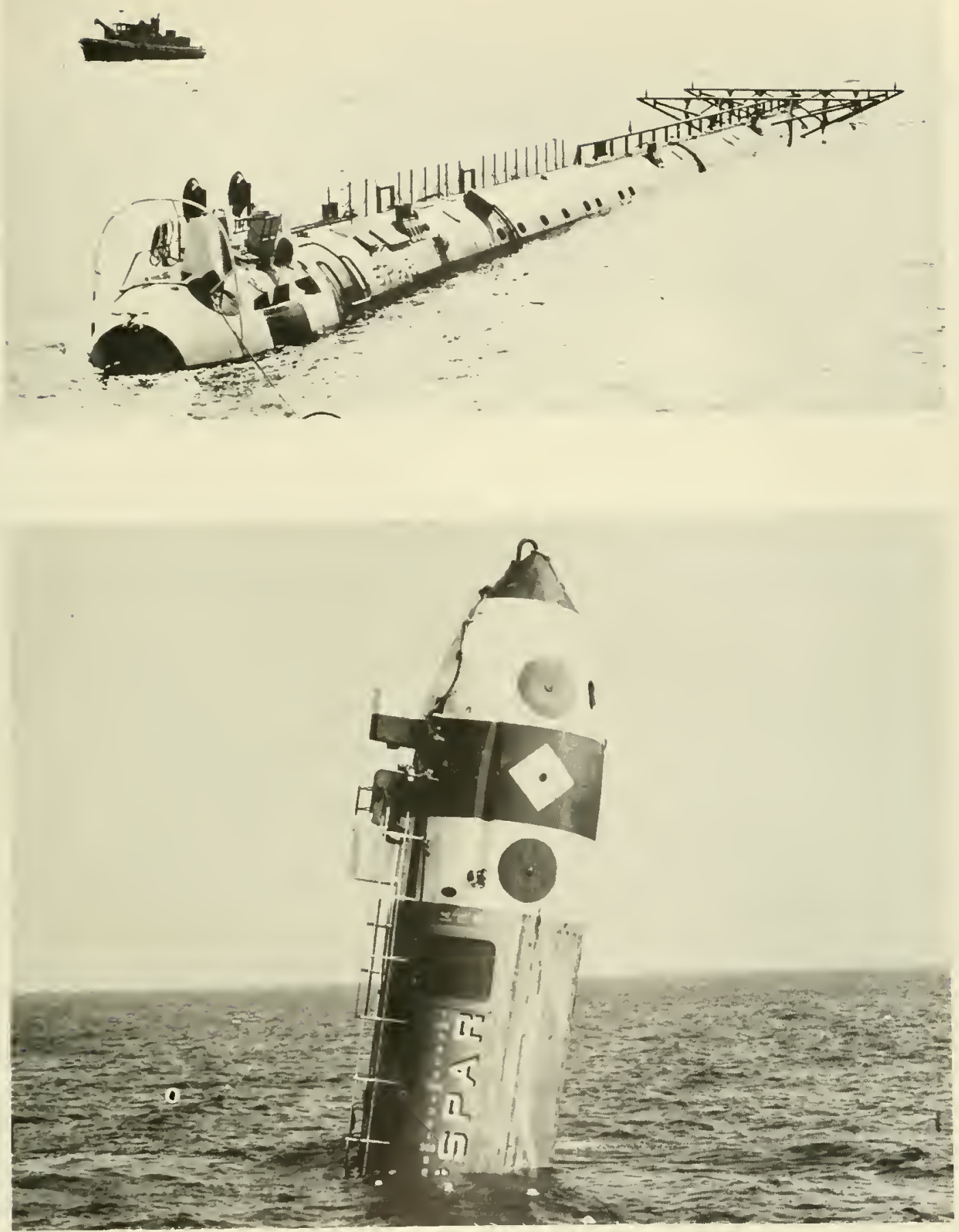

AG (SPAR)

The AG (SPAR) was built for the Navy in 1965 by Jacksonville Shipbuilding Corporation of Jacksonville, Florida. The 354-foot long, cigar-shaped Seagoing Platform for Acoustics Research (SPAR) is towed to its site in a horizontal position and then its after end is flooded to put into its vertical position. SPAR, which is operated by the Naval Ordnance Laboratory, is shown here in both its horizontal (towing) position and vertical (operational) position. 


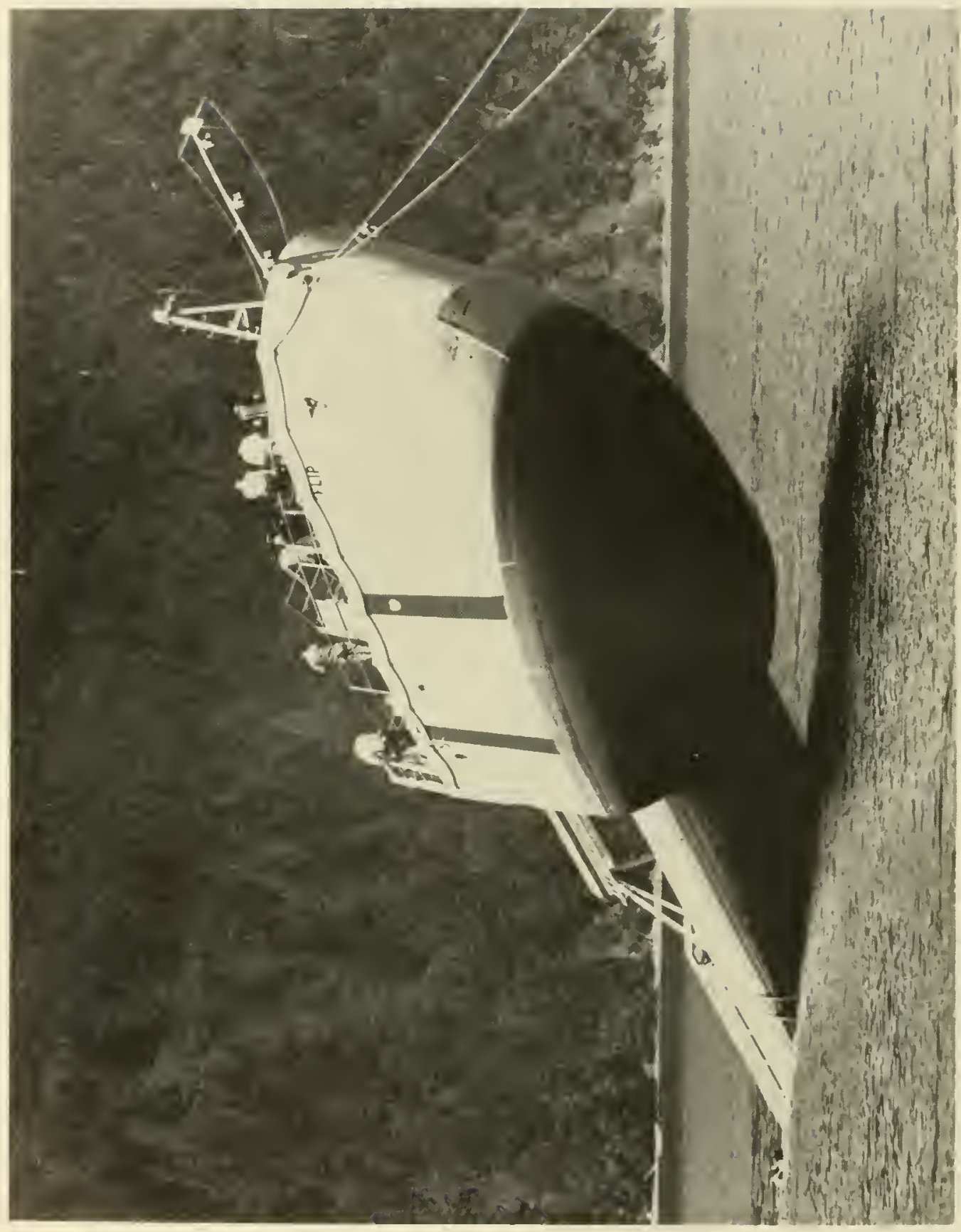

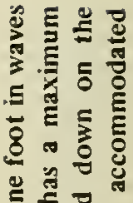

亏

들 을

象

굥

ฮี 를

\$ 9

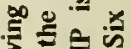

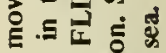

क्ष 5

ธิ

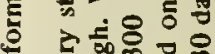

ज

2 .

Е

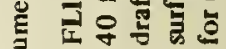

竞

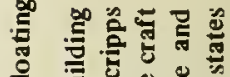

들 的

글 근

四

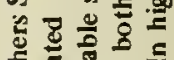

$\Xi$ ह

웅 흥

5 $\overline{8}$

. 용

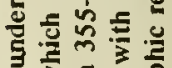

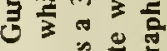
ते

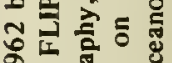
2. .

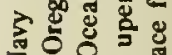

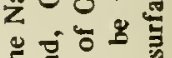
들

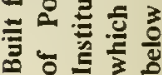



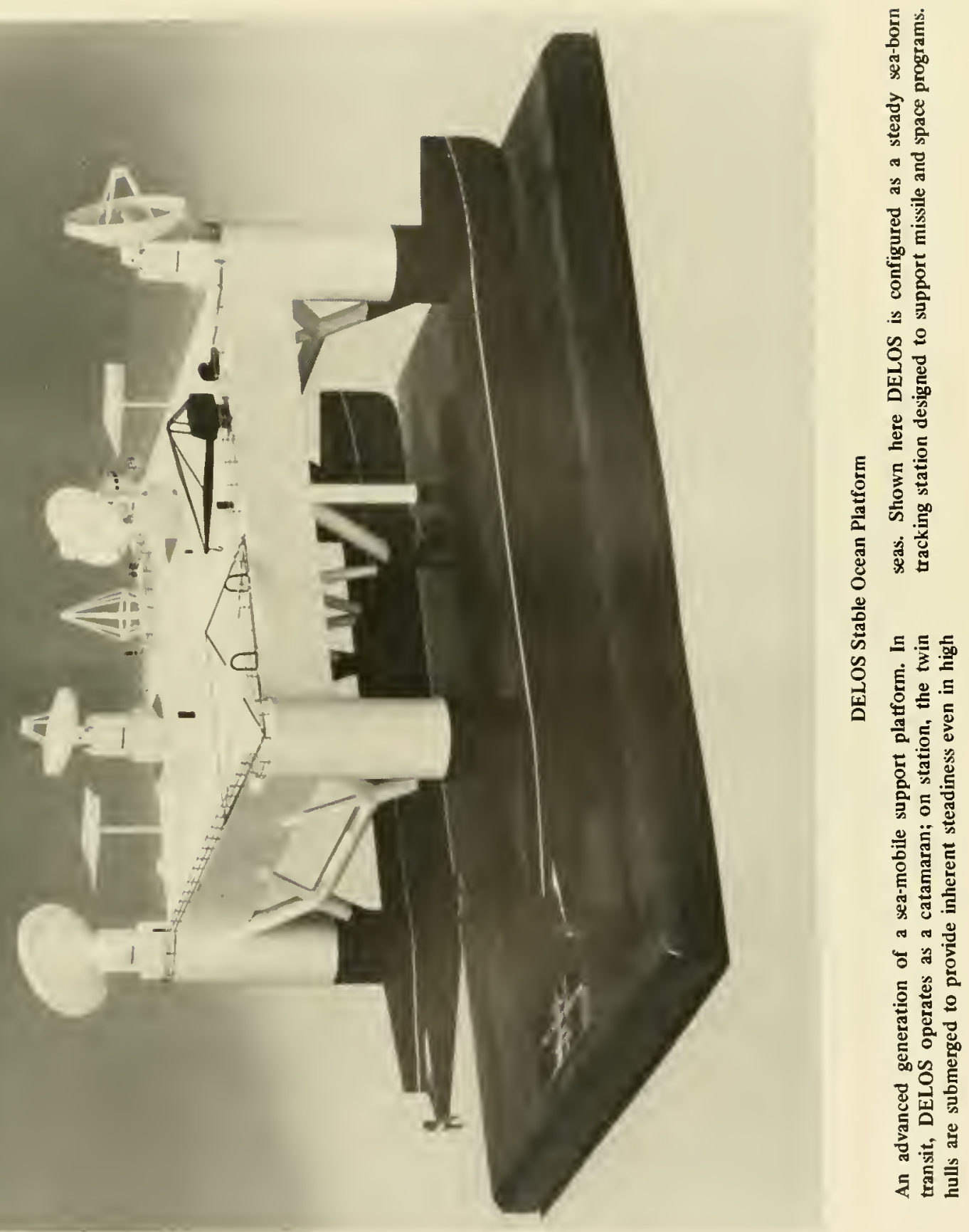



\section{CURRENT INVENTORY OF MAJOR U.S. OCEANOGRAPHIC SHIPS}

Author's Notes:

1. Data used in this tabulation reflects the following:

Year Built-Delivery to owner

Year Converted-Completion of work

Length-Length Overall

Displacement-Full Load (Long Tons)

The author recognizes that a ship's displacement, accommodations, etc. are subject to changes and variances, and the reader's indulgence is implored.

2. Since compilation of this Appendix the following changes were executed in 1970 by the Oceanographer of the Navy:

USNS Gilliss (T-AGOR 4) was reassigned to the University of Miami. Redesignated R/V Gilliss (AGOR 4), this Navy-owned ship will replace the University-owned R/V Pillsbury which will be retired in the Summer 1971.

USNS Davis (T-AGOR 5) was leased for five years to the Royal New Zealand Navy in support of cooperative research programs. She has been redesignated HMNZS TUI for the duration of the lease period.

USNS Lee (T-AGS 31) was reassigned to the Naval Undersea Research and Development Center, San Diego for a period of two years. To be employed as a research platform, the Lee's hull designation was temporarily changed to T-AG 192. 


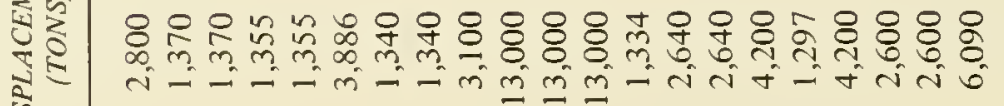

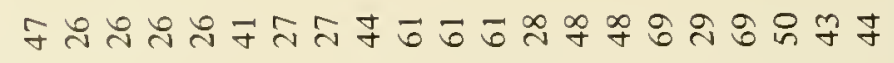

in in सुछ

₹

$\sum_{1 \rightarrow \infty}^{\infty}$

농ำ ले ले ते लिन-

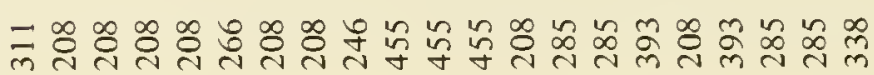

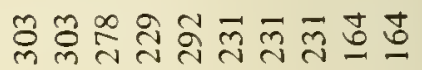

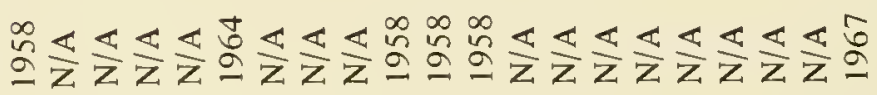

$\frac{\pi}{z} \frac{\pi}{z} \frac{\pi}{z} \frac{\pi}{z} \frac{\pi}{z} \frac{\pi}{z} \frac{\pi}{z} \frac{\pi}{z}$

(x) -Zżz

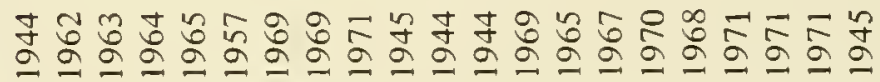

\begin{tabular}{l}
0 \\
\hdashline
\end{tabular}

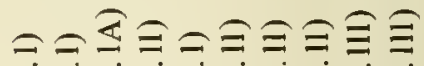

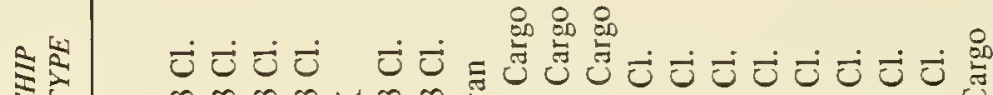
m m m m

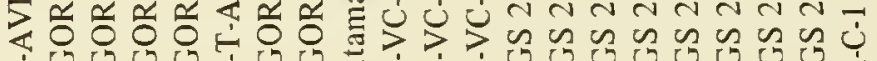

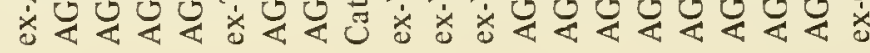

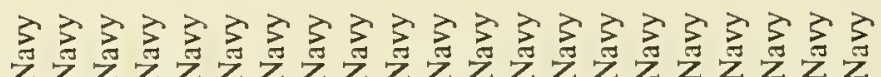

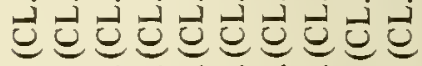

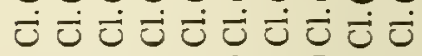
б

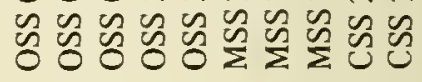

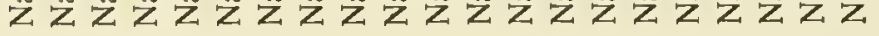

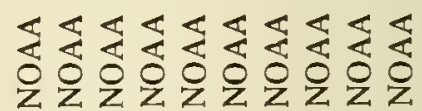

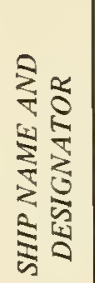

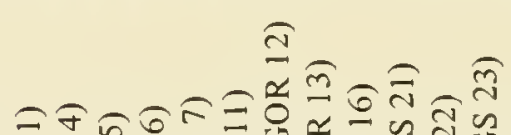

वे $\overparen{1}$

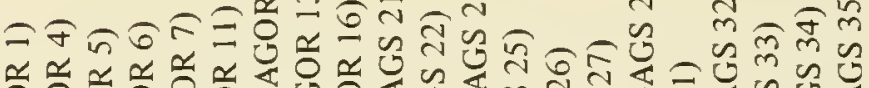

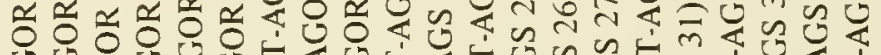

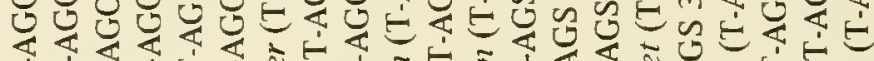

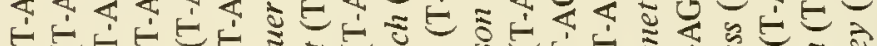

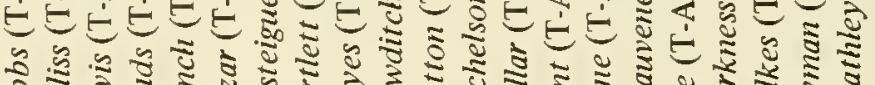

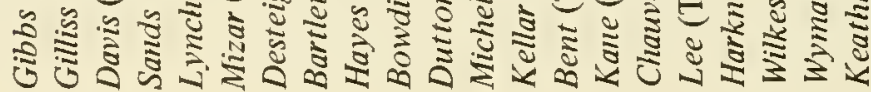

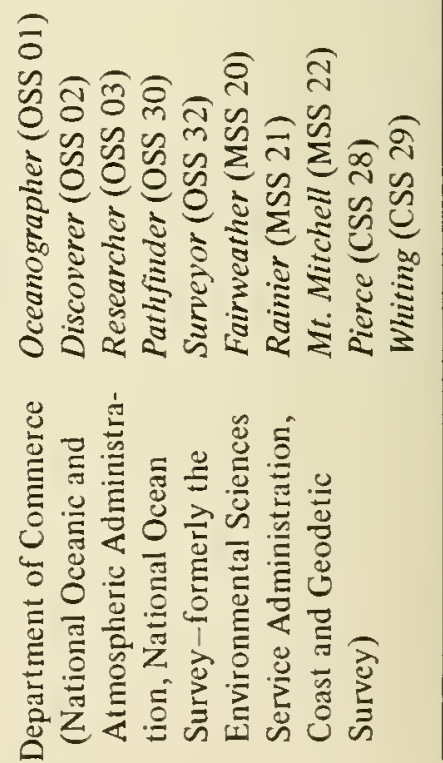




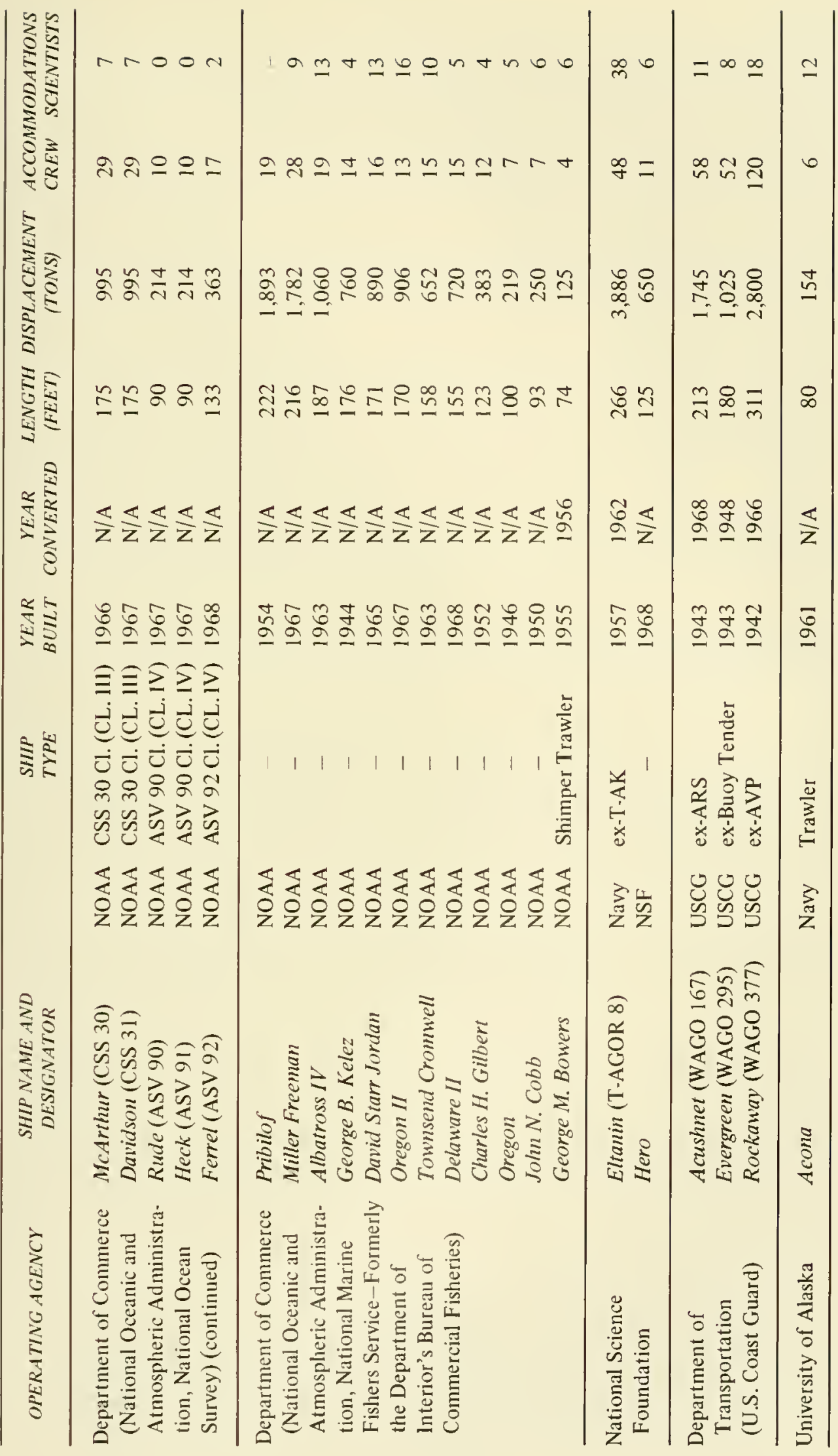




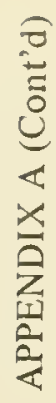

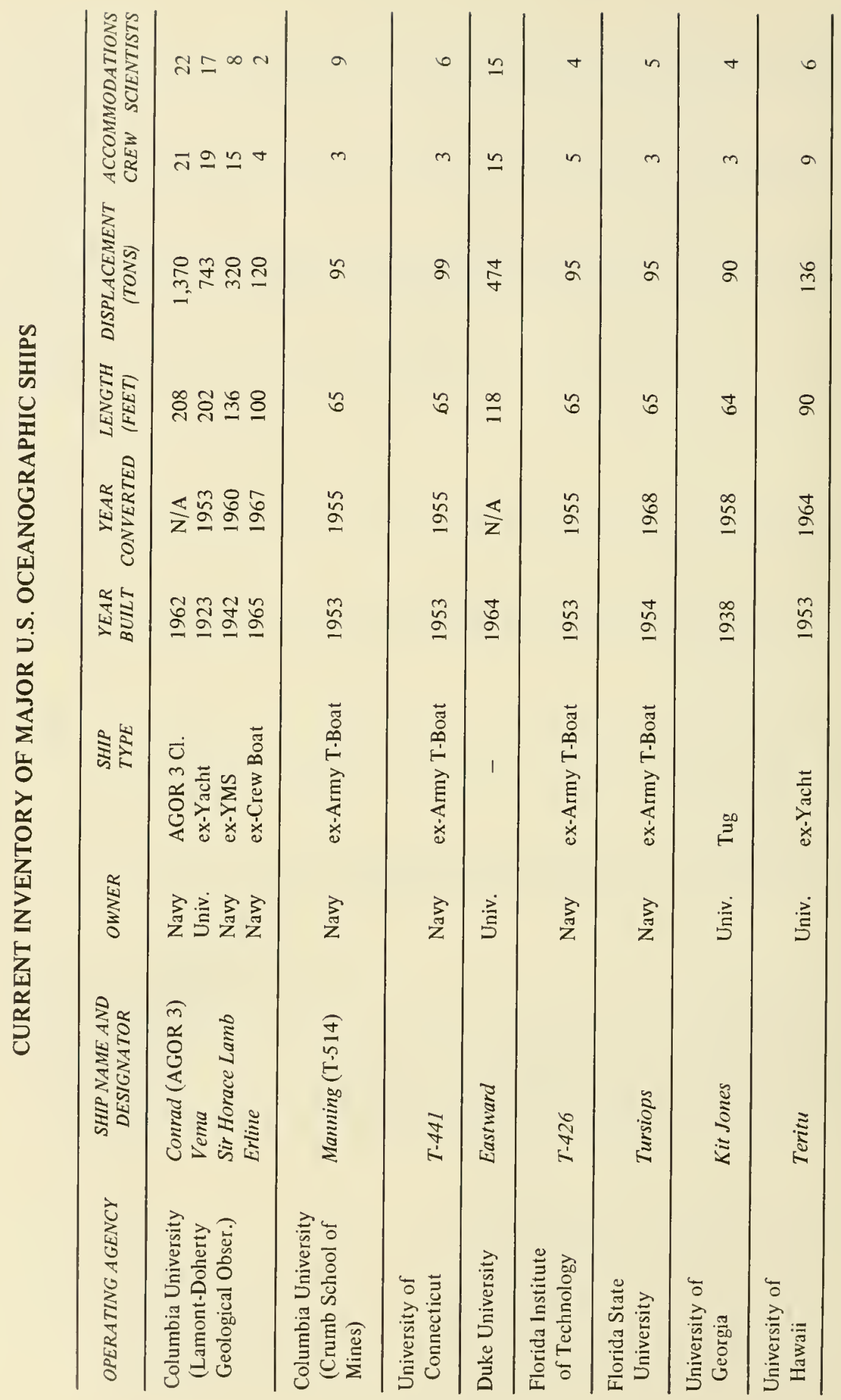




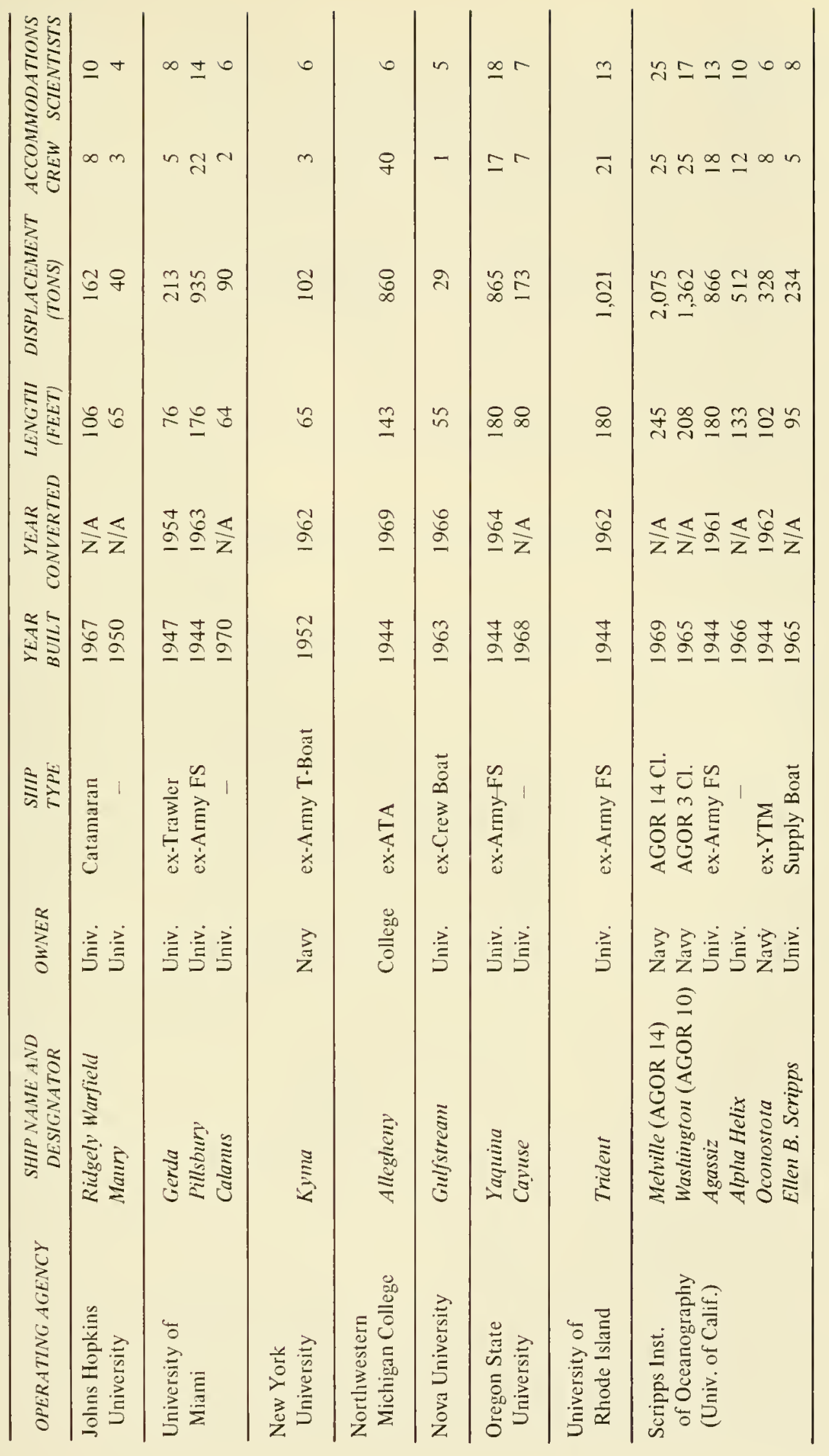




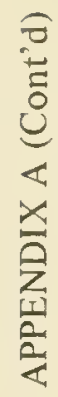

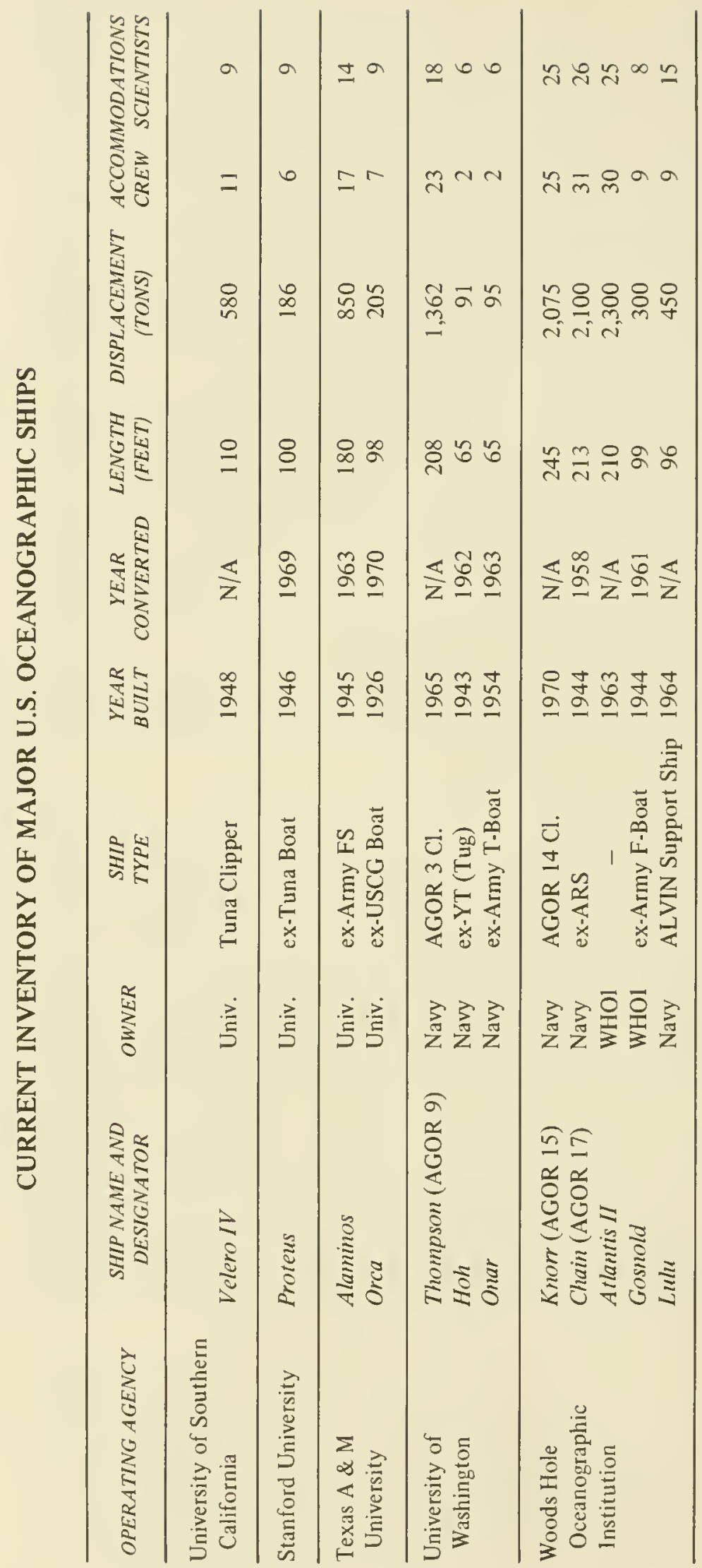




\section{APPENDIX B}

\section{ABBREVIATIONS AND SYMBOLS}

AG

AGC

AGOR

AGS

AGSC

AK

AKA

AM

AMCU

AMS

APC

ARS

AS

ASV

ATA

ATF

AUTEC

AVP

$\mathrm{CM}$

CSS

DD

EAG miscellaneous auxiliary ship

amphibious force flagship

oceanographic research ship

surveying ship

coastal surveying ship

cargo ship

attack cargo ship

minesweeper

minehunter

motor minesweeper

cavalry, transport

salvage ship

submarine tender

a uxiliary survey vessel (NOS designation)

auxiliary ocean tug

fleet ocean tug

Atlantic Underwater Test and Evaluation Center

small seaplane tender

mine layer

coastal survey ship (NOS

designation)

destroyer

experimental miscellaneous auxiliary ship
FLIP

FRV

FS

HMS

IX

LSM

LT

MSC

MSS

$\mathrm{M} / \mathrm{V}$

NASCO

NOAA

NOS

NRL

NSF

OCEANAV
Float ing Instrument

Platform

Fisheries Research Vessel

freight and supply vessel (Army)

His (Her) Majesty’s Ship

unclassified miscellaneous auxiliary ship

medium landing ship

large tug (Army)

Military Sealift Command (formerly the Military Sea Transportation Service

medium survey ship (NOS designation)

motor vessel

National Academy of Science's Committee on Oceanography

NAVOCEANO Naval Oceanographic Office National Oceanic and Atmospheric Administration

National Ocean Survey (formerly the Coast and Geodetic Survey)

Naval Research Laboratory National Science Foundation

Office of the Oceanographer of the Navy 


\begin{tabular}{|c|c|c|c|}
\hline ONR & Office of Naval Research & T-AGS & $\begin{array}{l}\text { T denotes surveying ship op- } \\
\text { erated by MSC }\end{array}$ \\
\hline OSS & $\begin{array}{l}\text { ocean survey ship (NOS } \\
\text { designation) }\end{array}$ & T-AK & $\begin{array}{l}\text { T denotes cargo ship operat- } \\
\text { ed MSC }\end{array}$ \\
\hline PCER & rescue escort & & \\
\hline PCS & submarine chaser & TENOC & $\begin{array}{l}\text { Navy's TEN YEAR PRO- } \\
\text { GR A M I N OCEANO- } \\
\text { GRAPHY }\end{array}$ \\
\hline PG & gunboat & U.S. & United States \\
\hline PY & patrol vessel converted yacht & USCG & United States Coast Guard \\
\hline $\mathrm{R} / \mathrm{V}$ & research vessel & USC\&GS & $\begin{array}{l}\text { United States Coast and } \\
\text { Geodetic Survey }\end{array}$ \\
\hline SPAR & $\begin{array}{l}\text { Seagoing Plat form for } \\
\text { Acoustics Research }\end{array}$ & USC\&GSS & $\begin{array}{l}\text { United States Coast and } \\
\text { Geodetic Survey Ship }\end{array}$ \\
\hline SS & $\begin{array}{l}\text { submarine, or merchant } \\
\text { steamer }\end{array}$ & USN & United States Navy \\
\hline $\mathbf{T}$ & $\begin{array}{l}\text { cargo and passenger boat } \\
\text { (Army) }\end{array}$ & USNS & $\begin{array}{l}\text { United States Naval Ship } \\
\text { (MSC designation) }\end{array}$ \\
\hline T-AG & $\begin{array}{l}\text { T denotes miscellaneous } \\
\text { a uxiliary ship operated by } \\
\text { MSC }\end{array}$ & $\begin{array}{l}\text { USS } \\
\text { I'S.S.R. }\end{array}$ & $\begin{array}{l}\text { United States Ship } \\
\text { Union of Soviet Socialist } \\
\text { Republics }\end{array}$ \\
\hline T-AGOR & $\begin{array}{l}\text { T denotes oceanographic re- } \\
\text { search ship operated by } \\
\text { MSC }\end{array}$ & WAGO & $\begin{array}{l}\text { oceanographic ship (USCG } \\
\text { designation) }\end{array}$ \\
\hline
\end{tabular}




\section{REFERENCES}

A.J. Barther, "Oceanography and the Mariner," U.S. Naval Oceanographic Office publication SCIENCE AND THE SEA, 1967.

L.A. Bauer, "The Most Curious Craft Afloat," National Geographic Magazine, March 1910.

L.A. Bauer, "The Work in the Pacific Ocean of the Magnetic Survey Yacht GALILEE," an address before the Washington Society of Engineers, 21 May 1907.

Commander George E. Belknap, U.S. Navy, "Deep Sea Soundings in the North Pacific Ocean Obtained in the United States Steamer TUSCARORA, "U.s. Navy Hydrographic Office, No. 54, Government Printing Office, 1874.

Major W. D. Brinkloe, U.S. Army, "Seaman and Ships of the Desert," U.S. Naval Institute Proceedings, September 1932.

Captain G.S. Bryan, U.S. Navy, "The Purpose, Equipment and Personnel of the Wilkes Expedition," Proceedings of the American Philosophical Soceity, Volume 82, No. 5, 1940.

Rachel L. Carson, The Sea Around Us, Mentor Books, New American Library, January 1954.

Lionel Casson, Illustrated History of Ships and Boats, Doubleday and Company, Inc. 1964.

Howard 1. Chapelle, American Sailing Craft, Crown Publishers, 1936.

Howard 1. Chapelle, The History of the American Sailing Navy, Bonanza Books, 1949.

Victor J. Danilov, “Oceanography on the Campus,” Oceanology Yearbook, 1967.

John Dermody, Jonathan Leiby and Maxwell Silverman, "An Evaluation of Recent Research Vessel Construction in the United States," paper presented at annual meeting of the Society of Naval Architects and Marine Engineers, New York, November 1964.

John and Alice Durant, Pictorial History of American Ships on the High Seas and Inland Waters, A. S. Barnes and Company, 1953.

J.C. Friod, "The Research Catamaran T-AGOR 16," U.S. Navy Institute Proceedings, No. 132, May 1969.

Don Groves, "History in the Sea," Naval Engineers Joumal, October 1968.

Lieutenant Commander Theodore F. Jewell, U.S. Navy, "Deep Sea Soundings," U.S. Naval Institute Proceedings, Volume 4, 1878.

Lieutenant (JG) Orrin E. Klapp, USNR, "Matthew Fontaine Maury, Naval Scientist," U.S. Naval Institute Proceedings, November 1945. 
Jonathan Lieby, "Design of a New Research Vessel for the Woods Hole Oceanographic Institution," paper prepared for the Research Vessel Forum held by the Food and Agriculture Organization of the United Nations, Tokyo, September 1961.

Captain E. John Long, USNR (Ret), editor, Ocean Sciences, U.S. Naval Institute, Annapolis. Maryland, 1964.

Francis E. McMurtrie, editor, Jane's Fighting Ships, Macmillan Company, 1947.

Richard T. Miller, "The Navy's Oceanographic Research Ship Designs," paper presented at First U.S. Navy Symposium on Military Oceanography, Washington, D.C., June 1944.

Vincent T. Miscoski, "U.S. Navy Oceanography-A Look Back," U.S. Naval Institute Proceedings No. 780, Vol. 94, No. 2, February 1968.

S.B. Nelson,"Resurrection of the Surveying Ship USNS KELLAR (T-AGS 25)," paper presented at the Fourth Annual Technical Symposium Association of Sensor Engineers, Navy Ship Systems Command, 1967.

Helen Raitt and Beatrice Moulton, Scripps Institution of Oceanography, The Ward Ritchie Press, 1967.

S.C. Reed, T. H. Sarchin and J. Leiby, "New Concepts Applied to Research Ship Design," paper presented at Chesapeake Section of the Society of Naval Architects and Marine Engineers, 16 May 1968.

Critchell Rimington, Fighting Fleets, Dodd, Mead and Company, New York, 1943.

Lester Rosenblatt, "The Design of Modern Oceanographic Research Ships," paper presented at Spring Meeting, the Society of Naval Architects and Marine Engineers, Washington, D.C., May 1960.

Paul H. Silverstone, U.S. Warships of World War II, Doubleday and Company, Inc. 1965.

Alfred Standford, Navigator-The Story of Nathaniel Bowditch, William Morrow and Co., 1927.

Commander Zera L. Tanner, "Deep-Sea Exploration: A General Description of the Steamer ALBATROSS, Her Appliances and Methods," U.S. Fish Commission Bulletin for 1896 , Government Printing Office, 1897.

Allyn C. Vine and J. Leiby, "Status of Oceanographic Ships in the United States with a View into Future Developments," paper presented at the Philadelphia Section, Society of Naval Architects and Marine Engineers, March 1967.

A. Joseph Wright and Elliott B. Roberts, The Coast and Geodetic Survey 1807-1957, 150 years of History, U.S. Department of Commerce, Government Printing Office, 1957.

"Annual Reports of the Hydrographer (Navy Department) and Commander, Naval Oceanographic Office 1884 - 1970," Government Printing Office. 
"Charting the Sea Lanes," in All Hands, The Bureau of Naval Personnel 1nformation Bulletin, July 1946.

Dictionary of American Naval Fighting Ships, Vol 1-IV, Office of the Chief of Naval Operations (Naval History Division), Government Printing Office.

"National Oceanographic Program, Fiscal Year 1967," Interagency Committee on Oceanography of the Federal Council for Science and Technology, 1CO Pamphlet No. 24, March 1966.

"Oceanography 1960 to 1970, A Report by the Committee on Oceanography," National Academy of Sciences, National Research Council, Chapter, I, 1959.

Research in the Sea, Woods Hole Oceanographic Institution, 1966.

"Special Notice to Mariners, One Hundredth Anniversary Number, 1830-1930," U.S. Hydrographic Office, Navy Department, 6 December 1930.

Suneys by the Hydrographic Office, Navy Department, Government Printing Office, 1924.

“Ten Year Program in Oceanography (TENOC) 1961-1970," Department ol the Navy, 13 March 1961.

The Methods and Results of the Suney of the West Coast of Lower Califonia by the Officers of the USS RANGER During the Season of 1889 and 1890, U.S. Navy Hydrographic Office, No. 101, Government Printing Office, 1892.

The Ocean Engineering Program of the U.S. Navy, Office of the Oceanographer of the Navy, Alexandria, Virginia, September 1967.

The Ocean Science Program of the U.S. Navy, Office of the Oceanographer of the Navy, Alexandria, Virginia, June 1967.

The Oceanographic Operations Program of the U.S. Navy, Office of the Oceanographer of the Navy, Alexandria, Virginia, December 1967.

"The United States Coast and Geodetic Survey, Its Work, Methods and Organization" Special Procedure No. 23, Government Printing Office, 1928.

"Twin Ships-Notes on the Chronological History of the Use of Multiple Hulled Vessels," The Mariner's Museum, Newport News, Virginia, 1939.

World War II History of the Coast and Geodetic Survey, U.S. Department of Commerce, Government Printing Office, 1951.

Your Navy, Bureau of Naval Personnel, Standards and Curriculum Division, Navy Training Courses Edition of 1946.

The Story of The Bureau of Commercial Fisheries Biological Laboratory. Woods Hole, Massachusetts, Paul S. Galtsoff, U.S. Department of Interior, Circular 145, Washington, D.C., May 1962. 
Acona, research vessel (modified Irawler) 162, 186 , 223

Action, schooner 131,136

Active, schooner (formerly the schooner Clara) 11

Achusnet (WAGO 167) 223

Advance, brig $15,48,50$

Aerojet-General Shipyard 203, 205

AG (SPAR) 214, 217

Agamemmon, II.M.S., battleship 13,42

Agassiz, Alexander 18,68, 78

Agassiz, research vessel (ex-Army "FS" vessel) see Alexander Agassiz

Agassiz, Jean Louis Randolphe 17, 18, 68

AGOR (UT1LITY) Class 214, 215

AGOR 3 Class 132, 161, 163

AGOR 14 Class 163

Alaminos, research vessel (ex-Army "FS" vessel) $162,183,226$

Alaska, gunboat 17, 53

Albany, sloop-of-war 13,40

Albatross, steamer 19,20,72, 73, 85, 87

Albatross 1I, fisheries research vessel (formerly the tug, Patuxent) 87, 106, 131

Albatross 111 , fisheries research vessel (formerly the USCG patrol craft Bellefonte, and previously the trawler Harrard) 131,144

Albatross $1 V$, fishcries research vessel 164, 208, 223

Albert 3, Printe of Monaco 23

Albina Engine and Machine Works 186

Albina Marine lron Works 126

Alcutian 1slands Survey Expedition 88

Alexander Agassiz, research vessel (ex-Army "FS" vessel) $162,191,225$

Allegheny (ATA 179) 131, 146, 225

Allegheny, steamer 13

Alpha Helix, biological research ship 162, 187, 225

Alvin, submersible rescarch vehicle 162,175

American Philosophical Society 3, 4, 9, 11

Ameriean Revolution 3, 9

American Shipbuilding Company 149, 193, 204, 208

America's Cup 84, 85

Amistad, slave ship 12

Ammunitions Products Corporation 91

"Antarctic Continent" 11

Antarctic Research Program 189, 190

Anton Brum, research vessel (formerly the presidential yacht Williamsburg, and previously the yacht Aras) 162,188

Arctic Expedition 19, 70

ARCTIC EXPLORATIONS

see Kane, Elisha Kent, U.S. Navy

Arctic, steamer (formerly the steamer Thomas $C$ Haight) 15

Argo (AGOR 18) (formerly the salvage ship Snatch) 154,155

Argus 1sland 179

Armistead Rust (AGS 9) (formerly the subchaser PCS 1404) 111,118
Army "IS" Vessel 182, 183, 184, 185, 191

Army "T" Boat 162, 177, 178, 179

"Around the World in Eighty Days" 105

Associated Shipbuilding Company 150

Atlantic Underwater Test and Evaluation Center (AUTEC) 132, 151

Atlantis I, research vessel (subsequently the $E$ l Austral of Argentina) 87, 104, 131, 132

Atlant is $I$, research vesse1 161, 163, 165, 226

ATLAS OF THE PACIFIC OCEAN

see Krusentern (Russian Admiral)

Atomic Energy Commission 131, 154

Austin, S. P. and Son Ltd. (shipyard) 91

AUTEC

see Atlantie Underwater Test and Evaluation Center

Avondale Marine Ways Inc. (shipyard) 189

Bache, Alexander D. 12

Bache, George M., U.S. Navy 12, 23

Bache, steamer 18,60,85

Baulassah, schooner 10,31, 32

Baicr, L. S. Company (shipyard) 186

Baird, Spencer Fullerton 14, 17, 18, 20, 59

Ballard Marine Railway Company (shipyard) 118 , 124

Barker, Albert S., U.S. Navy 20, 74

Bartlett, Robert 114

Bartlett (T-AGOR 13) 161, 171, 222

Bath Iron Works (shipyard) 95, 188

Bathymetric chart (first) 13, 86, 102

Bear (AG 29) (subsequently the sealing ship Arctic Sealer) 111,115

Bcar, research vessel (ex-coastal freighter) 131,140

Belknap, George Eugene, U.S. Navy 18, 62

Benicia, sloop-of-Ivar 17,53

Bennett, James Gordon 70, 7]

Bınt, Silas, U.S. Navy 13, 14, 44

THERMOMETRIC GATEWAYS TO THE POLE 44

Bent (T-AGS 26)

see Silas Bent (T-AGS 26)

Bermuda Biological Station 162

Bernhardt, Sarah 89

Bethlehem Shipbuilding Corporation 101

Bethlchem Steel Corporation (shipyard) 201

Bibb, steamer 17, 57

Bikini Atoll 110, 131

Bingham Oceanographic Laboratory

Birmingham, cruiser 85,95

Black Tide sec Kuroshio

Blake, George, U.S. Navy 10, 23

Blakt', stcamér 17, 18, 58, 78

Blish (AGS 10) see Joln Blish (AGS 10)

Bluelight, tug 18,60

Blumer, J. and Co. (shipyard) 90

Bourd of Navy Commissioners 10

Boland Machinc and Manufacturing Company (shipyard) 171 
Boston Harbor 25

Boston Navy Yard 18, 33, 35, 53, 54, 56, 57

Bow Propulsion Unit 170

Bowditch, Nathaniel 8,9

"Father of Modern Navigation" 8, 9

NEW' AMERICAN PRACTICAL

NA VTGATOR 8, 9

"Seamen's Bible" 8, 9

Bowditch (AGS 4) (formerly the S. S. Santa Inez) $111,112,131$

Bowditch (T-AGS 21) (lomerly the $S . S$. South Bend I'ictory') 154, 157, 222

Bowdoin, schooner 111,114

Brattleboro (PCER 852, 131, 142

Brooke, John Mercer, U.S. Navy 13,41

Brooklyn Navy Yard 35

Brown Bear, research vessel (ex-coastal freighter) 131,140

Brown, Townsend 88

Bureau of Commercial Fisheries

See National Marine Fisheries Service

Bureau of Navigation 17, 19

Bureau of Ordnance 10

Bureau of Ships see Naval Ship Systems Command

Burmeister and Wain (shipy ard) 112

Bushnell see Sumner (AGS 5)

Byrd, Robert E., U.S. Navy 1] 1, 115

Byrd's Antarctic Expedıtions 111

Calanus, research vessel 225

California Shipbuilding Corporation 117

camel "sealift" 16

Canton, merchantship 3,6

Cape of Good Hope 3

Carnegie, Andrew 85

Carnegie Corporation 87

Carnegic 1 nstitution of Washington $85,86,93,101$, 102

Carnegie, non-magnetic research yacht 85,94

Catalyst, research vessel (ex-yacht) 87,104

catamaran 163, 201, 202

Cayuse, research vessel (modified trawler) 162, 186,225

Chain (AGOR 17) (ex-salvage ship) 154, 155, 226

Challenger Exploring Expedition 18,68

Challenger, H.M.S., research vessel 18, 23

Charles H. Davis (T-AGOR 5) 161, 166, 222

Charles ff. Gilbert, survey launch 223

Charleston Naval Shipyard 151, 157

Chauchet (AGS 11) (formerly the minesweeper YMS 195, and subsequently the British mercantule Zipper) 111,116

Chaurenet (T-AGS 29) 163, 195, 222

Chesapeake Bay 16, 90, 113

Chester, C. M., U. S. Navy 23

Chester, cruiser 85, 95
Chewink, submarine rescue ship 88

Chicago fire 14

Christy Corporation (shipyard) 166, 194, 209

Civil War $11,14,16,17,38,54,67,73,78$

Clean IVaters, estuarine monitoring boat 164

Coast and Geodetic Survey see National Ocean Survey

Coast Guard 84, 85, 113, 115, 131, 138, 139, 144, $164,211,223$

Revenue Cutter Service 17, 37, 39, 77, 115

Revenue Service 18

Colbert Boat Works 118

Collins Distributors 84.85

Columbia University $131,146,154,160,162,174$, 179.224

Commerce Department 9,222, 223

Committee on Oceanography (NASCO) see National Academy of Sciences

Concord, gunboat 21, 76

Confederate States Navy 16, 37, 38

Conrad (AGOR 3) sec Robert D. Conrad (AGOR 3)

Consejo Nacional de Investigaciones Centificas y Tecnicas 104

Consort. brig 11,33

Constellation, frigate 3,5

Constitution, frigate 9, 12, 24, 25

"Old Ironsides" 9, 25

Coolidge, Calvin 84,85

Copeland, Charles W. 19,72

Corry, destroyer 86, 101, 102

Cramp Shipbuilding Company 100

Cramp, William and Son (slipyard) 106

Crawford, research vessel (ex-cutter) 131, 139

Crest, research vessel (ex-minesweeper) 131,134

Cretan warships 3

Crete 3

Cruiser O/ympia Association 93

Crumb School of Mines 162, 224

cycloidal propellers 163, 198, 199, 200

David Starr Jordan, fisheries research vessel 164, 209,223

Davidson, K. S. M. 132

Davidson (CSS 31) 164, 205, 223

Divis, Charles II., U.S. Navy ]7, 23

Davis (T-AGOR 5) sec Charles H. Daris (T-AGOR 5)

Davis, Jefferson 16

Dead Sea Expedition see Lynch, William Francis, U. S. Navy

Deep Sea Sounding Devices, John Mercer Brooke's $13,41,63$

Defoe Shipbuilding Company 173, 194, 196, 198, 200

Delaware River Iron Works (shipyard) 76

Delaware 11 , fisheries research vessel ] 64, 21 0, 223

DeLong, George Washington, U.S. Navy 19,70,71

Delos, stable ocean platform 219 
Denmead, A. W, and Son (shipyard) 55

Depot of Charts and Instruments see Naval Oceanographic office

Derickson (AGS 6) (formerly the subchaser PCS 1458) 111,124

De Steiguer (T-AGOR 12) 161, 169, 170, 222

Dewey, George, U. S. Navy 18, 57

Discoverer, survey ship (formerly the minesweeper Auk, and subsequently the salvage ship Discoverer) $11 \mathrm{I}, \mathrm{I} 20$

Discoverer (OSS 02) 164, 203, 204, 222

Dobbin, James D. 13, 16

Dodge, Horace E. 86,98

Dolphin, brig 13,40

Dolphin, gunboat 85,92

Drift, schooner 17

Duke University 162, 187, 224

Dutton (AGS 8) (formerly the subchaser PCS 1396) 111, 119, 131

Dutton (T-AGS 22) (formerly the S. S. Tuskegee Victory) 154, 158, 222

E. W. Scripps, research vessel (formerly the yacht Serena) 87, 105

Eagle, survey ship (formerly the yacht Almy) 85,89

East India Marine Society 3, 11

Eastward, Biological research ship 162, 187. 224

Edison electric lamps 20,72

Edison, Thomas 72

Edward VII, Prince of England 89

Effic M. Morrissey, schooner 111, 114

ligyptians 3

Eisenhower, Dwight D. 188

Ellen B. Scripps, research vessel (modified of tshore oil supply boay) $162,191,225$

Eltanin (T-AGOR 8) (ex-cargo ship) 162, 189, 223

Enterprise, corvette 20, 74

Equitable Equipment Company 179

Erie Concrete and Steel Company (shipyard) 151

Erline, research support boat (formerly the offshore water "tasi" Orrin) 162, 179, 224

Evergreen (WAGO 295) 164,211,223

Ewing, Maurice 154

Ewing, steamer 12

Exodus 194784,85

Experiment, schooner 10.29

Explorer (OSS 28) 111, 124

Explorer, steamer 85, 97

Fairlicw (PCER 850) 131

Fairweather (MSS 20) 164, 205, 222

Fall River Line 88, 106

"Father of Modern Navigation" see Bowditch, Nathaniel

Fathomer, steamer 23, 80, 113

"Fathometer" 86,87

Federal Water Quality Administration (formerly the Federal Water Pollution Control Administration) 164

"Teejee' Islands 11
Fenimore Cooper, schooner (formerly the New York pilot boat Skiddy) 14

Ferrel (ASV 92) 164, 206, 223

Field, Cyrus W. 42

Field, Richard M. 88

"first civilized American" see Franklin, Benjamin

first iron-hulled warship see Michigan, steamer

first steam warship 164

Fish Commission see National Marine Fisheries Service

Fish Hawk, steamer (floating "hatchery") 19,69,87

Fletcher, W. \& A. Company (shipyard) 121

J:L1P (1) loating Instrument Platform) 214, 218

FIorida 1 nstitute of Technology 162, 224

Jlorida State University 162, 179, 224

Flying Fish, schooner (formerly the New York pilot boat Independence, and subsequently the opium smuggler Spee) 11, 36

Folger, Timothy 3

Fore River Shipbuilding Company 95

"Founder of the Science of Oceanography" see Maury, Matthew Fontaine, U. S. Navy

liounders Gold Medal 11

Franklin, Benjamin 2, "first civilized American" 3

Postmaster General of the Colonies 3

Franklin, Sir John 14, 15, 48, 50

Fremont, W. B., U.S. Navy 23

"J:S" Vessel see Army "FS" Vessel

Fulton, floating battery (formerly named the Demologos) 164

Julton, Robert 164

Galilee, schooner 85, 93

Gamage, I] arvey F., Shipbuilder, I ne. 190

Ganmet, minesweeper 88, 107

Gas Engine and Power Company 91, 121

Gazelle, S.M.S., research vessel 23

Gedney Channel 10

Gedney, T. R., U. S. Navy 10, 12, 23

General Conference on Oceanography 86 General Dy namics, Electric Boat Division 143 General lingine and Drydock Company 147 General Seafoods Corporation 144

George B. Kelez, fisheries research vessel 223

George M. Bowers, fisheries research vessel 223

Georges Shoal and Bank, Chart of 10,32

Gcrda, research vessel (ex-yacht) 131, 138, 225

German South Atlantic Expedition 86

Gettl'sburg, steamer (formerly the steamer

Margaret and Jessic, and previously the

steamer Douglass) 18,67

giant wave 88

Gibbs (T-AC,OR 1)

see Josiah I'illard Gibbs (T-AGOR I)

Gibbs Corporation (shipyard) 160, 176 
Gibus Gas Engine Corporation see Gibbs Corporation

Gibson, William, U. S. Navy 13

Gielow, H. J. 94

Gilbcrt, survey launclı 113, ] 27

Gilliss (T-AGOR 4) see James $\boldsymbol{M}$. Gilliss (T-AGOR 4)

Gilliss (AGS 13) see James M. Gilliss (AGS 13)

Gilpin, John 3

Glasgow University 18

Goelet, Ogden 84, 85

Goldsborough, Louis M., U. S. Navy 10, 28

Gosnell, A. H., U. S. Navy (Reserve) 88

Gosnold, research vessel (ex-Army freighter) 162 , 192,226

Grace Lines 111, 112

Grant, Ulysses 17

Gravity-at-Sea Expedition 88

Greeley, Adolphus W. 48, 77, 115

Greeley Relief Expedition 111

Greeley's Arctic Expedition 77

Green, F. M., U. S. Navy 19

Grinnell Arctic Expeditions 14, 15, 48, 50

Grinnell, Henry ] 5, 50

Guide, survey ship (formerly the minesweepcr Flamingo, and subsequently the salvage ship Viking) 111,120

Gulf Stream 3, 12, 17, 18, 44

Gulf Stream, Franklin's Chart of 4

"Gulf Stream" of the Pacific see Kuroshio

Gulfstream, research vessel (ex-crew boat) 225

Gunderson Brothers Shipbuilding 218

H-bomb 162, 175

H. W. Streeter, esturaine monitoring boat 164

Haber, Fritz 86

Halter Marine Services Inc., (shipyard) 19]

Hancock, Allan 131

Hand. William H. 114

Hannibal, steamer (formerly the steamer Joseph Holland) 85, 86, 87, 88, 90, 111

Harding, Warren 84, 85

Harkness (AGS 12) (formerly the minesweeper YMS 242) 111, 116, 131

Harkness (T-AGS 32) 163, 195, 222

Harlan and Hollingsworth (shipyard) 75, 89, 98

"Harper's Monthly" 12

Hartt's Shipyard 25

IIarvard's Museum of Comparative Zoology 18,68 1larvard University 17,68

1lassler, Ferdinand Rudolph 9, 10, 12, 26, 27

Hassler, steamer 21, 23, 76

"hatchery" ship 19,69

Hayes, Harvey Cornelius $86,99,100,163$

Hayes (T-AGOR 16) 163, 164, 202, 222

IIay lew Fisheries Inc. 119

Heck (ASV 91) 164, 207, 223
Hero, research vessel (modified trawler) 162, 190 , 223

Hess, H. H. 88

Hidalgo, research vessel (ex-subeliaser) 162,183

Hilgard, wire drag vessel 113, 207

Hiltebrant Drydock Company (shipyard) 116

Hirondelle, yacht 23

Hirondelle II, yacht 23

Hodgdon Brothers (shipyard) 114

IIoh, research vessel (formerly used as the Alcatraz Prison ferry, and previously a harbor tug) $162,176,226$

Hoist (ARS 40) 117

Horace Lamb, research vessel (ex-minesweeper) see Sir Horace Lamb

Horizon, research vessel (formerly the ocean tug ATA 180) 131, 133

Hudson Laboratories 146, 154, 156, 162, 174

Hugh M. Smith, fisheries research vessel (ex-tuna clipper) 131, 137

Hull, destroyer $86,101,102$

Ihunting (EAG 398( 132, 15)

11urricane Betsy 162, 171, 172

IIy drographer (MSS 19) 111, 122

Hydrographer, survey launch 85,97

Hydrographer of the Navy $19,22,78,150$

Ilydrographic Office see Naval Oceanographic Office

1lydrographic Surveying and Charting Ship System 216

Indian Ocean Expedition 162, 188

Inland Seas, research vessel (ex-Army freighter) 162,182

Inter-American Tropical Tuna Commission 154

International Geophysical Year 154

International lce Patrol 85, 95

International Scientific Expedition (West Indies) 88

"Iron Steamer"

see Michigan, steamer

Iselin, Columbus O’D. 132, 154

Isis, steamer 85, 96

Jackson, Andrew 12

Jacksonville Shipbuilding Corporation 217

Jacob, Robert Inc. (shipyard) 119

Jakobson Shipyard 207

James and Tarr (shipyard) 114

James M. Gilliss (AGS 13) (formerly the minesweeper YMS 262) 111, 117, 131

James M. Gilliss (T-AGOR 4) 161, 166, 222

Jamestown, sloop-of-war 18,67

Japan Expedition see Perry, Matthew Calbraith

Jeannette, bark 19,70 71

Jefferson, Thomas 9.26

Jersey, schooner 10

"Jinrikisha" of the Navy see Monocacy, gunboat 
John Blish (AGS 10) (formerly the subchaser PCS 1457) 111, 118, 131

John Hancock, steamer 14, 47

John N. Cobb, fisheries research vessel 223

John P. Kennedy, storcship (formerly the sailing ship Sea $\mathrm{Ny} m \mathrm{~m} / \mathrm{l}) 14$

Johns Hopkins University 131, 163, 201, 225

Josiah Willard Gibbs (T-AGOR 1) (formerly the seaplane tender San Carlos) 154, 156, 222

Kalakaua, King of the II awaiian Islands 53

Kane Basin (formerly Smith Sound) 15,48

Kane, Elisha Kent, U. S. Navy 15, 48, 50 ARTIC EXPLORATIONS 48

Kane (T-AGS 27) 162, 194, 222

Kansas, gunboat 17,54

Keathley (T-AGS 35) see Sgt. George D. Keathley (T-AGS 35)

Kellar (T-AGS 25) 161, 162, 171, 172, 222

Kennedy Channel 15, 48

Kennedy, Joseph P. 15

Kit Jones, research vessel (ex-tug) 162, 192, 224

Knorr (AGOR 15) 163, 200, 226

Koczy, Fritz 154

Korean War 154

Krusenstern (Russian Admiral) 11 ATLAS OF THE PACIFIC OCEAN 1]

Kuroshio 13, 43, 44

"Gulf Stream" of the Pacific 13, 43

Black Tide 44

Kyma, research vessel (ex-Army " $T$ " boat) $162,178,225$

Lackawanna, sloop-of-war 17,55

Lake Washington Shipyards 123, 124, 150, 156

Lamont-Doherty Geological Observatory (formerly Lamont Geological Observatory) 13], 135, 154 , $160,161,162,224$

Lee (T-AGS 31) see $S . P$. Lee (T-AGS 31)

Leonidas, steamer (formerly the steamer Elizabeth Holland) 85, 91

Lester Jones, wire drag vessel 1 1 1, 125

Lexington, storeship 13

Lighthouse Service 15, 19

Lincoln, Abraham 16

Lincoln, cutter 17,58

Littlehales (AGS 7) (formerly the subchaser PCS 1388) 111, 119, 131

Littlehales (AGSC 15) (formerly the freight ligh ter YF 854) 132, 151

Livingstone Shipyard 146

Lord Kelvin see Thomson, Sir William

Lowry, O. W., U. S. Navy 21

Lulu, submirsible support ship 226

Lusitania, liner 85,96

Lydonia, survey ship (ex-yacht) 86, 103, 113

Lynch, William Francis, U. S. Navy 15, 16, 49, 51 Dead Sea Expedition 15, 16

Lynch (T-AGOR 7) 161, 167, 222
Macedonia, corvette 13

MacMillian, Donal D. 114

magnetic chart (first) 19

Maine, battleship 22, 78

Manning, research vessel (ex-Army " $\mathrm{T}$ " boat) 162,224

Mare Island Navy Yard 53, 57, 71

Maria, schooner 10,31, 32

Marietta Manufacturing Company 167, 171, 206

Marinduque, steamer 23, 81

Marine Corps 131, 163, 195

Marinette Marine Corporation (shipyard) 168

Maritime Administration 157, 158, 188, 197

Martinac, J. M. Company (shipyard) 187

Maryland Shipbuilding and Drydock Company 165

Marysville (PCER 857) 131, 141

Mason, John Y. 15

Massachusetts Institute of Technology 132

Maury, Matthew Fontaine, U. S. Navy 13, 16, 17, $38,40,41,87$

"Pathfinder of the Seas" 13, 38

"Founder of the Science of Oceanography" 13 THEORETICAL AND PRACTICAL TREATISE ON NAVIGATION 13 PHYSICAL GEOGRAPHY OF THE SEA 13

Maury (AGS 16) (formerly the attack cargo ship Renate) 131, 145, 163

Maury ( $65^{\prime}$ boat) 225

Maury United States Naval Oceanographic Research Expedition 87

Mayflower, surveying ship (formerly a yacht and subsequently a Combat lnformation Training Schoolship and later the Exodus ship Mala) 84.85

McArthur, W. P., U. S. Navy 13

McArthur (CSS 30) 164, 205, 223

McArthur, steamer 23, 79

Meinesz, F. A. Vening 88

Melville (AGOR 14) 163, 198, 199, 225

Meteor, gunboat 86

Michelson (T-AGS 23) (formerly the S. S. Joliet Victory) 154, 158, 222

Michigan, steamer (subsequently renamed Wolverine) 21,77

first iron-hulled warship 21, 77

"Iron Steamer" 21, 77

Military Sealift Command (formerly the Military Sea Transportation Service) 150, 164, 166, 167 , $169,171,175,202$

Miller Freeman, fisheries research vessel 164, 208, 223

Minot, Francis 132

Mission Capistrano (T-AG 162) (ex-T-2 tanker) 162,174

Mississippi, frigate 13,14

Mizar (T-AGOR 11) (ex-cargo ship) 162, 175, 222

Monocacy, gunboat 17,55

"Jinrikisha" of the Navy 55

Morgan, J. P. I11,121 
Morrissey, schooner see Effie M. Morrissey, schooner Hount Suribachi 111

Mt. Mitchell (MSS 22) 164, 205, 222

Multipendulum instrument 88

Nantucket whalers 3

Narragansett, sloop 17, 18, 57

NASCO see National Academy of Sciences

National Academy of Sciences 17, 87, 154 National Research Council 87 Committee on Oceanography (NASCO) 87, 154

National Bureau of Standards 10 Office of Weights and Measures 10

National Marine Fisheries Service 164, 208, 209. 210,223

Bureau of Commercial Fisheries 154, 164 Bureau of Fisheries 87, 106, 144 Fish Commission 17, 18, 19, 59, 60, 68, 69, 73

National Ocean Survey 9, 26, 164, 203, 204, 205, 206, 207, 222, 223

Coast and Geodetic Survey 9, 22, 23, 26, 79, $80,81,86,88,96,97,103,111,120,121$, $122,123,164$

Coast Survey $9,10,12,15,16,17,18,22,26$, $29,30,37,39,44,48,52,58,60,68,76,79$. 87

Survey of the Coast 9,10

National Oceanic and Atmospheric Administration 222,223

National Park Service 9

National Research Council see National Academy of Sciences

National Science Foundation 131, 161, 162, 163, $187,188,189,190,223$

National Steel and Shipbuilding Corporation 203

Nautilus, schooner 12

Naval Electronics Laboratory 131

Naval Experimental Station 86, 99

Naval Oceanographic Office $10,28,131,145$ Depot of Charts and Instruments $10,13,28$, 32,38

Hydrographic Office 10, 16, 17, 19, 38,67, $73,78,85,86.87,95,102,110,113,131,132$

Naval Observatory $10,16,17,38,47$

Naval Ordnance Laboratory 131, 146, 217

Naval Research Laboratory $86,88,99,131,132$, $141,151,156,162,163,174,175,202$

Naval Ship Systems Command 131 Bureau of Ships 136, 132, 161

Naval Underwater Sound Laboratory 131, 143

Netherlands Geodetic Commission 88

NEW AMERICAN PRACTICAL NA VIGATOR see Bowditch, Nathaniel

New Bedford Customs House 18

New Jersey Drydock and Transportation Company 120

New London Harbor 9, 24, 25

New York Customs House 10

New York Harbor 10

New York Navy Yard 34, 35, 40, 42, 55
New York pilot boat 11, 14, 36

New York University 131, 136, 162, 178, 225

Newark Harbor 10

Newcomb (AGS 14) sce Simon Newcomb (AGS 14)

New port News Shipbuilding and Drydock Company 107

Niagara, survey ship (ex-yacht) 86,98

Niogara, frigate 13,42

Nokomis, survey ship (formerly the yacht Kwoswind) $86,88,98$

non-magnetic researcli yacht se Carnegie, non-magnetic research yacht

Norfolk Navy Yard 13, 33, 40, 67, 106, 112, 145

Norfolk Shipbuilding and Drydock Corporation 205

Nor thern Pacific and Arctic Surveying Expedition $14,31,35,46,47$

Northwest Marine lron Works (shipyard) 169,171

Northwestern Michigan College 146, 225

Nova University 225

Oceanographer, survey ship (formerly the yacht Corsair II) 111,121

Oceanographer of the Navy 222

Oceanographer (OSS 01) 164, 203, 204, 222

Oceanography 1951 (NASCO Report) 154

Oceanography: 1960 - 1970 (NASCO Report) 154

Oconostota, research vessel (ex-tug) 162, 176, 225

Office of Naval Research 131, 132, 154, 163

Office of Weights and Measures see National Bureau of Standards

Oglalo, steamer (formerly the mine layer Shawmut, and previously the $S . S$. Massachusetts) 88,106

"Old I ronsides" see Constitution, frigate

Olympia, cruiser 85,93

Onar, research vessel (ex-Army " $\mathrm{T}$ " boat) 162 , 177,226

Oncorhynchus, motor launch 131, 139

Operation Crossroads 117, 118, 119,131

Orca, research vessel (ex-USCG patrol vessel) $131,138,226$

Oregon, brig (formerly the merchantship Thomas Perkins) 11

Orcgon, fisheries research vessel 223

Oregon II, fisheries research vessel 164, 223

Oregon Shipbuilding Company 157, 158

Oregon State University 131, 162, 185, 186, 225

Paducah, gunboat (subsequently the Exodus ship Gcula ) 85,9 I

Palos, gunboat $17,19,54$

Paolina-T, research vessel (ex-purse seiner) 131,137

Pathfinder (OSS 30) 111, 123

"Pathfinder of the Seas" see Maury, Matthew Fontaine

Pathfinder, steamer (subsequently renamed Research) 23, 80, 113

Patterson, steamer (subsequently the gunboat Forward) $23,79,85$

Patton, wire drag vessel 111,125 
Patrol Vessel 102 (Japanese) see Stewart, destroyer

Paulding, J. K. 11

Peabody Muscum 3

Peacock, sloop-of-war 11,35,

Pennsylvania Medical School 48

Pennsylvania Shipyards 147

Perry, Matthew Calbraith, U. S. Navy 13, 14, $43,44,45,46,51$

Japan Expedition 13, 44

Peterson, Harold 9

Philadelphia Navy Yard 37, 54, 56, 60, 84, 158

PHYSICAL GEOGRAPHY OF THE SEA see Maury, Matthew Fontaine, U.S. Navy

Pierce (CSS 28) 164, 206, 222

Pike, Sumner 154

Pillsbury, research vessel (ex-Army "FS" vessel) $162,184,225$

Pillsbury, J. E., U. S. Navy 23

Pilot, schooner 11,34

Pioneer, brig 11,33

Pioneer, survey ship (formerly the minesweeper Osprev, and subsequently the salvage ship Crusader) 111,121

Pittendrigh, Collin 154

Plymouth, sloop-oi-war 13,14

Porpoise, brig 10, 11, 14, 31, 32, 46

Porter, David D., U.S. Navy 16, 51

Portsmouth Navy Yard 53, 54, 60, 74, 89, 145

Postmaster General of the Colonies see Franklin, Benjamin

Powkatan, steamer 13

presidential yacht 84,85

Prevail (AGS 20) (ex-minesweeper) 131, 147

Pribilof, fisheries research vessel 223

Princess Alice, yacht 23

Prineess Alice II, yacht 23

Princeton, steamer 13

Princeton University 88, 154

producer gas engine 94

Propulsive Rudder Assembly 170

Proteus, research vessel (ex-fishing vessel) $162,181,226$

Pullman Standard Car Manufacturing Company (shipyard) 141,143

Pursuit (AGS 17) (ex-minesweeper) 131, 148

Pusey and Jones Company (shipyard) 19,69, $72,98,103$

Rainier (MSS 21) 164, 205, 222

Ramage and Ferguson (shipyard) 89

Ramapo, tanker 88, 107

Ranger, sloop-of-war (subsequently the nautical schoolships

Rockport and Nantucket) 21, 22, 75

Red lagle of Prussia 78

Rehoboth (AGS 50) (ex-seaplane tender) 132. 150,164
Release, bark 15

Relief, storeship 11, 37

Rensselaer Bay 15

Requisite (AGS 18) (ex-minesweeper) 131, 148

Rescue, brig 15, 50

Research, steamer see Patlifinder, steamer

Researcher (OSS 03) 164, 204, 222

Revelle, Roger 154

Revenue Cutter Service see Coast Guard

Revenue Service see Coast Guard

Rexburg (PCER 855) 131, 142

Reynolds, R. J. 192

Ridgely Warfield, catamaran research vessel 163201,225

Riley, Gordon 154

Ringgold, Cadwalader, U.S. Navy 14, 31, 35, 46,47

Roach and Sons, John (shipyard) 92

Robert D. Conrad (AGOR 3) 160, 161, 164, 224

Rockanay (WAGO 377) 223

Rockefeller Foundation 87

Rockville (PCER 851) 131, 141

Rodgers, John; Commodore, U. S. Navy $9,24,47$

Rodgers, John; Rear Admiral, U. S. Navy $14,47.53$

Roger B. Taney, schooner 13, 39, 40

Romblon, steamer 23, 81

Roosevelt, Theodore 84,85

Rosenblatt, M. and Son, Inc. 161

Rosenblatt, Mandel 132

Royal Geographic Society 12

Rude (ASV 90) 164, 207, 223

rum runner 89

Rust (AGS 9) see Armistead Rust (AGS 9)

S. P. Lee (T-AGS 31) 161, 163, 173, 222

$S-48$, submarine 88

Salem ships 3.9

San Pablo (AGS 30) (ex-seaplane tender) 132, 150

Sands (T-AGOR 6) 161, 167, 222

Saratoga, sloop-of-war 13,14

Schaefer, Milner R. 154

Scholield Board 87

Schofield, Frank H., U. S. Navy 87

Scorpion, submarine 162,175

Scripps Institution of Oceanography $87,88,105$, $131,132,133,134,137,138,154,161,162$, $163,168,176,178,187,191,198,218,225$

Scripps, Robert P. 105

Sea Gull, schooner (formerly the New York pilot boat New Jersev) 11, 36

Sea of Galilee 15, 49

Seabury Company, C. L. (shipy ard) 91 
Seagoing Platform for Acoustics Research see AG (SPAR)

"Seamen's Bible" see Bowditch, Nathaniel

Seattle Construction and Dry Dock Co. 110

Serrano (AGS 24) (ex-ocean tug) 131, 149, 163

Seward, H. L. 132

Sgt. Curtis F. Shoup (T-AG 175) (formerly the transport ship Spindle Eye) 163, 197

Sgt. George D. Keathley (T-AGS 35) (ex-cargo ship) $163,197,222$

Sheldrake (AGS 19) (ex-minesweeper) 131, 147, 163

Shenandoah, sloop-of-war 17, 56

Shoup (T-Ar, 175) see Sgt. Curtis F. Shoup (T-AG 175)

Sigsbee, Charles Dwight, U. S. Navy 22, 23, 78

Sigsbee Deep 78

Silas Bent (T-AGS 26) 162, 193, 194, 196, 222

Simon Newcomb (AGS 14) (formerly the minesweeper YMS 263) 111,117, 131

Sir Horace Lamb, research vessel (formerly the minesweeper Red Poll) 162, 176, 224

Smith Sound see Kane Basin

Smithsonian Institution 14, 17, 22, 59

Somersworth (PCER 849) 131, 143

sonic depth finder $86,99,100,101,163$

sonic echo sounders 88

South Coast Company (shipyard) 117, 119

Southampton, storeship 13

Southern Shipbuilding Corporation 208

Spanish-American War 22, 23, 78, 84, 89, 93

SPAR see AG (SPAR)

Spear Engine Works (shipyard) 122

Speneer Baird, research vessel (formerly the Army tug $L$ i 581, and subsequently the Vietnamese vessel Tien $\mathrm{Sa}$ ) 131, 133

Spilhaus, A thelstan 154

Stackhouse and Tombinson (shipyard) 77

Stallion (ATA 193) 131, 146

Stanford University 162,180,181,226

State Department 86

Steam Launch 75

Stephen, Alexander and Sons (shipyard) 77, 115

Stevens Institute of Technology 132

Stewart, destroyer 86, 100

Patrol Vessel 102 (Japanese) 100

Stone, Lewis 105

Stranger, research vessel (ex-yacht) 131, 134

Submarine Signal Company 86

Sumner (AGS 5) (formerly the submarine tender Bushnell) 88, 110,111, 131

Supply, storeship (formerly the merchant ship Crusader) $13,15,16,49,51$

Survey of the Coast see National Ocean Survey
Survey Launch \#1255 164, 207

Survey Launch \#1257 164, 207

Surveyor, steamer 85, 96, 111

Surveyor (OSS 32) 164, 203, 222

Susquehanna, frigate $13,14,46$

T-AGS (HYSURCH) Ship System 216

"T" Boat see Army " $T$ " Boat

$T-426$, research vessel (ex-A rmy " $T$ " boat) 162 , 224

$T-441$, research vessel (ex-Army " $T$ " boat) 162 , 178,224

Tacoma Boat Building Company 116

Taft, William Howard 84,85

Taney, schooner see Roger B. Taney, schooner

Tanner, Zera L., U. S. Navy 19, 20, 72, 73, 87

Tanner (AGS 15) (formerly the attack cargo ship Pamina) 117, 131, 145, 163

Tanner, USS 87

Te Vega, schooner 162,180

Tebo Yacht Basin Company (shipyard) 94

Teledy ne inc. 138

TEN YEAR PROGRAM IN OCEANOGRAPHY

(TENOC) 161, 164

Teritu, research vessel (formerly the yach t Glenmore) $162,181,224$

Tetlow, James (Shipyard) 54

Texas A\&M University 131, 138, 162, 183, 226

Theodelite, Ferdinand Hassler's 24-inch 10, 27

THEORETICAL AND PRACTICAL TREATISE

ON NA VIGATION

see Maury, Matthew Fontaine, U. S. Navy

THERMOMETRIC GATEWAYS TO THE POLE see Bent, Silas, U. S. Navy

Thetis, gunboat 22, 77

Thomas G. Thompson (AGOR 9) 161, 168, 226

Thomas Washington (AGOR 10) 161, 168, 225

Thompson, J. \& G. (shipyard) 84,85

Thompson (AGOR 9) see Thomas G. Thompson (AGOR 9)

Thomson, Sir William 18, 61, 62, 64 Lord Kelvin 18

Thomson, Sir Wy ville 68

Thomson Sounding Machine 18, 22, 62, 63, 65

Thresher, submarine $141,162,175$

Titanie, liner 85, 95

Todd Shipyard Corporation 107, 120, 202

Tokyo Bay 14, 43, 45 Yedo Bay 14

Towhee (AGS 28) (ex-minesweeper) 131, 149 , 163

Towrisend Cromwell, fisheries research vessel 164 , 210,223

Treasury Department $9,10,77,86$

Treaty of Ghent 10

Trident, research vessel (ex-Army "FS" vessel) $162,184,225$ 
Truman, Harry S. 162, 188

Truxton, Thomas, U.S. Navy 3, 5, 6

Turner, Mathew 85, 93

Tuscarora, sloop-of-war 17, 18, 61, 62, 63, 64, 65, 66

Tursiops, research vessel (ex-Army " $\mathrm{T}$ " boat) 162, 179,224

Tybee Island, Georgia 39

U-39 (German submarine) 85,96

Union College 10

Union I ron Works 93

United States Expedition to Japan see Peary, Mat thew Calbaith

United States Exploring Expedition 10, 14, 30, 31, $35,36,37,46$

Wilkes Exploring Expedition 33, 34, 35, 36

United States Military Academy (West Point) 10 , 16

University of Alaska 162, 223

University of Connecticut 162, 178, 224

University of Georgia 162, 192, 224

University of Hawaii 162, 181, 224

University of Miami 131, 138, 154, 162, 179, 184, 225

University of Michigan 162, 182

University of Minnesota 154

University of Puerto Rico 139

University of Rhode Island 131, 162, 184, 225

University of Southern California 130, 131, 226

University of Washington $87,88,105,131,139$, $140,161,162,168,177,226$

Upper Cly de Shipbuilders 195

Upshur, A.P. 77

Van Buren, Martin 11

Vandalia, sloop-of-war 13

Velero $I V$, research vessel (modified tuna clipper) $130,131,226$

Vema, schooner 131, 135, 224

Vermont, ship of the line 13

Vetter, Richard 154

Vincennes, sloop-of-war 11, 14, 35

Virginia Military Institute 16, 38

Wachusett, sloop-of-war 17, 56

Wainwright, wire dreg vessel 113, 127, 207

Walsh-Kaiser Shipyard 145

War Department 86

War of 181210

Washington (AGOR 10)

see Thomas Washington (AGOR 10)
Washington, brig 12, 37

Washington, George 3

Washington Navy Yard 29, 37, 124

Watson, George L. 84, 85

Weatherford, subchaser 131

Webb and Allen Company (shipyard) 39

West Point

see United States Military Academy (West

Point)

Westdahl, survey launch 111, 126

Wheelock, C. D., U. S. Navy 132

WHEO-701, oceanographic cutter 211

Whistler, James Abbot McNeill 16, 52

Whitehall, rescue escort craft 131

Whiting (CSS 29) 164, 206, 222

Wilkes, Charles, U. S. Navy 10, 11, 12, 30, 31, 32, $33,34,35,36,37,46$

Wilkes Exploring Expedition see United States Exploring Expedition

Wilkes (T-AGS 33) 163, 194, 222

William I, Emperor of Germany 78

Williamette 1 ron and Steel Company (shipyard) 197

Wilson, Woodrow 84, 85

Winslow Marine Shipyard 148

Woodbury, Levi 12

Woods Hole Oceanographic Institution 87, 88, 104, $131,132,139,140,154,161,163,165,188$, $192,200,226$

World War $119,85,90,91,96,97,103,121$

World War $1184,90,96,100,111,121,131,144$, 154,215

Wrangel 1 sland 14, 19

Wrangel "Land" 19

Wyman (T-AGS 34) 163, 196, 222

Yale University 132, 154

Yankton, gunboat (formerly a yacht bearing the successive names

Penelope, Cleopatra, and finally Sapphire) 85, 89

Yaquina, research vessel (ex-Army "FS" vessel) $162,185,225$

Yedo Bay

see Tokyo Bay

YP-41 111

YP-42 111

YP-56 111

Zigler Shipyards 206 







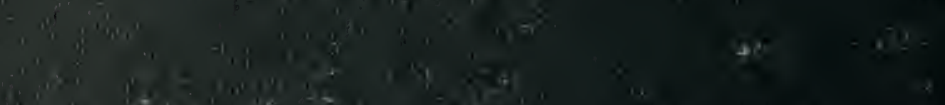

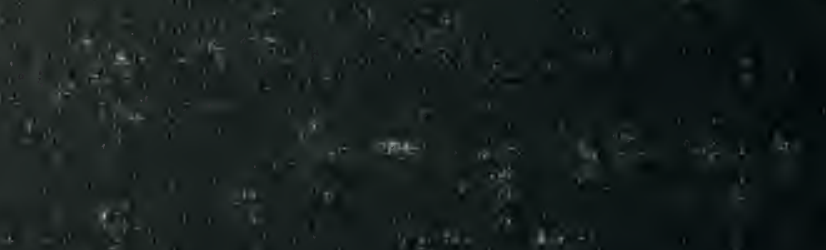

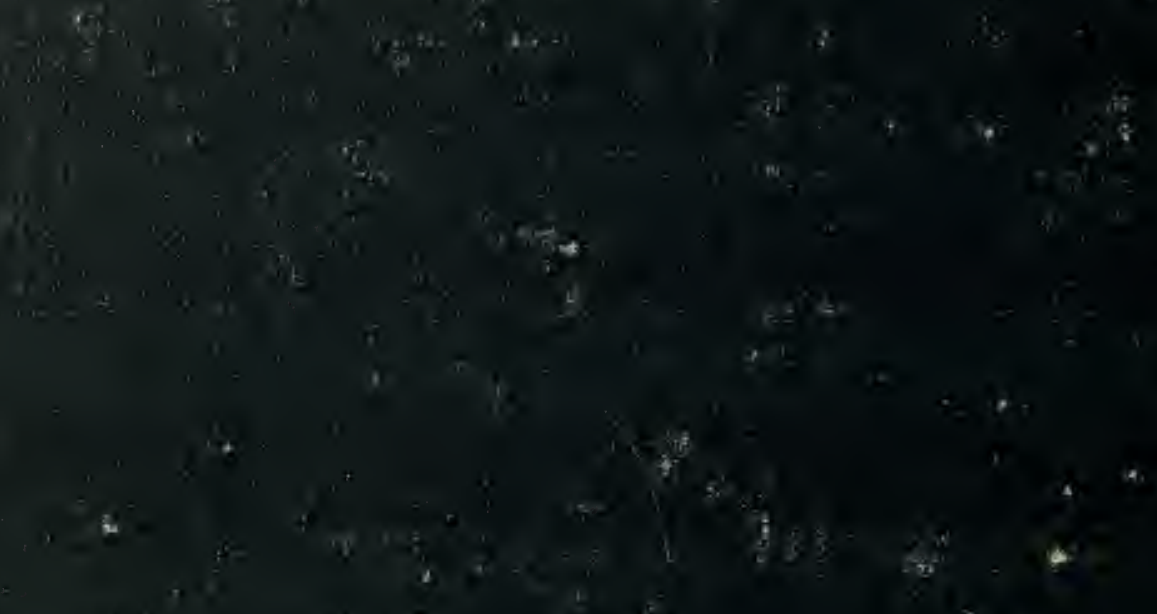

$x^{4}+x^{8}+1$

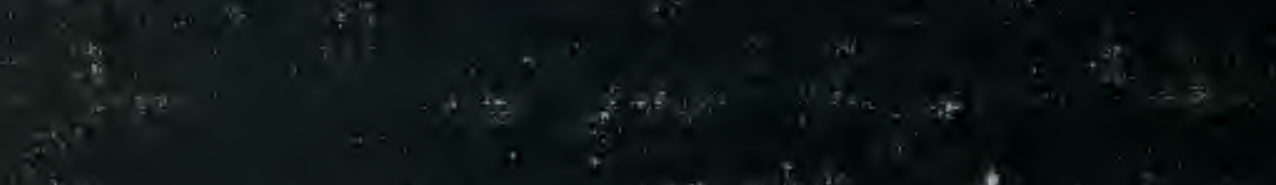

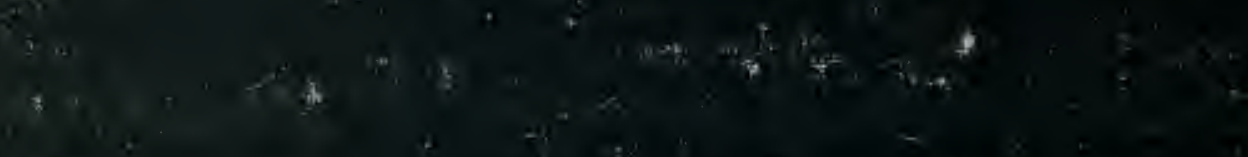
is $\frac{7}{6}$

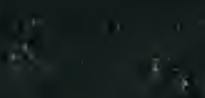

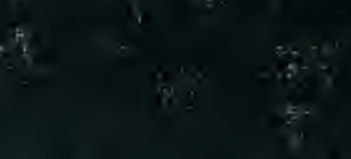

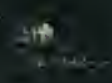

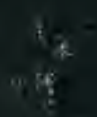

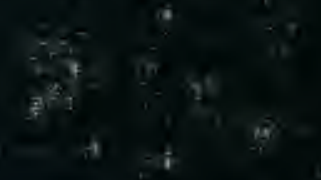

ats $=x^{2}+x^{2}$

$x^{2}$

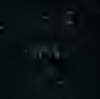

$a^{-x+2}=$

is

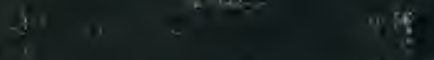
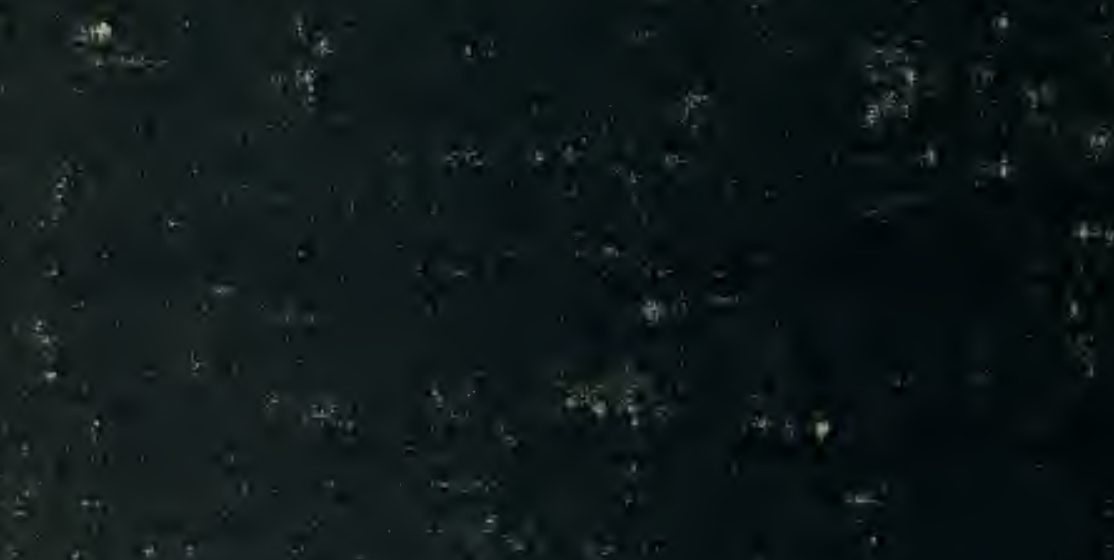